РОССИЙСКАЯ АКАДЕМИЯ НАУК

Институт русского языка имени В. В. Виноградова

\title{
RUSSIAN ACADEMY OF SCIENCES
}

V.V. Vinogradov Russian Language Institute 



\title{
Труды \\ Института русского языка им. В. В. Виноградова
}

\section{XIII}

\author{
Культура русской речи
}

Главный редактор А.М. Молдован

MOСКВА

2017 
Труды Института русского языка им. В. В. Виноградова. Вып. 13. Культура русской речи. - М., 2017. $496 \mathrm{c.}$

ISSN 2311-150X

Издание основано в 2013 г.

РЕДАКЦИОННЫЙ СОВЕТ

Ю. Д. Апресян, академик РАН, профессор (Москва, Россия); Бьёрн Вимер, доктор филологии, профессор (Майнц, Германия);

А. А. Гиппиус, член-корреспондент РАН, профессор (Москва, Россия);

М. Л. Каленчук, доктор филол. наук, профессор (Москва, Россия);

Туре Нессет, доктор филологии, профессор (Тромсё, Норвегия);

В. А. Плунгян, член-корреспондент РАН, профессор (Москва, Россия);

Вацлав Чермак, доктор филологии (Прага, Чехия);

А. Д. Шмелев, доктор филол. наук, профессор (Москва, Россия);

Ж. Ж. Варбот, доктор филол. наук, профессор (Москва, Россия).

ОТВЕТСТВЕННЫЙ РЕДАКТОР ВЫПУСКА

А. Д. Шмелев, доктор филол. наук, профессор (Москва, Россия)

РЕДАКЦИОННАЯ КОЛЛЕГИЯ ВЫПУСКА

Е. В. Бешенкова, к. филол. наук (Москва, Россия);

О. Е. Иванова, к. филол. наук (Москва, Россия);

М. С. Картышева (Москва, Россия);

Е. Я. Шмелева, к. филол. наук (Москва, Россия).

Выходит 4 раза в год

Адрес редакции:

119019, Москва, ул. Волхонка, д. 18/2

E-mail: ruslang@ruslang.ru

Издательство зарегистрировано Федеральной службой по надзору в сфере связи, информационных технологий и массовых коммуникаций.

Свидетельство о регистрации ПИ № ФС 77-57258 


\section{Proceedings of the V.V. Vinogradov Russian Language Institute}

\section{XIII}

Russian Linguistic Standards

Editor-in-Chief Alexander M. Moldovan 
Proceedings of the V.V. Vinogradov Russian Language Institute, 2017, No. 13. Russian Linguistic Standards. - M., 2017. 496 p.

ISSN 2311-150X

The Journal was founded in 2013

EDITORIAL BOARD

Yury D. Apresyan, D.Sc., Professor, Full Member of the RAS (Moscow, Russia);

Václav Čermák, Ph.D., (Prague, Czech Republic);

Alexey A. Gippius, D.Sc., Professor, Corresponding Member of the RAS, (Moscow, Russia);

Maria L. Kalenchuk, D.Sc., Professor (Moscow, Russia);

Tore Nesset, D.Sc., Professor (Tromsø, Norway);

Vladimir A. Plungian, D.Sc., Professor, Corresponding Member of the RAS (Moscow, Russia);

Bjoern Wiemer, D.Sc., Professor (Mainz, Germany);

Alexey D. Shmelev, D.Sc., Professor (Moscow, Russia);

Zhanna Zh. Varbot, D.Sc., Professor (Moscow, Russia).

CHIEF EDITOR OF THE ISSUE

Alexey D. Shmelev, D.Sc. (Moscow, Russia)

EDITORIAL BOARD OF THE ISSUE

Elena V. Beshenkova, Ph.D. (Moscow, Russia);

Olga E. Ivanova, Ph.D. (Moscow, Russia);

Maria S. Kartysheva (Moscow, Russia);

Elena Ya. Shmeleva, Ph.D. (Moscow, Russia).

Address:

18/2, Volkhonka street, Moscow, 119019

E-mail: ruslang@ruslang.ru

The journal is registered by the The Federal service for supervision of communications, information technology, and mass-media.

Registration certificate ПИ № ФС 77-57258.

(C) by Vinogradov Russian Language Institute of the Russian Academy of Sciences, 2017

(C) by Authors, 2017 


\section{СОДЕРЖАНИЕ}

\section{Новые явления в русском языке XXI века: проблемы кодификации нормы}

Н. Ю. Авина (Вильнюс)

«В какую сторону думать?»: о культуре русской речи студентов-билингвов в ситуации

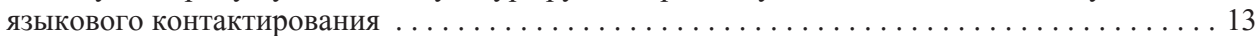

Н. В. Богданова-Бегларян (Санкт-Петербург) Агрессивный узус или эволюция языковой нормы? (приглашение к дискуссии) . . . . . . 21

Л.Н. Дьякова, Н. А. Козельская, И. А. Стернин (Воронеж) Опыт описания сферы незнания и интереса носителя языка (на материале языкового

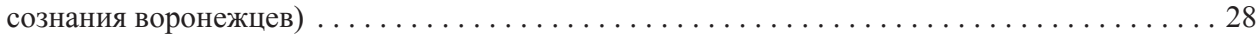

А. Г. Жукова (Москва)

Ненормы в современной коммуникации (на примере лексемы функционал) . . . . . . . 35

О.С. Иссерс (Омск) Дай Бог не последний! (о вирусной эвфемизации в контексте массовой

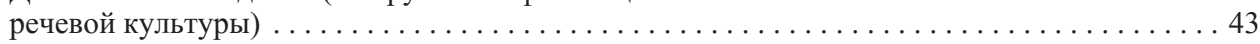

Е. М. Лазуткина (Москва)

О разрушении национальных языков в эпоху глобализации. . . . . . . . . . . . . . 53

М.В. Ляпон (Москва)

Игровая риторика — практикум по культуре речи. . . . . . . . . . . . . . . 59

Н. Б. Мечковская (Минск)

Языковая демократизация, либерализация и встречные процессы: соотношение стихии

и планирования . . . . . . . . . . . . . . . . . . . . . . . . . 68

О.В. Мякшева, О.Б. Сиротинина (Саратов)

Государственный (литературный) русский язык: обязательные и возможные сферы его использования, нормы и реальный узус. . . . . . . . . . . . . . . . . . . 82

Е. А. Никишина (Москва)

Наклейки на автомобилях как малый жанр в системе речевого взаимодействия на дороге . . . . . . . . . . . . . . . . . . . . . . . . . . . . . . . . . . . . . . . . 89

Е. Ю. Протасова (Хельсинки)

Соблюдение регламента на конференции: реплики участников . . . . . . . . . . . . . . . . . . . 97

Т.Б. Радбиль (Москва)

Культурная апроприация заимствований в свете теории языковой концептуализации

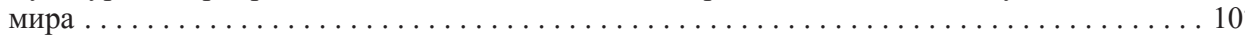

Р. Ратмайр (Вена)

Культура речи в этических кодексах компаний и реальное общение на примере обслуживания клиентов ...................................... 115

Н.Н. Розанова (Москва)

Разговорная лексика в «контексте» стереотипных ситуаций городского общения и проблемы ее словарного представления в «Толковом словаре русской

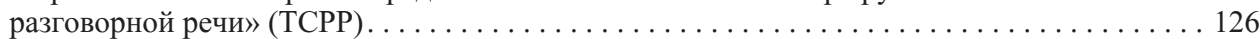

С. О. Савчук (Москва)

Устная научная речь в свете корпусных данных. . . . . . . . . . . . . . . . . . . . . . . 136

О.И. Северская (Москва)

«Через время, через расстояние»: стилистическая ошибка, эллипсис или рекурсия нормы? . . . . . . . . . . . . . . . . . . . . . . . . . . . . 145

Г.Н. Скляревская (Санкт-Петербург)

«Так не говорят», или Еще раз о системе, норме и узусе (взгляд лексикографа) . . . . . . . 153 
А. Э. Цумарев, Л. Л. Шестакова (Москва)

О кодификации языковых норм в «Академическом толковом словаре русского языка». . . 160

В. Д. Черняк (Санкт-Петербург) «Вечные вопросы» культуры речи в лексикографической традиции и современной

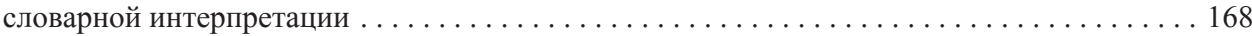

С. Д. Шелов (Москва)

Основные проблемы терминоведения: некоторые итоги . . . . . . . . . . . . . . . 176

А. Д. Шмелев (Москва)

Возможна ли кодификация языковых норм в эпоху социальных и культурных

изменений? . . . . . . . . . . . . . . . . . . . . . . . . . . . 184

Е. Я. Шмелева (Москва)

Язык «эффективныХ менеджеров»: общий жаргон или русский язык XXI века? . . . . . . 192

Т.В. Шмелева (Великий Новгород)

Грамматика новгородцев: региональная норма? . . . . . . . . . . . . . . . . . . . . . . . . . 199

Т.Е. Янко (Москва)

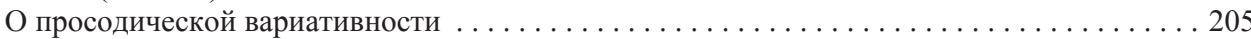

\section{Лексика и грамматика: узус и норма}

Е. Г. Борисова (Москва)

О факультативных фрагментах смысла высказывания (еще раз о словах-паразитах) . . . . 215

И. Т. Вепрева, Н. А. Купина (Екатеринбург)

Заметки об узуальных сдвигах в лексической семантике $\ldots \ldots \ldots \ldots \ldots \ldots \ldots \ldots \ldots \ldots \ldots$

М. Я. Дымарский (Санкт-Петербург)

Элиминация темы и постулат о базовом порядке слов в русском языке . . . . . . . . 230

С.М. Евграфова (Москва)

Грамматика понимания и грамматика порождения текста и проблемы вербального

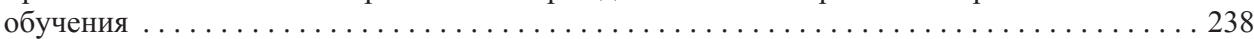

О. П. Ермакова (Калуга)

Возможности словообразования в сфере выражения логических категорий. . . . . . . . . 247

Г.И. Кустова (Москва)

Семантика и типы употребления наречных квазирелятивов . . . . . . . . . . . . . 257

А. Б. Летучий (Москва)

Асимметрия употребления местоимений что и кто и морфологическая

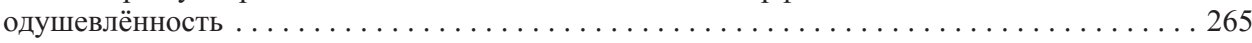

И. А. Магеррамов (Москва)

О типовых нарушениях синтаксиса в современных медиатекстах . . . . . . . . . 275

Е. В. Маринова (Нижний Новгород)

Ценностные эпитеты в системе этических представлений современных пользователей

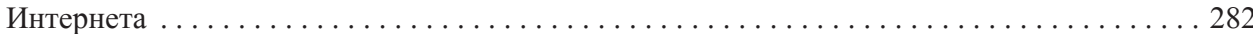

Н. А. Николина (Москва)

Типы и функции контаминированных образований в современной русской речи . . . . . . 288

М.В. Трубицина (Москва)

Согласование в конструкциях с названиями в русском языке. . . . . . . . . . . . . . . . . 295

Е. В. Урысон (Москва)

Наречие сразу: семантика и грамматика . . . . . . . . . . . . . . . . . . . 304

М. Ю. Федосюк (Москва)

Предложение как текст: стилистический и культурно-речевой аспекты . . . . . . . . . . 314

О.Е. Фролова (Москва)

Социальная стратификация: от метафоры к словообразованию . . . . . . . . . 323

В.Н. Шапошников (Москва)

Семантический потенциал частиц и развитие лексико-грамматических вариантов:

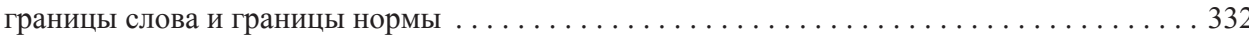


И. А. Шаронов (Москва)

Мода на неизменяемость: история разрастания и современное состояние . . . . . . . 340

М. В. Шульга (Москва)

О развитии синтетических средств в динамике русского языка . . . . . . . . . . . . . . 349

С. Янурик (Будапешт)

Английские заимствования с исходом на -Ш(Е)Н И -Ж(Е)Н

в русском языке последних лет в свете словарных и корпусных данных

\section{Орфография и орфоэпия}

Е.В. Бешенкова (Москва)

Ретроспекция как фактор ортологической политики орфографистов. Часть $1 \ldots \ldots \ldots . . .367$

Л. А. Вербицкая (Москва)

Особенности фиксации орфоэпической нормы сегодня $\ldots \ldots \ldots \ldots \ldots \ldots \ldots \ldots \ldots \ldots$

С. В. Друговейко-Должанская (Санкт-Петербург)

К чему (зиц)председателю дефис, или Графиксация как симптом . . . . . . . . . . . . 395

Л. В. Зубова (Санкт-Петербург)

Орфографическая стилистика . . . . . . . . . . . . . . . . . . . . 407

О. Е. Иванова (Москва)

Орфографическая кодификация и социальная динамика. . . . . . . . . . . . 417

И. Б. Иткин, В. Д. Пекарская (Москва)

Международный скандал (сложные слова с первым компонентом меж- между-

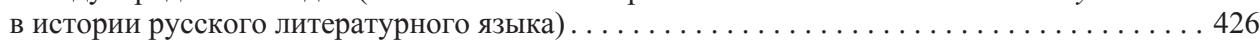

В. В. Каверина (Москва)

Основные тенденции употребления консонантного удвоения в заимствованных словах . . .435

М. С. Картышева (Москва)

Современное употребление и историческая динамика распределения первых

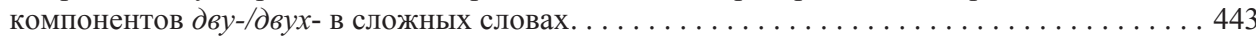

И. В. Нечаева (Москва)

Употребление прописной графемы: аргументы и факторы . . . . . . . . . . . . . 449

Н. В. Николенкова (Москва)

Употребление прописной буквы: история и современная кодификация . . . . . . . . . . 459

А. А. Плетнева (Москва)

Народное правописание и реформа орфографии $1917-1918$ годов. . . . . . . . . . 466

С. К. Пожарицкая (Москва)

Орфоэпия в эпоху корпусной лингвистики: динамика вариантов и их оценка . . . . . . . 474

С. В. Феликсов (Москва)

Типы вариантных написаний религиозной лексики в лексикографических

произведениях гражданской печати второй половины XVIII века . . 


\section{CONTENTS}

\section{New Trends in Russian: Problems of Codification of Linguistic Standards}

N. J. Avina (Vilnius) «V KAKUJU STORONU DUMAT’?»: the Russian Speech Culture of Bilingual Students

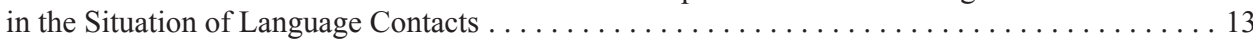

N. V. Bogdanova-Beglarian (Saint Petersburg) Aggressive Colloquial Usage or Language Norm Evolution? (Invitation to Discussion) . . . . . . 21

L. N. Dyakova, N. A. Kozelskaya, I. A. Sternin (Voronezh) On the Description of the Sphere of Ignorance and Interest of the Russian Language Speaker (in Language Consciousness of the Voronezh Region) ....................... 28

A. G. Zhukova (Moscow)

Abnormalities in Modern Communication (the Case of the Lexical Unit 'funktsional') ...... . 35

O. S. Issers (Omsk)

DAJ BOG NE POSLEDNIJ! (Viral Euphemization in Mass Speech Culture) . . . . . . . . . 43

E. M. Lazutkina (Moscow)

The Destruction of National Languages in the Era of Globalization . . . . . . . . . . . 53

M. V. Lyapon (Moscow)

Game Rhetoric: a Guide to Speech Culture . . . . . . . . . . . . . . . . . . . . . 59

N.B. Mechkovskaya (Minsk)

Language Democratization, Liberalization and Counter Processes: Spontaneous Tendencies

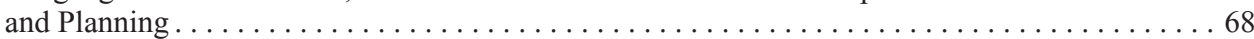

O. V. Myaksheva, O. B. Sirotinina (Saratov)

Russian as State (Literary) Language: Mandatory and Possible Spheres of Application, Norms and Real Usage . . . . . . . . . . . . . . . . . . . . . . . . . . . . 82

E. A. Nikishina (Moscow)

Bumper Stickers as a Small Genre in The System of Speech Interaction on the Road . . . . . . . 89

E. Yu. Protasova (Helsinki)

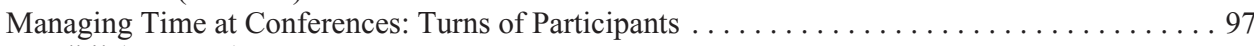

T. B. Radbil (Moscow)

Cultural Appropriation of Borrowed Words in the Light of the Theory of Language

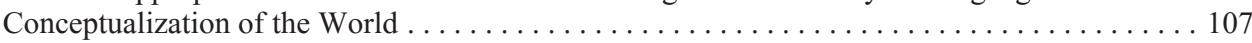

R. Rathmayr (Vienna)

Speech Culture in Codes of Ethics and Real Business Communication Using the Example

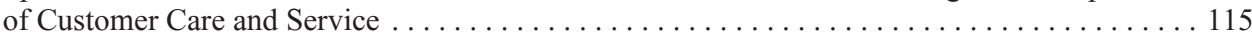

N. N. Rozanova (Moscow)

Colloquial Vocabulary in the Context of Typical Everyday Urban Situations

and Its Lexicographic Description in "Explanatory Dictionary of Russian Everyday Speech". . 126

S. O. Savchuk (Moscow)

Oral Scientific Speech in the Light of Corpus Data ....................... 136

O. I. Severskaya (Moscow)

«Through Time, through Distance»: Stylistic Error, Ellipse or Recursive Norm?

G. N. Sklyarevskaya (Saint Petersburg)

"This is not the way to say it" or One More Time About the System, Norms and Usage

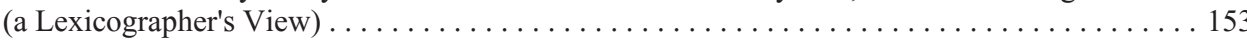

A.E. Tsumarev, L. L. Shestakova (Moscow)

Language Norms in the "Academic Explanatory Dictionary of the Russian Language". . . . . . . 160 
V.D. Chernyak (Saint Petersburg)

The Eternal Questions of Speech Standards in Lexicographic Tradition and Contemporary

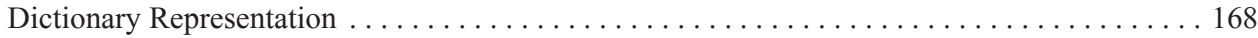

S.D. Shelov (Moscow)

Vivid Problems of Terninology Science: Some Results $\ldots \ldots \ldots \ldots \ldots \ldots \ldots \ldots \ldots$

A. D. Shmelev (Moscow)

Codification of Linguistic Standards in the Context of Social and Cultural Changes . . . . . . . 184

E. Ya. Shmeleva (Moscow)

Language of Effective Managers: Common Jargon or Russian of the XXI Century . . . . . . . 192

T.V. Shmeleva (Veliky Novgorod)

Grammar of the Novgorodians: a Regional Norm? . . . . . . . . . . . . . . . . . . . . . . . 199

T.E. Yanko (Moscow)

Intonational Variation in Russian.

\section{Lexicon and Grammar: Language Usage and Norm}

E. G. Borisova (Moscow)

Non-Obligatory Components of Utterances (New Approach to "Empty Words") . . . . . . . . 215

I. T. Vepreva, N. A. Kupina (Ekaterinburg)

Notes on Usual Shifts in Lexical Semantics.

M. Ya. Dymarskij (Saint Petersburg)

Topic Elimination and the Postulate of Basic Word Order in Russian

S. M. Evgrafova (Moscow)

Grammar of Comprehension and Grammar of Text Generation in the Context

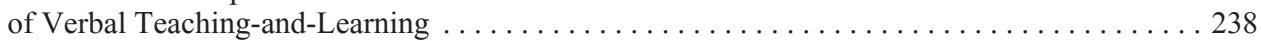

O.P. Ermakova (Kaluga)

Possibilities of Word Formation in the Sphere of Expression of Logical Categories . . . . . . . 247

G. I. Kustova (Moscow)

Adverbial Free Relative KAK POLOZHENO: Semantics and the Types of Use . . .

A. B. Letuchiy (Moscow)

Syntactic Asymmetry of the Russian Pronouns CHTO 'what' vs. KTO 'who'

and Morphological Animacy . . . . . . . . . . . . . . . . . . . . . . . . 265

I.A. Magerramov (Moscow)

Concerning Standard Violations of Syntax in Modern Media Texts . . . . . . . . . . 282

E. V. Marinova (Nizhny Novgorod)

Value-based Epithets in the Ethnical System of Modern Internet users . . . . . . . . . . 275

N. A. Nikolina (Moscow)

Types and Functions of Contaminated Constructions in Modern Russian Speech . . . . . . . . 288

M. V. Trubitsina (Moscow)

Agreement in Constructions with Names in Russian . . . . . . . . . . . . . . . . . . . 295

E. V. Uryson (Moscow)

Semantics and Syntax of the Russian Adverb SRAZU 'immediately' . . . . . . . . . . . . . . 304

M. Yu. Fedosyuk (Moscow)

A Sentence as a Text: the Aspects of Stylistics and Speech Culture . . . . . . . . . . . . 314

O. E. Frolova (Moscow)

Social Stratification: from Metaphor to Derivation

V.N. Shaposhnikov (Moscow)

Semantic Potential of Particles and the Development of Lexical and Grammatical Options:

the Word and Norm Borders . . . . . . . . . . . . . . . . . . . . . . . . . . 332

I.A. Sharonov (Moscow)

About the Tendency not to Decline Borrowed Nouns in the Historical and Contemporary

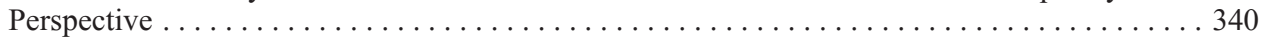

M. V. Shulga (Moscow)

On the Development of Synthetic Means in the Dynamics of Russian Language. 
Sz. Janurik (Budapest)

English Loanwords Words Ending in $-s h(e) n$ and $-z h(e) n$ in Present-Day Russian

(on the Basis of Lexicographic and Corpus Data) .

\section{Orthography and Orthoepy}

E. V. Beshenkova (Moscow)

Retrospection as a Factor in the Orthologic Policy of Spelling. Part $1 \ldots \ldots \ldots \ldots \ldots \ldots \ldots 7$

L. A. Verbitskaya (Moscow)

Present-day Documentation of the Orthoepic Norm

S. V. Drugoveyko-Dolzhanskaya (Saint Petersburg)

What Does the Word (SITZ) PREDSEDATEL' Have a Hyphen for, or Graphisation

as a Symptom . . . . . . . . . . . . . . . . . . . . . . . . . . . . . . . . . . 395

L. V. Zubova (Saint Petersburg)

Orthographic Style . . . . . . . . . . . . . . . . . . . . . . . . . . . . . . . . . 407

O.E. Ivanova (Moscow)

Orthographic Codification and Social Dynamics........................... 417

I. B. Itkin, V.D. Pekarskaya (Moscow)

An International Scandal (Compound Words with the First Component

MEZH- $\sim$ MEZHDU- in the History of Russian Literary Language) $\ldots \ldots \ldots \ldots \ldots \ldots \ldots .426$

V.V. Kaverina (Moscow)

Main Trends in Russian Consonant Doubling in Loan Words. . . . . . . . . . . . . . 435

M. S. Kartysheva (Moscow)

Modern Usage and Historical Dynamic of Distribution of the First Components

DVU-/DVUKH- in Compound Words. . . . . . . . . . . . . . . . . . . . . . . . . . . . 443

I. V. Nechaeva (Moscow)

The Use of Capital Grapheme: Arguments and Factors. . . . . . . . . . . . . . . . . . . . . . . . . 449

N. V. Nikolenkova (Moscow)

Usage of Capital Letters: History and Modern Codification . . . . . . . . . . . . . . . . . . 459

A. A. Pletneva (Moscow)

Popular Spelling and the Orthography Reform $1917-1918 \ldots \ldots \ldots \ldots \ldots \ldots \ldots \ldots \ldots$

S. K. Pozharitskaja (Moscow)

Orthoepy under the Scrutiny of Corpus Linguistics: Dynamics of Variation

and Dynamics of Attitudes . . . . . . . . . . . . . . . . . . . . . . . . . 474

S. V. Feliksov (Moscow)

Types of Alternative Writing of Religious Lexicon in Lexicographic Works

of the Civil Press of the Second Half of the $18^{\text {th }}$ Century. 


\title{
НОВЫЕ ЯВЛЕНИЯ В РУССКОМ ЯЗЫКЕ ХХІ ВЕКА: ПРОБЛЕМЫ КОДИФИКАЦИИ НОРМЫ
}

\author{
Н. Ю. Авина \\ Литовский эдукологический университет \\ (Литва, Вильнюс) \\ natalja.avina@leu.lt
}

\section{«В КАКУЮ СТОРОНУ ДУМАТЬ?»: О КУЛЬТУРЕ РУССКОЙ РЕЧИ СТУДЕНТОВ-БИЛИНГВОВ В СИТУАЦИИ ЯЗЫКОВОГО КОНТАКТИРОВАНИЯ}

В данной статье рассматриваются проблемы культуры русской речи билингвов, касающиеся несоблюдения норм современного русского литературного языка, в ситуации языкового контактирования. Исследуемые билингвы - студенты вузов г. Вильнюса, изучающие русский язык как неродной.

В речи билингвов выделяются следующие типичные отступления от литературной нормы: нарушение правильности словоупотребления - смешение паронимов, синонимов или близких по значению слов, разрушение фразеологизмов и устойчивых сочетаний, активизация стилистически сниженной лексики; нарушение грамматической правильности - отклонения от синтаксической нормы, связанные с построением словосочетания; активизация разговорно-просторечных грамматических форм. Это приводит к трансформации лексической и грамматической сочетаемости, коллоквиализации языка, расшатыванию литературной нормы, нарушению коммуникативных качеств речи.

С одной стороны, подобные явления в речи билингвов, характерные также и для русскоязычных монолингвов, - отражение типичных особенностей культуры речи, обусловленных активными процессами в русском языке новейшего периода. С другой стороны, проблемы культуры речи, связанные с правильностью речи, в ситуации языкового контактирования проявляются наиболее ярко и имеют свои особенности: отступления от литературной нормы в речи студентов-билингвов можно рассматривать как определенное упрощение языковой системы.

Проблемы культуры речи билингвов требуют специфического подхода к преподаванию русского языка в конкретной ситуации языкового контактирования.

Ключевые слова: культура речи, отступления от литературной нормы, билингв, ситуация языкового контактирования. 


\section{1. Вводные замечания}

Культура русской речи в России и за ее пределами характеризуется своими особенностями: «...русская речевая культура имеет как внутриэтнические, так и межэтнические измерения, тем самым проявляясь в качестве трансэтнического феномена, и должна квалифицироваться с учетом всех этих измерений» [Тарланов 2011: 59-60].

В связи с этим интерес представляют работы, посвященные культуре русской речи в различных ситуациях иноязычного окружения. Е. А. Земская, рассматривая речь русских эмигрантов, отмечает своеобразие их речевых установок и речевого поведения, ортологические особенности, а также отношение к языковой норме в среде русской эмиграции первой волны: «Норма консервативна, ей чужд динамизм. Норма не всеобща. Норму диктует не общество, не социум, а семья или круг социально и духовно близких людей» [Земская 2000: 59]. В другой же, иноэтнической, среде проблемы освоения русского языка и проблемы русской речевой культуры тесно связаны, поскольку «...и те и другие возникают, как правило, в тождественной среде функционирования - в школьно-образовательной, научной, культурной сферах, которые обслуживаются литературным языком» [Тарланов 2011: 62].

В данной статье в ортологическом аспекте рассматриваются некоторые проблемы культуры русской речи билингвов в ситуации языкового контактирования. Исследуемые билингвы - студенты вузов г. Вильнюса, филологи, изучающие русский язык как неродной. Обычно это билингвы из смешанных литовско-русских семей. Для исследуемых респондентов типично стихийно усвоенное двуязычие, возникающее в данном языковом окружении в результате широкой речевой практики. Это продуктивное двуязычие, которое позволяет билингвам не только понимать и воспроизводить иноязычные тексты, но и создавать их; билингвы могут достаточно свободно говорить, а также писать на русском языке. Хотя уровень владения русским литературным языком у разных билингвов неодинаков, в целом для них характерна естественность и натуральность общения, а способность к быстрому переключению в речевой коммуникации с одного языка на другой создает иллюзию высокого уровня владения русским языком. В связи с этим можно рассматривать вопрос о культуре речи исследуемых билингвов, отличающейся, к сожалению, многочисленными и разнообразными отступлениями от литературной нормы, которые могут приводить к коммуникативным неудачам и курьезам в речевом общении, например: Не уверена в ответе на третий вопрос - подскажите направление, в какую сторону думать (ср.: в каком направлении думать); Этот дом, по нашим сегодняшним глазам, странный (с современной точки зрения); Попытались посадить чайные кусты, и это обвенчалось успехом (увенчалось).

Многие исследователи рассматривают речь таких билингвов как своеобразную систему, имеющую и новые качества, появляющиеся в иноязычном окружении, и черты исконного русского языка [Позднякова 2012; Ненонен 2014 и др.]. Соответственно, основные проблемы русской речи билингвов связаны прежде всего: a) с языковым взаимодействием и интерференцией, в результате которой появляются ошибки, специфические для билингвов определенной языковой группы и не 
характерные для речи монолингвов (при этом заметим, что обычно именно интерферентные ошибки становятся предметом исследования речи билингвов); б) с проблемами культуры речи, касающимися несоблюдения норм современного русского языка; в результате появляются ошибки, которые могут быть общими как для билингвов разных языковых групп, так и для русскоговорящих монолингвов; и именно эти культурно-речевые особенности студентов-билингвов, связанные с отступлениями от литературной нормы современного русского языка и нарушениями правильности речи, рассматриваются в данной статье. Материалом исследования является как письменная, так и устная монологическая и диалогическая речь студентов в различных ситуациях общения.

\section{2. Нарушение правильности речи}

Под правильностью речи понимается следование нормам современного литературного языка в процессе речевой коммуникации. Поскольку норма соотнесена с языком как системой, соответственно, принято выделять орфоэпию, грамматическую правильность, правильность словоупотребления, а также стилистическую правильность (например, [Виноградов 2003]). В русской речи исследуемых билингвов в ряду отступлений от литературной нормы, которые отмечаются на всех уровнях языковой системы, наиболее ярко проявляются нарушения правильности словоупотребления и грамматической правильности. Важно отметить, что активизацию подобных отклонений - например, смешение паронимов и близких по значению слов, нарушение синтаксической связи управления, высокую степень неустойчивости предлогов — отмечают многие исследователи русского языка в иноязычном окружении [Гловинская 2001 и др.].

\section{А. Нарущение правильности словоупотребления}

К подобным нарушениям относят обычно неточности лексического словоупотребления, смешение значений, разрушение фразеологизмов. Выделим наиболее распространенные нарушения правильности словоупотребления в исследуемой речи студентов-билингвов, обусловленные недостаточным владением русской лексикой и фразеологией и приводящие к трансформации сочетаемости в нормативно-стилистическом аспекте.

Смешение паронимов:

преимущественно это глагольные паронимы, связанные с заменой префикса: Я что-то попутала (перепутала); Шлю введение, что-то определенное уже рисуется (вырисовывается); Стараюсь понять систему всей работы, поэтому так медленно все передвигается (продвигается); Спасибо вам за терпение и помощь и еще раз извините за предоставленные неудобства (доставленные);

паронимы именных частей речи - существительных (часто с абстрактным значением) и прилагательных - обычно суффиксальные: Показать красоту и иирину природы (широту); Вы можете отправить мне задачи по морфологии? 
(задания); Я кое-что исправила и составила соответственный список литератуpbl (соответствующий); Там был песочный пляж (песчаный);

реже встречаются паронимы наречий: $M b$ трудно обходимся без телевизора (с трудом).

Смешение синонимов или близких по значению слов:

Пришлите, пожалуйста, заключительные оченки первого курса русской филологии (итоговые); Вас тревожит с заочной группь 2-го курса студентка (беспокоит); Извините, но хочу поправить время, завтра буду в 11.45 (уточнить); Солнце будет изготавливать электроэнергию, регулировать температуру в доме (давать); Я не отбрасываю возможности поступать в магистратуру в наш университет (не исключаю).

Разрушение фразеологизмов и устойчивых сочетаний:

замена близких по значению компонентов — Голова идет колесом (идет кругом); Важно получить информацию из первых рук (из первых уст); Мама пошла по следам бабушки и работает там же (пойти по стопам);

замена грамматических форм - Человек первыл делом будет выбирать брак с любовью (брак по любви); Наши соседи сделали это с доброй волей (по доброй воле);

смешение компонентов разных сочетаний (контаминация) - Чтобы это получить, нужно вложить немало желаний и усилий (ср.: иметь желание, приложить немало усилий).

Активизация стилистически сниженной лексики:

разговорно-просторечные слова и устойчивые выражения - Когда сделала суn, все девки ржали; Тогда уже по-любому усльишишь;

жаргонизмы, относящиеся как к студенческому сленгу - Была в универе, странный препод: уже лето, надо отдыхать, а не эгзы сдавать; так и к общему жаргону - Думала, как подарок этот шарфик прокатит; Очень хотелось потусить с подругами; Так все лево!

\section{Б. Нарушение грамматической правильности}

Грамматическая правильность связана с правильностью образования слов и их форм, которые представляют определенную трудность, а также с построением синтаксических конструкций. Отметим типичные нарушения грамматической правильности в исследуемой речи студентов-билингвов.

Отклонения от синтаксической нормы, связанные с построением словосочетания:

смешение предлогов в предложных сочетаниях - $\boldsymbol{K}$ этой группе войдут ещё несколько суффиксов (в эту группу); Люди на характер могут быть разныли (по характеру); Кошка кусается не из-зо зла (со зла); часто смешиваются предлоги

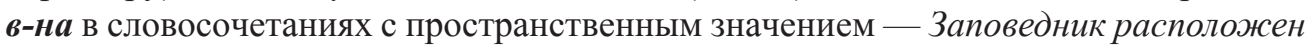
в юге от изентра города; Небольшой домик, который находится на деревне; реже отмечается употребление беспредложных конструкций вместо предложных Знаю, что будет задание выразительного чтения (по выразительному чтению); Жизнь людей отражается именами (в именах); 
нарушение синтаксической связи управления: Какое должно быть расстояние между строчек? (между строчками); Вполне возможно достичь семейную идиллию (семейной идиллии).

Активизация разговорно-просторечных грамматических форм:

глагола - Я плохо чувствовала и поэтому не поехала с друзьями (чувствовала себя); Не хотишь ехать с нами? (не хочешь); Завтра едь на рынок (поезжай);

различных именных частей речи, часто связанных с их склонением, употреблением — Ихние дела нас никогда не интересовали (их); Пожалуйста, скажите, до скольки времени вы завтра будете в университете? (до которого часа); Путевки стоили от шестиста литов (шестисот); Несколько метров от нас живут соседи (в нескольких метрах).

\section{В. Некоторые специфические черты ортологии}

Рассмотренные типичные отступления от литературной нормы как в устной, так и письменной речи студентов-билингвов в ситуации иноязычного окружения свидетельствуют об активизации ряда языковых явлений, в частности: трансформации лексической и грамматической сочетаемости, обусловленной смешением семантически близких слов, неточным выбором слова; коллоквиализации языка. Но аналогичные проблемы культуры речи исследователи отмечают также у российских студентов: активное употребление жаргона и просторечных форм - как в официальном, так и бытовом дискурсе; отклонения от нормы на письме и речевые сбои в письменном тексте, низкий уровень речевой культуры [Черняк 2011; Ахапкина 2014 и др.]. Как известно, подобные проблемы обусловлены активными процессами в русском языке новейшего периода: демократизацией языка, раскрепощением речевого поведения коммуникантов в различных жанрах публичного общения, стилистическим динамизмом, формированием общего сленга, изменением отношения к литературной норме, которая становится менее определенной и обязательной [Современный русский язык 2008]. Следовательно, нарушения правильности исследуемой речи студентов-билингвов можно рассматривать как отражение общих, типичных особенностей культуры русской речи в данный период.

Между тем проблемы культуры речи билингвов в ситуации языкового контактирования имеют свою специфику. Так, вряд ли характерны для русскоязычных монолингвов следующие употребления, отмеченные в письменной речи билингвов: В моем будущем доме был бы в гостинице большой телевизор (в гостиной); Нашей работой управляли преподаватели из университета (руководили); Сколько ей времени? (о возрасте кошки - ср.: сколько лет, месяцев); Я с счастьем прибегу на ваш девичник (с радостью); После много попыток он справится (многих); Храм был под угрозой снесения, но потом восстановлялся (восстанавливался); Все еще плохое самочувствие, могла с Вами встретиться в понедельник? (могла бы).

Такие употребления в речи билингвов можно рассматривать как определенное упрощение языковой системы. Это проявляется в создании неправильных языковых единиц посредством выбора моделей, типичных для русского языка, в частности: 
в выборе распространенных для данной части речи грамматических форм: Я очень еще извиняюсь, как называется книга А. Петровы? (ср. типичные формы на -bl имен существительных женского рода родительного падежа: сестры); Kaраоке петь будем, искай песню какую (ср. наиболее распространенные формы императива на -j от глаголов первого продуктивного класса: делай); Я читала, что не можно пить молоко котам, можно котятам (ср. типичное выражение отрицания сказуемого с помощью частицы не);

в выборе продуктивных деривационных моделей: Пить чай по-русскому (ср. типичные производные наречия на -ому: по-новому).

\section{3. Заключительные замечания}

Подобные распространенные отступления от ортологических норм свидетельствуют о том, что проблемы культуры речи билингвов, по сравнению с русскоязычными монолингвами, проявляются наиболее ярко: происходит расшатывание нормы русского литературного языка, нарушаются коммуникативные качества речи. Рассмотренные в статье примеры, касающиеся как устной, так и письменной речи, - это лишь «верхушка айсберга» многочисленных проблем, связанных с нормативностью речи студентов. В частности, важнейшей проблемой являются интерферентные ошибки, обусловленные языковым взаимодействием; отдельного исследования требует культура письменной речи, в которой могут быть нарушения одновременно нескольких норм - прежде всего орфографических, пунктуационных, графических, стилистических.

Проблемы культуры речи определяют специфику преподавания русского языка в конкретной межъязыковой ситуации и использование проблемно-ориентированного подхода в обучении с целью совершенствования культурно-языковой компетенции билингвов.

\section{Литература}

Ахапкина Я. Э. Речевые сбои в письменном тексте первокурсника // Труды Института русского языка им. В. В. Виноградова / отв. ред. А. Д. Шмелев. Вып. 2. М.: 2014. C. $154-168$.

Виноградов С.И. Правильность речи // Культура русской речи. Энциклопедический словарь-справочник / под ред. Л.Ю. Иванова, А.П. Сковородникова, Е. Н. Ширяева и др. М.: Флинта: Наука, 2003. С. 499-500.

Гловинская М.Я. Общие и специфические процессы в языке метрополии и эмиграции // Язык русского зарубежья / отв. ред. Е. А. Земская. М. - Вена: Языки славянской культуры, 2001. С. 341-492.

Земская Е.А. Язык русского зарубежья: проблемы нормы и речевого поведения // Культурно-речевая ситуация в современной России / под ред. Н. А. Купиной. Екатеринбург: Издательство Уральского университета, 2000. С. 57-73. 
Ненонен О. Ошибки в письменной речи у студентов-билингвов // Инструментарий русистики: ошибки и многоязычие. Slavica Helsingiensia 45 / ред. А. Никунласси, Е. Ю. Протасова. Helsinki: Helsingin yliopisto, 2014. С. 261-280 [Электронный pecypc]. URL: http://www.helsinki.fi/slavicahelsingiensia/preview/sh45/pdf/20-sh45.pdf

Позднякова А. А. Лингводидактические методы преодоления интерференции в речи студентов-билингвов // Преподаватель XXI век. 2012. №3. Ч. 1. С. 161-165 [Электронный ресурс]. URL: https://cyberleninka.ru/article/v/lingvodidakticheskiemetody-preodoleniya-interferentsii-v-rechi-studentov-bilingvov

Современный русский язык. Активные процессы на рубеже XX-XXI веков / отв. ред. Л.П. Крысин. М.: Языки славянских культур, 2008. 712 с.

Тарланов 3.К. Русская речевая культура как трансэтнический феномен // Вопросы культуры речи / отв. ред. А.Д. Шмелев. М.: АСТ-ПРЕСС КНИГА, 2011. C. 58-66.

Черняк В.Д. «Мы все учились понемногу...»: речевая культура и культурная грамотность // Вопросы культуры речи / отв. ред. А. Д. Шмелев. М.: АСТ-ПРЕСС КНИГА, 2011. С. 77-81.

\author{
Natalia Ju. Avina \\ Lithuanian University of Educational Sciences \\ (Lithuania, Vilnius) \\ natalja.avina@leu.lt
}

\title{
«V KAKUYU STORONU DUMAT'?»: THE RUSSIAN SPEECH CULTURE OF BILINGUAL STUDENTS IN THE SITUATION OF LANGUAGE CONTACTS
}

This article studies problems of the Russian speech culture of bilinguals related to non-observance of norms of the modern Russian literary language in the situation of lingual contacting. The studied bilinguals are higher school students from Vilnius who study the Russian language as a non-native language.

The speech of bilinguals distinguishes the following typical deviations from the literary norm: violation of the correctness of word usage - mixing of paronyms, synonyms or words having close meaning, destruction of phraseological units and stable combinations, activation of stylistically reduced vocabulary; violation of grammatical correctness - deviations from the syntactic norm associated with the construction of the word combination; activation of colloquial-speech grammatical forms. This leads to the transformation of lexical and grammatical compatibility, colloquialization of the language, loosening of the literary norm, and the defects of the communicative qualities of speech.

On the one hand, similar phenomena in the speech of bilinguals, which are also characteristic for Russian-speaking monolinguals, are the reflection of typical features of the speech culture, associated with active processes in the Russian language of the newest period. On the other hand, the problems of the speech culture associated with the correctness of speech in the situation of lingual contacting are most pronounced and have their 
own peculiarities: deviations from the literary norm in the speech of bilingual students can be considered as a certain simplification of their secondary linguistic system.

The problems of speech culture of bilinguals determine the specifics of teaching the Russian language in the specific situation of lingual contacting.

Key words: speech culture, deviations from the literary norm, bilingual, situation of lingual contacting.

\section{References}

Akhapkina Ya. E. [Speech Errors in Written Tests of the First Year Students]. Trudy Instituta russkogo yazyka im. V.V. Vinogradova [Proceedings of the V. V. Vinogradov Russian Language Institute]. 2014, no. 2, pp. 154-168. (In Russ.)

Chernyak V.D. [«My vse uchilis' ponemnogu...»: The Speech Culture and Cultural Literacy]. Voprosy kul'tury rechi [Questions of speech culture]. A.D. Shmelev (Ed.). Moscow: AST-PRESS KNIGA Publ., 2011, pp. 77-81. (In Russ.)

Glovinskaya M. Ya. [General and specific processes in the language of the mother country and emigration]. Yazyk russkogo zarubezh'ya [Language of the Russian Emigration]. E. A. Zemskaya (Ed.). Moscow — Vien: Yazyki slavyanskoi kul'tury Publ., 2001, pp. 341-492. (In Russ.)

Nenonen O. [Errors in the Written Language of Bilingual Students]. Instrumentarii rusistiki: oshibki i mnogoyazychie. Slavica Helsingiensia 45 [Russian Instrumentation: Errors and Multilingualism, Slavica Helsingiensia 45], Helsinki: Helsingin yliopisto, 2014, pp. 261-280. (In Russ.). Available at: http://www.helsinki.fi/slavicahelsingiensia/ preview/sh45/pdf/20-sh45.pdf (accessed 08.06.2017)

Pozdnyakova A. A. [The Linguodidactic Methods for Overcoming the Interference in the Speech of Bilingual Students]. Prepodavatel' XXI vek [Teacher of the 21 st Century], 2012, no. 3, part 1, pp. 161-165. (In Russ.). Available at: https://cyberleninka. $\mathrm{ru} /$ article/v/lingvodidakticheskie-metody-preodoleniya-interferentsii-v-rechi-studentovbilingvov (accessed 16.06.2017)

Sovremennyi russkii yazyk. Aktivnye protsessy na rubezhe XX-XXI vekov [The Modern Russian Language. Active Processes at the Turn of the 20th-21st cent.]. L. P. Krysin (Ed.). Moscow: Yazyki slavyanskikh kul'tur Publ., 2008. 712 p. (In Russ.)

Tarlanov Z.K. [The Russian Speech Culture as a Trans-Ethnic Phenomenon]. Voprosy kul'tury rechi [Questions of speech culture]. A. D. Shmelev (Ed.). Moscow: ASTPRESS KNIGA Publ., 2011, pp. 58-66. (In Russ.)

Vinogradov S.I. [The Correctness of Speech]. Kul'tura russkoi rechi. Entsiklopedicheskii slovar'-spravochnik [Culture of Russian speech: Encyclopedic Dictionary Directory]. L. Ju. Ivanov, A. P. Skovorodnikov, E. N. Shiriaev (Eds.). Moscow: Flinta: Nauka Publ., 2003, pp. 499-500. (In Russ.)

Zemskaya E. A. [The Russian Language Abroad: The Problems of Norm and Speech Behavior]. Kul'turno-rechevaya situatsiya v sovremennoi Rossii [Cultural-Speech Situation in the Modern Russia]. N. A. Kupina (Ed.). Ekaterinburg: Ural University Publ., 2000, pp. 57-73. (In Russ.) 


\author{
Н.В. Богданова-Бегларян \\ Санкт-Петербургский государственный университет \\ (Россия, Санкт-Петербург) \\ n.bogdanova@spbu.ru
}

\title{
АГРЕССИВНЫЙ УЗУС ИЛИ ЭВОЛЮЦИЯ ЯЗЫКОВОЙ НОРМЫ? (ПРИГЛАШЕНИЕ К ДИСКУССИИ)
}

В статье рассматривается одна чрезвычайно распространенная в устной речи грамматическая черта: замена союзной связи главного предложения с придаточным изъяснительным на местоименно-соотносительную (Я сказал то что он придёт вм. Я сказал что он придёт). Статья является своего рода приглашением к дискуссии, поскольку в литературе встретилось утверждение, что данная конструкция демонстрирует «рождение» в русском языке нового изъяснительного союза то что. В статье в критическом свете обсуждаются те аргументы, на которых базировалось такое утверждение: распространенность этого явления, слитное произнесение то и что, а также общий интонационный рисунок подобных высказываний. В противоположность утверждению о «новом» союзе, в статье отстаивается позиция, что это всего лишь нарушение синтаксической нормы, вызванное гиперкоррекцией говорящего. В заключение приводится целый ряд примеров действительного рождения в устной речи новых союзов, таких как не говоря о том что/чтобы, учитывая что, в том плане что, единственно что, типа того что, вроде того что и некот. др. Все положения проиллюстрированы контекстами из двух корпусов русского языка: Национального (НКРЯ) и Звукового (ЗКРЯ), включающего два разных модуля: корпус повседневной спонтанной речи (по преимуществу диалоги и полилоги) «Один речевой день» (ОРД) и Сбалансированная аннотированная текстотека (САТ) - собрание монологических текстов разного типа. Активность процесса конъюнкиионализации в повседневной разговорной речи оставляет, как представляется, возможность включиться в него и для единицы то что, но на сегодняшний момент говорить об этом все же несколько преждевременно.

Ключевые слова: языковая норма, узус, разговорная речь, языковая эволюция, культура речи, языковой корпус, речевой корпус.

На конференции «Культура русской речи», которая состоялась в ноябре 2014 г., я представляла доклад почти с таким же названием: «Агрессивный узус - или 
эволюция языковой нормы?» [Богданова-Бегларян 2015]. При всей полемичности заголовка никакой дискуссии тогда вовсе не предполагалось. В докладе рассматривалось, в частности, такое навязчивое узуальное явление современной русской речи, как замена связи изъяснительного придаточного с главным предложением с помощью союза что (я сказал, ЧТО он придет) на местоименно-соотносительную (я сказал ТО, ЧТО он придет):

- нету их // вот мне Женя даёт записочку / то что нету ничего (ОРД; И92, муж., 46 лет, предприниматель) $)^{1}$;

- (э-э) мыл (э-э) договаривались то что в пятницу (:) с мамой придём ... (ОРД; И7, муж., 45 лет, военный).

В докладе ставился «вопрос о статусе этих узуальных явлений, которые, что называется, режут слух грамотного человека и вызывают желание как-то сопротивляться этой очевидной речевой агрессии» [Богданова-Бегларян 2015: 26]. На примерах из двух корпусов было показано, что это явление однозначно ненормативно и его экспансии надо сопротивляться.

Однако вскоре обнаружилось и другое мнение - в статье Н.А. Коротаева «Союз то что в устной речи» (Учебно-научный центр лингвистической типологии Института лингвистики РГГУ) [Коротаев 2012]. Автор не видит в этой конструкции (Я сказал то что он придет) ничего агрессивного и утверждает, что «в современной русской устной речи “права гражданства” приобретает еще одна языковая единица, не зафиксированная в кодифицированной норме, а именно изъяснительный союз то что» [Там же: 91]. Такая позиция вынудила меня вернуться к данному явлению и все же, хоть и несколько запоздало, вступить в дискуссию с уважаемым автором статьи.

Хочется настоять на том мнении, которое было высказано три года назад: перед нами никакой не новый союз, а обычная гиперкоррекция: человек хочет говорить лучше, но, не владея языком в достаточной мере, «перегибает палку» и совершает «ошибку от усердия». Примеров такого типа множество, ср.:

- нуя и говорю / то что (...) пе... первый факультет они не подводники (ОРД; И7, муж., 45 лет, мичман);

- [№ 10, жен, 55] Я считаю то / что контроль / осуществляется контроль [Беседа с социологом на общественно-политические темы (Москва) // Фонд «Общественное мнение», 2003];

${ }^{1}$ Все примеры в статье - из двух корпусов русского языка: Национального (НКРЯ) и Звукового (ЗКРЯ), включающего два модуля: корпус повседневной спонтанной речи (по преимуществу диалоги и полилоги) «Один речевой день» (ОРД) [Русский язык... 2016; Богданова-Бегларян и др. 2017а] и Сбалансированная аннотированная текстотека (САТ) - собрание монологических текстов разного типа [Богданова-Бегларян и др. 2017б]. Примеры из ОРД определенным образом атрибутированы: в скобках указан номер информанта (И) или его коммуникантов (М/Ж - мужчина/женщина), а также пол, возраст и профессия говорящего. Об особенностях орфографического представления материалов ОРД см.: [Русский язык... 2016: 242-243]. 
- Я знал, что есть команда СПбГУ // м-м н-ну вот и-и я думал то что // надо бы мне // поиграть за эту команду потренироваться (САТ; И4, студент-филолог, 20 лет; рассказ $)^{2}$;

В статье Н.А. Коротаева приводятся и аргументы в пользу «нового» союза, на которых целесообразно остановиться подробнее.

Первый из них: конструкции такого типа «становятся все более распространенными» [Коротаев 2012: 93]. Спорить с этим, конечно, невозможно, но вряд ли это весомый аргумент. Узуальные явления как раз и отличаются тем, что они чрезвычайно распространены, но при этом далеко не всегда нормативны (см., например: [Ожегов 1955: 14; Крысин 2017]).

В качестве еще двух аргументов автор отмечает, что то и что произносится слитно, а то лишено фразового ударения и интонационно оторвано от вершинной предикации [Коротаев 2012: 92-93]. Думается, что и это недостаточно веские аргументы. О сложной связи интонации и синтаксиса писал еще А. М. Пешковский, сформулировавший так называемый «принцип замены» (здесь и далее в цитатах разрядка автора. - Н. Б.-Б.): «Чем яснее выражено какое-либо синтаксическое значение чисто грамматическими средствами, тем слабее может быть его интонационное выражение (вплоть до полного исчезновения), и, наоборот, чем сильнее интонационное выражение, тем слабее может быть грамматическое (тоже до полного исчезновения)» [Пешковский 1959: 181]; «В огромном < ..> большинстве случаев интонационные средства отличаются подвижным, свободным характером. Они наслаиваются сложными прихотливыми узорами на звуковые средства, не срастаясь с ними в определенные типы связи, а, напротив, расходясь с ними на каждом шагу, они, так сказать, блуждают по грамматической поверхности языка» [Там же: 191]. Такую же мысль находим и в работе Т.М. Николаевой: «в интонационной сфере есть свои типы и формы отношений между элементами речи, и они не соотносятся, во всяком случае единообразно, с традиционными единицами синтаксиса» [Николаева 1969: 5]. В устной речи, таким образом, отличающейся, как известно, весьма слабо выраженной грамматической (синтаксической) структурой, можно ожидать, во-первых, большого разнообразия интонационных средств выражения, которые, во-вторых, очень мало связаны с этой синтаксической структурой. Еще более, по-видимому, эти особенности проявляются в спонтанной - неподготовленной, непринужденной и неофициальной - речи. Даже появление обычной паузы в спонтанной речи (СР) практически не зависит от грамматической структуры текста и диктуется совсем иными - не фонетическими и не грамматическими, а, скорее, социо- и/или психолингвистическими - причинами. Так и в рассматриваемой ситуации мы имеем дело с устной речью, интонационное оформление которой очень слабо коррелирует с синтаксическим строением. Невозможно описывать специфику СР, опираясь на закономерности интонационного оформления кодифицированного языка.

2 Примеры из САТ атрибутируются с указанием номера информанта, его возраста и профессии, а также типа монолога (пересказ сюжетного или несюжетного текста, описание сюжетного или несюжетного изображения, рассказ на заданную тему). 
Не случайно это явление пока еще слабо зафиксировано в письменной речи, которую человек продумывает и выверяет, в отличие от спонтанной устной, ср. немногие примеры, обнаруженные в основном подкорпусе НКРЯ:

- Кроме того, даже если у снайпера есть все иансы нейтрализовать террориста без риска для заложника, это ещзе не всегда значит то, что руководством будет отдана команда на применение оружия (подобная ситуация была описана в нашем журнале) [Выстрел на поражение (2004) // «Солдат удачи», 2004.05.05];

- Я думаю то, что мама увидела мою расческу - я теряла волосы клочьями [Маша Трауб. Плохая мать (2010)].

В письменной речи, как видно из приведенных примеров, даже еще ставят запятую перед что, усиливая тем самым независимость компонентов «нового» союза.

Думаю, таким образом, что пока еще рано говорить о новом союзе. Разве что о некоторой общей тенденции к конъюнкционализации, когда разные части речи в устном дискурсе образуют действительно то, что можно назвать новыми союзами. Такая тенденция, вне всякого сомнения, наблюдается в современной устной речи. Приведем несколько примеров (уже без атрибуции) такого рода:

- (по идее, вроде, якобы, кажется еtс.) X, sed Y (частица / вводное слово $\rightarrow$ союз):

- что-то голова так грязниться стала // знаешь / вроде в шапке ходишь // *Па все равно;

- Эта общественная организация / по идее / есть в каждом районе / Управе / везде. Но звонка оттуда не дождешься.

- говоря $\rightarrow$ не говоря о $\rightarrow$ не говоря о том что/чтобы (деепричастие $\rightarrow$ предлог $\rightarrow$ союз):

- по общим критериям / не говоря о конкретных стандартах;

- ни одну группу ни в одном сезоне / кроме двух групп декабря мы не можем продать по 530 евро / уж не говоря о том чтобы продать по 510;

- учитывая $\rightarrow$ учитывая что (деепричастие $\rightarrow$ союз):

- муда ты идёшь спокойно ешё / вроде не замечая дороги / но назад // это ужасно // учитывая что приходится обычно тащить мне две корзины / так как муж тяжести носить не может после операциин;

-

- то есть я не была занята ни кастрюлями ни магазинами это единственно что южный рынок покупала для души себе что хотела;

- $\quad$ план $\rightarrow$ в том плане что (существительное $\rightarrow$ союз):

- день как назло не удался / в том плане что был дождь / моросил;

- $\boldsymbol{m u n} \rightarrow$ muna $\rightarrow$ muna mozо чmo (существительное $\rightarrow$ частица $\rightarrow$ союз) $)^{3}$ :

3 Последние две ситуации интересны еще и тем, что новые союзы типа того что и вроде того что, оставаясь внешне подчинительными, содержательно уже, скорее, сочинительные, что подтверждается возможностью замены их (в рамках этих контекстов) на пояснительный союз то есть. Возможна, впрочем, и другая интерпретация этих новых единиц: контексты вполне допускают их трактовку как маркеров-ксенопоказателей, вводящих в повествование чужую речь (в данном 
- он такой / я же сказал / надо () головой во все стороны крутить / чтобы шея / что / *B ну что / чтобы шея сломалась / типа того что не надо бояться;

- вроде $\rightarrow$ вроде того что (частица $\rightarrow$ союз):

- вот один из них спросил таким / *K *П так / это просто со странным немножко (...) отночением и взглядом / *П а зачем ? *П ну вроде того что их интересует только живая / (...) музыка // живой фольклор.

Видно, что процесс конъюнкционализации в устной речи захватывает довольно большой круг единиц, как других служебных, так и знаменательных. Может быть, в этот процесс со временем «втянется» и рассматриваемая конструкция то что. Впрочем, я готова выслушать и другие резоны. В споре, как известно, рождается истина. А наблюдать и анализировать факты устной речи всегда полезно и крайне интересно.

\section{Литература}

Богданова-Бегларян Н.В. Агрессивный узус - или эволюция языковой нормы? // Верхневолжский филологический вестник, № 1, 2015. С. 25-31.

Богданова-Бегларян Н.В., Шерстинова Т. Ю., Блинова О.В., Мартылненко Г.Я. Корпус «Один речевой день» в исследованиях социолингвистической вариативности русской разговорной речи // Анализ разговорной русской речи (AP3-2017): Труды седьмого междисциплинарного семинара / Ред. Д. А. Кочаров, П.А. Скрелин. СПб.: Политехника-принт, 2017а. С. 14-20.

Богданова-Бегларян Н.В., Шерстинова Т.Ю., Зайдес К.Д. Корпус «Сбалансированная Аннотированная Текстотека»: методика многоуровневого анализа русской монологической речи // Анализ разговорной русской речи (АР $\left.{ }^{3}-2017\right)$ : Труды седьмого междисциплинарного семинара / Ред. Д.А. Кочаров, П.А. Скрелин. СПб.: Политехника-принт, 2017б. С. 8-13.

Коротаев Н. А. Союз то что в устной речи // Девятая конференция по типологии и грамматике для молодых исследователей. Посвящается 80-летию В. С. Храковского. Материалы. СПб.: ИЛИ РАН, РГНФ, 2012. С. 91-95.

Крысин Л.П. К соотношению системы языка, его нормы и узуса // V международная конференция «Культура русской речи» (Гротовские чтения), 16-18 февраля 2017 г., Москва, ИРЯ им. В. В. Виноградова РАН. М., 2017 // https:// sites.google.com/site/grotconf/tezisy-2017.

Николаева T. М. Интонация сложного предложения в славянских языках: Опыт экспериментального исследования. М.: Наука, 1969. 286 с.

Ожегов С.И. Очередные вопросы культуры речи // Вопросы культуры речи. Вып. 1. М.: АН СССР, 1955. С. 5-33.

Пешковский A.M. Интонация и грамматика // А. М. Пешковский. Избранные труды. М.: Учпедгиз, 1959. С. 177-191.

случае возможна их замена на мол или дескать). Такая многозначность/полифункциональность многих частотных единиц устного дискурса является одной из его отличительных характеристик. 
Русский язык повседневного общения: особенности функционирования в разных социальных группах. Коллективная монография / Ред. Н. В. Богданова-Бегларян СПб.: ЛАЙКА, 2016. 244 с.

\author{
Natalia $V$. Bogdanova-Beglarian \\ Saint Petersburg State University \\ (Russia, Saint Petersburg) \\ n.bogdanova@spbu.ru
}

\title{
AGGRESSIVE COLLOQUIAL USAGE OR LANGUAGE NORM EVOLUTION? (INVITATION TO DISCUSSION)
}

The article is concerned with substitution of synthesis with pronominal correlation (Ja skazal to chto on prid'ot instead Ja skazal chto on prid'ot). The article is a bid for discussion evoked by our coming across a statement that this construction demonstrates "emerging" of a new subordinate conjunction to chto. The arguments supporting that, such as abundance and phonetic fusion of the word pair and the intonation contour of containing phrases are looked upon with a critical eye. In contrast to this "new conjunction" theory the author advocates that it's nothing but erratic syntax caused by speaker's hyper-correction. In conclusion a whole range of examples of new conjunctions that truly emerged in colloquial speech, such as ne govor'a o tom chto/chtoby, uchitavaja chto, $v$ tom plane chto, jedinstvenno chto, tipa togo chto, vrode togo chto, etc. is given. The propositions are supported by data from two corpora: The National Corpus of Russian Language (NCRL) and The Sound Corpus (SCRL), which contains two modules - everyday spontaneous speech corpus "One Speaker's Day" (primarily dialogues and polylogues) and the Balanced Annotated Text Collection (an archive of various monologues). Conjunctiolization in everyday speech appears to be a dynamic enough process to include to chto, but now it seems too early to speak about it.

Key words: language norm, usage, colloquial speech, language evolution, speech culture, language corpus, speech corpus.

\section{References}

Bogdanova-Beglarian, N. V. [Aggressive Colloquial Usage or Language Norm Evolution?]. Agressivnyj uzus - ili evol'ucia jazykovoj normy? [Verhnevolzhsky Philological Bulletin]. No. 1, 2015. Pp. 25-31. (In Russ.)

Bogdanova-Beglarian, N. V., Sherstinova, T. Ju., Blinova, O. V., Martynenko, G. Ja. [Corpus «One Speaker's Day» in Studies of Sociolinguistic Variability of Russian Colloquial Speech]. Korpus "Odin rechevoj den'» vissledovanijakh sociolingvisticheskoj variativnosti russkoj razgovornoj rechi. [Analysis of Spoken Russian Speech (AR $\left.{ }^{3}-2017\right)$ : 
Proceedings of the $7^{\text {th }}$ Interdisciplinary Seminar]. D. A. Kocharov, P. A. Skrelin (eds). St. Petersburg: Polytekhnica-print Publ., 2017a. Pp. 14-20. (In Russ.)

Bogdanova-Beglarian, N. V., Sherstinova, T. Ju., Zajdes K. D. [Corpus «Balanced Annotated Text Library»: Method of Multilevel Analysis of Russian Monological Speech]. Korpus «Sbalansirovannaja annotirovannaja tekstoteka»: metodika mnogourovnevogo analiza russkoj monologicheskoj rechi. [Analysis of Spoken Russian Speech (AR ${ }^{3}-$ 2017): Proceedings of the $7^{\text {th }}$ Interdisciplinary Seminar]. D. A. Kocharov, P.A. Skrelin (eds). St. Petersburg: Polytekhnica-print Publ., 2017b. Pp. 8-13. (In Russ.)

Korotaev, N.A. [Conjunction to chto in the Oral Speech]. Sojuz TO CHTO v ustnoj rechi. [The Ninth Conference on Typology and Grammar for Young Researchers. Dedicated to the 80th anniversary of V.S. Khrakovsky. Proceedings]. St. Petersburg, 2012. Pp. 91-95. (In Russ.)

Krysin, L.P. [To the Relation of the Language System, its Norm and Usage]. K sootnosheniju sistemy jazyka, ego normy i uzusa. [V International Conference «Culture of Russian Speech» (Grot's Readings)]. V mezhdunarodnaja konferensyja «Kul'tura russkoj rechi» (Grotovskie chtenia). February, 16-18, 2017, Moscow, Institute of Russian Language, Russian Academy of Science. https://sites.google.com/site/grotconf/tezisy-2017. (In Russ.)

Nikolaeva, T.M. [Intonation of a Complex Sentence in Slavic Languages: Experience of Experimental Research]. Intonacyja slozhnogo predlozhenia v slav'anskikh jazykakh: Opyt eksperimental'nogo issledovania. Moscow: Nauka Publ., 1969. 286 p. (In Russ.)

Ozhegov, S.I. [The Next Issues of the Culture of Speech]. Ocherednye voprosy kul'tury rechi. [Issues of Culture of Speech]. Voprosy kul'tury rechi. Iss. 1. Moscow, 1955. Pp. 5-33. (In Russ.)

Peshkovsky, A. M. [Intonation and Grammar]. Intonacyja i grammatika. [A. M. Peshkovsky. Selected Works]. A.M. Peshkovsky. Izbrannye Trudy. Moscow: Uchpedgiz Publ., 1959. Pp. 177-191. (In Russ.)

Bogdanova-Beglarian, N.V. (ed.). Russkij jazyk povsednevnogo obshchenia: osobennosti funkcionirovania $v$ raznykh social'nykh gruppakh. Kollektivnaja monografia [Everyday Russian Language in Different Social Groups. Collective Monograph]. St. Petersburg: LAIKA, 2016. 244 p. 
Л. Н.Дьякова, Н. А.Козельская, И. А.Стернин

Воронежский государственный университет

(Россия, Воронеж)

LaDya357@mail.ru,kozelskayan@mail.ru,sterninia@mail.ru

\section{ОПЫТ ОПИСАНИЯ \\ СФЕРЫ НЕЗНАНИЯ И ИНТЕРЕСА НОСИТЕЛЯ ЯЗЫКА (на материале языкового сознания воронежцев)}

В статье рассматривается «сфера незнания и интереса» в языке, выявленная с помощью анализа вопросов, заданных воронежцами лингвистам в 2011-2016 годах на различных общественных просветительских мероприятиях, в обращениях на радиопрограммы, службу русского языка. Характеризуются актуальные для массового носителя языка аспекты лингвистических знаний и побудительные мотивы запроса информации: 1) собственно незнание в области языковых норм (мотивированное и немотивированное); 2) интерес и любопытство, не связанные с проблемами нормативного употребления; 3) необходимость помочь детям в выполнении школьного задания; 4)потребность высказать личные (субъективные) представления о языке (гипотезы о значении и происхождении слов, тиражирование языковых мифов, комментирование языковой ситуации в городе и стране); 5) предложения по «совершенствованию» языка и речи, особенно в средствах массовой информации. Выявляются такие особенности обыденного языкового сознания носителей языка, как: отождествление слова и предмета; стремление найти мотивированность значений слов, объяснить происхождение слов на основе звукового сходства; неумение осмысливать образное употребление слов; подмена анализа языковых явлений анализом действительности; неприятие вариативности. По данным исследования устанавливается, что приоритеты жителей региона в области лингвистических знаний таковы: лексические нормы, грамматические нормы, сведения о собственных именах, орфографические нормы. Положительной тенденцией является постоянная требовательность воронежцев к правильности речи в средствах массовой информации.

Ключевые слова: культура речи, языковые нормы, языковое сознание, языковые мифы.

Важным аспектом языкового сознания носителя языка является сфера незнания, одним из способов изучения которой может быть анализ вопросов, задаваемых 
носителями языка на различных общественных просветительских мероприятиях, в обращениях на радиопрограммы, в газеты, службу русского языка.

В Воронеже с 2002 года действует просветительский проект «Территория слова», включающий еженедельную радиопрограмму «Территория слова» в прямом эфире, телефонную «Службу русского языка», ежегодный конкурс «Самый грамотный» и праздник «День родного языка», лекторий «Русский язык сегодня», лекции и беседы о языке в самых различных аудиториях, праздники русского языка в городе и районах области, школах и библиотеках. За 15 лет программа «Территория слова» и «Служба русского языка» ответили почти на 40 тысяч вопросов воронежцев. Регулярно проводимый нашим проектом мониторинг поступающих вопросов позволяет представить те сферы языка, которые более всего затрудняют воронежцев, а также вызывают у них повышенный интерес. Мы обозначаем эту сферу как «сферу незнания и интереса». За период 2011-2016 гг. эта сфера выглядит следующим образом.

Собственно незнание - воронежцы хотят знать, что значит то или иное слово, как правильно его употреблять, какая разница между теми или иными словами.

Можно выделить «немотивированное» незнание (отсутствие сведений об обязательной литературной норме, напр., в словах умЕриий, экспЕрm, ХвОя) и условно «мотивированное», вызванное имеющимися в языке дефектными парадигмами, несвободным употреблением (1-ого л. ед.ч. от гл. гудеть, лебезить, стонать, форсить; ср.степень от прилаг. жуткий и под.) или наличием равноправных вариантов (одноврЕмЕнно, $n E m л Я)$; конкурированием старшей и младшей норм (скучать по вас и по вам); стилистической/смысловой вариативностью (рюмка коньяка и коньяку; пропуска и пропуски; бобр (жив.) и бобер (мех)); влиянием профессиональных вариантов (осУжденный, возбУждено, квАртал) и другие.

У носителей языка, ориентирующихся на то, «как все говорят», ошибочное употребление поддерживается массовой языковой практикой, противоречащей норме (напр., обеспЕчение, свЁкла, щуавЕль, валовОй, мАстерски, предвосхИтить).

В целом вопросы о правильности - постановки ударения, образования формы, выбора падежа, написания слова - составляют $60 \%$ от общего корпуса вопросов горожан. По сравнению с предшествующим периодом (2005-2010 г.г.) стало меньше вопросов об ударении. Так, не отмечены как частотные вопросы об ударении в формах гл. звонить, сущ. договор; заметно меньше вопросов о постановке ударения в глаголах прошедшего времени ( прОдал - продАл, Отдал - от$\partial A л-O т \partial A л и)$, в формах кратких страдательных причастий прошедшего времени (проведён - провЕден). Вместе с тем по-прежнему актуальными остаются вопросы о постановке ударения в глаголах на -ить (типа «звонИть»): включить, облегчить, шевелиться; в словах обеспЕчение, упрОчение; в лексике, использующейся в профессиональных жаргонах: медицинском - opmonEдия и ортопедИя, бОлей и болЕй; в правоохранительном - возбужденО и возбУждено; осуждённый и осУжденный, медэкспЕрт и медЭксперт; экономическом - договОрный и договорнОй; квартАл и квАртал; техническом - кожУх или кОжух; в спорте и на транспорте - запаснОй и запАснылй; в религии - домовОй и домОвый (храм); 
акАфист и акафИст, блАга и благА, вероисповЕдание и вероисповедАние, просфо$p A$ и просфОра. (В приведенных примерах первые варианты являются нормативными).

В последние годы возросло количество вопросов об ударении в словах иноязычного происхождения: как старых заимствованиях (йогурт, пулОвер, $n$ Еня, унцุия), так и новых ( вариантные фейхОа и фейхоА, пиц̧церия и пицицерИя; грУмер, $n$ Инта). Интересным фактом является стремление говорящих выяснить нормативное ударение в разговорных, просторечных словах : нехай, внучОк (лит. внУчек), дешка, квашонка.

Произношение слов интересует воронежцев значительно меньше, чем ударение. В предшествующий период круг вопросов на эту тему был заметно разнообразнее: твердый /мягкий согласный перед гласным [э] в иноязычных словах: крем - [p'] или [p]; ошибочное смягчение/отвердение конечного согласного: наверx - [x] или [x']; четверг - [к] или [к']; качественные изменения согласного звука - позавчера — по[д]авчера или по[з]авчера; парикмахер - [км] или [хм]; петербургский[гc], [рс] или [жc]; ошибочная перемена согласных - [скур]пулёзнылй или [скру] пулёзный. Актуальными остались следующие аспекты: выпадение гласных и согласных звуков в разговорном языке при нормативном первом варианте: сколько [скол'ка] или [скока]; правила наименования букв русского алфавита - буква «ф»: [фэ] или [эф]. Единичными в рассматриваемый период были частотные прежде вопросы о произношении буквы «е», обозначающей в речи звук [о] или [э]: проведённыци, побелённыги; никто не обратил внимания на частотное ошибочное произношение слова иинель как [шынЭл’]).

Как и прежде, не были заданы вопросы о характерной для Воронежской области (как региона, относящегося к южнорусскому диалекту) особенности - произношении на месте взрывного [г] фрикативного [h]: [h]ород, за[h]aдка, о замене конечного согласного [к] согласным звуком [х]: сне [x], помо[x].

Значительное количество вопросов задается о грамматических нормах. Традиционно вызывающими трудности остаются следующие нормы: 1) окончания существительных в именительном и родительном падежах множественного числа (хотя и нет вопроса о формах договоры - договора) в словах: профессора, учителя, лагеря, прибыли, практики, подворья, работыл, экономики; татары, казаки; периь, окорочка, прожектора - прожекторы; другие падежные формы: вода из-под крана или из крана, в изеху или в изехе, по приезде или по приезду; 2) склонение фамилий (например, Юр, Черных, Головатыли) и топонимов: Иваново, Останкино, поселок «Первое Мая», село Хреновое; названий местных водоемов, рек: Битюг, Елань, Потудань, Эртиль, Льлк, Хава и др.; иноязычных названий магазинов:«Окей» и «Икеа»; 3) склонение числительных (особенно в форме род. пад.): не хватает 400 (четьлехста вместо четырехсот), в 2016 (в двухтысячношестнадиатом году вместо в две тысячи шестнадиатом); 4) употребление предлогов в и на: с Воронежа или из Воронежа, поехать на Украину или в Украину.

Много вопросов по-прежнему вызывает: 1) образование глагольных форм: 1-ого л. ед.ч. глаголов пылесосить, гудеть, клей-мить, лебезить, форсить, стонать, 
простудиться, лечь, постричь; 3-его л. ед.ч. гл. лезть, бороться, глаголать; несов. вид: начали сплачиваться - начали сплочаться, удостаиваться - удостоиваться, подсоливать - подсаливать, обезболивать - обезбаливать, оспаривать оспоривать ; повелит. накл. : не плачь - не плакай, не трогай - не трожь; 2) глагольное управление скучать по вам или по вас, представлять себя или представлять собой, оплатить (заплатить) газ или за газ, стреляют в нас или по нам, ехать на метро или в метро; адаптирована под условия или к условиям; выйти на памятнике Славы или у памятника Славы?

Неизменно внимание горожан к значению слов и фразеологизмов: выясняют различия синонимичных слов, паронимов, омонимов, однокоренных, жаргонных (профурсетка), диалектных (гльзнуть) и просторечных (заворошка) слов, историзмов (кольчуга, ушкульник) и др.. Среди тематических групп, интересующих людей, лидируют слова не из сферы экономики, как прежде, а политики, человеческих качеств, религии, причем запрашиваются как иноязычные слова, так и исконные или давние заимствования.

Живой интерес горожан вызывают нормы словоупотребления. Были заданы, например, следующие вопросы:

- Можно ли говорить "пройдите по стеночке"?, "тут" вместо "здесь"?, "порядка 30-40\%"?, "прочитать аудиокнигу"?, "вполне себе хороший"?

— Как правильно сказать "я прочитала книгу или прочла"? Бог в помощь или помочь? выписать или прописать лекарство? окончил или закончил институт? "сосульки " или "сосули"? сперва или сначала, глянь или посмотрим, перевертьвать или переворачивать? "я убираю в квартире" или "я убираюсь"? нет или нету? увидел или увидал, стал или встал в очередь?

- Как правильно употребить слово "продукт"? "Сперва" - это литературное слово? Норма или нет слово "покуда"? Правильно ли говорить "преступление против человечности"? Когда можно использовать глагол "кушать" и когда "есть"?

Вопросы о словоупотреблении часто свидетельствуют о том, что люди знают норму, но услышав речевые ошибки в СМИ, хотят убедиться в своих знаниях, напр.: можно ли употреблять выражение «две большие разницы»; можно ли говорить «передача будет в апреле месяцее»? и другие.

Заметно меньше по сравнению с предшествующим периодом стало вопросов о правописании, единичны вопросы о пунктуации.

Интерес и любопытство, не связанные с проблемами нормативного употребления: воронежцы хотят знать, когда и откуда пришло слово в язык (георгин, пельмени, фобия), происхождение и значение имен (Лука, Саломея, Дарья) и фамилий людей (Космодемьянская, Киркоров, Крамаров); местных топонимов (Синие Липяги, Айдарово, Эртиль, Рождественская Хава, Потудань). Больше стало вопросов о происхождении названий разных городских объектов (магазины "Касторама","Рубль-бум", корабль "Гото Предистинация", отель "Рамада-плаца", "Романовский").

Отмечается и небольшой процент общих «теоретических» вопросов о языке и культуре речи: Был ли один язык в Европе ? Существует ли книга, как образовьвались правила русского языка? В чем причина безграмотности людей? 


\section{Потребность помочь детям в выполнении домашних заданий}

Особенно частотны здесь вопросы о словообразовании (Какой суффикс в словах "привлекательный", "вмять"? Как разобрать по составу слово"привереда", "двое", "взросльии"? Какой корень у слов: наобум, опознали? Корень у слова "сорокалетие", "старинный"?); о частеречной принадлежности слов (Какая часть речи слово "русский" и почему? В словосочетании "актив обучаюшихся" какой частью речи является слово "обучающихся"?); об образовании грамматических форм (Как правильно образовать сравнительную степень от слова "жуткий"? Приведите примеры супплетивной формы).

\section{Актуализация субъективных (личных) представлений о языке}

Этот аспект интереса к языку имеет явную тенденцию к росту. Здесь можно выделить такие сферы:

- высказывание собственных гипотез о значении и происхождении слов и выражений, о правильности словоупотребления;

- комментирование языковой ситуации в стране, в городе: $B$ чем причина безграмотности людей? Сегодня у нас так много рабочей силы в лице таджиков и узбеков. Они несут такие слова в наш язык, что он постепенно разрушается. Зачем нам нужны иностранные названия кафе («Ереван», «Джамбул»)? Нужно быть патриотом! и под.;

- комментарии и тиражирование языковых мифов (якобы по Словарю Даля жлобы - жители Воронежской губернии; у русских раньше не было ругательств; все слова с приставкой «бес» связаны с бесом; изначально существовал один язык в Европе, русский язык самый древний в мире и др. ).

Предложения по «совершенствованию» русского языка устойчиво сохраняются:

— предложения по «исправлению» русского языка и языка СМИ (нельзя произносить «в прямом эфире», потому что эфира нет; нельзя говорить «будние дни»; нельзя говорить «в 7.00 ровно», «нельзя говорить по радио — «в следующем часЕ», недопустимы такие слоганы, как «Езжай, куда шёл», нужно вернуть точки над Ё и под.;

- субъективные претензии к русскому языку, языку СМИ (много иностранных слов; почему ведущие радиостанций все время смеются и под.);

- предложения по принятию запрещающих законов в области русского языка (запретить использование твёрдого знака в названиях магазинов (Наследникъ, Гастрономъ; наказать авторов рекламы «Бисплатно замена шин» и «Самые дешёвые цены»).

Обобщая вопросы воронежцев, можно сделать некоторые наблюдения над особенностями обыденного языкового сознания жителей региона. Отметим такие характерные черты:

- отождествление слова и предмета, о чем свидетельствуют вопросы такого типа: Откуда к нам пришли пельмени? Что такое "чай"? Какое качество жизни вложено в "прожиточный минимум"?;

- стремление найти мотивированность значений слов, объяснить происхождение слов на основе внешнего сходства, например: 
Одинаковые ли слова аксель и аксельбант? Есть ли связь у слов "олово" и Олька? Есть ли сходство в словах "суп" и "насупишься"? Есть ли что-то общее у слов "кошмар" и "кошмарить"? Есть ли связь между словами "ягода" и "ягодица"? В слове "гой" есть ли связь со словом "изгой"?;

- неприятие вариативности: Каким словарям верить? Все дают разные рекомендации. Почему на лентяя ещё говорят лоботряс? В рекламе "лекарство от сердияа, от желудка" правильно ли это? Почему у имени Анна есть столько народных вариантов?

- неумение осмысливать образное употребление слов:

Можно ли сказать "Россия сосредотачивается"?

"Давайте делать паузы в словах..." но ведь нельзя делать паузы в словах. Это неправильно.

Итак, анализ вопросов, поступивших на радиопередачу «Территория слова» и в «Службу русского языка» в 2011-2016 г.г., показывает, что для жителей региона наиболее актуальны знания в области лексических норм, на втором месте грамматические нормы, на третьем - сведения о собственных именах. Орфоэпические нормы на четвертом месте. Мало вопросов по орфографии и пунктуации. Таким образом, наиболее трудные нормы не вызывают активного интереса у носителей языка.

По сравнению с предшествующим периодом мониторинга (2005-2010.гг.) сошли на нет вопросы из сферы коммуникативных правил и речевого этикета (данное обстоятельство требует отдельного изучения: либо основные правила общения уже установились в сознании носителей языка, либо эти правила не рассматриваются носителями языка как важные, достойные освоения).

Положительной тенденцией является постоянная требовательность воронежцев к правильности речи в средствах массовой информации, а также рекламном дискурсе.

Трудно переоценить важность исследования сферы незнания и интереса носителей языка. Это необходимо как для проведения эффективной региональной языковой политики, так и для просветительской деятельности филологов в области русского языка в регионе.

\author{
Larisa N. Dyakova, Natalia A. Kozelskaya, Iosiph A. Sternin \\ Voronezh State University \\ (Russia, Voronezh) \\ LaDya357@mail.ru,kozelskayan@mail.ru,sterninia@mail.ru
}

\title{
ON THE DESCRIPTION OF THE SPHERE IGNORANCE AND INTEREST OF THE RUSSIAN LANGUAGE SPEAKER (IN LANGUAGE CONSCIOUSNESS OF THE VORONEZH REGION)
}

The article deals with the "sphere of ignorance and interest" in the language, revealed through the analysis of questions posed to Voronezh linguists in 2011-2016, at various 
public educational events, in applications for radio programs, and telephone service of the Russian language. The aspects of linguistic knowledge relevant to the average speacker of the language and the motives for requesting information are characterized: 1) the actual lack of knowledge in the field of language norms (motivated and unmotivated); 2) interest and curiosity, not related to problems of normative use; 3 ) the need to help children in their school assignments; 4) the need to express personal (subjective) ideas about language (hypotheses about the meaning and origin of words, replicating the language myths, commenting on the language situation in the city and country); 5) proposals for "improving" the language and speech, especially in media. Such features of the everyday language consciousness of native speakers are revealed as identification of words and objects; desire to find the motivation of the meanings of words, to explain the origin of words on the basis of sound similarity; Inability to comprehend figurative use of words; substitution of analysis of linguistic phenomena by analysis of reality; rejection of variability. According to the research, it is established that the priorities of the inhabitants of the region in the field of linguistic knowledge are: lexical norms, grammatical norms, information about one's own names, spelling norms. A positive trend is the constant demanding of the Voronezh people for the correctness of speech in the mass media.

Key words: culture of speech, language norms, linguistic consciousness, language myths. 


\author{
А.Г. Жукова \\ Государственный институт русского языка им. А. С. Пушкина \\ (Россия, Москва) \\ arinazhukova2013@gmail.com
}

\title{
НЕНОРМЫ В СОВРЕМЕННОЙ КОММУНИКАЦИИ (НА ПРИМЕРЕ ЛЕКСЕМЫ ФУНКЦИОНАЛ)
}

В статье рассматриваются вопросы типологизации явлений современной речи с точки зрения их нормативного статуса. В центре внимания находится разграничение нормы (ядерной части литературного языка), ненормы (в слитном написании, как термин) и антинормы (противостоящих норме явлений деструкции). Акцент делается на таксоне ненорм, представленном широким пластом явлений «промежуточного» характера, которые не являются нормой, но и не входят в «зону запрета», репрезентируя разные типы языковой избыточности. Особенности функционирования ненорм рассматриваются на примере существительного функиионал. До недавнего времени данная лексема фиксировалась только специальными словарями и энциклопедиями как термин высшей математики и программирования. Сегодня мы встречаем слово функционал в широком употреблении в других, нетерминологических значениях. Новые значения лексемы проявляют себя в устной и письменной коммуникации, в профессиональном, корпоративном употреблении и в публикациях СМИ, посвященных техническим новинкам, программным продуктам, управленческим и кадровым вопросам. В статье анализируется текстовый контент СМИ и интернет-ресурсов, телемагазинов. Привлекаются материалы «Справочной службы» портала Грамота.ру. Делается вывод о необходимости оценки нормативного потенциала подобных явлений, в том числе для принятия решений в отсутствие кодификации.

Ключевые слова: норма, ненорма, антинорма, нормативный потенциал лексических единиц, лексема функиионал.

Как известно, литературная норма, опираясь на языковую традицию (устоявшиеся реализации) и кодификацию (свод правил и список «санкционированных» единиц), противопоставлена, с одной стороны, языковой системе, с другой - peчевой практике. В последней «вполне обычны большие или меньшие отклонения» как от традиции, так и от кодификационных предписаний [Крысин 2006: 298]. 
Одна из сравнительно новых попыток типологизации подобных явлений предпринята В.Г. Костомаровым, который различает норму (ядро «образованного языка»), антинорму («зону запрета»), а также промежуточный, но самый обширный, неоднородный таксон - ненорму, объединяющий большое количество разнородных явлений, не относящихся к нормативному «ядру», но и не попадающих в «зону запрета» [Костомаров 2014: 112]. Ненормы, по В. Г. Костомарову, не равны некодифицированным (узуальным) нормам, поскольку включают окказионализмы, а также употребления, представляющие локальный (профессиональный, корпоративный) узус, и новые явления, чей нормативный статус не определён.

В современной языковой действительности, с ее высокими темпами языковых изменений и «презентационными возможностями» разнообразных дискурсивных практик, роль ненорм возрастает. Ненормы представляют собой «избыточность полезную, бесполезную и вредную» [Там же: 119].

Рассмотрим особенности бытования ненорм в современной коммуникации на примере лексемы функицонал. Материалом для нашей работы явился текстовый контент интернет-магазинов, сайтов и блогов бизнес-тематики, а также публикаций СМИ, связанных с новыми технически сложными товарами и программными продуктами, бизнес-решениями и кадровыми назначениями.

Существительное функционал отсутствует в толковых словарях, и это не случайно, поскольку речь идет о специальном математическом термине: «Функционал - математическое понятие, первоначально возникшее в вариационном исчислении и означающее там переменную величину, зависящую от функции (линии) или от нескольких функций. Примерами Ф. являются площадь, ограниченная замкнутой кривой заданной длины, работа силового поля вдоль того или иного пути и т.д. С развитием функционального анализа термин 'Ф.' стал пониматься в более широком смысле, а именно: как числовая функция, определённая на некотором линейном пространстве» [БСЭ]. Термин широко используется в компьютерном программировании, а также многих других технических областях (см., например, [Англо-русский толковый словарь]).

Однако в современной русской речи довольно широко используется лексема функционал, имеющая другие значения: 1) 'совокупность функций, функциональных возможностей чего-л., набор опций’ (связано преимущественно с техникой, оборудованием, программным обеспечением, ср.: функиионал сайта, смартфона, автомобиля, гаджета и т.д.)', 2) 'совокупность чьих-либо обязанностей, функций, полномочий’ (ср.: функционал офис-менеджера, кладовщуика, начальника отдела, комиссии, банка) и даже (значительно реже) 3) 'совокупность полезных качеств чего-либо, практичных деталей, возможностей’.

Приведем примеры каждого из значений ${ }^{1}$ :

(1) Да и зачастую им не требуются сайты со сложным функционалом [«Новгородские ведомости», 2013]; Взять руль - он самый обычный, со стандартныл функционалом [РБК Дейли, 2013.08.29]; Это первая на нашем рынке

\footnotetext{
${ }^{1}$ В статье использованы примеры из Национального корпуса русского языка (ruscorpora.ru).
} 
модель с подобным функционалом в цуеновой категории «до 12000 рублей» [«Рсский репортер», 2012]; Функционал аппарата довольно беден: нет поддержки Јava, МР3, нет аудио и видео-плееров, нет выхода в интернет <... [Известия, 2011.12.08];

(2) Функционал Суворова в медиахолдинге был обцирным - финансовое и налоговое планирование, структурирование сложных сделок [《Эксперт», 2015]; Минэкономразвития <..> предлагает расширить функционал ВЭБа, предоставив ему право выдавать банковские гарантии в счет оплаты таможенных пошлин и сборов [Известия, 2014.03.12]; Очевидно, что назначение нового руководителя связано со сменой функционала [Известия, 2014.02.25]; Оформление документов, знакомство с функционалом и коллегами... [«Психология на каждый день», 2010];

(3) Посмотри, какой здесь функционал: и мех отстегивается, и капюшон, и рукава можно укоротить; А функционал какой: на этом пальто миллион карманов и кулисок! (телемагазин Shopping Live).

Лексема функционал в значениях $(1,2)$ имеет довольно широкую сочетаемость: расширить, изменить, реализовать, ввести в эксплуатацию, ввести в действие, обновить, улучшить, оптимизировать и т.д.; удобнылй, широкий, расширенньлй, развитый, бедный, богатый, новый, фантастический, сложный и т.д.; функционал банка, комиссии, сайта, гаджета, принтера, организаџии, мобильного приложения и т.д.

Круг письменных текстов, в которых востребованы указанные употребления, достаточно широк. Так, новые значения представлены на различных интернетpecypcax: PowerShape 2017 предлагает широкий функционал для эффективного 3D-моделирования сложных изделий и инструментальной оснастки [http:// delcam-m.ru/pdf/powershape-2017-whats-new-flyer_RU.pdf]; Почти каждую неделю создатели Инстаграм обновляют функционал сайта и мобильное приложение. Особенно активно обновления начали внедрять в этом году [http:// socprka.ru/blog/obnovlenie-instagram-2017/]; Так в Ebner Media Group исчезли руководители, а вместо них появились менеджеры изелевых групп. В функционал этих специалистов входит весь спектр задач, связанный с иелевыми группами - социальные сети, циифровые продукты и т.д. [http://neohr.ru/10-trendov-vrazvitii-media],

Значения (1) и (2), судя по данным Национального корпуса русского языка (НКРЯ), востребованы в текстах СМИ, посвящённых техническим новинкам, новостям бизнеса, кадровым назначениям и т.д. Статистика распределения по годам показывает, что с указанной семантикой слово стало употребляться с конца 1990-х гг., резко активизировавшись в 2010-х. В основном корпусе зафиксировано 55 документов, 86 вхождений, в газетном корпусе - 542 документа, 641 вхождение, причем подавляющее большинство из них демонстрируют новые значения.

Значение (1) связывают с компьютерным жаргоном ('набор функций, предоставляемых компьютерной программой’, ср., например, «Русский Викисловарь» https://ru.wiktionary.org). Можно предположить, что мы имеем дело не с развитием 
семантики термина, а с образованием существительного путем усечения основы прилагательного функциональный (ср. безнал, регионал, федерал, нелегал, неформал). С другой стороны, математический термин мог быть переосмыслен в жаргоне программистов как экспрессивная вариация к нейтральному функииональность (англ. functionality ‘функциональность, совокупность функций’). Возможно, здесь действовали, усиливая друг друга, оба фактора.

Первоначально значения (1) и (2) действительно воспринимались исключительно как элементы компьютерного или офисного (для второго значения) жаргона. Распространение этих употреблений в СМИ можно было расценивать как проявление языковой моды, однако постепенно они становятся привычными и, как выясняется, удобными, причем в стилистически нейтральных контекстах.

Функционал в значении (1) употребляется вместо слова функциональность, в значении (1) и (2) вместо функции ${ }^{2}$. При этом функциональность определяется словарями как «свойство функционального» [Крысин 2008: 850]. В «Большом толковом словаре русского языка» под ред. С.А. Кузнецова читаем: «ФУНКЦИОНАЛЬНЫЙ <..> 2. Основанный на вычленении разнообразных функций. $\Phi$-ое разделение труда. < ..>3. Служащий определённой цели, назначению. $Ф$-ая структура управления. < .. >// Имеющий практическое применение; утилитарный, прикладной. Ф-ое назначение прибора [БТС]; «ФУНКЦИЯ, -и; ж. [от лат. functio] 1. Значение, назначение чего-л. <..> Выполнять чью-л. функиию. // Направление деятельности в соответствии с назначением какой-л. организации, учреждения; задача, обязанность должностного лица и т.п. <...> Возложить на комитет функиии контроля) [Там же]. В «Толковом словаре иноязычных слов» находим «ФУНКЦИЯ, и, ж [нем. Function < лат. functio исполнение]. 1. Обязанность, круг деятельности, назначение. В чем состоят мои функции?» [Крысин 2008: 850]. В значении (3) 'полезные свойства', 'практичные детали' проявляет себя расширение семантики, «процесс, очень характерный для языка нашего времени» [Ермакова 2010: 76].

Показательно, что русское слово функционал в указанных значениях $\mathrm{d}$ в основном переводится на английский язык литературными средствами, такими как functionality 'совокупность функций', functions 'функции', features 'возможности', (см., например, контексты, приведенные на словарно-переводческом онлайн-реcypce https://www.linguee.ru).

Оценки новых значений лексемы функционал находим в контенте «Справочной службы» портала Грамота.ру. Так, на вопрос №240774: «B предложении: "За годы существования союз лицеестов приобрел сторонников, признанный функиионал, формальное управление..." корректно ли употребление слова "функционал" в значении "совокупность функиий" < ... >?» Служба дает ответ: «Слово «функционал» следует использовать только как математический термин. В данном тексте его употребление нельзя признать корректнылм (при этом никаких рекомендаций

2 Отметим, что именно эти слова рекомендуют употреблять вместо ненормативного функционал (например, в сочетании функционал сайта) в интернет-дискуссиях на эту тему (см., например, обсуждение на https://toster.ru/q/14928). 
на этот счет не дается). Интересно, что при ответах на другие вопросы, содержащие подобное употребление слова функционал, внимания на его некорректность, как правило, не обращается, ср.: вопрос №236993: < ..> выделяется ли выражение "на сегодняшний день" запятыми? Например: Программа объединяет в себе много решений и технологий, обеспечивая, на сегодняшний день, самый широкий и развёрнутый функичонал в одном продукте. Ответ: Верно без выделения. Понятно, что Служба отвечает на только заданный вопрос, однако в ряде случаев ответ включает комментарии по поводу других ненормативных явлений, ср.: Вопрос № 282781: «<..> как правильно писать: "функичонал не доступен в демо-режиме" или "функционал недоступен в демо-режиме"?». Ответ «Справочной службы»: Корректно слитное написание (речь о слитном / раздельном написании НЕ- с кратким прилагательным - А. Ж.). Обратите внимание: слово «деморежим» пишется слитно.

На вопрос № 236611: «<..> нужна ли запятая после слова "Однако"? "Функция затирания временно недоступна во всех версиях. Однако данная функциональность будет включена в ближайшем обновлении"» дается ответ: Запятая не требуется. Очень режет глаз слово функциональность, лучше перестроить фразу. Например: Функция затирания временно недоступна во всех версиях. Как видим, здесь дается дополнительный комментарий по поводу употребления слова функцчиональность, ближайшего конкурента лексемы функционал. Нами не было обнаружено подобных «не относящихся к делу» комментариев по поводу обсуждаемых употреблений слова функциионал, что может косвенно свидетельствовать о том, что они в определенных контекстах «не режут глаз».

Результаты проведенного нами опроса студентов-филологов (опрошено более 50 -ти человек) свидетельствуют о том, что значения $(1,2)$ молодым людям известны. Задание объяснить значение слова функционал у большинства студентов затруднений не вызвало (о том, что есть такой математический термин, знали единицы). Полученные нами толкования можно свести к двум позициям: 1) функциональные возможности какого-либо устройства, продукта (компьютера, телефона, сайта, программы, автомобиля); 2) выполняемая кем-либо работа, круг обязанностей.

Подведем итоги. Проведенный анализ позволяет отнести функциионал в значениях $(1,2)$ к тем ненормам, которые являют собой полезную избыточность. Есть основания считать, что функционал с указанной семантикой отражает стремление говорящих уточнить передаваемый смысл, причем более экономными средствами. С одной стороны, лексема функциональность как «свойство функционального» не слишком «приспособлена» для передачи семантики множественности, набора, совокупности, передаваемой лексемой функционал в значении (1). С другой, функиионал в значении (2) способен передать более широкий спектр сем, чем функиии: не только 'обязанности', ‘назначение', ‘круг деятельности', но и 'полномочия', ‘права', ‘возможности', ‘зона ответственности’. Отметим, что указанные употребления не вытесняют традиционные обозначения: функции, должностные обязанности, функииональные возможности, а дополняют их. Функционал в значении (3) пока выглядит маргинальным употреблением («бесполезная», или даже 
«вредная» избыточность), его нормативный потенциал можно оценить как самый низкий: перенос данного обозначения с технически и интеллектуально сложных объектов на любые другие (ср. функционал платья, сумки, обуви) кажется слишком претенциозным и потому неуместным.

На примере лексемы функционал, не имеющей нормативного статуса, но востребованной в широком круге текстов, мы наблюдаем проявления полезной (конструктивной) избыточности, расширяющей спектр наличных средств выражения, дающей дополнительные возможности для поиска более точного и экономного обозначения актуальных смыслов. С другой стороны, здесь имеют место проявления избыточности «бесполезной» или даже деструктивной. Рассмотренные нами употребления имеют разный нормативный потенциал, в разной степени удовлетворяют критерию обогащения, или, по крайней мере, «не обеднения» языковой системы, о котором пишет О.Б. Сиротинина [Сиротинина 2013]. У лексемы в значениях (1) и (2) есть все шансы закрепиться в языке, перейти в разряд устойчивых, регулярных средств, заняв свою семантическую «нишу». Представляется важным проводить регулярный «мониторинг» нормативного потенциала подобных явлений, особенно приближающихся к границе нормы. Это необходимо для принятия ортологически значимых решений в целях редактирования, экспертной оценки, преподавания и т. д.

\section{Литература}

Англо-русский толковый словарь терминов и сокращений по вычислительным технологиям, Интернету и программированию. [Электронный ресурc]. URL: http:// computers_en_ru.enacademic.com/

[БСЭ] - Большая советская энциклопедия [Электронный ресурc]. URL: www. вокабула.рф/энциклопедии/бсэ/ (дата обращения - 15.08.2017)

[БТС] — Большой толковый словарь русского языка. Гл. ред. С. А. Кузнецов. [Электронный ресурс]. URL: http://www. http://gramota.ru/slovari/info/bts/

Ермакова О.П. Слово в словаре и современной речевой практике // Современный русский язык: система - норма - узус: монография / Отв. ред. Л.П. Крысин; Российская акад. наук, Ин-т рус. яз. им. В. В. Виноградова, М.: Яз. славянских культур, 2010. С.71-95.

Костомаров В.Г. Язык текущего момента: понятие правильности. Спб.: Златоуст, 2014. 220 с.

Крысин Л. П. Толковый словарь иноязычных слов. М.: Эксмо, 2008. 944 с.

Крыссин Л. П. Языковая норма в проекции на современную речевую практику // Русский язык сегодня. Вып.4. Проблемы языковой нормы: Сб. статей / Ин-т рус.яз. им. В. В. Виноградова РАН. М.: 2006. С. 294-311.

Сиротинина О.Б. Русский язык: система, узус и создаваемые ими риски. Саратов: Изд-во Сарат. ун-та, 2013. 116 с. 


\author{
Arina G. Zhukova \\ Pushkin State Russian Language Institute \\ (Russia, Moscow) \\ agzhukova2013@gmail.com
}

\title{
ABNORMALITIES IN MODERN COMMUNICATION (THE CASE OF THE LEXICAL UNIT 'FUNKTSIONAL')
}

The article deals with the typology of the phenomena of modern language facts from the point of view of their normative status. In the focus of this research is distinction between the norm (the basic part of the literary language), the non-norm and the antinorm (opposing the norm as the phenomena of destruction). Attention is paid to taxonomy of the non-norms - a wide formation phenomena of "intermediate" nature that are not the norm, but not included in the "prohibited area" of communication. They are in the range of facts estimated from the regulatory "allowed with restrictions" to "very doubtful", and represent different types of linguistic redundancy.

The paper discuses the existence of non-norms in language and the specifics of their functions as in the case of the lexical unit функционал/functional. This lexical unit used to be recorded in dictionaries and enciclopedias as mathematical and programming term untill recently. Nowdays the word функционал has passed into generic usage with wide range of non-terminological meanings. New meanings are explicated in oral and wirtten communication, both in professional field and in media publications on cutting-edge goods and technics, softwares, management, HR policy etc. The paper provides analyses of the textual material extracted from different media, Internet and Tvshops. The data of gramota.ru enquiery service is used. The author's conclusion is that it is necessary to observe such phenomena and evaluate their normative potential.

Key words: norm, non-norm, antinorm, the normative potential of lexical units, the lexical unit функиионал (functional).

\section{References}

English-russian dictionary of terms and acronyms on computer engeneering, Internet and programming. Available at: http://computers en ru.enacademic.com/ (accessed 15.08.2017)

[BSE] - Big Soviet Encyclopedia. Available at: www.вокабула.рф/энциклопедии/ бce/ (accessed 15.08.2017)

[BTS] - Bol'shoj tolkovyj slovar' russkogo jazyka [Big Dictionary of Definitions of the Russian Language]. Edited by S. A. Kuznecov. Available at: http://www. http:// gramota.ru/slovari/info/bts/ (accessed 10.09.2017)

Issers O. S. Diskursivnye praktiki nashego vremeni [Discourse Practices of Our Time]. Moscow, LENAND, 2015. 272 p. 
Ermakova O.P. [A Word in a Dictionary in Modern Speech Practice]. Sovremennyj russkij jazyk: sistema - norma - uzus [Modern Russian language: System — Standard - Usage]. Edited by. L. P. Krysin; Russian Academy of Sciences, The Vinogradov Linguistics Institute of the RAS In. Moscow, Languages of the Slavic Culture Publ., 2010. pp.71-95. (In Russ.)

Kostomarov V.G. Jazyk tekushhego momenta: ponjatie pravil'nosti [The Language of the Current Moment: the Notion of Correctness]. St. Petersburg, Zlatoust, 2014. 220 p.

Krysin L.P. Tolkovyj slovar' inojazychnyh slov [Foreign-language Words Definition Dictionary]. Moscow, 2008. 944 p.

Krysin L.P. [Language Standard as Projected in Modern Speech Practice]. Russkij jazyk segodnja. Vyp.4. Problemy jazykovoj normyj [Russian Language Today no6. Problems of the Language Standard] / Moscow, The Vinogradov Linguistics Institute of the RAS In, 2006. pp. 294-311. (In Russ.)

Sirotinina O.B. Russkij jazyk: sistema, uzus i sozdavaemye imi riski [Russian Language: System, Usage and the Risks Created by Them]. Saratov, Saratov St. Univ. Publ., 2013. $116 \mathrm{p}$. 


\author{
О. С. Иссерс \\ Омский государственный университет им. Ф. М. Достоевского \\ (Россия, Омск) \\ isserso@mail.ru
}

\title{
ДАЙ БОГ НЕ ПОСЛЕДНИЙ! (О ВИРУСНОЙ ЭВФЕМИЗАЦИИ В КОНТЕКСТЕ МАССОВОЙ РЕЧЕВОЙ КУЛЬТУРЫ)
}

На примере проникновения во многие сферы русской речи прилагательного крайний как эвфемистического заменителя слова последний в статье рассматривается феномен «вирусного» распространения речевых новаций. По мнению автора, скорость и масштабы их внедрения в дискурсивные практики современного русского языка не позволяют относить данные факты к речевым ошибкам и требуют поиска иных причин, которые лежат в сфере коммуникативно-прагматической и когнитивной специфики функционирования языка.

Выборка материала по базе данных «Медиалогия» осуществлялась методом моделирования возможных сочетаний существительного с прилагательным крайний в эвфемистической функции. Гипотеза основывалась на фактах прецедентной встречаемости в СМИ и блогосфере сочетаний типа крайний матч, крайний конизерт, крайний отчет и поиске подобных сочетаний применительно к сферам деятельности, где имеется определенная доля риска и непредсказуемости.

На основании полученных данных были выявлены разнообразные сферы эвфемистической замены лексемы последний. Учитывая традицию культурно-речевых оценок данной замены в научной и «наивной» лингвистике, проведен анализ метаязыковой рефлексии носителей языка по поводу конкурирующих номинаций.

Исследование позволило сделать вывод о динамических процессах «новой русской эвфемизации». Они обусловлены особенностями распространения речевых новаций, мотивированных, с одной стороны, языковой модой, а с другой - ложными представлениями о магической силе слов. Обе причины побуждают говорящих репродуцировать эвфемистические модели на уровне речевого автоматизма, что приводит к их вирусному распространению, в первую очередь, в новых медиа и блогосфере.

Ключевые слова: эвфемизм, массовая речевая культура, языковая мода, культура речи. 
Вирусный характер распространения модных языковых новаций не однажды был предметом лингвистического анализа [Вепрева, Мустайоки 2015, Гусейнов 2012, Кронгауз 2010, 2012, Левонтина 2012, 2016, Мода в языке 2014, Новиков 2012 и др.]. Однако ученым далеко не всегда удается убедительно объяснить, почему те или иные языковые единицы попали в фокус общественного внимания и массового подражания. Вирусообразное распространение языковой моды заставляет обратиться к феномену массовой речевой культуры, без осмысления которого причины и следствия подобных явлений могут быть интерпретированы всего лишь как речевое бескультурье.

Исходя из потребностей дескриптивного описания можно определить массовую культуру русской речи как элементы дискурсивных практик, принимаемые большинством (вне зависимости от уровня образования) в качестве нормы. Их оценка как социально приемлемых основана на высокой частотности и обусловлена коммуникативными, социальными и когнитивными причинами [Иссерс 2016].

Современную медиасреду, и в первую очередь новые медиа, можно назвать зоной активного речевого заражения. Скорость и масштаб внедрения речевых новаций, нередко нарушающих нормы современного литературного языка, в дискурсивные практики не позволяют относить их к речевым ошибкам и требуют поиска иных причин, которые лежат в сфере коммуникативно-прагматической и когнитивной специфики функционирования языка в конкретной социокультурной общности. В частности, речевой выбор во многом мотивируется стремлением дать сигнал о нахождении «в тренде», о принадлежности к группе, являющейся, с точки зрения говорящего, престижной [Борисова 2014:53].

Примером может служить стремительное вытеснение слова последний в значении 'конечный в ряду однородных, явлений' прилагательным крайний. Лингвисты не раз давали объяснение причинам мифологизации «нехорошего» значения (точнее, одного из значений) слова последний, причем не единственное. Конкуренция данных прилагательных имеет давнюю историю, ограниченную, однако, конкретным коммуникативным контекстом - ситуацией очереди, особенно актуальной в советский период ввиду товарного дефицита. В то время (как, впрочем, и сейчас) выбор варианта крайний (Кто крайний?) свидетельствовал о невысоком уровне речевой культуры говорящего и регулярно обсуждался в научно-методической и научно-популярной литературе, посвященной культуре речи (см., например, Колесов 1988: 234-235). В данной ситуации, как и во многих других, где необходимо выразить значение 'конечный в ряду чего-нибудь’ нормативно закреплено прилагательное последний.

В социальных жаргонах ранее отмечалось употребление прилагательного крайний в эвфемистической функции табу — в основном в сфере деятельности, связанной с риском для жизни. Так, в «Большом словаре русского жаргона»

${ }^{1}$ Последний, -яя, -ее. 1. Крайний в ряду чего-н. П. день отпуска. П. сын в семье. В n. раз. П. в очереди [Ожегов, Шведова 1997]. Последний, -яя, -ее. 1. Конечный в ряду однородных явлений, предметов; такой, за которым не следует, не ожидается что-л. подобное [Большой словарь русского языка 2000]. 
В. М. Мокиенко и Т.Г. Никитиной слово крайний в значении 'последний’ сопровождается пометами 'авиа, косм.' [Мокиенко, Никитина 2000].

Однако в последние 5 лет мы стали свидетелями своего рода «цунами» массового речевого суеверия, стремительно обрушившегося на все сферы жизни, в которых так или иначе присутствует, с одной стороны, фактор удачи, везения, а с другой стороны - элемент непредсказуемости, даже фатальности. Они отнюдь не ограничиваются авиацией, космонавтикой, военной и другой опасной для жизни службой либо деятельностью. Спорт и искусство, творчество, бизнес и личная жизнь - во всех этих сферах активизировались эвфемистические замены лексемы последний на крайний.

В частности, в некоторых контекстах, к ситуации очереди отношения не имеющих, замена вызвана стремлением уйти от основного значения прилагательного последний - 'такой, за которым не следует, не ожидается что-либо подобное' [Головина 2014, Пахомов 2016 и др.].

Для понимания современных фактов экспансии эвфемистического обозначения табированных смыслов следует обратить внимание на причины данного явления. Сферу эвфемизмов можно отнести к одной из самых динамичных в составе любого языка. Среди стимулов эвфемистических новаций нельзя не заметить такие, которые не связаны ни с утратой заместительной функции, ни с «заражением денотата». Они объясняются особенностями современных средств коммуникации - в первую очередь сетевого общения. Однажды появившись в сети и получив одобрение сетевого сообщества, языковая единица молниеносно распространяется и тиражируется независимо от актуальной коммуникативной потребности пользователей. В этой своей способности она ведет себя как и другие единицы «когнитивного заражения» - мемы [Докинз 1993:173]. Вирусное проникновение во многие сферы функционирования русской речи прилагательного крайний как эвфемистического заменителя слова последний - яркий тому пример.

Источником материала явились данные, полученные из компьютерной базы СМИ «Медиалогия» ${ }^{2}$ в 2016 г. за трехмесячный период (февраль-апрель). Они дополнены примерами из блогосферы, СМИ и живой речи, собранными автором в период с апреля по ноябрь 2016 г. ${ }^{3}$ На основании полученных данных были выявлены преимущественные сферы эвфемистической замены лексемы последний, а также метаязыковые комментарии по этому поводу.

Выборка материала осуществлялась методом моделирования возможных сочетаний прилагательного крайний с существительным в эвфемистической функции. Гипотеза основывалась на фактах прецедентной встречаемости в СМИ и блогосфере сочетаний типа крайний матч, крайний концерт, крайний отчет и поиске

2 Автоматизированная система, осуществляющая мониторинг СМИ и медиаанализ. База данных: 30730 источников (по данным на 17.03.2016).

${ }^{3}$ Именно в этот период появился новый роман Виктора Пелевина «Лампа Мафусаила, или Крайняя битва чекистов с масонами» («Эксмо», 2016). Характерно обыгрывание названия в рецензии Дм. Быкова — «Бескрайняя битва Пелевина» (Собеседник, №32, 2016), где антоним коррелирует с иным значением слова крайний. 
подобных сочетаний применительно к сферам деятельности, где имеется определенная доля риска и непредсказуемости. По этому параметру несложно прогнозировать рассматриваемые замены в военной сфере, в авиации, космонавтике, у шахтеров и т.д., где риск входит в профессию. С другой стороны, нельзя исключить влияние примет и вербализацию суеверных представлений в речи людей творческих профессий - у актеров, режиссеров, певцов, танцовщиков, журналистов. Логически продолжая этот ряд, можно было предположить эффекты эвфемизации в речи деловых людей - бизнесменов, госслужащих и др., чья деятельность нередко определяется независимыми от исполнителей обстоятельствами и не исключает фактора удачи. Маловероятным представлялось употребление эвфемизма крайний в сфере образования, науки и межличностных отношений.

С учетом указанных предположений в поиске задавались сочетания с субстантивами, типичными для указанных сфер деятельности (матч, турнир, выступление, спектакль, фильм, репортаж, совещание и др.). Общее количество поисковых заданий - 40. Количество материала - более 400 сочетаний с эвфемизмом крайний. В ряде случаев получены отрицательные ответы на запрос: в указанный период не обнаружены сочетания крайняя поэма, крайний экзамен и др. Это, разумеется, не означает невозможности их фиксации в иной период по другим источникам. В силу специфики корпусных данных в ряде случаев контексты практически идентичны, т.к. являются перепечатками из одного источника, однако, учитывая нашу исходную посылку о вирусном характере распространения подобных языковых новаций, каждое упоминание считалось как отдельный пример.

Большинство зафиксированных языковых фактов обнаружено в конвергентных медиа на Интернет-порталах и сайтах, а также в блогосфере. Источники представляют различные СМИ России (как региональные, так и федеральные), а также русскоязычную прессу стран Ближнего Зарубежья (Казахстана, Украины, Белоруссии). Следует отметить, что среди них присутствуют и СМИ федерального уровня, которые принято относить к «качественной прессе», - газеты «Комсомольская правда», «Собеседник», телеканал «Россия 1», радиостанция «Эхо Москвы» и др.

Наблюдения за продуктивностью сочетаний прилагательного крайний с существительными позволяют определить сферы активной экспансии эвфемистической замены и тем самым выявить некоторые специфические изменения в массовом языковом сознании россиян.

Ниже приводятся типичные сферы «вирусного заражения» с наиболее частотными субстантивными словосочетаниями и контекстными употреблениями.

\section{1. Авиация}

\section{крайние выступления (11)}

9 мая на Параде Победы состоится одно из крайних выступлений российской авиагруппь высшего пилотажа "Стрижи" на боевых истребителях МиГ-29 (Русская планета. rusplt.ru) 


\section{крайний прыжок (14)}

Погодные условия в организации столь экстремального времяпрепровождения имеют решающее значение. Крайние прыжки - у парашютистов не принято употреблять слово "последний" - проводились в феврале, (Официальньий информационный портал акимата Карагандинской области. karaganda-region.gov.kz)

\section{2. Спорт}

\section{крайняя встреча (спортивная) 144}

Челси постарается отыграть в яркий футбол, который ребята Гуса Хиддинка показали в двух крайних встречах (Overbetting.net)

\section{Крайний турнир (11)}

Но сейчас у нас команда стабильная, поэтому на крайних турнирах занимаем первые места. (Красноуфимск онлайн. ksk66.ru)

крайний подход (5)

В спортзале: - Вам ещзе долго? - Последний подход. - Крайний. Надо говоpить крайний подход. (http://club443.ru/index.php? showtopic $=194429 \& s t=200$ )

крайний прыжок (2)

Уже после вручения медалей Густик признался, что тренеры перед крайним прыжккм, именно так по аналогии с летчиками называют свою заключительную попьтку воздушные акробаты, предлагали ему выполнить разминку. (Беларусь Сегодня. sb.by)

\section{3. Искусство, журналистика, литература}

\section{крайняя роль (16)}

Крайняя роль в популярной среди молодежи постановке "Ромео и Джульетта"... (Тюменская правда)

\section{крайний фильм (15)}

Командир батальона «Ангел» Алексей Смирнов - московский режиссер. Не доснял свой крайний фильм, потратив деньги на помощьь населению Донбасса (Комсомольская правда).

... Виталий рассказывает о том, как снимал свой последний, пока что крайний фильм... (Эхо Москвьг)

крайний танец (12)

Наталья Бичан готовится поставить крайний танеи (kak2z.ru)

крайний концерт (11)

23 апреля состоялся крайний концеерт сезона 2015-2016. (http://vk.com/... Gorod60)

\section{крайняя песня (6)}

Хочу вам пожелать одного - берегите наше Отечество. У меня есть песня, это крайняя песня, как говорится, которую я исполнял нашим соотечественникам в Сирии, нашим летчикам. (Иосиф Кобзон. Комсомольская правда. Кр.ги) 


\section{крайний спектакль (3)}

... сложилось, что и в феврале 2015-го в Тюмени, и сейчас в Екатеринбурге я смотрела крайние спектакли тура, слово "последние" в театре не любят (Вслух. ru. (vsluh.ru)

\section{крайний репортаж (1)}

Крайний репортаж в СМИ о 400 тысячах протестующих с требованием запретить строительство одного завода — этому подтверждение (Новости КБР (07kbr.ru)

\section{крайнее интервью (1)}

Соглашусь, Моцарт меня вообще не цуеплял, прошлогодний танец был неплох, а от этого ПТ просто глаз не... хотя даже давая крайнее интервью ребята отмечают...(forum.fsonline.ru)

\section{крайняя статья (1)}

Но вот сегодня прочел твои последние статьи, и особенно мне понравились две крайние. (Красноярское время. krasvremуа.ru)

\section{крайний роман (1)}

В крайних романах ему был уже шестой десяток, а он продолжал свое саморазвитие. (Sports.ru/tribuna Москва)

\section{крайняя книга (1)}

Моя крайняя книга "Национальный футуризм" должна выйти в апреле, в издательстве "Алгоритм". (livejournal.com)

\section{4. Деловая жизнь, бизнес}

\section{совещание (23)}

Это особо подчеркнул Верховный Главнокомандующий на крайнем совещзании с руководящим составом Вооруженных Сил. (TK 24 KZ. 24.kz)

\section{крайний отчет (9)}

Крайний отчет о состоянии рынка труда США произвел громкий эффект. (Elitetrader (elitetrader.ru))

\section{5. Образование и наука}

\section{крайняя лекция (2)}

В музеях есть что посмотреть и узнать. Символично, что на крайней лекцุии участники прогулок поздравили с 10-летием один из старейших орловских сайтов о прекрасном... (ОрелИнфо-Сити. Infoorel.ru)

\section{исследование (1)}

Компания "Авиаперсонал" опубликовала даннье крайнего исследования: Руководящий состав и топ-менеджеры потеряли 10-42\% дохода. (Avia.pro Москва)

\section{6. Другие}

\section{крайняя встреча (19)}

Nissan Fairlady Серебряная мечта. Крайняя встреча. Ну вот пришлось время прощаться. Крайний раз за рулём (Бортжурнал Nissan. drive2.ru) 


\section{крайняя встреча (в политике) (8)}

Вспоминая крайнюю встречу Путина и его ответ на вопрос, какой период сейчас переживает Россия, можно с уверенностью сказать... (Нефакт.инфо. nеfakt. info)

По результатам проведенного эксперимента подтвердилась гипотеза о широкой употребительности эвфемизма крайний (вместо последний) в разнообразных сферах деятельности - спорте, искусстве, журналистике, бизнесе, образовании и др., отнюдь не связанных с риском для жизни и экстримом. Это позволяет говорить об изменении прагматической функции данного эвфемизма: из осознанного употребления слова в эвфемистической функции с учетом специфики опасных профессий оно переходит в разряд речевых автоматизмов, к которым можно отнести многие коммуникативные действия, имеющие лингвокультурную специфику «народных примет» и соответствующих им речевых и неречевых действий.

Признаком десемантизации первичного табу могут служить сочетания, где значение последний по логике здравого смысла не предполагает семантики 'такой, за которым ничто не следует':

F-2 - самолет крайнего поколения (телеканал «Россия», «Вести», 22.08.2016). (Конструкторы перестанут разрабатывать новые модели самолетов?)

Для понимания процессов «самоочищения языка» существенную роль играет метаязыковая рефлексия его носителей, которая позволяет высветить немотивированность и даже абсурд эвфемизации тех явлений внеязыковой действительности, которые с точки зрения социально-этических и речевых норм в ней не нуждаются.

В качестве подтверждения абсурдности подобных замен приводятся яркие примеры и рассуждения, с которыми трудно спорить. ${ }^{4}$

Гражданский летчик - это опасная профессия? Тогда и пассажир опасная. У меня, кстати, двоюродный брат - бывший военный летчик. Ни разу слово "крайний" вместо "последний" от него не сльшиал. Моя подруга работает сисадмином, тоже, видимо, очень опасная работа, потому что она говорит "крайний". "Когда я крайний раз была в отпуске, когда я крайний раз ходила кмаме в гости".

Высказываются вполне соответствующие научному взгляду идеи относительно перспективы дисфемизации слова крайний:

Потом это совсем станет нормой, надо будет придумать какой-нибудь суеверный синоним, который не будет означать такую предсказательную терминальность, как "крайний", умные люди найдут подходящеее для этого слово. "Последний" выглядит удачным. И все завертится с начала.

Предметом многих сетевых комментариев является ироническая рефлексия по поводу нелепости речевого выражения суеверий.

Главред одного из предыдущчих изданий говорил: "Что там за статья была в нашем последнем... извините, крайнем номере?" (т.е., боялся, что издание закроют,

4 Здесь и далее приводятся комментарии с форумов без указания авторов: https://afflatus.dirty. ru/krainii-814036/; http://www.yaplakal.com/forum7/topic993548.html 
и номер и вправду станет последним). Кстати, издание таки закрыли, и примитивная магия не спасла))

Показателем появления у новомодного употребления иронического модуса могут служить авторские кавычки:

У 55-летнего Дмитрия Диброва в творческой биографии 4 жень. Причем две «крайние»-из племени младого, незнакомого, (Комсомольская правда, 13.10.2015).

Активное обсуждение эвфемистических новаций как специалистами, так и пользователями социальных сетей является, на наш взгляд, убедительным доказательством сопротивления вирусному заражению в сфере массовой речевой культуры.

\section{Литература}

Большой толковый словарь русского языка. Гл. ред. С. А. Кузнецов. - СПб.: Норинт, 2000.

Борисова Е.Г. Мода и узус: моделирование влияния социума на речь // Мода в языке и коммуникации: Сб. статей / Сост. и отв. ред. Л.Л. Федорова. М.: РГГУ, 2014. С. 47-55.

Вепрева И. Т. Мустайоки А. Метаязыковой портрет модных слов. www.dialog-21. ru/digests/dialog2015/.../pdf/MustajokiAVeprevaIT.pdf. (Режим доступа 10.10.2016)

Головина Э. Д. Крайний или последний // Русская речь. 2014. № 4. С.59-64.

Гусейнов Г. Нулевые на кончике языка. Краткий путеводитель по русскому дискурсу. М., 2012.

Докинз Р. Эгоистичный ген. М., 1993.

Иссерс О.С. Массовая речевая культура как феномен современной коммуникации: в поисках речевого идеала // Материалы V Международной научной конференции «Экология языка и речи» (Тамбов, 3-5 ноября 2016 г.). С. 352-356.

Колесов В. В. Культура речи — культура поведения. Л.: Лениздат, 1988.

Кронгауз M.A. Русский язык на грани нервного срыва. 3 D. M., 2012.

Кронгауз М. А. Русский язык на грани нервного срыва. М., 2010.

Левонтина И. Б. О чем речь? М.: АСТ, 2016. 512 с.

Левонтина И. Б. Русский со словарем. М.: Издательский центр «Азбуковник», 2012.335 c.

Мода в языке и коммуникации: Сб. статей / Сост. и отв. ред. Л. Л. Федорова. М.: РГГУ, 2014. С. 47-55.

Мокиенко В. М., Никитина Т.Г. Большой словарь русского жаргона. СПб.: Норинт 2000.

Новиков В.Н. Словарь модных слов: Языковая картина современности. М.: АСТ-ПРЕСС КНИГА, 2012.

Ожегов С.И., Шведова Н. Ю. Толковый словарь русского языка. - М., 1997.

Пахомов В. М. Последний или крайний? Садитесь или присаживайтесь? http:// gramota.ru/class/istiny/istiny_6_krainij/ (Режим доступа 23.04.2016) 


\section{Oksana S. Issers}

Omsk F. M. Dostoevsky State University

(Russia, Omsk)

isserso@mail.ru

\section{DAJ BOG NE POSLEDNIJ! (VIRAL EUPHEMIZATION IN MASS SPEECH CULTURE)}

Based on the example of the euphemistic adjective 'kraynii' ('extreme', 'utmost', 'final') for the word 'poslednii' ('last') that has spread in many spheres of Russian speech, the article considers the phenomenon of the "viral" spread of speech innovations. In the author's opinion, the speed and scale of their penetration in discursive practices of the modern Russian language do not allow to attribute these facts to verbal errors and require search for other reasons are rooted in communicative-pragmatic and cognitive specificity of the functional language.

The material was sampled from the database Medialoguia by modeling possible combinations of the noun with the adjective kraynii in its euphemistic function. The hypothesis was based on the precedent occurrences of combinations in the media and the blogosphere such as kraynii match (last match), kraynii concert (last concert), kraynii otchet (last report). The search for these and similar combinations was conducted in spheres with a certain level of risk and unpredictability.

On the basis of the data obtained, various areas of euphemistic substitution of the lexeme 'poslednyi' ('last') were identified. The author took into account the tradition of cultural and speech evaluations of such substitution in scholarly and "naive" linguistics, and analysed metalinguistic reflection of native speakers about competing nominations.

The study draws a conclusion about the dynamic processes of the "new Russian euphemisation". They are based on the peculiarities of the spread of speech innovations that are motivated, on the one hand, by linguistic trend, and on the other hand by false notions about the magical power of words. Both reasons encourage speakers to reproduce such euphemistic speech stereotypes unconciously, which leads to their viral spread, primarily in new media and the blogosphere.

Key words: euphemism, mass speech culture, language trend, speech culture.

\section{References}

Bol'shoj tolkovyj slovar' russkogo yazyka. [The Unabriged Dictionary of the Russian language]. Ch. Ed. S. A. Kuznetsov. - St. Petersburg: Norint, 2000. (In Russ.)

Borisova E. G. Moda i uzus: modelirovanie vliyaniya sotsiuma na rech' [Trend and Usage: Modeling the Influence of Society on Speech] // Trends in Language and Communication: Collection of articles / Comp. and ed. L. L. Fedorov. Moscow: RGGU, 2014. P. 16-21. (In Russ.) 
Vepreva I. T., Mustajoki A. Metayazykovoj portret modnykh slov [Meta-lingual portrait of trending words.] www.dialog-21.ru/digests/dialog2015/.../pdf/MustajokiAVeprevaIT.pdf. (Retrieved on 10/10/2016) (In Russ.)

Golovina E. D. Kraynii or Poslednii [Kraynii or Poslednii] // Russian speech. 2014. № 4 P. 16-21. (In Russ.)

Guseinov G. Nulevye na konchike yazyka. Kratkij putevoditel' po russkomu diskursu [The noughties on the tip of the tongue. A short guide to Russian discourse.] M., 2012. (In Russ.)

Dawkins R. Egoistichnyj gen [The selfish gene]. M., 1993. (In Russ.)

Issers O. S. Massovaya rechevaya kul'tura kak fenomen sovremennoj kommunikatsii: $v$ poiskakh rechevogo ideala [Mass speech culture as a phenomenon of modern communication: in search of a speech ideal] // Proceedings of the 5th International Conference "Ecology of Language and Speech" (Tambov, November 3-5, 2016 ). P. 352-356. (In Russ.)

Krongauz M.A. Russkij yazyk na grani nervnogo sryva [Russian language on the verge of a nervous breakdown] 3 D. M., 2012. (In Russ.)

Krongauz M. Russkij yazyk na grani nervnogo sryva [The Russian language is on the verge of a nervous breakdown] M., 2010. (In Russ.)

Levontina I. B. O chem rech"? [What are we talking about?] Moscow: AST, 2016. 512 p. (In Russ.)

Levontina I. B. Russkij so slovarem. [Russian with a dictionary] M .: "Azbukovnik" Publishing Center, 2012. 335 p. (In Russ.)

Moda v yazyke i kommunikatsii [Trends in language and communication]: Collection of articles / Comp. and ed. L. L. Fedorova. Moscow: RGGU, 2014. P. 47-55. (In Russ.)

Mokienko V.M., Nikitina T. G. Bol'shoj slovar' russkogo zhargona. [The Unbridged Dictionary of the Russian Jargon]. SPb .: Norint 2000. (In Russ.)

Novikov V.N. Slovar' modnykh slov: Yazykovaya kartina sovremennosti. [Dictionary of trending words: The linguistic landscape of modernity]. M .: AST-PRESS BOOK, 2012. (In Russ.)

Ozhegov S. I., Shvedova N. Yu. Tolkovyj slovar' russkogo yazyka. [The Dictionary of the Russian language]. - M., 1997. (In Russ.)

Pakhomov V.M. Poslednii or kraynii? Sadites' or prisazhivaytes'? [Last or final? Sit down or have a seat?] http:/gramota.ru/class/istiny/istiny_6_krainij/ (Retrieved on 04/23/2016) (In Russ.) 


\author{
Е.М. Лазуткина \\ Институт русского языка им. В. В. Виноградова РАН \\ (Россия, Москва) \\ lazutkelena@yandex.ru
}

\title{
О РАЗРУШЕНИИ НАЦИОНАЛЬНЫХ ЯЗЫКОВ В ЭПОХУ ГЛОБАЛИЗАЦИИ
}

Статья посвящена проблеме сохранения и развития национального языка. Автор пишет, что в XXI веке в различных странах планомерно проводится политика косвенного влияния, частью которой является культурная глобализация. Намеренно создаются факторы разрушения культуры и национального языка: нарушаются этические правила общения, исторически сложившиеся в лингвокультурном сообществе, подрывается диалоговая основа языка, формируется неприятие языковых норм и культуры речевого поведения, отрицается престиж высокого уровня языковой компетенции, оказывается негативное влияние на прагматикон языковой личности, в узус внедряются англоязычные речевые образцы.

Глобализаторы стремятся уничтожить в России общее пространство культурного коммуникативного взаимодействия и распространяют тезис об отсутствии общеупотребительного литературного языка и функциональных стилей, о существовании региональных вариантов русского языка. Они разрушают и науку о языке: замалчивают или подвергают критике признанные во всем мире достижения отечественного языкознания, игнорируют высокий уровень теоретических разработок XX века в области методологии исследования языковой системы и смысловой организации речи, а также намеренно предают забвению имена отечественных ученых. Агенты глобализации ограничивают задачи русистики регистрацией лежащих на поверхности речевых фактов и составлением словарей дескриптивного типа.

Автор считает, что необходима последовательная государственная языковая политика, способствующая естественному развитию национального языка (такая политика проводится в Японии, Израиле, Франции и других странах), а также пропаганда лингвистических знаний и культуры речи.

Ключевые слова: глобализация, литературный русский язык, лингвистическая прагматика, языковая политика. 
Специалисты по теории глобализации спорят, нужна ли глобализация для прогресса человечества, многие ее категорически отвергают, но планетарный процесс глобализации продолжается. Он формирует деструктивные тенденции в социумах и оказывает разрушающее действие на национальные культуры и языки, подчиняя государства. Это часть целенаправленной политики косвенного влияния США, которую называют культурной глобализацией.

Агенты глобализации внедряют и распространяют мнение об отсутствии литературного языка и стилевой дифференциации языка, отрицают престижность высокого уровня владения родным языком.

Некоторые либералы от науки говорят, что негативные явления в языке носят стихийный характер, а появление в узусе большого числа американизмов, вульгарных выражений и ошибок разного рода связано с событиями в социально-политической жизни. Однако в эпоху глобализации в разных странах планомерно создаются условия, препятствующие процессу естественного функционирования языка. При этом оказывается влияние на сферу употребления языка, которая, как известно, зависит от многофакторного пространства языковой прагматики. Пропаганда под флагом либерализации отказа от языковых норм - это репрезентация установки на уничтожение национального языка.

1. Язык имеет социальную, диалогическую природу, и все мыслительные процессы неразрывно связаны с речью, с ориентированными на восприятие адресата исторически сложившимися — в соответствии с этическими принципами общества - формами выражения.

В эпоху культурной глобализации прежде всего СМИ становятся способом внедрения в русский язык чужеродных элементов. Появляются различные ошибки в словоупотреблении и неправильные грамматические построения - интонационные конструкции английского языка (с повышением тона в конце повествовательных предложений), неграмотные синтаксические образования с неправильными падежными формами имен существительных, с ошибками в употреблении форм, категорий грамматического рода, одушевленности - неодушевленности, абстрактности - конкретности; например: *Немецкие мигранты домогаются к немецким женщинам (следует: домогаются немецких женщин); *Есть обоснованность, вернутся ли они в это здание (следует: Есть обоснованное сомнение, вернутся ли...); *3десь надо положсть лежачего полицейского (следует: положить лежачий полицейский). Такие примеры расшатывают грамматическую систему языка, которая, как известно, является способом представления знаний народа о мире, национальным смысловым кодом.

Особенно много грамматических нарушений в рекламных текстах; например: * Мальишу удобно с памперс (Следует: Мальиму удобно с памперсами); *При стирке добавляю «Ваниша» (Следует: При стирке добавляю «Ваниш»); *Капли «Длянос» (Следует: Капли «Для носа»); *Живите с найз, живите без боли! (реклама геля). Кроме того, в нарушение Закона о государственном языке РФ, в текстах встречается употребление букв латинского алфавита.

Через СМИ вводится неоправданно большое количество слов из американского варианта английского языка, в то время как в русском языке есть аналоги 
или близкие по значению слова; например: *Хочу попасть на закрытую пати (англ. party - вечеринка; канал «Муз-ТВ»); *История подростков, которые издеваются над животными, до сих пор в топе Интернета («Россия-24», 12 января 2017); контент (в речи ведущего передачи «60 минут»). Новые слова часто заменяют уже укоренившиеся в русском языке более ранние заимствования из немецкого языка или французского, например: мейкап вместо макияж, хит вместо илягер, рейтинг вместо популярность, сленг вместо жаргон, мониторить вместо контролировать.

Большую роль в распространении заимствованных слов играет свободное функционирование в языке СМИ профессиональной лексики из разных терминологических систем - речи политтехнологов, шоу-бизнеса и др. Так, в русском языке в подъязыке финансово-экономической сферы - сосуществуют исконно русская терминология и заимствованная, т.е. соседствует парная номинация.

О том, что язык может подвергаться опасности внедрения иноязычных элементов и неправильных речевых образцов, которые уничтожают диалоговую основу языка, писали известные отечественные языковеды и культурологи XIX и XX века; см., например: «снижающая тенденция в речи» (М. М. Бахтин); «преступное вмешательство в естественное развитие языка», которое грозит разрушением национального языка (И.А. Бодуэн де Куртенэ); «...никто не имеет права влагать в язык народа того, чего сам этот народ в своем языке не находит» (А. А. Потебня); «забота (о правильности языка) означает борьбу с тем, что противоречит духу языка, т.е. закономерностям его развития» (С.И. Ожегов).

2. Диапазон узуса - различные типы коммуникативного взаимодействия: от употребления языка в быту, разговорной спонтанной речи - до подготовленной речи, употребления литературного языка в письменной или устной форме в публичной речи. В эпоху глобализации в целях воздействия на узус происходит искусственное формирование прагматикона говорящего. Это происходит следующим образом. В соответствии с теорией речевой деятельности, замысел говорящего рождается вместе с оценочной палитрой высказывания, включающей отношение говорящего к адресату сообщения, т.е. среди прагматических факторов речи центральная роль принадлежит отношению «говорящий - адресат». Тональность речи задает также предмет высказывания: правилу «тема диктует способ своего выражения» говорящие следуют со времен «Риторики» Аристотеля. Она проходит красной нитью и в "Кратком руководстве к красноречию" М. В.Ломоносова. Следовательно, в СМИ при описании трагических событий неуместны фразы с разговорным словом пара: На мине подорвалась пара человек; Пару дней назад здесь было совершено нападение на отряд ОМОНа.

Содержательный импульс говорящего, обогащенный ценностными ориентирами личного опыта, неразрывно связан со стилистическим модусом высказывания, который руководит линейной организацией содержания - отбором грамматических структур и лексического состава. Вследствие этого, авторские установки угадываются адресатом в первую очередь. Прагматический уровень языка представляет собой высший уровень в модели языка, а прагматикон - завершающий 
уровень языковой личности. Таким образом, замысел принадлежит культуре в широком смысле слова, поскольку связан с культурой эпохи, с культурой социума и отношений в социуме.

Поэтому мишенью глобализаторов становится изменение исторически сложившихся культурных канонов общения, уничтожение диалоговой основы языка, и один из приемов воздействия на прагматикон личности - ослабление оси взаимодействия «говорящий - слушающий», т.е. понижение статуса собеседника, нарушение этических правил ведения разговора.

3. В мир потенциального адресата агрессивно внедряется пошлость путем подбора стилистически сниженных «вариантов» для общеупотребительных фраз и включения в языковое сознание адресата отношения к вульгарным выражениям как к обычным. Примеры из речи ведущих ТВ: блин, на хрен, хреновый, до хрена, бухать и пр. Многомиллионная аудитория СМИ, изо дня в день слыша чуждые литературному русскому языку речевые клише, жаргон криминальной среды, может утратить языковое чутье и навыки речевой культуры. Ср. распространение в СМИ просторечных элементов: да ладно (вместо не может быть или неужели); по-любому (следует: в любом случае), походу (следует: похоже), по жизни (следует: в жизни), касаемо (следует: касательно или что касается), за кого ты меня держишь (следует: за кого ты меня принимаешь); диалектных и устаревших образований, нарушающих нормы современного русского языка, например: в ночи, в осени, днями. Формирование «моды» на неграмотную речь, просторечие и использование языка только на бытовом уровне сказывается на чувстве стиля и на грамотности, увеличивая разрыв между представителями элитарной языковой культуры и малограмотными людьми, а в целом - на состоянии языковой системы.

Одним из каналов распространения чужеродных элементов являются иностранные фирмы, в которых внедряются правила корпоративного общении, нарушающие наши традиции общения в официальной обстановке. Вне зависимости от возраста, в общении внутри корпорации или в деловой переписке между сотрудниками Майкрософта предписывается обращение без отчества. Сотрудники называются полным именем (Павел, Виктор, Анна) или кратким именем (Дима, Саша, Лена). Правила внутриведомственного общения накладывают отпечаток на общение людей вне рабочего времени и, в целом, на человеческие отношения, уменьшая уважительность, внедряя элемент панибратства, что несвойственно нашей речевой культуре.

4. Каналы проведения политики культурной глобализации.

1) Язык СМИ; реклама;

2) речь ведущих и участников шоу, реплики персонажей х/ф и т/ф;

3) публичная речь, интервью известных личностей;

4) научно-популярные передачи ТВ и радио;

5) издательская деятельность, книжные выставки, книжные магазины, ярмарки;

6) корпоративное общение в иностранных фирмах;

7) заданные результаты научных исследований, резолюции конференций;

8) составление словарей дескриптивного типа; 
9) сокращение курсов преподавания русского языка как средства межнационального общения, русского языка как иностранного;

10) изменение языкового ландшафта городов и посёлков (например вывески: «Нагатино I-LAND», «VAHИЛЬ», «PRESSA», «Весталка shoеs»).

5. Разрушение национального языка в эпоху глобализации сопровождается уничтожением науки о языке. В Европе под флагом либерализации распространяется мнение, что понятие «языковая норма» неполиткорректно. Составителям словарей рекомендуется фиксировать любое встретившееся написание или произнесение (в то время как сосуществование разных вариантов написания или произнесения таит опасность неузнавания слова в потоке речи); составлять толковые словари дескриптивного типа с картинками. Агенты глобализации подвергают критике признанные во всем мире достижения отечественного языкознания, игнорируют высокий уровень теоретических разработок XX века в области методологии исследования языковой системы и смысловой организации речи, а также намеренно предают забвению имена отечественных ученых.

Заключение. Тема противодействия процессам культурной глобализации затрагивает широкий спектр гуманитарных проблем в жизни страны. Общественная значимость литературного языка имеет в своей основе национальную культуру и государственность. Необходима последовательная государственная языковая политика, способствующая естественному развитию национального языка. Примером служат сильные «охранительные» традиции во Франции, Израиле, Японии, Китае.

Этический аспект - главный в жизни языка, он обусловлен его диалогической и социальной природой. Концепт «этика» содержит такие категории, как «свобода», «желательность», «допустимость», а в рамках этого поля - существование категории «принуждение» - как принуждение следовать языковым нормам, принуждение как противление злу, как защита прав всего языкового сообщества. Защита литературного языка — это условие национальной безопасности.

\section{Elena M. Lazutkina}

V. V. Vinogradov Russian Language Institute of the Russian Academy of Sciences (Russia, Moscow) lazutkelena@yandex.ru

\section{THE DESTRUCTION OF NATIONAL LANGUAGES IN THE ERA OF GLOBALIZATION}

XXI century - era of globalization. In various countries consistently pursues a policy of indirect influence, which is part of cultural globalization. The author addresses the problem of preservation and development of the national language.

The process of globalization throughout the world creates, through political pressure, economic conditions and ideology, the factors of the destruction of languages and 
national culture. The following phenomena can be attributed to such factors: violation of historically established ethical rules of communication, destruction of the dialogue basis of language, non-observance of linguistic norms, denial of prestige of high level of language competence, change of pragmatics of communication, introduction of Englishspeaking elements into speech practice.

Globalizers seek to destroy the common space of cultural communicative interaction in Russia and spread the thesis that there is no commonly used literary language and functional styles, and the existence of regional variants of the Russian language.

Agents of globalization also destroy the science of language: they ignore or criticize the achievements of the national linguistics recognized all over the world, ignore the high level of theoretical developments of the 20th century in the field of methodology for studying the language system and the semantic organization of speech, and deliberately neglect the names of Russian scientists. Globalizers limit the tasks of Russian philology by registering verbal facts lying on the surface and compiling descriptive type dictionaries.

The author believes that a consistent state language policy is needed that promotes the natural development of the national language, as well as the promotion of linguistic knowledge and the culture of speech.

Key words: globalization, literary Russian language, linguistic pragmatics, ethics of communication, language policy. 


\author{
М. В. Ляпон \\ Институт русского языка им. В. В. Виноградова РАН \\ Россия, Москва \\ lyapon@list.ru
}

\title{
ИГРОВАЯ РИТОРИКА - ПРАКТИКУМ ПО КУЛЬТУРЕ РЕЧИ
}

В статье представлены результаты изучения современных кроссвордов в когнитивно-лингвистическом аспекте. В центре внимания автора статьи: (1) кроссворд как продукт остроумия и как специфическая модель общения с читателем-разгадчиком; оценка (в первом приближении) жанрово-стилистических особенностей языковой игры-загадки; (2) кроссворд как приобщение разгадчика к проблемам, относящимся к собственно лингвистической компетенции (лексическая полисемия; полиноминализация; эллипсис в конструкциях с прилагательными и др.); (3) смысловые смещения, обусловленные фигуральной логикой; окказиональная метафорика в комбинации с «тайнописью» идиомы и др. приемы, дезориентирующие и одновременно выполняющие роль подсказки. Аргументация тезиса, согласно которому современный кроссворд представляет собой практикум по культуре речи, сводится к следующему. Искомое слово в кроссворде не толкуется, а подсказывается по опознавательным приметам, избираемым произвольно. Объект «толкования» здесь свободно модифицирует свой статус: составитель то имеет в виду экстралингвистическую реалию (означаемое), то фиксирует внимание на само́м способе означивания. Изучаемый кроссворд широко использует идиоматику различного синтаксического формата и функциональностилистической принадлежности, включая (I) афоризмы и (II) коллокации (клишированные речения, не являющиеся законченными и обобщающими суждениями). Задача разгадчика - мысленно реконструировать (опознать) подразумеваемый фразеологический контекст, включающий искомое слово. Компоненты подразумеваемых клишированных словосочетаний творчески перефразируются на основе произвольных аналогий. Ассоциируемый признак угадывается не только по расхожему речению, наводящему на правильный ответ, но также по ключевому слову, которое служит специфическим «культурным знаком», намекающим

${ }^{1}$ Работа выполнена при финансовой поддержке РГНФ № 15-04-00208 («Автор — адресат текст. Когнитивно-лингвистические аспекты феномена “чтения”»). 
на обычай, поверье, народную примету. Разгадывание кроссворда - это своего рода добровольный самоэкзамен: читатель получает возможность оценить уровень своей образованности как член социума, и свою интуицию как носитель языка.

Ключевые слова: русский язык, культура речи, игровая риторика, экспериментальная метафора, когнитивно-лингвистическая интерпретация текста.

Эмпирический материал статьи - избранные кроссворды, приоритетная роль которых - стимулировать творческую инициативу адресата при расшифровке «тайнописи», к которой прибегает автор (использованы материалы кроссвордов, опубликованных в 2011-2017 гг.).

Языковая игра-задача, о которой идет речь, адресована носителю языка, заинтересованному в обретении (или в совершенствовании) своей лингвистической компетентности, в познании универсальных законов естественного языка и правил риторики (как науки и искусства эффективной коммуникации). Современный кроссворд вводит читателя-разгадчика в состояние продуктивного поиска. Очевидно, что кроссворд, который имитирует словарное толкование, имеет меньше шансов увлечь читателя.

Успешный - стимулирующий - кроссворд творчески использует идиоматику (в широком смысле слова), комические модуляции лексических значений, окказиональную метафорику, в том числе буквализм (антиметафору, контрметафору) и др. приемы, которые приобщают носителя языка к проблемам, относящимся к собственно лингвистической компетенции (полисемия, полиноминализация, синтаксис грамматических классов слов и др.).

В соответствии с игровым режимом загадки вопрос во многих случаях прозрачно намекает на внутреннюю форму искомого слова. Вопрос: Лодырь, «мотающий головой» (ответ: лоботряс). Вопрос: Насмешник, не скрывающий белоснежную улыбку (ответ: зубоскал). Вопрос: Кусачая муха с «плохим зрением» (ответ: слепень). Вопрос: Формалист, «пожирающий алфавит» (ответ: буквоед). Вопрос: «Единогласная» часть слова (ответ: слог). Вопрос: Жучок-«фонарик» (ответ: светлячок). Вопрос: «Расчёска» среди моллюсков (ответ: гребешок). Вопрос: Трактирообразный овощ (ответ: кабачок). Вопрос: Гладкоствольное охотничье ружьё, заряжаемое «нецелыми числами» (ответ: дробовик). Вопрос: Клиент, «дающий денег взаймы» банку (ответ: вкладчик). Вопрос: «Таинственный» шкаф с откидной доской, заменяющей письменный стол (ответ: секретер). Вопрос: Участница «маскарада» из молочных продуктов (ответ: ряженка). Вопрос: «Прокуренный» пиджак джентльмена (omвет: смокинг). Вопрос: Поражение, в отличие от победы, у которой тысяча отцов (ответ: сирота). Подразумеваемая искомая метафора в данном случае угадывается по антитезе, о чем оговаривается в вопросе. Bonрос: «Идущая ко дну» красивая несбыточная мечта (ответ: утопия). Слово утопия, созданное Т. Мором, буквально значит: 'место, которого нет' [ТСРЯ 2007: 1039].

Кроссворд - это игра альтернативными номинациями, стимулирующая поисковую активность разгадчика, его интерес к этимологии, к продуцирующим механизмам звуковой плоти языка. Вопрос: Злак, «выросший» на глазу (ответ: 
ячмень). Вопрос: Хамелеон в мире животных (ответ: ящерица). Вопрос: Богомол, которым интересуется энтомолог (ответ: насекомое). В цитируемых выше случаях специализированные значения (ячмень в офтальмологии; хамелеон в зоологии; богомол в энтомологии) сопоставлены с дезориентирующими омонимами в нетерминологическом смысле.

Кроссворд - это опыт блуждания вокруг денотата. Смысловое смещение, обусловленное фигуральной логикой; окказиональная метафорика в комбинации с тайнописью идиомы; вариативность фоно-акустических паронимов; дезориентирующая полисемия - все это убеждает в том, что язык - открытая система, податливая для творческого эксперимента. «Каждая эпоха добавляет к запасам языка горсть новых значимых метафор» [Парандовский 1990: 160].

В отличие от массового адресата (ему достаточно, не задумываясь над тем, какие ресурсы языка задействованы инициатором задачи, довериться собственной интуиции), цель лингвиста — «прочитать» кроссворд бифокальным взглядом, фиксируя внимание на приемах риторики, задействованных в языковом эксперименте.

Изучаемый материал содержит остроумные эвфемизмы, - маскирующие альтернативные номинации, диктуемые правилами речевого этикета. Вопрос: Культурное название нелепости (ответ: нонсенс). Вопрос: Корректное название чужой бессмыслицы (ответ: абсурд). Вопрос: Обидное прозвище плохо видящего ученика (ответ: очкарик). Вопрос: Актер, которому не верят зрители (ответ: бездарь). Вопрос: Юнец, «страдающий вечным насморком» (omвеm: сопляк). Bonpoc: «Несветлый» эпитет для необразованного человека (ответ: темнота). Bonрос: «Банкет» пенсионеров, не употребляющих спиртные напитки (ответ: чаепитие). В данном контексте искомый ответ (чаепитие), как и его «смягчающая» интерпретация, прочитываются с иронической коннотацией, так что стилистическая оппозиция (эвфемизм / нейтральньій аналог) разрушается. Пример парадоксальной мены позиций (в роли эвфемизма - ответное слово охотник). Вопрос: Ходячий зверобой с ружьём (ответ: охотник).

$$
* * *
$$

Строго говоря, кроссворд - это явная оппозиция лексикографической практике. Искомое слово в кроссворде не толкуется, а скорее подсказывается по опознавательным приметам, избираемым произвольно. Объект «толкования» здесь свободно модифицирует свой статус: составитель имеет в виду то экстралингвистическую реалию (означаемое), то фиксирует внимание на само́м способе означивания, маскируя и одновременно подсказывая разгадку. Согласимся, что термин метафора «должен соответствовать скорее тому, что сами говорящие ощущают как яркое, нестандартное употребление слова, чем относиться к таким выражениям, как ножка стола» [Блэк 1990: 171].

Примеры экспериментальных метафорических проекций, в которых обе позиции (образный «донор» и цель) занимают именования из предметного мира. Вопрос: «Макраме» в лодке рыбака (ответ: сеть). Вопрос: «Вентилятор» в руках раба (ответ: опахало). Вопрос: «Патронташ» Амура (ответ: колчан). 
Bопрос: «Кий» в руке учительницы (ответ: указка). Вопрос: «Капкан» для радиоволн (ответ: антенна). Вопрос: «Респиратор» для кусачей собаки (ответ: намордник). Bonрос: Белый «зуб» рояля (ответ: клавиша). Вопрос: Плёнка, на которой негр побелел (ответ: негатив). Вопрос: «Костыли» для приборов (ответ: тренога). Boпрос: «Обложка», что отсутствовала у солдатского треугольника (ответ: конверт). Вопрос: Металлический гараж «с берега морского» (ответ: ракушка).

Представление предметного мира в образах, относящихся к живым существам. Bопрос: «Ладошка» пропеллера (ответ: лопасть). Вопрос: «Орган слуха» у иголки (ответ: ушко). Вопрос: Шаг самой шустрой стрелки на часах (ответ: секунда). Вопрос: Висящий за окошком «синоптик» с ртутным столбиком (ответ: термометр). Вопрос: «Буревестник» среди приборов (ответ: барометр). Вопрос: Знойная «талия» земного шара (ответ: экватор). Вопрос: «Макияж» черно-белой фотографии (ответ: ретушь). Вопрос: «Жабры» водолаза (ответ: акваланг).

Представление животного мира в образах, относящихся к человеку. Вопрос: Морской интеллектуал - друг человека (ответ: дельфин). Вопрос: «Император» Антарктиды, занесенный в Красную книгу (ответ: пингвин). Вопрос: «Электрик» подводного мира (ответ: скат). Вопрос: «Гардеробщица» среди бабочек (ответ: моль). Вопрос: Слепой диверсант, вскрывающий газоны (oтвет: крот). Вопрос: Лентяй из пчелиной семьи (ответ: трутень). Вопрос: Двукрылая осенняя «флегма» на оконном стекле (ответ: муха). Вопрос: Курица «в декретном отпуске» (ответ: наседка). Вопрос: Рак, который живет «как монах» (ответ: отшельник).

Представление животного фигуральным аналогом из предметного мира. Bonрос: Морской «зонтик» с жгучими щупальцами (ответ: медуза). Вопрос: «Подъемный кран» у индийцев (ответ: слон).

Представление растительного мира в образах человека. Вопрос: Цветок, «лысеющий» от дуновения ветра (ответ: одуванчик). Вопрос: Цветочный «оракул» для влюбленных (ответ: ромашка). Вопрос: Зелёный участник фотосинтеза (ответ: растение). При соположении паронимов фигуральный аналог (донор) и объект фигуральной номинации (цель) $)^{2}$ могут менять свои позиции: образный донор — растение, цель - человек. Вопрос: «Морозоустойчивый» россиянин (omвет: сибиряк).

Нетривиальные аналогии в обозначении внутренних ментальных состояний и ощущений человека. Вопрос: Душевный «вакуум» (ответ: пустота). Воnрос: «Винегрет» из мыслей в голове (ответ: мешанина). Вопрос: «Пожар», который гасят содовым раствором (ответ: изжога). Вопрос: «Нотки» соды в столовском коржике (ответ: привкус). Вопрос: «Вопль» голодного желудка (ответ: урчание).

Представление природных явлений в образах, относящихся к человеку (олицетворение природных явлений). Вопрос: Речной «попутчик» пассивно

2 Термины «донор» и «цель» (для обозначения метафорической проекции) соответствуют понятиям «образ сравнения» и «предмет сравнения», которыми пользуются авторы проекта «Материалы к словарю метафор и сравнений русской литературы XIX-XX вв.» [Кожевникова, Петрова 2010: 294, 296]. 
плывущего (ответ: течение). Вопрос: Процесс, «выводящий из себя» воду (ответ: кипение). Вопрос: «Безмолвие» перед грозой (ответ: затишье). Вопрос: «Ноша» атмосферного циклона (ответ: осадки). Вопрос: Временная «отключка» Солнца (ответ: затмение). Вопрос: «Беговая дорожка» Земли (ответ: орбита).

Изучаемый стимулирующий кроссворд широко использует идиоматику различного синтаксического формата и функционально-стилистической принадлежности, включая (I) афоризмы и (II) коллокации (клишированные речения, не являющиеся законченными и обобщающими суждениями). Задача разгадчика - мысленно реконструировать (опознать) подразумеваемый фразеологический контекст, включающий искомое слово.

(I) Bonрос: «Пришелец» во время еды (ответ: аппетит). Вопрос: «Особа», отдыхающая на детях гениев (ответ: природа). Вопрос: Философская «начинка» вина (ответ: истина). Вопрос: «Рупор» истины у младенца (ответ: уста). Вопрос: Платон, который дешевле истины (ответ: друг). Вопрос: «Медицинская специальность» времени (ответ: лекарь). Вопрос: Птица в небе, которая хуже синицы в руке (ответ: журавль). Вопрос: Забава, которой отведен лишь час (ответ: потеха). Вопрос: Золото по сравнению со словом-серебром (ответ: молчание). Вопрос: Запретная тема для споров (ответ: вкус). Вопрос: Блюдо, которое не надо путать с божьим даром (ответ: яичница). Вопрос: Чужое хлебобулочное изделие, на которое не советуют рот разевать (ответ: каравай). Вопрос: «Устройство» для бесплатного сыра (ответ: мышеловка).

(II) Bопрос: Сосуд, переполняющийся терпением (ответ: чаша). Bonpoc: Минимальная порция свежего воздуха (ответ: глоток). Вопрос: Спор, который держат (ответ: пари). Вопрос: Мрак, в котором блуждают (ответ: потёмки). Вопрос: Сустав, который пытаются кусать с досады (ответ: локоть). Вопрос: Голова, в которой «варятся мысли» (ответ: котелок). Вопрос: Чувство, сменяемое на милость (ответ: гнев). Вопрос: Высь, которую коптят (ответ: небо). Вопрос: «Соринка», не замечаемая в своем глазу (ответ: бревно). Вопрос: Мастер, съевший собаку в своем деле(ответ: дока). Вопрос: Зверь, наступивший на ухо певцу (ответ: медведь). Вопрос: «Ладан», которого моль боится (ответ: нафталин). Вопрос: «Лавочка» для человека, уже готового к путешествию (ответ: чемодан). Вопрос: «Необидная» плотность (ответ: теснота). Вопрос: Повозка, обходящаяся без пятого колеса (ответ: телега). Вопрос: Письменная жалоба «на колёсах» (ответ: телега). Bonpoc: Фрукт, который «не может найти себе места» на переполненном пляже (ответ: яблоко). Вопрос: Металл, из которого «сделаны» грозовые тучи (ответ: свинец). Вопрос: Металл, «вызывающий» лихорадку (ответ: золото). Вопрос: Слово, дополняющее «свободу» и «равенство» в национальном девизе Французской республики (ответ: братство). Вопрос: «Довесок» к хлебу, что требовали древние римляне (ответ: зрелища).

Расхожее речение-коллокат используется как экспериментальный образный донор, т. е. в роли подсобной метафоры второго уровня. Вопрос: «Северный полюс» в холодильнике (ответ: морозилка). Вопрос: «Геенна огненная» в газовой плите (ответ: духовка). Вопрос: «Персона нон грата» на грядке (ответ: сорняк). Вопрос: 
Виртуальное «окно в Европу» (ответ: интернет). Вопрос: Автомобиль, у которого «крыша едет» (ответ: кабриолет). Данный пример иллюстрирует пересечение разных мотиваций: (1) крышиа едет (намек на идиому крышиа поехала); (2) автомобиль актуализирует два значения: ‘автомашина' и 'самодвижущийся механизм' (применительно к автоматически складывающемуся верху кабриолета).

Преимущество игры-загадки заключается в том, что в таком формате открывается возможность продемонстрировать нестандартные модели метафорических проекций и оригинальные сопряжения фигуральной логики с идиоматикой. Экспериментальная метафора может использоваться и при отсылке к мифологическому контексту. Вопрос: «Тренажёр» Сизифа, вкатывающего камень (oтвет: гора) ${ }^{3}$.

Изучаемый материал показывает, что компоненты подразумеваемых клишированных словосочетаний творчески перефразируются на основе произвольных аналогий. Ассоциируемый признак угадывается не только по расхожему речению, наводящему на правильный ответ, но также по ключевому слову, которое служит специфическим «культурным знаком», намекающим на обычай, поверье, народную примету. Вопрос: «Прибыль» от найденной подковы (oтвет: счастье). Вопрос: «Счастье», прибитое над дверью (ответ: подкова). Вопрос: Воспитательный стык стен (ответ: угол). Вопрос: «Холостое» место за столом (ответ: угол). Воnрос: Человек, отпугивающий деньги (ответ: свистун).

$$
* * *
$$

При всей широте тематического размаха кроссворд фиксирует в ответах исключительно субстантивные номинации: искомое слово может быть только именем существительным. Поэтому кроссворд, разумеется, нельзя абсолютизировать как исчерпывающий источник обогащения внутреннего (индивидуального) лексикона человека. Вместе с тем вопрос составителя может быть информативен для изучения активных тенденций в синтаксисе других частей речи, например, имени прилагательного.

В поисках нестандартного аналога словарной дефиниции составитель кроссворда, предпочитая форму живого общения, использует оправданный разговорной нормой прием семантического эллипсиса. Вопрос: «Меховое» название наждачной бумаги (ответ: шкурка). Вопрос: «Морское» название металлического разборного гаража (ответ: ракушка). Вопрос: Съедобный гриб с «холестериновым» названием (ответ: масленок). Вопрос: Ручная граната с «цитрусовым» названием (ответ: лимонка). Вопрос: Шапка с «кулинарным» названием (ответ: пирожок). Bonpoc: Советский колхоз с «утренним» названием (ответ: рассвет). Вопрос: Раковина на ножке с цветочным названием (ответ: тюльпан). Вопрос: Взрывное прозвище узбекской дыни (ответ: торпеда). Вопрос: Кочанный салат с «ледяным» названием (ответ: айсберг). Вопрос: Российская эстрадная певица с «сахарным» псевдонимом (ответ: глюкоза).

${ }^{3}$ Сизиф, наказанный за свои преступления, должен был вкатывать в гору тяжелый камень, который, достигая вершины, срывался вниз, так что всю работу надо было начинать сначала [Мифы народов мира 1982: 439]. 
Как видно из цитируемых выше примеров, когнитивная цепочка восстанавливается при поддержке слов: «название», «псевдоним» «прозвище». При отсутствии такой подсказки связь прилагательного с искомым словом оказывается менее прозрачной. Вопрос: «Недеревенская игра» (ответ: городки). Вопрос: «Фруктовый» танец матросов (ответ: яблочко). Вопрос: «Белокочанный» театральный междусобойчик (ответ: капустник). Вопрос: «Съедобное» слово-паразит в речи (ответ: блин). Bопрос: «Игрушечная» стадия бабочки (ответ: куколка). Вопрос: «Игрушечная» порода собак (ответ: той-терьер). Вопрос: «Почтовое» одеяло для грудных детей (ответ: конверт). Вопрос: Морозный «макияж» щек (ответ: румянец). Bопрос: Обувная улика для сыщика (ответ: след). Вопрос: Весёлое лекарство от всех болезней (ответ: смех).

Семантический эллипсис настораживает разгадчика явным алогизмом: прилагательное реализует только формально-грамматическую валентность (род, число). Поводом для игровой модуляции может служить дезориентирующее столкновение функциональных параметров прилагательного: (1) значения качественного (оценочно-квалифицирующего) и (2) значения относительного. Вопрос: Клёвое хобби мужа (ответ: рыбалка). В данном случае клёвый окказионально соотнесено со словом клёв (о рыбной ловле). Аналогичная двойственность мотивации отмечается в цитируемых ниже случаях. Вопрос: «Гнусный отряд» в заболоченных местах (ответ: мошкара). Вопрос: «Ослепительная» добавка к фотоаппарату (ответ: вспышка). Bonрос: Пламенный отпечаток на коже (ответ: ожог). Вопрос: «Вековая» косметика (ответ: тени). Вопрос: «Фундаментальный» роман Андрея Платонова (ответ: котлован). Вопрос: «Монументальная» повесть Василя Быкова (ответ: обелиск).

В условиях кроссворда прилагательное оказывается в роли самодостаточного посредника, подсказывая искомое слово по смысловой аналогии; при этом диапазон мотиваций, наводящих на правильный ответ, оказывается весьма широким: речь идет о метонимии, понимаемой максимально гибко ('смежность', 'причастность', 'ассоциируемость').

$$
* * *
$$

Стимулирующий кроссворд «метит дальше цели». Даже если эту дальнюю цель составитель не преследует, мы невольно в ходе поиска вовлечены в постижение фундаментальных законов жизнедеятельности естественного языка. Разгадывание кроссворда - это своего рода экзамен, точнее, добровольный самоэкзамен: читатель получает возможность оценить уровень своей образованности как член социума, и свою интуицию как носитель языка. Кроссворд как бы тестирует разгадчика с разных сторон; и вопрос о том, какая из «сверхзадач» является первостепенной, а какая - второстепенной - вопрос не праздный. «До того как человек заслужил себе аристотелевское определение zõon politikon - общественное животное, он уже давно дорос до права называться zõon poiētikon - поэтическое животное» [Парандовский 1990: 159].

Рассматриваемый материал принадлежит компетенции культуры речи как специальной лингвистической дисциплины, исполняющей важную гуманитарную 
миссию. Современный стимулирующий кроссворд - это практикум, который обогащает внутренний лексикон индивида. «Социологи признают “горькую правду”, - писал Р. Якобсон, — о том, что проникновение в язык может дать социологии больше, чем социология лингвистике» [Якобсон 1985: 384].

\section{Литература}

Блэк М. Метафора // Теория метафоры. М.: Прогресс, 1990. С. 153-172.

Кожевникова Н.А., Петрова 3. Ю. Материалы к словарю метафор и сравнений русской литературы XIX-XX вв. М.: Языки славянских культур, 2010. 512 с.

Мифы народов мира. В 2-х томах. Т. II. М.: Издательство «Советская энциклопедия», 1982. 719 с.

Парандовский Я. Алхимия слова. М.: Правда, 1990. 656 с.

ТСРЯ - Толковый словарь русского языка с включением сведений о происхождении слов / РАН. Институт русского языка им. В.В. Виноградова. Отв. ред. Н. Ю. Шведова. М.: Издательский центр «Азбуковник», 2007. 1175 с.

Якобсон Р. Лингвистика в ее отношении к другим наукам // Якобсон Р. Избранные работы. М.: Прогресс, 1985. С. 369-420.

\section{Maya V. Lyapon}

V. V. Vinogradov Russian Language Institute of the Russian Academy of Sciences

(Russia, Moscow)

lyapon@list.ru

\section{GAME RHETORIC: A GUIDE TO SPEECH CULTURE}

The paper deals with the results of studying contemporary crosswords from the cognitive linguistic standpoint. The author focuses on the following aspects: (i) the crossword as a product of wit and as a specific model of interaction between the author and the reader/solver; preliminary evaluation of genre-specific and stylistic peculiarities of the riddle as a language game; (2) the crossword as a way of familiarizing the solver with problems pertaining to language faculty per se (lexical polysemy; polynominalization; ellipsis in adjectival constructions, etc.); (3) semantic shifts caused by figurative logic; occasional metaphorical models combined with idioms' "cryptography" and other devices that are both disorienting and prompting the solver. One can prove that the contemporary crossword is a guide to speech culture by the following: the words being unriddled in a crossword are not interpreted but rather hinted at by means of identifying characteristics taken arbitrarily. The object of "interpretation" modifies its status freely, as the crossword compiler either means the extralinguistic fragment of reality (i.e. the signified), or focuses on the very means of denotation. The crossword uses idioms of varying syntactic structure and style, including (a) aphorisms and (b) restricted collocations (viz. clichéd 
expressions that do not serve as definitive and general assertions). The solver is supposed to reconstruct and recognize the implied idiomatic context comprising the desired word. The constituents of implicit clichéd word-groups are creatively rephrased by means of arbitrary analogy. The feature used for association with the desired word can be guessed by means of a familiar idiom or cliché hinting at the right answer, as well as by a key word that serves as a specific cultural sign identifying a custom, a popular belief or a piece of country lore. Solving a crossword is not unlike voluntarily passing a self-examination, with the reader/solver getting an opportunity of evaluating their education (as s member of a community) and their intuition (as a native speaker).

Key words: the Russian language, speech culture, game rhetoric, experimental metaphor, cognitive-linguistic text interpretation.

\section{References}

Black, M. Metafora [Models and Metaphors]. Teoriya metafory [Theory of Metaphor]. Moscow: Progress Publ., 1990. P. 171.

Jakobson, R. Lingvistika v ee otnoshenii k drugim naukam [Lignuistics in its relation to other sciences]. Jakobson, R. Izbrannye raboty [Selected Papers]. Moscow: Progress Publ., 1985. P. 384.

Kozhevnikova, N. A., Petrova, Z. Yu. Materialy k slovaryu metafor i sravnenij russkoj literatury $X I X-X X v v$. [Materials for the Dictionary of Metaphors and Similes in the Russian Literature of $19^{\text {th }}$ and $20^{\text {th }}$ Centuries]. Moscow: Yazyki slavyanskikh kul' tur Publ., 2010. 512 p.

Mify narodov mira [World Mythologies]. Vol. II. M., 1982. P. 439.

Parandowski, J. Alkhimiya slova [The Alchemy of Word]. Moscow: Pravda Publ., 1990. P. 159. 


\author{
Н.Б. Мечковская \\ Белорусский государственный университет \\ (Беларусь, Минск) \\ nina.mechkovskaya@gmail.com
}

\title{
ЯЗЫКОВАЯ ДЕМОКРАТИЗАЦИЯ, ЛИБЕРАЛИЗАЦИЯ И ВСТРЕЧНЫЕ ПРОЦЕССЫ: СООТНОШЕНИЕ СТИХИИ И ПЛАНИРОВАНИЯ
}

В истории письменно-литературного общения есть два этапа в развитии языковых ситуаций, каждому из которых соответствует свой тип литературного языка с глубоко различными (в каждом типе) взаимоотношениями между нормативным языком и естественной («живой») разговорной речью. Литературные языки первого (раннего) типа складывались по мере распространения мировых религий Писания в ситуациях культурно-религиозного двуязычия, когда в одном социуме используются два идиома: 1) надэтнический культовый язык, признаваемый правильным и единственно допустимым в религии и высокой культуре, и 2) этнический (народный) язык, мыслимый вне нормативных оценок. Исторически первая лингвистическая идеология была чужда тому, что сейчас ассоциируется с языковым демократизмом. Ее характерные черты таковы: стремление удержать культовый язык в церкви и близких к ней престижных сферах жизни, сохранить культовый язык в его первоначальном виде; консервативно-реставрационная направленность филологической работы. Литературные языки современного типа начинали складываться в послефеодальное время, по мере секуляризации образования и культуры. Религиозное двуязычие постепенно уступало место национальному одноязычию. Наиболее глубокое типологическое различие между литературным языком раннего и современного типа состоит в том, что в народных языках разговорная речь стала сниженным регистром нормативного коммуницирования. В результате расширились области использования нормированной речи; во всем народонаселении резко вырос процент носителей языкового стандарта. В недалеком будущем объемы категорий «общенародный язык» и «литературный язык» совпадут. Демократизация литературных языков обусловлена тысячелетними стихийным тенденциям в истории человечества и является языковой компонентой двух трендов - интенсификации жизни и гомогенизации людских сообществ. Параллельно распространению признаков внешней (стилистической) демократичности языков присходит их структурно-синтаксическое и терминологическое усложнение. 
Ключевые слова: культурно-религиозное двуязычие, типология литературных (стандартных) языков, демократизирующие реформы в истории литературных языков, либеральная кодификация, факторы демократизации литературных языков, графико-орфографические реформы, пределы и противовесы языковой демократизации.

\section{1. Рабочие определения терминов «демократизация» и «либерализация»} применительно к языку. Явления и процессы, соответствующие представлениям о «демократизации» и «либерализации» языка, имеют место в истории литературных (стандартных) языков, владение которыми требует от говорящих усвоения языковых норм и следования им в своей речевой практике. Демократизация состоит в принятии кодификационных решений, направленных на уменьшение усилий говорящих при усвоении норм «правильного» языка и общения (таковы, например, реформа письма в России 1708-1710 гг.; реформа русской графики и орфографии 1912-1918 гг.); реформа немецкого правописания 1996-2006 гг. и др.). Демократизация выражается в большей коллоквиализации культурной речи: в школе, в радио-/телеэфире не надо переходить на более ли менее другой язык или стиль; можно говорить как дома, как обычно среди своих. Демократизация обедняет язык: она ведет к отказу от архаизмов, редких, идиоматичных и немотивированных форм в пользу наглядного, обычного, легко объяснимого.

Либерализм в кодификации привносит в социум бо́льшую терпимость к жаргонизмам, диалектизмам, просторечным формам и другим вариантам речи, которые еще недавно казались ошибкой и подлежали исправлению. В лингвистических работах подобные явления иногда трактуют как «расшатывание нормы». Так, по данным М.Я. Гловинской, на исходе XX в. редакторы оставляли без исправлений, в том числе на письме, построения, которые прежде считались ошибкой, например, ряд конструкций с «независимым деепричастным» оборотом; употребление местоимения свой вместо личного притяжательного местоимения (твой, ваш, его, $u x)^{1}$ и т.п. В годы языковой либерализации в справочниках по культуре речи возрастает количество допустимых вариантов.

Языковому либерализму противостоят две тенденции разного генезиса: 1) запреты и ограничения, идущие от языковой политики и обычно обусловленные общим политическим антилиберализмом (ср. начатый в 1930-х гг. М. Горьким крестовый поход против диалектизмов в литературе); 2) забота о культуре речи: внимание и чувствительность к языку в условиях расцвета литературы, прививаемые хорошей гимназией, литературной критикой, просветительской лингвистикой (см. адресованные широкому читателю работы 1910-х гг. В.И. Чернышева, А. М. Пешковского, Л.В. Щербы).

${ }^{1}$ Ср. у А. Битова в «Пушкинском доме»: Взгляд у него был особый: приходилось думать, вставной ли у него глаз, но, присмотревшись, оказывалось, что не вставной [Гловинская 1996: 286]; в учебнике русского языка 1993 г.: Почитайте рассказ В.И. Сурикова о своем <вместо его> детстве [Там же: 294]. 


\section{2. Является ли демократизация универсальным трендом в истории литера-} турных языков? В 1928 г. Б. А. Ларин писал, что «в последнем полустолетии» в Европе и Америке усиливается «просачивание в разговорную (и художественно-литературную) речь» экспрессивных средств из языка социальных низов. Ларин считал эту тенденцию универсальной: «Историческая эволюция любого литературного языка может быть представлена как ряд последовательных “снижений”, варваризаций [...]» [Ларин 1928/1977: 176]. Однако этот тезис нуждается в существенном ограничении: демократизация литературных языков характерна для новой, послефеодальной Европы, но в истории сложения первых литературных языков вектор развития был прямо противоположным - отталкивание от живого «естественного» языка говорящих.

Б. А. Успенский в «Истории русского литературного языка (XI-XVII вв.)» (1987) показал, что в культуре Древней Руси принятие «литературного» (церковнославянского [далее — ц.сл]) языка, древнеболгарского в своей основе, и семь веков его истории были нарастающим противостоянием «книжного» и «живого» «некнижного» языка, которое вписывается «в противопоставление культуры и природы» [Успенский 1987: 8-9]. При этом принятие и история литературного языка предстает как «отталкивание от разговорной речи»; второе южнославянское влияние книжной реформы болгарского патриарха Евфимия Тырновского XIV в., давшей начало «книжной справе» на Руси, несло с собой пурификаторские и реставрационные тенденции, что приводило к усилению различий между книжным и некнижным языком [Успенский 1987: 181-191].

Таким образом, само появление литературного («правильного») языка отнюдь не было «демократизацией» естественной речевой практики говорящих. Напротив, идея «правильного» или «должного» в языке, искусственное удерживание особенностей книжного языка, которым надо специально учиться, - всё это вело к появлению элитарной речи, уходившей от естественной «речевой демократии» бесписьменного общения. Языковая дистанция между книжным и разговорным языком была особенно значительной в тех типичных для истории письма ситуациях, когда письменная культура зарождалась не на родном языке этноса (материнском, т.е. естественно доступном для людей, образующих этнос), но на языке более или менее чужом — на том языке, на котором народ принимал новую религию, общую для соседних народов.

Ситуации культурно-религиозного двуязычия складывались в I тысячелетии н.э., по мере распространения теизма, религий Писания (иудаизм, христианство, ислам), полиэтнических (индуизм, конфуцианство и др.) и мировых религий (буддизм, христианство, ислам). В разных регионах Евразии складывались культурно-религиозные миры - мир индуизма, мир конфуцианства, мир буддизма, христианства (с последующим разделением на католичество и православие), мир ислама. Культурно-религиозный мир, в который входили разноязычные этносы, внутри себя был объединен вероисповеданием, книгами своей веры и языком вероучительных книг. Единство веры и языка Писания было сильнее этнических различий. Так сложились ареалы культурно-религиозного двуязычия, в которых противостояли друг другу, с одной стороны, «свой» язык (народный, местный, лат. vernacula 'туземный'), а с другой, - надэтнический язык церкви, Писания (lingua sacra), — книжный язык 
новой религиозной культуры — и потому язык «правильный», престижный, в современных терминах, - «литературный». Общение на народных языках, и устное и письменное, находилось вне нормативного пространства, в глазах элиты - вне престижной культуры. См. также [Мечковская 2017: 125-136].

\section{3. Почему культурно-религиозное двуязычие, несмотря на свою внутрен- нюю конфликтность, сохранялось в разных ареалах средневекового мира} на протяжении веков? Использование двух языков в границах одного социума в принципе избыточно, чревато конкуренцией языков и потому конфликтно. Однако ситуации культурно-религиозного двуязычия (особенно в условиях его более радикальной разновидности - диглоссии) сохраняются веками, потому что по своим функциям народный (местный) язык и престижный надэтнический язык находятся в «дополнительном» распределении и не конкурируют между собой в конкретных сферах общения: надэтнический язык используется в «высоком» (небытовом) общении (в церкви, книжно-письменной культуре, науке, образовании) и не принят в повседневном общении. Народный язык, напротив, возможен только в устном повседневном общении и в немногих жанрах письменности (тексты законов, деловая документация, частная переписка), иногда в «низовых» жанрах беллетристики. В ситуациях диглоссии, особенно при генеалогической близости между надэтническим и народным языком, надэтнический язык может восприниматься как высокая разновидность (вроде стиля) своего народного языка. Таким было отношение к ц.-сл языку у православных славян: в украинских и белорусских землях - до появления во второй половине XVI в. переводов библейских книг на народные языки, в допетровской Руси до начала XVIII в., у болгар — до 1760-х гг., у сербов до конца XVIII в. В Московской Руси подобное понимание различий между ц.-сл и русским позволяло увидеть русский язык в аспекте ц.-сл: тогда русский представал как «простая» разновидность ц.сл. Именно так писал о русском языке Аврамий Фирсов в предисловии к своему русскому переводу Псалтыри: преведена [...] Чалтїрь на нашъ простои, шбыклои словенскои Азыкъ [Псалтырь 1683 / 2006: 180].

Несмотря на престиж надэтнических книжных текстов, на их изучение в школах и университетах Европы, на рано появившиеся латинские и ц.-сл словари и грамматики, дистанция между языками учеными и народными, даже если они были в близком родстве, возрастала. Между тем культурные запросы народов расширялись, усиливалась потребность говорить в церкви и книжной культуре на более понятном языке. Однако стремления к демократизации книжного языка столкнулись с фидеистическим сознанием, которое веками противилось переводам Писания и особенно храмового богослужения на народные языки. Для религиозного сознания характерно трепетное, иррационально-пристрастное отношение к богослужебным книгам; отсюда - словесный «средневековый фетишизм» (В. В. Виноградов), характерное для мифологического сознания «неконвенциональное отношение к знаку» (Б. А. Успенский), т.е. убежденность в том, что слово - не условная метка предмета, но его часть. «В силу неконвенциональности понимания знака сакральность содержания [Писания и богослужебных книг. - Н. М.] переносится на средства выражения, и самый язык воспринимается как сакральный» [Успенский 1987: 
20]. Отсюда запрет и страх не только переводить, но и изменить самую малость в церковной книге; отсюда вера, что только по «правильным» книгам спасешься, а по неправильным - будешь гореть в аду.

В христианстве, иудаизме, исламе требования к уровню компетенции в церковном языке, к качеству филологической работы «при Писании» выходили за пределы грамматики в богословие. Труд переводчиков, справщиков, переписчиков, позже наборщиков был опасен: ошибки письма, неточности перевода, нередко сама попытка перевода грозили обвинениями в ереси. Вокруг библейских переводов, служебников и катехизисов, толковых псалтырей и учительных евангелий кипели страсти и лилась кровь. В Западной Европе, в Slavia Latina, Slavia Orthodoxa история библейских переводов и церковной литературы исполнена трагизма, с анафемами и сожжениями не только книг, но и переводчиков.

Чтобы понять, почему на протяжении столетий разные народы в качестве своих литературных языков использовали чужие языки, следует принять во внимание весь комплекс разнородных и разномасштабных факторов: 1) распространение мировых религий и сложение полиэтничных культурно-религиозных миров; 2) психолого-семиотические преграды и институциональные запреты на пути переводов или иной адаптации церковных книг, обусловленные неконвенциональным отношением к языку и тексту Писания; 3) близкое к дополнительному распределение социальных функций между надэтническим литературным и народным языком (своего ареала), что делало ситуации культурно-религиозного двуязычия достаточно устойчивыми; 4) разная генеалогическая близость между надэтническим литературным и конкретным народным языком в качестве фактора, влиявшего на продолжительность сохранения надэтнического языка в качестве «своего» литературного языка; поэтому, в частности, переводы Библии с латыни на народные языки Европы, в том числе на языки Slavia Latina, создаются раньше, чем переводы ц.сл Библии на языки Slavia Orthodoxa; 5) фактор религиозных идеологий и движений, в том числе в века, переходные к Новому времени: так, в Московской Руси церковь противилась идеям Возрождения и Реформации, поэтому первый русский библейский перевод (Псалтыри) появляется на 120 лет позже (в 1683 г.), чем переводы из Писания и учительные книги (включая православные) на староукраинском и старобелорусский языках ${ }^{2}$.

2 Хронология переводов такая: староукраинское рукописное православное Пересопницкое евангелие, переведеное на Волыни в 1556-1561 гг.; старобелорусский печатный протестантский Катехизис Сымона Будного (Несвиж, 1562); украинский Креховский Апостол, переведенный с протестантской польской Радзивилловской Библии (Брест 1563); первопечатное старобелорусское Евангелие от Матфея (и начало Евангелия от Марка) в переводе полоцкого шляхтича социанина Василия Тяпинского (1570-ые гг.); украинское Хорошевское Евангелие (тетр) протестанта Валентина Негалевского (1581); переведенные с церковнославянского Волынское Евангелие (1571) и недатированное Летковское Евангелие. В Московской Руси в ответ на вызовы Реформации была усилена защита ц.сл языка Писания: в 1581 г. Иван IV санкционировал печатание в Остроге (современная Украина) ц.сл Библии, подготовленной Иваном Федоровым (издание вошло в историю как Острожская Библия). Первая библейская книга на русском языке - рукописная Псалтырь в переложении переводчика Посольского приказа Аврамия Фирсова — появляется веком позже - в 1683 г. 


\section{4. Демократизация литературных языков как преобладающая в Новое вре-} мя тенденция в их истории. Самый крупный, разноаспектный, самый длительный и значительный по последствиям процесс языковой демократизации состоит в преодолении культурно-религиозного двуязычия: оно трансформировалось в этническое одноязычие. Процесс заключался в формировании литературных языков на народной основе, вытеснявших надэтнические языки из важнейших сфер жизни: раньше всего из образования и науки, позже всего - из религиозной коммуникации, особенно из богослужения. В разных ареалах процесс демократизации языкового общения начинался в разное время и протекал с разной интенсивностью; трудно считать, что в некотором социуме процесс языковой демократизации завершен.

У В.В. Виноградова в «Очерках по истории русского литературного языка XVII-XIX веков» не раз говорится о «национальной демократизации русского литературного языка», «национально-демократических стилях», об «общем национально-разговорном языке» и т.п. [Виноградов 1934/1982: 10, 42, 46, 48, 53, 463466]. Дело в том, что в процессе демократизации культурного общения, помимо изменений в лингвистической идеологии общества и материально-языковых изменений, была еще и демографическая компонента: в культурное общение включались широкие слои народонаселения, что вело к стиранию диалектных и социально-образовательных языковых различий; складывался общенародный культурный язык. Формирование литературного языка, наддиалектного и в перспективе общенародного, является частью процессов образования нации как наиболее продвинутой ступени этнической консолидации народа.

Принятие социумом своего этнического языка в функции языка школы, образования, высокой культуры, а в перспективе также и церкви означало появление литературного языка нового типа — не замкнутого в узкой сфере особо важных функций, но языка открытого и многофункционального. На латыни или церковнославянском невозможно было говорить на рынке, с крестьянином, ремесленником, с женщиной, с детьми. В народных литературных языках эти ограничения отпадали. Наиболее глубокое типологическое различие между литературными языками старого и нового типа связано с тем, что в новых (народных) языках разговорная речь вошла в «нормативное пространство» коммуникации. В современном общении в Европе и Северной Америке нет ситуации, в которой литературный язык был бы неуместен: все виды неофициального общения (семейно-бытовое, дружеское, интимное, фамильярное) возможны на литературном языке.

5. Факторы демократизации литературных языков. Язык, эта «самодовлеющая, живущая по своим законам величественная стихия» (А.М. Пешковский), изменяется в основном стихийно. Возможности сознательного вмешательства людей в жизнь языка ограничены графико-орфографическими реформами, упорядочением и созданием терминов, реже - выбором языковых ориентиров и/или диалектной базы на этапе начальной кодификации языковых норм. Процессы, ведущие к демократизации литературных языков (за исключением реформ письма), также никем не планируются и развиваются стихийно - как следствия и проявления фундаментальных тенденций в истории человечества, включая историю коммуникации. Неостановимый 
и ускоренный количественный рост объемов коммуникации (один из трендов истории человечества), уже сам по себе, — это мощный демократизирующий фактор. Демократизация письменного общения представляет собой сквозную линию в истории коммуникации. Это видно по истории письма. В древнейших культурах письменность возникала как элитарное, нередко эзотерическое средство общения, преимущественно в сфере ритуально-религиозной коммуникации. Однако внешняя история письменности состояла в возрастании объемов письменной коммуникации, в неуклонном расширении ее географического и социального пространства, и это демократизировало письменное общение. По большому счету, это стихийный процесс.

Стихийные движущие силы языковой демократизации выступают как макрофакторы истории: они взаимно связаны и влияют на многие феномены бытия, включая язык. Ниже, в перечне макрофакторов языковой демократизации, их языковые следствия обозначены лишь пунктирно.

\section{1. Снижение социальной роли религий (начиная от эпохи Возрождения).} На смену полиэтническим культурно-религиозным мирам приходят сообщества, консолидированные на национально-государственной основе; языковые ситуации культурно-религиозного двуязычия постепенно уступали место национальному одноязычию.

\section{2. Переход от мануфактурного к машинному производству, возрастание} товарности рынка, развитие науки и технологий. В эпоху Возрождения на смену познавательному консерватизму Средневековья приходит стремление к безграничному знанию и личному творчеству индивида. Социальная жизнь становится более интенсивной, растет городское население, растут объемы информации, циркулирующей в социумах. Все названные процессы протекают с использование народных языков. В XVIII в. народные языки вытесняют латынь из ее последнего светского бастиона - науки. Усложнение жизни и производств приводит к обязательному школьному образованию, продолжительность которого в самых разных странах постепенно растет. В массовом школьном и университетском образовании, как правило, преобладают народные языки.

5.3. Книгопечатание. Для истории демократизации литературных языков в книгопечатании важны две его черты: 1) единообразие типографских экземпляров одной книги: в рамках тиража (хотя бы и многотысячного) стала возможной такое единообразие текста, какое было немыслимо в рукописной книге; 2) мобильность печати, что вело к невозможному прежде разнообразию изданий, в том числе к появлению периодической печати, первоисточнику СМИ. Демократизм книгопечатания связан с тем, что типографии были частной собственностью (а не монастырской и не университетской) и свободно печатали товар «для всех». Издатели с самого начала думали о потребностях покупателя, о тиражах, о доступности языка книг всем грамотным, включая женщин. Как выразился М. Мак-Люэн, «проблема “чего хочет публика" была главной для книгопечатания с самого начала» [Мак-Люэн 1962 / 2004: 305].

Воздействие книгопечатания на языки и коммуникацию проявлялось в ряде тенденций: 1) благодаря книгопечатанию расширились социальные функции народных языков; примерно в то время, когда книгопечатание по объему продукции превзошло 
книгописание (1500-1510 гг.), печатные книги на народных языках стали преобладать над латинскими изданиями; 2) только в условиях книгопечатания языковые нормы могут войти в сознание множества людей; до печатного станка попытки “исправления книжного" оставались утопией; типографские тиражи школьных книг внедряли языковые нормы народных языков в сознание всё более широких слоев населения; 3) только при книгопечатании грамотность становится общедоступной: письменное общение (“пером по бумаге”) стало массовым, дешевым и заурядным делом; люди перестают относиться к письменному (и печатному) тексту с бо́льшим доверием и уважением, чем к устному слову; 4) книгопечатание демократизировало университет и школу. См. подробней [Мечковская 2009: 414-426].

5.4. Активность людей. Человек живет в своем недолгом времени (он, как сказал поэт, «вечности заложник у времени в плену»), и своих планах и поступках человек руководствуется собственным пониманием проблем своего времени и своей личной заинтересованностью в том или ином решении очередной проблемы.

Для Лаврентия Зизания, учителя братских школ во Львове, Бресте, в 1596 г. в Вильне, важно было составить и напечатать здесь же, в Вильне, книги, которые были бы полезны на уроках — ц.сл букварь, ц.сл. грамматику и словарь, в котором непонятные для школяров ц.сл слова были бы на просты ${ }^{\text {й }}$ руски ${ }^{\text {й }}$ кованы. В грамматике, очевидно, «для пользы дела» Зизаний считает нужным добавить к первым определениям на ц.-сл языке их перевод на «про́сту мову»: Что есть Грамматіка. Грамматіка есть извъстное въжство еже благш глаголати и писати. Толкованїе. Граматіка естъ певное въдане жебы мы доб ре мовили и писали. В восточнославянской книжности перевод ц.сл фразы на просты ${ }^{\text {й }}$ рускй ${ }^{\breve{~}}$ діллекть было первой ласточкой языковой демократизации школьной книги. Судя по предисловию Мелетия Смотрицкого к его ц.сл грамматике (Евье (под Вильной), 1619) Учителемъ школнымъ Авторъ, устные толкования ц.сл текстов на народном языке были обычны в школьной практике: наука грамматики тогда будет успешной, пишет Смотрицкий (на народном языке), гды приней заповинымъ потщанїемъ вашимъ читаны будутъ звыклымъ шкюлъ способомъ Славенскїи Лекцїи и на Рускій назыкъ перекладаны. Толкуя трудные ц.сл обороты, особенно синтаксические кальки с греческого, или объясняя различия между синонимическими конструкциями, Смотрицкий довольно регулярно использует параллели на народном языке. Ср. [после цитаты на греческом]: Славенски преводимъ Оудержи назык свой зла и оустнђ свођ еже не глаголати л злогш и оуста твои нехай не мовАтъ зрады (л. 221)3.

Таким образом, Зизаний и Смотрицкий в своих грамматиках (книгах, по старинным представлениям, почти церковных) обращаются к народному языку по вполне рациональным и практическим мотивам.

${ }^{3}$ В московском издании грамматики Смотрицкого (1648) предисловие на народном языке, как и все "руские" переводы ц.-сл слов и предложений, были исключены, а «юс большой», который Смотрицкий полагал лишним, восстановлен. 
В 1730 г., через 111 лет после грамматики Смотрицкого, В.К. Тредиаковский, объясняя, почему он решил переводить французский роман «Езда в Остров Любви» не на ц.сл язык, но «почти самымъ простымъ Рускимъ словомъ», в дополнение к тому, что «языкъ славенскои въ нынђшнемъ вђкъ» у насъ очюнь теменъ, и многія наши читая неразумњютъ», выдвигает два новых довода для отказа от ц.сл языка: его функциональная обособленность («языкъ славенскои, унас есть языкъ церковнои; а сія книга мирская») и довод эстетический, подчеркнуто индивидуально-субъективный: третья причина, «которая вам покажется можетъ быть самая легкая, но которая у меня идетъ за самую важную, то есть, что языкъ славенскои нынъ жестокъ моимъ ушамъ слышится, хотя прежде сего не толко я имъ писывалъ, но и разговаривал со всњми» (Цит по: [Обнорский, Бархударов 1948: 149-150].

Можно думать, что у представленных решений Зизания, Смотрицкого, Тредиаковского были и некоторые другие мотивы - из тех, которые лежат что называется на глубине души и эксплицируются с трудом и редко: ренессансная тяга к творчеству и небоязнь быть первым; скорее всего, также и честолюбивые стимулы (стремление к известности, признанию учености и заслуг, к росту собственного авторитета и т.п.) и материальные интересы.

Языковой консерватизм, неприятие инноваций (особенно графико-орфографических) отвечают психологии людей в большей мере, чем языковое новаторство. В ситуациях культурно-религиозного двуязычия «естественный» языковой консерватизм усиливается неконвенциональной трактовкой церковного слова и буквы; отсюда - осознанное стремление ревнителей книжного языка очистить от изменений ц.сл письмо и сохранить его первозданный облик как залог чистоты и крепости веры, а также власти иерархов.

Удавшееся сопротивление демократизации и рационализации письма имело место и в истории Петровской реформы 1708-1710 гг. Императору Петру I противостоял директор Московского печатного двора и Синодальной типографии Федор Орлов-Поликарпов. Он сумел отстоять для церковной печати ц.-сл азбуку и ц.сл шрифты, имитирующие кириллический устав. Округлые легкие шрифты оказались возможны только в светских («гражданских») изданиях ${ }^{4}$. Настаивая на сохранении тех (реально избыточных) ц.сл букв, которые типографы предлагали Петру устранить, Федор Поликарпов приводил простой иррациональный аргумент: без юсов, без $\vartheta, \psi, \xi$ «книгъ церковныхъ печатать нево можно» (рукопись цит. по работе [Живов 1996: 75]). Он так чувствовал. Возможно, как и Евфимий Тырновский или старообрядцы, он искренне радел о сохранении истинной веры. В итоге радикализм петровской реформы был уменьшен; возникшее в результате реформы различие между гражданской и церковной печатью, резкое и мгновенно воспринимаемое, сохраняется в восточнославянских культурах до сих пор.

${ }^{4}$ Без малого за два века до Петровской реформы такие шрифты, округлые и светлые, близкие к ренессансной антикве, использовал в своих пражских (1517) и виленских (1525) библейских изданиях Франтишек Скарына. 
В сопротивлении реформам письма есть еще два субъективно-психологических мотива: один связан с властью, второй - массовый, народный. Устоявшаяся власть, особенно не склонная к либерализму, органически противится переменам в письме. Не случайно реформы письма обычно становились возможны в русле более широких социальных преобразований. В истории русского письма таковы Петровская реформа и реформа 1918 г. Как известно, проект реформы 1918 г. был разработан Академией наук еще в 1912 г., но ввели ее только после Октябрьской революции, декретом наркома просвещения А. В. Луначарского.

Политическая обусловленность замораживания планов демократизации письма легко видеть на примере двух неудавшихся попыток оптимизации орфографии, предпринятых в Польше и СССР в годы послесталинской оттепели. В 1961 г. в Польше готовилось новое, 13-ое, издание "Pisowni Polskiej" PAN5; в 1962-1963 гг. в Институте РЯ АН СССР под руководством М.В.Панова разрабатывались новые правила орфографии. Оба проекта были направлены на уменьшение непоследовательности в правилах письма, на генерализацию и укрупнение ряда орфографических норм, что могло бы серьезно облегчить школьное усвоение орфографии. И в Варшаве и в Москве работы по демократизации орфографий были остановлены «сверху», что не случайно совпало с концом «оттепели» ${ }^{6}$.

Что касается «народной» нелюбви к орфографическим переменам, то этот фактор прост: инертность и лень. В СССР проект реформы бурно обсуждался в прессе: московские газеты за 2 года получили более 10 тыс. писем об орфографии. Подавляющее большинство учителей и писателей отнеслись к проекту резко отрицательно, что, по оценке В. М. Алпатова [1995: 113], было не более, чем нормальной реакцией «взрослого грамотного носителя языка, которому прежде всего не хочется переучиваться».

6. Предел демократизации литературных языков. Б. А. Успенский писал, что литературный язык воспринимается как литературный до тех пор, пока сохраняется разрыв между ним и живой речью. «Стремясь догнать живую речь, литературный язык как бы стремится к самоуничтожению» [Успенский 1987: 9]. Для тех литературных языков, которые отталкиваются от живой речи, «самоуничтожение» невозможно по определению: они не «стремятся догнать живую речь», а противостоят ей.

В Новое время (XVIII-XXI вв.) европейские литературные языки в аспекте социальной типологии относятся к демократическому типу языков, ориентированных на разговорную речь. Они не противостоят разговорной речи, но включают ее в себя в качестве нижнего регистра «культурного» речевого обихода. Для общенародного языка, литературная форма которого ориентирована на разговорную речь, характерна тенденция ко всё большей проницаемости границ между литературным языком и ненормативными формами существования языка (диалектами, просторечием,

${ }^{5}$ Наиболее радикальные предложения: отмена различения ó:u, rz:ż, ch:h (см. [Smulkowa, Żurawski 1961: 41]).

${ }^{6}$ См. главу "Charakterystyka niedoszłego wydania XIII Pisowni Polskiej PAN" в [Jodlowski 1979]. Подробней см. [Мечковская 2004] Об истории несостоявшейся реформы русской орфографии см. [Булатова и др. 2001]. 
арго, сленгами). По мере того, как новые речевые манеры и стили становятся приемлемы для слуха социума (пусть и с какими-то оговорками), нормативное пространство общенародного языка всё более расширяется. В недалекой перспективе объемы категорий «общенародный язык» и «литературный язык» совпадут.

7. Что противостоит языковой демократизации? У демократизации народных языков по большому счету нет альтернативы, потому что это стихийный и неостановимый процесс, одно из проявлений нарастающей гомогенизации человечества и в то же время один из факторов гомогенизации. Равная по масштабу антитеза демократизации языков состоит в их усложнении. Параллельно распространению черт внешней (стилистической) демократичности языков присходит их глубинное (терминологическое и структурно-синтаксическое) усложнение, что обусловлено возрастанием информационно-семиотической насыщенности жизни и дифференциацией форм общения.

В парадигматике происходит рост количества знаков; в синтагматике - рост численности правил сочетания знаков. Растет число новых слов, прежде всего терминов. Происходит все более тонкая дифференциация вариантных и синонимических средств; вырабатываются более сложные формы синтаксической организации высказываний и целых текстов. В научно-техническую документацию, отчеты, статьи, делопроизводство, служебную переписку вводятся все более сложные и специализированные стандарты представления информации. Письменные подъязыки научно-технического и делового общения становятся все более специальными, жесткими (не вариабельными), но именно эти свойства делают их удобными для профессионалов, позволяя специалисту создавать документ (статью для научного журнала, научный отчет т.п.) как бы монтируя его из терминов и композиционно-синтаксических модулей. Легкость научно-технического письма обеспечена развитием научно-деловых стилей современных языков в направлении ко все большей стандартности.

Таким образом, сложение специальных подъязыков - это не альтернатива демократизации литературного языка, а ее осуществление другими средствами.

\section{Литература}

Алпатов B. М. Литературный язык в России и Японии (Опыт сопоставительного анализа) // Вопросы языкознания, 1995, № 1. С. 93-116.

Булатова Л.Н., Земская Е.А., Кузьмина С. М., Новиков В.И. Диапазон дарования. К 80-летию М. В. Панова // Вопросы языкознания, 2001, № 1, с. 3-13.

Виноградов B.B. Очерки по истории русского литературного языка XVIIXIX веков [1934, 1938]. М.: Высшая школа, 1982. 528 с.

Гловинская М.Я. Активные процессы в грамматике (на материале инноваций и массовых языковых ошибок) // Русский язык конца столетия (1985-1995) / Отв. ред. Е.А. Земская. М.: Языки русской культуры, 1996. С. 237-304.

Живов В. М. Язык и культура в России XVIII века. М.: Языки русской культуры, 1996. $591 \mathrm{c}$. 
Лаптева О.А. Внутристилевая эволюция современной русской научной прозы // Развитие функциональных стилей современного русского языка. М.: Наука, 1968. C. $126-185$.

Ларин Б.А. О лингвистическом изучении города [1928] // Ларин Б. А. История русского языка и общее языкознание. М.: Просвещение, 1977. С. 175-189.

Мак-Люэн М. Галактика Гутенберга: Сотворение человека печатной культуры [1962]. Киев: Ника-Центр, 2004. 432 с.

Мечковская Н.Б. О диагностической ценности орфографических перемен: из истории белорусского, украинского, польского и русского письма // Normen, Namen und Tendenzen in der Slavia / Festschrift für Karl Gutschmidt zum 65. Geburtstag / Volkmar Lehmann und Ludger Udolph (Herausgeber). München, 2004. S. 87-95. [Перепечатано в: Мячкоуская Н.Б. Мовы і культура Беларусі. Нарысы. Мінск: Права і эканоміка, 2008. (Серыя "Моваведы Беларусі"). С. 143-151].

Мечковская Н. Б. История языка и история коммуникации: От клинописи до Интернета. М.: Флинта; Наука, 2009. 584 с.

Мечковская Н. Б. Философия языка и коммуникации. М.: Флинта; Наука, 2017. $520 \mathrm{c}$.

Обнорский С.П., Бархударов С.Г. Хрестоматия по истории русского языка: Ч. 2-ая; вып. 2-ой. М.: Учпедгиз, 1948. 343 с.

Псалтырь 1683 г. в переводе Аврамия Фирсова: текст, словоуказатель, исследование / Предисловие, исследование, подготовка текста и составление словоуказателя Е. А. Целуновой. М.: Язык славянской культуры, 2006. 624 с.

Судные списки Максима Грека и Исака Собаки [1540-ые гг.] / Изд. Н.Н. Покровский, под ред. С. О. Шмидта. М.: Наука, 1971. 186 с.

Успенский Б. А. История русского литературного языка (XI-XVII вв.). München, 1987. XII, $367 \mathrm{~S}$.

Jodlowski St. Losy polskiej ortografii. Warszawa: PWN, 1979. 179 s.

Smulkowa E., Żurawski A. O polskich i niepolskich klopotach ortograficznych. 3. Podstawowe trudności ortografii bialoruskiej // Język polski, XLI, 1961, № 1. C. 41-51.

\author{
Nina B. Mechkovskaya \\ Belorussian State University \\ (Belarus, Minsk) \\ nina.mechkovskaya@gmail.com
}

\title{
LANGUAGE DEMOCRATIZATION, LIBERALIZATION AND COUNTER PROCESSES: SPONTANEOUS TENDENCIES AND PLANNING
}

Democratization of literary (standard) language consists in the codification for to reduce efforts of people at acquisition of a standard language (reform of the letter in Russia 1708-1710; Russian graphic-orthography reform in 1918 etc). Democratization is shown 
in a colloquialization of well-bred speech, in refusal of archaisms, rare, idiomatic and unmotivated forms and preference simple, evident and easily explainable. The liberal codification increases the number of admissible speech fluctuations.

In the history of written communication there are two stages in development of language situations, to each of which there corresponds the own special type of the literary language, with cardinally different (in each type) relationship between a standard language and the natural ("live") speech. The literary languages of the first (old) type developed in situations of cultural- religious bilingualism, when in one society are used two an idiom: the supra-ethnic cult language and ethnic (national) language which is out of standard estimates. Historically the first linguistic ideology was far from language democratism. Its characteristic features there are as follows: aspiration to hold cult language in church and other prestigious spheres of life, to keep cult language in his original form; conservative and restoration purposes of philological work.

The literary languages of new type began to develop in postfeudal time, in process of laicisation of education and culture. The religious bilingualism gradually gave way to national monolingualism. The deepest typological difference between the literary language of old and new type consists that in national languages informal conversation became a type of standard communication. The fields of use of the rated speech have as a result extended; in all population the percent speaking a standard language sharply has grown. In the near future volumes of categories "public language" and "standard language" will coincide.

Democratization of the literary languages is caused by spontaneous thousand-year tendencies in the history of mankind. Democratization is a language component of two trends - intensifications of life and homogenization of human communities. Parallel to distribution of features of external (stylistic) democratic character of languages their structural-syntactic and terminological complication takes place.

Key words: cultural-religious bilingualism, typology of literary (standard) languages, language democratization, liberal codification, factors of literary language democratization, graphic-orthography reforms, historical tendencies in common (cumulative) national language, borders and counterbalances of language democratization.

\section{References}

Alpatov V.M. [The literary language in Russia and Japan (An attempt of the comparative analysis)]. Voprosy jazykoznanija, 1995, no. 1, pp. 93-116. (In Russ.)

Bulatova L. N., Zemskaja E. A., Kuz'mina S. M., Novikov V. I. [Diapazon of talent. To M.V. Panov's 80 anniversary]. Voprosy jazykoznanija, 2001, no. 1, pp. 3-13. (In Russ.)

Vinogradov V.V. Ocherki po istorii russkogo literaturnogo jazyka XVII-XIX vekov [Sketches on history of the Russian literary language of the 17-19th centuries]. Moscow, "Vysshaja shkola" Publ., 1982. 528 p.

Glovinskaja M. Ja. [Active processes in grammar (on material of innovations and mass language mistakes)]. Russkij jazyk konca stoletija (1985-1995) [Russian of the end of century (1985-1995)]. Moscow, "Jazyki russkoj kul'tury” Publ., 1996, pp. 237-304. (In Russ.) 
Zhivov V. M. Jazyk i kul'tura v Rossii XVIII veka [Language and culture in Russia the XVIII century]. Moscow, "Jazyki russkoj kul'tury” Publ., 1996. 591 p.

Lapteva O.A. [Intrastylistic evolution of modern Russian scientific prose]. Razvitie funkcional'nyh stilej sovremennogo russkogo jazyka [Development of functional styles of modern Russian]. Moscow, "Nauka" Publ., 1968, pp. 126-185. (In Russ.)

Larin B. A. [About linguistic studying of the city]. Larin B. A. Istorija russkogo jazyka i obshhee jazykoznanie [History of Russian and general linguistics]. Moscow, "Prosveshhenie" Publ., 1977, pp. 175-189. (In Russ.)

McLuhan M. The Gutenberg Galaxy: The Making of Typographic Man. Toronto, University of Toronto Press, 1962. 293 p. (Ukr. ed: Mak-Ljujen M. Galaktika Gutenberga: Sotvorenie cheloveka pechatnoj kul'tury. Kiev, "Nika-Centr" Publ., 2004. 432 p.).

Mechkovskaja N. B. [About the diagnostic value of spelling changes: from history of the Belarusian, Ukrainian, Polish and Russian letter]. Normen, Namen und Tendenzen in der Slavia. Festschrift für Karl Gutschmidt zum 65. Geburtstag. München, 2004, pp. 87-95. (In Russ.)

Mechkovskaja N. B. Istorija jazyka i istorija kommunikacii: Ot klinopisi do Interneta [History of language and history of communication: From a cuneiform to the Internet]. Moscow, "Flinta; Nauka" Publ., 2009. 584 p.

Mechkovskaja N.B. Filosofija jazyka i kommunikacii [Philosophy of language and communication]. Moscow, "Flinta; Nauka" Publ., 2017. 520 p.

Obnorskij S.P., Barhudarov S. G. Hrestomatija po istorii russkogo jazyka: Chast' 2, vyp. 2 [Anthology of Russian history: P. 2nd; 2nd issue]. Moscow, "Uchpedgiz" Publ., 1948. $343 \mathrm{p}$.

Psaltyr' 1683 g. v perevode Avramija Firsova: tekst, slovoukazatel', issledovanie E. A. Celunovoj [The Psalter of 1683 in Avramij Firsov's translation: text, index of words, research by E. A. Tselunova]. Moscow, "Jazyk slavjanskoj kul'tury” Publ., 2006. 624 p.

Sudnye spiski Maksima Greka i Isaka Sobaki Izd. N. N. Pokrovskij, pod red. S. O. Shmidta [Maxim the Greek's and Isak Sobaki's judgment lists Publ. by N. N. Pokrovsky, under the editorship of S. O. Schmidt]. Moscow, "Nauka" Publ., 1971. 186 p.

Uspenskij B. A. Istorija russkogo literaturnogo jazyka (XI-XVII vv.) [History of the Russian literary language (the 11-17th centuries)]. München, 1987. XII, $367 \mathrm{p}$.

Jodlowski St. Losy polskiej ortografii [Fate of the Polish orthography]. Warszawa, PWN, 1979. 179 p. (In Polish)

Smulkowa E., Żurawski A. [About the Polish and non-Polish cares of orthography. 3. Main difficulties of the Belarusian spelling]. Język polski, XLI, 1961, no. 1, pp. 41-51. (In Polish) 


\section{О.В. Мякшева, О.Б. Сиротинина}

Саратовский национальный исследовательский государственный университет имени Н.Г. Чернышевского

(Россия, Саратов)

myakshev@mail.ru,skunak@mail.ru

\section{ГОСУДАРСТВЕННЫЙ (ЛИТЕРАТУРНЫЙ) РУССКИЙ ЯЗЫК: ОБЯЗАТЕЛЬНЫЕ И ВОЗМОЖНЫЕ СФЕРЫ ЕГО ИСПОЛЬЗОВАНИЯ, НОРМЫ И РЕАЛЬНЫЙ УЗУС}

В статье утверждается, что Закон о государственном языке закрепляет статус литературного русского языка как государственного в силу присущей ему полифункциональности и нормативности, которые позволяют его использование на всей территории страны в любой сфере общения. Доказывается, что государственным языком является весь литературный язык, но в разных сферах жизни он используется не целиком, а тот или иной функциональный стиль, даже его разновидность строго в соответствии с целями и задачами общения. Язык живет, а значит, изменяется и, к сожалению, не только в сторону усложнения системы и её обогащения. Изменения в языке начинаются в речи, а под её влиянием меняется и язык, поэтому в такой огромной стране с до сих пор живыми диалектными различиями и с влиянием, в зависимости от территории, других национальных языков особенно необходимо сдерживание изменений через соблюдение единых норм литературного языка. Отстаивается мысль, что речевая культура требует владения функционально-стилевой дифференциацией всего литературного языка и наличия хотя бы представлений о нелитературных стратах национального языка. Занимающие государственные должности и, шире, публичные люди обязаны владеть не только своей профессиональной разновидностью функционального стиля, а быть носителями, а не пользователями всего литературного языка. Высокий уровень владения литературным языком - одно из надежных доказательств пригодности человека для решения государственных задач. Указывается, что особого внимания заслуживает обсуждение вопроса о преподавании русского языка как иностранного, в частности, утверждается, что учебники для иностранцев должны проходить многоаспектную экспертизу.

Ключевые слова: государственный язык, литературный русский язык, полифункциональность, нормативность, национальный язык и его страты, речевая культура, русский как иностранный. 
Закон о государственном языке закрепляет статус литературного русского языка как государственного (ср.: [Рябова 2016], [Дайджест 2016]) в силу присущей ему полифункциональности и нормативности, которые позволяют его использование на всей территории страны в любой сфере общения. Полифункциональность главное отличие литературного языка от монофункциональных, в основном устных, страт национального русского языка, ориентированных только на одну сферу общения. Территориальные диалекты и просторечие обслуживают неофициальную коммуникацию (как и молодёжный жаргон), профессиональный сленг используется тоже в одной сфере (компьютерный, художников, воровское арго и т. д.). Как правило, это ещё и замкнутая социальная группа общающихся — так называемое рабочее общение (термин А.Н. Байкуловой).

Нормированность государственного языка - кодифицированная, а не только узуальная, как в остальных стратах, где нет официальной фиксации нормативного в учебниках и словарях/справочниках, нормы в них конвенциональные, но всё же не обязательные.

Следствием полифункциональности является функционально-стилевая дифференциация: каждый стиль (как часть литературного языка) используется в своей сфере, имеет своего адресата и отличается набором стилевых доминант и целей общения, разной степенью строгости норм в разновидностях.

Объединяет литературный язык с нелитературными стратами национального языка и языками малочисленных народов только одна сфера - повседневная неофициальная. Коммуникация жителей разных территорий не на едином для всех граждан данной страны языке невозможна. Только литературный язык может обеспечить единство всего населения страны, в этом и заключается необходимость его изучения в школе. Мнение о том, что, «поскольку литературным языком, его нормами владеют далеко не все носители русского языка, под государственным языком, быть может, следует понимать русский национальный язык в широком смысле - со всеми его нелитературными (малокультурными) формами» [Рябова 2016: 8], считаем неправомерным. В современном обществе право на образование имеет каждый и ориентироваться на говорящих на просторечии - значит ущемлять права большинства населения, всех, кто учился в школе с преподаванием на литературном русском языке.

Изначальной формой языка была его устная реализация, и выход за пределы повседневного общения стал возможен только с появлением письма. С появлением письменности полифункциональность последовательно расширяется и укрепляется, а это влечет за собой, с одной стороны, усиление функционально-стилевой дифференциации (идет спор о выделении уже особого церковнорелигиозного стиля или разновидности публицистического; рабочего общения из официально-делового и обиходно-разговорного и т. д.) и, с другой, - усиление нормативности каждой из разновидностей того или иного стиля. Началось выделение как допустимых старшей и младшей нормы, а также особых профессиональных норм произношения и формообразования, но всегда единых для всей страны. 
Язык живет, а значит, изменяется, и не только в сторону усложнения системы и её обогащения. Для современного русского языка характерно явление, названное диффузацией. Приведём пример из СМИ: крайне плодотворная и объективная, данное употребление неверно потому, что не учитывается наличие в слове крайне, как усилителя признака, сем предела и негатива. Другой пример - употребление диффузного достаточно: достаточно криминальная обстановка. Хотелось бы спросить: для кого достаточно?

Обеднение языка происходит и из-за такого явления: слова типа совесть, сочувствие, кощунство, беззащчитность, храбрость, благородство, отражающие моральнонравственные ориентиры человека, вообще уходят, например, у молодёжи, из сфер их деятельностного использования и образуют там семантические лакуны. Обороты типа совесть не позволила так поступить становятся анахронизмами (в рекламном ролике один из авторов статьи недавно услышал фразу: Tеперь Совесть всегда со мной, но оказалось, что речь идет о пластиковой карточке с таким названием). Эти слова продолжают использоваться образованной частью молодежи, но в сферах, так сказать, вторичного применения - эссе, сочинениях, цель их употребления смещена в сторону меркантильного интереса: получить доступ к высшему образованию, будущему карьерному росту и обеспеченной жизни. Семантические лакуны в широкой сфере неофициального общения заполняются жаргонной лексикой, учёные говорят о «жаргонизации» России, ставшей доминантой современного языкового развития. Можно говорить даже о её «обсценизации»: наблюдения не только за «уличной» речью не оставляют сомнений в правомерности такого вывода.

Изменения в языке начинаются в речи, а под её влиянием меняется и язык. Кодификация норм эти изменения принимает, но изо всех сил сдерживает (кофе, договор и под.; сейчас в узуальной норме одеть/надеть, диффузное достаточно), иначе следующее поколение фактически не понимало бы предшествующее, как мы с трудом понимаем древнерусский язык, а итальянцы, французы - латинский. Сдерживание необходимо особенно в такой огромной стране, как наша, с до сих пор живыми диалектными различиями и с влиянием, в зависимости от территории, других национальных языков. Только единые нормы литературного языка обеспечивают единство страны. И тем не менее, нарушения такого единства встречаются: в 1993 г. один из авторов статьи столкнулся в Красноярске с непониманием продавцов универмага литературного русского слова кошелёк при использовании даже на торговом ярлыке гаманок женский.

Именно с неизбежным изменением норм связано требование пользоваться современными словарями. При этом из-за особенно сильного влияния на речь масс теперь уже не художественной литературы, а СМИ (сейчас, увы, и интернет-речи) в словарях для работников СМИ принято давать один вариант нормы без оговорок типа допустимо (например, только одноврЕменно и, конечно, никаких профессиональных вариантов).

Естественно, что играетрольвстепенистрогостисоблюдения кодифицированных норм письменная или устная коммуникация официального или неофициального общения. 
Строгая нормированность (прежде всего однозначность терминов) необходима для собственно научной разновидности научного и для законодательной официально-делового стилей. Канцелярскую разновидность делового стиля пытаются максимально формализовать разного рода стандартными бланками, значительно меньшую нормированность наблюдаем в научно-популярной разновидности.

Самая яркая индивидуализация и эмотивность речи характерны для художественного и разговорного стилей. В повседневной речи (разговорный стиль) огромную роль играет ситуация, она (по выражению Е.А. Земской) «вплавляется в речь». Цели всех других стилей требуют полноты выражения мыслей в тексте.

В научном и публицистическом стилях широко используются разные типы метатекстовой вспомогательной информации - дискурсивы (во-первых, таким образом, прямо скажем, к сожалению и т.д.), в устных формах любого стиля появляются хезитативы (как бы, вот, там, короче, на самом деле, скажем так и т.д.), в том числе не входящие в состав литературного языка, а если входящие, то в другой функции (сказать короче). Хезитативы широко используются в узуальных устных реализациях стилей, ещё шире - в нелитературном узусе.

Обязательной формой использования государственного (литературного) языка является прежде всего письменная, с возможностью отступлений от него в сторону нелитературных страт в художественной речи. Спорна такая возможность в газетной речи. К сожалению, в современном узусе под влиянием Интернета даже не в интернет-версиях газет, а в их печатных изданиях нормы литературного языка нарушаются и в лексике, и в синтаксисе, и даже в орфографии. Воздействие на реальный узус литературного языка классической литературы ослабело, а массовая литература, СМИ и Интернет его, как назвал это действие Г. Я. Солганик, «опускают» [Солганик 2015].

В изданном в СПбГУ дайджесте «Государственный язык Российской Федерации в жизни современной России», который составлен из докладов и газетных статей юристов во главе с ректором СПбГУ Н.М. Кропачёвым, поднимается целый ряд очень важных вопросов: об основных целях государственного языка, обязательных сферах его использования, недопустимости отсутствия в стандартах большинства специальностей требований владения русским языком и т.д. Однако этот дайджест изобилует лингвистическими терминологическими неточностями, в нём даётся противоречивое определение государственного языка и фактически (вероятно потому, что дайджест написан не лингвистами) предлагается расширить функции официально-делового стиля до статуса государственного языка: «Многие ли из нас знают, почему слова бедняк и нищий не входят в словарный состав государственного русского языка и почему вместо них используется слово малоимущиий?» [Дайджест 2016, 3]. Авторы по той же причине пытаются исключить из его лексикона всё оценочно-эмоциональное, сниженное и даже такие слова, как мама и паna.

Государственным языком является весь литературный язык, но в разных сферах жизни он используется не целиком, а тот или иной функциональный стиль, 
даже его разновидность, строго в соответствии с целями и задачами общения. Не выдерживает никакой критики фраза из дайджеста о том, что должны существовать «нормы современного русского языка при его использовании в качестве государственного» [Дайджест 2016, 12]. Речевая культура требует владения функционально-стилевой дифференциацией всего литературного языка и наличия хотя бы представлений о нелитературных стратах национального языка. Занимающие государственные должности, публичные люди обязаны владеть не только своей профессиональной разновидностью функционального стиля, а быть носителями, а не пользователями (термин Г. П. Нещименко) всего литературного языка, чтобы уметь, например, и писать проекты законов, и объяснять их понятно для граждан (даже если они носители просторечья), и использовать трибуны для разъяснения содержания этих законов и необходимости их введения. Нельзя сужать статус государственного языка до его официально-документальной разновидности. Безусловно, обязать всех жителей страны знать нормы официальной речи документальной разновидности значительно проще, чем быть вооружённым всем богатством литературного языка как сложной самоорганизующейся системы, отражающего менталитет нации, являющегося её «охранительной памятью». Высокий уровень владения литературным языком - одно из надежных доказательств пригодности человека для решения государственных задач.

Особого внимания заслуживает обсуждение вопроса о преподавании русского языка как иностранного. Разумеется, обучать надо литературному языку (и в этом отношении мы сталкиваемся с проблемой ножниц между тем, какой язык как предмет изучения предлагаем мигрантам и какой они слышат при попытках неофициального и даже официального общения в наиболее востребованных ими ситуациях). В каком объеме необходим им литературный язык, на какие тексты (и функциональные стили) ориентироваться на каждом этапе его овладевания? К сожалению, современные учебники по русскому языку для иностранных граждан еще далеки от необходимого уровня. И за примерами далеко ходить не приходится - почему иностранные студенты должны упражняться в лексике на примерах слов типа ресторан, водка, похмелье, почему они же изучают основы нашего общественного устройства посредством фраз типа деnymambl - это те, кто много говорят и мало делают? Учебники для иностранцев должны проходить многоаспектную экспертизу. Эксперты среди ученых и методистов найдутся. Пусть будет меньше учебников, пусть они будут менее красочными и форматными, но они должны быть качественными.

Соглашаясь с высказанным мнением авторов дайджеста о необходимости повысить минимальные требования к мигрантам, которые хотят получить право проживания в России, обращаем внимание на актуальную в системе современного высшего образования проблему обучения иностранных граждан. Коммерциализация вузов не должна мешать целевому отбору этих граждан (бакалавры, магистранты, аспиранты), тем более что в России имеются дифференцированные Стандарты входного тестирования. 


\section{Литература}

Байкулова А.Н. Рабочее общение как разновидность деловой коммуникации : соотношение понятий и терминов // Русский язык сегодня. Проблемы речевого общения : сб. докладов / Ин-т русского языка им. В.В. Виноградова РАН / отв. ред. Н. Н. Розанова. М.: Наука, 2012. Вып. 5. С. 14-22.

Дайджест 2016 - Государственный язык Российской Федерации в жизни современной России. СПб., 2016. 36 с.

Солганик Г.Я. О современной культурно-речевой ситуации // Актуальные проблемы стилистики : ежегодный международный журнал. 2015. № 1. С. 22-38.

Рябова Л. Г. Государственный язык как лингвистическая категория // Успехи современной науки. 2016. Т. 7. № 12. С. 37-43.

\section{Olga V. Myaksheva, Olga B. Sirotinina}

National Research Saratov State University named after N. G. Chernyshevsky

(Russia, Saratov)

myakshev@mail.ru,skunak@mail.ru

\section{RUSSIAN AS STATE (LITERARY) LANGUAGE: MANDATORY AND POSSIBLE SPHERES OF APPLICATION, NORMS AND REAL USAGE}

The paper clames that the Law on the State Language established the status of the literary Russian language as a state language due to its inherent polyfunctionality and normativity, allowing its usage in any sphere of communication throughout the country. Thus, it is proved that the entire literary language is the state language, however, in different spheres of life it is not used as a whole, but only as a certain functional style, even its variety, that is chosen according to the aims and goals of communication. Language is alive, and therefore, is evolving, and, unfortunately, not always in the direction of complexity and enrichment of the system. First, modifications in language are observed in speech, and gradually the language itself changes under this influence, so the control of these changes through a more rigorous enforcement of uniform norms of the literary language is particularly needed in regard to the presence of dialectal differences and the influence of other national languages (depending on the region) in such a huge country. The idea that speech culture requires functional-style differentiated literary language skills and at least the general notion of non-literary strata of the national language is upheld. The public position holders and, more broadly, public figures are responsible not only for acquiring their professional variety of functional style, but, more importantly, for becoming the role model of the native speaker who effectively communicates in any style of literary language, rather than acts as careless language user. The high level of literary language proficiency is one of the reliable proofs of a person's suitability for solving 
state's problems. It is pointed out that special attention should be paid to the discussion of the question of teaching Russian as a foreign language, in particular, it is stated that textbooks for foreigners should undergo a multidimensional examination.

Key words: state language, the literary Russian language, polyfunctionality, normativity, national language and its strata, speech culture, Russian as a foreign language.

\section{References}

Baikulova A.N. [Communication at work as a form of business communication: the correlation of concepts and terms]. Russkii yazyk segodnya. Problemy rechevogo obshcheniya: sb. Dokladov. In-t russkogo yazyka im. V.V. Vinogradova RAN [Russian language today. The issues of speech communication. Proc. of the V.V. Vinogradov Russian Language Institute of the Russian Academy of Sciences]. Moscow, 2012. no. 5. pp. 14-22. (In Russ.)

[Digest 2016 - State language of the Russian Federation in modern Russia]. Daidzhect 2016 - Gosudarstvennyi yazyk Rossiiskoi Federatsii v zhizni sovremennoi Rossii. $\mathrm{SPb} ., 2016.36$ p. (In Russ.)

Solganik G. Ya. [The current cultural-speech situation]. Aktual'nye problemy stilistiki: ezhegodnyi mezhdunarodnyi zhurnal. 2015. no. 1. pp. 22-38. (In Russ.)

Ryabova L. G. [The state language as a linguistic category]. Uspekhi sovremennoi nauki. 2016, Vol. 7, no. 12. pp. 37-43. (In Russ.) 


\section{Е. А. Никишина \\ Нацииональный исследовательский университет Высшая школа экономики \\ (Россия, Москва) \\ helene_nikichina@mail.ru}

\section{НАКЛЕЙКИ НА АВТОМОБИЛЯХ КАК МАЛЫЙ ЖАНР В СИСТЕМЕ РЕЧЕВОГО ВЗАИМОДЕЙСТВИЯ НА ДОРОГЕ}

Статья посвящена относительно новой форме городского общения - наклейкам на автомобилях (речь идет о разных надписях и слоганах нерекламного характера, которые автовладельцы приклеивают на стекла, двери и бамперы своих автомобилей). Наклейки на автомобилях рассматриваются как малый речевой жанр. Прежде всего мы даем характеристику коммуникативной ситуации, в которой данный жанр реализуется. Основными тенденциями речевого общения в ситуации трафика являются интерактивность, языковая игра, творческое начало и конкуренция. Участники коммуникации взаимодействуют в рамках трех основных ситуаций: «водитель $\leftrightarrow$ водитель», «водитель $\leftrightarrow$ сотрудник дорожной полиции», «водитель $\leftrightarrow$ пешеход». В зависимости от этого в наклейках реализуются различные коммуникативные стратегии: сообщение, оправдание, предупреждение, самоутверждение, угроза, призыв и другие. Наклейки на автомобилях различаются не только по своей коммуникативной направленности, но и по тематическому содержанию. Среди основных тематических категорий, представленных в наклейках, можно перечислить следующие: дорожное движение, личная информация о водителе, политический и патриотический дискурс. Велико число наклеек, имеющих сугубо фатическую направленность: это, например, наклейки-благодарности. Помимо прочего, в статье приводится сравнение речевого взаимодействия на дороге посредством наклеек с интернет-общением в чате, где определяющим фактором является анонимность участников.

Ключевые слова: речевой жанр, городская коммуникация, партнеры коммуникации, интерактивность, языковая игра, коммуникативная стратегия, наклейки на автомобилях.

Настоящая статья посвящена относительно новой форме городского общения, участниками которой являются владельцы личных автомобилей. Речь идет о так называемых «репликах-наклейках» - разных надписях, слоганах, которые автовладельцы приклеивают на стекла, двери и бамперы своих автомобилей (появление 
этой формы коммуникативного взаимодействия в рамках городского пространства отмечается в [Китайгородская, Розанова 2001; 2003; 2010: 279], описание данного жанра см. в [Иссерс: 2009]). Спрос на подобные наклейки настолько велик, что уже повсеместно налажено их массовое производство. Разнообразие тем и форм слоганов так широко, что наклейки вполне можно считать совершенно самостоятельной процветающей формой дорожного фольклора.

Материалом исследования послужили наклейки-реплики нерекламного характера. То есть наклейки типа «IKEA - Везёт кому-то!» или «Строительство деревянных домов и бань + телефон» не рассматривались.

Прежде всего, следует сказать несколько слов об основных характеристиках коммуникативной ситуации, в которой функционирует рассматриваемый жанр. В наклейках на автомобилях выражаются основные тенденции коммуникации в городском пространстве, отмечавшиеся в ряде работ Н.Н. Розановой и М.В. Китайгородской, а именно: прицел на интерактивность, использование различных приемов языковой игры и демонстрация творческого начала. Правда, возможно, в последнее время личностное творческое начало в подобного рода текстах несколько редуцировалось, поскольку спрос на наклейки настолько возрос, что уже повсеместно налажено их массовое производство. Сейчас правильнее было бы сказать, что владелец автомобиля заявляет о своем настрое на творческий лад уже самим фактом размещения наклейки на принадлежащим ему транспортном средстве.

Что касается участников коммуникативной ситуации «общение на дороге», то тут можно говорить о том, что они выступают в следующих ролях: «водитель $\leftrightarrow$ водитель», «водитель ↔ сотрудник ДПС», «водитель $\leftrightarrow$ пешеход». Чаще всего при этом реализуется ситуация общения между водителями. Одной из определяющих характеристик общения в данном случае становится конкуренция, конкурируют водители по двух основным параметрам: компетенция в управлении транспортным средством и престижность марки автомобиля. Интересно отметить, что в этой ситуации конкуренции наиболее «многословны» как раз те, кто находится в более уязвимой позиции. То есть если говорить о конкуренции в области компетентности управления автомобилем, гораздо шире представлены реплики неопытных водителей (этот тип наклеек является самым многочисленным). При этом коммуникативные стратегии, которые они выбирают в данном случае могут быть разными:

Это и оправдание, и предупреждение, и самоутверждение, и шутливые угрозы: Еду/паркуюсь какмогу!; Я не пьяный! Я объезжаю ямы !; Могу учудить!; Осторожно! Путаю педали!; Осторожно! Люблю целоваться! (Явная отсылка к рок-песне «иномарки ичелуются»); Извините! За рулем девушка! Нервные клетки не восстанавливаются!; Не волнуйтесь! За рулем уже 5-й день!; Целуюсь лучше, чем паркуюсь!; Студент!; За рулем блондинка!; Я учусь, имейте совесть!; Голоса в моей голове заставляют меня ехать именно так. Цель таких реплик предупредить других участников дорожного движения о том, что с данной машиной нужно вести себя осторожно и не слишком обращать внимание на возможные ошибки в вождении. Как видно из примеров, среди наклеек-реплик неопытных водителей особенно много таких, которые указывают на статус водителя, обычно с долей самоиронии. 
В рамках данного типа наклеек не может не обращать на себя внимание совершенно очевидный сексизм: женщины, вне зависимости от их стажа и уровня вождения, по умолчанию большинством участников трафика считаются представителями категории неопытных водителей. Наряду с наклейками типа: Мне можна! Я девачка!; За рулем блондинка! За рулем этой машины иногда ездит моя жена, прошу понять и простить; Уважай меня! этот стереотип имеет устоявшееся невербальное воплощение (наклейка в виде дорожного знака с женской туфелькой на каблуке), это лишний раз подтверждает его укорененность в системе коммуникации на дороге.

Опытные водители, по-видимому, не испытывают необходимости самовыражаться и самоутверждаться посредством наклеек, указывающих на их статус. Зато они реализуют свой творческий потенциал, выступая в роли блюстителей за соблюдением ПДД и корпоративного поведения на дороге. В данном случае их основные стратегии - это совет, наставление и реже угроза:

Не води свой автомобиль быстрее, чем летает твой ангел хранитель!; Я тебя пропустил, ты аварийкой не поморгал, не надо так; Ещее раз посигналишь, вообще никуда не поеду!; Тише едешь - больше командировочных!; Тише едешь - меньше должен!; Едь куда думаешь и думай, куда едешь!; Не можешь обогнать, перепрыгни!; Прижимайся ближе - одного научила, научу и другого (на машине с оторванным бампером); Соблюдай дистанцию! Возможен выброс тормозного парашюта; Обгоняй! Кто-то ждет твои почки! В последнем примере даже использован черный юмор.

Среди водителей выделяется категория тех, кто щеголяет своим лихачеством: Тише едешь - меньше русский!; За рулем мотоциклист!; Мужик за рулем!; За рулем Шумахер!; Тормоза для трусов!; ПДД? Не, не сльшиал!

Вернемся к идее конкуренции в ситуации трафика и поговорим теперь о конкуренции между обладателями дорогих и дешевых машин. Как и в случае с конкуренцией по параметру «компетенция водителя», в данном случае наблюдается такая же асимметрия: более многословны те, кто находится в более уязвимой позиции, т.е. в данном случае владельцы дешевых и, как правило, старых машин отечественного производства. Им присуще стремление оправдаться за несоответствие уровня своего транспортного средства общепринятым стандартам. Чаще всего это самооправдание выливается в реплику-самоутверждение, смысл которой можно передать пословицей «мал золотник, да дорог»: Зато не в кредит (о старой разбитой русской машине); Зато не пешком!; Ад был переполнен, пришлось вернуться назад!; “Газель”, на которой вверху и крупно написано: “Мерседес”, ниже и чуть мельче: “болел в детстве много”; на Оке: «Вырасту — джипом стану!»; на УАЗе: Меня не возьмет никакая зараза, я русский мужик, я водитель УАЗа. Таким же образом обыгрываются приобретенные недостатки автомобилей:

- царапины и вмятины: Чак Норрис was here!; Моль погрызла!; В салки больше не играю!;

— загрязнение: Чистый джип - позор хозяина!; Танки грязи не боятся!; Это не грязь - это пот; Это не грязь — это загар; Грязь лечебная! Не смывать!; Мыть не буду - она наказана! 
Владельцы дорогих автомобилей практически не испытывают потребности дополнительно заявлять о статусе своей машины, за редким исключением: (Нa Lincoln Navigator) Размер имеет значение! (пример О.С. Иссерс); Двухлитровым должен быть только пакет сока (наклейка на крупном автомобиле с намеком на объем двигателя).

Напомним, что все приведенные выше наклейки относятся к теме дорожного движения и представляют ситуацию общения водитель $\leftrightarrow$ водитель. Продолжим эту тему, но теперь перейдем к менее распространенной ситуации, где партнеры коммуникации - это водитель ↔ сотрудник ДПС, например: Понять и простить; Понять, простить и отпустить; Остановка без причины - признак дурачинь;; Официальный спонсор ГИБДД; Памятка сотруднику ДПС: 1. Представиться (ФИО, звание, должность); 2. Назвать причину остановки; 3. Разъяснить права и обязанности; 4. Быть сдержанным и вежливым при общении. В последнем примере налицо игра со статусным распределением ролей партнеров коммуникации. Совершенно очевидно, что подобные экземпляры появляются как результат работы механизма языковой самообороны. Они вырастают из официальных объявлений и построены по их образу и подобию, только обращены в противоположную сторону.

Еще более редкой в рассматриваемом коммуникативном пространстве является ситуация взаимодействия между водителем и пешеходом. Основная стратегия, которая используется здесь: косвенными средствами запугать пешехода: Одного понять не могу, почему пешеходы уверены в исправности моих тормозов больше, чем я?!; Пешеходы бывают двух видов - иустрые и мертвые.

Пока мы рассмотрели только то, как в жанре «автомобильных наклеек» реализуется тема дорожного движения, но круг тем, затрагиваемых этими наклейками гораздо шире. Помимо дорожной темы, можно выделить следующие типы дискурса: дискурс, связанный с частной жизнью владельца автомобиля, политический дискурс и патриотический. К дискурсу, связанному с частной жизнью автомобилиста, мы относим наклейки, в которых содержится какая-то информация, напрямую связанная с водителем и, как правило, выполняющая какую-либо утилитарную функцию, например, сообщить другим участникам дорожного движения о том, кто и куда едет в автомобиле, включая пассажиров: Baby on board!; Hежный груз; Мaльии / ребенок в машине; Хреначу на дачу; Кто куда, а мы жениться!; Молодожеhbl; Just married; За рулем двое! Как вы думаете, что здесь имеется в виду?

В случае наклеек У меня родился сын!; Еду за дочкой!; Ураa! Я стал папой! к сообщению информации добавляется фатическая интенция 'поделиться положительными эмоциями, похвастаться’. Нередки наклейки-благодарности: Cnacuбо, дорогая, за дочку!; Любимая, спасибо за сына! Случается даже такое, что с помощью автомобильных наклеек делают предложение руки и сердца: Любимая, выходи за меня замуж! Как видно из примеров, в этом типе наклеек несколько реже используется языковая игра - возможно потому, что здесь на первый план выдвигается всё же информативный компонент сообщения. Кроме того, важно отметить, что в данном сегменте наклеек не столь важно разграничение ситуаций 
по параметру «партнеры коммуникации» - это связано с тем, что адресатами этих наклеек могут быть, как другие водители, так и все остальные обитатели городского пространства. В данном случае это никак не влияет на текстовое воплощение жанра.

Если наклейки, посвященные дорожной тематике и личной жизни водителя, существуют сравнительно давно, то наклейки, реализующие политический и патриотический типы дискурса, появились совсем недавно. Вот несколько примеров наклеек на тему политики: Обама пЛОХой!; Куплю шкуру Обамыл! Дорого!; Какая власть, такие и дороги; Бомблю Игил; Страной правят 3,14дарасы!; Путин, как тыл всем O 100 3,14здел!; Единая Россия - партия жуликов и воров! Автовладелец может использовать наклейку как способ сообщить о своих политических воззрениях и даже как инструмент агитации: За Навального!

Как мы уже успели заметить, неотъемлемой чертой автомобильных наклеек является их лаконичность, это связано с тем, что язык трафика в целом весьма ограничен: в ходе дорожного движения из соображений безопасности и экономии времени водители не могут использовать весь арсенал вербальных и невербальных средств, которым обычно пользуется человек в ситуации устного контактного общения. Чтение длинных надписей возможно только в условиях городской пробки. Поскольку эта ситуация давно уже не редкость для жителей мегаполисов, некоторые водители размещают на своих автомобилях целые поэмы. В данной поэме пересекаются две темы - дорожное движение и политика:

Отпускаю я сиепление, нажимаю плавно газ,

С мазохистским наслаждением еду, тихо матерясь,

Оторвать бы руки-ноги и мужицкий инструмент,

Кто построил те дороги, что рассыпались в момент.

Не дошло до нас иунами, и давно уж нет войны,

Так откуда ж эти ямы на дорогах всей страны?

Господа Единороссы Дима, Вова, Леня М.!

Расскажите, где бабосы на ремонт асфальтных ям?

Прозвучит, конечно, резко, но достал всю страну

По весне менять подвеску и платить налог в казну!

Совершенно очевидно, что политический дискурс, сформировавшийся в рамках жанра «наклейки на автомобилях», — это своего рода антитоталитарный язык нашего времени.

Патриотический дискурс в автомобильных наклейках начал активно развиваться в последние годы вместе с пропагандой праздника победы над фашистской Германией в Великой отечественной войне, обычно размещение наклейки на автомобиле сопровождается завязыванием георгиевской ленточки на антенне, зеркале заднего вида и т.п. Вот примеры таких наклеек: Спасибо деду за победу!; Подвиг героев бессмертен - 1941-1945; Мы помним, мы гордимся!; На Берлин!; Т-34 Броня крепка и танки наши быстры! 
И политические, и патриотические наклейки не дифференцируются по параметру «адресата», они адресованы в одинаковой мере всем участникам городской коммуникации.

Нетрудно заметить, что многие автомобильные наклейки излучают агрессию (особенно ярко это выражается в «политических» наклейках). Вообще, можно сказать, что интеракция на дороге балансирует между двумя основными формами общения: игровой, шутливой формой и агрессией. Агрессия выражается в первую очередь в употреблении грубой, инвективной и подчас даже обсценной лексики, при этом языковая игра может сочетаться с агрессивным словоупотреблением, например, в способе эвфемизации употребляемой лексики: используется шифр, основанный на ребусах: $A$ дороги здесь - 3,14здец!; Путин, как ты всем O, 100, 3,14здел!; Страной правят 3,14дарасыл!; Үаһооею от этих дорог! Кроме того, может использоваться рифма: Хреначу на дачу!; нестандартное обыгрывание пословиц и поговорок: Бабло побеждает зло. Однако встречается и агрессия в чистом виде, т. е. не прикрытая языковой игрой, как в следующем примере: Мэр за*бал уже с этими пробками! Идите на $x * \breve{u}$ с такими ценами на бензин! Не менее распространены случаи, когда агрессия выражается непосредственно в выборе речевого акта - прямой или ироничной угрозы, например: Еще раз посигналишь, вообщзе никуда не поеду!; Обгоняй! Кто-то ждет твои почки!

Вероятно, повышенная агрессия в коммуникации на дороге связана с анонимностью (водитель транспортного средства обезличен в системе трафика). Кроме того, важным фактором является практически полное отсутствие обратной связи, характерное для многих типов опосредованного общения. Т. Вандербильт в своей книге о психологии поведения на дорогах проводит такую параллель: «Быть участником дорожного движения - все равно что выходить в интернет-чат под псевдонимом. Мы свободны от своей личности, нас окружают люди, известные лишь под «никами» (на дороге - спрятавшиеся за номерными знаками). В чатах мы забываем обычные ограничения. Психологи называют это «эффектом онлайнового растормаживания». Как и внутри машины, мы скрыты облаком анонимности, и нам кажется, что мы можем позволить себе стать самими собой» [Вандербильт 2013: 24]. Как и в чатах, никто не отвечает за свои слова. Они могут написать кому-то неприятное сообщение, а затем просто выйти из системы, оставив своего собеседника в бессильной злобе. Это сравнение можно обобщить, поскольку в некоторой степени все сказанное Т. Вандербильтом верно не только для коммуникации в системе трафика, но и для всего городского пространства: сила города в том, что человек попадая туда становится анонимным, и эта анонимность открывает ему гораздо большие возможности, чем в ситуации, где все знакомы.

Если говорить о сходстве речевого взаимодействия на дороге с общением в Интернете, то невозможно оставить без внимания совершенно новый тип автомобильных наклеек, сформировавшийся под влиянием социальных сетей: Бибикни, если гордишься Россией!; Бибикни, если любишь!; Обаму в яму! Если согласен, посигналь!; Если веришь в Деда Мороза! Посигналь два раза и т.п. Здесь налицо 
стремление автомобилистов смоделировать поведение интернет-пользователей в социальных сетях с их системой «лайков».

В качестве заключения отметим, что жанр «автомобильная наклейка» лингвоспецифичен не в меньшей мере, чем, скажем, анекдот. Нередко смысл наклейки понятен адресату лишь потому, что ему знакомы и понятны приемы языковой игры, лежащей в основе текста наклейки, равно как и визуальный ряд, сопровождающий этот текст. Только это и делает возможным адекватное функционирование данного жанра в системе городской коммуникации. Носители другой культуры, даже если они хорошо знают русский язык, могут не понять смысла, заложенного в тексте автомобильных наклеек.

\title{
Литература
}

Вандербильт T. Трафик. Психология поведения на дорогах. М.: «Эксмо», «Манн, Иванов и Фербер», 2013. 432 с.

Иссерс О. С. «Речевые коллекции» как объект лингвистического анализа // Жанры речи. Вып. 6. Жанр и язык. Саратов, 2009. С. 150-161.

Китайгородская М.В., Розанова Н.Н. Малые письменные жанры в городском общении: на пути к диалогу // Капанадзе Л.А. (сост.), Кузьмина С. М. (отв. ред.). Жизнь языка: Сб. ст. к 80-летию М.В. Панова. М.: Языки славянской культуры, 2001. С. 256-262.

Китайгородская М.В., Розанова Н.Н. Современное городское общение: типы коммуникативных ситуаций и их жанровая реализация (на примере Москвы) // Современный русский язык: Социальная и функциональная дифференциация. М., 2003. С. 103-126.

Китайгородская М.В., Розанова Н.Н. Языковое существование современного горожанина: На материале языка Москвы. М.: Языки славянских культур, 2010. 496 c.

\author{
Elena A. Nikishina \\ National Research University Higher School of Economics \\ (Russia, Moscow) \\ helene_nikichina@mail.ru
}

\section{BUMPER STICKERS AS A SMALL GENRE IN THE SYSTEM OF SPEECH INTERACTION ON THE ROAD}

The article addresses a new form of city urban communication, namely, car stickers. By this term I mean non advertising inscriptions and slogans that car owners stick to glasses, doors and bumpers. I regard these stickers as a small speech genre. In the beginning the situation where this genre is used is briefly described. The main properties 
of communication in the situation of road traffic are interactivity, a wide use of language game, creativity and concurrence. The interaction of participants in this sphere of communication is covered by three main sub-situations: "driver $\leftrightarrow$ driver", "driver $\leftrightarrow$ road police officer" and "driver $\leftrightarrow$ pedestrian". The stickers can realize various communicative strategies and functions: information, excuse, warning, self-affirmation, threat, appeal, and so on. Another parameter that distinguishes the stickers is thematic content. It can include the following categories: road traffic in general, personal information about the driver, political and patriotic discourse. A large number of stickers, for instance, expressions of gratitude have only a phatic function. The article also includes a comparison between the stickers and communication in internet chats, which is also to a high extent regulated by the anonymity of participants.

Key words: speech genre, urban communication, participants of communication, interactivity, speech game, communicative strategy, car stickers.

\section{References}

Vanderbilt T. Trafik. Psikhologiya povedeniya na dorogakh [Traffic: Why We Drive the Way We Do (and What It Says About Us)]. Moscow, «Eksmo», «Mann, Ivanov i Ferber», 2013.432 p. (In Russ.)

Issers O. S. ["Speech collections" as an object of linguistic analysis]. Genres of speech. Genre and language. 2009, Issue. 6. Saratov. pp. 150-161. (In Russ.)

Kitaigorodskaya M. V., Rozanova N. N. [Small written genres in urban communication: on the way to dialogue]. Kapanadze L. A. (Comp.), Kuzmina S. M. (Edited). Zhizn' yazyka: Sb. st. k 80-letiyu M. V. Panova [Life of language: Collected articles to the 80th anniversary of M. V. Panov]. Moscow, Languages of Slavic Culture, 2001. pp. 256-262. (In Russ.)

Kitaigorodskaya M.V., Rozanova N.N. [Modern urban communication: types of communicative situations and their genre realization (on the example of Moscow)]. Sovremennyi russkii yazyk: Sotsial'naya i funktsional'naya differentsiatsiya [Modern Russian language: Social and functional differentiation]. Moscow, 2003. pp. 103-126. (In Russ.)

Kitaigorodskaya M.V., Rozanova N. N. Yazykovoe sushchestvovanie sovremennogo gorozhanina: Na materiale yazyka Moskvy [Linguistic existence of a modern citizen: On the data of the language of Moscow]. Moscow, Languages of Slavic Cultures, 2010. 496 p. (In Russ.) 


\author{
Е. Ю. Протасова \\ Хельсинкский университет \\ (Финляндия, Хельсинки) \\ ekaterina.protassova@helsinki.fi
}

\title{
СОБЛЮДЕНИЕ РЕГЛАМЕНТА НА КОНФЕРЕНЦИИ: РЕПЛИКИ УЧАСТНИКОВ
}

В статье рассматривается речевое поведение выступающих на конференциях в связи с соблюдением регламента, их отношение к тайм-менеджменту, выраженное в словесной форме. Объектом исследования являются фразы, высказывания и случаи обмена репликами перед докладом, в его ходе и в конце выступления, а также оформление начала и конца дискуссии. Утверждается, что на конференции происходит параллельно два дискурса - один по содержанию сообщения, а другой по обсуждению его временных рамок и их соблюдения. Выявляется разница между традиционным и новым подходом к проведению научных конференций. Показано, как ведущий собрания и выступающий следят за временем, пытаются соблюсти установленные правила, радуются тому, что могут это сделать, либо же расстраиваются из-за того, что это не удалось. В некоторых случаях докладчик извиняется перед аудиторией, иногда сердится на председательствующего, либо же модератор упрекает оратора в несоблюдении регламента. Демонстрируются способы выразить свое отношение к происходящему. Материалом для исследования послужили ручные записи, сделанные на нескольких десятках конференций и семинаров в течение нескольких лет.

Ключевые слова: речевое поведение докладчика, риторика устного выступления, тайм-менеджмент, цейтнот, регламент.

Поведение человека на конференциях может быть рассмотрено в разных аспектах: вклад в науку и ученую дискуссию, человеческие отношения, карьерный менеджмент и т. п. Сообщество организуется и демократическим способом по определенным законам вежливости регулирует коммуникацию на мероприятии. Параллельно ученому дискурсу возникает обсуждение тайм-менеджмента, сопровождающее конференцию как событие. Присутствующие оказываются вовлеченными в два параллельных дискурса: собственно научный и тот, который обсуждает временные рамки события. 
Взаимная договоренность между говорящими и слушающими о регламенте должна помогать следить за временем в большинстве жизненных ситуаций. Общим местом многих конференций является установка на соблюдение регламента как тягостной необходимости, ограничивающей свободу выступления. Н. Г. Брагина [2007: 288] пишет: «В мифологии хаос амбивалентен: он - и ядовитый отход миротворения, и энергетический источник мироздания. В языке и культуре хаос сохраняет смысловую амбивалентность». Право на высказывание, вероятно, принадлежит к числу самых важных прав ученого, а в стереотипы, с которыми по старинке связан этот образ, входит забывчивость и увлеченность, способность без памяти погрузиться в любимый предмет и - как следствие - рассеянность. Примеры из НКРЯ:

жуткие, тысячелетние культы сей очень ученый, рассеянный муж, спотыкаясь о тысячелетья, привел за собою в Париж [Андрей Белый. Начало века (1930)] Альберт Эйнштейн был последним из могикан этого как бы вечного типа ученого, рассеянного неряхи. [Варлам Шаламов. Дневники (1954-1979)]

Некоторых оскорбляет предложение выступать в течение 20 минут, потому что их мысли в это прокрустово ложе не укладываются. Иногда же докладчик, встав перед всеми, говорит, что ему нечего добавить к тому, что уже написано в его книгах. Умение сократить свою речь бывает значимым, как в знаменитом случае с генералом И. Родионовым, которого уволил Б. Ельцин, когда тот не смог редуцировать свой доклад [Родионов 2010].

Тайм-менеджмент нередко воспринимают как современное западное явление, которому нужно специально учиться. Соблюдение времени «начала и завершения каждого этапа делового мероприятия» - выражение уважения и престижа. Чтобы успеть вовремя, нужны техническая подготовка, резервы времени, таймер, таблички, реплики модератора [Архангельский 2013, Деловой интернет]. Рекомендуется не задерживаться больше чем на две минуты, не ждать кого-то, не забирать время у следующего выступающего или от перерыва. Если докладчик не заканчивает вовремя, ведущий должен встать и стоять полминуты-минуту, глядя на выступающего, в крайнем случае - прервать словами: «Спасибо! Вопросы к докладчику!» или «Следующий доклад...». Ведущий также «дирижирует» вопросами, отметает провокационные, использует свои заготовки и т.п. [там же].

Нервная обстановка, выход из регламента вызывают негативные чувства и нежелание внимательно слушать докладчика. Ведущий может сказать: Mbl можем задержаться, без нас пленарное заседание не начнут; Тут недалеко, до зала, где будет презентация книги, всего 5 минут, так что у нас есть ещче 10 минут; Я думаю, все готовы пожертвовать обедом ради того, чтобы послушать нашего уважаемого А; Я надеюсь, что никому не будет обидно, если мы отъедим немного от перерыва; Мы можем еще откусить от перерыва.

По наблюдениям, тот, кто сообщает, что отведенное время использовать полностью не сможет, говорит намного больше, чем обещал (Я думаю, что я все время 
не займу. Я не буду, долго времени не займу у вас). Многие просто не чувствуют времени и не способны оценить, сколько займет их выступление. У других есть установка, что выступление - что-то обязательно скучное и нудное: Я постараюсь очень не мучить, я понимаю, что всем тяжело сидеть; Я многое пропустил, чтобы не утомлять вас.

Когда меняются модераторы, им случается своеобразным образом отомстить или обговорить то, что происходило до того, как они поменялись ролями: Когда Bы говорили, я Вас не прерывал; Дайте мне досказать, я же вам давал высказатьcя; а когда выступает в качестве докладчика модератор, ранее запрещавший всем говорить долго: Тема такая интересная, что и речи не может быть о том, чтобы ограничивать докладчика по времени. Пусть говорит сколько хочет.

В ходе выступления люди сообщают о том, что у них много интересного материала и они его либо пропустят, либо предоставят возможность прочитать в статье / тезисах / на слайде / на сайте / или потом пришлют, а некоторые, естественно, устраивают «театр»: Что, у меня так мало времени? Я не успею рассказать вам самое интересное. Так, это я пропущу, на это тоже нет времени. Если хотите узнать, задайте мне после доклада вопрос; Подождите: посмотрю, что я могу выбросить, что не так важно; Я за недостатком времени опустил ...

Руководители конференции могут предупредить о том, как будут работать модераторы: От вас ожидают прямо такой диктаторской работь; Модератор будет показывать каждому выступающему эти таблички (5 минут, 2 минуть u cmon). Введение табличек вызывает противоречивые чувства, часто отталкивание: Меня снабдили такими табличками, вы, пожалуйста, не пугайтесь, еще есть такая и такая. Когда я покажу STOP, это значит все, конец; Мы можем говорить 15 минут, потом дискуссия, а когда я покажу эту табличку, тогда конеи дискуссии. Мне сказали, что это помогает; У меня такие страшилки, я сразу всем показываю; Мы всем будем показывать такую табличку; Когда пройдет 20 минут, я постучу по графину. Если модератор не справляется, он извиняется: Это я виновата, я куда-то потеряла бумагу, на которой написано: 2 минуты. Выступающий и сам может попросить: Прошу показать мне / покажите мне эту табличку, когда останется 5 минут.

Особыми репликами сопровождается начало секции: (Давайте) подождем еще 5 минут, чтобы все собрались; Будем рассчитьвать на академическое опоздание; Не надо ли подождать? Мы можем / давайте уже начинать; Ну, что же, пора открывать заседание; Приступим; Счетчик стоит; Я слежу за временем.

Перед началом и по ходу ведущий обсуждает регламент: Давайте все-таки установим регламент. Не более, к сожалению, 15 минут, не более; Буквально 13 минуточек на доклад и 2 минутки на вопросы; B мои обязанности входит организовать сессию так, чтобы все начинали вовремя; В коние мы продолжим обсуждение; Запомнитесвоивопросыи сохранитеихдляобщейдискуссии; Поскольку мы являемся (со)председателями этой секции, мы должны показать пример / придерживаться регламента особенно строго / имеем право на 5 дополнительньх минут; Давайте будем обсуждать все вопросы после всех докладов / после того 
как состоятся / мы прослушаем все доклады; Я выступаю в роли непривычной полицейского; Я над Вами нависаю. Иногда играют в демократичность: Мы можем просить задавать вопросы сразу или устроить дискуссию после всех докладов; Как поступим? Послушаем еще один доклад и тогда закончим на полчаса раньше или пораньше уйдем на перерыв, а после перерыва послушаем ещзе 4 доклада? Если мы будем укладываться во временные рамки, у нас останется 15 минут на дискуссию; О, мы уже еще больше отстаем. Я плохой председатель у нас. Есть и особые права модератора: Я на правах председателя нарушила лимит времени; Я была очень жёсткой, чтобы мне тоже уложиться.

Необходимость вовремя поесть мотивирует сжатое изложение: Я поняла, что если я заберу все свое время, мы останемся без обеда; Пока что я только скажу..., потому что мы можем лишиться обеда; Сберегая наше обеденное время, скажу о предварительных итогах.

О своей приверженности конвенции, связанной с соблюдением времени, сообщают все участники события, но делают это по-разному: Постараюсь уложиться в регламент; Буду дисииплинироваться; Я себе даже будильник поставила; Я дальше опущу, мне еще хочется успеть сказать кое-что; Я специально 2 минуты вперед поставила, чтобы было время закончить; Мне сказали, что я могу говорить в течение 10 минут. Я думаю, что я уложусь в этот срок; У меня одна проблема: я забыл часы и телефон в гостинице, поэтому за временем не могу следить; Я буду еще говорить ровно 4 минутьл. Это чтобь всех успокоить; Я сейчас быстро все объясню, буквально за 5 минут; Мне дали 10 минут, и это, конечно, проблема; Мне дали 25 минут. Постараюсь уместиться; Я буду говорить так, чтобы успеть сказать как можно больше; У меня поразительно, безумно мало времени, поэтому я впервые в жизни написал тезисы. Обычные диалоги: Регламент какой? - Ну, так скажем, 5 минут; - Я повторяю, уважаемье коллеги: 10 минут. - Я постараюсь еще короче. - Спасибо; - Вы не сказали о регламенте. - Регламент - мы подумали, что не нужно.

Обсуждаются и те моменты, когда оказывается больше или меньше времени, чем нужно, а также как им распорядиться: Bbl можете закончить пораньше, тогда останется / будет больше времени на вопросы. Наверняка слушатели захотят Вам их задать; Все выступающие продемонстрировали уважение друг к другу, поэтому у нас есть время для дискуссии; Мьл сэкономили время, и теперь в виде бонуса послушаем одно краткое сообщение; У нас ещё в следующей секичи будет время, потому что на самом деле время уже вышло на дискуссию; У меня еще больше времени, осталась одна минута; Теперь мь идем даже с опережением графика; Mbl сэкономили некоторое время, поэтому потратили его сейчас на стучание по микрофону; Так как мы выигрываем время, не страшно, что я иду какое-то время. Я какое-то время буду подходить, но это не страшно, у нас есть ещзе 15 минут.

Выступающие часто говорят об экономии: В целях / ради экономии времени я пропущу... не буду всё зачитывать / специально останавливаться на своих выводах; Если хотите, я их перечислю, но пока сэкономлю время; За счет своего 
выступления, если можно (вставляет флэшку); Я не буду подробно об этом говорить - времени не хватит; Я ряд форм тут называю - просто нет времени их перечислить; Хочу только сказать, чтобы не затягивать / вылграть время. Иногда откуда-то неожиданно появляется лишнее время: Пока у нас такое «собирательное» настроение, мы решили предоставить слово для презентации; Одного докладчика нет, вы можете поделить между собой его время; Мы ей дадим пару минут; Вы спокойно докладывайте, мы задержим немного нашу секцию; Начали позже, поэтому все время скатываемся... Если не послушать доклад сейчас, то остальным достанется по 10 минут.

Регламент комментируется по ходу секции: $\mathrm{Mbl}$ (не) соблюдаем регламент; хорошо / точно укладываемся в регламент; отлично успеваем; идем по графику / нашему плану / программе; задерживаемся (на одну минуту); отстаем; вышли за рамки регламента; очень просим не выходить из графика; немножко выбились из / отстаем от / выпадаем из графика, но время на один вопрос у нас точно есть; Поскольку я перебрала свое время, мы оставим все вопросы на потом, зададим и обсудим их после докладов; Если мы начнем задавать вопросы, то на обед мы не уйдем; Главное, что все вопросы можно задавать и потом, и в обед; Я решился задержать вас еще на несколько минут; Мы уложились в регламент благодаря тому, что в расписании была опечатка / что один из докладчиков не приехал / не пришел / что одного доклада не было / один доклад выпал; У нас не было первого доклада, поэтому мы могли себе позволить взять немного больше времени. Нет-нет, мы могли себе это позволить; Давайте все же регламентироваться.

За соблюдение регламента хвалят: Обостренное чувство времени, правда же? Bы хорошо укладываетесь; Вы перфекционист, уложились вовремя; Bы-то perfect in time, но мыл-то всё-таки на 5 минут отстаем; Вы точно рассчитали время; Какой, однако, утешительно короткий доклад; Спасибо, что соблюли регламент; Отдельное спасибо за краткость / за интересный и компактный доклад / за то, что Вы помогли нам войти в график; Все были очень дисциплинированы, и никому не надо было напоминать о времени.

Частотны слова короткий, (максимально/очень) коротко, кратко / быстро: Я постараюсь быть как можно более ...; рассказать/представить (очень) ..., в течение буквально 15, 17, ну, максимум 20 минут; Я буду говорить ..., потому что здесь так принято / потому что здесь это изенят / потому что я не хочу отнимать у вас время / потому что я не хочу занимать много времени; Поскольку мой доклад последний перед обедом, я постараюсь не задерживаться и сделать мой доклад ...; Для краткости я так позволю себе сократиться; Я традииионно обешаю быть краткой; Очень коротко, можно один вопрос. Для трех вопросов, которые я собираюсь задать, осталось меньше двух минут, но я постараюсь (как можно) (по)быстрее / быть краткой. Наоборот, если возникает препятствие, например, завис компьютер, говорят: Ну всё, это надолго.

Комментируется также и то, что все торопятся / спешат, что речь идет о быстром движении: Бегу просто, чтобы дойти до этой темы конференции; Время бежит, 
и я бегу; Для скорости; чтобы не терять время; Ой, извините, я поскольку спешу ...; Дальше я просто проскочу, раз меня торопят; Я ускорюсь, некоторые слайды буду пропускать. Возможны и диалоги типа: - Нужно торопиться? - Можете не спешить; - Это несправедливо. Я начинала позже. - Я Вас не тороплю. Стремление соблюсти регламент выражается и так: Я буквально несколько слов хочу сказать; Я очень быстро, буквально 5 минут; Я даже сокрашу, но дальше будет скороговоркой.

Множественное чужое время ощущается как что-то, за что несут ответственность, за задержку извиняются, за краткость благодарят: Постарайтесь, ну, перед обедом; Спасибо, спасибо, голубчики, ну, полицейский же я надел мундир и соответствую; Извините, пожалуйста, я должен также смотреть и за регламентом, чтобы все успели выступить; Дорогие коллеги, я вынужден напомнить о соблюдении регламента; Не ругайтесь, пожалуйста, на меня, но давайте в 7 минут попробуем уложиться; Еще один доклад остался, придется немного потерпеть; К сожалению, вам придется еще немного потерпеть, потому что я должна...; Спасибо, что вы дождались; Спасибо за терпение; Я знаю, что говорю слишком долго, но слова предыдущего оратора меня задели; Я всетаки займу 2 минуты, в одну я точно не уложусь, извините меня, пожалуйста; Я очень извиняюсь перед уважаемьли модераторами за потраченное время; Я чувствую себя виноватой; Тут всё загружается, прошу прощения; Мы опаздываем, и по моей вине тоже; На правах председателя я позволю себе вас прервать, потому что времени мало, извините за такую неэтикетность; Извините, я знаю, что многие хотели бы задать вопрос, но у нас конференция, и мьл идем по расписанию.

Иногда модератор понукает отвлекшегося докладчика: $У$ вас / нас (ещуе) 8 мuнут; Вы уже точно должны заканчивать; Пошла последняя минута; Давайте дальще, а то у нас времени уже мало. Из нижеследующих диалогов между выступающим и председателем становится понятным, как происходит проверка оставшегося времени:

- Сколько у меня времени? - 25 минут. - Ну, давайте я займу 20 минут. Успею. /.../ Ой, время. Да, я скоро заканчиваю. /.../ И вот я укладываюсь.

- Сколько у меня осталось? Всё, да? - 15 минут. - Чуть-чуть.

- Вы следите за временем? - Мы немножко выходим из графика.

- У меня сколько осталось? - Ну, еще есть время.

- Простите, что у меня со временем? - Есть 6 минут до самого конца Вашего доклада. - Ага, 6 минут. - Вы можете закончить раньше и оставить время на вопросы.

— Показать Вам, когда останется 5 минут? - Ой, да, пожалуйста. — Я покажу Вам так: (растопыривает пальцы поднятой ладони)

- (показ бумаги) - кивок, сложенные руки, «да»

- Анна Ивановна! (говорящий останавливается) - Да, заканчиваю.

- (глядя на табличку) Спасибо, заканчиваю / Ах! (всплёскивает руками)

- Елена Михайловна! - Да, я слежу. 
- Время! — Я (уже) заканчиваю, да.

- Время кончается. - Тогда очень коротко.

- Голубчик, у Вас минута! - Ага, я успею.

— Я хочу Вам напомнить, что буквально минута у Вас осталась. — Я в минуту уложусь.

- Сколько у меня времени? - Вы уже говорите 20 минут. Вы можете говорить 2-3 минуты. - Значит, у меня 1-2 минуты.

- Времени у меня остается немного. - Вы можете не спешить. - Тогда я приведу все примеры, которые запланировал.

- Можно еще немножко? - Вот я смотрю: время-то все вышло. - Ну, я быстро. Не зря же я так готовилась.

- Сколько времени я еще могу говорить? - 5 минут. Ой, мне этого не хватит. Можно, я подольше? Я все-таки так долго ехала.

— Кто-нибудь следит за временем? Марина? - Извините, я увлеклась.

- 4 минуточки у вас осталось. - В общем-то постараюсь уложиться в одну минуту.

- Мне дали 10 минут, я говорил сколько? - 15.

— У нас ещё есть время? — Время как раз заканчивается.

- Мне уже напоминают. - Я бы с удовольствием не напоминала.

— Что, осталось 7 минут? - Нет, я показываю, что 7 минут прошло.

- Одна минута, да? Жалко. - И нам жалко, но ничего не поделаешь.

— Мы что, закончили раньше? - Нет, наоборот, мы опоздали. - А, это 10 минут опоздания.

— Я бы хотел еще это рассказать, если время еще осталось. - К сожалению, уже не осталось.

— Я прошу прощения, 5 минут осталось. - (позже) Я хочу сказать, если 5 минут еще идут...

Другие возможные реакции: Вижу-вижу; Угу; О!; Ого; Всё, поняла, дальше иду; Осталось время или нет? Ну, я так понимаю, что у нас уже совсем мало времени осталось; А вы знаете, я, пожалуй, уложусь; Тогда я тороплюсь; О, это много, я быстро говорю; Когда я должна закончить? Если я закончу без пяти, это нормально?; Я (как раз) успею; Практически 5 минут, ну шесть; Я ускорюсь; Уюе cmon? Нет? А я думала, что Вы мне стоп показали. Я ещуе не исчерпала, понятно; Это мне хватит; Я уже кончаю; Уэе, да? Ага, хорошо; Уменя ещуе 10 минут, я специально следила, я их и возьму; Я думаю, что я практически закончила; Я все-таки ещзе попрошу дать мне одну минуту; Я поняла, спасибо; Будьте добры, полминутки; Да, я понимаю, спасибо. Но это же не секунды?; Поскольку нужно закругляться, выводы; Я уже смотрю, мне показывают так строго 10 минут; Я расскажу очень быстро; Секундочку, да?; Вот мне немножечко осталось совсем; Я буду тезисно; Ну и так как у меня осталось мало времени, я вам скажу сразу про вывод; Я уже вижу, что мне пора, нужно заканчивать; Я уже перебираю время.

Все же есть реплики, выглядящие противоречиво по отношению к правилам: Поскольку у меня мало времени, я все думала, о чем вам рассказать; Здесь 
я просто пропущу, чтобы время не терять; Дайте мне ещё час!; Я знаю, что моё время закончилось / истекло, но я все-таки скажу; у нас нет времени это читать, если вдруг появится время это читать, я вам покажу; Этого я совершенно не коснусь, потому что времени совсем нет; Я собиралась много чего сказать, но из-за недостатка времени скажу коротко; Прошу полторы минуты мне добавить; Уже тут одна минута - я не знаю, что делать; Вот осталось сейчас два слайда - иначе мы не узнаем конца; У меня два примера к этому, я постараюсь коротко; Давайте так: 5 минут - и я постараюсь коротко ответить; Буквально несколько фраз еще; Мне напоминают о временном регламенте; Я немножко поторопилась, вернее, время мое заканчивается; На эту тему я могу говорить изельй семестр, не прерываясь. Слушатели иногда говорят, что согласны добавить время или делятся своим: Пусть ещуе говорит, нам интересно; Мы дарим свои 15 минут. Нам гораздо интересней послушать докладчика, чем выступить самим.

Докладчик начинает загодя маркировать конец доклада, а иногда и отмечает его репликой к ведущему или аудитории: (кивает карточке) B завершение хотелось бы сказать...; У меня уже 0 минут. Счас (я) (уже) (почти) (на этом) (всё) заканчиваю/закончу; Совсем последнее; Последнее, о чем я хочу сказать; Я уже последнее слово; Отмечу вкратие в коние своего выступления, уважая ваше время; Уже да, у меня конеи, я только последнее ещуе скажу; Я понимаю, что превысил всё; Ну и остановлюсь на двух последних чуть-чуть; Я так быстро говорила, что почти уложилась; На этом всё; Вот и всё. Кажется, я даже уложилась; То, что я хотела сказать по сущуеству, я сказала. Если уложилась в регламент - хорошо; Если коротко, это то, о чем я хотел сказать; У меня всё, спасибо; Спасибо, всё, это конеи; Я на этом, наверно/пожалуй, остановлюсь и уже отвечу на конкретные вопросы; Об этом можно говорить очень много, но времени у меня уже нет; Мне кажется, что я своё время уже исчерпал; Я понимаю, что я уже по времени выхожу за предель; Я уложилась? Перебрала?; Я не смог за 15 минут заменить оратора, но зато уложился в регламент.

После доклада ведущий сообщает, сколько минут «у нас» есть на вопросы, иногда уточняет: Каждый вопрос вместе с ответом 2 с половиной минуты; У нас еще 3 вопроса и 4 минуты, давайте по минуте на вопрос; Чтобы оставить время для следующих выступающих, я должен попросить задавать только очень короткие вопросы; Mbl успеем задать еще один вопрос; Есть время только для одного вопроса; Ну / может быть / пожалуй, один вопрос (мы все-таки можем / успеем задать); Несколько блищ-вопросов; $\mathrm{Mbl}$ сейчас в блиц-режиме: два вопроса - один ответ; Есть возможность только один вопрос задать, потому что мы уже исчерпали и время доклада, и время дискуссии. Чей вопрос короче? или говорит: И у нас много времени на вопросы; У нас не осталось времени, мьл исчерпали 25 минут.

Задавая вопрос, участники упоминают о том, что он (только) небольшой, короткий, совсем/ очень маленький, иногда спохватываются, что времени совсем не осталось, и отвечающий также подчеркивает соответствие ответа вопросу по длине. 
Отмечается переход к следующему выступлению: Я думаю, что у всех еще очень много вопросов, во всяком случае, у меня очень много вопросов, но мы должны завершить дискуссию; Вопросы к вам есть, но уже время; Давайте дискуссиями потом будем заниматься, потому что время ограничено; Ваш доклад вызвал бурю в моей душе, но я знаю, что мы не можем его обсудить; Если вопросов больше нет, поблагодарим еще раз докладчика; Не хочется мешать вашей дискуссии, но пора пригласить следующего докладчика; Я брутально все прерываю; Боюсь, вам не удастся продолжить; Коллеги, давайте сразу перейдем к следующему докладу; Следующее слово буквально ненадолго; Значит так, вот, хорошо, слушайте, мне очень жаль, но придется прервать сейчас; Дорогие друзья (я боюсь, что) мы, к сожалению, здесь уже должны прервать (эту) дискуссию и перейти к другому докладу; Наш последний выступающий...

В конце сессии или собрания произносятся ритуальные реплики: Если вопросов больше нет, то во временной лимит мы совершенно точно уложились; У нас есть расписание. Мы его соблюдаем. В 10.30 кофе-брейк; Это последнее замечание в этой секции, поспешим на кофе-брейк, чтобы успеть на следующее заседание; Думаю, что пора пить кофе; Дискуссия будет происходить за кофе; Мы готовь прерваться; Докладчик с нами весь день; Б. будет счастлив ответить на ваши вопросы во время перерыва; Это выходит за рамки нашего круглого стола; Продолжим в кулуарах; У нас практически не осталось времени. Нас предупреждают, что пора освобождать помещчение; Мы должны отпустить гардеробщиков; Вахтеры хотят домой.

Итак, некоторым кажется, что следить за временем - дело, недостойное взрослых, уважаемых людей, а делать замечания неприлично. График - тяжелая необходимость; если опаздывает один, то теряют время все. В разных ситуациях на одно и то же число оставшихся минут реакция различна. Обсуждение регламента нередко вызывает смешки и ужимки: ведущий, стесняясь, показывает приготовленные им самим или организаторами таблички, пожимает плечами, извиняется, реже - старается быть суровым и сообщает, что это не он так решил, а что это распоряжение свыше. Кажется, что чем меньше обсуждения самого процесса, тем лучше соблюдается регламент.

\section{Литература}

Архангельский $Г$. Как добиться от докладчиков соблюдения регламента. 16.04.2013. [Электронный ресурс]. URL: vedomosti.ru

Брагина Н.Г. Память в языке и культуре. М.: Языки славянских культур, 2007.

Деловой интернет. Инструкция ведущему секции на конференции [Электронный ресурc]. URL: http://di.by/rules/.

Родионов И. Самодурству Ельцина не было предела. 29.6.2010. [Электронный pecypc]. URL: https://operkor.wordpress.com 


\author{
Ekaterina Yu. Protasova \\ University of Helsinki \\ (Finland, Helsinki) \\ ekaterina.protassova@helsinki.fi
}

\title{
MANAGING TIME AT CONFERENCES: TURNS OF PARTICIPANTS
}

Time management practice is a hard and emotional topic in the intercultural communication with Russians, and conferences are not an exception. Nowadays, conferences held in Russian are gradually coming to the general standard of time-management and acquiring temporal-sequential ordering abilities. Contrarily to the previous times when the interest in the concrete speaker, importance of his talk and devotion to the matter defined the length of the turn, a more democratic way of scheduling papers is progressively taking place in the modern meetings. Pictures with the quantity of minutes left remain a rare tool. The article reveals typical and untypical ways of organizing events from the verbal point of view, as well as turn taking between moderator, presenter and audience. The data was collected at dozens of Russian conferences in humanities. Real dialogues and replies serve as basis for analysis. Discussions upon responsibilities of participants demonstrate how speakers and listeners express their opinions about working out and monitoring schedules.

Key words: presenters verbal behaviour, rhethorics of the oral presentation, time management, time pressure, time-limit.

\section{References}

Arhangel'skij G. Kak dobit'sya ot dokladchikov soblyudeniya reglamenta [How to make presenters keep up with the time schedule]. 16.04.2013. Available at vedomosti.ru (accessed 25.08.2017)

Bragina N. G. Pamyat'v yazyke i kul'ture [Memory in language and culture]. M.: Jazyki slavjanskih kul'tur, 2007.

Delovoj internet. Instruktsiya vedushchemu sektsii na konferentsii [Instruction for the session moderator at the conference]. Available at http://di.by/rules/ (accessed 25.08.2017).

Rodionov I. Samodurstvu El'cina ne bylo predela. 29.6.2010. Available at https:// operkor.wordpress.com (accessed 25.08.2017). 


\section{Т. Б. Радбиль}

Национальный исследовательский Нижегородский государственный университет им. Н. И. Лобачевского

(Россия, Нижний Новгород)

timur@radbil.ru

\section{КУЛЬТУРНАЯ АПРОПРИАЦИЯ ЗАИМСТВОВАНИЙ В СВЕТЕ ТЕОРИИ ЯЗЫКОВОЙ КОНЦЕПТУАЛИЗАЦИИ МИРА}

В статье рассматриваются основные принципы культурной апроприации иноязычных элементов в речевой практике современных носителей русского языка. Мы исходим из того, что для русского языка как отражения типично русского способа смотреть на вещи характерно своего рода «переиначивание» семантики и оценочной сферы заимствованных слов как знаков «чужих» ценностей или инокультурных моделей поведения. «Знаковые» в каком-либо отношении заимствованные слова (термины, идеологемы, аксиологемы и пр.) в дискурсивных практиках современных носителей языка подвергаются обязательной культурной апроприации в духе исконно русских моделей языковой концептуализации мира. Такие базовые доминанты «семантического универсума» русского языка, как установка на эмпатию (выраженная в субстантивных и адъективных диминутивах), чрезмерная гиперболизация (интенсификаторы и аугментативы), гипертрофия общей, моральной или эстетической оценки при номинации лиц, объектов и событий, острая реакция на ложные, с точки зрения носителя языка, ценности или претензии, соотнесенность самых простых вещей, свойств, процессов или явлений с духовным идеалом, ироническое «остранение» карнавального типа и пр., актуализуются и при вхождении заимствованных элементов в русскую речевую практику. Об этом свидетельствуют особенности словообразовательного освоения в русском языке заимствованных номинаций, а именно - образование окказиональных дериватов по типично русским моделям экспрессивного словообразования на базе иноязычных основ, таких, как смайл-, селфи-, френд- и под. При этом в производном слове с иноязычным по происхождению компонентом возникают культурнообусловленные коннотативно-оценочные приращения смысла, которые эксплуатируют исконно-русские культурные установки и ценностные стереотипы.

Ключевые слова: активные процессы в русском языке, заимствования, деривация, культурная апроприация, языковая концептуализация мира. 
Чтобы объективно оценить состояние русского языка в переживаемый нами период времени, необходимо выйти за пределы одной лишь фиксации лежащих на поверхности языковых изменений, которые в общем справедливо связываются с массивом лексических и словообразовательных заимствований, с определенной перестройкой стилистической системы и пр. Необходимо выяснить, в какой мере сегодня трансформируются национально-специфичные, традиционно русские способы языкового освоения действительности, насколько серьезны изменения в той концептуальной области, которую принято именовать «русская языковая картина мира» [Зализняк, Левонтина, Шмелев 2005].

Мы исходим из того, что для русского языка как отражения типично русского способа смотреть на вещи характерно своего рода «переиначивание» семантики и оценочной сферы заимствованных слов как знаков «чужих» ценностей или инокультурных моделей поведения. «Знаковые» в каком-либо отношении заимствованные слова (реалии новой действительности, термины, идеологемы, аксиологемы и пр.) в дискурсивных практиках современных носителей языка подвергаются обязательной культурной апроприации в духе исконно русских моделей языковой концептуализации мира [Новые тенденции... 2014].

В работах ряда отечественных и зарубежных ученых были выявлены разнообразные базовые доминанты «семантического универсума» (А. Вежбицкая) русского языка. Это, например, установка на эмпатию (выраженная в субстантивных и адъективных диминутивах), чрезмерная гиперболизация (интенсификаторы и аугментативы), гипертрофия общей, моральной или эстетической оценки при номинации лиц, объектов и событий, острая реакция на ложные, с точки зрения носителя языка, ценности или претензии, соотнесенность самых простых вещей, свойств, процессов или явлений с духовным идеалом, ироническое «остранение» карнавального типа и пр. [Вежбицкая 1996; Зализняк, Левонтина, Шмелев 2005; Радбиль, Рацибурская 2017].

Указанные тенденции активно «работают» и при вхождении заимствованных элементов в русскую речевую практику, о чем свидетельствуют особенности семантического и деривационного освоения в русском языке заимствованных номинаций, а именно - образование окказиональных дериватов по типично русским моделям экспрессивного словообразования на базе иноязычных основ. Например, зададимся вопросом, в какой мере воспринимается как заимствованная такая лексема, как безлимитище? Совершенно очевидно, что, несмотря на наличие формально иноязычного корня, сам характер деривации этого слова с размерно-оценочным суффиксом -ищ- на базе исходного прилагательного безлимитный (тариф) свидетельствует о его вхождении в типично русские модели номинации ситуации. Здесь мы видим сложный и нерасчлененный комплекс смыслов, с одной стороны, одним словом как бы схватывающих целый фрейм - систему опций и преференций при приобретении телефонного тарифа, а с другой - регламентирующих для говорящего и адресата определенное отношение к этому объекту номинации, вписывающих его в систему ценностных установок сложной природы (здесь можно видеть уже указанную выше чрезмерную гиперболизацию и даже гипертрофию эмоциональной реакции 
на в общем-то нейтральный объект, какую-то неформальность и «свойскость», делающую изначально внеоценочный денотат чем-то близким, родным).

Таким образом, весьма примечателен тот факт, что окказиональные дериваты на базе иноязычных элементов образуются по типично русским моделям экспрессивного словообразования, о специфике которых именно в плане выражения русского национального характера говорит А. Вежбицкая, размышляя о русских суффиксах субъективной оценки, выражающим специфически русскую черту эмпатию по отношению к объекту номинации, т.е. эмоциональную вовлеченность говорящего, его сопричастность объекту номинации. А. Вежбицкая вводит в толкование представление о неопределенном свободно плавающем «хорошем чувстве»: ‘когда я думаю о Х, я чувствую что-то хорошее' [Вежбицкая 1996].

В этом мы видим проявление тенденции эмоционально-экспрессивного и оценочного отношения к миру вообще, атмосферы особой эмоциональной насыщенности и личностной вовлеченности в номинацию вещей и событий, которая распространяется даже на самые обычные вещи, окружающие человека, которые в норме не подлежат какому-либо оцениванию или эмоциональному переживанию их бытия (нас окружают носики чайника, ножки стола, письменные ручки, форточки, зонтики, валики, ролики и пр. - каждый из нас легко продолжит этот список). Ни в одном случае речь не идет об указании на малый размер объекта (едва ли носик чайника меньше носа человека, а платочек в песне вовсе был не маленький, носовой, а вполне себе обычный платок).

Заимствованные лексемы естественным образом вовлекаются в этот круг тотальной эмпатии русского дискурса. Любопытно в этом смысле слово смайлик, которое в общем даже совсем не похоже на заимствование, потому что здесь иноязычный корень изначально вовлекается в сферу семантических и словообразовательных процессов, присущих русскому языку, т.е. приобретает несвойственное ему в языке-источнике структурное оформление, словообразовательный показатель - размерно-оценочный суффикс -ик, при отсутствии исходного смайл (в отличие, например, от модели стол $\rightarrow$ столик). Этот элемент -ик должен быть квалифицирован как субморф, но он является важным для понимания слова смайлик, потому что отражает типично русскую конфигурацию смыслов, характерную для полноценных уменьшительно-ласкательных суффиксов - указание на малый размер, совмещенное с особым эмоциональным, задушевным отношением говорящего к объекту номинации и к ситуации общения в целом. Ничего подобного не обнаруживаем в слове, ставшем источником для данного заимствования: smiley (1. прил. улыбчивый $\rightarrow$ 2. перен. смайлик; эмотикон, обозначающий улыбку). Понятно, что и в английском языке-источнике имплицитно содержится указание на малый размер и особую экспрессию, но в русском языке эти смыслы эксплицированы в показателе -ик.

Очевидно, что носители языка в своей речевой практике как бы присваивают (по слова Э. Бенвениста) иноязычные элементы как знаки инокультурного бытия. Языковое сознание словно не позволяет слову ничего не значить и не иметь никаких коннотативно-оценочных возможностей. Поэтому иноязычные аббревиатуры приобретают русские диминутивные суффиксы, что тут же погружает их в систему 
национальных «языковых привычек» выражать определенные культурно значимые эмоциональные и ценностные приоритеты: USB становится юэсбишкой, CD-ROM превращается в сидюк, а РС (аббревиатура от РC — personal computer) - в писюк. Так в иноязычном по происхождению слове возникают культурно-обусловленные коннотативно-оценочные приращения смысла, которые как бы «обнуляют» заимствованный характер этого слова, приобщают его к фонду типично русских способов вербальной реакции на действительность, концептуальной интерпретации явлений внешнего и внутреннего мира в словесном знаке. Слово становится элементом «русского мира» [Радбиль, Рацибурская 2017].

Аналогичное вовлечение заимствованных корней в круг «русского мира» эмоций и ценностей видим в глагольной лексике - троллить, приаттачить, запостить, законнектить (ся), фо́рсить, забанить и т.д. Нетрудно заметить, что данные лексемы, «обрусев» в плане грамматического оформления, присущего русским производным и членимым глаголам, также приобретают экспрессию и оценочность, несвойственную им в языке-источнике. Аккультурация иноязычных корней в русскую глагольную лексику осуществляется по русским способам видеть мир в слове, отражая такую черту «семантического универсума», как присущая русскому глаголу избыточная образная характеристика ситуации в целом с встроенным экспрессивно-оценочным отношением к ней.

В этом плане интересны дериваты от заимствованного слова селфи, изначально выражающего вполне нейтральную конфигурацию смыслов: 'фотография самого себя с помощью предназначеннных для этого технических устройств'. Однако иную картину мы наблюдаем в субстантивных дериватах этого слова по модели экспрессивного суффиксального словообразования с помощью диминутивов, когда спонтанно возникают экспрессивно-оценочные смыслы. При этом имеются дериваты как мужского рода - селфишко (по модели домишко, бельишко): И как же без новогоднего селфишка [www.imgrum.net/user/jeka_anik/], так и женского - селфишка (по модели землишка, мелочишка): Самый дорогой человек в моей жизни !!! Селфишка с папашкой!!! [https://m.ok.ru/profile/]. Обнаружен даже снижено-разговорный экспрессивный фонетический вариант, маркированный по женскому роду - селфя: Селфя с сегодняшнего хеллоуинского концерта... [www.diary.ru/ iolly/p206570911.htm].

То же приращение эмоционально-экспрессивных смыслов мы наблюдаем в глаголах, образованных на базе этого слова через ступень деривации, ср. глагол селфить и его возвратный коррелят селфиться: Учимся правильно селфить у мастера Жана-Франсуа Жонвелля [Ostrich.livejournal.com/10889524.html]; Как фотографироваться сейчас модно и как селфиться категорически нельзя [gubdaily.ru]; Как правильно селфиться [https://www.youtube.com/watch?v=-7H5DRzi9Aw]; Не на диване или коврике селфиться [olivkafrekenbok.myqip.ru].

От этого глагола и его дериватов также образуются причастия: $A$ на четвертом - ульгбаюшийся и селфящий себя в храме священник [www.yaplakal.com]; Уродки отселфенные! [myprikol.com/comments/] — и деепричастия: Вдоволь наульбавшись друг другу и населфившись публика направилась в зрительный зал [https://03grb.ru/opinions/]. 
Далее напомним, что в русском языке существует вполне специфичная лексикограмматическая категория способа глагольного действия, когда на базе одного глагола с помощью разных типовых словообразовательных формантов (приставок, суффиксов и постфикса -ся) образуется разветвленная система дериватов, которые обозначают разнообразные и порою непереводимые на другие языки аспекты действия, его различные временные, количественно-временные и результативные модификации действия (бегать $\rightarrow$ забегать, набегаться, отбегаться, разбегаться и т.д.). Наличие этой категории, несомненно, можно интерпретировать в духе исконных способов языковой концептуализации мира, так сказать, проявления «языковой ментальности»: русскому человек почему-то понадобилось выражать самые разные, порою довольно тонкие нюансы, оттенки и параметры описываемого действия в пределах одной лексемы, как бы схватывать в глаголе всю ситуацию в целом, при этом выражая и экспрессивно-эмоциональную реакцию на эту ситуацию или оценку описываемого действия.

Поэтому вовлечение некого иноязычного слова в разветвленный способ глагольного действия является несомненным свидетельством его «культурной русификации», так сказать, концептуального «обрусения». Именно это мы наблюдаем для глагола селфить / селфиться. От данного глагола образуются самые разнообразные дериваты с сильной степенью экспрессии:

— понаселфить: Понаселфили в общем [www.pictaram.com/tag/malcev];

- понаселфиться: Пока Доби бегал за водичкой, они понаселфились.. [https:// vk.com/wall/];

— отселфить: Я ровно два года назад отселфился на этой же камере [https:// www.drive2.ru/b/

— поселфиться: Из разряда помылись, убрались, поселфились [https://www. drive2.ru/];

—населфиться: Населфился до потери сознания! [https://otvet.mail.ru/question]; Петербуржиам и гостям города на Неве можно и бесплатно населфиться вдоволь [peterburg.center/ln/3d-selfi-v-peterburge-foto-s-dinozavrami-i-ne-tolko.html];

- уселфиться: Весь уселфился [https://vk.com/].

О том, что включение иноязычных корней в систему моделей русского экспрессивного глагольного словообразования (в том числе - русских способов глагольного действия) как примета культурной апроприации этих понятий является значимой тенденцией в активных процессах современного русского языка, свидетельствует то, что и другие иноязычные лексемы обнаруживают подобные эффекты.

Так, на базе заимствования лайк (условное выражение одобрения материалу, пользователю, фотографии, выражающееся нажатием одной кнопки) образуются экспрессивные глаголы лайкать и лайкнуть, которые также порождают ряд аффиксальных модификаций действия по значению производящего глагола:

- полайкать: Она попросила своих друзей «ВКонтакте» зайти на странииу ее сына и «полайкать» его ... [https://snob.ru/selected/entry/];

— полайкаться: Молодежь в проиессе деградаиии - главное побольше полайкаться в соисетях [sergey-anaxata.livejournal.com/2017/02/04/?get=prev]; 
- налайкаться: Зачем секс, если можно зайти на аск, найти девочку, которая ненавидит жизнь и людей примерно так же, как и ты, и налайкаться вдоволь [ask.fm/jratvaaadepressiontime/answers/119149814292].

От глагола френдить 'включать чью-либо учётную запись в список избранных контактов на интернет-ресурсе' также зафиксирован целый букет экспрессивных аффиксальных модификаций действия:

— зафрендить: Хотите меня зафрендить? [argo.academic.ru/]; зафрендиться: Зафрендиться с потребителем в последнее время [www.kommersant.ru/private/ pdoc?docsid=139182];

— отфрендить: Отфрендить нельзя помиловать. [www.cosmo.ru/sex-love/he and_you/otfrendit-nelzya-pomilovat/];

— расфрендить: Трудно расфрендить человека, который одновременно: сам по себе хороший и обаятельный [andrzejn.livejournal.com/555148.html];

- расфрендиться: Недавно пришлось расфрендиться с парой «иироко известных в узких кругах» блогеров [asiarussia.ru/blogs/11100/];

- пофрендиться: Ничего не имею против новых технологий, но когда они опускаются только до уровня "пофрендиться" и "полайкаться"... [forums.kuban.ru/ 43068749-post4820.html].

Культурная апроприация иноязычных корней также проявляется в активном вовлечении их в разнообразные модели пассивизации и имперсонализации. Прежде всего это касается распространенности безличных форм глагола: Подскажите, ... можно ли ее подключить к домашнему вай-фаю так, чтоб нигде ничего не забанилось, не заблокировались... [4pda.ru/forum/lofiversion/index.php?t693103-60.html]; Забанил в одном месте - забанилось везде [forum.sape.ru]; Правда, плюс в том, что законнектилось очень быстро и настроек минимум [forum.electrostal.com/ index.php?topic $=37137.285$;wap2].

В целом отметим, что иноязычная лексика вполне на равных вовлекается в ту динамичную зону активных процессов, происходящих в русском языке последних лет, которая связана с активизацией игрового, лингвокреативного начала, с установкой на карнавализацию и несерьезное отношение к жизни, с некой эстетикой виртуализации реальности, в которой дружить меняется на френдить, а нравиться - на лайкать. При этом очевидный экспрессивный, образный и воздействующий потенциал рассмотренных моделей словообразовательных инноваций на базе иноязычных элементов во многом опирается на культурный фон, который содержится в исконно русских способах языковой концептуализации мира.

В плане общей оценки рассмотренных процессов аккультурации заимствованных слов можно утверждать, что разные уровни языка обладают разной степенью релевантности в плане апроприации инокультурных концептуальных структур. Вполне естественно, что в условиях новых социокультурных реалий и коммуникативных потребностей изменения именно в сфере лексики представляются наиболее активными. Но в плане языковой концептуализации мира лексические заимствования носят относительно поверхностный характер, тогда как именно изменения в сфере так называемой «языковой облигаторности» (словообразовательных 
моделей, грамматических категорий и под.) как глубинного концептуального каркаса мысли о мире, запечатленной в коллективном языковом сознании, представляются наиболее релевантными. А в этой сфере мы все же наблюдаем доминирование именно традиционно русского способа концептуализировать действительность в слове. Проще говоря, вместе с иноязычным компонентом сначала усваивается некий общий денотативный или сигнификативный слой, необходимый для заполнения имеющейся лакуны в когнитивной базе этноса или для обозначения появившейся в нашей жизни реалии, затем он подлежит концептуальному переосмыслению и эмоционально-оценочной трансформации уже в соответствии с «ключевыми идеями русской языковой картины мира» [Зализняк, Левонтина, Шмелев 2005].

Таким образом, наши наблюдения показали, что наиболее фундаментальные способы познания и оценивания мира и наиболее типичные речеповеденческие модели, присущие исконно русскому «взгляду на мир в слове», даже расширяют свою «представленность» в языковом сознании этноса последних лет за счет включения в зону своей «семантической активности» лексики заимствованного происхождения, которая осваивается и даже присваивается носителями языка как часть их естественной речевой практики.

\title{
Литература
}

Вежбицкая А. Язык. Культура. Познание / пер. с англ.; отв. ред. и сост. М. А. Кронгауз; авт. вступ. ст. Е. В. Падучева. М.: Русские словари, 1996. 411 с.

Зализняк А. А., Левонтина И.Б., Шмелев А. Д. Ключевые идеи русской языковой картины мира: Сб. ст. М.: Языки славянской культуры, 2005. 544 с.

Новые тенденции в русском языке начала XXI века: кол. монография / Т.Б. Радбиль, Е. В. Маринова, Л. В. Рацибурская, Н. А. Самыличева, А. В. Шумилова, Е. В. Щеникова, С.Н. Виноградов; под ред. Л.В. Рацибурской. М.: Флинта; Наука, 2014. 304 с.

Радбиль Т. Б., Рацибурская Л. В. Словообразовательные инновации на базе заимствованных элементов в современном русском языке: лингвокультурологический аспект // Мир русского слова. 2017. №2. С. 33-39.

\author{
Timur.B. Radbil \\ National Research Lobachevsky State University of Nizhni Novgorod \\ (Russia, Nizhni Novgorod) \\ timur@radbil.ru
}

\section{CULTURAL APPROPRIATION OF BORROWED WORDS IN THE LIGHT OF THE THEORY OF LANGUAGE CONCEPTUALIZATION OF THE WORLD}

The work studies basic principles of cultural appropriation of foreign elements in speech practice of contemporary Russian native speakers. The author proceeds from the 
point that a sort of distorting semantic and axiological spheres of loanwords as signs of "alien" values or diverse cultural models of behavior is quite typical of Russian language as reflection of typically Russian ways to look at things. "Emblematic" (in some sense) loanwords (terms, ideologems, axiologems etc.) receive obligatory cultural appropriation in discursive practice of contemporary Russian native speakers in the spirit of primordially Russian models of language conceptualization of the world. Such basic dominants of Russian "semantic universe" as: set on empathy (in Russian substantive and adjective diminutives), excessive hyperbolization (in Russian intensificators and augmentatives), overgrowth of general, moral or esthetic evaluation in nomination of persons, things or events, acute reaction to false, from the standpoint of a native speaker, value or pretension, correlation of the very simple things, properties, processes or phenomena with high spiritual ideals, ironic distorting in the spirit of "carnivalization" etc. — are being actualized even when foreign elements come into contemporary Russian speech practice. The evidence of this is specificity of word-formative adoption of foreign nomination, that is phenomena of occasional derivation by typically Russian models of expressive wordformation in the basis of foreign stems, such as smile-, self-, friend-etc. Hereat there are culturally conditioned connotative-evaluative increments of sense in derivative word with foreign components, and these sense increments use primordially Russian cultural sets and evaluative stereotypes.

Key words: active processes in Russian, loanwords, derivation, cultural appropriation, language conceptualization of the world.

\section{References}

Novye tendentsii v russkom yazyke nachala XXI veka [New tendencies in Russian in the beginning of $21^{\text {th }}$ century]. Col. monogfaph, T. B. Radbil', E. V. Marinova, L. V. Ratsiburskaya, N. A. Samylicheva, A. V. Shumilova, E. V. Shchenikova, S. N. Vinogradov; L.V. Ratsiburskaya (eds.). Moscow, Flinta-Nauka Publ., 2014, 304 p.

Radbil' T.B., Ratsiburskaya L. V. [Word-formative innovations on the basis of foreign elements in modern Russian]. Mir russkogo slova, 2017, no 2. pp. 33-39. (In Russ.)

Vezhbitskaya A. Yazyk. Kul'tura. Poznanie [Language. Culture. Cognition]. M. A. Krongauz (trans., ed. and comp.), E. V. Paducheva (introd. art.). Moscow, Russkie slovari Publ., 1996, 411 p.

Zaliznyak A.A., Levontina I.B., Shmelev A.D. Klyuchevye idei russkoi yazy-kovoi kartiny mira [The key ideas of the Russian language picture of the world]. Col. art. Moscow, Yazyki slavyanskoi kul'tury Publ., 2005, 544 p. 


\author{
Ренате Ратмайр \\ Экономический Университет \\ (Австрия, Вена) \\ renate.rathmayr@wu.ac.at
}

\title{
КУЛЬТУРА РЕЧИ В ЭТИЧЕСКИХ КОДЕКСАХ КОМПАНИЙ И РЕАЛЬНОЕ ОБЩЕНИЕ НА ПРИМЕРЕ ОБСЛУЖИВАНИЯ КЛИЕНТОВ
}

Этические кодексы - новый жанр корпоративной коммуникации, который после 2000 г. стал распространяться и в российских компаниях. Они устанавливают морально-этические и деловые нормы корпорации [Минаева 2010: 76], в них задаются определенные модели поведения и единые стандарты отношений и совместной деятельности (Стернин, Панферова 2003, по Рисинзон, Скрипник2017]). Примерно половина кодексов из корпуса содержит рекомендации для общения внутри компании (внутренняя коммуникация) и с партнерами, клиентами, учреждениями (внешняя коммуникация) как на одном, так и на разных уровнях иерархии участников (снизу вверх и сверху вниз).

В статье приводятся отрывки таких рекомендаций как на разных уровнях коммуникации: вербальном, паравербальном, невербальном — так и на уровне установок и поведения.

Далее сопоставляются приведенные в этических кодексах российских компаний нормы и рекомендации с реальной корпоративной коммуникацией при обслуживании клиентов. Практика обслуживания клиентов во многих случаях соответствует предписанным нормам и рекомендациям, однако встречаются и отклонения. Подводя итоги, можно сказать, что особенности русского стиля общения [Куликова 2009] пока сильно влияют на реализацию норм (западного) менеджмента в области корпоративной коммуникации. Это, в первую очередь, касается предпочтения неформального стиля общения и смешения личной сферы общения с профессиональной.

Ключевые слова: корпоративная коммуникация, деловая речь, этический кодекс, обслуживание клиентов, культура речи, вежливость.

\section{1. Вступление}

Считается, что коммуникация - это «живительное средство» любой организации [Rieland Fombrun 2007: 1], и не секрет, что многие сделки остаются без успеха вследствие коммуникативных неудач и, наоборот, венчаются успехом благодаря удачному общению. С введением рыночной экономики в России стали применяться 
и разные инструменты западного маркетинга и менеджмента, в том числе этические кодексы. Многие из них учитывают важность коммуникации и содержат рекомендации для общения как на одном, так и на разных уровнях иерархии участников (снизу вверх и сверху вниз). Объявленная «языковая политика» и «языковой менеджмент компаний» касаются только вопросов употребления и знания иностранных языков [Гарстенауер 2017: 153-184], а особенностей употребления русского языка не учитывают.

«Под давлением ли внешней среды или исходя из внутренних побуждений, можно констатировать, что ведущие российские компании с начала 2000-х гг. начали внедрять в свою практику такой механизм «мягкого» управления, как кодексы корпоративной этики» [Иванова 2017: 101]. Этические кодексы должны содержать нормы корпоративной этики и правила делового поведения. В научной литературе отмечается, что этический кодекс устанавливает морально-этические и деловые нормы корпорации [Минаева 2010: 76], в нем задаются определенные модели поведения и единые стандарты отношений и совместной деятельности (Стернин, Панферова 2003 [Рисинзон, Скрипник 2017]). Для лингвиста рекомендации по культуре речи заслуживают особого внимания. Посмотрим, как большой банк определяет «правильную речь»: «Правильная речь - это сочетание верного тона, артикуляции, произношения, громкости и точного подбора слов» («Инвестторгбанк», «Социнвестбанк» [Скрипник 2012:52]).

В дальнейшем ${ }^{1}$ мы приводим примеры для рекомендаций на вербальном уровне, на уровне установок и поведения. Во второй части приводятся правила для общения на одном уровне и при наличии различий по статусу, рекомендации для общения с клиентами, а также правила невербального и паравербального общения. Инструментализации вежливого поведения и общения посвящен отдельный подраздел. В третьей части рассматриваются соблюдение и отклонение от установленных в кодексах норм на примере ситуации обслуживания клиентов.

Используется корпус кодексов двух глав коллективной монографии [Рисинзон, Скрипник 2017 и Иванова 2017 в монографии Милехина, Ратмайр 2017] и дипломной работы О. Скрипник [Скрипник 2012], которая затем стала соавтором монографии. Корпус дополняется собранными мною в 2017 г. кодексами. Для сопоставления установленных в кодексах норм с практикой корпоративного общения используются части корпуса корпоративного общения [Милехина, Ратмайр 2017]. Центральный вопрос данного исследования: какие уровни общения регулируются в кодексах? Как установленные в кодексах нормы и правила соблюдаются на практике корпоративной коммуникации? Какой жанр корпоративной коммуникации выбирается для общения с клиентами?

${ }^{1}$ Настоящая статья является переработанным и сокращенным вариантом работы „Sprachregelungen in den Ethikkodices und reale Sprachverwendung in der russischen Unternehmenskommunikation.“ В сборнике: Ceci n'estpas une festschrift. Texte zur Angewandten und Romanistischen Sprachwissenschaft für Martin Stegu. Ed. P. Handler, K. Kaindl, H. Wochele. Logos Berlin, 2017 (в печати). 
Используется метод функционально-прагматического лингвистического дискурсивного анализа [Brünner2009: 153 и сл.], который позволяет интерпретацию особенностей речевого поведения в социальном и общественном контексте. Учитываются также итоги опроса о вежливости, проведенного мною в 2016 г.

\section{2. Примеры установленных в кодексах норм общения}

Здесь нужна оговорка: далеко не все кодексы содержат раздел о коммуникации, например, из 59 анализируемых О. Скрипник [Скрипник 2012], только 29 - то есть примерно половина - содержат такой раздел, а просмотр кодексов в 2017 г. тоже показал примеры без такого раздела; например, этический кодекс Ростелеком содержит много информации о возможной коррупции и отмывании денег, но не о речевом этикете (http://www.rostelecom.ru/ir/corporate_governance/docs/\%D0 \%A1ode_of_Ethics_2014_ru.pdf (3.1.2017)). Такое же соотношение и в кодексах, собранных Е. Ивановой [Иванова 2017]: 43 из 79 кодексов, то есть $54 \%$, содержат правила вежливости речи и поведения в компаниях. Все рекомендации показывают тесную связь культуры речи с вежливостью и являются вариациями общего требования, сформулированного как констатация факта в одном из кодексов: Работник Компании независимо от уровня, вида и способа общения - вежлив, доброжелателен, отзывчив [«Русгидро», по Рисинзон, Скрипник2017: 354].

\section{1. Какие рекомендации даются для корректного общения?}

Некоторые рекомендации сформулированы с удивительными деталями, например: При общении с клиентами сотрудники должны придерживаться следующих правил: встречать клиента, посетившего отделение (зрительный контакт не более 3 сек.), ульгаться; приветствовать клиента перед началом обслуживания: "Добрый (день, утро, вечер) <...> В общении с акиионерами, партнерами и клиентами сотрудник банка должен проявлять вежливость, уважение, терпимость и предупредительность. Дружелюбие и любезность помогают составить благоприятное впечатление об организации («Социнвестбанк» [Скрипник 2012: 42]). Другой банк практически требует соблюдения постулатов количества, релевантности и ясности Грайса [Grice 1975]: Сотрудник Банка обязан: предоставлять клиенту как можно более полную информацию о Банке и услугах, быть внимательнылм к потребностям клиента, стараться предложить те услуги, которые могут его заинтересовать; максимально удовлетворять запросы клиента («Профит Банк» [Скрипник 2012: 44]).

Из примеров норм общения по телефону особенно интересен запрет «футболить» клиентов, что в одном из приведённых ниже примеров реально практикуется: В Компании принято: <..> не допускать интонащий безразличия или превосходства, только взаимоуважение и готовность помочь; решать проблему самостоятельно, если это возможно, а не устраивать “футбол”, отправляя звонящего от одного сотрудника к другому (Торговая компания «Смайли» [Скрипник 2012: 55]). 
Рекомендации сформулированы либо (как в данном примере) как констатация факта, либо — чаще всего — в императиве: Проявляйте доброжелательность и открытость, чаще ульљайтесь («Газпромбанк» [Скрипник 2012:31]).

\section{2. Требования в зависимости от статуса собеседников}

В вертикальном общении сверху вниз требуется ясность изложения и полнота переданной информации и предоставление необходимых для выполнения поручений полномочий [Рисинзон, Скрипник 2017: 366]. А критику нужно сформулировать так, чтобы она была тактичной, конструктивной и относилась к работе сотрудника, а не к его личным качествам [там же]. В критике не должно прозвучать раздражение: Критика руководителем сотрудников не должна быть средством проявления раздражения [Центр судоремонта «Звездочка»», по Скрипник 2012:28]

Регулируется также, хотя и в меньшей степени, вертикальное общение снизувверх. В литературе о межкультурном бизнесе с Россией часто говорят о том, что одна из проблем - это невозможность напрямую выражать мнение, противоречащее мнению руководителя [Yoosefi, Thomas 2003]. Считается, что и самый конструктивный совет действовать можно передать вверх только через посредников и самым скрытым образом. В кодексах можно найти только общие рекомендации. Например, о том, что приветствуется обратная связь: Приветствуется личная и коллективная инициатива» («Объединённый Банк Промышленных Инвестиций [Скрипник 2012: 367]].

Для горизонтального общения между сотрудниками рекомендации также весьма общие: В Компании принято: здороваться и прощуаться; вне зависимости от должности проявлять уважение к своим коллегам; ... В Компании не принято: допускать грубость, использовать нечензурную или оскорбительную речь... (Торговая компания «Смайли» [Скрипник 2012:31]).

\section{3. Общение с клиентами}

Внешнее общение строго регулируется, особенно общение с клиентами. Росбанк формулирует правило рыночной экономики «клиент - король» таким образом: Потребность клиента - главный закон для Банка и его сотрудников («Росбанк» [Рисинзон, Скрипник 2017: 369]).

По Т.А. Милехиной [2017: 277], обслуживание клиентов дополнительно регулируется специальной методической литературой по технологии обслуживания, последними разработками в сфере теории коммуникации, определяется условиями организации работы в компании. В консалтинговом бизнесе умение общаться является даже предпосылкой для получения места работы: Клиенты - это единственный источник дохода, поэтому они представляют для нас особую иценность! Если Bы не умеете общаться с клиентами, Вам нечего делать в консалтинговом бизнесе! (Консалтинговая компания «ВРТ Offshore» [Скрипник 2012: 41]). 
В кодексе именно этой компании подробно разъясняется, что такое успешное общение с клиентами: Первая встреча - это есть начало отношений! На первую встречу, как правило, человек приходит, осознав задачу, которую ему надо решить! Он уже знает или думает, что знает, как сформулировать перед Вами задачу! Поэтому Вы должны начать с вопросов! Дайте рассказать Вашему заказчику о всех желаниях, задачах и потребностях, которые перед ним стоят! Не перебивайте, не прерывайте, слушайте активно, искренне и заинтересовано! Задавайте уточняющие вопросы! Во время этой встречи Вы должны выяснить все потребности явные и скрытые! Записывайте основныле задачи, которые формулирует Вам клиент в рабочий блокнот! Для клиента первая встреча - это необходимость и возможность убедиться, что с Вами можно работать, оценить Вас как потенциальных партнеров! (Консалтинговая компания «ВРТ Offshore» [Скрипник 2012: 45]).

\section{4. Правила употребления невербальных и паравербальных средств общения}

Кроме вербального уровня регламентируются и паравербальный и невербальный уровни общения, включая проксемику. В контакте с клиентами требуется, например: поддержание визуального контакта, контроль выражения лица и позы, соблюдение границ личного пространства. В кодексе одного банка особенно подчеркивается зеркальность: «Зеркальность»: Никогда не говорите быстрее собеседника, это создает у него ощущение давления и контроля. Скорость речи совпадает со скоростью работь мозга. Говорите с той же скоростью, что и собеседник, или чуть медленнее. («Крайинвестбанк» [Скрипник 2012: 46]).

А в кодексе другого банка уточняется зависимость успеха банка от невербальных и паравербальных элементов коммуникации ${ }^{2}$ : Успешность контакта с Клиентом более чем наполовину зависит от невербального поведения сотрудника - его жестов, приветливого лица, внешнего вида, хорошего настроения, треть успеха — от тона и тембра голоса сотрудника <... Ульбайтесь! («Объединенный Банк Промышленных Инвестиций»).

\section{5. Инструментализация}

В кодексах можно увидеть эксплицитную инструментализацию таких стратегий, как вежливость, приветливость, любезность и дружелюбие. В «нормальной» жизни мы любим, когда эти эмоции нам показывают искренне, а как только чувствуется присутствие стратегии, реагируем отрицательно. Хотя в ситуации обслуживания мы участвуем в взаимной игре, мы, тем не менее, предпочитаем приветливость грубости. Однако, если слишком много стратегий, то эффект будет

${ }^{2}$ Кажется, что эти цифры взяты из давно известного исследования, в котором, однако, использовался искусственный язык, так что содержание слов было бессмысленным, и из него ничего нельзя было понять. 
отрицательным. То есть целью должна быть спонтанность или хотя бы впечатление спонтанности.

Это требует высокого уровня актерских талантов у обслуживающего персонала. Необходимость создания эффекта искренности присутствует во многих кодексах, особенно ярко, например, в рамках работы с жалобами клиентов: После того как вы показали Клиенту, что усльшиали его жалобу, возникает следующая трудность - извиниться. Просто искренне, без всяких оправданий, объяснений и раздражения. ... Просто скажите: «Мне очень жаль» или «Мне жаль, что вы так расстроены». Существует много способов это сказать, но смысл в том, чтобы ваши извинения звучали искренне («Крайниневстбанк» [Скрипник 2012: 50]).

В России, где больше принято показывать эмоции, чем, например, в немецкоговорящих культурах, в кодексах прямо требуется контроль эмоций, особенно негативных, так как иначе принимаются неправильные решения: Положительное впечатление, производимое Вами, - важный фактор успешного решения деловых вопросов. Как бы ни складывалась ситуащия, управляйте свочми эмоциями. Раздражение не способствует принятию верного решения («Газпромбанк» [Скрипник 2012: 31]).

Не менее инструментализируется общение между сотрудниками, внутренними клиентами, которые требуют не меньше внимания, чем внешние клиенты: $B O A O$ АКБ «РОСБАНК» приняты единые стандарты общения с внешними и внутренними клиентами. Каждый коллега считается внутренним клиентом и общение с ним требует не меньшего профессионализма, корректности и заинтересованности, чем общение с внешними клиентами. Доброжелательность, открытость и взаимное уважение сотрудников помогают клиентам составить благоприятное впечатление о Банке в изелом («Росбанк» [Скрипник 2012: 33]).

\section{3. Соблюдение и отклонение от установленных в кодексах норм в ситуации обслуживания клиентов}

Если кодексы легко доступны в Интернете, то реальная корпоративная коммуникация доступна только с разрешения присутствующих, которое получить не так легко. Для этого используется как собственный опыт, опыт друзей и коллег в общении с обслуживающим персоналом, так и литература. Т.А. Милехина оценивает степень вежливости обслуживания достаточно высоко: Bblсокий уровень обслуживания клиентов проявляется в том, что коммуникация с клиентом осуществляется с предельным уровнем вежливости. Так, например, во многих офисах крупных банков, торговых организациях сотрудники приветствуют всех входящих клиентов. Во время обслуживания в банковских структурах даже при выполнении незначительной операции к клиенту обращаются по имени-отчеству, задают вопрос о том, в каких купюрах выдать требуемую сумму, предлагают выпить чай или кофе, если есть необходимость подождать [Милехина 2017:279]. 
Однако встречаются и остатки привычной в советское время невежливости и грубости обслуживающего персонала. Оправданием тогда служило легендарное Вас много, я одна! в обращении продавщиц к стоящим в длинной очереди клиентам. Т.А. Милехина, кроме положительных примеров общения с клиентами, приводит и отрицательные. В частности, достаточно часто смешиваются служебная и личная сферы: я такую же блузку купила себе/маме/дочери - реплика, которую можно услышать и в австрийских магазинах. Т. А. Милехина [Милехина 2017: 279] приводит следующий пример: На своем рабочем месте сотрудница одного из банков допускает подробный монолог о своей квартире, характере своего мужа и даже о любимой собаке. При оформлении потребительского кредита возможен посторонний звонок по мобильному телефону, после которого молодой сотрудник банка, игнорируя клиента, говорит, обращуаясь к молодой девушке - сотруднице другого банка: Прикинь/ щас мне друг звонил/ предлагает коньяк по 500 рублей/ а он в магазине 800 // (дело обстоит накануне празднования Нового года).

Своим отрицательным опытом общения в сфере обслуживания поделилась Наталья Ханьшева, директор Маркетингово агентства «МаркетКом»: Расскажу случай из практики. Мы осуществляем ежемесячную проверку одного крупного банка, головной которого офис находится в Москве. В компании разработаны стандарты работы консультанта, на основании которых мы и проверяем. При первой проверке консультант нехотя с нами пообщался (она была очень занята компьютером), немного рассказала о предлагаемых условиях, в итоге не дала нам даже визитку и не попрощяалась —мы были немного шокированы!! [Ханьшева 2009: 1416, по Скрипник 2012: 61].

В дальнейшем Ханьшева приводит отрицательный пример телефонного разговора, в котором сотрудник маркетингового агентства звонит в офис строительно-риелторской компании, где вместо того, чтобы дать ответ, даже бросают трубку:

C: алло, а с кем можно поговорить о квартире-долёвке?

В: секундочку, сейчас соединю...

A: да, я слушаю

С: здравствуйте, а можно с вами поговорить по поводу покупки квартиры-долёвки?

A: слушаю

С: молодая семья...

A (перебивает): ну у нас под ипотеку нет ничего

C: нет такого, да?

A: неа

$C:$ a что есть тогда?

A: ну в смысле что есть?

С: ну если без ипотеки, а сразу всю сумму?

С: алло? алло?

БРОСИЛ ТРУБКУ ... [Ханьшева 2009: 14-16, по Скрипник 2012: 61]. 


\section{4. Резюме}

Этические кодексы, как и другие области современной деловой практики в России, находятся под сильным влиянием западного менеджмента и глобализации. В кодексах регулируются все уровни коммуникации: вербальный (особенно лексический, фонетический, прагматический), паравербальный (громкость, темп, тембр), невербальный (проксемика, мимика, жесты, язык тела), распределение ролей, уровень установок и поведения.

Было проанализировано, как соблюдаются и нарушаются эти нормы в корпоративной коммуникации в России. Примером служило общение с клиентами, в котором правила культуры речи и вежливости по преимуществу соблюдаются. Однако вопреки рекомендациям часто смываются границы между профессиональной и личной сферами, например, тем, что в присутствии клиентов ведутся сугубо личные телефонные разговоры. А вообще для этого жанра характерно предпочтение неформального тона общения.

\section{Литература}

Гарстенауер $T$. Преодоление языковых барьеров. Использование иностранных языков и языковой менеджмент в компаниях в России. // Корпоративная коммуникация в России: дискурсивный анализ / отв. ред. Т. А. Милехина, Р. Ратмайр. М: Языки Славянской культуры, 2017. С. 153-184.

Иванова Е.И. Корпоративный этический кодекс в российской практике управления// Корпоративная коммуникация в России: дискурсивный анализ / отв. ред. Т. А. Милехина, Р. Ратмайр. М: Языки Славянской культуры, 2017. С. 99-123.

Куликова, Л. В. Коммуникативный стиль в межкультурном общении. М.: Флинта: Наука, 2009.

Милехина T.A., Ратмайр Р. (отв.ред.) Корпоративная коммуникация в России: дискурсивный анализ. Коллективная монография. М.: Языки славянской культуры, 2017. 632 с.

Милехина T.A., Ратмайр Р. Совещание. // Корпоративная коммуникация в России: дискурсивный анализ / отв. ред. Т. А. Милехина, Р. Ратмайр. М: Языки Славянской культуры, 2017. С. 213-231.

Милехина, Т.А. Обслуживание клиентов. // Корпоративная коммуникация в России: дискурсивный анализ / отв. ред. Т. А. Милехина, Р. Ратмайр. М: Языки Славянской культуры, 2017. С. 277-291.

Минаева, Л. В. Внутрикорпоративные связи с общественностью. Теория и практика. М.: Аспект Пресс. 2010.

Прохоров Ю.Е., Стернин И.А. Русские: коммуникативное поведение. М.: Флинта Наука, 2 изд. 2006.

Ратмайр, Р. Русская речь и рынок, М.: Языки славянской культуры, 2013.

Ратмайр Р., Рисинзон С. А. Речевой этикет и вежливость ///Корпоративная коммуникация в России: дискурсивный анализ / отв. ред. Т. А. Милехина, Р. Ратмайр. М.: Языки Славянской культуры, 2017. С. 77-79. 
Рисинзон С. А., Скрипник Е. Корпоративные этические кодексы //Корпоративная коммуникация в России: дискурсивный анализ / отв. ред. Т.А. Милехина, Р. Ратмайр. М: Языки Славянской культуры, 2017. С. 353-371.

Скрипник, E. Эксплицитная коммуникационная политика в российских компаниях на примере корпоративных кодексов этики, Дипломная работа, Вена 2012.

Стернин И. Г., Панферовса Н.Г. Кодекс корпоративной этики: каждой компании - свой кодекс. Сообщество менеджеров Экзекутиве. http://old.e-xecutive.ru/ publications/specialization/article_1597 (10.11.2014).

Ханшева H. 2009. Корпоративные стандарты обслуживания клиентов. Marketcom.ru (http://www.marketkom.ru/files/articles/Korporativnye_standarty_ obsluzhivanija_klientov.pdf, 16.11.2011).

Brown P., Levinson S.C. Politeness: some universals in language usage, Studies in interactional sociolinguistics. Cambridge Cambridgeshire; New York: Cambridge University Press, 1987.

Brünner G. 2009. Linguistische Diskursanalyse und ihre Anwendung auf die Wirtschaftskommunikation. // Diskurs und Ökonomie: Diskursanalytische Perspektiven auf Märkte und Organisationen, Rainer Diaz-Bone; Gertraude Krell, Wiesbaden: VS Verlag für Sozialwissenschaften, 1987. S. 153-176.

Grice, H. P. Logic and conversation. // Syntax and Semantics. Vol. 3: Speech Acts, Peter Cole; Jerry L. Morgan, New York: Academic Press, 1975. Pp. 41-58.

Hofstede, G. Cultural Constraints in Management Theories /Academy of Management Executive 7 (1) 1993. pp. 81-94.

Riel, C.B. M. van, Fombrun Ch. J. Essentials of corporate communication: Implementing practices for effective reputation management. London \& New York: Routledge, 2007.

Yoosefi, T., Thomas A. Beruflich in Russland: Trainingsprogramm für Manager, Fachund Führungskräfte. Göttingen: Vandenhoeck\& Ruprecht. 2003.

\author{
Renate Rathmayr \\ Wirtschaftsuniversität Wien \\ (Austria Vienna) \\ renate.rathmayr@wu.ac.at
}

\title{
SPEECH CULTURE IN CODES OF ETHICS AND REAL BUSINESS COMMUNICATION USING THE EXAMPLE OF CUSTOMER CARE AND SERVICE
}

Codes of ethics are a new genre of corporate communication, implemented since 2000 also in Russian companies. Following Minaeva [2010: 76] they establish moral - ethic and business norms of cooperation. They contain models of behaviour and prescribe unified standards of relationship and cooperation [Sternin, Panferova 2003, following 
Risinzon, Skripnik 2017]. About half of the codes include recommendations concerning communication in the company (intern communication) and with partners, clients, institutions (extern communication), as well on one level of status equality as on different levels of status (bottom-up and top down).

The paper contains excerpts of such recommendations on different levels of communication: verbal, paraverbal, nonverbal, as well as on the level of attitude and behaviour. Than the norms and recommendations in the codes were contrasted to the real verbal, paraverbal and nonverbal behaviour in authentic situations of customer care and service. The practice of customer care and service in general corresponds to the norms and recommendations in the codes, but there are also deviations. To sum up we can say, that the Russian style of speech [Kulikova 2009] still influences the realization of new (western) management norms in the Russian corporate communication. This concerns in the first place the preference of informal style of speech and the unstable border between private and professional levels of communication.

Key words: corporate communications, business speech, a code of ethics, customer service, culture of speech, politeness.

\section{References}

Brown P., Levinson S. C. Politeness: some universals in language usage, Studies in interactional sociolinguistics. Cambridge Cambridgeshire; New York: Cambridge University Press, 1987.

Brünner G. 2009. Linguistische Diskursanalyse und ihre Anwendung auf die Wirtschaftskommunikation. Diskurs und Ökonomie: Diskursanalytische Perspektiven auf Märkte und Organisationen, Rainer Diaz-Bone; Gertraude Krell, Wiesbaden: VS Verlag für Sozialwissenschaften, 1987. S. 153-176.

Chanševa N. Korporativnye standarty obsluživanija klientov. Marketcom.ru 2009. [Corporate customer service standards] (http://www.marketkom.ru/files/articles/Korporativnye_standarty_obsluzhivanija_klientov.pdf, accessed 16.11.2011).

Garstenauer, T. Preodolenie jazykovych bar'erov. Ispol'zovanie inostrannych Jazykov I jazykovoj menedžment v kompanijach v Rossii [Overcoming language barriers. The use of foreign languages and language management in companies in Russia]. Korporativnaja kommunikacija $v$ Rossii: diskursivnyj analiz [Corporate communication in Russia: discourse analysis]. Milechina, T.A., Ratmajr, R.M. (Eds.) : Jazyki slavjanskoj kul'tury Publ.. 2017: P. 153-184.

Grice, Herbert Paul. 1975. Logic and conversation. In: Syntax and Semantics. Vol. 3: Speech Acts, Peter Cole; Jerry L. Morgan, New York: Academic Press, 41-58.

Hofstede, Geert. 1993. Cultural Constraints in Management Theories. In: Academy of Management Executive 7 (1), 81-94.

Ivanova, E. I. Korporativnyjė tičeskij kodeks v rossijskoj praktike upravlenija [Corporate code of ethics in practice management]. Korporativnaja kommunikacija $v$ Rossii: diskursivnyj analiz [Corporate communication in Russia: discourse analysis]. Milechina, T. A., Ratmajr, R. M. (Eds.): Jazyki slavjanskoj kul'tury Publ.. 2017: Pp. 99-123. 
Kulikova, L. V. Kommunikativnyj stil'v mežkul'turnom obščenii [Communication style in intercultural communication]. M.: Flinta-Nauka, 2009.

Milechina, T.A. Obsluživanie klientov [Customer service]. Korporativnaja kommunikacija v Rossii: diskursivnyj analiz [Corporate communication in Russia: discourse analysis]. Milechina, T.A., Ratmajr, R. M. (Eds.) : Jazyki slavjanskoj kul'tury Publ.. 2017: P.277-291.

Milechina T.A., Ratmajr, R. Soveščanie [Meeting]. Korporativnaja kommunikacija v Rossii: diskursivnyj analiz [Corporate communication in Russia: discourse analysis]. Milechina, T.A., Ratmajr, R. M. (Eds.) : Jazyki slavjanskoj kul'tury Publ. 2017: P.213231.

Milechina, T.A., Ratmajr, R. (Eds.). Korporativnaja kommunikacija v Rossii: diskursivnyj analiz [Corporate communication in Russia: discourse analysis]. M.: Jazyki slavjanskoj kul'tury. 2017. $632 \mathrm{P}$.

Minaeva, L. V. Vnutri korporativnye svjazi s obščestvennost'ju teorija i praktika [Corporate public relations. Theory and practice]. M.: Aspekt Press, 2010.

Ratmajr, R. Russkajareč' i rynok [Russian language and the market]. Moskva: Jazyki slavjanskoj kul’tury, 2013.

Ratmajr R., Risinzon, S. A. Rečevoj ètiket i vežlivost' [Speech etiquette and politeness]. Korporativnaja kommunikacija v Rossii: diskursivnyj analiz [Corporate communication in Russia: discourse analysis]. Milechina, T.A., Ratmajr R. M. (Eds.), Jazyki slavjanskoj kul'tury Publ. 2017. P. 77-97.

Risinzon, S. A., Skripnik, E. Korporativnye ètičeskie kodeksy [Corporate codes of ethics]. Korporativnaja kommunikacija v Rossii: diskursivnyj analiz [Corporate communication in Russia: discourse analysis]. Milechina, T.A., Ratmajr, R. M. (Eds.) : Jazyki slavjanskoj kul'tury Publ.. 2017: P. 353-371.

Riel, C. B. M. van, Fombrun Ch. J. 2007. Essentials of corporate communication: Implementing practices for effective reputation management. London \& New York: Routledge, 2007.

Prochorov, J.E., Sternin, I. A. 2006. Russkie: kommunikativnoe povedenie. 2. Aufl. M.: Flinta-Nauka.2006.

Skripnik, E. Eksplicitnaja kommunikacionnaja politika v rossijskich kompanijach na primere korporativnych kodeksov ètiki [Explicit communication policy in Russian companies, for example corporate codes of ethics]. Diplomarbeit an der WU Wien. 2012.

Sternin, I.G., Panferova, N.G. 2003. Kodeks korporativnoj ètiki: každoj kompanii - svoj kodeks. Soobščestvo menedžerov Eksekutive [Code of conduct: each company a code. Community managers Esecutive]. Aviable at: http://old.e-xecutive.ru/publications/specialization/article_1597 (accessed 10.11.2014).

Yoosefi, T., Thomas A. Beruflich in Russland: Trainingsprogramm für Manager, Fach- und Führungskräfte. Göttingen: Vandenhoeck\& Ruprecht. 2003. 


\author{
Н.Н. Розанова \\ Институт русского языка им. В. В. Виноградова РАН \\ (Россия, Москва) \\ ninarozanova13@yandex.ru
}

\title{
РАЗГОВОРНАЯ ЛЕКСИКА В «КОНТЕКСТЕ» СТЕРЕОТИПНЫХ СИТУАЦИЙ ГОРОДСКОГО ОБЩЕНИЯ И ПРОБЛЕМЫ ЕЕ СЛОВАРНОГО ПРЕДСТАВЛЕНИЯ В «ТОЛКОВОМ СЛОВАРЕ РУССКОЙ РАЗГОВОРНОЙ РЕЧИ» (ТСРР)
}

В статье рассматриваются семантические особенности лексики города, отмечается функционально-стилистическая неоднородность подобной лексики, а также ее тесная связь с типовыми ситуациями городского общения. Городские номинации входят в активный словарь современного горожанина и составляют важную часть повседневных речевых практик жителей города. Именно поэтому слова, регулярно воспроизводимые в высокочастотных стереотипных ситуациях городского общения (вне зависимости от их функционально-стилистической принадлежности), должны найти отражение в «Толковом словаре русской разговорной речи». Каждая типовая ситуация имеет свой набор лексических средств и актуальных значений. Нередко в подобных случаях актуализируются специфические именно для данной ситуации значения общеупотребительных слов. В толковых словарях эти семантические варианты обычно сопровождаются пометами разг. или прост., однако сфера функционирования слова, как правило, не отмечается. «Встраиваясь» в стереотипную ситуацию, слово приобретает специфическое значение, а нередко - и новые сочетаемостные возможности. На примере ряда общеупотребительных слов рассматриваются их некоторые специфические значения в составе стереотипных городских ситуаций: уступить, разойтись (ситуация «Рынок»), сесть (ситуация «Городской транспорт»). Особое внимание уделяется синкретичным номинациям, включающим в свое значение целый ситуационный контекст и поэтому получившим название «имя ситуации». Рассматриваются значения и сочетаемостные возможности слов картошка (организованный сбор урожая картофеля городскими жителями, в основном студентами ') и обед (перерыв в работе учреждения, предприятия и т. п.'). Городские стереотипы - явление динамическое. Изменение реалий повседневной жизни влечет за собой изменение или исчезновение самого речевого стереотипа и, соответственно, входящих в его состав лексем. 
Ключевые слова: разговорная речь, язык города, просторечие, городской стереотип, лексика разговорной речи, словарная статья.

I. Повседневные речевые практики горожанина достаточно сложны и многообразны. Для успешной интеграции в городское сообщество жителю большого города необходимо уметь ориентироваться в самых разных типовых ситуациях и владеть разнообразными формами их языкового воплощения. Подобные типовые ситуации реализуются обычно в виде набора речевых и прагматических клише - городских стереотипов ${ }^{1}$. Горожанин, чтобы быть понятым и понимать других, должен следовать определенным правилам, существующим как традиция, узус: так говорят / так не говорят, так принято говорить / так не принято говорить. Необходимо подчеркнуть «наддиалектный» характер городских стереотипов, которые могут включать в свой состав элементы практически всех разновидностей городской речи: РР, просторечия, профессиональных жаргонов. Это неслучайно, поскольку отражает основной принцип языкового существования горожанина - его полиглотизм (Б.А. Ларин). Проникнув в городскую речь из разных социальных и функциональных сфер, слова и речевые формулы, которыми мы обмениваемся при общении, становятся неотъемлемой частью повседневного речевого узуса. Ср., например, неправильное с точки зрения кодифицированной нормы употребление глагола подсказать в значении 'сообщить кому-л. то, о чем спрашивают', в некоторых типовых ситуациях общения между незнакомыми людьми на улице («Как пройти, проехать?»; «Который час?»): Вы не подскажете/ где здесь детская поликлиника?; Новая Басманная/как пройти/ подскажите//; Время сколько не подскажете?

Интересна эволюция словарного представления данного значения подсказать. В словаре под ред. Д.Н. Ушакова это значение еще не зафиксировано. В словаре под ред. А.П. Евгеньевой (МАС) оно дается как просторечный вариант к основному значению ('сказать или незаметно шепнуть кому-л. то, что тот должен произнести'): || Прост. Указать, посоветовать. - Хотелось повидать сначала тебя, потом уж в гостинииу... Адрес подсказал дежурный. Герман. Я отвечаю за всё [Евгеньева 1999, т. III: 217]. В словаре под ред. Н. Ю. Шведовой это значение уже представлено как самостоятельное, 3-е (правда, с пометой прост.). Характерно, что примеры даются из городской речи: 3. Сказать, сообщить (то, о чем спрашивают, чего не знают) (прост.) Сколько сейчас времени, не подскажете? Не подскажете, где здесь аптека? [Шведова 2007: 674].

Лексика, обслуживающая стереотипные ситуации, входит в активный словарь современного горожанина и составляет важную часть его повседневных речевых практик. Как представляется, лексические единицы, регулярно воспроизводимые в высокочастотных стереотипных ситуациях городского общения (вне зависимости от их функционально-стилистической принадлежности), должны найти отражение в ТСРР.

${ }^{1}$ О городских стереотипах, их коммуникативных свойствах, жанровом своеобразии и особенностях текстовой организации см. в [Китайгородская, Розанова 2010: 258-278]. 
II. Каждая типовая ситуация имеет свой набор лексических средств и актуальных значений. Например, в ситуации купли-продажи на рынке наряду с особыми «рыночными» словами типа местоименного наречия почём, обращений хозяин, хозяйка, хозяюшка актуализируются специфические именно для данной ситуации значения общеупотребительных слов: брать — 'покупать товар' (Женщи на/ вы клубнику брать будете?); отдать - продать за определенную цену, часто более низкую, чем ранее заявленная' (Берите яблоки/ последние// Дёшево отдам//); просить — 'назначать цену' (-Почём яблоки? - Прошу сорок//); поход — 'небольшой излишек в весе товара' (Вот женщчина/ смотрите/ кило сто/ с походом отдаю//) [ТСРР: Проспект 2010: 127-133].

В толковых словарях эти варианты значений обычно сопровождаются пометами разг. или прост., однако сфера функционирования слова, как правило, не отмечается. В ТСРР отнесенность данного значения к определенной ситуации либо дается в зоне толкования (DEF), либо включается в комментарий к зоне PRAGM:

\section{УСТУПИ́ть.}

DEF: в условиях рыночной торговли: продать за цену, более низкую, чем ранее объявленная. - Почем яблоки? - Шестьдесят// - A подешевле? Не уступите? Будете брать/yступлю//; (Разговор с продавцом обувного лотка:) - Сколько такие? - Пятьсот пийсят// - Дороговато// - Но мы уступим// - Hem// - Mbl много уступим//.

MORPH: сов.; несов. уступать.

SYNT: что кому или без доп.

SYN: отдать.

PRAGM: обычно употребляется в ситуации купли-продажи на рынке при торге, часто в составе речевого клише Будете брать/ уступлю// [ТСРР: Проспект 2010: 132-133; автор словарной статьи - М.В. Китайгородская].

Значения, актуальные для той или иной повседневной ситуации, не всегда получают отражение в толковых словарях русского языка. В качестве примера можно привести одно из значений глагола разойтись, типичное для ситуации денежного расчета на рынке, в магазинах и т.п.:

\section{РАЗОЙТИ́СЬ.}

DEF: произвести расчет, подобрав купюры необходимого достоинства, чтобы расплатиться за покупку, услугу и т.п. (На рынке продавщица покупательнице, подающей ей крупную купюру:) Mы с вами не разойдёмся// Постойте/ я схожу разменяю//; (На рынке продавщица просит соседку разменять ей деньги:) -Тань/ штуку не разобъёшь? А то вон с дамой никак не разойдусь//-Щас/ вот пятьсот/ и сотнями/ пойдёт? - Ага/ теперь разойдёмся//; (Разговор соседок по даче:) Танюш/ вы мне сто тысяч не разменяете? А то вечером за молоко платить/ мы [с молочницей] не разойдёмся// - Сейчас посмотрю// [возвращается с кошельком] Угу// (Записи устной речи, 1995, 2010, 2015); - Люди добрые! А деньги как 
известно/ счёт любят// - Сдурел ты папаша? Давай на глаз разойдёмся// В накладе не останешься// — Будем... считать! (К/ф «Менялы», 1992).

MORPH: сов.; несов. (расходиться) неупотр.

SYNT: с кем или без доп.

ANALOG: сосчитаться, счесться.

PRAGM: обычно употребляется в ситуации расчета на рынке или в магазине, когда продавец не может дать сдачу покупателю.

III. «Встраиваясь» в стереотипную ситуацию, слово приобретает специфическое значение, а нередко - и новые сочетаемостные возможности. Наблюдения над лексико-грамматическими свойствами подобных слов позволяют убедиться в справедливости тезиса первых исследователей разговорной речи о том, что в РР ситуация «вплавляется» в речь ${ }^{2}$. Так, например, во время поездки на городском транспорте мы нередко употребляем глагол сесть (садиться) в значении войти в транспортное средство, оказаться внутри него': Смотри сколько народу/ мьл в этот автобус не сядем//; Ух ть/ толпа какая! Давай на этот не будем садитьcя/ скоро другой придёт//. В этом значении внутренняя форма слова оказывается затемненной (положение пассажира - «сидячее» или «стоячее» в данном случае не существенно, важно, что он вошел внутрь автобуса, вагона поезда и т. п. и готов ехать на нем $)^{3}$. Глагол употребляется обычно в сочетании со словами, обозначающими вид транспортного средства в вин. с предлогами в или на (сесть в автобус, на автобус, в вагон, на трамвай и т. п.), либо со словами, обозначающими направление движения (сесть не в ту сторону, в сторону Сокольников и т. п.), возможно также абсолютивное употребление (Мы не сядем, Слава богу, сели!).

$\mathrm{C}$ «транспортной» темой связано и другое значение глагола сесть — 'воспользоваться каким-л. транспортным средством'. Ср. примеры: - Как ты доберешься? - Да на метро сяду/ и через полчаса буду уже дома//; - Скажите/ до 31-ой больницы/ это мне куда? - Вам надо сесть на автобус/ пешком здесь далеко//.

Отмеченные «транспортные» значения для слова сесть можно представить в виде словарной статьи:

\section{СЕСТЬ.}

1. DEF: войти в транспортное средство, оказаться внутри него. (В метро, войдя в переполненный вагон:) Ну слава богу сели! Я уж думала не влезем/ столько

${ }^{2} \mathrm{Cp} .:$ «В РР ситуация является полноправной составной частью акта коммуникации, она вплавляется в речь. Многие элементы коммуникации не имеют вербального выражения, так как они даны в ситуации. Эту особенность РР можно назвать конситуативностью» [Русская разговорная речь 1973: 19].

${ }^{3}$ В Толковом под редакцией Д.Н. Ушакова «транспортное» значение глагола представлено как вариант основного ('принять сидячее положение, стать сидящим'): 'занять место, расположиться где-нибудь для поездки’ - С. в трамвай, С. в автомобиль, С. в самолет [Ушаков 1994, т. IV: 164]. В словаре под редакцией Н. Ю. Шведовой это значение дается уже как самостоятельное, при этом «сидячее положение» субъекта в толковании не отмечено: Войдя, поместиться где-н. (для поездки). С. в автомобиль. С. в (на) поезд. С. на теплоход [Шведова 2007: 877]. 
народу//; (На остановке перед подошедшим автобусом:) - Hy что/ caдимся? Нет/ это не наш/ нам на сто двадияатый надо// - Молодой человек/ ну вы садитесь/ или нет? Народ входит/ а вы стоите прям на дороге/ мешаете//; (В вагоне метро:) - Что-то никак не пойму/ это я-а в сторону Переображенки села/ или куда? - Нет/ это вы сели в другую сторону/ к Юго-Западной// - Ой/ не туда/ не туда/ надо выходить// (Записи устной речи, 2015); На остановке «театр оперы и балета» мне удалось сесть в «двенадияатый» в 0.15 (Комсомольская правда, 22.10.2008); Только не по дороге беги, а вдоль рощчицы - там, в конце, станция. Сядешь на электричку, доедешь до Москвы (Т. Тронина. Никогда не говори «навсегда» $)^{4}$.

MORPH: сов.; несов. садиться.

SYNT: на что, во что, куда или без доп.; в сочетании со словами, обозначающими вид транспортного средства или направление движения.

ANALOG: вскочить (во 2 знач.), запрыгнуть, заскочить (в 1 знач.).

PRAGM: активно употр. в городском общении в ситуации «Транспорт».

2. DEF: воспользоваться каким-л. транспортным средством. - Kaк mbl доберешься? - Да на метро сяду/ и через полчаса буду уже дома//; - Скажите/ до 31-ой больницы/ это мне куда? - Вам надо сесть на автобус/ пешком здесь далеко// (Записи устной речи, 2010); Время поджимает, поэтому выкобениваться особо не будем. Сядем на первый же подвернувшийся самолет и улетим подальше от всего этого российского кошмара (А. Грачев. Ярый-3); - Может быть, сядем на трамвай? - спросил Лопатин. - Из-за того, что я устала, да? - Да (К. Симонов. Так называемая личная жизнь); На гребной канал под Пекином проникнуть никакого труда не составляет. Садись на машину и езжай (Советский спорт, 13.08.2008) ${ }^{5}$.

MORPH: сов.; несов. садиться.

SYNT: на что; в сочетании со словами, обозначающими вид транспортного средства.

IV. В РP получила распространение особая группа лексем, которые Л. А. Капанадзе, впервые исследовавшая этот тип номинации, называла «именами ситуации». Значение таких слов связано не с каким-либо предметом, лицом, действием и т. п., а «втягивает» в себя целый ситуационный контекст. Ср.: «Во многих случаях в РР приходится говорить не о значении отдельных слов, а о значении, вернее, смысле высказывания в целом. <..> Слияние смыслов, синкретизм, идиоматичность - одна из специфических особенностей разговорной речи. Слияние смыслов чаще осуществляется в высказывании в целом, но иногда концентрируется в одном слове. Тогда образуются своеобразные синкретичные номинации, которые

${ }^{4}$ В качестве примеров помимо записей живой устной речи, сделанных автором, используются материалы Национального корпуса русского языка (НКРЯ).

${ }^{5}$ Если для поездки используется какой-нибудь частный транспорт (такси, попутная машина), то в этом же значении могут выступать слова взять (брать), поймать (ловить): - Уже поздно/ как же ты доберешься [домой]? - Да на такси сяду (такси возьму, поймаю). Для рейсового городского транспорта такое употребление невозможно: * Возьму, поймаю метро, трамвай, автобус. 
условно можно назвать именами ситуации» [Русская разговорная речь 1973: 436]. Подобные синкретичные наименования также нашли отражение в ТСРР. Ср. фрагмент словарной статьи КАРТОШКА, где 2-ое значение слова представляет собой имя ситуации:

\section{КАРТО́ШКА.}

2. DEF: организованный сбор урожая картофеля городскими жителями, в основном студентами. Студентов каждый год гоняли на картошку// Не только студентов/ гоняли и инженеров/ гоняли и рабочих// (Из материалов Санкт-Петербургского университета, 2002); Фабрично-заводской люд превосходил по численности колхозно-совхозный, но отвлекать на картошку тысячные массы квалифицированных рабочих казалось нелепостью (А. Азольский. Лопушок); А осенью, как было положено, поехал со своим курсом на картошку, в псковскую глубинку (Русский репортер, 4-11.10 2007); Много лет назад, нас студентов-первокурсников, отправили на картошку (Д. Донцова. Уха из золотой рыбки); Они начали приглядываться друг к другу еще на картошке, сразу на первом курсе (С. Таранов. Черт за спиной).

MORPH: ж.; мн. нет.

SYNT: обычно в конструкциях на картошку и на картошке [ТСРP. T.2 2017 автор словарной статьи - М. Я. Гловинская]

Яркое свойство таких слов - их необычная сочетаемость, обусловленная их высокой конситуативной зависимостью, «встроенностью» в ситуацию. Ср., например, возможные контексты употребления для слова обед (перерыв в работе учреждения, предприятия и т. п., во время которого его сотрудники отдыхают и обедают'): закрыться на обед, пойти на обед, вернуться с обеда, открыться после обеда, не попасть куда-л. из-за обеда и т.п. В качестве иллюстрации ниже приводится фрагмент словарной статьи ОБЕД, где это слово во 2-м значении представляет собой имя ситуации:

\section{ОБЕ์Д.}

2. DEF: перерыв в работе учреждения, предприятия и т. п. (обычно в середине рабочего дня), во время которого его сотрудники отдыхают и обедают. (Разговор около почтового отделения:) (Разговор посетителей у окошечка сберкассы:) - Mbl наверно не успеем/ у них через десять минут обед// - А перед нами сколько? Да пять человек// (Запись устной речи, 1990); Я его [пациента] поставила после своего обеда/чтобы никого перед не было/ а следующего ребенка вызвала через час/ а на него у меня было минут сорок// (Беседа с массажисткой // Из материалов Санкт-Петербургского университета, 2006); Ладно/ ладно! Только постарайся с обеда не опоздать// А характеристику я тебе пожалуй подпишу// После обеда Катя отвезёт её в трест// Да? (К/ф «Неисправимый лгун», 1973); Нашел [станцию техобслуживания] в районе Одинцяово// Приехал// Народу никого// Работают без обеда// (Радиопередача «Байкпост» // Радио «Вести FM», 15.04.2015); Пожар 
в монинском музее авиации начался около часа дня. В это время все сотрудники музея находились на обеде (Известия, 24.12.2007); (Объявление на двери мастерской:) Закрыто на обед.

MORPH: $м$; только ед.

SYNT: обычно в сочетании с предлогами: без, в, на, после, перед, с.

PHRAS: от забора до обеда (шутл.) — о какой-л. бессмысленной непродуктивной работе, производимой в течение длительного времени (из армейского анекдота: Старшина отдал солдатам приказ рыть траншею от забора до обеда). Сидение в сортире, в связи с иррацииональностью этого занятия, мы называли «копанием траншеи от забора до обеда» (Б. Левин. Блуждающие огни); До этого он работал стариим специалистом в телекоммуникационной компании. "Я просто просиживал там итаны, ничему новому не учился, пахал от забора до обеда и получал зарплату» (Труд, 12.12.2008).

V. Городские стереотипы - явление динамичное, они чутко реагируют на меняющиеся социально-коммуникативные условия. Изменение реалий повседневной жизни влечет за собой изменение или исчезновение самого речевого стереотипа и, соответственно, входящих в его состав лексем. Так, к деактуализированному пласту лексики относятся многие слова, характерные для советского речевого быта, тесно связанного с ситуацией товарного дефицита: дефицит ('товар, не имеющийся в магазине в достаточном количестве'), вылбросить ('пустить товар в продажу'), достать ('приобрести, купить что-л., прилагая к этому усилия'), заказ ('набор продуктов, продаваемый определенным группам населения; одна из форм закрытой торговли'), талон (документ в виде листка, удостоверяющий право бесплатного приобретения или покупки некоторых товаров и услуг') и др.

В то же время у слова может появиться и новое узуальное значение, соотносимое с новой актуальной ситуацией. Многие слова, относящиеся к сфере городского быта, многозначны. Нередко за каждым из значений подобного слова стоит определенная типовая ситуация, поэтому каждое из таких значений нуждается в определенном прагматическом комментарии. Ср. словарную статью ДВУШКА, где первое, неактуальное для современной РР значение дается с пометой ист.:

\section{ДВУ́ШКА.}

1. DEF: монета достоинством в две копейки. Он поднялся в холл, посмотрел на себя в зеркало и занял очередь к телефону. Потом, сообразив, что может позвонить и по автомату, нащупал в кармане двушку и завернул за угол (Е. Парнов. Третий глаз Шивы); На Алла/ возьми двушки пока не забыла// (Запись устной речи, 1972); Слушай, меня жена задушит, / Не трать напрасно двушек, / Закончим разговор (Популярная в 70-е гг. песня, которую исполняли И. Корнелюк и Э. Пьеха).

MORPH: .

SYN: двухкопеечная монета.

STYL: ucm. 
ANALOG: гривенник, двугривенный, десятикопеечная, полтинник (в 1 знач.), пятак, пятиалтынный, пятнашка (в 1 знач.).

PRAGM: в советское время с помощью двухкопеечной монеты можно было звонить по городскому телефону-автомату, поэтому номинация двушка прочно ассоциировалась с данной актуальной ситуацией городского общения. Ср. типичную просьбу тех лет: У вас двушки не найдется/ срочно позвонить надо//.

2. DEF: двухкомнатная отдельная квартира. (О квартире своих знакомых:) У них двухкомнатная/но очень удобная/вообще их двушка лучше даже нашей трёшки//; Вашу четырехкомнатную/ вы спокойно на две двушки разменяете// (Записи устной речи, 2012, 1991); А вообще я думаю, что если кто в однокомнатной пожил, тот и в двушке как-нибудь разместится (Блоги, 2010); Спустя несколько лет переселили семью из четырех человек в более просторную «двушку» (Российская газета, 07.09.2017).

MORPH: ж.

ANALOG: однушка, трёшка (во 2 знач.).

PRAGM: пришло в повседневную речь из профессионального жаргона риелторов; типично для ситуаций «Покупка, обмен квартиры», «Переезд».

Заключая, необходимо еще раз отметить, что в каждой ситуации городского общения складываются свои, предельно спаянные с актуальной ситуацией стереотипы. Выработанные в речевой практике горожан стереотипы коммуникативного и речевого поведения являются узуальными, обязательными для каждого горожанина (независимо от того, является он носителем литературной нормы или просторечия). Владение ими - необходимое условие успешной коммуникации. Таким образом, лексика стереотипных ситуаций отражает повседневный речевой быт современных носителей РР и должна быть включена в состав толкового словаря русской разговорной речи.

\section{Литература}

Китайгородская М.В., Розанова Н.Н. Языковое существование современного горожанина: На материале языка Москвы. М.: Языки славянских культур, 2010. $496 \mathrm{c}$.

НКРЯ - Национальный корпус русского языка: http://ruscorpora.ru/index.html

Русская разговорная речь / отв. ред. Е. А. Земская. М.: Наука, 1973. 485 с.

Словарь русского языка: в 4-х т. / под ред. А. П. Евгеньевой. 4-е издание, стереотипное. Т. 3. М.: Русский язык, Полиграфресурсы, 1999. 752 с.

Толковый словарь русского языка: в 4 т. / под ред Д.Н. Ушакова. М.: Русские словари, 1994.

Толковый словарь русского языка с включением сведений о происхождении слов, отв. ред. Н. Ю. Шведова. М.: Азбуковник, 2007. 1175 с.

Толковый словарь русской разговорной речи. Вып.1: А-И / отв. ред. Л. П. Крысин. М.: Языки славянской культуры, 2014. 776 с. 
Толковый словарь русской разговорной речи. Вып.1: А-И / отв. ред. Л.П. Крысин. М.: Языки славянской культуры (в печати).

Толковый словарь русской разговорной речи: Проспект / отв. ред. Л.П. Крысин. М.: Ин-т русского языка им. В. В. Виноградова РАН, 2010. 346 с.

\section{Nina N. Rozanova}

V.V. Vinogradov Russian Language Institute of the Russian Academy of Sciences (Russia, Moscow) ninarozanoval3@yandex.ru

\section{COLLOQUIAL VOCABULARY IN CONTEXT OF THE TYPICAL EVERYDAY URBAN SITUATIONS AND ITS LEXICOGRAPHIC DESCRIPTION IN "EXPLANATORY DICTIONARY OF RUSSIAN EVERYDAY SPEECH"}

The article considers the semantic features of the urban lexicon: its functional-stylistic diversity and the close connection with the typical everyday situations. Such words regularly repeated in everyday common speech (regardless of their functional-stylistic peculiarities) should be included and interpreted in the "Explanatory Dictionary of Russian Everyday Speech". Once specific words are generally adopted in typical daily interaction, they take on new meaning and interpretation. Traditionally, dictionaries indicate colloquial usage of a words razg. or prost. without providing the larger context and its provenance. The article highlights several examples where commonly used words become charged not only with new meaning but often lead to new word-combinations, i.e. ustupit', razoytis' (situation "Market"), sest' (situation "Public transportation"). We emphasize words where the meaning goes way beyond their original connotation and describe set of activities, i.e. kartoshka meaning 'sending city workers, usually students, to help with the harvest', or obed meaning 'taking a break in factories and offices'. However, typical everyday urban situations are a dynamic phenomenon. Changes in the realities of everyday life entail a change or even disappearance of situational words and their meanings.

Key words: everyday speech, language of the city, popular language, urban stereotype, dictionary entry.

\section{References}

Kitaygorodskaya M.V., Rozanova N.N. Yazykovoye cushestvovaniye sovremennogo gorozhanina: na materiale yazyka Moskvy. [The Linguistic Existence of Modern Citizens: the Speech of Moscovites]. Moscow, Yazyki slav'anskoy kultury Publ., 2010. 496 p. (In Russ.).

Nacional'nyy korpus russkogo yazyra [The Russian National Corpus]: http://ruscorpora.ru/index.html 
Russkaya razgovornaya rech'. [The Russian Colloquial Speech] / E. A. Zemskaya (ed.). Moscow, Nauka Publ., 1973. 485 p. (In Russ.).

Slovar' russkogo yazyka: in 4 Vol. [The Dictionary of the Russian Language] / A.P. Evgenyeva (ed/) /. Vol. 3. Moscow, Russkiy yazyk, Poligrafresursy Publ., 1999. 752 p. (In Russ.).

Tolkovyj slovar' russkoy razgovornoy rechi [The Explanatory Dictionary of the Russian Everyday Speech] / L. P. Krysin (ed.). Vol. 1/ Moscow, Yazyki slav'anskoy kultury Publ., 2014. 776 p. (In Russ.).

Tolkovyj slovar' russkoy razgovornoy rechi [The Explanatory Dictionary of the Russian Everyday Speech] / L.P. Krysin (ed.). Vol. 2. Moscow, Yazyki slav'anskoy kultury Publ - in print. (In Russ.).

Tolkovyj slovar' russkoy razgovornoy rechi: Prospect. [The Explanatory Dictionary of the Russian Everyday Speech: Prospect] / L.P. Krysin (ed.). Moscow, 2010. 346 p. (In Russ.).

Tolkovyj slovar' russkogo yazyka: in 4 Vol. [The Explanatory Dictionary of the Russian Language] / D. N. Ushakov (ed.). Moscow, Russkiye slovari Publ., 1994. (In Russ.).

Tolkovyj slovar' russkogo yazyka. [The Explanatory Dictionary of the Russian Language] / N. Yu. Shvedova (ed.). Moscow, Azbukovnik Publ., 2007. 1175 p. (In Russ.). 


\section{C.О. Савчук}

Институт русского языка им. В. В. Виноградова РАН

(Россия, Москва)

savsvetlana@mail.ru

\section{УСТНАЯ НАУЧНАЯ РЕЧЬ В СВЕТЕ КОРПУСНЫХ ДАННЫХ*}

В настоящее время наблюдается значительное расширение сферы функционирования устной научной речи. Научная тематика представлена не только в академических выступлениях и в учебной аудитории, но и в радиои телепрограммах, в интернет-проектах, дискуссионных клубах, даже в рекламе.

В исследованиях устной научной речи конца прошлого века материалом служили в основном записи лекций и семинаров, докладов, сообщений и дискуссионных выступлений на конференциях и других научных мероприятиях. В настоящее время мы имеем в своем распоряжении такой инструмент, как Национальный корпус русского языка, а в его составе три корпуса устных текстов: устный, акцентологический и мультимедийный. Наибольшие возможности предоставляет мультимедийный корпус, в котором текстовая фиксация звучащего фрагмента сопровождается аудио- или видеозаписью, благодаря чему становятся доступны для изучения как вербальные, так и невербальные компоненты высказывания. В настоящее время в составе корпуса активно формируется коллекция текстов, относящихся к устной научной речи. Коллекция достаточно представительна по составу авторов (более 100), областей науки (естественные, гуманитарные, прикладные), по разнообразию типов текстов, временному диапазону.

Будут отмечены изменения, которые происходят в устной научной речи с точки зрения жанрового соотношения, сферы бытования, аудитории, существенных лингвистических особенностей в сравнении с описаниями прошлого века.

Ключевые слова: устная научная речь, жанры, Национальный корпус русского языка.

\section{Устная научная речь как предмет изучения}

Устная научная речь (УНР), возможно, в силу своей двойственной природы долгое время не попадала в фокус внимания исследователей. Для функциональной стилистики ядром научного стиля является, несомненно, письменная речь,

\footnotetext{
* Работа выполнена при поддержке РФФИ (грант № 15-06-04334).
} 
которая хорошо изучена и описана в работах М.Н. Кожиной, Л. В. Славгородской, Е. С. Троянской, Н.М. Разинкиной, М.Л. Котюровой, О.Д. Митрофановой и др. Что касается устной формы научной речи, то она упоминалась при описании функциональных стилей, но редко оказывалась предметом специального углубленного исследования. Для исследователей же устной речи в центре внимания всегда была спонтанная разговорная речь, в ней искали специфические черты устности, противопоставляющие ее книжно-письменному языку. Устная научная речь, как речь подготовленная, интересовала исследователей меньше.

Всплеск интереса к изучению устной литературной речи в ее функциональных разновидностях приходится на 1970-1980-е гг. С 1975 по 1982 г. в Институте русского языка им. А.С. Пушкина русско-чешским коллективом под руководством О.А. Лаптевой проводилось комплексное исследование особенностей устной научной речи как разновидности современного русского литературного языка ${ }^{1}$. В работе принимали участие 28 научных работников, среди них Г.Г. Инфантова, Т. М. Николаева, Н. М. Разинкина, М. Ю. Федосюк, Н. М. Краевская, В. В. Борисенко, В.И. Аннушкин и др., с чешской стороны - Вл. Барнет, Дагмар Брчакова, Кв. Кожевникова и др. В результате этой работы появилась четырехтомная коллективная монография «Современная русская устная научная речь» [Современная 1985], которая до настоящего времени является самым авторитетным трудом по УНР. Исследование выполнялось на материале собранных авторами записей устной научной речи общим объемом 600 часов звучания (фонотека Института русского языка им. Пушкина). Записи были сделаны в Москве, Ленинграде и Праге, они отражают основные жанры УНР (доклад, лекция, сообщение, выступление), в меньшей степени - диалогические жанры (интервью, беседа-диалог, дискуссия), представлены гуманитарные, естественные и технические науки. Из этого материала были отобраны записи для расшифровок, объем которых превысил 600 машинописных страниц 2 . Расшифровки составили последний, четвертый том монографии, вышедший в 1999 г. В первых трех томах подробно описан жанровый состав, а также фонетические, синтаксические, лексические, словообразовательные, текстовые особенности УНР второй половины 1970-х годов.

Как представляется, сегодня было бы интересно вернуться к системному изучению устной научной речи по нескольким причинам. Во-первых, в настоящее время наблюдается значительное расширение сферы функционирования устной научной речи. Научная тематика и способ изложения представлены не только в академических выступлениях и в учебной аудитории, но и в радио- и телепрограммах, в интернет-проектах, дискуссионных клубах, даже в рекламе. Если говорить только о телевидении, то в сравнении с пятью популярными передачами о науке в 19701980-е годы («Очевидное — невероятное», «Человек. Земля. Вселенная», «Под

${ }^{1}$ В дальнейшем интерес сместился на изучение телевизионной речи, исследование рекламного дискурса, деловой коммуникации, причем скорее в практическом аспекте. УНР оказалась в стороне от интересов коллоквиалистики.

2 В переводе на привычную для корпусной лингвистики единицу измерения, около 150 тыс. словоупотреблений. 
знаком Пи», «В мире животных» и детская «Хочу все знать»), в 2000-е годы зрителю предлагается целый спектр передач о науке, рассчитанных на разный уровень подготовки аудитории, среди которых: «Гордон» (НTВ, 2001-2003), Проект «Академия» («Культура»), «Вопрос науки», «Идеи, которые изменили мир» (Россия-24), «Истории из будущего» (5 канал), «ЕХперименты» (канал «Наука»2.0). Кроме того, следует упомянуть научные сайты в интернете, предлагающие записи лекций и программы научной тематики, аудитория которых приближается к телевизионной («Эксперт-ТВ», лекторий «Прямая речь», «Постнаука» и др.).

Вся эта плотная информационная среда, контакт со средствами массовой коммуникации не может не влиять на функционирование устной научной речи и приводить к трансформациям жанровой системы. За сорок лет, прошедших со времени исследования 1970-1980-х годов, в языке и стиле УНР могли накопиться изменения, которые, возможно, удастся обнаружить в ходе современного обследования.

Другой причиной для возобновления исследования современной устной научной речи является то, что в наше время его можно проводить на новом уровне, поскольку у исследователей звучащей речи появились новые инструменты. С одной стороны, это специальные программы, позволяющие анализировать фонетическую сторону речи (Speech Analyzer, ELAN, Praat и др.), с другой стороны, это инструментарий корпусной лингвистики. Что касается именно устной научной речи, то из всех известных корпусов звучащей речи («Один речевой день», «Корпус сновидений» и др.) УНР в достаточном количестве представлена в Национальном корпусе русского языка.

Устный модуль в составе НКРЯ включает три подкорпуса: а) устный корпус; б) акцентологический корпус; в) мультимедийный корпус, которые отличаются по объему, характеру материала и форме его представления, видам лингвистической разметки, составу текстов, а также назначению корпуса и возможностям его использования.

\section{Устная научная речь в Национальном корпусе русского языка}

Устный корпус - самый большой в модуле устных текстов НКРЯ, его объем составляет более 12 млн словоупотреблений. Материал представлен в виде транскриптов, соответствующий звучащий текст недоступен. Тексты охватывают значительный временной диапазон (1958-2016 гг.) и демонстрируют большое функциональное разнообразие. Они снабжены стандартной для НКРЯ метатекстовой, морфологической, семантической разметкой и специфической для устного корпуса социологической разметкой. Разметка позволяет отобрать для изучения свой подкорпус более или менее однородных текстов, например, научных текстов разных временных срезов.

Доля УНР в устном корпусе составляет более 1,5 млн словоупотреблений. Самые ранние тексты - материалы фонотеки ИРЯ РАН: выступления на Международном съезде славистов 1958 г. (А. А. Реформатский, С.И. Ожегов, П. С. Кузнецов, Р.О. Якобсон, М.Р. Фасмер, Б.Г. Унбегаун и др.). Другие уникальные 
коллекции - записи из собрания фонодокументов им. В. Д. Дувакина, из архива О.А. Лаптевой (1975-1982 гг.), из коллекций Саратовского и Ульяновского университетов. Собственные записи из коллекции НКРЯ относятся к 2007-2016 гг. Они, как правило, имеют аудиоисточники и включены в акцентологический корпус.

Акцентологический корпус по составу и объему текстов уступает устному, однако отличается большей глубиной разметки. Транскрипты дополнительно выверены по звучащему оригиналу, и в них расставлены ударения в соответствии с реальным произношением. Доступ к акцентуированным текстам УНР возможен как со страницы акцентологического корпуса, так и со страницы устного корпуса, где эти тексты представлены наряду с неакцентуированными транскриптами.

Мультимедийный корпус (МУРКО) предоставляет наиболее широкие возможности для изучения устной речи, поскольку текстовая фиксация звучащего фрагмента сопровождается аудио- или видеозаписью, благодаря чему становятся доступны для изучения как вербальные, так и невербальные компоненты высказывания. Объем корпуса превышает 4,6 млн словоупотреблений, для онлайн-поиска доступен и транскрипт, и сопровождающий его аудио- или видеоклип. В составе раздела публичной речи в настоящее время формируются подкорпуса устной научной и политической речи (подробнее см. [Савчук, Махова 2017: 83-89]).

Объем устной научной речи в мультимедийном корпусе составляет более 850 тыс. словоупотреблений. Она представлена следующими основными жанрами: монологическими (доклад, лекция, сообщение, короткое выступление) и диалогическими, включая полилоги (дискуссия, конференция, семинар, совещание). Разновидности научного дискурса - специиальная научная речь, учебная научная речь, научно-популярная речь - обусловлены различными ситуациями общения. Для каждой разновидности характерны своя иерархия жанров и жанровые варианты, а также специфические жанры, не представленные в других разновидностях (подробнее см. [Савчук 2017: 315-320]). В раздел устной научной речи включены записи учебных лекций по математике, химии, информатике, экономике, правоведению, психологии, искусствоведению и др., предназначенные для студентов и школьников, записи мастер-классов и семинаров. Для пополнения коллекции научно-популярной разновидности собраны записи телепередач и интернет-проектов научно-просветительского характера.

\section{Новые явления в современной устной научной речи}

В процессе формирования подкорпуса УНР подтвердилось предположение об изменениях в жанровом составе устной научной речи и стилистических сдвигах. В качестве примера приведем характеристику одного из новых жанров УНР — краткого выступления на научную тему в формате Science Slam ${ }^{3}$. Научный слэм — это

${ }^{3}$ Первоначально слэм (от английского slam 'сталкиваться, ругаться') - действие публики на музыкальных концертах, при котором люди толкаются и врезаются друг в друга. В качестве названия интеллектуального поединка стали использовать это заимствование вместе с его 
мероприятие, направленное на популяризацию науки и создание положительного образа молодого ученого. Представляет собой серию 10-минутных выступлений со сцены, с использованием зрелищных мультимедийных презентаций, с привлечением помощников для постановки опытов и т. д. «Научные бои» имеют черты игрового обучения, соревнования, конкурса; лучшего участника публика определяет аплодисментами. Этот международный проект зародился в Германии, в России первый поединок состоялся в сентябре 2012 года на сцене Парка Горького в Москве и быстро приобрел популярность. В настоящее время поединки проводятся в 19 регионах и существуют в разных форматах: городской, университетский, школьный, корпоративный, международный [http://scienceslam.ru/]. Наиболее близкими форматами являются поэтический поединок Poetry Slam, а также стендап. Аудитория Science Slam - студенты старших курсов, преподаватели вузов, молодые профессионалы из сферы технологий и IT и интересующиеся наукой люди.

К выступлению выдвигаются минимальные требования. Первое правило: выступление должно быть не более десяти минут. Второе правило: только свои собственные исследования. Третье правило: доклады должны быть очень просты [http://www.ru.scienceslam.net].

Покажем на примере одного из выступлений, как отражаются на стиле и языке научного выступления целевая установка на простоту, а также на то, чтобы заинтересовать, удивить, эмоционально зарядить зрителей и в конечном счете добиться признания.

«Мы же выбрали для себя ген более такой нормальный, с которым можно хотя бы о чём-то разговаривать. И мало того, что можно разговаривать, можно ещее какую-то найти... какие-то конструктивные отношения выстроить. И это наша микрофлора. Итак, собственно, что же это такое. У нас вот примерно в этой части кишечника (указывает на живот) болтается клеток в десять раз больше бактериальных клеток, чем наших собственных. Они просто очень крохотные и маленькие. Их десять тысяч видов. Просто вот такое безумное разнообразие, u что самое интересное: если взять весь геном всех микроорганизмов объединить, что называется сейчас микробиомом, то весь суммарный геном наших микробов в триста шестьдесят раз больше, чем наш собственный геном. И причём для каждого человека ээ соотношение микробов разное. То есть условно, они у нас всех одинаковый набор. Но соотношение абсолютно индивидуально. И возвращаясь к генам, на самом деле, каждый ген по факту - это функция» (А. Шестаков. Как микробиом формирует наши предпочтения в еде и привычки).

В этом фрагменте прямым шрифтом даны словоформы, передающие фактуальную информацию: это небольшое количество терминов (выделены полужирным шрифтом) и слов, относящихся к книжной лексике (ген, геном, микроб, микроорганизм, микрофлора, микробиом, бактериальньй, суммарный, функция, соотномение

производными: слэмер ‘участник поединка', слэмиться ‘состязаться’ (см., например, Слэмиться по-научному: в Москве пройдет Science Slam // Популярная механика, 2017, № 11 https://www. popmech.ru/science/185271-slemitsya-po-nauchnomu-v-moskve-proydet-science-slam/). 
и др.). Остальная часть текста - дискурсивные элементы (они выделены курсивом), среди которых преобладают средства диалогизации высказывания и средства активизации внимания слушателей [Викторова 2015: 57-60; Очерки 1998: 139, 316 ]. Автор использует открытые формы разговора со слушателем, приглашая к совместному рассуждению: Мы же выбрали для себя, наша микрофлора, у нас, наших микробов, наш собственный геном, у нас всех. К средствам активизации внимания относятся вопросно-ответные комплексы: Итак, собственно, что же это такое. Широко используются оценочные средства, с помощью которых автор эксплицирует свою уверенность и заражает своей оценкой слушателей: ген более такой нормальныци, с которым можно хотя бы о чём-то разговаривать; и что самое интересное...; Просто вот такое безумное разнообразие; Они просто очень крохотные и маленькие; абсолютно индивидуально. Образные средства также привлекают внимание слушателей: болтается клеток в десять раз больше; ген, с которым можно хотя бы о чём-то разговаривать; какие-то конструктивнье отночения выстроить.

Как видим, простота и доступность данного фрагмента достигается тем, что большую его часть составляют дискурсивные средства, управляющие вниманием слушателей и облегчающие восприятие научной информации, которая представлена в этом фрагменте в слабой концентрации: доля лексики, передающей фактуальную информацию, составляет всего $24 \%$. Для сравнения: в аналогичном по объему фрагменте передачи «Очевидное - невероятное» представлено обратное соотношение: средства, передающие фактуальную информацию, составляют около $70 \%$, а дискурсивные элементы - 30\%.

Многие исследователи отмечают гибридный характер УНР: с одной стороны, она продуцируется по законам устной речи (отсюда сегментация потока речи, исправления, перестройка, хезитации, инвертированный порядок слов), а с другой стороны, отбор речевых средств производится из арсенала книжно-письменного научного стиля (термины, синтаксические клише научной речи и др.) [Шатилов 2010: 244-246].

В современных условиях можно говорить о гибридности УНР и в другом аспекте. Это связано с тем, что устные научные сообщения в настоящее время строятся в сопровождении тщательно подготовленной презентации, в которой используются графические средства, зрительные образы и мультимедиа. Таким образом, адресат выступает в роли и слушателя, и зрителя, воспринимает по двум каналам сразу три потока информации. По слуховому каналу - звучащее слово лектора в линейном развертывании, включая невербальные компоненты, по зрительному каналу во-первых, жестовое сопровождение речи, мимику, позы лектора и, во-вторых, представленную на слайдах структурированную, фрагментированную, дополненную информацию, переработанную для зрительного восприятия и запоминания.

Что из этого следует? Устное сообщение, которое строится с опорой на презентацию, оказывается в зависимости от ее содержания и формы. Если презентация содержит основную научную информацию выступления, в «привычной» для научного стиля наглядно-зрительной форме, то звучащая речь доклада представляет собой комментарий к слайдам. Отсюда в тексте - обращения 
к изображениям и к слушателям: Boт здесь слайд достаточно сложный, это то, какие связи могут быть слабыми, какие связи могут быть сложными. Но основная нагрузка этого слайда в том, что... Давайте мы с вами посмотрим ещзе... Вот на слайде здесь приведен пример валиномицина... (Ю.Т. Горбунова, лекция); Я первично, по ходу презентации, буду давать фотографии всего люминисцирующего... Ну вот, в частности, люминисциирующая медуза... А это уже люминисиенция каких-то кристаллов... (В.В. Уточникова, лекция). Устная часть доклада - и в этом случае подготовленная УНР в монологической форме, однако воспринимать и изучать такую речь в отрыве от видеоряда затруднительно.

Большинство жанров устной научной речи соотносимо с жанрами письменной научной речи: монография, учебник - цикл лекций; раздел монографии, учебника - лекция; статья - доклад, содоклад; рецензия - дискуссионное, полемическое сообщение; инструкция - консультация, беседа и др. Все они представлены в НКРЯ, что позволяет изучать особенности письменной и устной научной речи в сопоставительном аспекте и в диахронической перспективе. Как представляется, подобное исследование поможет выявить существенные, неизменные и периферийные, вариативные признаки устной научной речи и показать их в динамике.

\section{Литература}

Викторова Е.Ю. Дискурсивы, специфические для устной научной речи (на материале лекций) // Известия высших учебных заведений. Поволжский регион. Гуманитарные науки. 2015. № 4. С. 55-65.

Очерки истории научного стиля русского литературного языка XVIII-XX вв. / Под ред. М.Н. Кожиной: В 3 т. Т. 2. Стилистика научного текста (общие параметры). Ч. 2. Категории научного текста: функционально-стилистический аспект. Пермь: Изд-во Пермского ун-та, 1998. 396 с.

Савчук С.О. Устная публичная речь в мультимедийном модуле НКРЯ // Труды международной конференции «Корпусная лингвистика - 2017». СПб., 2017. С. 315-320.

Савчук С. О., Махова А.А. Мультимедийный модуль в составе Национального корпуса русского языка: направления развития // Анализ разговорной русской речи (AР $\left.{ }^{3}-2017\right):$ Труды седьмого междисциплинарного семинара. СПб.: Политехникапринт, 2017. С. 83-89.

Современная русская устная научная речь. Общие свойства и фонетические особенности. Т. I / Под ред. О.А. Лаптевой. Красноярск; Изд-во Красноярск. ун-та, $1985.336 \mathrm{c.}$

Шатилов А. С. Особенности построения высказывания в устной научной речи // Вестник Санкт-Петербургского университета. Серия 9. Филология. Востоковедение. Журналистика. 2010, № 1. С. 211-215.

Национальный корпус русского языка [Электронный ресурс]. URL: ruscorpora.ru

Science Slam Россия [Электронный ресурc] URL:http:/www.ru.scienceslam.net

Science Slam [Электронный ресурс] URL: http://scienceslam.ru/ 


\section{Svetlana O. Savchuk \\ V.V. Vinogradov Russian Language Institute of the Russian Academy of Sciences \\ (Russia, Moscow) \\ savsvetlana@mail.ru}

\section{ORAL SCIENTIFIC SPEECH IN THE LIGHT OF CORPUS DATA}

At present, there is a significant expansion in the scope of the functioning of oral scientific speech. The scientific topics are presented not only in academic speeches and in the classroom, but also in radio and television programs, in Internet projects, discussion clubs, and even in advertising.

Researches of oral scientific speech of the end of the last century were mainly based on the analyses of the recordings of lectures and seminars, reports and discussion speeches at conferences and other scientific events. Currently, we have at our disposal three corpora of oral texts within the Russian National Corpus: Speech Corpus, Accentological Corpus and Multimedia Corpus. In Multimedia Corpus, text transcript of a sounding fragment is accompanied by an audio or video recording that allows studying both verbal and non-verbal components of the sentence.

Nowadays, we are actively forming a subcorpus of texts representing the oral scientific speech within the RNC. The collection includes texts of more than 100 authors, different sciences (natural, humanitarian, applied), and variety of text types. Corpus based studies will reveal the changes that have occurred in oral scientific speech in comparison with the descriptions of the last century.

Key words: oral scientific speech, genres, the Russian National Corpus.

\section{References}

Ocherki istorii nauchnogo stilya russkogo literaturnogo yazyka XVIII-XX vv. [Essays on the history of the scientific style of the Russian literary language of the XVIII$\mathrm{XX}^{\text {th }}$ centuries]/ M.N. Kozhina (Ed.). V. 2. Stilistika nauchnogo teksta: obshchiye parametry [Stylistics of the scientific text: general parameters]. P. 2. Kategorii nauchnogo teksta: funktsional'no-stilisticheskii aspekt [Categories of scientific text: functional and stylistic aspect]. Perm': Publishing house of Perm University, 1998. 396 p. (In Russ.)

Savchuk S. O. [Oral public speech in Multimodal module of the Russian National Corpus]. Trudy mezhdunarodnoy konferentsii "Korpusnaya lingvistika - 2017" [Proceedings of the International Conference "Corpus Linguistics - 2017"]. St. Petersburg: Philological Faculty of St. Petersburg State University, 2017, pp. 315-320

Savchuk S. O., Makhova A. A.[Multimedia module in the National Corpus of the Russian language: directions of development]. Analiz razgovornoi russkoi rechi (AR3-2017): Trudy sed'mogo mezhdistsiplinarnogo seminara. ["Russian Speech Analysis". Proseedings of the 7th interdisciplinary seminar]. St. Petersburg: Philological Faculty of St. Petersburg State University, 2017, pp. 83-89 (In Russ.) 
Shatilov A. S. [Oral Discourse in Science]. Vestnik Sankt-Peterburgskogo universiteta. Seriya 9. Filologiya. Vostokovedeniye. Zhurnalistika. [Bulletin of St. Petersburg University. Series 9. Philology. Oriental studies. Journalism]. 2010, no. 1, pp. 211-215 (In Russ.)

Sovremennaya russkaya ustnaya nauchnaya rech. Obshchie svoistva $i$ foneticheskie osobennosti [Modern Russian oral speech. Common properties and phonetic features.O. A. Lapteva (Ed.). Krasnoyarsk: Krasnoyarsk State University, 1985. 336 p. (In Russ.)

Viktorova E. Yu. [Discourse Markers Specific for Spoken Academic Speech (Based on Texts of Lectures)]. Izvestiya vysshikh uchebnykh zavedenii. Povolzhskii region. Gumanitarnye nauki. [University proceedings. Volga region]. 2015, no. 4, pp. 55-65 (In Russ.)

Russian National Corpus. Available at: ruscorpora.ru (accessed 30.09.2017)

Science Slam Russia. Available at: http://www.ru.scienceslam.net (accessed 30.09.2017)

Science Slam. Available at: http://scienceslam.ru/ (accessed 30.09.2017) 


\section{О.И. Северская}

Институт русского языка им. В.В. Виноградова РАН

(Россия, Москва)

oseverskaya@yandex.ru

\section{«ЧЕРЕЗ ВРЕМЯ, ЧЕРЕЗ РАССТОЯНИЕ»: СТИЛИСТИЧЕСКАЯ ОШИБКА, ЭЛЛИПСИС ИЛИ РЕКУРСИЯ НОРМЫ?}

В статье рассматриваются случаи грамматических «неправильностей», встречающихся в современной речи. Особое внимание уделяется оборотам, обозначающим временные последовательности: через время и спустя время, в которых, вопреки актуальной языковой норме, отсутствуют уточняющие определения, указания на временной промежуток. Проведя анализ на материале Национального корпуса русского языка, автор приходит к выводу о наличии «старшей» и «младшей» норм употребления лексемы время в сочетании с предлогами, о переходе от хронотопического восприятия пространства и време$н и$ к представлению о дискретности времени. В статье рассматриваются и значения предлогов, отражающие смену восприятия пространственно-временных координат. Резкое увеличение «архаичных» словоупотреблений в последнее десятилетие, по наблюдениям автора, характерно и для некоторых других лексем. Это подтверждается примерами «старшей» и «младшей» норм управления глагола интересоваться и кратких прилагательных рад и счастлив. Подобные факты позволяют поставить вопрос о сохранении в языковом сознании говорящих «речевой памяти», закрепляющей прежние состояния языковой системы. Это явление автор предлагает назвать спонтанной рекурсией нормы, тем самым расширяя представление о формировании нормы и ее отражения в культуре речи.

Ключевые слова: Пространство и время, рекурсия нормы, «старшая» и «младшая» норма, коллокации, вариативность управления, культура речи.

В последнее время в речи (как устной, так и письменной) довольно часто встречаются обороты, обозначающие временное следование событий одного за другим: через время, спустя время / время спустя - без уточняющих определений (ср.: через какое-то время, спустя некоторое время, немного времени спустя и т.п.). Они настолько не соответствуют доминантному варианту с «распостранителями», что 
носителям русского языка кажутся ошибочными, в том числе практически стопроцентно воспринимаются как таковые лингвистами ${ }^{1}$.

Между тем Национальный корпус русского языка (НКРЯ) ${ }^{2}$ дает немало примеров таких употреблений в речи людей, которых трудно назвать неграмотными.

В XVIII-XIX вв. оборот через время в норме использовался для обозначения неопределенного временного промежутка: Через время все это он узнал и ни от кого прежде, как от меня [И. М. Долгоруков. Повесть о рождении моем, происхождении и всей моей жизни, писанная мной самим и начатая в Москве, 1788-го года в августе месяце, на 25-ом году моей жизни / Части 1-2 (1788-1822)], и это, по-видимому, было связано с хронотопическим, континуальным восприятием времени в его протяженности: Да позволено будет мне <...> перескакивать, как я хочу, через время и пространство, предупреждать первое и совершенно забывать о сущзествовании второго... [А. А. Григорьев. Мои литературные и нравственные скитальчества (1862)].

В XX в. оборот встречается, в частности, в речи писателей-классиков: $O H$ как-то муслил, муслил, слепил цицарку кое-как из промокашки, а она не курится. Шлепнул дед ичигарку оземь, вдаль уставился, борода у него заходила вверх-вниз, вверх-вниз - тогда-то я и увел из бабушкиного сундука ичерковную книгу. Дед ее полистал, полистал, посмотрел страшные картинки и испуганно прошептал: «Ташши обратно, от греха... - и через время смущенно добавил: - Да в ей, в этой божецккй книжке, и бумага на курево негодная» [Виктор Астафьев. Последний поклон (1968-1991)]; В России, как нигде, новизна любой идеи оборачивается через время своим выворотом [Владимир Маканин. Андеграунд, или герой нашего времени (1996-1997)]; и не только у прозаиков, но и у поэтов: Не смею доверяться пустоте, / ее исконной, лживой простоте, / в ней столько душ, не видимых для глаза, / но стоит только в сторону взглянуть, / как несколько из них или одну / увидишь через время или сразу [Л. Л. Аронзон. «В пустых домах, в которых всё тревожно...» (1967) $]^{3}$.

В XXI в. так уже говорят повсеместно. В НКРЯ встречаются примеры из сети: [Новикова, nick] Через время, когда захотела пересмотреть этот фильм, обнаружила, что почти везде в описании фильма говорится о побеге, а кое-где был описан даже способ побега [Форум: Обсуждение фильма «Побег из Шоушенка» (2009-2011)] и др. Происходящее через время отражают, как показывает сетевой поиск, и популярные Atkritk'и: Бывает, думаешь: «Жаль, что потерял человека», - а через время понимаешь, как хорошо, что избавился; и демотиваторы: Минус одиночества в том, что через время начинаешь получать от этого кайф. И просто не пускаешь никого в свою жизнь; Через время поймешь цеенность каждой встречи.

${ }^{1}$ Стилистической ошибкой назвали эти обороты 10 из 10 коллег-языковедов, опрошенных на одной из представительных конференций, проходивших в ИРЯ РАН в 2016 г.

${ }^{2}$ Иллюстративный материал, используемый в статье, взят из этого ресурса (www.ruscorpora.ru).

3 В основном корпусе НКРЯ отражено 79 случаев такого употребления в 55 документах, в газетном - 47 в 45 документах, 5 примеров есть и в поэтическом корпусе. 
Примерно та же картина наблюдается и в отношении оборота спустя время, который встречается еще чаще ${ }^{4}$ : Немного спустя время еду к ним [М. П. Загряжский. Записки (1770-1811)]; Кто идет в лес по малину спустя время, тому одно средство: встретил кого с кузовом и отсыпь себе в кузовок [Н. С. Лесков. На ножах (1870)]; Годков пять поколобродит: апельсины, лимоны... а спустя время, смотришь, имение-то с аукииона продают [М.Е. Салтыков-Щедрин. Пошехонская старина. Житие Никанора Затрапезного, пошехонского дворянина (18871889)]; Надо помнить, что многие навыки у собак, все равно, как и людей, являются не прямо вслед за примером, а спустя время, в которое пример дозреет в себе [М. М. Пришвин. Дневники (1927)]; Люди ушли и спустя время вернулись... [Саша Соколов. Школа для дураков (1976)]; Спустя время это состояние уже не было новым. [Евгений Водолазкин. Лавр (2012)] и др.

Вариант же время спустя в изолированном употреблении встречается редко, но все-таки отмечен — как в художественной литературе: И откуда вы, такие, взялись тут? Все отступают, а вы наступаете... То, что ответил ему лейтенант, перед тем как закрыть над собою тяжелую крышку люка, сказать правду, не произвело на Шестерикова особенного впечатления. Но время спустя он вспомнил эти слова отчетливо - и с горьким сожалением, что никогда никому невозможно их повторить: - Запоминай, кореш: Двадияатая армия наступает! Командующий-то у нас Власов Андрей Андреич. Он же шуток не понимает, все всерьез [Г.Н. Владимов. Генерал и его армия (1994)], так и в прессе: - Как-то товарищ познакомил с Германом Грефом. Летели одним рейсом, разговорились. Время спустя от Грефа по почте прислали подарок - книжку Маршалла Голдсмита «Прыгни выле головы! 20 вредных привычек, от которых нужно отказаться, чтобы покорить вериину успеха» [Сергей Федоров: «Доверился другу — и потерял все...»// Спорт-Экспресс, 09.12.2016].

Доминируют, тем не менее, конструкции с определениями времени, указывающими на его промежуток: мало(е), немало(е), (не)долгое, (не)определенное, некоторое, какое-то и т. д.

Таким образом, можно говорить о «старшей», опирающейся на континуальное восприятие времени, и «младшей», соответствующей временной дискретности, нормах. Переход от одной нормы к другой, по всей вероятности, был мотивирован сменой языковой картины мира, в которой время из абстрактного стало конкретным, разделившись на века, годы, месяцьь, дни, часы, минутыл, секунды. Судя по НКРЯ, поворот в языковом сознании произошел примерно в середине XIX века, когда формы через несколько/сколько-то или мало/много времени, некоторое или краткое/долгое/длительное/продолжительное время, определенньй промежуток или год/час/полчаса/минуту времени, до того единичные, начинают преобладать 5 .

${ }^{4}$ В НКРЯ зарегистрировано 102 документа, 136 вхождений.

5 По данным основного корпуса НКРЯ, наиболее частотным оказываются варианты через некоторое время и несколько времени, на долю которых приходится, соответственно, 3460 и 600 употреблений; среди определенных временных промежутков чаще всего упоминается час (34 примера, тогда как год и минута становятся мерилом времени по 1 разу). 
Косвенно об этом переходе свидетельствуют толковые словари, в которых предлог через имеет в большинстве толкований пространственное значение, а временное предстает как производное, например, в «Большом толковом словаре русского языка» С. А. Кузнецова: «ЧЕРЕЗ, предлог кого-что 1. Указывает наместо, пространство, предмет, которые преодолеваются, а также располагаются на другой стороне или с промежутком друг от друга. <..> 6. Указывает на срок, промежуток времени, по истечении которого, спустя который происходит, совершается, повторяется что-л. или на какие-л. промежутки времени» [БТСРЯ 2008]. На пространственное восприятие времени, стоящее за этим предлогом, указывают и современные справочники по психологии ${ }^{6}$.

Что касается предлога сnустя, то его толкования лишены представлений о пространственности, а иллюстрации употребления говорят, скорее, о временной дискретности: «СПУСТЯ, предлог. кого-что. По прошествии какого-л. времени. С. час двинулись дальше. С. несколько месяцев мы встретились снова. $\square$ (после обстоятельства времени). Только год с. они узнали эту новость. Немного времени с. гости собрались уходить. $<$ Немного спустя, в зн. нареч. Разг. = Немного времени спустя. Немного спустя путники выцил к реке» [БТСРЯ 2008]. Синонимами к обороту спустя время также называются слова и словосочетания, подразумевающие членимую на отрезки временную последовательность (немного погодя, позднее/позже, вскоре, впоследствии, с годами и под.), — за редким исключением: лишь дальше и вслед в ряду приводимых в словарях синонимов отсылают к архаичным хронотопическим представлениям ${ }^{7}$. В пословицах, собранных и подготовленных в 1853 г. к изданию В.И. Далем, отразились оба взгляда: Cпустя время учиться, что по ушлому гонять; Спустя лето по малину в лес не ходят [Даль $1989]^{8}$.

Сервис распределения употреблений по годам показывает, что нормативными сочетания предлогов с не имеющим определений существительным время были до первой трети XIX в., затем они постепенно вышли из употребления и резко вернулись в речевой оборот уже в XXI в. - примерно к 2005 г.

И это не единственный пример такого возвратного движения.

Например, как просторечные воспринимаются сообщения от популярной социальной сети: Г-н (или г-жа) $N$ интересуется о Bac на Facebook. Обратившись же к НКРЯ, мы найдем десяток-другой примеров того, как высокообразованные люди, в частности, писатели - Гоголь, Тургенев, - интересовались о ком-то или о чьем-то здоровье. А, например, в «Дневнике писателя» Достоевского (1876)

${ }^{6}$ По их определениям, представлять себе что-то через время значит «иметь линию времени, на которой прошлое, настоящее и будущее находится перед вами»: например, время может быть «пространственно представлено как план на текущий год» [СНП 2003; БПЭ 2007].

${ }^{7}$ Например, в электронном словаре синонимов В.Н. Тришина [2013] из 29 эквивалентов только 2 имеют пространственно-временное значение.

${ }^{8}$ Интересно, что впоследствии в толковых словарях как пример употребления предлога спустя приводилась только вторая пословица (в частности, в словарях М.И. Михельсона [1896-1912] и Д.Н. Ушакова [1935-1940]). 
мы найдем похвалу спиритам - за то, что «в материальный век интересуются о душе».

Все же такая форма редка и относится к старой норме. Раньше вполне можно было интересоваться и о чем-то, и чем-то. Однако значения у глагола были разными: в первом случае человек хотел что-то узнать, во втором — глубоко погружался в изучение чего-то. В современном русском языке оба значения совпали. И процесс слияния двух значений в одном, как показывает корпус, был постепенным: если в начале XIX века люди интересовались, например, о шахматах, то в конце его интересовались уже шахматами. Точно так же интересовались о знакомых, о причинах милостивого внимания к ним августейших особ или же о монаршей немилости, а потом стали интересоваться друзьями, их здоровьем, настроением...

В последнее время встречаются и другие непривычные словосочетания, например: Я счастлива тому, что мне многое удается, что меня любят и мне есть, кого любить. А кто-то, наоборот, говорит, что рад тем, что удача ему во всем сопутствует. По правилам же нужно радоваться чему-то, а счастливыл быть от чего-то. Однако можно вспомнить народную мудрость чем богаты, тем и рады и предположить, что так и говорили раньше.

Корпусное исследование даст несколько подтверждающих эту гипотезу примеров. В частности, Бестужев-Марлинский рассказывает, как упросил генерала Ермолова отпустить плененного и приговоренного к смерти горца: Я был так рад успехом, что, поблагодаря наскоро главнокомандующего, побежал в палатку, в которой содержался Аммалат-бек [А.А. Бестужев-Марлинский. Аммалат-бек (1831)]. Или Скобелев в «Рассказах русского инвалида» (1838-1844) описывает отслужившего двадцать пять лет в артиллерии героя: Любил беседы, pad был хлебом-солью, не забывал и бедных. В «Ювенильном море» Платонова (1934) один из героев вытер заслезившиеся от восторга глаза и встал на ноги, будучи рад всеобцей радостью. Таким образом, форма рад чем-то встречалась еще в первой трети XX века, а позже была утрачена.

Творительный же падеж «выжил» не только в идиоме чем богаты, тем и paдbl, но и еще в двух устойчивых выражениях: рад радостью и рад душою. Поиск указывает, например, на «Отрывки из воспоминаний своих и чужих» Тургенева (1881), там на просьбу «поправить дело» следует ответ: и рад бы радостью, но как быть? И таких «радых радостью» в русской литературе XIX — начала XX века довольно много. Как и тех, кто рад душою. Например, Макар Алексеич в «Бедных людях» Достоевского попросившему у него в долг — «хоть гривенничек какой-нибудь», отвечал: рад бы душой, да нет у меня ничего, ровно ничего нет. И рад бы душойпомочь, а как? — писал Шукшин [Василий Шукшин. Беседы при ясной луне (197274)]; Рад бы душой, да хлеб-то чужой, - встречается у Гранина [Даниил Гранин. Искатели (1954)]. А у Горького можно найти вот какой пассаж: Баба... жуёт и, вытащчив пальцем из своего рта жвачку, отправляет её в рот ребёнка. Ребёнок присасывается кеё пальиу, раскрыввает глаза, закрывает их и урчит... Это, знаете, странный такой голодный звук маленького животного, которое долго хотело 
есть и вот ест, наконеи, - ест и радо всеми фибрами своего тела [Максим Горький. Голодные (1899)].

Подобные примеры подтверждают, что форму я рад тем, что... не стоит считать безусловно ошибочной: она, скорее, требует пометы «устарелое».

Что касается отношения к счастью, то примеров современного «неправильного» управления в НКРЯ достаточно: Я счастлив тому, что экспедиция завериилась успешно в такой светльй день, - признался Федор Конюхов эфиопским журналистам, - спасибо за трогательную встречу, да хранит всех вас Бог [В Эфиопии Федору Конюхову вручили аксумский обелиск, но скрыли Ковчег Завета // Комсомольская правда, 2011.05.12]; Я счастлив тому, что в моей жизни появляются какие-то общечеловеческие иенности [Сергей Светлаков: «Ребенок - веская причина, чтобы я чаще бывал дома» // Труд-7, 2009.06.18]; Я чувствовал себя артистом, танцуовщиком и был счастлив тому, что нашу пару хвалили [Виктор Сухоруков: «Актером я был уже в утробе матери» // Известия, 2006.03.02]; А теперь я счастлив тому, что новое поколение даже не знает, что такое «выездная комиссия», и весь мир по праву принадлежит Всем [Евгений Евтушенко приглашает всех в Кремль! // Комсомольская правда, 2002.05.24] и т. д.

Обратившись к НКРЯ, опять-таки можно установить «старшую» норму, к примеру: $Я<\ldots>$ счастлив тому, что имел личную возможность убедиться, насколько успел в короткое время развиться и укрепиться в своем благосостоянии обширный край, прорезанный железною дорогою, как отрадно мне было видеть несомненнье доказательства проявления мирной и дружной жизни русского населения в полосе дороги с китайским населением, как трогательно было мне видеть русских детей, посещявших вместе с китайскими детьми русскую школу в некоmopыx пунктах [В.Н. Коковцов. Из моего прошлого (1933)].

То, что подобных возвратов к «старшей» норме в современной речевой практике немало (и затрагивают они все уровни языковой системы), позволяет поставить вопрос о спонтанной рекурсии литературной нормы, о сохранении в языковом сознании говорящих «речевой памяти», закрепляющей прежние состояния языковой системы. Вопрос в том, почему так опять начинают говорить сейчас: возможно, просто ошибаются, не владея нормой, но вероятно и то, что язык решил вернуться на круги своя.

\section{Литература}

Большая психологическая энииклопедия (БПЭ): более 5000 психологических терминов и понятий / А. Б. Альмуханова и др. М. : Эксмо, 2007. 542 с. [Электронный ресурс]. URL: http://psychology.academic.ru/.

Большой толковый словарь русского языка (БТСРЯ) / Кузнецов С.А. (ред.). СПб.-М.: Рипол-Норинт, 2008. 1536 с. [Электронный ресурс]. URL: http://www. gramota.ru/slovari/info/bts/.

Даль В. И. Пословицы русского народа. М.: Художественная литература, 1989. 447 с., илл. [Электронный ресурс]. URL: http://dslov.ru/txt/t81.html. 
Михельсон М.И. Русская мысль и речь. Свое и чужое. Опыт русской фразеологии. Сборник образных слов и иносказаний. Т. 1-2. СПб., Тип. Академии наук, 1896-1912. 2208 с. [Электронный ресурc]. URL: http://dic.academic.ru/contents.nsf/ michelson_new/.

Национальный корпус русского языка (НКРЯ) [Электронный ресурс]. URL: www.ruscorpora.ru.

Словарь нейролингвистического программирования (СНП) / В. Ценёв (сост.). M., 2003 [Электронный ресурс]. URL: http://nlp.academic.ru/.

Тришин В.Н. Большой русский словарь синонимов ASIS. M., 2013 [Электронный ресурc]. URL: http://trishin.net/.

Ушаков Д.Н. Толковый словарь русского языка: в 4-х томах. М.: Сов. энциклопедия - ОГИЗ, 1935-1940. URL: http://dic.academic.ru/contents.nsf/ushakov/.

\section{Olga I. Severskaya}

V.V. Vinogradov Russian Language Institute of the Russian Academy of Sciences

(Russia, Moscow)

oseverskaya@yandex.ru

\section{«THROUGH TIME, THROUGH DISTANCE»: STYLISTIC ERROR, ELLIPSE OR RECURSIVE NORM?}

The article deals with cases of grammatical «irregularities» that occur in modern speech. Particular attention is paid to collocations that denote temporal sequences: cherez vremya 'through time' and spustya vremya 'after time', in which, contrary to the current language norm, there are no specifying definitions, indications for the time interval. As a result of the corpus analysis on the material of the Russian National Corpus, the author comes to the conclusion that there is a «older» and «younger» (i.e., earlier and later) norms and rates of use of the lexeme vremya, combined with prepositions, a transition from the chronotopic perception of space and time to the idea of temporal discreteness. The article also considers the meanings of prepositions, reflecting the change in the perception of spatio-temporal coordinates. The sharp increase in «archaic» usage in the last decade, according to the author's observations, is typical for some other lexemes. This is confirmed by examples of the «older» and «younger» norms of proper government for interesovat'sya 'to be interested' and for the categories of state of gladness and happiness ( rad 'glad' and schastliv 'happy'). Such facts suggest that in the speakers' linguistic consciousness there is something like «speech memory» that fixes the previous states of the language system. This phenomenon the author proposes to call a spontaneous recursion of the norm, thereby broadening the notion of the formation of a norm and its reflection in a culture of speech.

Key words: Space and time, norm recursion, «older» and «younger» norm, collocation, variation of proper government, speech culture. 


\section{References}

Bol'shaya psikhologicheskaya entsiklopediya: 5000 psikhologicheskikh terminov i ponyatii [The Great Psychological Encyclopedia: more than 5000 psychological terms and concepts]. A. B. Al'mukhanova \& others, red. Moscow, Eksmo Publ., 2007. 542 p. Available at: http://psychology.academic.ru/ (accessed 01.10.2017).

Bol'shoi tolkovyi slovar' russkogo yazyka [A Large Explanatory Dictionary of the Russian language]. Kuznetsov S.A. (red.). St. Petersburg-Moscow, Ripol-Norint Publ., 2008. 1536 p. Available at: http://www.gramota.ru/slovari/info/bts/ (accessed 01.10.2017).

Dal' V.I. Poslovitsy russkogo naroda [Russian folk proverbs]. Moscow, Khudozhestvennaya literatura Publ., 1989. 447 p., ill. Available at: http://dslov.ru/txt/ t81.htm (accessed 01.10.2017).

Mikhel'son M.I. Russkaya mysl' i rech'. Svoe i chuzhoe. Opyt russkoi frazeologii. Sbornik obraznykh slov i inoskazanii [Russian thought and speech. «Own» and «alien». Experience of Russian phraseology. Collection of figurative words and parables]. Vol. 1-2. St. Petersburg, Academy of Sciences Publ., 1896-1912. 2208 p. Available at: http://dic.academic.ru/contents.nsf/michelson_new/ (accessed 01.10.2017).

Natsional'nyi korpus russkogo yazyka [Russian National Corpus]. Available at: www. ruscorpora.ru (accessed 01.10.2017).

Slovar' neirolingvisticheskogo programmirovaniya [Dictionary of Neuro-Linguistic Programming]. Tsenev V. (red.). Moscow, 2003. Available at: http://nlp.academic.ru/ (accessed 01.10.2017).

Trishin V.N. Bol'shoi russkii slovar' sinonimov ASIS [The Great Russian Dictionary of Synonyms ASIS]. Moscow, 2013. Available at: http://trishin.net/ (accessed 01.10.2017).

Ushakov D. N. Tolkovyi slovar' russkogo yazyka [Russian Explanatory Dictionary]. Vol. 1-4. Moscow: Sov. Entsiklopediya - OGIZ Publ., 1935-1940. Available at: http:// dic.academic.ru/contents.nsf/ushakov/ (accessed 01.10.2017). 


\section{Г.Н. Скляревская}

Российский государственный педагогический университет им. А. И. Гериена (Россия, Санкт-Петербург)

gsklyarevskaya@mail.ru

\section{«ТАК НЕ ГОВОРЯТ», ИЛИ ЕЩЕ РАЗ О СИСТЕМЕ, НОРМЕ И УЗУСЕ (ВЗГЛЯД ЛЕКСИКОГРАФА)}

В статье рассматривается соотношение системы, речевой практики и нормы в лексикографическом аспекте применительно к проблемам и возможностям формирования словников толковых словарей разных типов. На основании анализа лексического материала выявлены три типа речевых ситуаций: 1) речевая практика основана на системе и поддержана нормой («так говорить можно и нужно»); 2) речевая практика основана на системе и не поддержана нормой («так говорить нельзя»); 3) речевая практика основана на системе, но не существует в реальном употреблении («так можно было бы сказать, но так не говорят»). С точки зрения лексикографии неузуальная, искусственно образованная лексика может найти место как своего рода база лексических потенций только в орфографических словарях и тех толковых словарях, которые сознательно и прицельно ориентированы на систему и не ставят задачи показать реальную жизнь слова в речевом употреблении.

Ключевые слова: языковая система, языковая норма, речевая практика, толковый словарь, принципы формирования словника.

Описанная Э. Косериу триада «система-норма-узус» во всех ее противоречиях оказалась очень востребованной в лингвистике, и ее обсуждение, уточнение и развитие мы наблюдаем на протяжении более полувека (см., например, [Крысин 2007; Сиротинина 2013]).

В своих рассуждениях мы будем традиционно исходить из сформулированного Э. Косериу постулата: «Система есть “система возможностей, координат, которые указывают открытые и закрытые пути” в речи, “понятной” данному коллективу; норма, напротив, — это “система обязательных реализаций” < ..>, принятых в данном обществе и данной культурой: норма соответствует не тому, что “можно сказать", а тому, что уже “сказано" и что по традиции “говорится" в рассматриваемом обществе» [Косериу 2010: 36-37]. При этом под системой понимается целостное упорядоченное единство связанных между собой языковых элементов, как 
реализуемых в процессе речевого общения, так и невостребованных, неких стереотипов, потенциальных слов, существующих в виде абстрактных моделей (в этом отношении система шире узуса). Узус, иначе речевая деятельность, речевая практика - использование языка в разных сферах человеческой деятельности. В узусе могут быть реализованы как элементы системы, так и различные новообразования, одноразовые слова, возникшие в спонтанной речи. В этом отношении узус шире системы. Под нормой понимается совокупность более или менее стабильных и унифицированных языковых средств и правил, которые приняты в данном обществе в данное время. Норма является своеобразным регулятором, который, связывает систему и узус и представляет их в единстве.

В лексикографическом аспекте при обосновании словника особую роль играет противоречие между узусом и возможностями лексической системы. Основу словника любого толкового словаря традиционно составляет узуальная лексика, не противоречащая системе и в своей ядерной части поддержанная нормой - это нейтральные, «чистые» и «правильные» слова типа земля, вода, рука, дом, друг, речь, небо, ходить, думать, играть, давать, держать, спать, думать, умньий, бельй, хороший, близко, плохо, вдруг, давно и т. п. Массив такой лексики формирует ситуацию, которую можно обозначить утверждением «так говорят, и так говорить можно и нужно».

Однако узус, как мы знаем, использует не только нейтральные, чистые и правильные слова. И при формировании словника наиболее актуальной становится проблема включения/невключения периферийных групп лексики - устарелой, профессиональной, жаргонной, сниженной и т. п. - которая встречается в узусе, но не поддерживается или отвергается современной стандартной нормой. Значительная часть этой узуальной лексики, особенно жаргон, чрезвычайно популярна в обществе: бабло, безбашенныи, влазить, лажа, л'ожить, лопухнуться, лохануться, ментовка, отморозок, офигенный, охренеть, порнуха, пофиг, прибабахнутьй, халява, мне по барабану, меня не кольшет и т. п. Этот конфликт между узусом и нормой в русской лексикографической традиции успешно разрешается посредством стилистических и функциональных помет, таких, как Разг., Разг. Сниж., Жарг., Проф., Устар. (см., в частности, [Скляревская 2004: 29-31]), а также запретительной пометой «Неправильно!», апробированной в некоторых словарях нормализаторской направленности (в частности, в серии кратких словарей-справочников под общей рубрикой «Давайте говорить правильно!», изданной в СПбГУ в 20022008 гг.). Употребление этой лексики соответствует ситуации «так говорят, но так говорить в культурной среде нельзя».

Особенно остро лексикографическая проблема «правильно/неправильно» встала в конце XX века, в пору антропоцентрической лексикографии, то есть словарного описания лексической системы, опосредованной обществом и говорящим человеком. И если словарь ставит задачу описать не ячейки лексической системы, а живое употребление слов, обусловленное языковым сознанием современников, то вопрос «так не говорят» приобретает особую значимость.

Здесь уместно вспомнить известный пример академика Л.В. Щербы: «Совершенно очевидно, что на упрек: Чего ты не стерег моих вещей?, ответ, самый 
естественный, будет: Надоело мне это стережение твоих вещзей» [Щерба 1957: 118]. К примеру Щербы можно было бы добавить целую серию подобных высказываний: *дети вымчались из комнаты; *в ответ он всякий раз смущенно проранивал «не надо»; *нам наконец удалось протолпиться к кассе; *хватит судачить, надоело ваше судаченье; * перестань огрызаться, ты получишь за свое огрызание; *туристы нередко ограбляются местными грабителями; *что ты каждый раз промахиваешься, ни разу в кольцуо не попал; *Зинаида Гиппиус была мистичкой; *заказал щучину под хреном и т. п.

Эти слова воспринимаются как одноразовые, возникшие в спонтанной речи и, хотя вполне понятные, поскольку работает закон аналогии, но не вышедшие за рамки конкретного акта коммуникации и не ставшие фактом речевой практики. Иными словами, в этом случае, по Косериу, перед нами инновация без принятия [Косериу 2010: 55]. Тем не менее многие из них находим в [Даль]: все подчеркнутые в перечне приведенных выше примеров, а также докаиваться, занравиться, заратовать, зарачить 'начать ловить раков', заскороходить, интересничанье, исклёвывание, дерзословить и многие другие подобные.

Построенный с ориентацией на Даля «Словарь русского языкового расширения» [Солженицын 1990] состоит из областных и устарелых слов, а также в значительной мере из слов потенциальных, составленных автором по существующим системным моделям, нередко способом контаминации: внимчиво (от внимательно и вдумчиво); нахльн (от нахлынуть по модели наплыв); безтоварица 1 (по модели бесхлебица); безъиконная изба; белосветныий (обо всем, что есть на свете); беспоминный (кого не помнят, забыли); ветродырая хижина; занравчивылй (умеющий понравиться); запредылущчий, запредшедший (позапрошлый); затинное место (тенистое), затолчка (заталкивание); затулье, затулище (скрывище, убежище, приют); златоплечий (о погонах); обсамился (вышел из-под родительской воли), угостки (небольшая пирушка). Сам автор в предисловии к Словарю охотно демонстрирует апробацию этих не существующих в речевом употреблении слов: «Я сперва читал подряд все четыре тома Даля, очень внимчиво» [Солженицын 1990: 3]. «Но нельзя упустить здесь и других опасностей языку, например, современного нахлына международной английской волны»» [там же: 4].

Из современных словарей неузуальную (потенциальную) лексику, образованную по стандартным системным моделям, охотно фиксируют словари, ориентированные на систему и не имеющие задачи показать реальное речевое употребление - прежде всего орфографические, а из толковых - словарь Ефремовой. В этом словаре мы находим: вомчаться; вымчаться; занумеровывание; западнизация 'навязывание незападным странам и народам социального строя, экономического развития, идеологии, культуры, образа жизни, свойственного или подобного тому, который есть в западных странах'; кователь 'тот; кто кует'; проранивать 'нечаянно ронять'//перен. 'говорить; произносить; обычно после молчания и коротко, сдержанно’; судачение 'процесс действия по знач. глаг. судачить'; щ’ 'учина 'мясо щуки,

\footnotetext{
1 Здесь и далее в примерах сохранена орфография А. И. Солженицына
} 
употребляемое в пищу'; огрызание 'процесс действия по знач. глаг. огрызаться'; встрёпанно 'испуганно, беспокойно'; всходчивылй = всхожий; домыкивать 'с трудом, в трудных условиях доживать какой-л. срок'; зам'ыкаться 'начать мыкаться'; оговорщица 'женск. к оговорщик'; оговорщчик 'тот, кто возводит на кого-л. обвинение; оговаривает'; ограбляться 'страд к глаг. ограблять'; перемащчивать 'мостить что-л. снова, еще раз’ и перемащииваться 'страд. к глаг. перемащивать'.

О неузуальном характере приведенных выше слов из словаря Ефремовой, объективно свидетельствует тот факт, что они в массе своей отсутствуют в НКРЯ (основной корпус), а некоторые представлены единичными вхождениями: волчатник (охотник на волков) - 3 вхождения; выстилка (подстилка) - 3 (все из специальных текстов); мистичка (женск. к мистик) - 1 (из Амфитеатрова); протолпиться (пройти, протолкаться сквозь толпу) — 4; судачина (мясо судака, употребляемое в пищу) - 2 .

Подобная лексика отражает процесс, называемый «выравниванием форм под действием закона аналогии». Для системы безразлично, задействована хранимая в ней лексическая единица в речи или нет. И, если нет фонетических препятствий, по системной модели может быть образовано любое слово: если система признает

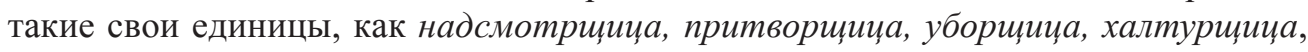
то в этот системный ряд вполне закономерно встраивается и неупотребительное в речи оговорщици; если определенную системную ячейку занимает осетрина, севрюжина, свинина, телятина, то почему бы соседние ячейки не могли занять судачина и иучина; если в системе есть католичка, астматичка, неврастеничка, алкоголичка, шизофреничка, истеричка, географичка, математичка, химичка, фанатичка, то свою системную ячейку законно займет и мистичка.

Употребление этой лексики связано с ситуацией «так можно было бы сказать, но так не говорят».

Перед лексикографом встает вопрос, должны ли подобные лексические единицы, образованные по закону языковой аналогии и поддержанные системой, но при этом не представленные в узусе, войти в словник большого толкового словаря? Ведь любая из них может оказаться востребованной в оригинальном авторском тексте. Возьмем слово радование, зафиксированное у Даля и повторенное у Солженицына, но в современном языке несомненно не принадлежащее узусу: встречается в церковном языке в акафистах и молитвах и в названии одной из икон Пресвятой Богородицы («Великое Радование»), а также оказалось задействованным в названиях некоторых учреждений (развивающий центр при гимназии «Радование», лесопитомник «Радование», коттеджный поселок «Радование» и т. п.). Слово явно маргинальное, вместе с тем ничто не препятствует его употреблению в современном оригинальном художественном тексте: «Моя покойная мама, от природы одаренная дивной способностью радования всему на свете, очень меня жалела» ${ }^{2}$.

В принципе неузуальное слово может быть использовано и реализовано в любом тексте, нацеленном на разрушение автоматизма восприятия. Так, непроизносимое

\footnotetext{
2 Л. Улицкая. Священный мусор. М., 2012. С. 461.
} 
слово занумеровывание выглядит вполне органично в тексте В.В. Розанова: «К сожалению, это самонужнейшее дело не могло бы нарастить никакого номера в сериях текущих дел, а это наращение, занумеровывание все новых неспособных учителей, всеновыхмалокчемупригодныхгимназийирост, всерост статистических uчифр обратились в какую-то кантовскую «вещзь в себе»... ${ }^{3}$. Ср. также: «Сейчас я вышагнул в никуда» ${ }^{4}$. «Уйдите от рывков, путаницыь, раздвоения, растроения... $»^{5}$. «Мощеный в середке, он [двор] давно не перемащивался, и бульюнник густо порос плоской кудрявой травкой» ${ }^{6}$. «Мне пришлось выказать почтение к непригодным даже для ностальжирования кователям наших щуитов и мечей» ${ }^{7}$. Tb тоже становишься ульбчив, услужлив и говорлив: уровень еврейскости (грубее - жидкости) в твоей крови падает почти до нуляв ».

Другая возможность реализации потенциального слова - его широкая употребительность в профессиональном языке, из которого оно - при особой общественной активности и значимости данной профессии - имеет шанс войти в общий язык. Примером такой реализации может служить ставшее узуальным и получившее широкое распространение типичное «системное» образование замятие (отмеченное в [Даль] и [Лопатин]) в единичной сочетаемости замятие бумаги в принтере.

Наши рассуждения и примеры приводят к следующим выводам.

Вывод первый: виды соотношений системы, узуса и нормы могут формировать три типовые речевые ситуации: (1) так говорят, и так говорить можно и нужно; (2) так говорят, но так говорить в образованном обществе нельзя; (3) так можно было бы сказать, но так не говорят.

Вывод второй: с точки зрения лексикографии неузуальная, искусственно образованная лексика должна найти место в орфографических словарях и тех толковых словарях, которые сознательно и прицельно ориентированы на систему и не ставят задачи показать реальную жизнь слова в речевом употреблении. Это своего рода хранилище лексических потенций, которые могут быть реализованы при определенных обстоятельствах и с определенной целью. Что касается толковых словарей антропоцентрического типа, которые описывают лексическую систему, опосредованную говорящим человеком и обществом (что демонстрируется, в частности, лексикографическими иллюстрациями, то есть подтверждением

\footnotetext{
${ }^{3}$ В. В. Розанов. Сумерки просвещения / В. В. Розанов. Сумерки просвещения. М. Педагогика, 1990. - 624 с. С. 52 (сноска).

${ }^{4}$ Г. Семенов. Жизнь за столом складывается так.... Переписка Т. Ю. Хмельницкой и Г. С. Семенова (1966-1970) // Звезда, 2014 №3. С. 140-170. С. 153.

5 Т. Ю. Хмельницкая. Там же.

${ }^{6}$ Б. Пастернак. Детство Люверс. / Б. Пастернак. Избранное. В 2 кн. Кн. 2. Проза. М.: Просвещение. 1991. -208 с. С. 21.

7 А. Мелихов. Изгнание из памяти / А. Мелихов. И нет им воздаяния. М., 2015. 702 с. С. 477.

8 А. Мелихов. Во имя четыреста первого или Исповедь еврея. / А. Мелихов. Исповедь еврея. СПб.: Новый Геликон, 1994. 317 с. С. 183.
} 
каждой единицы словника примерами живого словоупотребления), то в них, я полагаю, нет места неузуальным словам.

\title{
Литература
}

Даль В.И. Толковый словарь живого великорусского языка. М.: Государственное издательство иностранных и национальных словарей. - 1955. - Набрано и напечатано со второго издания 1880-1882гг: Толковый словарь живого великорусского языка Владимира Даля. Второе изд., исправленное и значительно умноженное по рукописи автора. СПб-М.: издание книгопродавца-типографа М. О. Вольфа.

Ефремова T. Ф. Новый словарь русского языка. Толково-словообразовательный. - М.: Рус. Яз., 2000 (Б-ка словарей рус. яз).

Косериу Э. Синхрония, диахрония и история: Проблема языкового изменения. Пер. с исп. Изд. 3-е. - М.: Едиториал УРСС, 2010. — 208 с.

Крысин Л.П. Русская литературная норма и современная речевая практика. // Русский язык в научном освещении. 2007, №2 (14). С. 5-17.

Лопатин В.В. Русский орфографический словарь. Около 200000 слов. / Под ред. Лопатина В. В. Ивановой О.Е. - 4-е изд., испр. и доп. - М.: 2013. — 896 с.

Сиротинина О.Б. Русский язык: система, узус и создаваемые ими риски. Саратов: Изд.-во Саратовского ун-та, 2013. - 116 с.

Скляревская Г.Н. Современный толковый словарь живого русского языка. Обоснование концепции. Пробные словарные статьи. - СПб.: Филологический факультет СПбГУ, 2004. - 80 с.

Солженицын А.И. Словарь русского языкового расширения. М.: Наука. 1990. $272 \mathrm{c}$.

Щерба Л.В. Современный русский язык / Л.В. Щерба Избранные работы по русскому языку. М., 1957. С. 110-129.

\author{
G. N. Sklyarevskaya \\ The Herzen State pedagogical University of Russia \\ (Russia, St Petersburg) \\ gsklyarevskaya@mail.ru
}

\section{"THIS IS NOT THE WAY TO SAY IT" OR ONE MORE TIME ABOUT THE SYSTEM, THE NORM AND THE USAGE (A LEXICOGRAPHER'S VIEW)}

The article considers the relationship between the system, speech practice and the norm in the lexicographical aspect and with regard to problems and opportunities of creating word lists for various kinds of comprehensive dictionaries. Having analyzed lexical material the author has come up with three types of speech situations: 1) speaking is 
based on a system and is supported by the norm ("it is both possible and correct to say that") 2) speaking is based on a system but is not supported by the norm ("it is not correct to say that") 3) speaking is based on a system but does not exist in real usage ("you could say that, but no one speaks this way"). From the point of view of lexicography the unused, artificially created vocabulary can only play a meaningful role as a storage of lexical possibilities in orthographic dictionaries and those comprehensive ones that are aimed at a system and not concerned with showing the real life of a word in its everyday usage.

Key words: language system, language norm, comprehensive dictionary, word list formation principles.

\section{References}

Dal V.I. Tolkovyy slovar zhivogo velikorusskogo yazyka [Explanatory dictionary of the living great Russian language]. M.: Gosudarstvennoye izdatelstvo inostrannykh i natsionalnykh slovarey. 1955.

Efremova T.F. Novyy slovar russkogo yazyka. Tolkovo-slovoobrazovatelnyy [New dictionary of the Russian language. Sensible-word-formation]. M.: Rus. Yaz., 2000.

Koseriu E. Sinkhroniya. diakhroniya i istoriya: Problema yazykovogo izmeneniya [Synchrony, diachrony and history: the Problem of language change]. 3d edition. M.: Editorial URSS. 2010. 208 p.

Krysin L. P. Russkaya literaturnaya norma i sovremennaya rechevaya praktika [Russian literary norm and speech practice modern]. Russkiy yazyk v nauchnom osveshchenii. 2007, no. 2 (14), pp. 5-17.

Lopatin V. V. Russkiy orfograficheskiy slovar. Okolo 200000 slov [Russian spelling dictionary. About 200000 words.]. Lopatin V. V. Ivanova O. E. (Eds.). 4th edition. M.: 2013. 896 p.

Sirotinina O. B. Russkiy yazyk: sistema, uzus i sozdavaemye imi riski [Russian language: system, language usage, and they create risks.]. Saratov. 2013. 116 p.

Sklyarevskaya G. N. Sovremennyy tolkovyy slovar zhivogo russkogo yazyka. Obosnovaniye kontseptsii. Probnyye slovarnyye stati [Modern explanatory dictionary of the living Russian language. Substantiation of the concept. Trial entries]. SPb.: Filologicheskiy fakultet SPbGU. 2004. 80 p.

Solzhenitsyn A.I. Slovar russkogo yazykovogo rasshireniya [Dictionary of the Russian language extensions]. M.: Nauka Publ., 1990. 272 p.

Shcherba L. V. Sovremennyy russkiy yazyk [Modern Russian language]. L. V. Shcherba Izbrannyye raboty po russkomu yazyku [Selected works on Russian language]. M. 1957, pp. 110-129. 


\section{А. Э. Цумарев, Л.Л. Шестакова}

Институт русского языка им. В. В. Виноградова РАН

(Россия, Москва)

zumarew@yandex.ru,lara.shestakova@mail.ru

\section{О КОДИФИКАЦИИ ЯЗЫКОВЫХ НОРМ В «АКАДЕМИЧЕСКОМ ТОЛКОВОМ СЛОВАРЕ РУССКОГО ЯЗЫКА»}

В статье дается характеристика «Академического толкового словаря русского языка» как словаря нормативного типа. Отмечается, что нормативность нового словаря проявляется двояко: 1) в отказе от включения в него большинства нелитературных языковых единиц, 2) в нормативной оценке (с помощью помет) некоторого числа включенных в него единиц, которые функционируют за пределами литературного языка или на его границе. В лексикографическом аспекте раскрывается связь кодифицируемых в словаре норм с языковой системой и современным узусом. Затем рассматриваются, в связи с новшествами словаря, типы языковых норм (орфографическая, орфоэпическая, грамматическая, стилистическая, лексико-семантическая, фразеологическая) и способы их отражения в различных зонах словарной статьи. Так, в разборе орфографической нормы внимание сосредоточено на помете «с прописной буквы»», последовательно используемой в словаре в связи с остротой проблемы выбора прописной / строчной буквы. При характеристике грамматической нормы анализируются случаи словарного представления грамматической вариантности, а также одушевленности как признака существительного (с помощью пометы одуш.). Подчеркивается, что фиксация важнейших для толкового словаря лексико-семантической и фразеологической норм предусматривает корректировку имеющихся в других словарях толкований, выявление и семантическое описание не учтенных ранее значений слов и устойчивых сочетаний, истолкование новых, недавно вошедших в язык лексических и фразеологических единиц. Как показывают авторы статьи, лексикографическое представление языковых норм в «Академическом толковом словаре русского языка», с одной стороны, опирается на отечественную лексикографическую традицию, а с другой — направлено на ее развитие и обогащение новым содержанием.

Ключевые слова: современный русский литературный язык, языковая норма, языковая система, узус, кодификация, лексикография, толковый словарь, словник, словарная статья. 
1. В 2016 г. были опубликованы два первых тома нового «Академического толкового словаря русского языка» [АТоС] (т. 1: А - Вилять, т. 2: Вина - Гяур). Эти тома, послужившие материалом для данной статьи, подготовлены под руководством Л. П. Крысина в Институте русского языка им. В. В. Виноградова РАН. Продолжая традиции академических толковых словарей, в первую очередь 4-томного «Словаря русского языка» под ред. А.П. Евгеньевой [MАС], АТоС выступает как толковый словарь нормативного типа, с комплексным, разносторонним описанием русской лексики.

1.1. Основу словника нового академического словаря составляет лексика и фразеология современного русского литературного языка в его книжной и разговорной разновидностях. Кроме того, в словник включены наиболее употребительные в современной речи слова просторечного, диалектного и жаргонного происхождения. Таким образом, в АТоСе находит свое продолжение лексикографическая традиция, в соответствии с которой нормативность толкового словаря проявляется двояко: 1) в отказе от включения в него большинства нелитературных языковых единиц, 2) в нормативной оценке (с помощью помет) некоторого числа включенных в него языковых единиц, которые, как принято говорить, «находятся за пределами литературного языка или стоят на его границе» [MAC: 9].

По мнению авторов словаря, его словник «вполне адекватно отражает состав лексики современного русского литературного языка» [АТоС 1: 7].

1.2. Разработка АТоСа осуществляется по алфавитному принципу, при этом значительное внимание уделяется отражению в словаре языковой системности.

На уровне словника это видно, в частности, в том, что в целом ряде случаев в словарь включается не какое-либо одно слово, а целое словообразовательное гнездо, например: аудит, аудитор, аудиторский; байк, байкер, байкерский; виндсёрфер, виндсёрфинг, виндсёрфинговыц.

Другим примером отражения в АТоСе реализованности / нереализованности возможностей языковой системы может служить использование иллюстраций (речений и цитат) в отсылочных словарных статьях (к производным, которые в толковых словарях редко иллюстрируются; см., например, статью «Выправление»).

1.3. При создании АТоСа большое значение придается анализу узуса как «базы формирования литературного языка» (О. А. Лаптева). Изучение узуса и его динамики, основанное в первую очередь на данных Национального корпуса русского языка, позволяет во многих случаях представить более точное, полное и доказательное, чем в других толковых словарях, описание русской лексики, ее современных норм.

Так, например, изучение религиозно-философских контекстов употребления лексемы грех позволило выделить у нее ранее не отмеченный, но подтверждаемый множеством литературных примеров смысловой оттенок при основном значении 'нарушение моральных норм, религиозно-нравственных предписаний':

ГРЕХ, -á, м. 1. .. || только ед. ч. Злое, порочное начало, действующее в человеке, как источник такого нарушения. ... Как бы ни был человек праведен и чист, 
а есть в нем стихия греха, которая не может войти в Царство Небесное. А. Ельчанинов. Записи.

2. Словарная статья в новом академическом словаре включает в себя следующие зоны: заголовочное слово; помета об особенностях произношения слова; грамматические формы; грамматические характеристики; стилистические пометы; толкование; примеры употребления слова в виде типичных словосочетаний (речений) и в виде цитат из письменных (художественных, публицистических, научных и иных) текстов XIX — начала XXI века; фразеологические обороты и устойчивые терминологические сочетания с данным словом; справка о происхождении слова. Основным источником иллюстрирования в словаре служит Национальный корпус русского языка.

Каждая зона словарной статьи в АТоСе, как и в любом другом толковом словаpe, соотносится с одним, иногда с несколькими типами языковых норм. К примеру, заголовок статьи совмещает в себе орфографическую и акцентологическую нормы, иногда (при наличии вариантов) - указание на стилистическую, например: БИВА́К и (ycmap.) БИВУА́К; БА́РХАТКА и (разг.) БАРХО́ТКА. Покажем далее некоторые особенности фиксации в АТоСе нормы того или иного типа в связи с новшествами этого словаря.

\section{1. Орфографическая норма.}

Орфографическую норму фиксируют заголовки всех словарных статей. В дополнение к этому, учитывая остроту проблемы выбора прописной / строчной буквы, авторы словаря отмечают (по возможности последовательно, с опорой на соответствующие справочники) случаи написания слова с большой буквы. Для этого последовательно используется помета ( п прописной буквы). Названная помета предшествует толкованию и может занимать разные позиции в словарной статье: при слове, имеющем одно значение; при отдельном значении многозначного слова; при оттенке значения слова (после знака $\|$ ); при употреблении слова в качестве единицы другой части речи (после знака |); при фразеологическом сочетании (после знака $\diamond)$ и его отдельном значении, например:

БЫТИЕ́, -я, ср. ... 3. ( п прописной буквы). Религ. Первая книга Ветхого Завета, повествующая о сотворении мира и древнейшей истории человечества. Вслед за упоминанием «и был вечер, и было утро: день пятый», в первой главе книги «Бытие» появляется разъяснение деяниям Бога, ведущее к сотворению человека. Л. Васильева, В. Правоторов. Весть Василисы.

Орфографическая помета ( с прописной буквы) не только выполняет свою основную функцию, но и маркирует в словарной статье дифференциацию компонентов семантической структуры слова, словосочетания.

\section{2. Орфоэпическая норма.}

Называвшиеся выше зоны словарной статьи имеют в новом толковом словаре разный статус. Наряду с обязательными в нем предусмотрены факультативные зоны. К ним относится, в частности, зона, содержащая информацию о произношении слова. До настоящего времени большие и средние по словнику толковые словари если и давали ее, то обычно в минимальном объеме, несистематически. Вместе с тем очевидна актуальность этой информации, особенно в условиях, когда 
язык осваивает множество «чужих» слов. При выработке концепции словаря было решено во всех необходимых случаях, опираясь на данные орфоэпических справочников (в первую очередь изданий [ОэС; Каленчук и др. 2016]), фиксировать произносительную норму с помощью специальной пометы. Она дается сразу после заголовочного слова в квадратных скобках в виде сочетания букв, обозначающих соответствующие звуки. Такая информация сопровождает, как правило, заимствования, в том числе недавние, например: БАРОНЕ́Т [нэ], БА́РРЕЛЬ [рэ], БЕБИСИ́ТТЕР [бэ, ээ], БЕЗЕ́ [зэ], БЕСТСЕ́ЛЛЕР [ $c \ni$ ], ГАРДЕМАРИ́Н [əЭ], ГЕ́НЕЗИС [нэ], ГОРМОेНОТЕРАПИЯ [mэ и $m e]$, ГОРТЕ́НЗИЯ [mэ].

Отдельную группу заголовков с такими пометами образуют слова, написание которых не указывает на то, как надо произносить то или иное сочетание букв в их составе, например: БУЛьО́Н [льё], БОГ [бох], ГОРЧИ́ЧнИк $[u н]$.

\section{3. Грамматическая норма.}

При описании грамматической нормы большое внимание в словаре уделяется отражению вариантности языковых средств, что для говорящих (пишущих) особенно важно, поскольку наличие в языке вариантов обусловливает проблему выбора. Рассмотрим некоторые случаи словарного представления грамматической вариантности.

Например, в МАСе начало статьи слова грунт выглядит так:

ГРУНТ, -а, м. 1. Земля, почва;

В АТоСе соответствующий отрезок статьи имеет вид:

ГРУНТ, -а (-у), предл. в (на) гру́нте и (разг.) в (на) грунту́, мн. -ы, -ов и (проф.) -ы, -ов, м. 1. Земля, почва.

Таким образом, в новом словаре получила отражение вариантность двух грамматических форм: Род. пад. ед. ч. - грунта́/грунти́, Предл. пад. ед. ч. - в грунте́/ в грунти́; кроме того, показаны акцентологические варианты - пары гру́нmы/грунmb́́ и гру́нтов/грунто́в, вторые члены которых свойственны речи представителей определенных профессий.

Говоря о грамматической норме, следует упомянуть также используемую в словаре помету одуш., обозначающую одушевленность как признак существительного, например:

БАРАБА́НЩИК, -а, м., одуш. ... В толпе гремели погремушки, нежничали флейты, а большой барабан был украшен красными иветами и скрывал маленького барабанщика. В. Рецептер. Ностальгия по Японии.

В некоторых случаях необходимо использование пометы «одуш. и неодуш.», например:

БАНКРО́т, -а, м. 1. Одуш. и неодуш. Несостоятельный должник; тот, кто потерпел банкротство, разорился. Закрыть предприятие-банкрот. $\square$ Все деньги были уплачены вперед, и пропади этот эщелон где-нибудь по дороге - - и Максим банкрот! Э. Володарский. Дневник самоубийцы.

\section{4. Стилистическая норма.}

Важной задачей для авторов словаря является фиксация стилистических свойств описываемых единиц. В связи с развитием науки, общества, языка возникает 
необходимость пополнения традиционного для толковой лексикографии арсенала словарных помет. В разрабатываемом словаре появились новые (по отношению к академическим толковым словарям советского времени) пометы, отражающие сферу употребления, стилистическую окраску, функциональные особенности слова, например: инф. - термин информатики, жарг. - жаргонное слово, проф. профессиональное слово, эвфем. — эвфемизм (см., например, статьи «Байт», «Без-

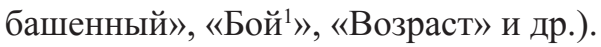

Достойны упоминания случаи использования двух стилистических помет, например, когда слово (значение) не используется в современном литературном языке, но при этом продолжает функционировать в диалектах, просторечии или разговорной речи, в связи с чем попадает на страницы произведений художественной литературы, например:

БЫЛЬЁ, -я́, сp. Устар. и обл. Трава (обычно увядшая), стебли травы. На вершине ее [покатости] покачивалось несколько стебельков полевого былья. Н. Гоголь. Тарас Бульба. ... Иногда им попадался лисий след, который ровной и в то же время извилистой строчкой тянулся от былья к былью, от кочки к кочке. Ю. Казаков. Двое в декабре.

Следует отметить, что ряд помет в списке сокращений АТоСа имеет не только расшифровку, но и краткий комментарий, позволяющий отличить данную помету от другой, сходной по содержанию. Так, помета прост. (ср. разг.) имеет следующий комментарий: «...приписывается словам, которые на воображаемой шкале стилистических различий занимают место ниже разговорных и употребляются в эмоционально раскованной повседневной речи, например: алкаш (ср. разговорное пьяниц̧а), вобла 'худая и некрасивая женщина' (ср. разговорное худылика), ... ржать 'громко хохотать'» [АТоС 1:34].

\section{5. Лексико-семантическая норма.}

Значительных усилий от автора толкового словаря требует работа над важнейшей частью словарной статьи - толкованием слова. Она включает в себя корректировку имеющихся в словарях толкований, выявление и семантическое описание неучтенных значений слов, истолкование новых, недавно вошедших в язык слов и значений.

Так, например, у слова армеец впервые в академической толковой лексикографии зафиксировано широко употребительное разговорное значение 'спортсмен член спортивного клуба российской армии’ (В последнем матче «Спартак» с круnным счетом обыграл армейцев). У слова богоискательство помимо выделенного в предшествующих словарях значения 'религиозно-философское течение...' было зафиксировано значение 'о поиске человеком Бога (в 1 знач.), пути к вере, к религии’: “Что же всё-таки толкнуло эту девочку к Богу?..» Сходила в ичерковь, познакомилась со священником, поиграла в богоискательство и... испугалась возмездия. Л. Овалов. Помни обо мне.

\section{6. Фразеологическая норма.}

Фразеологическая норма - явление комплексное, поскольку касается разных сторон устойчивых сочетаний. Осуществляемая в АТоСе кодификация фразеологической нормы включает в себя следующий круг задач: уточнение имеющихся 
в словарях толкований; лексикографирование новых устойчивых выражений, а также недавно возникших в языке значений; показ вариативности и факультативности компонентов устойчивых выражений, а также фразеологической синонимии; отражение особенностей порядка слов и других грамматических характеристик; демонстрация специфических черт произношения и ударения; уточнение стилистических свойств (включая появление устарелой окраски); реализация принципа последовательного иллюстрирования основных характеристик устойчивой единицы.

Подробное раскрытие перечисленных вопросов в настоящей работе едва ли возможно. Приведем лишь один пример кодификации фразеологической нормы в AToCe:

белый и пушистый кто (неодобр., ирон.) - сравнительно недавно появившийся в языке фразеологизм помимо двух помет, обозначающих его эмоциональную окраску (неодобр., ирон.), имеет при себе синтаксическую помету кто, указывающую на предикативную функцию фразеологизма в предложении.

2.7. В целях иллюстрирования в АТоСе используются разнообразные речения, а также цитаты из художественных произведений, публицистических, научных, научно-популярных, официально-деловых, религиозно-философских текстов различных жанров. Иллюстрации играют значимую роль в демонстрации сочетаемостных норм употребления описываемого слова.

Необходимо подчеркнуть важную особенность нового словаря: в нем «даются примеры, иллюстрирующие по возможности все компоненты смысла, предусмотренные толкованием (например, если слова типа вальс, танго и т.п. толкуются как ‘... танец, а также музыка к этому танцу', то в зоне иллюстраций по крайней мере один пример должен иллюстрировать компонент 'танец', а другой — компонент 'музыка': танщевать вальс и сыграть вальс), а также разные грамматические формы и грамматические характеристики, указанные в соответствующих зонах словарной статьи» [АТоС 1: 24]. Так, например, существительное батик, содержащее в толковании две части: 'возникшая в Индонезии, Индии техника росписи по ткани; многоцветная ткань, выполненная в такой технике', сопровождается примерами, которые иллюстрируют каждую из частей. Это цитата из произведения Л. Улицкой «Медея и ее дети»: Косыночка была собственноручная, одна из тех, на которых она осваивала батик ещзе в училище... - и речение: Изделия из батика.

3. Материалы этой статьи и приведенные в ней примеры, как мы полагаем, показывают, что лексикографическое представление языковых норм в «Академическом толковом словаре русского языка», с одной стороны, опирается на отечественную лексикографическую традицию, а с другой - направлено на ее развитие и обогащение новым содержанием.

\section{Литература}

АТоС 1, АТоС 2 - Академический толковый словарь русского языка. Том 1: А - Вилять; Том 2: Вина - Гяур / Отв. ред. Л. П. Крысин. М. : Издательский Дом ЯСК, 2016. 
Каленчук М.Л., Касаткин Л. Л., Касаткина Р. Ф. Большой орфоэпический словарь русского языка. Литературное произношение и ударение начала XXI века: норма и ее варианты. М. : АСТ-ПРЕСС КНИГА, 2016. 1008 с.

МАС - Словарь русского языка: В 4 т. / Под ред. А. П. Евгеньевой. 4-е изд., стер. М. : Рус. яз., Полиграфресурсы, 1999.

ОэС - Орфоэпический словарь русского языка: произношение, ударение, грамматические формы: свыше 70000 слов / Под ред. Н.А. Еськовой. 10-е изд., испр. и доп. М. : АСТ, 2015. 1008 с.

Alexey E. Tsumarev, Larisa L. Shestakova

V. V. Vinogradov Russian Language Institute of the Russian Academy of Sciences (Russia, Moscow)

zumarew@yandex.ru,lara.shestakova@mail.ru

\section{LANGUAGE NORMS IN THE "ACADEMIC EXPLANATORY DICTIONARY OF THE RUSSIAN LANGUAGE”}

The article describes the "Academic explanatory dictionary of the Russian language" as a normative (prescriptive) dictionary. It is noted that the normativity of the new dictionary is manifested in two ways: 1) in rejection of including of most nonstandard language units in it, 2) in normative evaluation (by means of normative lables) of a number of non-standard units included in. The connection of the norms codified in the dictionary with the language system and modern usage is revealed. Then the ways (including new of them) of reflection of the types of language norms (spelling, orthoepic, grammatical, stylistic, lexico-semantic, phraseological) in different zones of the dictionary entry are considered. Thus, in the analysis of the spelling norm, attention is focused on the label "с прописной буквы" (i.e. "with capital letter"), consistently used in the dictionary in connection with the problem of choosing a capital/small letter. When characterizing the grammatical norm, cases of the lexicographic presentation of grammatical variance, as well as animacy of nouns (by means of lable "oдyu.", i.e. "animate") are analyzed. It is emphasized that the fixation of the lexical-semantic and phraseological norms (that are most important for the explanatory dictionary) provides for the correction of available definitions, the identification and semantic description of words and phraseological units that have recently entered into the language. It is shown that the lexicographic presentation of language norms in the "Academic explanatory dictionary of the Russian language" on the one hand is based on the domestic lexicographic tradition, and on the other hand is aimed at its development and enrichment with new content.

Key words: modern Russian standard language, language norm, language system, usage, codification, lexicography, explanatory dictionary, word list, dictionary entry. 


\section{References}

Akademicheskij tolkovyj slovar' russkogo jazyka [Academic dictionary of the Russian language]. Vol. 1: A - Vilyat'; Vol. 2: Vina - Gyaur. Ed. L. P. Krysin. Moscow, YaSK Publ., 2016 [AToS].

Kalenchuk M.L., Kasatkin L.L., Kasatkina R.F. Bol'shoj orfojepicheskij slovar' russkogo jazyka [The great orthoepic dictionary of the Russian language. Standard pronunciation and stress of the early $21^{\text {th }}$ century: The norm and its variants]. M. : ASTPRESS KNIGA Publ., 2012, 1008 p.

Orfojepicheskij slovar' russkogo jazyka: proiznoshenie, udarenie, grammaticheskie formy: svyshe 70000 slov [Orthoepic dictionary of the Russian language: pronunciation, stress, grammatical forms: above 70000 words]. Ed. N.A. Es'kova. 10 $0^{\text {th }}$ edition. Moscow: AST Publ., 2015, 1008 p.

Slovar' russkogo jazyka [The dictionary of the Russian language in 4 vol.]. Ed. A.P. Evgen'eva. $4^{\text {th }}$ edition. Moscow: Russian language Publ., "Poligrafresursy" Publ., 1999. 


\section{В.Д. Черняк}

Российский государственный педагогический университет им. А. И. Гериена

(Россия, Санкт-Петербург)

vdcher@yandex.ru

\section{«ВЕЧНЫЕ ВОПРОСЫ» КУЛЬТУРЫ РЕЧИ В ЛЕКСИКОГРАФИЧЕСКОЙ ТРАДИЦИИ И СОВРЕМЕННОЙ СЛОВАРНОЙ ИНТЕРПРЕТАЦИИ}

В статье рассматривается традиция составления ортологических словарей русского языка. Показано, что сопоставление ортологических словарей, созданных в разное время, дает материал для определённых выводов о динамике языковой нормы, о статусе вариантов, их предпочтительности в тот или иной период развития языка. Ортологические словари в широком смысле - это словари строго нормативные, фиксирующие норму с большим или меньшим признанием вариантности (орфографические, орфоэпические, акцентологические), ортологические словари в узком смысле - это словари трудностей (словари неправильностей или словари ошибок). В статье подробно рассматриваются материалы одного из первых русских ортологических словарей — «Опыта словаря неправильностей в русской разговорной речи» В.Р. Долопчева (1886 г.). Словарь Долопчева является комплексным, в нем фиксируются акцентологические, орфоэпические, лексические ошибки. Анализ материалов словаря показывает, что, с одной стороны, его рекомендации (при наивности их лексикографического представления) совпадают с рекомендациями современных речеведческих словарей и пособий, демонстрируя «вечные вопросы» речевой культуры, с другой стороны, на разных уровнях языка наблюдаются изменения нормы, что ведет к кардинальному пересмотру словарных указаний.

Анализ ортологических словарей XIX - XXI вв. убеждает, что жизнь любого ортологического словаря как актуального речеведческого руководства ограничена сравнительно небольшим временным промежутком, в то же время болевые точки речевой культуры остаются таковыми на протяжении десятилетий, несмотря на самые квалифицированные рекомендации словарей.

Ключевые слова: ортологические словари, речевая культура, динамика нормы.

Мощные и разнонаправленные динамические процессы в современной речи, их разноречивые оценки как в научных, так и в общественных дискуссиях, вызвали 
к жизни большое количество разнообразных (и различных по авторитетности) ортологических словарей.

Ортологические словари (орфографические, орфоэпические, акцентологические, специальные словари трудностей) - своеобразные «словари скорой помощи» - занимают особое место в системе словарей русского языка. Являясь подручными справочниками, они дают оперативные ответы на возникающие у пользователя вопросы. Многие словари трудностей носят комплексный характер, отражая разные стороны бытования слов.

Сопоставление ортологических словарей, созданных в разное время, позволяет делать определённые выводы о динамике языковой нормы, о статусе вариантов, их предпочтительности в тот или иной период развития языка.

В книге «Лексикография русского языка: век нынешний и век минувший» из 3200 описанных словарей 420 можно отнести к ортологическим: 116 - орфографических, 41 - орфоэпический, 38 - словарей трудностей, 15 - комплексных, 118 - учебных орфографических, 43 учебных орфоэпических, 23 - учебных словаря трудностей, 28 учебных комплексных [Козырев, Черняк 2014]. В названиях ортологических словарей всё чаще появляются слова «большой», «новый», «универсальный», «самый полный», призванные привлечь внимание потенциальных пользователей. Основная масса ортологических словарей - словари «послеушаковского» этапа отечественной лексикографии.

Между тем ортологическая лексикография зародилась в XIX веке. Первым словарём этого жанра можно считать «Справочное место русского слова» А.Н. Греча (1839). К наиболее известным словарям трудностей («неправильностей») XIX начала ХХ вв. относятся словарь К.П. Зеленецкого «О русском языке в Новороссийском крае» (1855), «Опыт словаря неправильностей в русской разговорной речи» В.Р. Долопчева (1886, 2-е изд. 1909), «Словарь неправильных, трудных и сомнительных слов, синонимов и выражений в русской разговорной речи...» И.И. Огиенко (1911), выдержавший четыре издания, «Словарь “Правильное ударение"» М. Агаяна (1911) и некоторые другие.

В конце XIX и особенно в первой трети XX в. издаётся большое количество словарей-справочников («словарей-толкователей»), совмещающих функции словаря лексических трудностей и словаря новых слов и значений, например: «Всероссийский “словарь-толкователь”» под редакцией В. А. Жукова, вышедший в 36-ти выпусках (1893-1895), «Карманная энциклопедия и словотолкователь» Д.Н. Сеславина (1902), «Словотолкователь непонятных слов, встречающихся при чтении книг и газет» А. Белины (1906), «Краткий народный словарь: пособие при чтении газет и популярных политико-экономических брошюр» Н. Смирнова (1906), «Словарь политических, социально-экономических и некоторых других слов: пособие для чтения газет, журналов и книг по общественным вопросам» Ф.А. Данилова (1906), «Народный толковый словарь (пособие при чтении газет и журналов» Кия (1919), «Наш словарь: краткое объяснение мудрёных слов, встречающихся в газетах» В. Волгина (1923), «Словарь политических и иностранных слов» (1925), «Словарь для читателей газет» (1930) и многие другие. 
Для ортологических словарей, как впрочем и для словарей других типов, чрезвычайно значимой оказывается ориентация на потенциального адресата, что нередко фиксируется в названиях словарей или в подзаголовках: «для учащихся», «для самообразования», «для всех сословий», «народный словарь» и т.п. Лексикографические параметры, фиксируемые в доушаковских ортологических словарях, немногочисленны: это прежде всего правописание, ударение и «разделение каждого слова на части для правильного переноса их из одной строки в другую» (этот параметр, в отличие от современных словарей, представлен во многих изданиях). Эпизодически даются стилистические комментарии. Орфоэпические нормы и трудности в большинстве ортологических словарей не отмечались, сам жанр орфоэпического словаря сложился лишь во второй половине ХХ в.

Примечательно, что во многих дореволюционных ортологических словарях присутствуют ссылки (в развернутом названии или в предисловии) на руководства академика Я.К. Грота.

Если ортологические словари в широком смысле - это словари строго нормативные, фиксирующие норму с большим или меньшим признанием вариантности, то ортологические словари в узком смысле - это словари трудностей (иногда обозначаемые как словари неправильностей или словари ошибок). Эти лексикографические издания обозначают «зоны риска» на разных уровнях языка и служат инструментом для устранения коммуникативных неудач. Современные словари трудностей чаще всего фиксируют внимание на сложных вопросах акцентологии, орфоэпии, вариантности морфологических форм.

Сопоставление ортологических словарей разных эпох позволяет не только проследить динамику нормы, точки ее расшатывания, даже те, которые до определенного момента казались незыблемыми, но и выделить своего рода «вечные вопросы» речевой культуры. В этом отношении несомненный интерес представляет «Опыт словаря неправильностей в русской разговорной речи» В. Р. Долопчева [Долопчев 1886], первый комплексный ортологический словарь. Ориентированный прежде всего на описание речи на Юге России, он явился и описанием регионализмов. Второе издание вышло в Варшаве в 1909 г. под грифом Ученого комитета Министерства народного просвещения, что говорит об общественном признании этого издания. Автор пишет в предисловии: «В устной речи нет обдуманности и правильности, господствует произвол, не руководимый чутьем языка и вкусом, а слух неприятно поражается дурным произношением, произвольною и неправильною постановкою произношения» [Долопчев 1886: II].

Автор постоянно подчеркивает свою ориентацию на труды Я.К. Грота, а во втором издании отмечает, что его словарь выдержал строгую критику покойного академика: «Я.К. Грот не пропустил ни одного слова без своей отметки». Однако нельзя не заметить предельной упрощенности лексикографических приемов, наивности некоторых рекомендаций и комментариев.

Остановимся на некоторых выразительных материалах словаря. В центре внимания автора оказываются акцентологические ошибки. Выделяются как уже одиозные для XXI века ошибки (алфавит, документ), так и по-прежнему актуальные 
для современной ортологической лексикографии (вероисповедание, кедровый), в том числе и те, которые во многих современных словарях рассматриваются как допустимые варианты (мышление, обеспечение). Как и через 130 лет, фиксируется ошибочное афёра.

Интересна фиксация акцентологической ошибки жалузи с указанием «правильного» жалузи. Здесь обращает на себя внимание и то, что в современной речи типичной оказывается иная ошибка в ударении, и устарелое орфографическое /орфоэпическое оформление.

Т.В. Шмелева, оценивая многочисленные ошибки / варианты (типа звонит, обеспечение), подчеркивает, что «расхождение словарей и реальной речевой практики отмечается именно в таких случаях, когда зафиксированная в словаре норма приходит в противоречие с действием аналогии» [Шмелева 2006: 633]. В этой связи примечательны рекомендации Долопчева: как нормативные отмечаются абсолютно устаревшие сегодня формы дружишь, куришь (ошибки: дружишь, куришь), и с тем же нормативным ударением на окончании неизменная для всех современных рекомендаций по культуре речи форма звонишь (как известно, лингвистические прогнозы предсказывают изменение акцентологической нормы и в глаголе звонить, как и в указанных выше, но пока для ортологии она остается незыблемой).

Нельзя не отметить и случаи безусловного изменения нормы: как ошибочные представлены формы заслуженный, лавировать, по-английски, пастор, паспорт, этнограф и др. (рекомендуются ударения: заслужённый, лавировать, по-английски, nастор, nаспорт, этнограф). Противоречивы акцентологические рекомендации по употреблению имен собственных. Ср.: Байрон - Байрон, но Моцуарт - Моцарт (первой у Долопчева всегда указывается «неправильность»). Явно устарели акцентологические рекомендации для ряда устойчивых сочетаний, например: под Богом ходить - под Богом ходить, видом не видать, слыхом не сльхать - видом не видать, сльххм не сльхать.

Как уже отмечалось, проблемы орфоэпии не были объектом специального описания в словарях конца XIX - начала XX века, однако в словаре Долопчева отмечается ряд сохраняющихся и по сей день орфоэпических ошибок (например, иничиндент, константировать, сохраняющаяся и сегодня конкуренция твердого / мягкого произношения согласных: коррэспондэнт, фонэтика). Отмечу, что как нормативное утверждается произношение грешневый, до сих пор сохраняющееся у носителей старой московской произносительной нормы, и даже пашпорm (со ссылкой на авторитеты «по Далю и Гроту», указывающей на ощущаемую лексикографом архаичность такой нормы).

Многие отмеченные словарем ошибки в использовании морфологических форм характерны и для современного городского просторечия: играться вместо играть, выброси, выбросите вместо выбрось, выбросьте и т.п.

Являясь комплексным ортологическим словарем, словарь Долопчева уделяет внимание и лексическим нормам, в частности паронимам. Так, неизменным для ортологической лексикографии на протяжении десятилетий остается указание 
на ошибочность употребления глагола одевать вместо надевать. В то же время ряд рекомендаций явно устарел. Так, как ошибочные указываются словосочетания апельсиновое мороженое, апельсиновое варенье, вкус, сок вместо апельсинное. Некоторые замечания Долопчева вызывают улыбку: бородастый (обросший большою бородою) - бородатый (имеющий бороду), однако вспомним, что до появления первых словарей паронимов остается более 70 лет.

Характерный для конца XIX — начала XX века пуризм в использовании иноязычных слов проявился в целом ряде предлагаемых Долопчевым замен (недостаток вместо дефект, гостиница вместо отель, переселенец вместо эмигрант, подарок вместо презент, гостиничный вместо отельный). Очевидная неадекватность ряда предлагаемых рекомендаций для современной речи подтверждает общее положение, касающееся и многих новейших культурноречевых рекомендаций: при конкуренции своего слова и заимствования или укоренившегося и нового заимствований обязательно актуализируются те или иные различительные признаки.

Именно в области лексических норм обнаруживается наивность, а иногда и курьезность рекомендаций Долопчева. Ср.: вместо блузка рекомендуется кофточка, вместо костюм - платье, одежда, вместо картошка - картофель, вместо хата, хатка - изба, избушка.

Чтение «Опыта словаря неправильностей в русской разговорной речи» занимательно и поучительно. С одной стороны, очевиден «век недолгий» любого ортологического словаря как актуального речеведческого руководства, с другой - его неустаревающая ценность для наблюдения за динамикой норм и для осознания того, что болевые точки речевой культуры остаются таковыми на протяжении десятилетий, несмотря на самые квалифицированные рекомендации словарей.

Как уже отмечалось, в советское время собственно ортологических словарей (словарей трудностей, за исключением орфографических) до 60-х гг. практически не было. Первым словарем этого типа можно считать вышедший 55 лет назад и предвосхитившему многие современные ортологические словари опыт словаря-справочника «Правильность русской речи : Трудные случаи современного словоупотребления» [Правильность русской речи 1962]. Это издание демонстрирует неизменность круга вопросов, связанных с нормами словоупотребления (ср. актуальные и сегодня рекомендации по употреблению слов и выражений кушать, волнительно, последний - крайний, представить - предоставить, зачитать, один за одним, роспись, на сегодняшний день, иметь место (по поводу последних словосочетаний составители отмечают: «подобные выражения оказёнивают речь»).

Словарь не только демонстрирует нормы словоупотребления в их динамике, но и воссоздает речевой климат эпохи. Отмечу лишь несколько показательных комментариев: коллега - «товарищ по учению или работе». Слово это книжное и во многом устаревшее, употребляемое теперь обычно в устной речи только в среде преподавателей, врачей, ученых, а иногда и студентов по старой традиции»; реализовать - «в значении «продать» этот глагол является специальным и употребляется в товароведении, в финансовой, экономической и т.п. литературе, например: реализовать полученную продукцию. Употребление его в общелитературном 
языке вместо слова продать не рекомендуется; дефицит - «во 2-м значении слово дефицит в разговорной, обиходной речи часто употребляется без надобности вместо соответствующих русских слов недостаток, нехватка, редкость и т.п. Например: «Эта книга теперь - дефицит» [т.е. редкость] (запись живой речи)».

Многочисленные ортологические словари, созданные в последние два-три десятилетия, давая культурноречевые рекомендации с использованием помет «допустимо», «не рекомендуется», «неправильно», «в просторечии», «устарелое», «устаревающее» и т.п., нередко существенно различаются по степени демократизма и толерантности. Наблюдаемая противоречивость характеристик даже в разных изданиях одного и того же словаря может поставить пользователя в тупик. Известно, что рядовые носители языка, снисходительно относясь к ошибкам в собственной речи, не готовы принять допустимость вариантных форм в нормативных рекомендациях словарей и учебников (именно такой подход культивируют и установки составителей заданий ЕГЭ). Особенно актуальны вопросы, связанные с использованием новых, прежде всего заимствованных, лексических единиц (ср., например, расхождения в лексикографическом представлении слов хай-те' к и хайте'к, китч и кич, масс-ме'диа и массме'диа, ма'ркетинг и марке'тинг, фаст-фуд и фастфуд, таун-хауз и таунхауз, секве 'стор и секве'стр, риэ'лтер и риэ'лтор, па'бликриле'йшнз, па'блик рил'ейшнз и па'блик риле'йшенз, лапто'n и лэпто'n, риме'йк и реме 'йк, пле 'йер и пле 'ер. Говоря о принципиальной возможности освоения нормой новых языковых феноменов, Л.П. Крысин справедливо отмечает, что есть основания для введения некоей «шкалы толерантности», на одном полюсе которой располагаются оценки «консерваторов», а на другом — тех, кто легко допускает в собственную речь новшества [Крысин 2003: 64]. При этом восприятие таких оценок не всегда происходит безболезненно, поскольку в действие вступают факторы речевого вкуса и речевой моды.

Один из авторитетных составителей новейших орфоэпических словарей М.Л. Каленчук в своих публикациях и интервью неоднократно отмечала что 25 лет - это время смены языкового стандарта. Лексикографы в своих рекомендациях должны учитывать этот фактор, расширяя влияние узуса. С этим положением нельзя не согласиться. В то же время, как показывают словари разных эпох, и в речевой практике, и в лексикографических интерпретациях остается ряд «вечных вопросов» культуры речи, по отношению к которым распознается уровень речевой компетенции носителя языка.

\section{Литература}

Долопчев В. [P.] Опыт словаря неправильностей в русской разговорной речи: (преимущественно в Южной России). Одесса : Одес. вести, 1886.180 с.

Козырев В.А., Черняк В.Д. Лексикография русского языка: век нынешний и век минувший. СПб.: Изд. РГПУ им. А. И. Герцена, 2014. 571 с.

Крысин Л. П. Языковая норма: жёсткость vs. толерантность // Массовая культура на рубеже XX-XXI веков: Человек и его дискурс. М.: Азбуковник, 2003. С. 58-66. 
Правильность русской речи: Трудные случаи современного словоупотребления. Опыт словаря-справочника / сост. Л.П. Крысин, Л.И. Скворцов, под ред. С.И. Ожегова. М. : Изд. АН СССР, 1962. 84 с.

Шмелева Т. В. Дело о картузе // Русский язык сегодня. Вып. 4. Проблемы языковой нормы. М.: Азбуковник, 2006. С. 625 - 643.

\author{
Valentina D. Chernyak \\ Herzen State Pedagogical University \\ (Russia, Saint Petersburg) \\ vdcher@yandex.ru
}

\title{
THE ETERNAL QUESTIONS OF SPEECH STANDARDS IN LEXICOGRAPHIC TRADITION AND CONTEMPORARY DICTIONARY REPRESENTATION
}

The article discusses the Russian tradition of orthological lexicography. The comparison of orthological dictionaries of different time periods allows for making certain conclusions about the dynamics of speech standards and the status of variants at different stages of language development. In the broad sense, orthological dictionaries are standard-oriented but allow for different flexibility depending on the type (orthographic, orthoepic, accentological). When narrowly defined, orthological dictionaries contain difficult cases based on common mistakes and irregularities.

This article analyzes the materials of one of the first orthological dictionaries of the Russian language, "An Attempt of the Dictionary of Mistakes in Colloquial Russian" by V.R. Dolopchev (1886). Dolopchev's dictionary is integrative and covers mistakes of pronunciation, word stress, and word choice. The analysis of the dictionary shows that its guidelines, despite the naivety of their lexicographic representation, are similar to contemporary textbook and dictionary guidelines, which points to the eternal nature of speech standards issues. On the other hand, on different linguistic levels, the shift of the standard can be traced, which eventually leads to drastic changes of dictionary information.

The research on orthological dictionaries of XX-XXI centuries proves that the lifetime of any orthological dictionary in the entirety of its guidelines is short, but the hot issues of speech standards stay the same across decades, despite high-quality dictionary recommendations.

Key words: orthological dictionaries, speech standards, the dynamics of speech standards.

\section{References}

Dolopchev V.[R.] Opyt slovarya nepravil'nostej v russkoj razgovornoj rechi: (preimushhestvenno v Yuzhnoj Rossii). [An Attempt of the Dictionary of Errors in Russian Speech (Primarily in Southern Regions)] Odessa : Odes. vesti, 1886.180 p. (In Russ.) 
Kozyrev V. A., Chernyak V.D. Leksikografiya russkogo yazyka: vek nyneshnij i vek minuvshij. [Russian Lexicography: Past and Present]. St. Petersburg: Izd. RGPU im. A. I. Gertsena, 2014. 571 p. (In Russ.)

Krysin L.P. Yazykovaya norma: zhyostkost' vs tolerantnost' [Speech Standard: Rigidity vs. Tolerance] // Massovaya kul'tura na rubezhe XX-XXI vekov: Chelovek i ego diskurs. [Mass Culture on the Edge of the Centuries (XX-XXI): People and Discourse]. Moscow, Azbukovnik, 2003. pp. 58-66. (In Russ.)

Pravil'nost' russkoj rechi: Trudnye sluchai sovremennogo slovoupotrebleniya. Opyt slovarya-spravochnika [The Correctness of Russian Speech: The Difficult Cases of Contemporary Speech Choices. An Attempt of a Reference Guide]. M. : Izd. AN SSSR, 1962. 84 p. (In Russ.)

Shmeleva T. V. [The case of kartus] Delo o kartuze // Russkij yazyk segodnya. Vyp. 4. Problemy yazykovoj normy. [The Russian language today. Vol. 4. The problems of the language norms]. Moscow, 2006. pp. 625 - 643. (In Russ.) 


\section{С.Д. Шелов}

Институт русского языка им. В. В. Виноградова РАН

(Россия, Москва)

volehs@mail.ru

\section{ОСНОВНЫЕ ПРОБЛЕМЫ ТЕРМИНОВЕДЕНИЯ: НЕКОТОРЫЕ ИТОГИ}

Настоящие материалы обобщают исследования автора по терминоведению за многолетний период научной работы в этой области. Объектом исследования послужила русская терминология $1985-2005$ гг., как она представлена в текстах различных работ и толковых терминологических словарях. Анализ проводился на материале терминологии самых различных областей знаний, дисциплин и сфер деятельности - от техники до философии, от математики до религии, от естественных наук до гуманитарных.

Ключевые слова: терминология, терминоведение, вариативность термина, мотивированность термина, понятийная структура терминологии, терминологическое поле, номенклатура, профессиональная лексика.

Ниже кратко, почти в реферативной форме, приводятся ответы на следующие, как представляется, основные вопросы науки о терминологии и терминах:

1. Каковы критерии отнесения языковых единиц к терминологии и каковы критерии выделения этих единиц в текстах? Иными словами, что есть термин?

2. Идентифицировав несколько различные по форме или по значению языковые знаки как термины, чаще всего мы сталкиваемся с вопросом: имеем ли мы дело с одним и тем же термином (т.е. с различными разновидностями одного термина) или с разными терминами, иными словами, с вопросом о том, каковы варианты термина и где пределы вариативности термина?

3. Другая проблема касается оценки мотивированности термина как языкового знака. Она является частным, но важным случаем одной из самых древних и острых проблем общего языкознания о мотивированности или немотивированности языкового знака. На исследуемом материале она осложняется еще и вопросом о наличии или отсутствии сугубо специфических типов мотивации терминов на фоне мотивации общеязыковых единиц.

4. Еще один вопрос огромной теоретической и практической важности - вопрос о понятийной структуре терминологии. В самом деле, какова понятийная 
организация научной терминологии и каково ее соотношение с так называемыми «терминологическими полями»? Возможно ли объединение терминологический полей в понятийную структуру терминологии в целом? В связи с тем, что особо важную роль в понятийной организации терминологии играют, по мнению значительного числа исследователей, родо-видовые (гиперо-гипонимические) и цело-частные (тотативно-партитивные) отношения, возникает также следующий вопрос: какова в соответствии с принятыми исходными положениями родовидовая структура и цело-частная структура терминологии и в какой мере эти структуры охватывают понятийную структуру терминологии в целом?

5. Вместе с тем положение о природе термина и достижение ясности в том, что такое термин, теснейшим образом связаны с еще одной группой вопросов: имеются ли другие и какие именно отличные от терминологии типы специальной лексики и каково их соотношение с терминологией с точки зрения сущностных характеристик как терминов, так и этих нетерминологических лексических единиц? Известно, что при ответе на этот вопрос часто упоминаются и противопоставляются терминам номены (участвующие в образовании обширных классов номенклатуры). Однако ясности в соотношении этих единиц с терминологией до настоящего времени не существует, в связи с чем решение вопроса о соотношении терминологии и номенклатуры, безусловно, представляет и общелингвистический, и прикладной интерес.

Другой класс языковых единиц, традиционно обсуждаемый в связи с терминологией, но с терминологией как будто бы не совпадающий - это профессиональная лексика. И здесь точки зрения весьма различны, причем соотношение терминологии и профессиональной лексики остается весьма далеким от ясности. В этой связи уточнение места терминологии среди других классов специальной лексики - и, в первую очередь, ее соотношение с профессиональной лексикой остается весьма актуальным. Это уточнение представляется целесообразным провести, по крайней мере, первоначально на материале функционирования термина в своей «родной стихии» - в научных исследованиях, в научно-технической документации, в профессиональных публикациях, в терминологических словарях, энциклопедиях, справочниках и т.п., и лишь затем, с учетом полученных результатов, расширить исследование до изучения использования терминов в иных сфеpax — в средствах массовой информации, в художественной литературе, в публицистике и др.

Выбранная форма изложения сводится только к формулировке итоговых результатов и не позволяет прибегать к многочисленным иллюстрациям-примерам, обоснованию или тем более полемике с другими точками зрения. Автор все же надеется, что актуальность предложенных решений заключается, во-первых, в их комплексном решении, во-вторых, в конструктивном характере этих решений, которые допускают их верификацию (что связано с интересами автора к компьютерным приложениям терминологической проблематики), и, в-третьих, в применимости предложенных решений к самому разнообразному как в языковом, так и в научно-тематическом отношении материалу специальной лексики. 
1. Были проанализированы многочисленные определения понятия ‘термин' как в отечественных, так и в зарубежных работах, с учетом устойчиво повторяющихся критериев отнесения языковых знаков к термину: профессиональность и специальность называемого термином понятия, правомерность и неправомерность отнесение термина к лексике литературного языка или к другим формам существования развитых национальных языков, необходимость и достаточность наличия у языкового знака дефиниции (толкования, объяснения) для его идентификации как термина, точность, строгость обозначенного понятия (или его определения) для признания соответствующего языкового обозначения термином.

Нами была предложена следующая дефиниция понятия 'термин':

А. Языковой знак (слово, словосочетание, сочетание слова или словосочетания с особыми символами и т.п.), соответствующий норме его употребления в профессиональном или ином сообществе и выражающий специальное понятие какой-либо области знания и в силу этого имеющий дефиницию (толкование, объяснение), является термином.

Б. Языковой знак (слово, словосочетание, сочетание слова или словосочетания с особыми символами и т.П.), соответствующий норме его употребления в профессионльном или ином сообществе является термином, если он выражает специальное понятие какой-либо области знания и мотивируется языковыми знаками (словами, словосочетаниями, сочетанием слова или словосочетания с особыми символами и т.п.), хотя бы один из которых признается термином в силу п. $\mathbf{A}^{1}$.

Такое определение, с нашей точки зрения, более соответствует сути термина, чем те традиционные его формулировки, которые ориентированы на непременную связь термина с его дефиницией. Во-первых, оно напрямую связывает “специальность”, “специфичность” понятия, называемого термином, с необходимостью его объяснять именно в силу этой “специальности” и “специфичности” (что часто остается незамеченным). Во-вторых, оно включает в процесс объяснения понятийного содержания термина не только определение, но и постоянно происходящие процедуры понятийной мотивации термина. В-третьих, при всей принципиальной роли дефиниции (толкования) или объяснения содержания термина, которая им отводится при таком определении термина, чрезвычайно важно, что это определение охватывает и такие языковые обозначения, которые интуитивно включаются в терминологию, несмотря на отсутствие каких бы то ни было дефиниций или толкования поименованными этими обозначениями понятий. Действительно, невозможно не считать терминами более сложные в лексическом, синтаксическом и семантическом отношении словосочетания, содержащие уже дефинированные терминологические фрагменты в качестве своих компонентов.

${ }^{1}$ Полагая, что любое закрепление понятийного содержания языкового знака может быть сведено к его определению (что, на наш взгляд, является существенным огрублением сути дела), в приведенных формулировках можно всюду вместо слова “объяснение” вставить более частное “определение” (или “дефиниция”). 
Именно эту принципиальную возможность атрибуции как терминов словосочетаний, не имеющих собственных дефиниций, возможность, связанную с важнейшим явлением лексико-синтаксической мотивации термина, и учитывает предложенное понимание понятия термина.

2. Исходя из такого понимания термина и свойства терминологичности, мы подошли к понятию вариативности термина, относительно которого имеются весьма разнообразные и частично противоречащие друг другу точки зрения. Специфические свойства термина настоятельно требуют учета разграничения общеязыкового и специального знания, разграничения индивидуальных особенностей языкового знака как представителя той или иной предметной области или дисциплины (прежде всего, в понятийной семантике) и как представителя единицы общего языка, подчиняющейся регулярным соотношениям и трансформациям общего языка. Предложенное понимание термина позволяет по-новому решать вопросы соотношения синонимии и вариативности терминов, а также смежные задачи соотношения и того, и другого с дублетностью и эквивалентностью терминов. Вариативность терминов может представлять собой факты терминологической синонимии, а синонимия терминов, в свою очередь, может включать и значительное число терминологических вариантов. В то же время регулярность лексико-синтаксических преобразований, выполняемых в общем языке, не затрагивающих специфическую природу термина, позволяет говорить о существовании весьма различных форм одного и того же термина, особенно в случае терминологического словосочетания, когда говорить о тех же единицах как о вариантах одного словосочетания общего языка невозможно. В силу этого в общем плане вариативность терминов и их синонимия далеко не совпадают и не связаны родо-видовыми (гиперо-гипонимическими) отношениями; ни синонимия терминов не является частным случаем их вариативности, ни вариативность не является частным случаем синонимии.

Предлагаются следующие дефиниции терминов синонимия, дублетность, эквивалентность и вариативность терминов, которые позволяют их различать.

Синонимия терминов (терминологическая синонимия) - идентичность значения того, что обозначено этими терминами, объяснимая лексической синонимией в рамках общего языка (и, следовательно, объяснимая, например, синонимией аффиксов, синонимией синтаксических конструкций и т.п.).

Дублетность терминов (терминологическая дублетность) - разновидность синонимии терминов, при которой для обозначения одного и того же специального понятия наряду с исконным термином-словом или терминологическим словосочетанием используются терминологические слова или словосочетания, заимствованные из другого языка.

Эквивалентность терминов (терминологическая эквивалентность) - денотативная идентичность обозначенного этими терминами, не объяснимая фактами общего языка (например, синонимией аффиксов, синонимией синтаксических конструкций, лексической синонимией и т.п.) и устанавливаемая только путем анализа фактов предметной области или традицией номинации в ней. 
Вариативность (вариантность) терминов (терминологическая вариативность (вариантность)) - соотношение ряда терминов, при котором все они имеют общность понятийного содержания, обусловленную соответствующим определением (толкованием или объяснением) одного из них, а все различия в понятийном содержании терминов того же ряда, во-первых, не касаются собственно специального понятийного содержания данной области знания и, во-вторых, могут быть полностью объяснены регулярными преобразованиями (трансформациями) языковой структуры терминов того же ряда, которые имеют место в общем (неспециальном) языке (синонимией аффиксов, синонимией синтаксических конструкций, их наращиванием (добавлением) или редукцией, добавлением служебных слов, изменением синтаксической структуры и т.п.).

Особый интерес вызывает мало изученная вариативность терминов, допускающая соотношение языковых единиц, не тождественных ни по форме, ни по содержанию, но в силу регулярности соответствующих соотношений в общем языке обеспечивающая единство термина как функциональной единицы и прогнозируемость ее вариативной модификации, в качестве которой можно рассматривать и, насколько нам известно, впервые выявленные автором данной работы категориально-синтаксические варианты терминов.

3. В заключение по необходимости краткого исторического обзора точек зрения, с опорой на те же представления, исследуются вопросы мотивированности термина. Несколько положений здесь представляются принципиальными: утверждения о мотивированности как о количественно градуированном свойстве термина, проявляющемся в большей или меньшей степени, и тезис о том, что мотивированность не является непременным атрибутом термина и даже непременно желательным его свойством (только в отношении термина-словосочетания можно говорить о желательной его точности относительно мотивирующих этот термин компонентов).

Вместе с тем терминологическая мотивация может допускать совершенно уникальные характеристики по сравнению с мотивацией общеязыковых единиц: в отдельных терминах-словосочетаниях мотивация может активно использовать специфическую семантику области, что приводит к тому, что термин, будучи абсолютно мотивированным, не является мотивированным только с помощью своих материальных компонентов, но предполагает «мотивировочный вывод» своего содержания также и с помощью других терминов, обозначающая (материальная) часть которых непосредственно в составе мотивированного термина не содержится.

4. При выяснении характера понятийной организации терминологии два момента считаются весьма существенными: разграничение ономасиологического и семасиологического подхода, во-первых, и различие в ориентации семантического изучения терминологии ее функционирования на фоне и в рамках общего языка (в сфере лексиса, по терминологии А. А. Реформатского), и на фоне и в рамках специального языка (подъязыка) данной области знания, дисциплины, тематической области (в сфере логоса, по терминологии А. А. Реформатского), во-вторых. 
При этом для адекватного представления понятийной организации терминологии полезно ввести несколько однотипных, но существенно различных понятий, уточняющих общую идею терминологического поля - поля того или иного термина: 1) семантическое поле термина, 2) понятийное поле термина, 3) понятийнотерминологическое поле термина, 4) лексическое поле термина, 5) терминологическое поле термина и 6. базовое (собственно) терминологическое поле термина.

Все введенные понятия основаны на одной и той же идее - идее семантической или понятийной производности одних единиц (односторонних или двусторонних) от других. В практике словарных определений эта идея воплощается в отношении определимости одних единиц через другие, причем соотношения между всеми уточнениями идеи “поля” достаточно прозрачны: понятийное поле является частью семантического поля так же, как понятийно-терминологическое поле является частью понятийного поля, а базовое терминологическое поле - частью понятийно-терминологического поля. Совершенно аналогично терминологическое поле является структурной частью лексического, а базовое (собственно) терминологическое - частью терминологического.

Введенные понятия таковы, что позволяют объединением всех полей отдельных терминологических единиц получить соответствующую общую терминологическую и базовую терминологическую структуру (картину) науки, научной дисциплины или тематической области. Таким образом, решается задача не членения понятийного пространства (понятийного плана) области, заданного каким-то образом извне, но его построения на пути от понятийного поля отдельного термина до формирования понятийных полей потенциально всех терминов науки, дисциплины области знания, в своей совокупности и задающих понятийную структуру терминологии.

Предлагается считать, что терминологическое поле термина - это множество всех понятийных связей данного термина с другими базовыми терминами (т.е. терминами, имеющими собственную дефиницию (толкование, объяснение)), необходимыми для его понятийной идентификации, или с базовыми терминами, для понятийной идентификации которых необходим данный термин. Термины, необходимые для понятийной идентификации данного, либо явно используются в системе объяснения понятийного содержания данного термина (чаще всего в тексте определяющего выражения соответствующей дефиниции), либо являются мотивирующими его содержание (если термин является мотивированным). Таким образом, состав (базового) терминологического поля отдельного термина полностью обусловлен системой дефиниций (толкований), включающей дефиницию (толкование) данного термина; состав терминологического поля мотивированного термина обусловлен мотивацией терминов и включает все самостоятельные, автономные термины, мотивирующие данный. Свойство определимости термина через другие формирует уровневую понятийную структуру всей терминологии, в которой каждый термин характеризуется своим уровнем (нулевым, первым, вторым, третьим и т.д.), что позволяет наглядно представить и использовать эту понятийную структуру в различных практических приложениях. 
Вместе с тем следует признать, что при наличии у любого термина своего семантического и понятийного поля не у всех терминов, вопреки традиционной точке зрения, имеются собственные понятийно-терминологические поля или тем более базовые поля. Возможна ситуация уточнения понятийного содержания термина посредством дефиниции, при которой уточненный термин понятийно непосредственно не связан ни с одним термином данной области, причем такая ситуация не препятствует выполнению термином своих номинативных функций.

Мы представили попытку описать понятийно-терминологические и базовые поля терминов самых различных наук, дисциплин и областей знания. В частности, на материале популярного учебника по языкознанию Ю. С. Маслова была дана характеристика понятийной структуры терминологии языкознания, охватывающей 2067 терминов (из которых 581 базовый) и, в частности, характеристика ее родовидовой и цело-частной подструктуры.

5. Уточнение природы термина и понятийной организации терминологии остро ставит вопросы о других классах языковых единиц, не являющихся терминами, но «соседствующих» с ними по функциям и сфере использования. Что это за лексические единицы и каково их соотношение с терминологией? Наиболее часто упоминаемые в этой связи языковые единицы - это представители номенклатурных обозначений и профессиональной лексики.

Обращение к противопоставлению терминологии и номенклатуры выявило несколько глубоко различных подходов к пониманию «номенклатуры», некоторые из которых имеют глубокие философские и общенаучные корни. В этой связи в работе пришлось отказаться от весьма запутанных терминологических номинаций в рамках самого терминоведения и говорить о номенклатуре как о совокупности номенклатурных наименований и о номенах как части номенклатурного наименования. Номены при таком подходе, действительно, оказываются противопоставленными терминологии, однако номенклатура как совокупность всех номенклатурных наименований оказывается лишь частью (хотя и особой частью) терминологии. В работе предпринята попытка последовательно провести это решение на материале самых различных наук и областей знаний - от технических до философских и от гуманитарных до точных и естественно-научных; это решение, по-видимому, актуально и для самых различных европейских языков. Предложенное понимание номенклатуры позволяет установить место различных номенклатурных наименований в их общей совокупности и различать топонимическую и антропонимическую номенклатуру (включая и эпонимическую номенклатуру), объектную и метаобъектную номенклатуру, буквенную, цифровую и буквенно-цифровую номенклатуру и т.п. При всем разнообразии понимаемых таким образом номенклатурных наименований их плюсы и минусы по сравнению с другой частью терминологии имеют одинаковую природу: проигрывая аналитическим, частично или полностью мотивированным терминам в прозрачности своей смысловой и логической структуры, в своей мотивированности и аналитичности, они выигрывают в краткости и синтетичности номинации, обозначении сложного сочетания различных признаков понятия или объекта лаконичным способом. 
6. Сложным образом соотносятся друг с другом терминология и профессиональная лексика. С одной стороны, имеются сотни тысяч и даже миллионы наименований, которые справедливо могут быть одновременно отнесены и к терминологии, и к профессиональной лексике. С другой стороны, во-первых, существует терминология, представляющая непрофессиональные занятия, в силу чего обнаруживаются классы единиц, относящихся к терминологии, но не входящих в профессиональную лексику. Во-вторых, в профессиональной лексике имеются единицы, не соответствующие ни литературной, ни профессиональной норме, хотя и обозначающие специальные понятия; к таковым в настоящем исследовании отнесены профессионализмы (профессиональные коллоквиализмы), профессиональные жаргонизмы, единицы профессионального просторечия. Кроме того, в составе профессиональных номинаций существуют особые лексические единицы и выражения, не обозначающие специальных понятий, но принятые к употреблению именно в соответствующей среде профессионалов - профессиональные арготизмы (не жаргонизмы!) или профессиональные характеризмы. Безусловно входя в профессиональный лексикон, такие образования не могут считаться терминами, от которых традиционно и не без основания требуется обозначение специальных понятий и соответствие либо литературной, либо профессиональной норме. Следовательно, ни терминология не является частью профессиональной лексики, ни профессиональная лексика не образует части терминологии, а профессиональная лексика в каких-то своих частях оказывается шире терминологии, достаточно далеко выходя за ее рамки.

\section{Sergey D. Shelov}

V. V. Vinogradov Russian Language Institute of the Russian Academy of Sciences (Russia, Moscow)

Volehs@mail.com

\section{VIVID PROBLEMS OF TERNINOLOGY SCIENCE: SOME RESULTS}

The paper summarizes the author's research on terminology conducted for a long period of scientific work in this area. The object of the research was Russian terminology 1985 - 2005, as represented in the texts of various papers and explanatory terminological dictionaries. Analysis was performed on terminological evidence of various fields of knowledge, disciplines and fields - from engineering to philosophy, from mathematics to religion, from natural Sciences to Humanities.

Key words: terms, terminology science, term variability, term motivation, concept structure of terminology, terminological field, nomenclature, professional vocabulary. 


\author{
А. Д. Шмелев \\ Московский педагогический государственный университет \\ Институт русского языка им. В. В. Виноградова РАН, \\ Православный Свято-Тихоновский гуманитарный университет \\ (Россия, Москва) \\ shmelev.alexei@gmail.com
}

\title{
ВОЗМОЖНА ЛИ КОДИФИКАЦИЯ ЯЗЫКОВЫХ НОРМ В ЭПОХУ СОЦИАЛЬНЫХ И КУЛЬТУРНЫХ ИЗМЕНЕНИЙ?*
}

В статье рассматриваются общие вопросы кодификации языковых норм и их применение к русскому языку начала XXI в. (при этом языковые нормы понимаются широко и включают нормы правописания и речевого этикета). Сама необходимость кодификации языковой нормы возникает в том случае, если в узусе регулярно встречаются или могут встретиться явления, воспринимаемые языковым сообществом как отклонения от нормы. В триаде узус — норма — кодификация непосредственному наблюдению подвержены первый и последний члены триады: реальная речевая практика носителей языка и описание языковой нормы в нормативных словарях и справочниках. При этом кодификация в целом более консервативна, нежели узус. Что касается нормы, она реконструируется на основе наблюдения над узусом и соотнесения данных наблюдений как с данными словарей и справочников, так и с эксплицитными суждениями носителей нормы (образованных носителей языка). При установлении нормы предлагается ориентироваться не столько на узус, сколько на сознательную оценку, которую носители нормы дают степени нормативности существующих вариантов. При этом множество носителей нормы устанавливается отдельно для каждой отдельной рекомендации (в любом случае в их число попадают специалисты, занимающиеся нормализацией). Особое внимание уделяется несоответствиям между узусом и существующей кодификацией, между рекомендациями различных словарей и справочников, а также между рекомендациями словарей и справочников, с одной стороны, и эксплицитными суждениями «компетентных» носителей языка - с другой.

* Статья написана при поддержке РГНФ, проект № 15-04-00488 «Изменения узуса и кодификация норм русского литературного языка» (2015-2017). 
Ключевые слова: языковая норма, кодификация, орфография, орфоэпия, узус, вариативность, речевой этикет.

В последующем изложении не проводится непроходимая граница между нормами правописания и прочими языковыми нормами. Среди лингвистов в течение долгого времени было распространено мнение, согласно которому нормы правописания имеют совсем другой статус, нежели прочие языковые нормы: они являются чем-то внешним по отношению к языку и, в отличие от прочих языковых норм, складывающихся в некотором смысле стихийно, вводятся решением компетентных инстанций и потому являются относительно «произвольными». Представляется, что это связано с тем, что нормы правописания гораздо легче вводить и поддерживать (т. е. следить за их соблюдением), используя различного рода механизмы, предоставляемые государством (напр., необходимость следовать этим нормам при выполнении экзаменационных работ в государственных учебных заведениях). Однако многочисленные факты, касающиеся истории как русского правописания, так и правописания ряда других языков, свидетельствуют, что граница никак не является абсолютной. С одной стороны, мощь государственных механизмов в области правописания не следует преувеличивать. В свободном обществе принудить пишущего следовать на практике установленным нормам правописания можно только в том случае, если сам пишущий считает установленные нормы разумными, а инстанцию, установившую нормы, - достаточно авторитетной. С другой стороны, в определенных случаях использование государственных механизмов позволяет установить или даже изменить нормы, не относящиеся к правописанию. То, что с некоторого момента официальные бумаги, основной текст которых начинается со слова «прошу», стали называться заявлениями, а не прошениями, было не стихийным изменением, а сознательно принятым решением.

Следует иметь в виду, что сама необходимость кодификации языковой нормы возникает только в том случае, если в узусе регулярно встречаются или могут встретиться явления, воспринимаемые языковым сообществом как отклонения от нормы (для словоформы стол неуместной была бы орфографическая или орфоэпическая кодификация). При этом отклонения от нормы могут быть связаны с различными причинами: с тем, что говорящему/ пишущему неизвестна норма, с тем, что следование ей противоречит его сложившимся речевым привычкам, со случайными описками или lapsi linguae, с сознательным отклонением от нормы в целях языковой игры. Иными словами, потребность в кодификации нормы существует постольку, поскольку в узусе имеется вариативность и при этом некоторые варианты воспринимаются языковым сообществом как ненормативные.

Что же такое языковая норма? В повседневном русском языке слово «норма» употребляется по-разному; при этом отчетливо различаются два значения или, точнее, два круга употреблений. С одной стороны, нормой называют то, что распространено в действительности, является «обычным» явлением. С другой стороны, к норме часто относят нечто безупречное или хотя бы удовлетворяющее неким 
минимальным требованиям (нормы поведения). Как известно, применительно к языку в отечественной лингвистике «норму» принято понимать во втором смысле. То, как люди обычно говорят, называют «узусом», а термин «норма» обозначает то, что признается «правильным». Чаще всего этот термин используют, когда обсуждают нормы литературного языка: к нормам относят те языковые средства, которые используются в преподавании и культивируются словарями и справочниками. Именно кодификация, т. е. закрепление в словарях и справочниках, признается одной из самых важных характеристик литературной нормы.

Таким образом, частотность некоторого языкового явления в узусе сама по себе не может служить доказательством его нормативности: частотные явления могут отвергаться языковым сообществом как ненормативные. Это особенно ясно, когда речь идет о нормах правописания: в этом случае никому не кажется парадоксальным понятие «распространенной ошибки», т. е. отклонения от норм, регулярно встречающегося в узусе. Неразличение частиц не и ни (с явным перевесом не) обычно для современного узуса; однако едва ли кто-то сочтет это достаточным основанием для изменения правил правописания частиц не и ни. Тем самым встает вопрос: каким образом языковое сообщество устанавливает нормативность языковых явлений? Определить, каков узус, можно непосредственным наблюдением; однако для установления «правильности» или «неправильности» недостаточно чистого наблюдения, поскольку «правильность» представляет собою ненаблюдаемую сущность.

Представляется, что оценка языкового сообщества в целом базируется на оценке языкового явления компетентными носителями языка, или «экспертами» (сама речь этих компетентных носителей не обязана во всех случаях быть нормативной - существенна именно их оценка языковых явлений) ${ }^{1}$. Тем самым ключевыми оказываются представления экспертов, и возникает вопрос, как выявляется само множество «экспертов». По-видимому, следует признать, что границы этого множества оказываются нечеткими: к нему принадлежат те, кого готово признать «компетентными» языковое сообщество в целом. В частности, к «компетентным экспертам» следует отнести авторов существующих пособий и справочников, в которых зафиксированы нормы русского литературного языка. В самом деле, значительная часть членов языкового сообщества для решения вопроса, какой из встречающихся в узусе вариантов правилен, готова обратиться к словарям и справочникам. Тем самым кодификация норм отчасти оказывается замкнутой сама на себе: кодификация норм должна, среди прочего, опираться на уже имеющуюся кодификацию; проще говоря, понимающие люди, прежде чем высказать собственное суждение по поводу конкретной языковой нормы, смотрят, что по этому поводу сказано в уже имеющихся словарях и справочниках. Следствием этого оказывается неоднократно отмечавшаяся консервативность языковой нормы.

${ }^{1}$ Подчеркнем, что отдельные члены языкового сообщества не обязаны следовать рекомендациям экспертов, даже если признают их компетентность: каждый человек может предпочесть говорить так, как ему «удобно», и не быть озабоченным вопросами «нормы». 
Далее, если кодификатор ориентируется на собственные представления о (не) нормативности, это означает, что он выступает в роли одного из экспертов (в число которых, как правило, попадает уже в силу самого статуса кодификатора). В этом случае его суждение имеет вес как субъективное мнение эксперта, подлежащее объективному описанию в ряду других экспертных суждений. В определенных случаях вес суждения кодификатора особенно велик; в частности, это касается указаний словарей и справочников (особенно академических) в области правописания. Однако во всех случаях, когда имеет место разброс мнений экспертов, это можно рассматривать как признак вариативности нормы. Такой разброс бывает особенно велик в период социальных и культурных изменений.

Для разных конкретных случаев оценки нормативности того или иного явления релевантными могут оказаться разные множества «экспертов»; степень «компетентности» тоже может быть различной (и так и оцениваться языковым сообществом). Наконец, важную роль играет степень категоричности суждения эксперта, причем эта категоричность может касаться как оценки степени неправильности («не рекомендуется» vs. «ни в коем случае не допустимо»), так и уверенности в оценке.

Если справочные пособия говорят одно и то же и эксперты в целом согласны с данной в них кодификацией, то никакой проблемы не возникает. Ситуации, когда основания кодификации не столь очевидны, можно отнести к одному из следующих случаев: имеются разногласия в рамках уже существующей кодификации (справочные пособия противоречат друг другу); мнение экспертов не соответствует существующей кодификации; в существующей кодификации обнаруживается лакуна. Кратко рассмотрим эти случаи.

Ситуация, когда мнения экспертов различаются или даже противоречат одно другому, была рассмотрена в [Шмелев 2004] на материале орфоэпических норм; там же обсуждались аргументы, которые приводятся экспертами в обоснование своего мнения (преобладание в узусе, требования языковой системы, тенденции развития языка, ссылки на языковые авторитеты, в том числе словари и справочники, данные языка-источника для заимствованных слов и т. д.). Во многих случаях в такой ситуации дополнительное исследование разброса оценок дает возможность говорить о тех или иных закономерностях: «старшей» и «младшей» норме, региональном варьировании нормы, «профессиональной» норме и т. п.

Приведем несколько примеров.

Широко известно, что название столицы Португалии в текстах на русском языке пишется двояким образом: Лисабон и Лиссабон. При этом написание Лиссабон встречается существенно чаще; это же касается производных слов лисабонский и лиссабонский, лисабонец и лиссабонец. В соответствии с отечественной традицией, имена собственные в орфографические словари не включаются; однако в академическом «Русском орфографическом словаре» [РОС] есть прилагательное лисабонский и существительное лисабонщы, причем после прилагательного в скобках указано «от Лисабон». Тем самым рекомендации РОС находятся в полном противоречии с тенденциями в узусе, и возникает необходимость отнестись к этому казусу внимательнее. Вообще говоря, причины расхождения в написании известны: 
традиционно имеет место несогласие между энциклопедистами и географами (энциклопедисты предпочитают написание Лисабон, а географы Лиссабон). Представляется, что однозначное предпочтение, которое РОС оказывает выбору энциклопедистов, затушевывает это несогласие. Существенно более взвешенное решение принимается в приложении к словарю [Зализняк 2008] - едва ли не единственном надежном справочнике, из которого можно извлечь информацию о правописании и грамматическом поведении собственных имен в русском языке 2 . В нем приведены оба написания, причем написание Лиссабон сопровождено пометой «устар.». Тем самым в данном случае признается возможность вариативного написания, что, как кажется, отражает реально существующее несогласие экспертов ${ }^{3}$.

В словаре [Штудинер 2004] для прилагательного комплексный указан единственный вариант ударения (на первом слоге). В словаре [Еськова и др. 2015] принято более взвешенное решение: для слова комплексный как прилагательного, соотносимого со словом комплекс, указано ударение на первом слоге, а как математического термина - на втором. Это соответствует ударению, принятому у математиков, и представляется, что в отношении произношения и употребления терминов в качестве экспертов могут выступать специалисты в соответствующей области знания ${ }^{4}$.

Для слова обрезание в словаре [Штудинер 2004] указан единственный вариант ударения (на третьем слоге, причем специально помечено: «во всех значениях»). В словаре [Еськова и др. 2015], как и в предыдущем случае, принято более взвешенное решение: для слова обрезание указано ударение на третьем слоге, но для употребления в значении 'circumcision' в качестве нормативного указывается ударение на втором слоге (ударение на третьем слоге помечено как допустимое). Понятно, что для множества контекстов ударение, предлагаемое М.А. Штудинером, противоречит не только устоявшемуся узусу, но и мнению большинства «экспертов» - людей, знакомых с устоявшимися названиями церковных праздников. В самом деле, в названии праздника «Обрезание Господне» невозможно произнести первое слово с ударением на третьем слоге; точнее, это ударение будет воспринято как малограмотное едва ли не всеми «компетентными» людьми.

Для слова обретение в словаре [Штудинер 2004] также указан единственный вариант ударения на третьем слоге, а ударение на втором слоге отвергается как ненормативное. В словаре [Еськова и др. 2015] обретение вообще отсутствует. Между тем в сочетаниях «обретение мощей» и «обретение главы» в названиях церковных праздников принято ставить ударение на втором слоге (во многих церковных

${ }^{2}$ Напомним, кстати, что указанный словарь - один из тех, в которых, по решению Министерства образования и науки, фиксируются нормы русского языка при его использовании в качестве государственного.

3 Правда, я бы не согласился с пометой «устар.»: в новейших текстах написание Лиссабон по-прежнему преобладает.

4 Это не значит, что следует узаконить хотя бы в качестве допустимого ударение на первом слоге в слове добыча, принятое у нефтяников. Слово добыча не является специальным термином, и потому нефтяники здесь не могут считаться экспертами. 
календарях ударение специально проставлено), и представляется, что указанную традицию следовало бы учесть при кодификации.

Для слова патриархия в словаре [Штудинер 2004] указан единственный вариант ударения на четвертом слоге, а словаре [Еськова и др. 2015] - на третьем слоге, однако приводится и ударение на четвертом слоге с оговоркой «у представителей духовенства» ${ }^{5}$. На самом деле ударение на четвертом слоге, конечно, используется не только представителями духовенства, но и практически всеми, кто имеет дело с патриархийными структурами, поэтому оговорка представляется излишней.

Даже эти немногие примеры свидетельствуют, что в ситуации расхождения мнений кодификаторов бывает необходимо учитывать мнение более широкого круга «экспертов». При этом в эпоху социальных и культурных изменений в обществе может отсутствовать согласие относительно степени компетентности и тем самым авторитетности мнения тех или иных экспертов. Для современного русского языка целый ряд факторов препятствует кодификации языковых норм, принимаемой всем языковым сообществом. Языковые сферы, требующие экспертизы, весьма разнообразны, и это связано как с возникновением новых явлений, по отношению к которым норма не устоялась, так и с появлением политической окраски у некоторых старых вариантов, по отношению к которым, казалось уже достигнуто согласие среди кодификаторов (ср. выбор предлога в/на Украине). Как в языковом сообществе, так и среди потенциальных экспертов наблюдается различная культурная ориентация, коррелирующая с культурной ориентацией потенциальных экспертов (это особенно заметно в отношении норм русского речевого этикета): ориентация на языковые традиции (в том числе языковые) «старой России», на традиции языковой кодификации советского времени, на «западное» словоупотребление; различается и отношение к языковым элементам, проникающим в речь образованных носителей языка из субстандартных его разновидностей. Стала в большей степени осознаваться роль регионального варьирования русского языка, необходимость учитывать не только московский и петербургский варианты литературного языка, но и языковые представления образованных носителей языка иных регионов, а также русской диаспоры (так, в русском языке в России устойчиво используется предложно-падежная форма в Интернете, тогда как среди русских, живущих за границей, до последнего времени преобладала форма на Интернете).

Представляется, что полезно было бы иметь академическую комиссию (отчасти подобную Орфографической комиссии Российской академии наук), оценивающую новые явления в узусе с точки зрения их нормативности (на данном этапе некоторые из таких оценок могли бы даваться и в рамках работы Орфографической комиссии). Однако необходима высокая авторитетность такой комиссии, чтобы ее рекомендации признавались во всем русскоязычном мире.

${ }^{5}$ В предыдущих изданиях данного словаря ударение на третьем слоге приводилось в качестве единственного варианта. 


\title{
Литература
}

Еськова Н.А., Борунова С.Н., Воронщова В.Л. Орфоэпический словарь русского языка: произношение, ударение, грамматические формы / под ред. Н.А. Еськовой. - 10-е изд., испр. и доп. - М.: АСТ, 2015. 1008 с.

Зализняк А. А. Грамматический словарь русского языка. М.: АСТ-ПРЕСС КНИГА, 2008. $800 \mathrm{c}$.

РОС - Русский орфографический словарь РАН / Под ред. В.В. Лопатина, О.Е. Ивановой. — 4-е изд., испр. и доп. — М.: АСТ-ПРЕСС, 2012. 896 с.

Шмелев А. Д. Проблема кодификации в сфере орфоэпии: личный вкус или объективные данные? // Культура русской звучащей речи: традиции и современность. Тезисы докладов международной научной конференции 26-28 апреля 2004 г. М., 2004. C. 116-119.

Штудинер М.А. Словарь образцового русского ударения. 2-е изд., испр. - М.: Айрис-пресс, 2004. - 576 с.

\author{
Alexey D. Shmelev \\ Moscow Pedagogical State University \\ V.V. Vinogradov Russian Language Institute of the Russian Academy of Sciences, \\ Orthodox St. Tikhon University \\ (Russia, Moscow) \\ shmelev.alexei@gmail.com
}

\section{CODIFICATION OF LINGUISTIC STANDARDS IN THE CONTEXT OF SOCIAL AND CULTURAL CHANGES}

The paper deals with the Russian linguistic standards and the problem of their codification in the context of social and cultural changes taking into account various types of linguistic standards (including orthography and speech etiquette). The need for the codification of linguistic standards arises if there is variation in common usage. As far as the triple usage-norm-codification is concerned, one can immediately observe the first and the last members of the triple (codification being more "conservative" than the usage). The norm should be reconstructed and codified on the basis of observation of the usage and correlation of the observations with the data of dictionaries and reference guides as well as with the explicit judgments of native speakers. It pays special attention to the discrepancies between the usage and the existing codification, between different dictionaries and reference guides, between different dictionaries and reference guides on the one hand and the judgments of "experts" on the other.

Key words: linguistic standards, codification, orthography, orthoepy, usage, variation, speech etiquette. 


\section{References}

Es'kova N. A., Borunova S. N., Vorontsova V.L. Orfoepicheskii slovar' russkogo yazyka: proiznoshenie, udarenie, grammaticheskie formy [Russian orthoepic dictionary: pronunciation, stress, grammatical forms]. Moscow, AST Publ., 2015. 1008 p.

Zaliznyak A. A. Grammaticheskii slovar' russkogo yazyka [Russian grammatical dictionary]. Moscow, AST-PRESS KNIGA Publ., 2008. 800 p.

Russkii orfograficheskii slovar' RAN [Russian orthographic dictionary]. Moscow, AST-PRESS KNIGA Publ.,. 896 p.

Shmelev A.D. [The problem of orthoepic codification: personal taste or external evidence?] Tezisy dokladov mezhdunarodnoi nauchnoi konferentsii "Kul'tura russkoi zvuchashchei rechi: traditsii i sovremennost"' [Proc. Int. Conf. "The culture of the Russian oral speech: traditions and modernity]. Moscow, 2004, pp. 116-119.

Shtudiner M. A. Slovar' obraztsovogo russkogo udareniya [The dictionary of the Russian perfect stress]. Moscow, Airis-press Publ, 2004, 576 p. 


\section{Е.Я. Шмелева}

Институт русского языка им. В. В. Виноградова РАН

(Россия, Москва)

eshkind@mail.ru

\section{ЯЗЫК «ЭФФЕКТИВНЫХ МЕНЕДЖЕРОВ»: ОБЩИЙ ЖАРГОН ИЛИ РУССКИЙ ЯЗЫК ХХІ ВЕКА?*}

В современной России одной из основных социальных и профессиональных групп является группа сотрудников разного типа офисов — от «менеджеров по клинингу» (уборщиц) до «топ-менеджеров». Несмотря на то что в русском языке XXI в. появилось пренебрежительное выражение «офисный планктон», а словосочетание (мем) «эффективный менеджер» употребляется чаще всего в ироническом смысле, именно выражения из жаргона офисных работников постепенно переходят, а многие уже перешли в так называемый «общий жаргон». Более того, офисный новояз оказывает влияние на русский язык новейшего времени в целом, вводя в широкое употребление не только новые слова и словосочетания, но и новый этикет устной и письменной речи, и новые стратегии построения текста. В статье рассматривается лексика русского офисного новояза: записанные кириллицей английские аббревиатуры (ебитда, кэпиай); англицизмы, постепенно входящие (кейс, митинг) или уже вошедшие в общий жаргон (креатив, бонус, тренд), словосочетания (внешняя встреча, удаленная работа) и обороты речи (я вас усльшил). Рассматривается также новый этикет деловой переписки и устной деловой коммуникации.

Ключевые слова: офисный новояз, общий жаргон, профессиональная лексика, заимствованные слова, обороты речи.

В статье рассматривается профессиональный жаргон одной из самых больших социальных групп современной России - работников офисов ${ }^{1}$, от «мене-

* Работа выполнена при поддержке гранта РГНФ №15-04-00488, 2015-2017 «Изменение узуса и кодификация норм русского литературного языка». В статье использованы материалы совместного с В.А. Шмелевым доклада Office Newspeak: Russian Vocabulary of the Twenty-first Century (https://www.aatseel.org/100111/pdf/abstracts/1593/Shmeleva.pdf).

1 По данным на 2010 год общее количество офисных работников в современной России 35130000 человек (http://www.trud.ru/article/26-11-2010/254726_pochemu_rabochie_i_ofisnyj_ plankton_nenavidjat_drug_druga.html). 
джеров по клинингу» (уборщиц) до топ-менеджеров крупных компаний. Хотя в русском языке XXI в. появилось пренебрежительное выражение «офисный планктон» ${ }^{2}$, а словосочетание (интернет-мем) «эффективный менеджер» ${ }^{3}$ употребляется чаще всего в ироническом смысле, на самом деле, это престижная социальная группа, представители которой ощущают себя новым «креативным классом». Кроме того, менеджеры по продажам, специалисты по рекламе или пиару находятся в постоянном взаимодействии и общении с клиентами, покупателями, заказчиками, то есть со всеми нами, и тем самым влияют на современную русскую речь в целом. Я попытаюсь показать, что именно офисные работники являются транслятором целого ряда новых слов и выражений, которые уже вошли или имеют все шансы войти в так называемый «общий жаргон» (см. [Ермакова, Земская, Розина 1999]) или даже со временем в литературный русский язык. Как ни странно, офисный новояз ранее не привлекал внимания исследователей, его описанием занимаются сами носители этого «языка». Ср., например, предисловие ко второму изданию «Словаря великорусского языка делового»: «Исходный словарик из примерно 60 слов был составлен со слов коллег, однокурсников, друзей, друзей друзей и врагов друзей. Перечисленные словечки замечены в ходу в Евраз-Холдинге, Сибале, Альфе, Прайсе, многочисленных финансовых, производственных, торговых, консалтинговых и других компаниях. В дальнейшем над словарем работали выпускники экономфака 1999/01 гг. и другие авторитетные знатоки языка бизнес-общения. Будем благодарны за вклад в увековечивание языка неразвитого капитализма» ${ }^{4}$. Также коллективными усилиями пользователей составлялся «Живой офисный словарь»: в течении полутора лет (с июня 2006 по ноябрь 2007 года) регулярно публиковались выпуски словаря с подзаголовком «Подвесь свой язык», в которых приводились списки офисных слов с объяснениями, а читателям предлагалось дополнить словник и уточнить толкования 5 . В Интернете можно найти и другие любительские толковые словари офисного сленга ${ }^{6}$, а также статьи и блоги, в ко-

2 «Офисный планктон (он же “офисное быдло”, “канцелярская крыса”, и т. п.) - работники умственного труда с пониженной творческой составляющей, проводящие жизнь в офисах и прочих управлениях, но не относимые к инженерам: низшие менеджеры, бухгалтеры, секретутки, и т. д. Являют собой передаточные механизмы, винтики и смазку в механизмах управления, учета, планирования, финансов. Быстрорастущий пролетариат постиндустриального мира» ( http:// lurkmore.co/Офисный_планктон).

3 «Эпик мем путинского режима» (http://lurkmore.co/Обсуждение:Эффективный_менеджер). «“Эффективный менеджер” приватизировал народное богатство. “Эффективный менеджер” стал определять национальную политику страны, от экономики до культуры и массмедиа. “Эффективный менеджер” стал символом постсоветского периода» (http://friend.livejournal.com/1844507. html?thread=64193307).

${ }^{4}$ Словарь великорусского языка делового общения. Издание третье, дополненное и переработанное. 0,4 тыс. слов (http://posada.com.ua/useful/employer/15/172/).

5 «Живой офисный словарь» https://www.rabota.ru/fishki/slovar/l.html

${ }^{6}$ Словарь бизнес-сленга https://business_slang.academic.ru; Словарь офисной лексики http://posada.com.ua/useful/employer/15/264/; Корпоративный сленг http://www.covacation.ru/ 
торых обсуждаются отдельные слова и выражения, которые необходимо выучить, чтобы «влиться в коллектив офисных работников»7.

Я попыталась на основе этого материала, а также собственных наблюдений и опроса «информантов» - менеджеров ряда крупных московских компаний кратко охарактеризовать основные группы лексики офисного жаргона, обращая особое внимание на слова и выражения, которые, как кажется, уже перешли из профессионального в русский общий жаргон и имеют все шансы в будущем войти в толковые словари русского языка XXI века. Офисную лексику можно с некоторой долей условности разделить на две большие группы. Во-первых, это термины и профессионализмы, то есть слова, непосредственно связанные с профессиональной деятельностью сотрудников той или иной организации, а также внутрикорпоративный жаргон, прозвища и т.п., во-вторых, это офисные слова и выражения, которыми пользуется более-менее весь «креативный класс». В статье основное внимание уделяется общему жаргону офисных работников, хотя для целого ряда слов очевидно из какой профессиональной сферы деятельности они перешли в общее употребление: из жаргона компьютерщиков, специалистов по рекламе и маркетингу или банковских служащих. Новым словам и выражениям, по большей части заимствованным из английского языка, а также новым значениям, появившимся у русских (или давно освоенных русским языком) слов, посвящена большая литература (см., например, [Кронгауз 2007] [Левонтина 2012, 2015]. Но если мы зададимся вопросом, из какой области человеческой деятельности пришли в нашу речь «модные слова» [Новиков 2011], то мы увидим, что большая часть из них - это профессионализмы, пришедшие из офисного жаргона. Это и относительно недавние английские заимствования, такие, как креативный (креатив), бренд, бонус, тренд, пул, тренинг и многие другие, и изменившие под влиянием английского языка свое значение старые слова, такие, как оптимизировать, мотивировать, позичионировать, проект, формат, опция и др. Несколько слов имеют в офисном жаргоне другое значение, нежели в литературном русском языке, хотя мы все чаще сталкиваемся с «офисным» значением этих слов в разговорной речи и в интернет-коммуникации. Так, в «Толковом словаре иноязычных слов» [Крысин 1998] интервью толкуется как «предназначенная для распространения в средствах массовой информации беседа с каким-л. лицом в форме вопросов и ответов на актуальные темы», а в офисном жаргоне интервью - это

mmenu.php?id=129; Виктор Кутырь. Толковый словарь офисного планктона http://www.proza. ru/2009/07/01/303; Словарь менеджера. 55 золотых слов топ-менеджера http://bg.ru/society/55 zolotyh_slov_top_menedzhera_ili_slovar_dlya_teh-5370/; Офисный словарь. Почему не любят Бивисов и не хотят злить Гену. 17 слов для продвинутых пользователей https://weekend.rambler.ru/ read/ofisnyi-slovar-2016-03-22/; Словарь офисных терминов http://www.officemagazine.ru/articles/ atmosphere/10091/.

7 От "асапа" до "факапа": сленг московских офисов http://hr-portal.ru/article/ot-asapa-do-fakapasleng-moskovskih-ofisov; На каком языке говорит офис: сленг 21 века, джобиздан и десижнмейкеры http://icanchoose.ru/blog/na-kakom-yazyke-govorit-ofis-sleng-21-veka-dzhobizdan-i-desi/; Эллочка-людоедка стала офисным планктоном https://rg.ru/2012/07/05/sleng-site.html. 
собеседование при приеме на работу; митинг — это массовое собрание для обсуждения острых политических, социальных, экономических и т.п. вопросов текущей жизни, в речи офисных работников - встреча, рабочее совещание. Ср. также кейс - «то же, что дипломат 3, небольшой плоский чемодан» [Крысин 1998] и кейс - случай из практики, который наглядно демонстрирует какую-либо теорию.

Конечно, большая часть офисных слов, даже имеющих широкое употребление в современной речи, по-прежнему ощущаются многими носителями русского языка как стилистически маркированные. Это такие заимствованные из английского языка или образованные с помощью английских корней слова, как дедлайн (deadline) - крайний срок, к которому поставленная задача должна быть выполнена; cmapman, cmapmanep (startup) - новый бизнес-проект, тот, кто осуществляет новый проект; фриланс, фрилансер (freelance) - работа не в штате, выполнение заказов для разных клиентов; работник по договору на выполнение определенного проекта; дресс-код (dress code) — форма одежды, требуемая при посещении определённых мероприятий, организаций, заведений; ресепшн/ресепшен (reception) - приемная в офисе или гостинице; aтmач (attach)- файл, прикрепленный к электронному письму, ср. также приаттачить; апдейтить, проапдейтить (to update) - обновлять; апгрейдить, проапгрейдить (to upgrade) - модернизировать, обновить; шерить, шарить (to share) - поделиться ссылкой, информацией и многие другие. Сюда же можно отнести такие широко употребительные в переписке и устной речи офисных работников записанные русскими буквами английские аббревиатуры, как фуй (FYI 'For Your Information') - к вашему сведению и acan (ASAP 'As Soon As Possible') — как можно быстрее 8 . Так же, как и все заимствования, аббревиатуры быстро русифицируются и начинают склоняться, ср., например, офисную поговорку: нет асапа — нет факапа (факап — провал, ср. также эпик фейл).

Есть «внутренние» слова общего офисного жаргона, которые, как кажется, пока еще редко употребляются вне офиса. Это такие слова, как стаф / cmaфф (staff) персонал, штат сотрудников; костьі (costs) — затраты, ср. резать кость, рубить косты; фича (feature) - из компьютерного жаргона — особенность программы, особенность чего бы то ни было, фишка или аббревиатуры — русские или английские, записанные русскими буквами: егрюл - единый государственный реестр юридических лиц; кэпиай (KPI 'Key Performance Indicators') — показатель эффективности работы сотрудника и ебитда (EBITDA 'earnings before interest, taxes, depreciation and amortization') - показатель успешности бизнеса, ср. не могу найти эту фирму в егрюле; с таким кэпиаем и сидеть в нашей конторе!

Основной массив лексики офисного новояза составляют, как и следовало ожидать, заимствования из английского языка. При этом встречаются и не столь

${ }^{8} \mathrm{Cp}$. широко использующиеся в интернет-коммуникации аббревиатуры имхо (IMHO 'In My Humble Opinion') — по моему мнению и лол (LOL 'Laugh Out Loud', 'Lots Of Laughs') — очень смешно. 
многочисленные заимствования из других языков: канбан, канбан-доска (яп. камбан) - метод управления задачами, реализующий принцип «точно в срок» и способствующий равномерному распределению нагрузки между работниками; буххать (нем. buchen) - проводить по бухгалтерии, различные документы, занести информацию в базу данных компании; и русские слова: копье - небольшие для компании суммы денег; пятнадцатая (тридиатая, семидесятая) доходность доход в размере пятнадцати (тридцати, семидесяти) процентов). Среди офисных слов есть немало словообразовательных неологизмов с русскими или давно освоенными русским языком корнями: продажник - менеджер по продажам; совещцалово - совещание; схематоз - схема действий, часто не совсем законных (новый схематоз по уходу от налогов). Многие офисные должности также «обрусели» и получили шутливые наименования: босc (general manager) - генерал манагер, генерал или просто Гена, ср. также физики (физический лица) и юрики (юридические лица).

Есть целый ряд выражений, которые также постепенно дрейфуют из офисного сленга в общий жаргон: удаленная работа — работа вне офиса; внешняя встреча - встреча вне офиса; блудные темь - периферийные, не основные темы.

За последние годы сложился новый этикет деловой переписки (как правило, это переписка по электронной почте), который также постепенно выходит за пределы офисов. Так, в начале письма вместо традиционного обращения к адресату «Глубокоуважаемый / уважаемый) Иван Иванович!» стоит приветствие: Иван Иванович, добрый день! Сергей, доброго времени суток! Екатерина, добрый вечер! В конце письма вместо традиционного «с глубоким уважением / с уважением)» чаще пишут: спишемся; отпишусь, на связи, до связи! Поскольку электронные письма часто посылают нескольким адресатам, появилось выражение ставлю в копию. Интересно, что вначале офисные сотрудники использовали оборот с английским корнем: сисикнуть или поставить в сиси (сc 'carbon сору'), но затем все-таки победило выражение с освоенным русским языком словом копия.

Под влиянием офисного жаргона сложился новый этикет телефонных разговоров (как правило, по мобильному телефону), например, вместо я вам позвоню / позвоните мне чаще говорят я вам наберу / наберите мне. Ср. также выражения возврашаю звоночек; созвонимся по результатам; я к вам вернусь / я вернусь к вам через час (завтра, через неделю и т.д.) 'пока ответить не могу, выясню и свяжусь с вами'; надо как-то к этому отнестись или просто отнеситесь к этому 'надо на это как-то реагировать, например, написать ответ'. Как в телефонном разговоре, так и при личной беседе в ответ на какую-то просьбу или рассуждение говорят: Я вас (тебя) усльшиал. Этот ответ, который многим носителям русского языка (и мне в том числе) кажется очень невежливым, - калька с формулы офисного английского жаргона I hear you, которая также, по словам моих американских коллег, представляется им не слишком вежливой. Однако носители русского офисного жаргона продолжают ее активно употреблять и объясняют ее значение следующим образом: я понял все, что вы мне хотели сказать, но дело серьезное, надо еще подумать. 
К сожалению, в рамках короткой статьи невозможно описать такое многогранное явление, как офисный жаргон. Представляется, однако, что даже беглый обзор показывает, что офисный новояз оказывает влияние на русский язык новейшего времени в целом, вводя в широкое употребление не только новые слова и словосочетания, но и новый этикет устной и письменной речи, и новые стратегии построения текста.

\section{Литература}

Ермакова О.П., Земская Е.А., Розина Р.И. Слова, с которыми мы все встречались: Толковый словарь русского общего жаргона. М.: Азбуковник, 1999. 320 с.

Кронгауз М.А. Русский язык на грани нервного срыва. М.: Языки славянских культур, 2007. $232 \mathrm{c.}$

Крысин Л.П. Толковый словарь иноязычных слов. М.: Русский язык, 1998. 848 c.

Левонтина И. Б. Русский со словарем. М.: Азбуковник, 2010. 335 с.

Левонтина И.Б. О чем речь. М.: АСТ: Corpus, 2016. 512 c.

Новиков В. И. Словарь модных слов. М.: АСТ-ПРЕСС КНИГА, 2011. 256 с.

\section{Elena Ya. Shmeleva}

V.V. Vinogradov Russian Language Institute of the Russian Academy of Sciences

(Russia, Moscow)

eshkind@mail.ru

\section{LANGUAGE OF EFFECTIVE MANAGERS: COMMON JARGON OR RUSSIAN OF THE XXI CENTURY?}

One of the main social and professional groups in Russia is a group of office workers, from "cleaning managers" (cleaners) to top managers. Despite the fact that in modern Russian there is a disparaging expression "office plankton", and the phrase (meme) "effective manager" is used most often in an ironic sense, many words and phrases from the jargon of office workers became the words of so-called "common jargon" or even standart Russian words. Furthermore, the office newspeak is not only the source of new words and phrases, but also the source of new etiquette of oral and written speech, and new strategies of text generation. The article deals with the vocabulary of Russian office jargon - English abbreviation written in Cyrillic; more or less wellknown borrowed words, Russian words that changed the meaning, new cliché and phrases. There is also a short description of the new etiquette of business correspondence and business communication.

Key words: Office newspeak, common jargon, professional vocabulary, borrowed words, cliché. 


\section{References}

Ermakova O. P, Zemskaya E. A, Rosina R.I. Slova, s kotorymi my vse vstrechalis': Tolkovyy slovar' russkogo obshchego zhargona [Words with which we all met: Explanatory dictionary of Russian common jargon]. Moscow, Azbukovnok Publ., 1999. 320 p.

Krongauz M.A. Russkiy yazyk na grani nervnogo sryva [Russian on the verge of a nervous breakdown]. Moscow, Yazyki slavyanskikh kul'tur Publ., 2007. 232 p.

Krysin L.P. Tolkovyy slovar' inoyazychnykh slov [Explanatory dictionary of foreign words]. Moscow, Russkiy yazyk Publ. , 1998. 848 p.

Levontina I. B. Russkiy so slovarem [Russian with dictionary]. Moscow, Azbukovnik Publ., 2010. 335 p.

Levontina I. B. O chem rech' [What are you talking about?]. Moscow, AST: Corpus Publ., 2016. 512 p.

Novikov V.I. Slovar' modnykh slov [Dictionary of fashion words]. Moscow, ASTPRESS KNIGA Publ., 2011. 256 p. 


\author{
Т.В. Шмелева \\ Новгородский государственный университет имени Ярослава Мудрого \\ (Россия, Великий Новгород) \\ szmiel@mail.ru
}

\title{
ГРАММАТИКА НОВГОРОДЦЕВ: РЕГИОНАЛЬНАЯ НОРМА?
}

В статье ставится проблема соотношения языковой нормы и регионального узуса в грамматике. Анализируются языковые факты, характерные для жителей Великого Новгорода. Эти факты относятся к грамматике глагола, в том числе его морфемики и управляемых форм субстантива. Первый случай представляют формы типа уехавши, привыкши, оставши и причастные конструкции типа У Володи там полотенце повешено; У немщев разбито. Второй случай выглядит как предпочтение префикса на-, с помощью которого образуют формы намылась, наругает, тогда как в других городах скажут nомыть, вылылть, отругать. Наконец, в управлении субстантивом родительному падежу предпочитают дательный, в результате говорят Ему день рождения и Ему юбилей. Обсуждаются вопросы происхождения рассмотренных форм, их связь с диалектной речью и кодифицированным литературным языком, восприятие их языковым сознанием новгородцев и тех, кто приезжает в город и высказывается об особенностях местной речи. Приводятся суждения лингвистов о подобных фактах в диалектах и просторечии. В теоретическом плане ставится вопрос о соотношении норм литературного языка и регионального узуса, о возможности интерпретировать рассматриваемые факты как региональную норму

Ключевые слова: Великий Новгород, русский язык, грамматика, глагол, причастие, префикс, падеж.

Языковая норма литературного языка в принципе не предполагает территориального варьирования, это противоречивало бы ее природе. Но узус на разных территориях бытования русского языка дает возможность наблюдать вариативность в функционировании языковых единиц разных уровней. В первую очередь это проявляется в произношении, что хорошо известно и за пределами лингвистического сообщества: оканье на севере, фрикативное Г на юге и т.п. Во вторую очередь вариации обнаруживаются в лексике, что стимулировало идеи специальных наблюдений над ней [Капанадзе, Красильникова 1982] и создания региональных 
словарей [Михалап, Шмелева 1987], некоторых из них опубликованы, например, [Словарь 2003].

Кажется, сегодня лингвисты уже не думают, что во всех городах, в отличие от сельской местности, говорят на литературном русском языке и - менее образованная часть горожан - на просторечии. Но довольно распространено представление о том, что лексикой, да еще городским ономастиконом, рекламой [Михайлюкова 2017] варьирование языка современного города ограничивается.

Между тем языковая реальность Великого Новгорода предъявляет факты, которые заставляют задуматься о грамматической специфике городской речи. Предлагая описание таких фактов, в данной работе предполагается обсудить вопрос о том, каково должно быть отношение к ним лингвиста, тем более преподающего в высшей школе. Обсуждение таких фактов языка города может быть более плодотворным с учетом языкового сознания носителей русского языка Великого Новгорода - как считающих свой язык единственно возможным, так и тех, кто приезжает в город и удивляется некоторым языковым привычкам новгородцев.

Речь новгородев давно привлекает внимание лингвистов. Многие факты новгородской речи зафиксированы в словаре В.И. Даля; систематическое изучение диалектов началось в 1950-е годы, его результаты опубликованы в виде фундаментального лексикографического описания новгородских говоров [Новгородский 2010], наблюдения над языком города обобщены и систематизированы в [Шмелева 2016: 50-58]. Это дает возможность проверить ряд фактов, сопоставить их разные описания и интерпретации.

Начиная с грамматики глагола, отметим формы типа привыкши (и более редкая - ушодиы), которые уже вошли в легенду. Эти диалектные формы, давно перешагнувшие городские границы. Исследователи городского просторечия в 1980-е годы отмечали их в речи москвичей и ленинградцев: Муж ленинградеи / тоже здесь родивши: Каждый поженивши / было тесновато. Отмечалось, что такие конструкции «чаще встречаются в Ленинграде, чем в Москве» [Земская, Китайгородская 1984: 86]. Это можно объяснить: значительную часть ленинградцев составляли выходцы из Новгорода и Пскова. Новгородские формы уверенно можно считать заимствованными непосредственно из новгородских или псковских говоров, фиксируемые в словарях: $A$ в доме-то всё задёрнувши павчинам; $У$ ей с яблони падулочек наваливше под окнам-то [Новгородский 2010: 779; 781]. Вместе с тем они известны и в летописях: придоша печенези первое на роускую земли и створивще мирь с игорем.

Современные записи говорят о том, что эти формы сохраняются в речи пожилых людей. Вот несколько ситуаций. Смотрительница в храме Спаса Преображения на Ильине доверительно сообщает: тут только фрески Феофана оставши с ударением на первом слоге. Удивившись тому, что можно войти в храм Андрея Стратилата в Кремле, слышим объяснение от служительницы: так мы только открывши. Ее ровесница в автобусе рассказывает про кого-то: он не раз женивши, несамостоятельный парень. Пожилая новгородка рассказывает, как много у нее дома несделанных дел, самокритично заключает: Заленивши вся вдрызг; она же 
о себе: Какое здоровье? Износивии всё; и о своей родине: Ничего там не оставши. Но и молодые работницы почты, задерживающие клиентов из-за того, что замок не открывается, объясняют: краска приклеивии. Кондуктор в автобусе кричит: проходите вперед, что вы на задней площзадке сгруппировавши. Последний пример убеждает, что перед нами не воспроизводимые, а живые тут же образованные формы.

Показателен такой эпизод: молодой человек, забежав на минутку по делу, отказывается от приглашения сесть за стол: я дома поевщи. Видя мою реакцию, смущается: Дая не местный, это я привыкши. Кроме этих результатов непосредственного наблюдения, можно привести рассказ мамы школьницы, которая перевела ее в новую школу, потому что в предыдущей учительница может сказать приехавии. Это расценивается как некультурность, а заметили и рассказали об этом дети.

Итак, формы глагола прошедшего времени на -вши хоть и редко, но можно услышать в городе. Во всяком случае, они никого не удивляют и всем понятны. Это усвоенная из диалектной речи грамматическая черта осмыслена новгородцами, всем понятно, что это нелитературная форма, она служит предметом шуток и анекдотов.

Второе грамматическое явление, связанное с грамматикой глагола, можно заметить буквально на каждом шагу, в том числе и в университетской аудитории. Это причастные конструкции типа У Володи там полотенце повешено. Вот примеры ситуаций, в которых звучат такие предложения. На кафедру приходит сотрудница, у которой совсем недавно родился ребенок. На вопрос «А где же сын»? отвечает: Муж оставлен. Про другую сотрудницу говорят: Она в больнииу положена. Фразы У меня такая кофточка куплена!; На Джамильке (улица Мусы Джалиля - Т.Ш.) у них дом построен; У нее торт был спечён; Ваша папочка подписана у ректора звучат постоянно и никого не удивляют. Но фразе одной студентки $У$ меня у самой Библию начато читать нельзя не удивиться, учитывая, что это сказано в университетской аудитории.

В литературном языке возможны конструкции типа У меня настроение испорчено, У него рука сломана. Но субъект, обозначенный субстантивом с предлогом У, называет того, о ком идет речь. Тогда как в новгородских конструкциях эта форма именует агенс - действующий субъект: Ваша папочка подписана у ректора означает: ректор подписал документы в «папочке».

Естественность таких конструкций для новгородской речи объясняет их проникновение в печатные тексты. Вот примеры из областной газеты «Новгородские ведомости»: У немцев были установлены на высоких колах маскировочные сети, чтобы не просматривалось передвижение войск по городу (А. Орлов. 18.02.1997); У нас уже написано во все инстанции неимоверное количество писем с просьбой, чтобы нам эту ссуду пролонгировали и на следующий год (Е. Мальков. 25.10.2002); Как-то подружка принесла в школу «Гарри Поттера»... Сейчас у меня прочитаны все книги о нем, и оба фильма тоже видела (Я. Иванова. 27.03.2004). Нетрудно заметить, что во всех случаях конструкция - в речи героев: участника освобождения Новгорода, сотрудницы областной администрации, школьницы. Ни одного из них нельзя считать носителем диалекта, да и состав приведенных фраз говорит 
об этом. Но ни авторы материалов, ни редакторы не сочли возможным «перевести» эти фразы на литературный язык: немщь установили, мы написали, я прочитала или немцами установлены, нами написаны, мною прочитаны.

Отмечено, что такие конструкции можно встретить и в литературных текстах, например, У nапь записаны ваши высказывания (Д. Гранин) [Князев 1997]. В городской речи их семантический репертуар уже, чем в диалектной, где возможны реплики $У$ кота на печку забранось. Такую фразу в городе вряд ди услышишь, но субъект-лицо фигурирует в конструкции с причастеим регулярно и никого не удивляет.

Необходимо сделать стилистическое замечание. Новгородская конструкция не связана с выражением пассивного залога. Поэтому новгородцев трудно убедить в том, что такие предложения воспринимаются как страдательные конструкции и производят впечатление казенного стиля, канцелярита, если речь идет не о документах или юридической литературе.

Говоря о грамматике глагола, следует отметить одну особенность его морфемики. Не только лингвисты, но и многие гости города замечают, что у новгородцев приставка на- заменяет целый префиксальный ряд и стремится к монополии: Голову намыла, Иди руки намой, Меня мама наругает. Никого из них не удается убедить, что это ненормативные или сомнительные формы, им в речи жителей других городов соответствуют префиксы no-, выl-, .om- : помой, вымыла, отругает. Приставка на- в этих словах кажется новгородцам единственно возможной, и попытки убедить их в том, что глагол намыть означает множество объектов, например, намыл яблок два ведра, не имеют успеха.

В части управления формами субстантива все замечают, что новгородцы в ряде случаев родительному падежу предпочитают дательный. Почти все говорят Емy день рождения и Ему юбилей; можно услышать вопрос Как ей фамилия? Такие высказывания записаны от преподавателей-филологов. Объяснить это управление можно аналогией: eй 50 лет = ей день рождения=ей юбилей. Логично, но не нормативно: во всех этих случаях нормой предписывается родительный падеж с предлогом У.

Эти точечные грамматические явления, видимо, диалектного происхождения (но не собственно диалектные!), в разной степени осознаваемые горожанами как специфические, ставят перед лингвистом, преподающим, например, будущим учителям или журналистам, вопрос об отношении к ним. Пытаться отучивать от таких словечек и конструкций? Признать это региональной нормой? Первое кажется бесперспективным, но обращать внимание на эти языковые факты, объяснять их специфичность (часто возникают вопросы «А как еще-то можно сказать?»), то есть активизировать языковую рефлексию молодых новгородцев, представляется необходимым.

Видимо, такие грамматические регионализмы можно обнаружить и в других российских городах, хотя мой опыт говорит о том, что бросаются в глаза скорее лексические особенности, их замечают и непрофессионалы. Признание региональных норм в грамматике наряду с лексикой и орфоэпией не кажется нереалистичным, вопрос этот заслуживает серьезного обсуждения. 


\title{
Литература
}

Земская Е.А., Китайгородская М.В. Наблюдения над просторечной морфологией // Городское просторечие: Проблемы изучения / отв. ред. Е.А. Земская, Д.Н. Шмелев. М.: Наука, 1984. С.66-102.

Капанадзе Л.А., Красильникова Е.В. Лексика города (К постановке проблемы) // Способы номинации в современном русском языке. М.: Наука,, 1982. С. 282-285.

Князев Ю.П. Поссесивный перфект в литературном русском языке и северозападных говорах // Русские народные говоры: история и современное состояние: Тезисы докл. межвуз. науч. конф. Новгород, 1997. С.45-47.

Михайлюкова Н.В. Языковой облик современного города. Владивосток, 2017. $360 \mathrm{c}$.

Михалап К.П., Шмелева Т.В. Словарь города // Филологические науки. №4. 1987. C.81-85.

Новгородский областной словарь / Ин-т лингв. исслед. РАН; изд. подгот. А. Н. Левочкин и С.А. Мызников. СПб.: Наука, 2010. XXVIII, 1435 с.

Словарь современного русского города / Под ред. Б.И. Осипова. М.: АСТ, Русские словари, 2003. 565 с.

Шмелева Т. В. Новгородская словесность. Великий Новгород, 2016. 183 с.

\author{
Tatiana V. Shmeleva \\ Jaroslav-the-Wise Novgorod State University \\ (Russia, Veliky Novgorod) \\ szmiel@mail.ru
}

\section{GRAMMAR OF THE NOVGORODIANS: A REGIONAL NORM?}

The article raises the problem of the relation of language and regional standards of usage in grammar. Language the facts about the grammar of the residents of Veliky Novgorod are explores. These facts relate to the grammar of the verb forms managed substantive and morphemic of the verb. The first case is of the form tyре уехавши, привыкши, оставши and participle construction У Володи там полотенце повешено; У немцев разбито. The second case is the preference for the dative in sentence Ему день рождения; Ему юбилей. In morphemic specific verb is the prefix $н а--$, with the help of which form formes намылась, наругает, whereas in other cities will tell помыть, вылиыть, отругать. Discusses the origin of the considered forms, their relationship with the dialect of speech and codified literary language, perception of their linguistic consciousness of the citizens and those who come to the city and speaks about the peculiarities of local speech. In theoretical terms the question of the ratio of the norms of the literary language and regional language usage, the ability to interpret the facts. as a regional norm.

Key words: Veliky Novgorod, Russian language, grammar, verb, participle, prefix, case. 


\section{References}

Zemskaya E. A., Kitajgorodskaya M. V. Nablyudeniya nad prostorechnoj morfologiej [Observations of vernacular morphology]//Gorodskoe prostorechie: Problemy izucheniya [Urban vernacular: problems of study] / otv. red. E. A. Zemskaya, D. N. Shmelev. M.: Nauka, 1984. p.66-102.

Kapanadze L.A., Krasil'nikova E.V. Leksika goroda (K postanovke problemy) [Vocabulary of the city (problem statement)] // Sposoby nominatsii v sovremennom russkom yazyke. [Methods of nomination in the modern Russian language]. M.: Nauka, 1982. p. 282-285.

Knyazev Yu. P. Possesivnyj perfekt v literaturnom russkom yazyke i severo-zapadnykh govorakh [Possesiv perfekt in the Russian literary language and the North-Western dialects] // Russkie narodnye govory: istoriya i sovremennoe sostoyanie [Russian dialects: history and current status]: Tezisy dokl. mezhvuz. nauch. konf. Novgorod, 1997. S.4547.

Mikhajlyukova N.V. Yazykovoj oblik sovremennogo goroda [Language in modern city]. Vladivostok, 2017.360 s.

Mikhalap K.P., Shmeleva T.V. Slovar' goroda [Dictionary of the city] // Filologicheskie nauki. №4. 1987. S.81-85.

Novgorodskij oblastnoj slovar' [Novgorod regional dictionary] / In-t lingv. issled. RAN; izd. podgot. A.N. Levochkin i S. A. Myznikov. SPb.: Nauka, 2010. XXXVIII, $1435 \mathrm{c}$.

Slovar' sovremennogo russkogo goroda. [Dictionary of the modern Russian city] / Pod red. B. I. Osipova. M.: AST, Russkie slovari, 2003. 565 s.

Shmeleva T. V. Novgorodskaya slovesnost'. Velikij Novgorod, 2016. $183 \mathrm{~s}$. 


\author{
Т. Е. Янко \\ Институт языкознания РАН \\ (Россия, Москва) \\ tanya_yanko@list.ru
}

\title{
О ПРОСОДИЧЕСКОЙ ВАРИАТИВНОСТИ*
}

Немаркированным средством выражения дискурсивной незавершенности в русском языке служит интонационная конструкция с подъемом на ударном слоге словоформы-акцентоносителя незавершенности плюс падение на заударных слогах (если они есть), или ИК-3 по Брызгуновой. К маркированным просодиям, которые осложнены дополнительными значениями и которые тоже обслуживают дискурсивную незавершенность, относятся интонационная конструкция ИК-4, говорящая о т.н. «рассказе по порядку», и ИК-6, указывающая на режим воспоминаний или мечтаний о ряде событий, которые имели место в прошлом или произойдут в будущем. Между тем анализ рабочего массива устной речи говорит о том, что у ИК-3 как у показателя незавершенного дискурса имеется вариант с подъемом на ударном слоге и дальнейшим подъемом на заударных слогах, который мы называем градуальным подъемом. В русском языке градуальный подъем регулярно используется в речи девушек (старшеклассниц и студенток) как фонетический вариант ИК-3, а также в речи людей, испытавших влияние одесского регионального варианта русского языка. Мы предлагаем рассматривать градуальный подъем в речи юных особ женского пола как гендерно-возрастной вариант русской нормы, а в речи говорящих обоего пола и различного возраста, которые, кроме градуального подъема, сохраняют другие особенности одесского варианта русского языка (как суперсегментные, так и сегментные), — как ненормативное проявление регионального влияния.

Ключевые слова: интонация, вариативность, норма, региональный вариант, гендерно-возрастной вариант, речь девушек, градуальный подъем, незавершенность.

Немаркированным средством выражения дискурсивной незавершенности в русском языке служит акцент с подъемом на ударном слоге словоформы-акцентоносителя незавершенности плюс падение на заударных слогах (если они есть), или ИК-3 по [Брызгунова 1982: 111], ср. пример (1):

\footnotetext{
* Работа выполнена при финансовой поддержке РФФИ (грант 16-06-00226).
} 


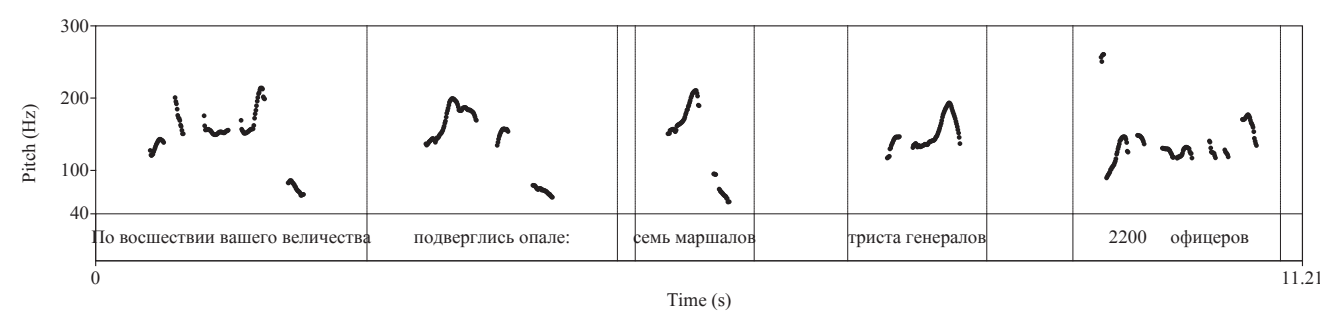

Рис. 1. Тонограмма примера (1)

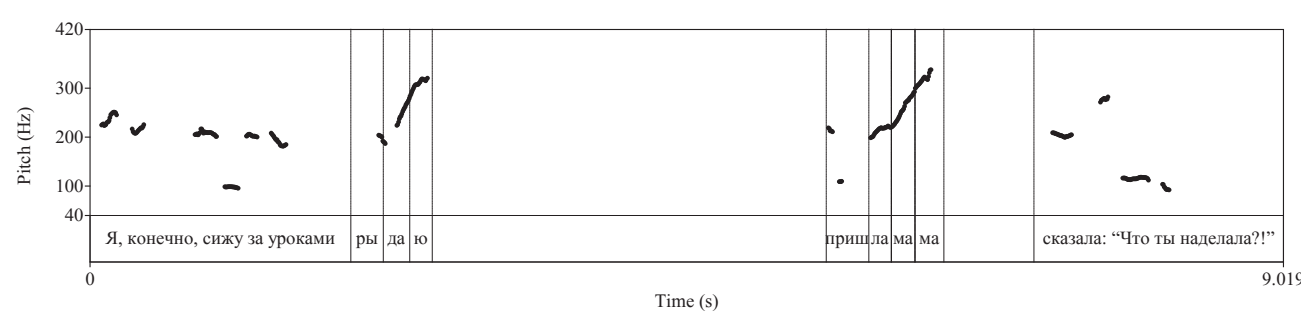

Рис. 2. Тонограмма примера (2)

(1) По восшествии вашего величества подверглись опале: семь маршалов, триста генералов, две тысячи двести офицеров... [НКРЯ].

Тонограмма ${ }^{1}$ примера демонстрирует рельефные подъемы на ударных слогах словоформ маршалов, генералов и офицеров; заударные слоги несут рельефное падение частоты тона.

К маркированным (т.е. осложненным дополнительными значениями) просодиям, которые тоже обслуживают дискурсивную незавершенность, относятся акцент ИК-4 (по [Брызгунова 1982: 114]), говорящий о т.н. «рассказе по порядку», и ИК-6 (по [Брызгунова 1982: 118]), указывающий на режим воспоминаний или мечтаний о ряде событий, которые имели место в прошлом или произойдут в будущем.

Между тем наши записи устной речи говорят о том, что у ИК-3 как у показателя незавершенного дискурса имеется вариант с подъемом на ударном слоге и дальнейшим подъемом на заударных слогах, см. пример (2):

(2) Я, конечно, сижу за уроками рыдаю, пришла мама, сказала «что ты наделала?»².

График частоты основного тона говорит о том, что на акцентоносителях незавершенности словоформах рыдаю и мама ударный слог несет подъем частоты, который продолжается на заударном слоге. Этот акцент отсутствует в списке

1 Тонограмма - это кривая изменения частоты основного тона звучащего голоса. По оси ординат на графике откладывается частота в герцах, по оси абсцисс - время, прошедшее с начала речи в секундах. Тонограмма - один из основных способов передачи на бумаге значимых интонационных параметров речи. Тонограммы получены с помощью компьютерной системы анализа устной речи Praat [Boersma, Weenink 2012].

2 Пример получен из аннотированного корпуса звучащей речи «Рассказы о сновидениях», содержащего, в частности, отчеты детей и подростков о том, что они видели во сне (см. spokencorpora.ru; [Кибрик, Подлесская 2009]. 
интонационных конструкций Е.А. Брызгуновой. Мы предлагаем называть его градуальным подъемом.

В принципе, можно найти определенные аргументы в пользу того, чтобы считать градуальный подъем в русском языке вариантом ИК-4. Так, в одном из определений ИК-4 Е.А. Брызгунова говорит о том, что гласный центра (ударного слога) 1) «произносится на уровне тона ниже предцентровой части» и 2) «при этом варьируется ровное, нисходящее, нисходяще-восходящее направление тона». Кроме того, 3) «постцентровая часть произносится выше уровня центра и предцентровой части» [Брызгунова 1982: 114]. Таким образом, нетривиальное требование параметра 2), выделенного Е.А. Брызгуновой, значению которого разрешается иметь восходящий фрагмент изменения частоты основного тона, у градуального подъема выполняется. Требование 3 ) в рассмотренных нами примерах градуального подъема выполняется всегда. Однако требования параметра 1) градуальные подъемы, которые мы имеем в нашей выборке, не выдерживают: частоты ударного гласного в наших примерах превышают частоты предударной части. Таким образом, есть все основания полагать, что перед нами не вариант ИК-4 и что градуальный подъем в описаниях русской просодии не зафиксирован.

\section{Градуальный подъем в русской речи}

Как и в примере (2), в примерах (3)-(4) из записей открытого урока по литератуpe (https://www.youtube.com/watch?v=gqyHO_nj7w) у старшеклассников (и в других примерах, которые мы здесь не приводим) также наблюдается градуальный подъем при выражении дискурсивной незавершенности.

(3) Меня зовут Алла...

Здесь уровень частоты на предударном контексте акцентоносителя словоформы Алла ниже уровня частоты ударного слога. Ударный слог несет восходящее движение тона, и на заударном слоге акцентоносителя также фиксируется специфический подъем частоты, который начинается от того уровня, который был достигнут в результате подъема на ударном слоге. Таким образом, в примере (3) предударное, ударное и заударное движение тона имеют последовательно восходящий характер. (4) Mь приходим на факультатив по дебатам...

Аналогично, в примере (4) на ударном слоге акцентоносителя незавершенности фиксируется подъем частоты основного тона, за которым опять же следует

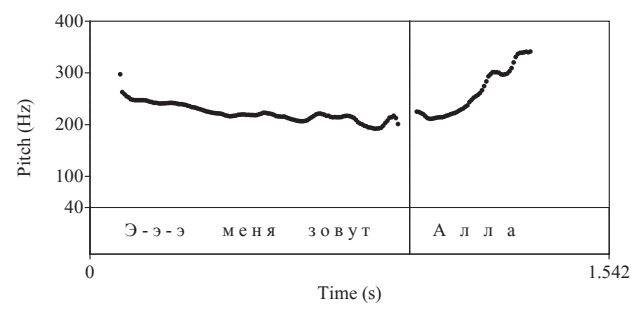

Рис. 3. Тонограмма примера (3) 


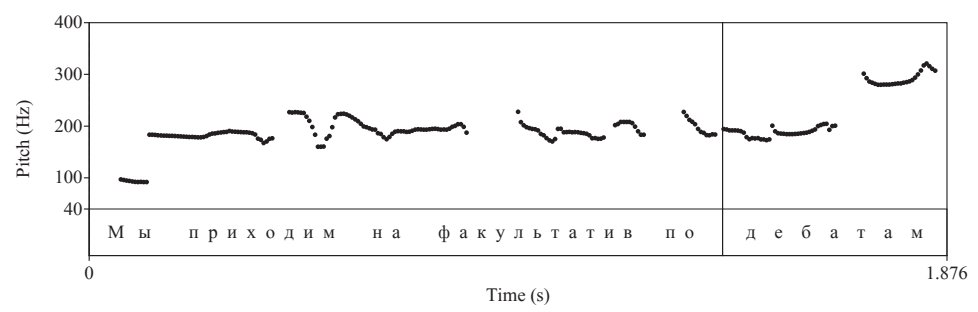

Рис. 4. Тонограмма примера (4)

подъем, берущий начало от уровня, достигнутого в результате подъема на ударном слоге. Частота основного тона на предударном слоге ниже частот ударного слога.

Таким образом, мы показали, что перед нами просодическая единица, которая отличается от единиц, зафиксированных в списке Е. А. Брызгуновой. Начиная с данного момента наша цель - зафиксировать контексты употребления градуального подъема и оценить статус градуального подъема в русской речи с точки зрения русской произносительной просодической нормы.

Возникают следующие вопросы: 1) имеется ли градуальный подъем в других языках?; 2) имеется ли градуальный подъем в русских региональных вариантах?; 3) какой семиотический статус имеет градуальный подъем в русском языке?; 4) что можно сказать о социальных параметрах говорящих, которые используют в речи градуальный подъем?

\section{Градуальный подъем в европейских языках}

Обратимся к градуальному подъему в немецком языке, где градуальный подъем имеет определенные дискурсивные функции.

(5) Ich war in Frankreich. Dann war ich einen Monat in China, <mit einer Freundin.

Und dort haben wir ihre Eltern besucht, also, sie ist direkt aus China. Und waren obendrein noch in Peking und Schanghai. >

Пример заимствован из работы [Палько 2008]. В графической версии примера полужирным шрифтом выделены словоформы-носители градуального подъема. Перед нами образец одной из немецких стратегий формирования незавершенного дискурса, а именно, т.н. рассказа по порядку. Градуальный подъем фиксируется на словоформах Frankreich и China (см. тонограмму), а также на словоформах Freundin, China и Schanghai. Рассказ по порядку дает возможность выстроить предметы или

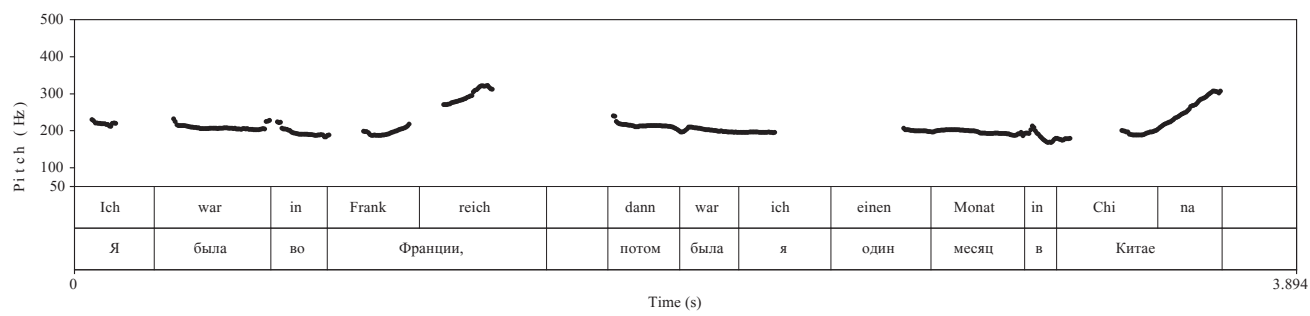

Рис. 5. Тонограмма примера (5) 
события в соответствии с их упорядоченностью во времени, в пространстве или в соответствии с их внутренней логикой. Эта просодия оформляет расписания, повестки дня, кулинарные рецепты (которые подразумевают строгую упорядоченность действий кулинара), отчеты о командировках и экскурсиях, которые воссоздают маршрут поездки. В русском языке в этой функции используется ИК-4. В немецком же языке у нисходяще-восходящего акцента типа русского ИК-4 другая дискурсивная функция: он выражает простую немаркированную незавершенность. Таким образом, в немецком языке градуальный подъем - это двусторонняя единица, за которой закреплена определенная дискурсивная функция, т.е. в немецком градуальный подъем имеет фонологический статус. Он зафиксирован в описаниях [Grice, Baumann, Benzmüller 2005], [Палько 2008] и принадлежит литературной норме.

Пример (6) иллюстрирует градуальный подъем в новозеландском английском. (6) You remembered the lilies?

Пример заимствован из работы [Fletcher, Grabe, Warren 2005]. График демонстрирует последовательное повышение частоты основного тона от предударной области к заударной. В данном случае функция градуального подъема - формирование вопроса.

Пример (7) демонстрирует градуальный подъем в нидерландском языке [Gussenhoven 2005].

(7) Zou ze werkelijk zo gek zijn om daarop in te gaan?

'Действительно ли она была настолько глупа, чтобы принять это приглашение?'

Примеры (5)-(7) иллюстрируют функции градуального подъема в ряде германских языков, а описания просодии этих языков говорят о том, что за градуальным подъемом в этих языках закреплен ряд функций, таких как незавершенность и формирование да-нет-вопроса. Можно предположить, что в рассмотренных языках градуальный подъем имеет фонологический статус.

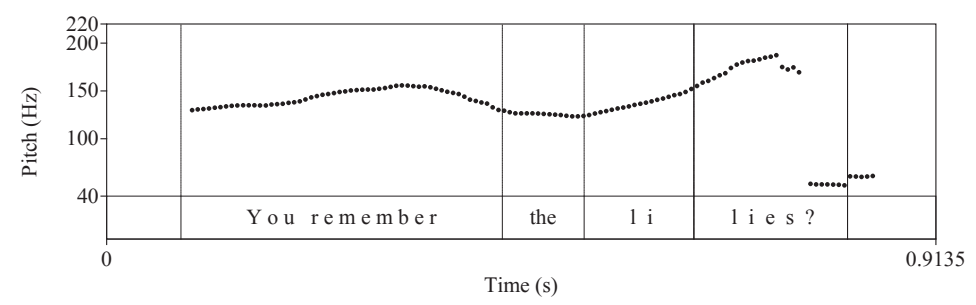

Рис. 6. Тонограмма примера (6)

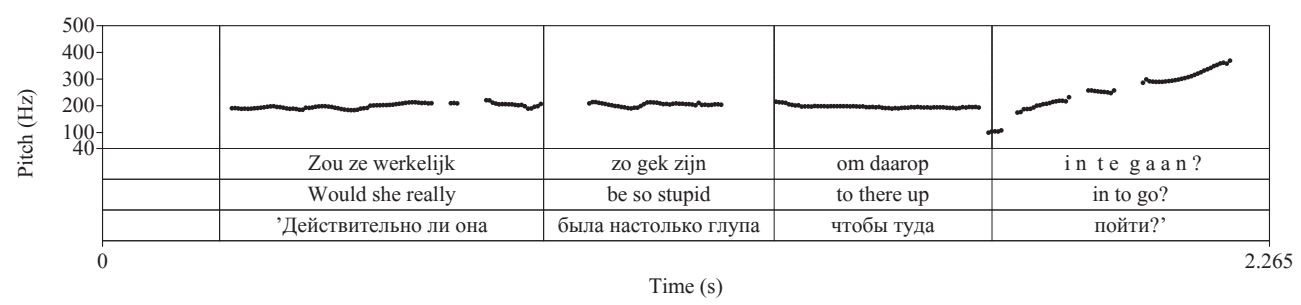

Рис. 7. Тонограмма примера (7) 


\section{Градуальный подъем в одесском региональном варианте русского языка}

В региональном варианте русского языка Одессы градуальный подъем достаточно регулярно используется при выражении дискурсивной незавершенности и да-нет-вопроса.

Пример (8) иллюстрирует дискурсивную незавершенность в рассказе одесситки о политических настроениях в городе.

(8)... убивает Украину, вот фотографии...

Здесь мы наблюдаем последовательное повышение частоты, начиная от предударного слога акцентоносителя незавершенности словоформы Украину до заударного слога акцентоносителя. Кроме того, «одесский акцент» здесь проявляется и на сегментном уровне, что, в частности, выражается в более существенной, чем в наддиалектном русском редукции первых предударных гласных, говорящий произносит: [укръину] и [фътъграфии].

Аналогично в примере (9) градуальный подъем выражает дискурсивную незавершенность, акцентоноситель - словоформа продукиия; первый предударный слог произносится с сильнейшей редукцией: [пръ].

(9) Естественно, не всегда распространялась полностью продукция ...

Несмотря на широкое распространение градуального подъема в речи одесситов, нельзя не заметить, что, скажем, в повествовании об одном и том же ряде событий для выражения незавершенности может использоваться не только градуальный подъем, но и акцент типа ИК-3. Это дает основания предположить, что у градуального подъема в одесском региональном варианте русского языка нет фонологического статуса: предположительно, градуальный подъем играет роль фонетического варианта акцента типа ИК-3 и используется для формирования дискурсивной незавершенности и да-нет-вопроса. Возможно, одесский градуальный

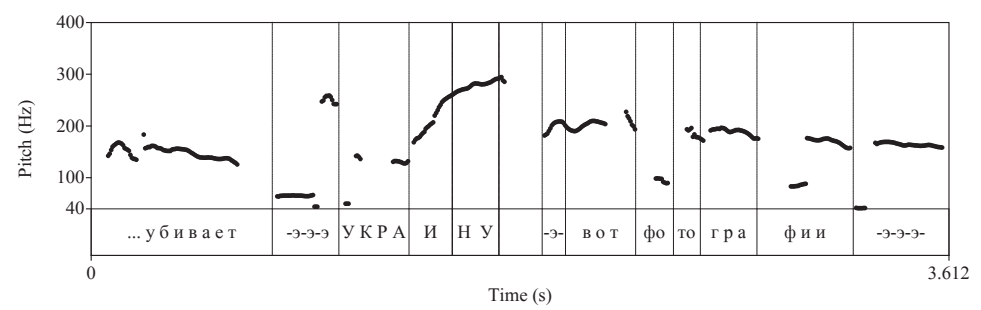

Рис. 8. Тонограмма примера (8)

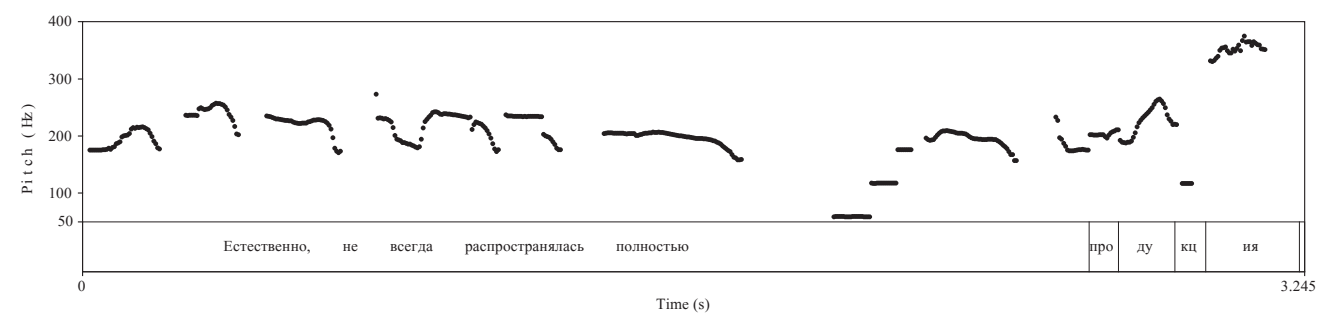

Рис. 9. Тонограмма примера (9) 


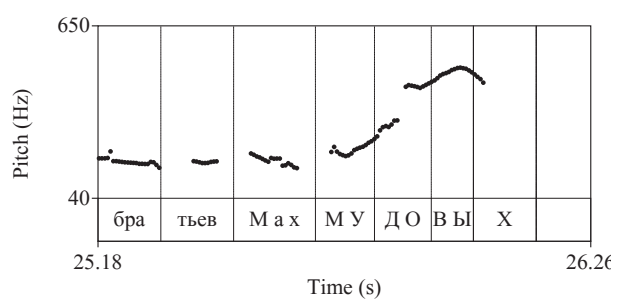

Рис. 10. Тонограмма примера (10)

подъем - это следствие германоязычного влияния (конкретно - идиша). «Одесские ноты» можно услышать и в Москве, ср. речь одной из ведущих программ на радио «Эхо Москвы».

(10) Важно, чтобы никто не говорил, что [ио] он капитулировал перед варварами ... тогда были взяты исполнители, и либералов в общем-то так замкнуло, и они стали защчщзать братьев Махмудовых, которые сейчас осуждень как убийцьл...

В данном образце речи обращают на себя внимание значения следующих параметров. 1) В речи присутствует нехарактерный для взрослого населения Москвы градуальный подъем, ср. кривую изменения частот на акцентоносителе словоформе Maxмyдовых; 2) градуальный подъем в данной речи отмечен расширенным диапазоном частот, а именно, максимум частоты превышает отметку в 500 герц, на которую как на максимум обычно настроены компьютерные программы анализа частот; 3) ведущая программы иногда произносит что как [шо], что говорит и о других ненормативных элементах в речи данного говорящего. Можно предположить, что здесь мы наблюдаем эффект «одесского» влияния.

Наблюдения над германскими языками и возможной зоной германского влияния возвращают нас к речи юных москвичек (примеры (2)-(4)), с которой мы начинали и в которой, кроме градуального подъема, мы не видим других отклонений от русской произносительной нормы. Мы предполагаем, что градуальный подъем в этом кругу говорящих формируется независимо от тех явлений, которые наблюдаются в Одессе.

\section{Заключение}

В речи говорящих на русском языке встречается акцент, имеющий градуальное повышение частоты основного тона, начиная от предударного слога словоформы-носителя акцента и заканчивая заударными слогами. Этот акцент отсутствует в описаниях русской просодии, и мы предлагаем называть его градуальным подъемом.

В ряду неконечных шагов повествования градуальный подъем (имеющий высокие заударные), как правило, соседствует с ИК-3 (имеющим низкие заударные), поэтому градуальный подъем в русском языке можно рассматривать как фонетический вариант ИК-3 при выражении дискурсивной незавершенности. По нашим данным при выражении темы и да-нет-вопроса градуальный подъем, в отличие от ИК-3, в русском языке не используется. 
Градуальный подъем фигурирует в различных функциях как акцент, имеющий фонологический статус, в немецком [Grice, Baumann, Benzmüller 2005] и голландском [Gussenhoven 2005] языках, в новозеландском диалекте английского языка (Fletcher, Grabe, Paul Warren 2005), а также, насколько нам известно, и в других языках.

В русском языке градуальный подъем регулярно используется (а) в речи девушек (старшеклассниц и студенток) как фонетический вариант ИК-3 при выражении дискурсивной незавершенности, а также (b) в речи людей, испытавших влияние одесского регионального варианта русского языка.

В связи со статусом градуального подъема в отношении русской просодической нормы мы предлагаем использовать дифференцированный подход. В речи юных особ женского пола градуальный подъем предлагается рассматривать как гендерно-возрастной вариант русской нормы, а в речи говорящих обоего пола и различного возраста, которые, кроме градуального подъема, сохраняют другие особенности одесского диалекта (как суперсегментные, так и сегментные), - как ненормативное проявление регионального влияния.

\section{Литература}

Брызгунова Е. А. Интонация // Русская грамматика. Том 1. М. Наука, 1982.

Кибрик А. А., Подлесская В. И. (eds). Рассказы о сновидениях: Корпусное исследование устного русского дискурса. М.: ЯСК, 2009.

Палько М.Л. Интонация незавершенности текста в немецком языке в сопоставлении с русским, Компьютерная лингвистика и интеллектуальные технологии: Труды международной конференции «Диалог-2008». - М.: РГГУ, 2008. - Вып. 7 (14). - C. 416-419, available at: http://www.dialog-21.ru/digests/dialog2008/materials/ $\mathrm{html} / 65 . \mathrm{htm}$

Янко T.E. Интонационные стратегии незавершенного текста // Динамические модели. Слово. Предложение. Текст. М.: ЯСК, 2007.

Янко T.E. К проблеме сопоставительного анализа просодии: одесский региональный вариант русского языка vs. русская разговорная норма // Компьютерная лингвистика и интеллектуальные технологии. Вып. 14. Т.1. М.: РГГУ, 2015.

Boersma P., Weenink D. (2012). Praat: Doing phonetics by computer. Version 5.3.04. Online: http://www.praat.org/.

Fletcher J., Grabe E., Paul Warren P. Intonational variation in four dialects of English: the high rising tune // Prosodic Typology: The Phonology of Intonation and Phrasing. Oxford University Press, 2005.

Grice M., Baumann S., Benzmüller R. German Intonation in Autosegmental-Metrical Phonology // Prosodic Typology: The Phonology of Intonation and Phrasing. Oxford University Press, 2005.

Gussenhoven C. Transcription of Dutch Intonation // Prosodic Typology: The Phonology of Intonation and Phrasing. Oxford University Press, 2005. 


\section{Tatiana E. Yanko \\ Institute of Linguistics of the Russian Academy of Sciences \\ (Russia, Moscow) \\ tanya_yanko@list.ru}

\section{INTONATIONAL VARIATION IN RUSSIAN*}

This paper aims at analyzing the intonational variation in expressing the discourse continuity in Russian. The main means of expressing the discourse continuity in Russian is the rise of frequency on the tonic syllable of the accent-bearer of continuity followed by the falling post-tonics (if any) or IK-3 in the terminology of Bryzgunova. The specific intonational patterns which also express the discourse continuity but at the same time carry some additional meanings are: 1) IK-4 (the fall on the tonic syllable followed by the rise on the post-tonics) which expresses the so-called "ordered account of events", and 2) IK-6 (the rise on the tonic syllable followed by the level post-tonics) which refers to recollecting, or dreaming of events taken place in the past, or going to take place in the future. However, the working corpus of the spoken speech (which has been set up specifically for this analysis) shows that IK-3 as a marker of the discourse continuity has a phonetic variant which has the rise on the tonic syllable followed by the further rise on the post-tonics. I call this pitch accent the gradual rise. The gradual rise exists in a variety of English dialects, German, Dutch, and in the regional variant of Russian, namely in Odessa Russian. Nevertheless, in the young girls' speech in Moscow and Saint-Petersburg the gradual rise appears as a phonetic variant of IK-3. The gradual rise also occurs in the speech of people influenced by the so-called Odessa accent. I propose to consider the gradual rise in the speech of young girls (high school, or university students) as a genderand age-based pattern of standard Russian. While in the speech of the speakers of both genders and various age who exhibit other parameters (both intonational and segmental) of Odessa Russian, the gradual rise should be viewed as a result of the non-standard regional influence.

Key words: intonation, intonational variation, young girls, regional variant, standard Russian, discourse continuity, gender-based pattern, age-based pattern.

\section{References}

Bryzgunova E. A. Intonatsiya [Intonation] // Russkaya grammatika. Tom 1. M. Nauka, 1982.

Kibrik A.A., Podlesskaya V.I. (eds). Rasskazy o snovideniyakh: Korpusnoe issledovanie ustnogo russkogo diskursa [The night-dreams stories: corpus study of the Russian discourse]. M.: YaSK, 2009.

* This study has been granted the financial support of the Russian Foundation for Humanities (project N 16-06-00226). 
Pal'ko M.L. Intonatsiya nezavershennosti teksta v nemetskom yazyke v sopostavlenii s russkim [Intonation of incompleteness in German in comparison with Russian] // Komp'yuternaya lingvistika i intellektual'nye tekhnologii. Trudy mezhdunarodnoy konferentsii «Dialog-2008». — M.: RGGU, 2008. — Vyp. 7 (14). — S. 416-419, available at: http://www.dialog-21.ru/digests/dialog2008/materials/html/65.htm

Yanko T.E. Intonatsionnye strategii nezavershennogo teksta [Intonational strategies of incompleteness] // Dinamicheskie modeli. Slovo. Predlozhenie. Tekst. M.: YaSK, 2007.

Yanko T.E. K probleme sopostavitel'nogo analiza prosodii: odesskiy regional'nyy variant russkogo yazyka vs. russkaya razgovornaya norma [Contrastive analysis of prosody: Odessa regional Russian vs. standard Russian] // Komp'yuternaya lingvistika i intellektual'nye tekhnologii. Vyp. 14. T.1. M.: RGGU, 2015.

Boersma P., Weenink D. (2012). Praat: Doing phonetics by computer. Version 5.3.04. Online: http://www.praat.org/.

Fletcher J., Grabe E., Paul Warren P. Intonational variation in four dialects of English: the high rising tune // Prosodic Typology: The Phonology of Intonation and Phrasing. Oxford University Press, 2005.

Grice M., Baumann S., Benzmüller R. German Intonation in Autosegmental-Metrical Phonology // Prosodic Typology: The Phonology of Intonation and Phrasing. Oxford University Press, 2005.

Gussenhoven C. Transcription of Dutch Intonation // Prosodic Typology: The Phonology of Intonation and Phrasing. Oxford University Press, 2005. 


\title{
ЛЕКСИКА И ГРАММАТИКА: УЗУС И НОРМА
}

\author{
Е. Г. Борисова \\ Московский государственный лингвистический университет \\ (Россия, Москва) \\ egbor@mail.ru
}

\section{О ФАКУЛЬТАТИВНЫХ ФРАГМЕНТАХ СМЫСЛА ВЫСКАЗЫВАНИЯ (ЕЩЕ РАЗ О СЛОВАХ-ПАРАЗИТАХ)}

Статья посвящена рассмотрению лексических единиц, употребление которых представляется избыточным с точки зрения передаваемой информации. В центре внимания - наиболее типичный класс слов, отличающийся «пустотой» содержания - слова-паразиты (hesitators, time fillers или empty words). Выявляются источники таких слов, и предлагается модель говорения, описывающая экспликацию модальной рамки.

Ключевые слова: высказывание, модус и диктум, речевой акт, слова-паразиты, маркеры дискурса, междометия.

\section{1. Что такое «слова-паразиты» и насколько они дозволяются правилами культурной речи?}

Общие установки грамотной и правильной речи соответствуют Максиме количества из постулатов Грайса: сказано должно быть не больше и не меньше, чем нужно для выражения замысла. Реальное устное общение нарушает это положение. Формирование высказывания связано и с затруднениями в выборе средств, и с внезапными изменениями программы высказывания, что влечет за собой недоконченные фразы, рассогласование, повторы [Fraser, Knowels 1987]. С этой же проблемой связывают и употребление слов-паразитов, т.е. единиц, не несущих информации и в этом смысле нарушающих грамотность устной речи. Употребление таких слов имеет отношение и к области культуры речи, и к общей теории языка [Шмелев 1998].

С позиций культуры речи употребление слов-паразитов безусловно осуждается. Однако степень допустимости этих единиц варьирует от неприемлемых до допустимых. Полностью неприемлемыми признаются слова из обсценной лексики, «хезитаторы воспоминания», т.е. собственно хезитаторы: это самое, того-этого, 
как его там и т.п. Также в разные периоды имеются «модные» хезитаторы (о моде на служебные слова см. [Борисова 2014]), которые вызывают особую неприязнь ревнителей чистоты речи. В 90-е годы таковым было слово как бbl, затем типа.

Однако в литературных текстах, передающих речь культурных людей, можно встретить явные хезитаторы доложу я вам, знаете ли, прямо скажем и т.п.:

(1) Но, видите ли, квартира... э-э-э... как бы это сказать поточнее... [НКРЯ]

(2) Так сказать, э-э-э... в соответствии с Гражданским кодексом. [НКРЯ]

И в устных выступлениях даже высокообразованных людей некоторое количество междометий э-э-э и $м$-м-м иногда не только терпят, но и приветствуют. Таким образом, можно исследовать степень приемлемости разных хезитаторов.

С точки зрения теории языка возникает задача определить источник возникновения хезитаторов и объяснить (с учетом неизбежных скидок на узус) варьирование приемлемости «слов-пустышек».

\section{2. Происхождение слов-паразитов}

Можно отметить следующие разряды слов, послужившие источником хезитаторов.

Во-первых, это междометия, причем в первую очередь, первообразные. В роли «заполнителя времени» выступают любые междометия структуры «долгий гласный» - $А a а$, Ооо, Ууy. Однако словом-паразитом считают преимущественно эээ. Это связано с тем, что междометия в функции хезитации в большинстве своем сохраняют свои значения, как бы размыты они ни были сами по себе. Однако для эээ в паразитическом употреблении это не выполняется.

Заполнять время могут и усилительные частицы. Причем некоторые: вот, ну, nросто - признаны в функции паразитов [Gainutdinova 2014].

Кроме того, в функции слов-«пустышек» используются дискурсивные слова:

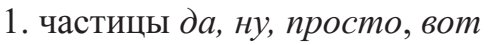

2. «вводные слова» так сказать, собственно

3. значащие слова как $б b l$, короче

4. ругательства черт, блин и др.

Отдельно отметим уже упомянутые нами вставные фрагменты высказывания, отражающие взаимодействие с адресатом (доложу я вам, можно сказать), припоминание это самое, как его. Это заставляет обратить внимание на возможность появления в речи элементов, значение которых дублирует уже переданную информацию, касающуюся речевых действий говорящего.

\section{3. Вербализация модальной рамки высказывания}

В связи с проблемой «пустых носителей информации» возникает и другая: проблема вербализации имплицитной информации в тексте.

Наряду с эксплицитной информацией, выраженной языковыми средствами: лексикой, интонацией, грамматическими конструкциями, - в смысл 
высказывания входит также значение модальной рамки [Арутюнова 1976]. Такое разделение соответствует разделению на модус и диктум, осуществленному еще Ш. Балли.

Любой речевой акт включает в себя смысл: «говорящий передает информацию адресату». К этому можно добавить также постоянный смысл «говорящий обращается к адресату». Кроме того, речевой акт может включать запрос информации, сообщение о желательности какого-то действия (просьба, приказ, совет и т.п.). Этот смысл обычно передается самим фактом говорения (как устного, так и письменного).

В некоторых случаях отдельные элементы этой рамки эксплицируются. В первую очередь, это относится к обозначению адресата: нередко, особенно в письменной речи, обращение желательно обозначить явно, особенно в начале коммуникации. В дальнейшем в этом, как правило, нет необходимости. Иногда бывает нужно и обозначение речевого акта, обычно тогда, когда он особый: клянусь, обещаю. Эта функция возлагается на слова-перформативы. В остальном, как правило, необходимости в экспликации нет: тип акта, равно как адресат, понятен из структуры сообщения и хода общения.

Тем не менее, мы встречаем немало случаев, когда эти элементы эксплицируются. Начнем с обращений. В устной речи и даже в ее фиксации в виде художественной литературы мы нередко встречаем обращения в середине коммуникации и даже отдельной реплики.

(3) «Ну почему никто не пьёт эту водку, её ведь надо будет кому-то выпить, чтобы она не пропала?» - воскликнула наконец она. — «Пайка — это святое. Пайку, что покойнику, что живому, отдай и забудь. Понимаете, Леночка, здесь всё глубоко душевно, хоть снаружи вроде бы обыкновенный натюрморт. Стакан- это могила. Чёрным хлебом накрывают - так могилу засыпают землёй. Водка в стакане, она же душа» [НКРЯ].

Здесь мы видим обращение Леночка, которое в принципе не нужно: из контекста понятно, к кому обращается говорящий. Тем не менее, появление этого обращения представляется коммуникативно оправданным: уменьшительная форма позволяет уточнить тональность, отношение к собеседнику.

Далеко не всегда экспликация прагматических компонентов высказывания может быть столь легко объяснима за счет семантики слов, составляющих «лишний» фрагмент. Иногда сам факт произнесения обращения в условиях очевидности адресации может свидетельствовать о дополнительном привлечении внимания, что влечет за собой подчеркивание значимости дальнейшего сообщения или введение новой информации, выявление причинных связей, повышение убедительности и целый ряд других имплицитных смыслов:

(4) Флотов был остзейский немец. Прадед его был из Кёнигсберга, фон Флотов, у него много родни там оставалось. Скрывал он... - Да что ты говоришь, Леночка? Это просто поразительно... Значит, и он был из виноватых [НКРЯ].

В этом примере обращение подчеркивает эмоциональность вопроса, передает удивление. 
(5) Так что не отнекивайся. На публику ты, Андрей Алексеевич, работаешь! — резюмировал Федчин. - И хочешь быть в изентре внимания. Скажите, Вероника Васильевна, - повернулся Филипп к Веронике, которая во время нашего разговора сосредоточенно ела пирожок с мясом. - А вот, когда вы вместе с Андреем Алексеичем учились, он тоже был таким? [НКРЯ].

В данном случае первое обращение «Андрей Алексеевич» явно лишнее, но оно позволяет подчеркнуть упрек (возможно, значимо и обращение по имени-отчеству в ты-коммуникации). В то же время обращение «Вероника Васильевна» полностью оправдано сменой адресата и вряд ли может быть опушено без нарушения этикета общения.

В целом вопрос экспликации прагматических элементов сообщения, затронутый здесь, требует гораздо более внимательного и глубокого изучения. Это относится не только к обращениям, но и к экспликации перформативной части модальной рамки, т.е. к высказываниям хочу сказать, утверждаю и т. п. Во многих случаях их употребление несет определенную смысловую нагрузку:

(6) Завершая наш разговор, хочу сказать, что жилищные споры - это не только самая распространённая категория гражданских дел, рассматриваемых судами общей юрисдикции, но и одна из самых сложных [НКРЯ].

(7) Я хотел бы отметить, что мы закончили следствие в рекордные сроки за 29 дней, хотя там было назначено 183 экспертизы, а потерпевшими были признаны 172 человека. Хочу сказать, что по другому аналогичному случаю, когда в Ростове-на-Дону пневмонией и ОРЗ заболели более 200 солдат и один из них, к сожалению, тоже скончался (это случилось в январе 2003 г.- М. Г.), уже состоялся приговор [НКРЯ].

В примере (7), где два раза употреблены экспликаторы модальной рамки, вопрос об их смысловой нагрузке вызывает сомнения. В употреблении выражения хотел бы отметить можно усмотреть привлечение внимания. А в словосочетании хочу сказать это значение если и просматривается, то в недостаточной степени. В целом при анализе экспликации речевых действий, составляющих модальную рамку, имеется полный спектр смысловой нагруженности - от содержательно значимых (причем содержание оказывается различным) до полностью «пустых». Однако в большинстве случаев они могут быть опущены, нередко - безо всякого ущерба для понимания.

\section{4. Факультативные элементы сообщения}

Аналогичный статус имеет большое количество так называемых дискурсивных слов, которые помогают адресату восстановить намерения говорящего. При этом степень выраженности значений этих слов может варьировать.

Рассмотрим дискурсивное слово собственно, а также фразеологизованное сочетание собственно говоря. В ряде предложений они имеют обычное для дискурсивных слов значение, т.е. могут выражать противопоставление ожидаемому: 
(8) [Магистр Йода, nick] Ненавижу актера из третьей части, играющего Дракулу (собственно из-за и не стал смотреть Побег) [НКРЯ].

Передаваемый этими единицами фрагмент смысла «не что-то другое, что можно было предположить, а именно Х» помогает слушателю точнее понять замысел говорящего [Кобозева, Щедрина 2009]. Однако чаще всего слушающий может понять этот замысел и без такой помощи, ср.:

(9) Деньги - это не так важно. Я, собственно не ради прибыли.

(9') Деньги - это не так важно. Я не ради прибыли.

Таким образом, употребление слова оказывается оправданным в разной степени. Однако признать неоправданность в ходе разговора оказывается непросто: слушающий понимает говорящего, но вряд ли вдумывается, помогло ли ему в этом слово собственно или и так всё было ясно. Получается, что слово собственно может быть использовано как пустое и в то же время в глазах слушателей это употребление выглядит оправданным, как пустое слово-паразит не воспринимается.

Аналогичный анализ может быть проведен и относительно большого числа единиц, реально используемых как хезитаторы. Даже печально известные слова типа, как бы вполне могут интерпретироваться в ряде случаев как уместные, употребленные со значением. Однако огромная их распространенность в роли словпаразитов, причем связываемая с невысокой репутацией употребляющих, «выдает» хезитацию (иногда несправедливо).

Сказанное относится не ко всем словам, трактуемым как «пустые». Несколько выражений, характеризующих именно процесс воспоминания: как его, это самое и ряд других, откровенно несут признаки «заполнителей времени воспоминаний» и, соответственно, не могут быть замаскированы под употребленные для других целей. Поэтому они практически все осуждаются с позиций культуры речи. Естественно, осуждение вызывают и нецензурные (обсценные) слова, выступающие в роли сложных междометий.

\section{Заключение}

Таким образом, мы видим, что в ряду единиц, используемых в роли хезитаторов, которые более или менее приемлемы с точки зрения культуры речи, основное место занимают слова, выражения и конструкции, которые допускают факультативное употребление. Это экспликаторы модальной рамки и действий говорящего по управлению пониманием адресата. Даже когда эта экспликация избыточна, они могут быть выданы за осмысленные употребления, поскольку выражают тонкие и слабо проверяемые намерения говорящего. Иными словами, при необходимости протянуть время лучше скрыть тот факт, что говорящий подыскивает нужное слово. А это возможно, если он использует те средства, употребление которых может оказаться факультативно, дублирует смыслы, выраженные имплицитно.

Именно поэтому, видимо, я хочу сказать, имею в виду, так сказать и т.п. выглядят в речи допустимо. А как его, это самое, в явном виде эксплицирующее 
поиск нужных слов, вызывает неодобрение. Конечно, это не единственная причина неодобрения: на какие-то единицы наложен запрет традицией. В других случаях мода, вызывающая неоправданный всплеск употреблений, заставляет прилагать осознанные усилия по избавлению от назойливого слова, как это происходит с как бы.

В целом использование единиц, связанных с речевым поведением, заслуживает подробных исследований.

\section{Литература}

Fraser B., Knowles, G. Patterns of Spoken English: An Introduction to English phonetics — London, Longman, 1987.

Sarbiya Gaynutdinova. Ну, как бы, всё! Слова-паразиты как дискурсивные маркеры в монологах и в устных последовательных переводах // http:/tampub.uta.fi/ bitstream/handle/10024/95985/gradu07190.pdf; sequence=1, 2014.

Арутюнова Н.Д. Предложение и его смысл. Логико-семантические проблемы. - М.: Наука, 1976. - 382c.

Борисова Е.Г. Мода и узус: моделирование влияния социума на речь // Мода в языке и коммуникации. РГ Сб.ст. Сост. И ред. Л. Л. Федорова, М.: РГГУ, 2014 c. $47-56$.

Борисова Е.Г. Роль дискурсивных слов в управлении пониманием текста //Лингвистика и интеллектуальные технологии: материалы Междунар. конф. «Диалог» (Бекасово, 30 мая- 3 июня2012 г.). М.: Изд-во РГГУ, 2012. Т. 1, вып. 11 (18), с. 93102.

Дараган Ю.В. Функции слов-«паразитов» в русской спонтанной речи // Русская филология. Сборник научных работ молодых филологов, № 11, Тарту, 2000, c. 201-209.

Земская Е.A. Русская разговорная речь: лингвистический анализ и проблемы обучения. - М., 1987.

Кобозева И. М., Щедрина Н.С. Дискурсивные единицы собственно и фактически как средство манипуляции представлениями адресата // Эффективность коммуникации. Сб. статей М.: МГПУ, 2009 - С. 95-101.

Кокошкина И.В. Десемантизированные элементы дискурса. Автореф. канд. филол. н. Сратов, 2011.

Ладыженская Б. Я. Особенности организации устной спонтанной речи (вставные элементы в речевом потоке). Дис. канд. наук. - М., 1985.

Шмелев А. Д. Слова-паразиты и их роль в построении дискурса // Русский язык в контексте современной культуры. Екатеринбург, 1998. 


\author{
Elena G. Borisova \\ Moscow State Linguistic University \\ (Russia, Moscow) \\ egbor@mail.ru
}

\section{NON-OBLIGATORY COMPONENTS OF UTTERANCES (NEW APPROACH TO "EMPTY WORDS")}

The article is focused on lexical units that seem to be unnecessary for delivering new information. The most typical class of "empty words" are hesitators or time fillers. Using such words is often regarded as the violation of rhetoric rules. Still some cases are regarded as more relevant than others. The article analyses this phenomenon highlighting the role of the modal frame of an utterance. It is declared that some words verbalizing modal frame and other nuances that are expressed by the speech acts (the sense of addressing, uttering etc.) are non-obligatory but nevertheless can be expressed by verbs and particles. This expressing can be a mode of hesitating still it looks like 'legal' usage of these words. Such hesitators are not regarded as the speech rules violation while others that cannot be justified by such explanation, are.

Key words: utterance, modus and dictum, speech act, hesitator, time filler. Discourse markers, interjections.

\section{References}

Arutyunova N.D. Predlozhenie I ego smysl Logiko-semanticheskie problem [Sentence and its sense. Logical and semantic problems]. M. Nauka Publ. 1976.

Borisova E. G. Rol diskursivnyh slov v upravlenii ponimaniem teksta [Discourse markers used for governing understanding texts]. Computational Linguistics and Intellectual Technologies: Proceedings of the International Conference "Dialog" Bekasovo 30.05- 3.06.2012. M.: RGGU, 2012. V.1, pp. 93-102.

Borisova E.G. Moda i uzus: modelirovanie vlijanija sotziuma na rech [Fashion and usage; models of social influence on speech]. L. Fedorova (ed) Moda v jazyke i kommunikatsii [Fashion in Speech and Communication]. M.: RGGU, 2014, pp. 47-56

Daragan J. V. Funkcii slov-"parazitov" v russkoj spontannoj rechi [Functions of fillers in spontaneous Russian Speech]. Russkaja filologija., Sbornik nauchnyh rabot molodyh filologov. No11, Tartto, Tartu Ülikooli Kirjastus, 2000. pp. 201-209.

Fraser B., Knowles, G. Patterns of Spoken English: An Introduction to English phonetics. London, Longman. 1987.

Sarbiya Gaynutdinova. Nu, kak by, vsjo - slova-parazity kak diskursivnye markery v monologah I russkih posledovatelnyh perevodah $[\mathrm{Nu}$, kak by, vsjo- empty words in the role of discourse markers in monologues and Russian translations]. Tampereen yliopisto 2014. http://tampub.uta.fi/bitstream/handle/10024/95985/gradu07190. pdf;sequence $=1$ 
Kobozeva I. M., Schedrina N. S. Diskursivnye edinitsy sobstvennoi fakticheski kak sredstvo manipulatii predstavlenijami adresata [Discourse entities sobstvenno and fakticheski as a tool of manipulation with representations of the Addressee]. Effektivnost' kommunikatsii [Efficiency of Communication]. Moscow. pp. 95-101.

Kokoshkina I. V. Desemantizirovannye elementy diskursa [Desemantized elements of Discourse]. Thes ...PhD Saratov. 2011.

Ladyzhenskaya B. Y. Osobennosti organizatsii ustnoj spontannoj rechi (vstavnye elementy $v$ rechevom potoke) [Specifics of spontaneous oral speech organization; implementic elements in speech]. PhD Thesis, V. 1985.

Shmelev A.D. Slova-parazity $i$ ich rol v posroenii diskursa [Time fillers and their role in discourse building]. Russkij jazyk v kontekste sovremennoj kultury, Ekaterinburg. 1998.

Zemskaya E. A. Russkaja razgovornaja rech: lingvisticheskij analiz i problemy obuchenija. [Russian informal speech: linguistics and teaching] M. Nauka Publ. 1987. 


\author{
И. Т. Вепрева, Н. А. Купина \\ Уральский федеральный университет \\ (Россия, Екатеринбург) \\ irina_vepreva@mail.ru,natalia_kupina@mail.ru
}

\title{
ЗАМЕТКИ ОБ УЗУАЛЬНЫХ СДВИГАХ В ЛЕКСИЧЕСКОЙ СЕМАНТИКЕ*
}

В статье на материале письменной речи рассматриваются узуальные сдвиги в лексической семантике, свидетельствующие об изменении кодифицированных языковых норм. На основе базы данных «Интегрум» осуществляется корпусная выборка высказываний, содержащих высокочастотные нестандартные сочетания лексемы девушка и лексемы юбилей. Установлено, что при реализации значения «молодая женщина / женщина, которая выглядит молодо» слово девушка употребляется в свободных синтаксических позициях. Типичными становятся модификации значения: девушка - юная молодая женщина, не вступившая в официальный брак; девушка - юная молодая женщина, расторгнувшая официальный брак и имеющая от этого брака детей. На основе критерия частотности сформулирован вывод о взаимосвязи сдвигов в лексической семантике с изменениями в системе традиционных семейных ценностей. В процессе функционально-семантического анализа лексемы юбилей в лингвокультурном контексте текущего времени выявлены факторы, обусловливающие расширение лексического значения слова. Культурный ограничитель (круглая дата) становится факультативным. Формируется тенденция свободной интерпретации смыслового наполнения лексемы юбилей. Характерно, что языковая кодификация поддерживается кодификацией документально-законодательной. В том случае, когда юбилейная дата является результатом личностного аксиологического выбора, наблюдается тенденция к отождествлению значений слов юбилей и годовщина. Отмечено, что узуальные сдвиги в контактной и дистантной лексической сочетаемости, которые приводят к изменениям кодифицированных лексических значений, обнаруживают связь с аксиологической реальностью.

Ключевые слова: норма, узус, значение слова, лексическая сочетаемость, аксиологический

* Работа выполнена при финансовой поддержке РФФИ, грант № 15-04-00239/17-ОГОН «Национальные базовые ценности и их отражение в коммуникативном пространстве провинциального города: традиции и динамика». 
Общим местом при характеристике современной языковой ситуации является мысль о том, что отсутствие жесткой лингвистической цензуры повлекло за собой ослабление кодифицированных языковых норм. Нарушение языковых правил привело к массовым речевым ошибкам, см: [Гловинская 1996]. Также наблюдается легализация ошибок в письменной речи.

Объект наблюдений - узуальные сдвиги в лексической семантике. В качестве предмета исследования взяты лексические единицы девушка и юбилей, активно использующиеся в повседневном общении. Материалом для исследования послужили письменные источники, свидетельствующие о закреплении узуального употребления лексем в литературном языке.

Первая единица анализа - лексема девушка в словосочетаниях беременная девушка, разведенная девушка, девушка с ребенком. В современной речевой практике слово девушка в значении «молодая женщина» употребляется в строго закрепленной синтаксической позиции обращения: «Обращение к молодой женщине (разг.)» [Толковый словарь 2008: 185]. Лексикографическое закрепление данного факта коммуникативной практики объяснимо. Действительно, отсутствие общепринятого одобряемого обращения к женщине послужило причиной заполнения языковой лакуны лексемой девушка как вежливой формы обращения к молодой женщине (зачастую не только к молодой).

Динамически меняющаяся лингвокультурная ситуация демонстрирует дальнейшее развитие отмеченного значения. Преодолевая закрепленную синтаксическую позицию обращения, слово девушка в значении «молодая женщина» стало употребляться в других синтаксических позициях. Современные контексты подтверждают сложившуюся тенденцию, например: Сегодня никто не уступил место в марирутке беременной девушке (Комсомольская правда; 07.05.2016).

Корпусная выборка материала (использовалась база данных «Интегрум», содержащая свыше трех с половиной тысяч источников СМИ) дает возможность собрать репрезентативный массив контекстов, позволяющий уточнить и конкретизировать лексическую семантику. Обращение к базе данных выявило 1559 контекстов, включающих сочетание беременная девушка, что в 10 раз превышает употребительность словосочетания беременная молодая женщина (153 контекста).

Наблюдения показывают, что словосочетание беременная девушка употребляется по отношению к очень молодым, а точнее, юным женщинам (выборка высказываний, включающих словосочетание юная женщина составила 1790 контекстов, что сопоставимо с употребительностью словосочетания беременная девушка). Например: На памяти госпожи Жидковой Законом воспользовались семь беременных девушек 14-15 лет (Коммерсантъ; 08.12.2004); Несомненно, существуют группь женщин с высоким риском, например, беременные девушки-подростки (Лечащий врач; 15.10.2005); В Оренбурге на одной остановке мы увидели беременную девушку, то есть женщину, но она была так молода, что хотелось назвать ее девочкой (Новый мир; 15.11.2009).

Анализируемое словосочетание активизируется в том случае, когда речь идет о молодых женщинах, не вступивших в официальный брак или живущих в так 
называемом гражданском браке: Аслану Черкесову разрешили расписаться с беременной девушкой (Комсомольская правда; 10.03.2011); Андрюша хочет уйти к своей беременной девушке, с которой уже год тайно встречается (Культура; 07.03.2014); Третьего дня по телевидению прошёл сюжет из криминальных новостей: «Потерпевшая беременная девушка пятнадиати лет живёт с подозреваемым в гражданском браке» (Литературная газета; 05.06.2007); Несколько месяцев назад жить в Вазиристан уехали две пары, некий 24-летний Ян с 22-летней женой Александрой и 20-летний мужчина с 17-летней беременной девушкой (Московский Комсомолец; 07.04.2010); 15-летняя беременная девушка зарегистрировала брак с 20-летним парнем с согласия родителей (Наша версия (Москва; 22.02.2016); Ему было 24 года, у парня осталась беременная девушка, 16 октября должна была быть свадьба (РБК; 23.10.2015).

Оттенки значения, которые удалось выявить, приводят к выводам лингвоаксиологического характера: в речевой практике отражается расшатывание системы традиционных семейных ценностей (ранняя половая жизнь в возрасте, переходном от отрочества к юности; половые отношения до заключения официального брака). Критерий частотности позволяет сформулировать узуальное значение лексемы девушка: «юная или молодая женщина, живущая в неофициальном браке».

Реализация значения «молодая женщина» наблюдается в словосочетаниях разведенная девушка, девушка с ребенком. Например: Вопрос: откуда у молодой разведенной девушки средства на такую роскошную жизнь? (Комсомольская правда; 06.07.2010); К кастингу также допускаются разведенные девушки с детьми (Метро (Челябинск); 09.07.2013). Активными бывают только молодые разведенные девуики с ребенком на руках, а вот те, кто не был замужем, почему-то не торопятся (Краснодарские известия; 30.07.2016).

Материал обнаруживает возможность употребления сочетаний с количественными указателями: Девуика с двумя детьми в обнимку рассказывает о себе, и ее дети в данном случае служат как бы товарным образиом (Комсомольская правда; 13.12.2016); Анатолий Степанович так и сделал, попросил 22-летнюю девушку с двумя детьми уйти к бывшему мужу (Яикъ (Оренбург); 28.11.2007); $B$ 2007м девушка с тремя детьми переехала в Кению и оборвала все связи с родиной (Комсомольская правда; 24.09.2013); А если брать возрастные рамки? - Была мама, которой исполнилось 14 лет. Другой случай - 19-летняя девушка с... тремя детьми (Хакасия (Абакан); 18.05.2016); Девуика с тремя детьми (из квартиpbl, где и рухнул пол) пока переехала жить к матери (Ленинская смена (Нижний Новгород); 14.02.2013).

Таким образом, в современной устной и письменной речи лексема девушка в значении «молодая женщина» / «женщина, которая выглядит молодо» употребляется в свободных синтаксических позициях. При этом у слова появляются новые смысловые приращения: речь может идти о молодых женщинах, не вступивших в официальный брак или живущих в так называемом гражданском браке; молодых женщинах, расторгнувших официальный брак и имеющих детей от этого брака. 
Второй единицей анализа стало слово юбилей, которое в современном русском языке также претерпевает смысловые изменения.

Слово юбилей, см. [Крысин 2005: 937], пришло в русский язык в эпоху Петра I через немецкий язык (Jubiläum) из латинского; восходит оно к древнееврейскому Jôbêl - так называли бараний рог и звуки рога, возвещавшего о наступлении Года свободы, который наступал раз в 50 лет. Важной особенностью древнееврейского юбилея была идея прощения: пятидесятый год начинался празднованием Дня очищения и «трубным гласом» бараньего рога. В дореволюционных словарях русского языка фиксируется значение, в котором слово закрепилось в девятнадцатом веке: «Юбилей - это торжество, празднество по поводу протекшаго пятидесятильтія, стольтія, тысячельтія. Юбилейное торжество. Юбилей пятидесятильтія службы, докторства. Ю. тысячел втіъя Руси» [Даль Т.4 1994: 1543].

Современные толковые словари регулярно отмечают два значения, которые сложились к новейшему времени: «1. Годовщина чьей-н. жизни, деятельности, существования кого-чего-н (обычно о круглой дате). Двухсотлетний ю. университета. 2. Празднование по этому случаю. Приглашен на ю.» [Толковый словарь 2008: 1131].

Обратим внимание на уточняющий компонент в толковании первого значения. Речь идет «о круглой дате», т.е. «о дне рождения, юбилее, исчисляемом только десятками. У него сегодня круглая дата - сорок лет» [Толковый словарь 2008: 180]. Попутно отметим, что есть особенности датировки юбилеев в странах Азии: юбилейный год должен состоять из одинаково повторяющихся цифр. В частности, Тамканский университет на Тайване в 2016 году праздновал свой юбилей, и юбилейный слоган университета звучал так: «Тамкану 66. - Вперед, навстречу 99-летнему юбилею».

Согласно нормативным словарям современного русского языка, юбилей - это праздник в честь круглой годовщины (заканчивающейся десятками) жизни человека или его деятельности, существования службы, государства, организации. В этот день чествуют человека или организацию, которым исполнилось немалое количество лет, достаточное, чтобы подвести итог осуществленной деятельности. Возникают правомерные вопросы: что считать «круглым» и в то же время «крупным» числом; когда можно подводить итоги? Данная неопределенность является основной причиной развития лексической семантики.

Анализ отдельных высказываний и текстов позволяет утверждать, что в современной речевой практике происходит расширение значения юбилей по нескольким параметрам.

Смещается временной промежуток юбилеев. Сегодня отмечают не только круглые даты. Уже традиционно стали отмечать количество лет, кратное пяти. Празднуют юбилеи в 55, в 65 лет и т.д., например: Великолепному струнному квартету им. Бородина в эти дни исполняется 55 лет. И ещуе один славньй юбилей связан с этим коллективом. 75 лет Валентину Берлинскому, одному из основателей и бессменному лидеру квартета (Аргументы и факты; 19.01.2000); 55 - дата не круглая. Но 55 лет Победы в Великой Отечественной войне - юбилей (Аргументы и факты; 03.05.2000). 
Молодеет возраст юбиляра. Например: На минувшей неделе Филипп Киркоров отметил первый юбилей своей дочери - 5 лет (Комсомольская правда; 08.12.2016); Обойдемся нынешним составом, у которого тоже свой юбилей мы вместе пять лет, как раз в декабре 2003-го и собрались (Известия; 25.11.2008).

Возраст юбиляра молодеет настолько, что перестает быть кратным даже пяти. В данном случае это относится к дням рождения различных организаций. В наш быстротечный и изменчивый двадцать первый век дождаться первой круглой и крупной даты надеются немногие, поэтому празднуют юбилеи чаще. Приведем примеры: В этом году проект «Библионочь» отметил маленький, но всетаки юбилей - три года (Независимая газета; 22.05.2014); 1 января телесеть ТНТ отметила маленький юбилей - два года (Новая газета; 10.01.2000); Свой первый юбилей - один год - коллектив Тамбовского молодежного театра справит 17 декабря (Тамбовский курьер; 02.11.2010); 18 и 19 сентября в международном театральном иентре Легкие люди будут праздновать забавный юбилей: один год и один месяц со дня основания центтра Санкт-Петербургские ведомости (Санкт-Петербург; 17.09.2010); Глава железнодорожной монополии Олег Белозеров отмечает свой первый юбилей на посту главы РЖД - 15 июня исполняется ровно 300 дней, как он сменил на этом посту Владимира Якунина (Компания; 13.06.2016).

Расширяется круг юбиляров. Юбилей можно устроить по любому поводу, даже весьма незначительному: Дело в том, что в этот день у предприятия маленький юбилей: два года со дня продажи первого сотового телефона в Ульяновске (Симбирский курьер; 11.09.1997); В понедельник в Казани отметили «мальй юбилей» - два года с того дня, как столицу Татарстана назвали хозяйкой Универсиады-2013 (Челнинские известия (Набережные Челны); 04.06.2010); Скоро у вас, можно сказать, будет печальный юбилей - два года назад вы получили тяжелую травму - порезали коньком ахиллово сухожсилие (Советский Спорт; 01.11.2003); 1 января 2009 года жители деревянного многоквартирного дома на улице Таврической, 4а, в городе Томске отметят печальный юбилей — два года с момента пожсара, и до сих пор их дом непригоден для жилья (Томская неделя; 19.12.2008); В марте у потерявиих работу жителей Гусевского района своеобразный юбилей: три года, как им прекратили регулярную выплату пособий по безработице (Калининградская правда; 25.02.1999); Фактически сегодня юбилей - пять лет, как День птиц празднуется уже в новой России (Солидарность; 07.04.2004); Неудивительно, что вскоре мы отметим скромный юбилей два года пребывания в "черном списке» ФАТФ (Международной организации по противодействию легализации (отмыванию) преступных капиталов (Московская правда; 08.06.2002).

Тенденция свободной интерпретации лексемы юбилей - это факт не только текущего времени. В Советском Союзе лексема юбилей получила нормативно-законодательную кодификацию. Известно, что существовало несколько постановлений ЦК КПСС и Совета Министров «О порядке празднования юбилеев». Первое постановление фиксировано 1925 годом. Следующее постановление Центрального 
комитета КПСС и Совета министров СССР «О наведении порядка в праздновании юбилеев» вышло 12 декабря 1958 года. В нем отмечается, что за последнее время «необоснованно и произвольно устанавливаются всякого рода юбилейные даты». В связи с этими обстоятельствами Центральный Комитет КПСС и Совет Министров Союза ССР постановляют: памятные даты исторических событий, юбилеи массовых общественных организаций, отдельных крупных предприятий, научных учреждений и учебных заведений в дни пятидесятилетия, столетия и далее через пятьдесят лет со дня существования организации или свершения события. Юбилейной датой для отдельных лиц считать пятидесятилетие со дня рождения или другое последующее затем десятилетие. В постановлении подчеркивается, что юбилеи необходимо отмечать скромно и юбилейную дату того или иного деятеля можно также отмечать за счет личных средств.

С распадом Советского Союза эти постановления утратили свою регламентирующую функцию. В сегодняшней практике российские учреждения устанавливают свои правила и нормативы празднования юбилейных дат. Приведем в качестве примера фрагмент целевой программы Мытищинского муниципального района на 2013-2015 гг.: «Единовременная денежная выплата в связи с юбилеем назначается и выплачивается жителям, достигшим юбилейного возраста 70, 75, 80, 85, 90, 95 лет, зарегистрированным на территории Мытищинского муниципального района».

Таким образом, анализ функционирования лексемы юбилей в современном русском языке обнаруживает определенную закономерность: языковая кодификация поддерживается кодификацией нормативно-законодательной. В тех случаях, когда юбилей проводится за свой, а не за государственный счет, значение лексемы юбилей получает свободную интерпретацию и может отождествляться со значением лексемы годовщина - «календарная дата, отмечающая, что со времени какого-либо события прошел очередной год» [Толковый словарь 2008: 158]. При этом культурный ограничитель «круглая дата» становится факультативным, а сама дата является результатом личностного аксиологического выбора.

Узуальные сдвиги в контактной и дистантной лексической сочетаемости, которые приводят к изменению кодифицированных языковых норм, обнаруживают свою связь с аксиологической реальностью текущего времени.

\section{Литература}

Гловинская М.Я. Глава VI. Активные процессы в грамматике // Русский язык конца ХХ столетия (1985-1995) / отв. ред. Е.А. Земская. М.: «Языки русской культуры», 1996. С. 237-304.

Даль В. Толковый словарь живого великорусского языка: Т. 1-4: Т. 4. М.: Издательская группа «Прогресс», «Универс», 1994, 864 с.

Крысин Л. П. Толковый словарь иностранных слов. М.: ЭСМО, 2005. 994 с.

Толковый словарь русского языка с включением сведений о происхождении слов / отв. ред. Н. Ю. Шведова. М.: Издательский дом «Азбуковник», 2008. 1175 с. 


\author{
Irina T. Vepreva, Natalia A. Kupina \\ The Ural Federal University \\ (Russia, Ekaterinburg) \\ irina_vepreva@mail.ru,natalia_kupina@mail.ru
}

\title{
NOTES ON USUAL SHIFTS IN LEXICAL SEMANTICS
}

The article examines the usual shifts of lexical semantics in written speech which indicate a change in the codified language norms. On the basis of the "Integrum" database, a corpus sample of statements containing high-frequency non-standard combinations of girl and jubilee lexemes is carried out. It is established while considering the meaning of a "young woman / woman who looks young", the word girl is used in free syntactic positions. The modifications of the meaning are the following: a girl - a very young woman who has not got officially married; a girl - a very young woman who has divorced but has children in this marriage. Based on the frequency criterion, a conclusion is drawn on the relationship between shifts in lexical semantics with changes in the system of traditional family values.

In the process of functional and semantic analysis of the jubilee lexeme in the linguistic and cultural context of the current time, the factors that determine the expansion of the lexical meaning of the word are revealed. The cultural limiter (anniversary) becomes optional. A tendency of free interpretation of the semantic content of the lexeme jubilee is being formed. It is typically that the language codification is supported by the documentary and legislative ones. In the case when the jubilee date is the result of personal axiological choice, there is a tendency to identify the meanings of the words jubilee and anniversary. It is noted that the usual shifts in the contact and distant lexical compatibility, which lead to changes in codified lexical meanings, reveal a connection with axiological reality.

Key words: norm, usual, word meaning, lexical compatibility, axiological.

\section{References}

Glovinskaya M. Ya. [Chapter VI. Active processes in the grammar]. Russkij yazyk konca XX stoletiya [Russian language of the late twentieth century]. Moscow, Yazyki russkoj kul'tury Publ., 1996, pp. 237-304. (In Russ.)

Dal' V. Tolkovyj slovar' zhivogo velikorusskogo yazyka [Explanatory dictionary of the living great Russian language]. Vols. 1-4: V. 4. Moscow, Izdatel'skaya gruppa «Progress», «Univers» Publ., 1994, 864 p.

Krysin L.P. Tolkovyj slovar' inostrannyh slov [Dictionary of foreign words]. Moscow, ESMO Publ., 2005, 994 p.

Tolkovyj slovar' russkogo yazyka s vklyucheniem svedenij o proiskhozhdenii slov [Explanatory dictionary of the Russian language, including information about the origin of words]. ed. by N. Yu. Shvedova. Moscow, Izdatel'skij dom «Azbukovnik» Publ., 2008. $1175 \mathrm{p}$. 


\author{
М.Я. Дымарский \\ РГПУ имени А. И. Гериена \\ (Россия, Санкт-Петербург) \\ dym2005@list.ru
}

\title{
ЭЛИМИНАЦИЯ ТЕМЫ И ПОСТУЛАТ О БАЗОВОМ ПОРЯДКЕ СЛОВ В РУССКОМ ЯЗЫКЕ
}

В работе рассматривается предложенный А.В. Циммерлингом постулат о базовом порядке слов в русском предложении, согласно которому подлежащее при базовом порядке всегда стоит слева от сказуемого. Утверждается, что этот постулат не соответствует фактам русского языка. Отвергается интерпретация предложений типа Цвела черемуха как производных от исходного нейтрального варианта Черемуха ивела. Предлагается альтернативная интерпретация, согласно которой предложения рассматриваемого типа могут рассматриваться как непроизводные (неполные реализации модели $B$ саду ияела черемуха) и как производные, образованные от той же полной модели. Для второго варианта интерпретации предлагается понятие линейно-акцентного преобразования Элиминация Темы.

Ключевые слова: русский язык, предложение, порядок слов, коммуникативная структура, линейно-акцентные преобразования, элиминация темы.

Строгое исчисление членов коммуникативной (к-) парадигмы русского предложения затрудняется тем, что она может включать более одного нейтрального варианта. Для устранения этого противоречия А.В. Циммерлинг предлагает «дополнить концепцию Л<инейно->A<кцентных>-преобразований постулатом о наличии единого порядка слов для всех конструкций данного языка: для русского языка достаточным будет постулат о том, что подлежащее при базовом порядке слов всегда стоит слева от сказуемого» [Циммерлинг 2013: 268]. Автор делает важное примечание: «Минусом такого решения является то, что предложения типа рус. тЧеремуха

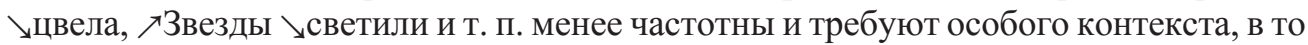

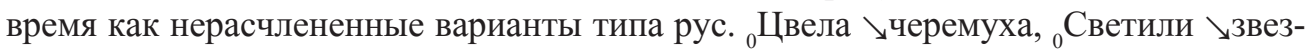
ды более частотны и естественны для высказывания с данным составом лексем ${ }^{1}$.

${ }^{1}$ Используется уже ставшая традиционной нотация: «Л》 и «】»- знаки коммуникативно значимых акцентов (соответственно, ИК-3, маркирующая тему, и ИК-1, маркирующая рему), 
Однако синтаксическая теория не должна при решении вопроса о производности / непроизводности предложения опираться на частотность употребления грамматически правильных комбинаций и на лексическую семантику слов, в них встречающихся» [Там же: 269].

Более поздняя работа [Циммерлинг 2016] специально посвящена «нерасчлененным предложениям»: в ней доказывается тезис о том, что «все русские нерасчлененные предложения получаются из расчлененных с помощью трансформационных правил» [Там же: 102], то есть высказывания с порядком и маркировкой компонентов ${ }_{0} \mathrm{~V} \searrow \mathrm{S}$ признаются производными ${ }^{2}$.

Если принять предложенный автором постулат о базовом порядке слов в русском языке за аксиому, то его рассуждения и выводы следует оценивать так, как оценивается решение математической задачи: неважно, какие натуральные величины и реальные процессы скрываются за цифрами, буквами и символами операций, — важна только логика. Автор стремится построить некоторую формальную модель в рамках некоторой системы координат — и в этих рамках модель получается последовательной и эффективной.

Однако при этом читатель должен заставить себя не обращать внимания на выражения типа «русские нерасчлененные предложения», «для русского языка», а лучше - научиться подставлять на их место выражения «нерасчлененные предложения языка L» и т.п. Если же читатель этого не делает, то у него возникают сомнения.

1. Признание высказываний типа ${ }_{[0]} \mathrm{V} \searrow \mathrm{S}$ производными равносильно признанию их ненейтральными (во всяком случае, иной трактовки автор не предлагает). Это вступает в противоречие с тезисом, который представляется неоспоримым: нейтральной является коммуникативная структура, «вносящая минимальный вклад в семантическую структуру предложения» [Янко 2001: 80]. Внешним признаком нейтральности коммуникативной структуры - и, следовательно, непроизводности модели - является отсутствие эмфатических акцентов и атонированных составляющих, в то время как их присутствие всегда свидетельствует о линейно-акцентных преобразованиях, которым была подвергнута исходная структура. В рассматриваемом случае, согласно авторской нотации, присутствует атонированный элемент, и с этим связано следующее сомнение.

2. Необходимо различать понятия «атонированный компонент коммуникативной структуры» и «элемент коммуникативной составляющей (= компонента коммуникативной структуры), не являющийся ее акцентоносителем». Т.Е. Янко, вводя понятие «атоническая тема», характеризует его следующим образом: это «компонент коммуникативной структуры, который, с точки зрения плана выражения, произносится на ровном тоне в аллегровом темпе и без внутренних пауз. Он

нижним индексом «0» помечается атонированный компонент коммуникативной структуры. Элементы нотации размещаются перед компонентом, несущим обозначаемый акцент. - М. Д.

${ }^{2}$ Использована нотация А. В. Циммерлинга. Далее символ атонирования элемента V будет даваться в квадратных скобках, поскольку, как будет показано ниже, самый факт этого атонирования отнюдь не очевиден и требует доказательств. 
расположен после другого, ударного, компонента коммуникативной структуры» [2001: 76].

В рассматриваемой модели (Цвела черемуха), прежде всего, отсутствует предшествующий атонированному элементу «ударный компонент коммуникативной структуры». Уже это заставляет усомниться в корректности интерпретации глагола как атонированного элемента. Кроме того, интерпретация его же как темы автором как будто не предусмотрена, поскольку он говорит о «нерасчлененных предложениях», - между тем атонирование, как следует из работ и Т.Е. Янко, и А.В. Циммерлинга, применяется в качестве сопутствующего ЛА-преобразования прежде всего к целым компонентам коммуникативной структуры. Возможно атонирование и не целого компонента коммуникативной структуры, а его элементов:

(1) $[\nearrow \text { Вася }]_{\mathrm{T}}[\text { купил новую \книжку }]_{\mathrm{R}} \rightarrow[\text { гВася }]_{\mathrm{T}}\left[\searrow \searrow к н и ж к у{ }_{0} \text { новую купил }\right]_{\mathrm{R}}$,

- но, как легко видеть из (1), причиной этого является сдвиг акцентоносителя ремы влево; в случае Цвела черемуха ничего подобного нет.

Вывод: интерпретация элементов прилетели в Прилетели грачи, извела в Цвела черемуха как атонированных ошибочна: их произнесение на ровном тоне без коммуникативно значимого акцента объясняется всего лишь тем, что это элементы коммуникативных составляющих, не являющиеся акцентоносителями.

3. Впрочем, трактовка предложений типов $<$ Tuше! > \Уабушка ${ }_{0}$ cnuт и ${ }_{[0]} Ц в е-$ ла \черемуха как «нерасчлененных» в указанной работе не вполне последовательна. Относительно первого из указанных типов, например, при обсуждении вопроса о предсказуемости эмфатического акцента ИК-2 неожиданно сообщается: «Атонирование темы (! - М.Д.) в русских нерасчлененных предложениях с порядком SV непосредственно выводится из условия (iv): в самом деле, если синтаксически релевантные акценты уровня предложения после акцента ремы в русском языке запрещены, при перемещении акцентоносителя ремы левее позиции элемента со статусом темы (! - М.Д.) приписывание последнему акцента темы ИК-3, ' $\nearrow$ ', тривиальным образом блокируется» [Циммерлинг 2016: 89]. Подразумевается,

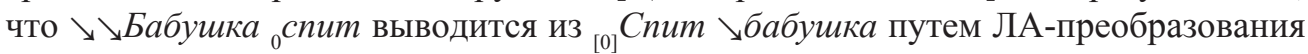
«сдвиг ремы влево» (Left Focus Movement); выходит, что в исходном предложении ${ }_{[0]}$ Cnит \бабушка автор видит тему, выраженную глаголом-сказуемым, что противоречит его собственной нотации: если глагол является темой, то должно быть

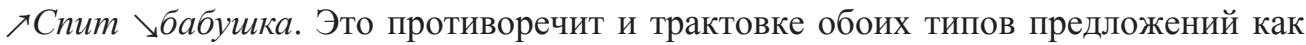
нерасчлененных; но в то же время это согласуется как с интуицией, так и с данными предварительного эксперимента. Однако сначала охарактеризуем наше видение этих конструкций, принеся читателю извинения за вынужденное напоминание ряда общеизвестных вещей.

4. Семантический тип предиката resp. семантический тип предложения естественным образом связаны с базовой функцией последнего в тексте / речи. Взаимодействие этих факторов определяет и базовый порядок слов, поэтому отказ от учета лексической семантики, вопреки цитированному выше утверждению А.В. Циммерлинга, не очищает синтаксическую теорию, а лишает ее важнейшей опоры. 
Предложения, вводящие новую информацию о некотором событии (B Kuтае состоялась встреча спортсменов), о состоянии окружающей среды (В садах иветут яблони) или некоторого субъекта (У кукль болит рука; У крана не работает тормоз) - а именно так выглядит прототип предложений, которые в обсуждаемой работе трактуются как «нерасчлененные», - отличаются семантической слабостью предиката: сказуемое в них способно функционировать полноценно только с именем агенса / экспериенцера, которые в русском языке при таких предикатах кодируются номинативом и приобретают статус подлежащего. В то же время вершинный носитель предицируемого признака в таких предложениях не совпадает с подлежащим и вынужденно кодируется иначе: как локатив или как косвенный субъект (в терминах Н.Ю. Шведовой, возникает или локальный, или субъектный детерминант). Валентности целых предикативных групп на локатив (где?) или на субъект ( $у$ кого?) обязательны: они отражают обязательность семантического субъекта при семантическом предикате. Возникает двухуровневая предикация: на высшем уровне носителем предицируемого признака является компонент, выраженный детерминантом; сам же предицируемый этому носителю признак формулируется предикативной группой. На низшем уровне носителем предикативного признака является каноническое подлежащее, предикатом - сказуемое. Предикативное отношение высшего уровня реализуется актуальным членением (носитель предицируемого признака - тема, детерминант), низшего - собственно предикативной структурой. Как убедительно показала еще И. И. Ковтунова, для таких предложений нейтральным, исходным является вариант с препозицией сказуемого подлежащему.

Порядок VS в этом случае объясняется правилами выбора акцентоносителя в глагольных и именных группах [Ковтунова 1976: 146; Николаева 1982: 9; Кодзасов 1993: 183], а также в «составляющих, равных целому предложению» [Янко 2001: 71-72]. В частности, согласно этим правилам, если предикативная группа, сообщая новую информацию, целиком составляет рему и при этом не распространена, то акцентоносителем становится не сказуемое, а подлежащее; если она распространена дополнением - то не подлежащее, а дополнение и т.д. При нейтральной коммуникативной структуре акцентоноситель коммуникативной составляющей должен занимать в ней финальную позицию: таким образом и порождаются совершенно закономерные порядки типа $[\text { УУ куклы }]_{\mathrm{T}}[\text { болит } \searrow \text { рука }]_{R}$.

Регулярны неполные реализации этой модели - с опущенной / нулевой темой, которая всегда без труда восстанавливается из контекста; это относится и к примерам типа Цвела черемуха или Светили звезды. Замена темы нулем в этих случаях, если из контекста / ситуации ясно, о каком фрагменте окружающего мира идет речь, столь же естественна, как и ноль подлежащего в определенно-личных предложениях. Считать эти предложения нерасчлененными неверно: если мы видим в них рему, то должны видеть и тему — и не только потому, что понятие ремы без понятия темы бессмысленно, но и потому, что тема действительно есть. Согласно удачному решению, предложенному в свое время Н. А. Слюсаревой [1986], в наиболее общем случае движение от темы к реме - это движение от более определенного 
(и потому менее информативного) к менее определенному (и потому более информативному). С этой точки зрения, высказывания типа Цветет черемуха содержат нулевую тему со значением прямого первичного дейксиса к окружающей говорящего в момент речи среде. Это значение характеризуется точно той же степенью определенности, что и сама фигура говорящего. Вербализовать этот дейксис коммуникативно избыточно. В плане же прошедшего, в том числе в нарративе, этот дейксис (уже вторичный) получает выражение или в том же предложении, или в контексте (в примерах разрядкой выделена собственно дейктическая тема, в том числе в ближнем контексте, или компоненты, которые служат эквивалентом такой темы по отношению к предложению рассматриваемого типа; полужирным - само это предложение):

(2) Здесь уже тепло, прилетели грачи, говорят, что сегодня даже видели жаворонка [Александр Морозов. Прежние слова (1985-2001) // «Знамя», 2002]; (3) Была середина мая. Прозрачной зеленью оделись березы. Цвела черемуха. Дни стояли сухие, теплье [Даниил Гранин. Искатели (1954)] ${ }^{3}$.

Роль эквивалента дейктической темы, распределенной между рядом элементов контекста, может поддерживаться временны́м планом повествования, как в следующем фрагменте, выдержанном в плане прошедшего узуального, ограниченного определенными временны́ми рамками:

(4) По воскресеньям Володя и Тина уезжали на лодке за реку. Пышно цвела черемуха. Тина и Володя лежали на молодой траве [Г. Е. Николаева. Битва в пути (1959)].

Исходя из сказанного, не представляется возможным согласиться с утверждением, будто «предложения с порядком LocVS, TempVS (то есть предложения типа В Москву прилетели грачи, которые автор признает расчлененными на детерминантную тему и предикативную группу — рему. - М.Д.) нельзя считать ЛА-вариантами нерасчлененных А-предложений ${ }^{4}$ с порядком VS, поскольку в них появляется новый синтаксический материал» [Циммерлинг 2016: 94]. Если в них и появляется новый материал, то лишь лексический; с синтаксической же точки зрения, компоненты Loc и Temp в них просто вербализованы в предсказанной структурой форме детерминанта. Видеть в таких компонентах, вербализуемых или, наоборот, экспонируемых нулем при легко описываемых (и поддающихся формализации) условиях, «новый синтаксический материал» - почти то же, что

\footnotetext{
3 Примеры из Национального корпуса русского языка. Поиск точных форм в НКРЯ по запросу «цвела черемуха» дал 13 вхождений; в $100 \%$ случаев дейктическая тема обнаруживается или в самом предложении, или в контексте (дата обращения 06.10.2017).

${ }^{4}$ Автор различает «нерасчлененные А-предложения» (Прилетели грачи), предикат которых «проецирует атипичную структуру события, где различение темы и ремы обычно является неестественным» (примерно тот же тип именуют еще entity-central thetics), и «нерасчлененные В-предложения» (<Tuше!> Бабушка сnит!), в которых «тема... может быть восстановлена из широкого контекста» (event-central thetics) [Там же: 78]. Заметим, что неестественной представляется прежде всего интерпретация структуры события в терминах актуального членения, поскольку онтологические и коммуникативные категории лежат в совершенно разных плоскостях.
} 
относить предложения типа Вася купил к нераспространенным, а Вася купил портфель - к распространенным, в то время как распространены, в силу семантики предиката, оба, первое же просто неполное.

5. Поскольку утверждение о том, что предложения с вербализованной детерминантной темой нельзя считать ЛА-вариантами «нерасчлененных» предложений, нами отвергается, следует выдвинуть альтернативное решение. Оно заключается в том, что здесь как раз можно видеть ЛА-преобразование (ЛАП), однако вектор деривации - противоположный. В результате этого ЛАП из прототипического высказывания с порядком LocVS, TempVS (В Москву прилетели грачи) получается высказывание типа Прилетели грачи.

Для того чтобы утверждать, что в этом случае действительно имеет место ЛА-преобразование, требуется показать, что в результирующем высказывании происходят линейные и / или акцентные изменения. Линейное изменение можно видеть в том, что, в отличие от исходного варианта, в инициальной позиции оказывается элемент, изначально не имевший статуса темы. Акцентное же изменение можно видеть в том, что этот элемент, в исходном варианте произносимый ровным тоном, при элиминации темы приобретает способность к маркированию ослабленным акцентом, который может восприниматься как своеобразное эхо тематического акцента ИК-3: [, Ү]Прилетели џграчи. В предварительном эксперименте, в ходе которого требовалось прочитать подряд две фразы: Наступила весна. Прилетели грачи, - 13 из 15 информантов прочитали слово прилетели с хорошо ощутимым подъемом тона, весьма напоминающим ИК-35 .

Если признать приведенные соображения релевантными, то придется дополнить существующую номенклатуру линейно-акцентных преобразований еще одним, которое можно назвать, допустим, Элиминацией Темы.

Элиминация Темы - ЛА-преобразование, которое заключается в устранении из высказывания вербализованной темы (преимущественно дейктической) и факультативно сопровождается тем, что исходно неакцентированный элемент ремы приобретает способность окрашиваться ослабленным тематическим акцентом, превращаясь в элемент с функциями компонента ремы и в то же время - ситуативного эквивалента темы.

При таком подходе высказывания типа ${ }_{[0]}$ Цвела \черемуха интерпретируются как производные, но не от расчлененных с (мифическим) исходным порядком

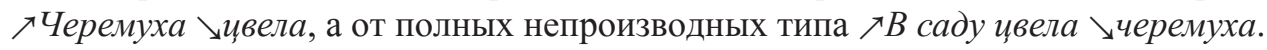

Если же не видеть в элиминации темы ЛА-преобразования, то непроизводными

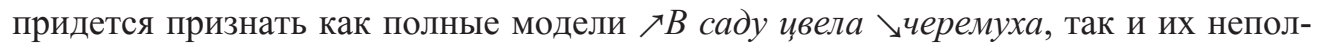
ные реализации.

В пользу признания как полного, так и неполного вариантов непроизводными свидетельствует, во-первых, отсутствие эмфатических акцентов, во-вторых их контекстуальная независимость и способность открывать текст. Между тем

5 Аудиозапись доступна по адресу: https://drive.google.com/open?id=0B9z58JGkcSOCVHhQM kQyaGFvLTA. 
варианты, от которых они, по А.В. Циммерлингу, «произведены» (Рука у кукль болит, Черемуха в садах ияетет, Встреча спортсменов в Шанхае состоялась / состоялась в Шанхае), контекстуально зависимы и открывать текст не способны.

Как бы ни решать вопрос о производности / непроизводности этой модели, вводить при этом постулат о едином базовом порядке слов, явно противоречащий фактам русского языка, представляется избыточным. Принятие этого постулата по отношению к русскому предложению вообще - примерно то же, что попытка построить вариант евклидовой геометрии на той посылке, что параллелограмм, окружность и все прочие фигуры планиметрии производны, скажем, от треугольника и могут быть получены из него путем изменения величин углов и длин сторон. Теория получилась бы, наверное, стройная... но неизвестно что описывающая.

\section{Литература}

Ковтунова И. И. Современный русский язык: Порядок слов и актуальное членение предложения. - М., 1976.

Кодзасов С.В. Интонация предложений с дискурсными словами. Группы: едва, действительно, вообще, совсем, прямо // Баранов А.Н., Плунгян В.А., Рахилина Е. В. Путеводитель по дискурсивным словам русского языка. М., 1993.

Николаева Т. М. Семантика акцентного выделения. - М., 1982.

Слюсарева Н. А. Категориальная основа тема-рематической организации высказывания-предложения // Вопросы языкознания. - 1986. - №4. - С. 3-15.

Циммерлинг A.B. Системы порядка слов славянских языков в типологическом аспекте. - М., 2013.

Циммерлинг A.B. Линейно-акцентная грамматика и коммуникативно нерасчлененные предложения в русском языке // Архитектура клаузы в параметрических моделях: синтаксис, информационная структура, порядок слов / Отв. ред. А. В. Циммерлинг, Е.А. Лютикова. - М., 2016. - С. 76-103.

Янко T. Е. Коммуникативные стратегии русской речи. - М., 2001.

\section{Mikhail Ya. Dymarskij}

The Herzen State Pedagogical University of Russia

(Russia, Saint Petersburg)

dym2005@list.ru

\section{TOPIC ELIMINATION AND THE POSTULATE OF THE BASIC WORD ORDER IN RUSSIAN}

The paper deals with the postulate of the basic word order in Russian introduced by Anton Zimmerling. According to it, within the basic word order the subject in a Russian sentence is always located to the left of the predicate. This postulate does not agree with 
the well-known facts of the Russian language. The interpretation of sentences like Цвела черемуха (Cvela čerетиха) as derived from the initial neutral variant Черемуха цвела (Čeremuxa cvela) is rejected. An alternative interpretation is substantiated according to which sentences under consideration may be seen both as non-derived (incomplete realizations of the model $B$ саду иявела черемуха [ $V$ sadu cvela čereтихa]) and as derived from the same complete initial model. For the second version of interpretation a notion of the Theme (Topic) Elimination as one more LAT — Lineal-Accent Transformation (in addition to the existing calculus of LAT) - is proposed.

Key words: Russian language, sentence, word order, communicative structure, linealaccent transformations, theme (topic) elimination.

\section{References}

Kovtunova I. I. Sovremennyi russkii yazyk: Poryadok slov i aktual'noe chlenenie predlozheniya [Modern Russian language: Word order and functional sentence perspective]. Moscow, 1976.

Kodzasov S. V. Intonatsiya predlozhenii s diskursnymi slovami. Gruppy: edva, deistvitel'no, voobshche, sovsem, pryamo [Intonation of sentences with discourse words. Groups: just, really, actually, really, right]. Putevoditel' po diskursivnym slovam russkogo yazyka [A guide to discourse the words of the Russian language]. Baranov A. N., Plungyan V.A., Rakhilina E. V (Eds.). Moscow, 1993.

Nikolaeva T.M. Semantika aktsentnogo vydeleniya [Semantics of the accent stressing]. Moscow, 1982.

Slyusareva N.A. Kategorial'naya osnova tema-rematicheskoi organizatsii vyskazyvaniya-predlozheniya [The categorical base of the functional sentence perspective]. Voprosy yazykoznaniya. 1986, no.4, pp. 3-15.

Tsimmerling A. V. Sistemy poryadka slov slavyanskikh yazykov v tipologicheskom aspekte [Word order systems of Slavic languages in the typological aspect]. Moscow, 2013.

Tsimmerling A. V. Lineino-aktsentnaya grammatika i kommunikativno neraschlenennye predlozheniya $\mathrm{v}$ russkom yazyke [Linear-accentual grammar and communicatively non-segmented sentences in the Russian language]. Arkhitektura klauzy v parametricheskikh modelyakh: sintaksis, informatsionnaya struktura, poryadok slov [Clause architecture in terms of parametric models: syntax, information structure, word order]. A. V. Tsimmerling, E. A. Lyutikova (Eds.), Moscow, 2016, pp. 76-103.

Yanko T.E. Kommunikativnye strategii russkoi rechi [Communicative strategies of Russian speech]. Moscow, 2001. 


\section{C. М. Евграфова}

Российский государственный гуманитарный университет

(Россия, Москва)

\section{ГРАММАТИКА ПОНИМАНИЯ И ГРАММАТИКА ПОРОЖДЕНИЯ ТЕКСТА И ПРОБЛЕМЫ ВЕРБАЛЬНОГО ОБУЧЕНИЯ}

Исследуя проблему снижения эффективности вербального обучения, автор анализирует ответы студентов на вопрос по содержанию лекции. Спонтанные высказывания, ставшие нормой под воздействием письменной онлайн-коммуникации, делают невозможным расценивать ответы студентов как полноценные утверждения, так как в них отражаются и различные этапы процесса мышления, и несовершенство навыков порождения письменного текста. Автор считает, что на материале спонтанной письменной речи можно исследовать асимметрию языковой системы. Анализ материала показывает, что «грамматика понимания» семантична и опирается на знание фреймов (у эксперта) и случайные ассоциации (у профана), a «грамматика порождения» синтаксична и опирается на знание точных значений непредикативных слов (умение выбирать из ряда синонимов) и богатство ментального словаря предикативных и связочных слов (они не воспроизводятся при пересказе текста).

Ключевые слова: вербальное обучение, спонтанная письменная речь, асимметрия языковой системы, грамматика понимания, грамматика порождения текста, язык и мышление.

Некоторые цепочки слов поддаются пониманию, но у нас отсутствует твердая уверенность, что говорящий использовал для продуцирования этих предложений тот же самый код, что мы используем для их толкования.

Стивен Пинкер

Еще Л.В. Щерба подчеркивал, что «процессы понимания, интерпретации знаков языка являются не менее активными и не менее важными в совокупности того явления, которое мы называем языком», но исследованы недостаточно [Щерба 1974: 25]. Сейчас, когда высокий уровень развития науки требует повышения 
эффективности обучения в школе и вузах, проблема понимания приобрела практическую значимость: ведь сложный учебный материал часто остается неосвоенным. В процессе обучения нередки недиагностируемые коммуникативные неудачи, снижающие эффективность обучения; тому виной и вынужденный характер педагогической коммуникации [Евграфова 2010]), и низкое качество учебно-научных текстов: (см. [Евграфова 2015б]), и сама специфика понимания при вербальном обучении.

Исследование процесса понимания в педагогической коммуникации проводилось на материале письменного блиц-опроса филологов первого курса'; были рассмотрены и смежные аспекты проблемы порождения высказывания. В результате были выявлены принципиальные отличия процессов понимания и порождения речи, обусловливающие асимметрию языковой системы.

На вводной лекции сообщались новые для студентов сведения об особенностях терминологического употребления знакомых им слов (язык, речь, коммуникация) и вводились смежные понятия. Выбранная формулировка («Что такое язык и что такое коммуникация и чем принципиально отличаются эти понятия?») исключала возможность прямого цитирования конспекта: в лекции заявленная пара понятий напрямую не сопоставлялась. Студенты знали, что их ответы не влияют на оценку, но помогут преподавателю лучше объяснять. Опрос проводился в условиях дефицита времени, так как необработанная письменная речь отражает ход процесса мышления и показывает уровень сформированности навыков письменной речи.

Моделирование процесса понимания лекции. При ответе студент должен (а) проинтерпретировать вопрос, (б) мысленно вернуться к услышанному (можно воспользоваться конспектом), (в) сформулировать свободное по форме высказывание о языке и коммуникации, опирающееся на материал прослушанной лекции.

В некоторых ответах студенты подменяют один из обсуждаемых объектов и рассматривают противопоставление «язык» / «речь». Это противопоставление обсуждалось на лекции, и в ответах явно воспроизводятся фрагменты конспектов лекции.

(1) Язык - это система. Речь - это реализация системы.

(2) Язык - система. Речь - реализация этой системы, сам акт говорения.

(3) Язык - это система, которая лежит в основе речевой деятельности. Речь - это акт говорения, реализация системы.

Подмена понятий свидетельствует о том, что, процесс понимания «не включается", и студенты лишь имитируют выполнение задания: находят по ключевому слову язык приблизительно подходящую цитату, не контролируя ее смысл: в приведенном ниже примере об этом говорит ошибочное употребление слова достоинство вместо достояние:

(4) Язык - это <..> вид звуковой системы предназначеный для передачи инфции. Речь - акт говорения. Это воплощение и реализация языка. Язык явл. достоинством общ-ва. Речь индивидуальна.

${ }^{1}$ Ответы студентов цитируются по оригиналу, зачеркивания и авторская правка сохраняются. 
Телеграфный стиль, типичный для конспекта, заставляет предположить, что техника «сору - paste» может использоваться и при поиске по двум ключевым словам - язык и коммуникация:

(5) Язык - система, речь - акт говорения и реализации системы. Коммуникация - умение общаться с людьми и миром. Коммуникативность - общение $\rightarrow$ вербальная $\rightarrow$ невербальная

Можно высказать предположение, что в примерах (1) - (4) поиск был ориентирован на обнаружение объекта, противопоставленного языку (глубинный предикат 'отличаться' и актант 'язык'), а во втором - на поиск заданных ключевых слов язык и коммуникация, которые связаны неустановленным отношением, причем задачу определения предикативного отношения студент не решил.

Больший интерес представляют случаи активного восприятия информации. Несмотря на некорректность порождаемых студентами высказываний (они не всегда точно подбирают имена и наименования предикатов), мы видим в них следы обдумывания услышанного: порождая высказывания, они самостоятельно выделяют актанты и пытаются выстроить граф отношений между ними:

(6) Коммуникация - общение, передача информации, подразумевающая использование языка. Язык - система звуковых и словарных средств.

(7) Коммуникация существует благодаря языку. Язык - система, которой мы пользуемся для коммуникаций в обществе.

Выбор актантов индивидуален, он отражает важный этап мыслительного процесса: (см. тж. [Евграфова 2014: 250]). Прослушав одно и то же, студенты обратили внимание на разное - на возможность невербального общения, на ситуативную обусловленность коммуникации, на системность языка, на природу языковых единиц и проч. Сравним:

(8) Язык - это определенный набор слов и фраз, а коммуникация - это набор жестов, мимики и поз. Коммуникация может происходить, даже если люди не произносят слов и фраз.

(9) Язык - это система, служит для классификации окружающего мира, коммуникация же вариативна и ситуативна.

Активное восприятие новых знаний чаще всего сопровождает эмоция удивления: реципиент выделяет в потоке информации неожиданный для него факт, и именно вокруг него возникает очаг перестроения семантических связей. Новые связи носят ассоциативный характер; так, в сознании некоторых студентов вскользь упомянутая идея существования индивидуальной языковой системы, высказанная Л.В. Щербой в [Щерба 1974: 25] и активно развиваемая в онтолингвистике: (см. [Цейтлин 2013]), преобразилась неузнаваемо:

(10) Язык - это способ выражения мыслей отдельного человека. Коммуникация - общение, взаимопонимание.

(11) Язык есть свойство человека говорить индивидуально, опираясь на общепринятые нормы и собственную изобретательность, в то время как коммуникация - форма взаимодействия между двумя или более людьми, у каждого из которых имеется свой, индивидуальный язык. 
Слово индивидуальная в составе терминологического сочетания было воспринято как признак языковой системы, и это стало основанием для противопоставления языка и коммуникации по признаку «индивидуальное / общее». Студенты проигнорировали информацию о том, что этот признак дифференцирует понятия «язык» и «речь».

Итак, понимание в процессе восприятия устного текста (а это восприятие линейно, и возможность рекурсии, обычной при чтении, практически исключена) основано на ассоциациях, которые могут закрепляться или блокироваться в зависимости от вызываемых ими эмоций. Перестроение семантических связей происходит во время подбора наименования предиката, и здесь понимание сопрягается с порождением речи.

Моделирование процесса порождения речи. В одном из ответов есть авторская правка; она позволяет воочию увидеть рекурсивность порождения высказывания:

(12) Язык - это система (букв, слов, конструкций и т.д.), которая складывается в сознании человека со временем. Речь Коммуникация — это реализация языка в данный момент.

Общение. (письменное, устное + жесты, интонация)

При порождении высказывания ассоциации сосуществуют с готовыми пропозициями (это могут быть клише, цитаты, списанные откуда-то или запомнившиеся фрагменты: которая складывается в сознании человека со временем), заготовками синтаксических конструкций (вопрос подталкивал к конструкции $X-$ это $Y$ ).

Выбор наименования предиката - это самый трудный этап порождения высказывания: при самостоятельном порождении высказывания студенты подбирают предикаты в собственном ментальном словаре, и если он беден, ошибки неизбежны. Неслучайно практически все студенты жалуются на бедность своего словаря [Евграфова 2015г].

Моделирование понимания текста экспертом. Заметим: анализируя ответы учащихся и оценивая их правильность, преподаватель не всегда понимает, в какой степени он оценивает знание предметной области, а в какой - сформированность навыка монологической речи. К тому же само по себе воспроизведение некоего известного «правильного ответа» обычно свидетельствует не о хороших знаниях и глубоком понимании, а о хорошей памяти ученика (или о том, что он списал ответ из подходящего источника).

Сравним несколько ответов; все они неудачны, но в (13) к тому же имеются неправильно построенные синтаксические конструкции, а в (14) используемые синтаксические клише не сочетаются с подставленными в них языковыми единицами. В (15) и (16) пишущие пользуются не просто синтаксическими клише, а гладкими готовыми блоками; однако там, где они пытаются самостоятельно построить пропозиции, наблюдаются нарушения сочетаемости отдельных слов и пропозиций.

(13) Язык - всеобъемлющая система, лежащая в понимании окр. мира у человека. Язык, в отлич. от коммуникации изменчив. Напр., те же диалекты. Коммуникация - способы общения людьми между собой и развитие индивиду-

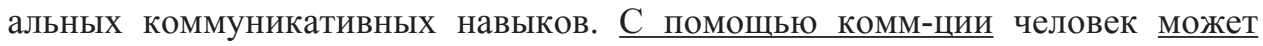


общаться разными способами. Коммуникативные способности начинают разв. еще в детстве.

(14) Коммуникация состоит в том, что язык является только частью общения, взаимопонимания людей. Коммуникация может состоять исключительно из жестов (не знаковых (жестов глухонемых). Но язык является основным средством коммуникации.

(15) Язык - система, которая лежит в самой основе понимания. Коммуникация непосредственный акт общения между людьми, она включает в себя множество деталей и способов более точной передачи информации.

(16) С первого взгляда кажется, что язык и коммуникация (речь) являются синонимичными словами. На самом деле, у данных слов разные значения, однако они помогают друг другу в развитии человека, так как речь является реализацией системы любого языка.

В школе недостаточно хорошо формируют навыки порождения текста; это касается и умения подбирать предикаты для синтаксического оформления отдельных пропозиций, и умения выбирать синтаксические скрепы для связи пропозиций между собой при оформлении предложений и сверхфразовых единств.

При проверке неопытный преподаватель легко пропускает ошибки в более гладких с синтаксической точки зрения высказываниях и строже оценивает синтаксически неряшливые; опытный не придает особого значения самим номинациям и формально-синтаксическим связям - он проверяет, скорее, точность референциальных значений выбранных номинаций и адекватность передачи ролевых отношений между участниками ситуации с помощью предикатов. Процесс «экспертного» понимания текста ориентирован на глубинно-синтаксический анализ.

Выводы. Психологи и онтолингвисты установили, что у ребенка понимание предшествует словесному обозначению (см. [Лепская 2013: 49], [Евграфова 2015а]); у взрослых пассивный лексикон многократно превосходит активный. Всё это свидетельствует в пользу того, что механизмы понимания закладывают фундамент языковой системы родного языка, а механизмы, обеспечивающие порождение высказываний, достраивают ее.

Исследование материала необработанной письменной речи показывает, что процессы понимания опираются преимущественно на семантику: при обсуждении незнакомой ситуации - на ассоциативные связи, при обсуждении знакомой на сформированные фреймы (обнаружив совпадающие вершины, реципиент проверяет истинность / ложность высказывания собеседника по совпадению / несовпадению соединяющих их ребер). Анализ поверхностно-синтаксических связей играет в процессе понимания лишь вспомогательную роль.

Огромную роль в процессах понимания играют ассоциативные связи, опирающиеся на чувственное познание мира [Залевская 2013]; даже освоение абстрактной лексики во многом опирается на ассоциации, восходящие к чувственному опыту [Успенский 1979]). Однако современная цивилизация резко изменила процессы познания [Евграфова 2015в]: чувственный опыт подменяется виртуальным, освоение понятий слабо подкрепляется практической деятельностью (см. [Евграфова 
2014: 253]), а знание новых слов ограничивается знакомством с означающим соответствующего языкового знака. Вместо понятия в индивидуальном лексиконе языковой личности нередко находится размытое облако ассоциаций. Неслучайно в последние десятилетия возрос интерес к изучению явления агнонимии [Морковкин, Морковкина 1997], [Мандрикова 2011], [Мандрикова 2017].

Процесс порождения высказывания требует различных умений и навыков: навыка подбирать клишированные формулы и готовые пропозиции, умения подставлять в синтаксические конструкции те или иные элементы (проверяя их синтаксическую и семантическую сочетаемость) и умения самостоятельно строить пропозиции из известных семантических предикатов и актантов. Последнее умение требует от говорящего / пишущего глубокого понимания экстралингвистической реальности и знания значений слов во всем многообразии их семантических связей (формируется в совместной практической деятельности с профессионалами при обязательной диалогической активности).

Реформирование образования, начавшееся еще в 1970 г. (см., например, [Занков 1970]), не учитывало всех факторов, влияющих на процессы освоения учебного материала, в частности, не была осмыслена роль родного языка как инструмента познания. Первые реформы были нацелены на интенсификацию и модернизацию обучения и игнорировали роль формирования навыков порождения текста; современные - меняют технологии обучения и стандартизируют формы контроля, стимулируя использование клише и шаблонов и снижая роль пропозиционального анализа и синтеза. В целом все эти реформы существенно ухудшили качество освоения русского языка и нарушили процессы формирования навыков, без которых вербальное обучение становится в лучшем случае неэффективным.

\section{Литература}

Евграфова С.M. Размышления о смысловых ошибках, или Последствия вынужденной коммуникации на уроках русского языка // Русский язык. № 15-16, 2010. — http://rus.1september.ru/topic.php?Page=2\&TopicID=7

Евграфова С. М. Феномен естественной письменной речи и его влияние на языковую систему // Антропоцентризм в языке и речи. Cep. «Acta Slavica Estonica V. Труды по русской и славянской филологии. Лингвистика XVI. Антропоцентризм в языке и речи». - Tartu: Tartu University Press, 2014. - C.248-260.

Евграфова С. М. Мышление, коммуникация, речь: начало начал // Проблемы онтолингвистики: механизмы усвоения языка и становление речевой компетенции 2015. Материалы международной конференции. Санкт-Петербург, 18-20 мая 2015. - Электронная публикация ИЛИ РАН. - С. 59-65.

Евграфова С.M. Проблема недиагностируемых коммуникативных неудач в учебно-научном дискурсе - см. электронная публикация результатов конференции «Маргиналии-2015» http://uni-persona.srcc.msu.ru/site/conf/marginalii-2015/ thesis.htm. 
Евграфова С.M. Проблемы освоения и преподавания родного языка в информационном обществе // Материалы научно-теоретической конференции «Модернизация языка: вызовы времени». 29-30 мая 2015 г. — Алматы: КазНУ им. Аль-Фараби, 2015. - С. 11-15.

Евграфова С.M. Хорошая речь в оценках современного студента // Хвала и хула в языке и коммуникации. - М.: РГГУ, 2015. - С. 260-283.

Залевская A. A. «Живой поликодовый гипертекст» как «внутренний контекст» процессов познания и общения // Проблемы информационного общества и прикладная психолингвистика: Материалы X Международного конгресса Международного общества по прикладной психолингвистике. - М.: РУДН, 2013. - С. 59.

Занков Л. В. Беседы с учителями (Вопросы обучения в начальных классах). М.: Просвещение, 1970. - 200 с.

Лепская Н.И. Язык ребенка: онтогенез речевой коммуникации. - М.: РГГУ, 2013. - 314 c.

Мандрикова Г.М. Русская лексическая система в теоретическом и прикладном рассмотрении: Категории агнонимии и таронимии. - АДД. - РИРЯ им. А. С. Пушкина, 2011. — http://dissers.ru/avtoreferati-dissertatsii-filologiya/a72.php

Мандрикова Г.М. Тотальный диктант: территория смыслов // \#ТОТСБОРНИК: Сборник научных трудов по материалам Тотального диктанта. Вып. 1. - Новосибирск, 2017. - С. 29-35.

Морковкин В. В., Морковкина А. В. Русские агнонимы: слова, которые мы не знаем. - М.: Астра Семь, 1997. - 414 с.

Успенский В.А. О вещных коннотациях абстрактных существительных // Семиотика и информатика. № 11 / 1979. - С.142-148.

Цейтлин С.Н. Индивидуальная языковая система ребенка: некоторые штрихи к портрету // Проблемы онтолингвистики - 2013. Материалы международной научной конференции. Санкт-Петербург, 26-28 июня 2013 г. СПб.: РПГУ им. Герцена. - С. 24-27.

Щерба Л.В. О трояком аспекте языковых явлений и эксперименте в языкознании // Л.В. Щерба. Языковая система и речевая деятельность. - Л., 1974. C. 24-39.

\author{
Svetlana M. Evgrafova \\ Russian State University of the Humanities \\ (Russia, Moscow)
}

\title{
GRAMMAR OF COMPREHENSION AND GRAMMAR OF TEXT GENERATION IN THE CONTEXT OF VERBAL TEACHING-AND-LEARNING
}

Studying the problem of verbal teaching-and-learning regress, the author researches the students' answers on a question concerning a lecture content. Spontaneous utterance, becoming quite a standard way of writing, cannot be considered as a real judgment 
because it conserves traces of thinking and reflects inadequate skills of text generation. The author finds that the spontaneous writing allows us to explore the asymmetry inherent to any language system. She demonstrates that the "grammar of comprehension" is based on semantics and works due to frames (if an expert tries to understand) or due to random associations (if an ignorant does). The "grammar of text generation" is based on syntax and demands a perfect knowledge of non-predicate words meanings (for the best selection of a word from the synonym variety) as a rich mental vocabulary of predicates and connectors (which aren't even replicated in the process of a text retelling).

Key words: verbal teaching-and-learning, spontaneous writing, language system asymmetry, grammar of comprehension, grammar of text generation, language and thought

\section{References}

Evgrafova S. M. Razmyshleniya o smyslovykh oshibkakh, ili Posledstviya vynuzhdennoi kommunikatsii na urokakh russkogo yazyka [Reflections on semantic errors, or the consequences of forced communication at the lessons of Russian language]. Russkii yazyk, no. 15-16, 2010. http://rus.1september.ru/topic.php?Page=2\&TopicID=7

Evgrafova S.M. Fenomen estestvennoi pis'mennoi rechi i ego vliya nie na yazykovuyu sistemu [The phenomenon of natural written speech and its impact on language system]. Antropotsentrizm v yazyke i rechi. Ser. «Acta Slavica Estonica V. Trudy po russkoi i slavyanskoi filologii. Lingvistika XVI. Antropotsentrizm v yazyke i rechi» [Works on Russian and Slavic Philology. Linguistics XVI. Anthropocentrism in language and speech]. Tartu: Tartu University Press, 2014, pp.248-260.

Evgrafova S. M. Myshlenie, kommunikatsiya, rech': nachalo nachal [Thinking, communication, speech: getting started]. Problemy ontolingvistiki: mekhanizmy usvoeniya yazyka i stanovlenie rechevoi kompetentsii - 2015. Materialy mezhdunarodnoi konferentsii. Sankt-Peterburg, 18-20 maya 2015 [Problems ecolinguistic: mechanisms of language acquisition and the formation of speech competence - 2015. Proceedings of the international conference. Saint-Petersburg, 18-20 of may 2015.].2015, pp. 59-65.

Evgrafova S.M. Problema nediagnostiruemykh kommunikativnykh neudach $\mathrm{v}$ uchebno-nauchnom diskurse [The problem non-diagnostics communication failures in the educational and scientific discourse]. «Marginalii-2015» [Proceedings of the conference «Marginalii-2015»] http://uni-persona.srcc.msu.ru/site/conf/marginalii-2015/ thesis.htm.

Evgrafova S. M. Problemy osvoeniya i prepodavaniya rodnogo yazyka v informatsionnom obshchestve [Problems in the development of teaching of the native language in the information society]. Materialy nauchno-teoreticheskoi konferentsii «Modernizatsiya yazyka: vyzovy vremeni». 29-30 maya 2015. [Materials of scientific-theoretical conference "Modernization of language: challenges of time". May 29-30, 2015]. Almaty: KazNU im. Al'-Farabi Publ., 2015, pp. 11-15.

Evgrafova S.M. Khoroshaya rech' v otsenkakh sovremennogo studenta [A good speech in the estimates of the modern student]. Khvala $i$ khula v yazyke $i$ kommunikatsii 
[Praise and blasphemy in language and communication]. Moscow: RGGU Publ., 2015, pp. 260-283.

Zalevskaya A.A. «Zhivoi polikodovyi gipertekst» kak «vnutrennii kontekst» protsessov poznaniya i obshcheniya ["Live policeguy hypertext" as "internal context" of the processes of cognition and communication]. Problemy informatsionnogo obshchestva i prikladnaya psikholingvistika: Materialy X Mezhdunarodnogo kongressa Mezhdunarodnogo obshchestva po prikladnoi psikholingvistike [Problems of information society and applied psycholinguistics: proceedings of the X International Congress of the International society of applied psycholinguistics]. Moscow: RUDN Publ., 2013, p. 59.

Zankov L.V. Besedy s uchitelyami (Voprosy obucheniya v nachal'nykh klassakh) [Conversations with teachers (teaching in primary school).]. Moscow: Prosveshchenie Publ., 1970. - 200 p.

Lepskaya N.I. Yazyk rebenka: ontogenez rechevoi kommunikatsii [Babys language: the ontogenesis of speech communication]. Moscow: RGGU Publ., 2013. 314 p.

Mandrikova G. M. Russkaya leksicheskaya sistema v teoreticheskom i prikladnom ras-smotrenii: Kategorii agnonimii i taronimii. ADD. RIRYa im. A. S. Pushkina, 2011. http://dissers.ru/avtoreferati-dissertatsii-filologiya/a72.php

Mandrikova G. M. Total'nyi diktant: territoriya smyslov [Total dictation: scientia]. \#TOTSBORNIK: Sbornik nauchnykh trudov po materialam Total'nogo diktanta [Collection of scientific works on materials of the Total dictation]. Iss. 1. Novosibirsk, 2017, pp. 29-35.

Morkovkin V.V., Morkovkina A. V. Russkie agnonimy: slova, kotorye my ne znaem [Russian agnonimi: words that we don't know]. Moscow: Astra Sem' Publ., 1997. 414 p.

Uspenskii V.A. O veshchnykh konnotatsiyakh abstraktnykh sushchestvitel'nykh [On proprietary connotations of abstract nouns]. Semiotika i informatika. no. 11, 1979, pp.142-148.

Tseitlin S. N. Individual'naya yazykovaya sistema rebenka: nekotorye shtrikhi k portretu [Individual language system of the child: some touches to the portrait]. Problemy ontolingvistiki - 2013. Materialy mezhdunarodnoi nauchnoi konferentsii. Sankt-Peterburg, 26-28 iyunya $2013 \mathrm{~g}$. [Problems ontolinguistic - 2013. Materials of international scientific conference. St. Petersburg, June 26-28, 2013]. Saint Petersburg.: RPGU im. Gertsena Publ., pp. 24-27.

Shcherba L.V. O troyakom aspekte yazykovykh yavlenii i eksperimente v yazykoznanii [About threefold aspect of linguistic phenomena and experiment in linguistics]. Yazykovaya sistema i rechevaya deyatel'nost' [Language system and speech activity]. Leningrad, 1974, pp. 24-39. 


\section{О.П. Ермакова}

Калужский государственный университет им. К. Э. Циолковского

(Россия, Калуга)

olga_ermakova.kaluga@mail.ru

\section{ВОЗМОЖНОСТИ СЛОВООБРАЗОВАНИЯ В СФЕРЕ ВЫРАЖЕНИЯ ЛОГИЧЕСКИХ КАТЕГОРИЙ}

В статье рассматривается возможность и невозможность выражения словообразовательными средствами семантических категорий субъекта, объекта, пространства, времени, причины и цели. Отмечаются ограничения словообразовательного выражения объекта, прежде всего одушевленного. В данной работе объект не рассматривается в философском смысле: как то, что существует вне нас и не зависит от нашего сознания, но лингвистически - как то, на что направлено действие. В связи с этим значение объекта может быть только в производных словах, мотивированных глаголами, однако подавляющее большинство таких производных называет не то, на что направлено действие, а то, что возникает в результате действия. Автор устанавливает зависимость словообразовательного выражения анализируемых категорий от их представленности в лексической системе русского языка. Наибольшую «привязанность» к лексике, по мнению автора статьи, обнаруживает категория пространства. Совсем иной характер свойственен категориям причины и цели. Эти категории по своей природе не могут быть выражены лексически: причинно-следственные отношения, как и целевые, возникают только при взаимодействии двух ситуаций и не могут быть выражены одним словом, соответственно невозможно также их словообразовательное выражение.

Ключевые слова: субъект, объект, пространство, время, причина, цель.

Статья посвящена описанию возможности выражения словообразовательными средствами логических категорий (их же можно назвать и семантическими) субъекта, объекта, пространства, времени, причины и цели. Как показывают наблюдения, словообразованию подвластно далеко не все.

Параллельно с аффиксальным словообразованием будут рассмотрены также некоторые образования по конверсии и чисто семантического порождения слов названных категорий. 
Привлечение этого материала, с нашей точки зрения, поможет выявить универсальность некоторых ограничений в сфере возможностей словообразования. Эти ограничения, как мы попытаемся показать, в одних случаях, определяются ресурсами языка (но не системой), в других, и это самое важное, самой природой некоторых логических категорий.

Я сразу выскажу мысль, к которой буду возвращаться: словообразовательно, как правило, выражается то, что может быть выражено в лексике - прямыми или переносными значениями.

Известно, что понятие субъекта (производителя действия) во всех славянских языках словообразовательно выражается очень разнообразно - множеством аффиксов, прежде всего суффиксов. Примеры общеизвестны. С аффиксальным выражением объекта дело обстоит несколько иначе.

Объект понимается в данной работе не в собственно философском смысле (как всё, что вне нас, вещный мир), а как то, на что направлено действие. Несмотря на видимое разнообразие суффиксов, отмеченных в грамматиках как производящих наряду со значением субъекта также и значение объекта, здесь бросаются в глаза заметные ограничения.

Так среди 45 суффиксальных типов существительных, мотивированных глаголами (сюда входят и 12 типов, представленных двумя-тремя словами), у 11 отмечено наряду со значением производителя действия и значение объекта. Объект неразрывно связан с действием, и вне действия ни одна реалия не может быть объектом. Поэтому непроизводные слова наименованиями объектов быть не могут. Производные же слова, обозначающие объект, естественно, могут быть только отглагольными.

Существительные, которые можно было бы отнести к обозначению объекта, в русском языке чаще всего называют предмет, возникающий в результате действия, названного мотивирующим словом: концентрат, фильтрат, конденсат; отрезок, обрубок, обрывок, отпечаток; записка, подачка, похлебка, плетушка и др. Прямого обозначения объекта среди таких слов нет, мотивирующее действие не направлено на то, что называют эти и подобные существительные: действия обрезать, обрывать, обгрызать, обрубать и т.п. не направлены на отрезок, обрывок, огрызок, обрубок, как и действия конденсировать, концентрировать и подобные не направлены на получаемые конденсат и концентрат. Они направлены на предметы, которые еще не являются отрезками, обрубками, огрызками и т.д., например, на ткань, дерево, плод и т.п. В большинстве случаев значения таких слов в грамматиках и определяются как «предмет, возникающий в результате действия, названного мотивирующим словом» [Грамматика современного русского литературного языка 1970: 54; Русская грамматика 1980: 154]. По нашим наблюдениям, группа производных слов с таким значением в русском языке немногочисленна: около 50 слов. Актантные метонимические значения очень близки к обозначению объекта: набойка, наклейка, выписка, выручка, нашивка, надстройка [Апресян 1974: 195]. Все они включают в свое значение компонент 'действие', но точнее - это все-таки не собственно объект, а, повторю, «предмет, 
возникший в результате действия». Неслучайно Ю.Д. Апресян отмечает в них синкретичность значения объекта и результата процесса [Апресян 1974: 197]. Что же касается объекта одушевленного, то здесь наблюдаются еще более заметные ограничения. Напомню, что вообще в русском словообразовании не разграничивается живое и неживое, ср.: молодняк и сушняк, тряпье и старичье, сухарь и глу$x a p b$, синяк и бедняк и т.д. Не разграничиваются средствами аффиксов и типы объектов - одушевленный и неодушевленный, ср.: делегат, кастрат, реферат и т.д. Как известно, специализируется только для названий лиц суффикс -ист-. Он не образует названий предметов и животных [Милославский 1980: 82; Земская 1992: 107]. Но он не образует и наименования лиц, подверженных действию со стороны другого лица.

Суффиксальных образований, называющих «живой» объект, в русском языке немного, по данным «Обратного словаря», 32, и не в каждом словообразовательном типе они встречаются, ср.: подкидыи, приемьи, делегат, кастрат; ставленник, воспитанник; назначенеи, выдвиженец и др. В определенных случаях на помощь аффиксации приходят образования по конверсии, тоже немногочисленные, ср.: обвиняемый, подозреваемый, осужденный, раненый, убитый и др. При этом и в том и в другом случае обозначается объект — лицо, а не животное. Вряд ли про убитого оленя (волка, зайца) кто-нибудь скажет: «Убитый лежал в кустах».

При этом не все аналогичные слова толкуются словарями как существительные (ср. преследуемый, оправданный, осужденный, не получившие «статуса» существительных), но образования «по случаю» почти не знают ограничений. Вот некоторые примеры.

Красавей-тяпнутый (доктор Борменталь, которого пес тяпнул за ногу) был уже без халата.

- Это плохо? - жуя, спрашивал Филипп Филиппович. - Плохо?

- Это бесподобно, - искренне ответил тяпнутый.

... И я того же мнения, - добавил Филипп Филиппович. Сам он с этими словами подцепил на лапчатую серебряную вилку что-то похожее на маленький темный хлебик. Укушенный последовал его примеру (М. Булгаков. Собачье сердце).

В то же время обращение врача к пациенту, которого укусила собака, словом «укушенный» может быть разве что шутливым.

Однако, выскажу предположение, что там, где страдательные причастия, называющие признак человека, встречаются в разговорной речи и могли бы быть субстантиватами, предпочитаются все же причастия или адъективаты. Это особенно касается оценочных слов: для их типичных функций характеризации они не нуждаются в субстантивной транспозиции. Так, в словарях разговорной речи слова долбанутый, замордованный, замороженный, заморенный, замороченный приводятся только как причастия или адъективаты [Толковый словарь русской разговорной речи 2014].

Очевидно, что и одушевленный объект тоже целесообразно определить как «тот, кто наделен определенными признаками в результате действия, названного мотивирующим словом». 
В некоторых случаях объединяются в пары аффиксальные образования со значением субъекта и его «жертвы», выраженной субстантиватом, ср.: победитель побежденный, спаситель - спасенный, обвинитель - обвиняемый. Но не все. Отдельные субъекты не имеют одушевленных объектов, выраженных субстантиватами, например, мститель, клеветник и др. Есть и другие случаи: когда «жертва» не имеет специально обозначенного субъекта действия, например, задержанный, осужденныц̆, приговореннылй, повешенный и др. В соответствующей ситуации это не создает никакого напряжения в языке, и в данном случае это не имеет значения. Аналогичная картина, по нашим наблюдениям, отмечается и в польском языке: суффиксальных образований со значением одушевленного объекта тоже немного, хотя несколько больше, чем в русском, и также «жертвы» карательных органов часто обозначаются субстантиватами в отличие от аффиксальных образований со значением субъекта, ср.: обвинитель - oskarżyciel, обвиняемьій - oskarżony, убийц̧а - zabójca, morderca, убитый — zabity, zamordowany, а также — podejrzany, raniony (ranny), poszkodowany, skazany (осужденный), но тут есть и skazaniec, как и при aresztowany есть aresztant (то же и в русском). Примеры такого распределения: аффиксы - для субъекта, конверсия - для одушевленного объекта (лица), есть и в немецком, ср.: Ankläger 'обвинитель' (юр. Kläger) — Angeklägte 'обвиняемый’ и подобные. Во всех случаях это субстантиваты страдательных причастий, и образования от них не являются регулярными, а приведенные примеры «обслуживают» почти исключительно юридическую сферу.

Как отмечается в работах по словообразованию, вторичные значения из сферы так называемой семантической деривации в определенных случаях могут «закрыть» лакуны в аффиксальных производных. Рассматривая примеры метонимических актантных значений объекта, которые приводятся лингвистами, нетрудно заметить, что среди них нет объекта одушевленного [Апресян 1974: 196-197]. Необычно для русского языка недавно появившееся сочетание в одном слове отказник значений ‘тот, кто отказался' и 'тот, от кого отказались' - отказники 'родители' и 'дети', отказница 'мать' и 'ее ребенок (дочь)'.

Таким образом, в отличие от грамматики, где винительный падеж при переходном глаголе может выражать объект «в чистом виде», в словообразовании (и не только аффиксальном) это всегда «предмет, возникший в результате действия, названного мотивирующим словом» или (реже) «лицо, ...». В сочетаниях: встретить мать, купить книгу и т.п., лицо не становится матерью в результате действия встретить, а предмет - книгой в результате действия купить (о так называемом винительном результата, ср.: печь пироги, гнуть дуги, см. [Пешковский 1956: 193]).

Выражение пространства в русском языке привязано к лексике.

Обобщая и упрощая разные толкования, примем в качестве рабочего такое определение: пространство — «это все, что имеет протяженность и объем», прежде всего, природные объекты.

Лексика пространства довольно разнообразна. Это прежде всего прямые названия природных объектов: земля, небо, океан, море, река, гора, бездна, пропасть, 
берег, степь. Это и объекты, созданные людьми, ср.: город, село, деревня, улица, переулок и т.д. Это и параметрические имена, ср.: верх, низ и т.д. Есть даже сказочные названия, ср.: тридевять земель, тридесятое царство.

Есть целый ряд метафор, ср.: рукав (реки), хребет (горный), горло (устье реки) и др. И сами пространственные наименования, метафоризируясь, могут называть другие пространства, оставаясь тем самым в пределах той же логической категории.

Известно, что для метафоры не очень характерно оставаться в пределах той же самой логической категории. Н. Д. Арутюнова за это свойство метафоры даже называла ее логической ошибкой [Арутюнова 1990: 190]. В самом деле, ср. ее примеры: заяц, медведь, свинья, орел - о человеке, а также - тряпка, лапоть, тормоз и т.П. Правда, этот переход из одной логической категории в другую бывает не всегда.

Большой материал, показывающий метафорические изменения слов в пределах той же логической категории: человек - человек, предмет - предмет, животное - животное и др. - содержится в книге Г. Н. Скляревской [Скляревская 2004: $79,80,105$ и др.].

У пространственной лексики метафора нередко может оставаться (хотя и не всегда) в пределах той же логической сферы, т.е. образно представлять одно пространство через другое. Так, горы, холмы, бугры могут быть не только на земле, ср. также: море (океан, озеро) о большом (или кажущимся большим) пространстве - воздушный океан; пустыня (о степи, небе, острове и т.д.); болото о грязном море, озере; бездна о море и небе и т.д. Вот некоторые текстовые примеры со словом пустыня: Пустыня (перен.) 'простирающееся на большое расстояние пространство': Водная, морская, снежная пустыня и др. Лежу на берегу на диком, голом берегу. Передо мной пустыня водяная (Тютчев «Кораблекрушение»); Тогда весь юг, все то пространство, что составляет нынешнюю Новороссию, было зеленою девственною пустынею (Гоголь «Тарас Бульба»). Пустыней также называют любое 'безлюдное место, пустое, ничем не заполненное пространство': Люди охотно сочувствуют больным. Но попробуйте заикнуться про венерическую болезнь. Вокруг вас немедленно образуется пустыня (Донцова «Страстная ночь в зоопарке»).

И даже когда слова пространство, земля, остров, обочина, материк, бугор (ср.: за бугром) включаются в политические контексты, их метафорическое употребление «недалеко» отходит от прямого, обогащая лексическое обозначение пространства, ср.:

Один из представителей Арзамаса-16, где я недавно побывал, сказал, что у них сохранились островки сочиализма. Задача коммунистов вместе с народом превратить наше государство в материк социилизма (АиФ, 07.02.93); Кстати, многие из далеких «бывших» вели себя адекватно на обоих склонах «бугра» (КП, 04.02.93); [...] эти методы дают прекрасные результаты «за бугром» (НМ., 1990, №5).

Кроме того, лексические наименования пространства пополняются и за счет регулярных метонимических переносов по модели: «действие - место действия», 
ср.: спуск (крутой), объезд (неудобный), переход (подземный), перевал (опасньй) и т.д. Таким образом, категория пространства выражается в лексике широко и разнообразно.

Грамматическое выражение пространства в русском языке также привязано к лексике. Любая грамматическая конструкция от падежных и предложно-падежных форм до сложного предложения опирается на лексику, ср.: идти лесом (полем, переулком), по улице, по лесу, по городу; стоять на дороге, на берегу, у оврага и т.п.; идти туда, откуда пришел и т.д.

И в словообразовании наименования пространства часто являются как бы некоторыми модификациями соответствующих лексических единиц, ср.: пригород, загород, подземелье, поднебесье, загорье, предгорье, пригорок, перелесок, заречье, побережье, приозерье, переулок, верховье, низина, вериина и т.д. Редкие сложные слова с пространственным значением тоже созданы на основе соответствующей лексики, например, лесостепь, лесосека, лесотундра, лесопарк. Образования названий пространств от признаковых слов единичны, ср.: пустыня, равнина и некоторые другие. Мы не рассматриваем здесь в категории пространства названия разного рода помещений, ср.: купальня, раздевалка, коровник, конюшня и др. В них сама пространственность приглушена функциональностью.

Как видно из наблюдений, и система языка, и средства словообразования позволяют производство разных наименований пространств. Ограничения здесь могут налагаться израсходованностью производящих основ на данное время и/или отсутствием потребности в новых пространственных названиях. Оба эти фактора неразрывно связаны. Так при описании космического полета (реального или фантастического) возможно возникновение потребности обозначить часть космического пространства перед достижением планеты как предпространство или запланетье, или нечто подобное. Такие названия вполне вписываются в ряд узуальных образований. Такое наименование мы находим, например, у Стругацких - подпространство («Волны гасят ветер»). А. В. Сорокину понадобилось образование Подмосква («Теллурия»); Глаза Надежды Антоновны смотрели в запространство ( Б. Пильняк. Волга впадает в Каспийское море).

Таким образом, наблюдается определенная связь словообразовательной возможности выражения пространства с выражением его в лексике.

Категория времени словообразовательно тоже обнаруживает определенную зависимость от лексических единиц временно́й семантики, ср.: час, год, неделя; зима, весна и т.д. Это, с одной стороны, чисто модификационные образования - годик, часик, часок, минутка, денек, ночка и др., и, с другой стороны, не очень многочисленные - година, предзимье, предвесенье, одночасье, полугодие, двухлетка, пятилетка, столетие, межсезонье и др. Связь с лексикой в сфере образований у категорий пространства и времени выражается и в том, что эти категории имеют в языке лексические обозначения непроизводными словами, так сказать, до и вне словопроизводства, а производные названия рождаются на базе этих лексических единиц. Иными словами, эти категории находят выражение и в лексике, и в словообразовании. 
Рассмотрим теперь словообразовательные возможности выражения категорий причины, следствия, цели. Предварительно обратимся к тому, выражаются ли эти категории на уровне лексики, поскольку, как мы пытались показать, здесь существует прямая связь.

В языке нет лексических единиц, называющих причину. Объяснение заключается в природе этого понятия. Его обозначение не опирается на предметные реалии, как скажем, пространство, или на то, что человек может наблюдать и воспринимать органами чувств, например, зрительно: смену дня и ночи, смену времен года и т.П. Причинные, целевые, условные, уступительные отношения возникают из взаимодействия двух ситуаций, ср.: покраснел от смущения, побледнел от стра$x a$, сорвал голос из-за простудbl. Причина возникает из взаимодействия ситуации покраснел (побледнел) и ситуации - смущение, ощущение страха и т.п. Сами же слова смущение, страх и т.д., отдельно взятые, причину не обозначают, в других контекстах они могут быть участниками отношений условия, уступки, а в причинных - быть следствием, ср.: Несмотря на страх перед тигром, он вошел в клетку; К моему смущению отец при всех похвалил меня и т.д.

Лексических обозначений причины нет ни среди прямых, ни среди метонимических номинаций, и не может быть. В предложениях, обозначающих взаимодействие двух ситуаций (в так называемых предложениях тождества) нередко выражаются причинно-следственные отношения. Например: Приезд тетки - для них одно беспокойство. Приезд при этом заключает в себе причину, а беспокойство следствие. Но это на уровне синтаксиса. При отсутствии взаимодействия этих двух ситуаций слова приезд и беспокойство не называют ни причину, ни следствие. Это отношения между подлежащим и сказуемым.

Итак, для выражения категории причины требуется отношение двух ситуаций (поэтому они есть в любом сложном предложении), но они не могут быть выражены лексически и словообразовательно.

Отмечу еще одно обстоятельство, объясняющее невозможность актантной метонимии со значением причины.

Мы исходим из необходимости постоянной связи между объектами (в том числе и абстрактными понятиями) как условия возможности метонимии, ср.: «Отражая постоянное взаимодействие объектов, метонимия типизируется, создавая семантические модели многозначных слов» [Арутюнова 1990: 142]. Об этом писал в свое время М. М. Покровский [Покровский 1959: 144-147]; о двух подходах к метонимии см. также [Гинзбург 1985: 54].

Между действием (состоянием) и причиной нет постоянной и регулярной связи: причина не привязана к определенному действию или состоянию. Она может быть у любого действия - сознательного или не сознательного, в отличие от цели, которая может быть только у сознательного произвольного действия.

Кроме того, повторю, актантные метонимические значения как значения слов возможны лишь тогда, когда в языке существуют и первичные лексические обозначения участников действия. Как это наблюдается со значениями субъекта 
действия, места действия, инструмента, средства действия, которые широко представлены в языке на лексическом уровне.

Что касается следствия, то, естественно, отдельного рассмотрения этого понятия здесь не требуется, поскольку, как известно, это неотъемлемая часть причинно-следственных отношений. Хотя в разных конструкциях - в простом и сложном предложении - причина и следствие имеют свое формальное выражение.

Ясно, что в языке нет лексических единиц, называющих следствие. Как и причина, следствие не имеет прямых номинаций в лексике основной системы частей речи и местоименной. Нет наименований для этого понятия и среди переносных значений, в частности, метонимических.

Как и понятие причины, понятие цели возникает из взаимодействия двух ситуаций - сознательно контролируемого действия, направленного на достижение другого действия, ср.: приехал учиться, сказал в утешение, послали (вертолет) для спасения (альпинистов). Аналогично категории причинности, категория цели не имеет лексического выражения: нет лексических единиц со значением «цель», ни в прямом, ни в переносном смысле, ни среди метафор, ни среди актантной метонимии. Соответственно, нет и не может быть и словообразовательного выражения этой категории, опять-таки, в силу ее природы. И причина, и цель, и другие близкие к ним категории, которых мы не коснулись в этой работе (условие, уступка), выражаются широко и разнообразно лишь на уровне синтаксиса.

Эта закономерность, как нам представляется, обнаруживается не только в русском языке, она носит универсальный характер.

\section{Литература}

Апресян Ю.Д. Лексическая семантика. Синонимические средства языка. М., $1974.367 \mathrm{c}$.

Арутюнова Н.Д. Метафора и дискурс // Теория метафоры. М.: «Прогресс», 1990. C. 5-33.

Гинзбург Е.Л. Конструкции полисемии в русском языке. Таксономия и метонимия. М.: Наука, 1985. 223 с.

Грамматика современного русского литературного языка. М.: Наука, 1970. $755 \mathrm{c}$.

Русская грамматика. В 2-х томах. Т. 1. М.: Наука, 1980. 784 с.

Земская Е. А. Словообразование как деятельность. М.: Наука, 1992. 224 с.

Краткая русская грамматика. М.: Русский язык, 1989. 639 с.

Милославский И.Г. Вопросы словообразовательного синтеза. М.: Наука, 1980. 296 c.

Обратный словарь русского языка. М.: Издательство «Советская энциклопедия», 1974. 944 с.

Пешковский А. М. Русский синтаксис в научном освещении. Изд. 7. М.: Учпедгиз, 1956. 511 с. 
Покровский М.M. Семасиологические исследования в области древних языков // М.М. Покровский. Избранные работы по языкознанию. М.: Изд-во Академии наук СССР, 1959. $382 \mathrm{c.}$

Скляревская Г.Н. Метафора в системе языка. СПб.: Наука, 2004. 165 с.

Толковый словарь русской разговорной речи. Вып. 1 / Под ред. Л.П. Крысина. М.: Языки славянских культур, 2014. 776 с.

\author{
Olga P. Ermakova \\ Tsiolkovsky Kaluga State University \\ (Russia, Kaluga) \\ olga_ermakova.kaluga@mail.ru
}

\title{
POSSIBILITIES OF WORD FORMATION IN THE SPHERE OF EXPRESSION OF LOGICAL CATEGORIES
}

In the article possibility and impossibility of expression are examined by word-formation facilities of semantic categories of subject, object, space, time, reason and aim. Limitations of word-formation expression of object are marked, before all animated. In hired an object is not examined in philosophical sense: as exists out of us and does not depend on our consciousness, but linguistically - as what an action is sent to. In this connection a value of object can be only in the derivatives motivated by verbs, but swingeing majority of such derivatives names not what an action is sent to, and then, that arises up as a result of action. An author sets dependence of word-formation expression of analysable categories on their presence in the lexical system of Russian. Most " attachment" to the vocabulary, in opinion of author of the article, a space category discovers. Quite another character to the свойственен categories of reason and aim. These categories on the nature can not be expressed lexically: causal relations, as well as having a special purpose, arise up only at co-operation of two situations and can not be expressed in a word, their word-formation expression is accordingly impossible also.

Key words: subject, object, space, time, cause, purpose.

\section{References}

Apresyan Y.D. Leksicheskaya semantika. Sinonimicheskie sredstva yazyka [Lexical semantics. Synonymous means of language]. Moscow, 1974. 367 p.

Arutyunova N.D. [Metaphor and discourse]. Teoriya metafory [Metaphor theory]. Moscow: Progress Publ, 1990. P 5-33 (In Russ.).

[A short Russian grammar]. Moscow, 1989.639 p.

Ginzburg E.L. Konstruktsii polisemii v russkom yazyke. Taksonomiya i metonimiya [Design of polysemy in Russian language. Taxonomy and metonymy]. Moscow: Science Publ., 1985. 223 p. 
Grammatika sovremennogo russkogo literaturnogo yazyka [The grammar of modern Russian literary language]. Moscow, 1970. 755p.

Miloslavskiy I. G. Voprosy slovoobrazovatel'nogo sinteza [The problems of derivational synthesis]. Moscow, 1980. $296 \mathrm{p}$.

Obratnyi slovar' russkogo yazyka [Reverse dictionary of the Russian language]. Moscow, 1974. $944 \mathrm{p}$.

Peshkovsky A.M. Russkii sintaksis $v$ nauchnom osveshchenii [Russian syntax in a scientific light]. Moscow, 1956. $511 \mathrm{p}$.

Pokrovsky M.M. [Semasiologically research in the field of ancient languages]. Izbrannye raboty po yazykoznaniyu [Selected works on linguistics]. Moscow, 1959. 382 p. (In Russ.).

Russkaya grammatika [Russian grammar]. Moscow, 1980-2005. 884 p.

Sklyarevskaya G. N. Metafora v sisteme yazyka [Metaphor in the language system]. St.-Petersburg, 2004. 165 p.

Tolkovyi slovar' russkoi razgovornoi rechi [Explanatory dictionary of the living Russian language]. Issue 1, edited by L.P. Krysin. Moscow, 2014. 776 p.

Zemskaya E. A. Slovoobrazovanie kak deyatel'nost' [Word-Formation as an activity]. Moscow, 1992. 224 p. 


\section{Г.И. Кустова}

Институт русского языка им. В. В. Виноградова РАН

(Россия, Москва)

galinak03@gmail.com

\section{НАРЕЧНЫЙ КВАЗИРЕЛЯТИВ КАК ПОЛОЖЕНО: СЕМАНТИКА И ТИПЫ УПОТРЕБЛЕНИЯ*}

В статье рассматриваются местоименные конструкции - свободные релятивы (квазирелятивы) типа [Сядь] как положено, — которые являются результатом редукции местоименных придаточных ([Сядь] так, как положено сидеть). Употребления свободных релятивов серии «как + модальный компонент» (как положено, как следует, как надо) разделяются на три группы. Первая группа - результат лексикализации: это развитие оценочного значения 'хорошо, нормально' (Процесс развивается как положено). Вторая группа - расшифровка: свободный релятив выступает как обобщенная оценка ситуации, затем конкретизируется ее денотативное содержание (Что подают? Как положено: расстегаи, икорку, бальчок, водочку...). Третья группа - интерпретация (квалификация): сначала дается денотативное содержание, затем - оценочный квазирелятив (Он пришел с иветами, как положено).

Ключевые слова: неопределенные местоимения, свободные релятивы (квазирелятивы), лексикализация, модальность, интерпретация.

Свободными релятивами, или квазирелятивами, принято называть безвершинные придаточные: Бери что хочешь; Бросает где попало; Сядь как следует; Ночует где придется; Делает ито прикажут. По происхождению это местоименно-соотносительные предложения (сложные предложения с местоименно-соотносительными придаточными [Крючков, Максимов 1977], [Максимов 2011], или, в терминологии [РГ-ІІ 1980, §§ 2924-2929], предложения с неориентированной анафорической связью, образованные местоименными парами), ср.: To,

* Исследование выполнено при поддержке РФФИ в рамках проекта № 17-04-00554 «Семантические процессы в сфере местоименной и предикатной лексики: стратегии референции и концептуализации». Литературные примеры извлечены из Национального корпуса русского языка (НКРЯ), www.ruscorpora.ru 
что лежит в коробке, не доставай; Он любит отдыхать там, где есть море или озеро; Бери всё, что хочешь. В русской грамматической традиции такие придаточные принято называть фразовыми номинациями [Крючков, Максимов 1977: 71], а также перифрастическими (описательными) обозначениями, предикативными перифразами [Максимов 2011: 343, 339, 346]: они прикрепляются к местоимению и изоморфны (изофункциональны) слову [Максимов 2011: 339].

Квазирелятивы образуются путем редукции исходной местоименной структуры: происходит опущение вершинного (соотносительного) местоимения в главной клаузе, к которому относится придаточное (этот процесс характерен для разговорной речи): Стой где стоишь; Делай что говорят; Ты спрятал что вчера принесли?; Tbl поговорил с кем я просил?; кроме того, может редуцироваться инфинитив, повторяющий глагол в главной клаузе: Сядь как положено $\leftarrow$ 'Сядь так, как положено сидеть'. В результате квазирелятив как бы передвигается в главную клаузу и занимает в ней позицию утраченного опорного местоимения - дополнения или обстоятельства: гуляй где хочешь $\approx$ гуляй в любом месте; приходи когда положено $\approx$ приходи в положенное время.

В традиционной русистике эти конструкции интересовали исследователей с точки зрения их синтаксического статуса: по структуре они являются предложениями (содержат предикат), но занимают позицию члена предложения, синтаксическое место слова ([Егорова 1967], [Верницкая 1969: 12-15], [Уханов: 1969], [Шведова 1969: 74]).

Современных исследователей интересует, главным образом, тот класс местоименных конструкций, которые подверглись максимальной редукции и морфологизации и превратились в аналоги (или даже эквиваленты) местоимений. Большая литература посвящена местоимениям, которые принято называть свободными релятивами, или квазирелятивами ([Haspelmath 1997], [Татевосов 2002], [Вуlinina, Testelets 2004], [Былинина, Тестелец 2005], [Assmann 2013]), ср.: кто угодно; что попало; где придется; куда не следует; сколько надо и под. Они функционируют как неопределенные местоимения, т.е. местоимения типа что-нибудь, кое-где, кто бы то ни было и под. Многие из них образуют серии с разными местоимениями: кто / что /где... угодно; кто / что /где... попало, что / куда / сколько / как... положено и т.п. Особым вниманием исследователей пользуются квазирелятивы свободного выбора (Free Choice): _ попало, _угодн и _хочешь, см. [Татевосов 2002], [Былинина, Тестелец 2005], [Кустова 2015], [Лютикова 2015].

В данной работе мы рассмотрим квазирелятив с наречным компонентом, или наречный квазирелятив (сокращенно - НКР) как положено. В качестве фона для сравнения будем привлекать НКР с наречными компонентами куда, где, когда [положено], а также НКР как следует и как надо с похожей модальной семантикой.

Общая семантика НКР группы положено определяется семантикой местоимения и семантикой модального компонента.

Положено выражает идею соответствия неким высшим требованиям: 
- либо есть какая-то инстанция (обычно - официальная), которая устанавливает требования, стандарт реализации ситуации (для разных типов ситуаций разные требования и стандарты реализации, которые субъект, вообще говоря, должен знать заранее): С утра пусть во всех подразделениях выберут уполномоченных. Протоколь оформлять как положено. Чтобы потом никто не придрался [Борис Екимов. Пиночет (1999)]; На работу надо приходить когда положено, а не когда вздумается; Он всегда держит оружие где положено [в сейфе];

- либо просто есть общепринятые представления о стандартной реализации какой-то ситуации: Саша полицию выбросил в окно. «Войдите как положено», сказал [Вячеслав Солдатенко. Ева (2010)]; Похороны организовали как положено. Проводили хорошо [Маша Трауб. Плохая мать (2010)]

Что касается местоименного компонента как, то он существенно отличается от других вопросительно-относительных местоимений, и этим, в частности, объясняется то, что у НКР с компонентом как больше типов употребления, чем у НКР с другими местоимениями.

Мы рассмотрим три основных типа употребления как положено: лексикализацию, а именно развитие оценочного значения; употребление в качестве обобщенного элемента с последующей расшифровкой; интерпретацию.

\section{Развитие оценочного значения}

Одно из направлений эволюции наречных оборотов - лексикализация.

В принципе, у качественных слов есть два довольно универсальных типа значения - это значения оценки и степени, которые образуются на базе качественной семантики у прилагательных и наречий. Хотя речь идет о местоимениях, у них тоже образуются значения оценки и степени. У неопределенных местоимений, в том числе квазирелятивов, возникают значения отрицательной оценки: Это тебе не кто-нибудь; Это тебе не какой-нибудь капитан, а изельй полковник; Он все делает как-нибудь / кое-как; Встречается с кем попало; Ночует где придется; Подумаешь, какой-то майор; аналогично - у отрицательных местоимений: Да он просто никто; Сегодня он был совершенно никакой. У восклицательных и указательных местоимений развиваются значения положительной оценки и высокой степени: Какой голос!; Как она пела!; Как он переживал!; Он так старался!.

НКР тоже претерпевают лексикализацию, приобретая значение оценки 'хорошо', ‘нормально': Резинки, идущие в комплекте, были установлены на кондициинер как положено [форум]; У вас всё идёт как положено. Сердиебиение плода ясное, ритмичное [Татьяна Соломатина. Девять месяцев, или «Комедия женских положений» (2010)] (аналогичное употребление есть у других НКР с семантикой долженствования: «Раз уж взялись, то нужно делать все как следует», - объясняет Смирнов [«Эксперт», 2014]; Рана чистенькая, аккуратная, затягивается, как надо [А. Моторов. Преступление доктора Паровозова (2013)] — 'хорошо'). 
Значение 'хорошо' является естественной импликацией той идеи соответствия норме, требованию, общепринятым стандартам, которая содержится в НКР: если что-то соответствует норме, а не нарушает ее, это хорошо.

Поскольку исходно НКР с как- обстоятельства образа действия, то самые благоприятные контексты для развития значения 'хорошо' - это два случая. Первый - ситуации с неодушевленными объектами и физическими процессами: $P e$ зинки установлены как положено; Эта штука не работает как положено; Рана затягивается как надо; Волосы лягут как надо - у процессов не может быть образа действия, остается оценочная интерпретация. Второй случай - предикаты с абстрактным значением: ведите себя как положено; сделаю как надо.

\section{Расшифровка}

НКР долженствования (в отличие от квазирелятивов свободного выбора типа что попало, что угодно, что хочешь) часто соответствуют конкретной, уже реализованной ситуации и имеют определенный или (практически однозначно) вычислимый референт. При этом НКР с как отличаются от НКР с другими наречиями. НКР с компонентами куда, где, когда функционируют как обычные обстоятельства. Они обозначают определенное место и время - либо известное из опыта: А у тя иконка-то есть ли? - Есть. Она, правда, в шифонере... - Bbl-ынь, вынь, матушка, грех. Чего же ее впотьмах держать? Вынь да повесь, куда положено [Василий Шукшин. Письмо (1970-1972)] — в красный угол; Мужчина покурил и ушел, бросив окурок куда положено [Людмила Улицкая. Генеле-сумочница (1992)] — в урну; Многие думают, что тут ничего не выдумаешь: дои корову когда положено - и вся наука [«Огонек». № 27, 1959] - в 5 утра и в 5 вечера; - либо вычислимое по ситуации или известное агенсу: Дай ключи, я потом сдам куда положено [Комсомольская правда, 2007.09.14].

Таким образом, где / куда / откуда положено и когда положено - это просто косвенное обозначение места и времени. Правда, называя место и время с помощью НКР, говорящий сообщает дополнительную информацию - что это конкретное место или время задано внешними требованиями, правилами, соответствует им.

Как устроено иначе и имеет особый статус в русской грамматической системе. В традиционной грамматике как считается обстоятельством образа действия, и как положено, в принципе, может соответствовать обстоятельству образа действия, выражаемому соответствующими наречиями: Сделал все как положено - быстро и аккуратно. Однако само понятие «образ действия» крайне расплывчатое. М.В. Филипенко [Филипенко 2003] при описании наречий и адвербиалов, относимых к образу действия, использует термин «состав ситуации». Это более широкое понятие, чем образ действия: состав - это отдельные вариативные аспекты содержания ситуации.

Однако реальное употребление как положено - еще шире. Если где, куда обозначает только место, когда - только время, то как может соответствовать не только образу действия: пришел с ияветами, как положено (это как раз самый редкий случай), - но вообще самым разным аспектам ситуации (в том числе месту 
и времени), а также ситуации в целом, как показывают приводимые ниже примеры, где как положено находится в препозиции и сопровождается своего рода пояснительной конструкцией.

Как положено - это некоторая интерпретация денотативного содержания: говорящий рассматривает какие-то аспекты ситуации и оценивает их соответствие норме, стандарту или требованию. Эти аспекты могут быть эксплицированы в том же предложении или ближайшем контексте:

Поднёс к губам и отпил как положено - большими глотками и сразу половину [Андрей Волос. Недвижимость (2000) // «Новый Мир», 2001] — как положено и сколько положено;

Наташу Петя похоронил как положено - на престижном кладбище [Маша Трауб. Ласточ...ка (2012)] — где положено;

Что подают? Как положено: расстегаи, икорку, бальчок, водочку... [Дина Рубина. Белая голубка Кордовы (2008-2009)] — что положено;

У величественных ступеней думы я чувствую себя как положено - человеком маленьким [«Русский репортер», 2013] — кем положено;

Все было как положено - поминки, девять дней [Маша Трауб. Замочная скважина (2012)] — целая ситуация;

Заканчиваем мы как положено: обмываем наши свершения у Васи на кухне [Олег Зайончковский. Счастье возможно: роман нашего времени (2008)] — целая ситуация.

\section{ПРИМЕЧАНИЕ}

У как надо и как следует аналогичная ситуация, но примеров такого употребления в НКРЯ существенно меньше, и конкретизация часто находится в другом предложении:

Неделю все ило как надо. Каждый день Костик под его руководством колотил nо груше [М. С. Аромштам. Мохнатый ребенок (2010)].

Вообще, шедшие в квартиру N 50 были снаряжены как следует. У двух из них в карманах были тонкие, легко разворачивающиеся шёлковые сети. Ещё у одного - аркан, ещё у одного - марлевые маски и ампулы с хлороформом [М. А. Булгаков. Мастер и Маргарита (1929-1940)].

В принципе, такой тип употребления вообще свойствен местоимениям (и не только местоимениям, но и абстрактным существительным, ср.: Купили коекакую мебель: стол, стулья и диван) именно в силу их природы: местоимения (кроме 1 и 2 лица) нуждаются в расшифровке.

\section{Интерпретация (квалифицирующая конструкция)}

В квалифицирующей конструкции обратный порядок следования НКР и его денотативного содержания: сначала сообщается конкретное содержание ситуации или ее аспекта, а потом оно оценивается с точки зрения соответствия каким-либо 
требованиям или общепринятой норме. В постпозиции как положено находится существенно реже, чем в препозиции (а как следует и как надо в нашей выборке вообще не встретились).

В постпозиции как положено выполняет функцию интерпретации, квалификации денотативного содержания с точки зрения соответствия норме или требованиям:

Однажды она пригласила его на спектакль в Учебный театр. Конечно, он пришел - с изветами, как положено [Анна Берсенева. Полет над разлукой (2003-2005)]

Милиция приехала быстро, с мигалками, оружием на изготовку - все как положено [Маша Трауб. Замочная скважина (2012)].

Юрика я сама бросила. Нехорочо, конечно, получилось. Он так к свадьбе готовился. Хотел, чтобы и платье, и машины, и ресторан - как положено [Маша Трауб. Ласточ...ка (2012)].

Другие НКР в такой конструкции неупотребительны, но при этом они легко заменяются на как положено, ср.: ?Оружие он хранит в сейфе, где положено vs. Оружие он хранит в сейфе, как положено; 'Коров доят в 5 утра, когда положено vs. Коров доят в 5 утра, как положено.

Рассмотренный материал еще раз подтверждает, что конструкции и единицы, содержащие местоименный компонент как, занимают в русской грамматической системе особое место и имеют более широкую систему типов значений и употреблений, чем конструкции и единицы с другими местоимениями.

\section{Литература}

Былинина Е.Г., Тестелеи Я.Г. О некоторых конструкциях со значением неопределенных местоимений: амальгамы и квазирелятивы. Доклад на семинаре «Теоретическая семантика» под. рук. акад. РАН Ю. Д. Апресяна. М., 2005.

Верницкая С.Г. Предложения с предикативными единицами, выполняющими функцию членов предложения: автореф. дисс. ...канд. филол. наук. М., 1969. 18 с.

Егорова И. Н. Позиционные эквиваленты слова в составе предложения (к изучению вариативных синтаксических рядов) // Русский язык. Грамматические исследования. М.: Наука, 1967. С. 78-95.

Крючков С. Е., Максимов Л. Ю. Современный русский язык. Синтаксис сложного предложения. М.: Просвещение, 1977. 191 с.

Кустова Г.И. Прагматические факторы в редуцированных конструкциях: квазирелятивы типа что хочешь // Вестник Новосибирского государственного педагогического университета. 2015. № 5. С. 122-133.

Лютикова E. A. Безвершинные относительные предложения в русском языке: эмпирические данные и теоретические проблемы // Rhema. Рема [Вестник Московского государственного гуманитарного университета им. М.А. Шолохова. Серия Филологические науки], 2015, № 3. С. 74-85.

Максимов Л. Ю. Многомерная классификация сложноподчиненных предложений. Ставрополь / Пятигорск, 2011. 675 с. 
РГ-ІІ 1980 - Русская грамматика. Т. ІІ. Синтаксис / Под. ред. Н. Ю. Шведовой. М.: Наука, 1980. 709 с.

Татевосов С. Г. Семантика составляющих именной группы: кванторные слова. М.: ИМЛИ РАН, 2002. 239 с.

Уханов Г. П. Двусоставные конструкции с придаточным во второй части // Мысли о современном русском языке. М.: Просвещение, 1969. С. 105-117.

Филипенко М. В. Семантика наречий и адвербиальных выражений. М., 2003. 304 с.

Шведова Н. Ю. О понятии «регулярная реализация структурной схемы простого предложения» // Мысли о современном русском языке. М.: Просвещение, 1969. C. 67-80.

Assmann A. Three Stages in the Derivation of Free Relatives. Rule Interaction in Grammar (Linguistische Arbeitsberichte 90). F. Heck \& A. Assmann (eds.). Universität Leipzig, Leipzig, 2013, pp. 203-245.

Bylinina E. G., Testelets Ya. G. Sluicing-Based Indefinites in Russian. Formal Approaches to Slavic Linguistics 13: The South Carolina Meeting. Steven Franks, Frank Y. Gladney and Mila Tasseva-Kurktchieva (eds.). Ann Arbor, MI: Michigan Slavic Publications. 2004, pp. 355-365.

Haspelmath M. Indefinite Pronouns. - Oxford: Oxford University Press, 1997. 364 p.

\section{Galina I. Kustova}

V. V. Vinogradov Russian Language Institute of the Russian Academy of Sciences

(Russia, Moscow)

galinak03@gmail.com

\section{THE SEMANTICS AND THE TYPES OF USING OF THE ADVERBIAL FREE RELATIVE}

The paper deals with pronominal constructions — free relatives like [Syad'] kak polozheno ('Sit down as it should be / as expected'). They are the result of pronoun clauses reduction (Syad' tak, kak polozheno sidet'). Russian free relatives «kak + modal component» (kak polozheno; kak sleduet, kak nado) have three types of uses. The first type is a result of lexicalization: free relative has idiomatic evaluative meaning (Protsess razvivaetsya kak polozheno 'the process is developing normally / well'). The second type is decoding: free relative is presented as a generalized evaluation of the situation; then its denotative content is specified (Chto podayut? Kak polozheno: rasstegai, ikorku, balychok, vodochku 'What is served? As it should be: pies, caviar, balyk, vodka ...'). The third type is the interpretation (qualification): the denotative content is given first, then the evaluative free relative follows (On prishel s tsvetami, kak polozheno 'he came with flowers, as expected').

Key words: indefinite pronouns, free relatives, reduction, lexicalization, modality, interpretation. 


\section{References}

Assmann, Anke. Three Stages in the Derivation of Free Relatives // In: F. Heck \& A. Assmann, eds, Rule Interaction in Grammar (Linguistische Arbeitsberichte 90). - Universität Leipzig, Leipzig, 2013, pp. 203-245.

Bylinina E. G., Testelets Ya. On some indefinite pronouns constructions: amalgams and free relatives. Report of the workshop «Theoretical semantics» under the direction of Ju.D. Apresjan. Moscow, 2005. (In Russ.)

Bylinina E. G., Testelets Ya. G. Sluicing-Based Indefinites in Russian // Formal Approaches to Slavic Linguistics 13: The South Carolina Meeting, 2004, pp. 355-365, ed. Steven Franks, Frank Y. Gladney and Mila Tasseva-Kurktchieva. Ann Arbor, MI: Michigan Slavic Publications.

Egorova I.N. Positional equivalents of words in sentence (to analysis of syntactic variable series) // Russkii yazyk. Grammaticheskie issledovaniya [The Russian: Grammatical studies]. Moscow: Nauka Publ., 1967, pp. 78-95. (In Russ.)

Filipenko M.V. Semantika narechii i adverbial'nykh vyrazhenii [The Semantics of Adverbials]. Moscow: Azbukovnik Publ., 2003. 304 p.

Haspelmath M. Indefinite Pronouns. Oxford: Oxford University Press, 1997. 364 p.

Kryuchkov S.E., Maksimov L.Yu. Sovremennyi russkii yazyk. Sintaksis slozhnogo predlozheniya. [The Modern Russian. The syntax of complex sentence]. Moscow: Prosveshchenie Publ., 1977. 191 p. (In Russ.)

Kustova G. I. [Pragmatic factors in reduced constructions: free relatives chto khochesh] // Vestnik Novosibirskogo gosudarstvennogo pedagogicheskogo universiteta [Bulletin of the Novosibirsk State Pedagogical University]. 2015. №5, pp. 122-133. (In Russ.)

Lyutikova E. A. [Free relatives in Russian: empirical data and theoretical issues] // Rhema. Rema. [Vestnik Moskovskogo gosudarstvennogo gumanitarnogo universiteta im. M. A. Sholokhova. Seriya Filologicheskie nauki], 2015, №3, pp. 74-85. (In Russ.)

Maksimov L. Yu. Mnogomernaya klassifikatsiya slozhnopodchinennykh predlozhenii [Multivariate classification of complex sentence]. Stavropol / Pyatigorsk, 2011. 675 p. (In Russ.)

Russkaya grammatika [Russian Grammar], Vol. II. (ed.) N.Yu. Shvedova. Moscow: Nauka Publ., 1980. 709 p. (In Russ.)

Shvedova N. Yu. [About regular alternant of formal model of simple sentence] // Mysli o sovremennom russkom yazyke [Essays on the Modern Russian]. Moscow: Prosveshchenie Publ., 1969, pp. 67-80. (In Russ.)

Tatevosov S. G. Semantika sostavlyayushchikh imennoi gruppy: kvantornye slova [Semantics of constituents of noun phrase: quantifier words]. Moscow: IMLI RAS, 2002. 239 p. (In Russ.)

Ukhanov G.P. [Two-member constructions with a subordinate clause in the second part] // Mysli o sovremennom russkom yazyke [Essays on the Modern Russian]. Moscow: Prosveshchenie Publ., 1969, pp. 105-117. (In Russ.)

Vernitskaia S.G. Predlozheniya s predikativnymi edinitsami, vypolnyayushchimi funktsiyu chlenov predlozheniya [Sentences with a predicative units as sentence part]. Abst. phil. sciences. cand. Moscow, 1969. 18 p. (In Russ.) 


\author{
А. Б. Летучий \\ Нацииональный исследовательский университет Высшая школа экономики \\ (Москва, Россия) \\ alexander.letuchiy@gmail.com
}

\title{
АСИММЕТРИЯ УПОТРЕБЛЕНИЯ МЕСТОИМЕНИЙ ЧТО И КТО И МОРФОЛОГИЧЕСКАЯ ОДУШЕВЛЁННОСТЬ
}

В статье рассматривается одно ограничение на употребление вопросительного местоимения что. Это местоимение избегает конструкций, где оно синтаксически параллельно и кореферентно анафорическим местоимениям он / она / оно. Например, в конструкции уточнения антецедента типа - Я ему позвоню. - Кому «ему»? местоимение что не употребляется в случаях, когда его форма отличается от формы анафорического местоимения (невозможно или сомнительно, например, - Я его купил. - Что «его»?). Мы рассматриваем разные возможные объяснения этого факта и приходим к выводу, что ни объяснение в терминах буквального совпадения форм, ни объяснение, ориентированное на референцию, не описывают ситуации. Скорее, речь о том, что должны совпадать грамматические характеристики местоимений: тип склонения, одушевлённость и род.

Ключевые слова: одушевлённость, вопросительные местоимения, анафорические местоимения, тип склонения

\section{1. Введение}

Давно замечено, что в русском языке категория грамматической одушевлённости не полностью соответствует одушевлённости семантической. Часто приводится пример со словами покойник и труn, из которых первое относится к грамматически одушевлённым а второе - к неодушевлённым:

(1) Я видел покойника (*покойник) / труп (*трупа).

В частности, одно из проявлений этого несоответствия состоит в том, что местоимение он всегда грамматически одушевлено - вне зависимости от того, к какому типу объекта оно относится. В предложении (2):

(2) Я её уже видел.

- местоимение его может относиться, например, к Маше, а может - к новой машине. 
С другой стороны, местоимения что и кто в своём поведении более соответствуют семантической одушевлённости: что грамматически не одушевлено, а кто одушевлено: (3) Что / кого ты видел?

Ниже мы покажем, что грамматическая природа категории одушевлённости проявляется ещё и в сочетаемости «одушевлённых» и «неодушевлённых» местоимений.

Грамматическая категория одушевлённости, как указано в работе [Крысько 1994], сформировалась к XVII в. В русском языке это противопоставление напрямую завязано на одушевлённость, однако в целом, согласно [Воейкова 2011] и [Malchukov, de Swart 2009], входит в круг явлений, называемых «differential object marking» («дифференциального объектного маркирования»). Явление подразумевает, что различные типы объектов получают разное маркирование.

\section{2. Конструкции уточнения антецедента}

В русском языке есть специальная конструкция переспроса типа (4), относящаяся к местоимениям:

(4) Сказывай, бесстыюжая, где ты с ним познакомилась? - обращуается она к сестрице. - С кем «с ним»? - С ним, с иематоном с своим? [М.Е. СалтыковЩедрин. Пошехонская старина. Житие Никанора Затрапезного, пошехонского дворянина (1887-1889)]

(5) Tы его хорошо знаешь? - Кого - его? - не понял я. - Ну мента этого ... [Вера Белоусова. Второй выстрел (2000)]

(6) - Да не нервничай ть - я все равно собиралась тебе ее показать. - Кого eе? [Дина Сабитова. Цирк в шкатулке (2007)]

Если слушающему неочевидно, к чему говорящий относит местоимение, для уточнения антецедента кто и анафорическое местоимение просто ставятся рядом. Конструкция сочетается со всеми формами местоимений он и она - например, с винительным (5), (6) и с творительным (4) падежами. Если исходное местоимение употреблялось при предлоге, при переспросе предлог употребляется и перед вопросительным, и перед анафорическим местоимением.

Хотя теоретически эта конструкция могла бы относиться не только к местоимениям, но и к существительным, этого на деле не происходит. Например, слова поэт или человек могут иметь разных референтов, употребляясь как средства анафоры, однако конструкцию переспроса не допускают:

(7) Говорят, что перед смертью поэт перестал верить в Бога. *Кто - поэт?

(8) - Мне человек говорил, что ты уехал. — *Кто человек?

В аналогичной функции в (7) и (8) нужно использовать нормальную именную группу с вопросительным местоимением типа какой человек или какой именно поэт.

\section{3. Нестандартная одушевлённость}

Перейдём теперь к нестандартному свойству рассматриваемой конструкции. Как показывают контексты ниже, кто при переспросе может относиться 
к неодушевлённым предметам: в (9) — к ожерелью, в (10) - к шкатулке, а в (11) — к взрыву.

(9) Он положил перед Кариной снимок. Та бросила сперва незаинтересованньй короткий взгляд, потом поднесла к глазам и побледнела. - Значит, Лёня все-таки сделал его... - Кого - его? - Погодите. - Карина сжала голову ладонями, зажмурилась, потом снова долго рассматривала ожерелье на фотографии. Да, это оно. [Александра Маринина. Последний рассвет (2013)]

(10) - Да не нервничай ты - я все равно собиралась тебе ее показать. — Кого - ее? Шкатулка взяла его за руку и потянула за собой - в фургон. ... - Вот она, на столе, - сказала за его спиной Эва. На столе, в самом ичентре, на клетчатой скатерти стояла музыкальная шкатулка. [Дина Сабитова. Цирк в шкатулке (2007)]

(11) Но ты его видел? - Кого - его? - Взрыв, конечно! (Э.-Э. Шмидт. Человек, который видел сквозь лица).

Даже более существенно то, что употребление что в таких контекстах практически невозможно:

(12) ?? - Но ты его видел? - Что - его? - Взрыв, конечно!

(13) ?? - Я всё равно собиралась тебе её показать. - Что - её?

Местоимение что допустимо только в том случае, когда совпадает по форме с анафорическим - то есть во всех падежах, кроме винительного:

(14) Оно с вечера, когда нужно, так и не болит... - А что - оно? Оно - что болит? - Да разобраться, бывает, и ничего не болит. [Александр Солженицын. Один день Ивана Денисовича (1961)]

(15) А ведь это - оно... - Что? Что - оно? - То, что мы искали. (М. Успенский, А. Лазарчук. Гиперборейская чума).

По примерам (14) и (15) может показаться, что обязательно только совпадение граммем падежа. В действительности, однако, странно выглядят даже примеры, где что сочетается с он или она в именительном падеже:

(16) ? - Это она / он. - Что - она / он?

При этом, если выкинуть из рассмотрения винительный падеж, в котором есть различие между что и он / она / оно по одушевлённости, остальные падежи тоже ведут себя не одинаково. В именительном падеже, как в (14) и (15), допустимо местоимение оно. В косвенных падежах возможны оно и он, но сомнительно она, поскольку окончания совпадают у мужского и среднего родов, а для женского используются другие:

(17) - С ним при эксперименте возникает другая проблема. - С чем «с ним»? С этим минералом.

(18) - С ней при эксперименте возникает другая проблема. - ?С чем «с ней»? С этой шеёлочью.

Надо сказать, что некоторая асимметрия возникает даже при местоимении кто, хотя она гораздо слабее, чем при что. Эта асимметрия касается случаев, когда форма анафорического местоимения сильно отличается от кто - не только по форме, но и по количеству слогов: вопрос Кому «ей»? несколько более шероховат, чем Кому «ему», хотя вряд ли неприемлем. 


\section{4. Другие конструкции с ограничением на употребление что}

\section{1. Переспрос без повтора анафорического местоимения}

Сходное ограничение действует и просто для переспроса о референте анафорического местоимения, без конструкции с повтором он, она, оно:

(19) ?-Я его потерял. - Что?

(20) ?- Покажи мне её. - Что?

Тем самым, что сомнительно и в других случаях, когда непосредственно следует или предшествует анафорическому местоимению и кореферентно ему, не обязательно, чтобы два местоимения выступали в рамках одной конструкции. Правда, в этих случаях вряд ли допустимо местоимение кто - при его употреблении будет навязываться понимание, что говорящий интерпретирует референт анафорического местоимения как одушевлённый:

(21) \#-Я его потерял. - Кого?

Естественно, и здесь при одушевлённом референте последовательность с кто звучит абсолютно нормально:

(22) 一 Я его боюсь. - Кого? - Да этого доктора.

\section{2. Контекст «присвоения референта»}

Ещё один контекст асимметрии - случай, когда референт для анафорического местоимения выбирается постфактум самим говорящим. И здесь «одушевлённые» контексты нормальны:

(23) Ну, убью я его... Неважно кого: личейского друга Мишу Яковлева, шалопая

Вульфа или добрейтего Сергея Абрамовича Баратынского, влюбленного в мою жену и тоже обманутого ею, или другого, неизвестного ... [Ю. М. Нагибин. У Крестовского перевоза (1972-1979)]

«Неодушевлённые» выглядят сомнительно:

(24) ?Ну куплю я её. Неважно, что кровать или кушетку.

(25) ?Ну куплю я его. Неважно, что стол или телевизор.

Как и в предыдущем случае, кто в этом «неодушевлённом» контексте также недопустимо.

\section{3. Отсутствие ограничений в других типах конструкций}

Для сравнения приведём похожие конструкции, где ограничения отсутствуют. Например, ограничения не возникают в случае противопоставления, когда его и что (и его дериваты что-то, что-нибудь и др.) относятся к разным референтам: (26) Принесли мне явно не его, а что-то из дешевого и противного. (shisha-nsk.ru/ index.php/restaurant/reviews.html)

Точно так же, видимо, отсутствуют ограничения на контексты, где референт его включается в число возможных референтов, предполагаемых при вопросе со что: 
(27) - У меня была мысль подарить дедушке телефон. - Так что ты всё-таки даришь: его или что-нибудь другое?

(28) - У меня была мысль пригласить Кёнига на конференцию. - Так кого ты всётаки приглашаешь: его или кого-нибудь другого?

Наконец, ограничения обычно отсутствуют в случаях, когда местоимения что и он / она / оно кореферентны, но расположены на некотором расстоянии друг от друга, например, разделены полной именной группой с тем же референтом:

(29) — Что ты купил? - Ноутбук. - А зачем ты его купил?

\section{5. Возможные объяснения}

В этом разделе мы рассмотрим возможные объяснения ограничений на употребление что в примерах типа (12) и (13). Как мы покажем, ни строго формальная гипотеза (полное совпадение форм), ни семантическая / референциальная не проходят. Скорее объяснение должно быть парадигматическим: требуется совпадение типа склонения.

\section{1. Идентичность форм}

Известно, что и некоторые другие процессы в языке регулируются именно формальной идентичностью форм или основ. Так, другая русская конструкция Pmb-mo он Pm (лежать-то он лежит, прыгать-то он прыгает) невозможна в том случае, когда у глагола не совпадают основы инфинитива и настоящего времени:

(30) *быль-то он есть

В этом случае надо предположить, что сочетания типа Что - она или Что он запрещены потому, что местоимения она и он не имеют окончания -о в отличие от местоимения оно - именно поэтому сочетание Что - оно возможно.

Тем не менее, это объяснение маловероятно. Хотя и что, и оно - формы именительного падежа, гласный -о в форме что вряд ли осознаётся как показатель именительного падежа. Это означает, что сочетания типа (12) и (13) запрещены не из-за формального различия между окончаниями, а именно из-за различия в граммемах рода и типе склонения.

\section{2. Подход Идиатова: асимметрия одушевлённых и неодушевлённых объектов}

Ещё один подход, ориентированный в большей мере на семантику и референтные свойства объектов, предложен в работах Д. Идиатова [2007]. Автор показывает, например, что в первом из приведённых ниже предложений нормально выглядит «одушевлённое» местоимение who, а во втором «неодушевлённое» what неприемлемо:

(31) There are plenty of women. Who / which (one) is Mary?

(32) There are plenty of books. Which (one) / *what is "Anna Karenina". 
Этот контраст объясняется контрастом в референтных свойствах двух типов объектов. Считается, что местоимение who стандартно предполагает в качестве ответа именно конкретный объект, что соответствует заданной ситуации. Напротив, what нередко сочетается с названиями классов объектов или их типовых представителей. Поэтому для вопроса о том, какая именно книга из класса является конкретной книгой «Анна Каренина» нужно использовать which или which one.

Однако этот подход, весьма продуктивный для типологии вопросительных элементов, едва ли подходит для нашего случая. Во-первых, он не объясняет, почему в контекстах типа (9) и (10) может нестандартно, в применении к неодушевлённому референту, использоваться местоимение кто. Естественно, вне контекста переспроса об антецеденте употребление типа (33) невозможно:

(33) *Кого тьл хочешь мне показать - шкатулку или монету?

Во-вторых, контекст переспроса в целом (не переспроса о референте местоимения) допускает что, но вне рассматриваемой конструкции:

(34) — Я купил газету. - Что? Газету?

В-третьих, сама природа переспроса предполагает, что никакого выделения из класса не предполагается - говорящий только уточняет референт встретившегося в речи местоимения. Тем самым, вряд ли контраст по референции здесь вообще может играть роль.

Исключением может быть конструкция «присвоения референта», как в примерах (23)-(25). Она может быть объяснена через референтные свойства, однако не совсем так, как это делает Идиатов. По-видимому, (24) и (25) хуже, чем (23) потому, что все одушевлённые объекты принадлежат к одному довольно гомогенному классу — классу живых существ (а в очень большом проценте случаев - даже к классу людей). Именно поэтому допустимо употребить местоимение его, а затем подобрать референта. Напротив, для неодушевлённых контекстов это странно - слишком уж немотивированным представляется употребление анафорического местоимения при полном отсутствии указания на класс, из которого выбирается референт (класс неодушевлённых предметов крайне гетерогенен).

\section{3. Объяснение}

Мы предлагаем объяснение, связанное с идентичностью форм, но не тождественное ему. Мы считаем, что ключевым для запрета на примеры типа (12) или (13) является не абсолютное тождество формы, а тип склонения.

С этим связано два наблюдаемых запрета: (1) запрет на переспрос типа Что «его»? (различается тип образования винительного падежа — «одушевлённый» у его и «неодушевлённый» у что) и (2) запрет в косвенных падежах на переспрос типа Что «он»? или Что «она»? при возможном Что «оно»? (несовпадение рода автоматически влечёт за собой несовпадение типа образования формы). 


\section{6. Грамматический контекст: другие ограничения на употребление местоимения что}

Рассматриваемые нами конструкции - не единственные, где контексты употребления местоимений с одушевлённым и неодушевлённым антецедентом асимметричны. Так, Е.В. Падучева [1985] убедительно показывает, что местоимения он, она, оно употребляется по-разному по отношению к одушевлённым и неодушевлённым объектам. Рассматривалась и асимметрия в употреблении вопросительных местоимений. Не претендуя на исчисление случаев такой асимметрии, мы упомянем некоторые из них.

Например, в работе [Летучий 2015] показано, что что ограниченно употребляется в вопросительных конструкциях с нулевой связкой:

(35) Кто твой любимый герой? [Виктор Астафьев. Последний поклон (1968-1991)]

(36) *Что твоё любимое стихотворение?

(37) Кто из них писатель?

(38) *Что из них музей?

Для данных контекстов внешне подходит гипотеза Идиатова [2007] о различии в референции. Казалость бы, можно считать, что что недопустимо потому, что стандартно не указывает на единичный объект. Однако при применении этого подхода возникают сложности: например, неясно, почему что сомнительно именно в конструкциях с нулевой связкой. Сходные контексты приемлемы, если предикат выражен лексически:

(39) *Что главный фактор победы в Великой Отечественной?

(40) Что было главным фактором победы в Великой Отечественной?

Мы посчитали, что неграмматичность предложений типа (36), (38) и (39) обусловлена ещё и природой конструкций с нулевой связкой. Стандартно они фиксируют некоторое свойство субъекта, выраженное именной частью сказуемого. Для одушевлённых объектов такие конструкции очень естественны, поскольку они концептуализуются языком как имеющие несколько свойств: например, любимый герой является не только героем, но и человеком, представителем какой-то профессии, социальной группы и так далее. Напротив, неодушевлённые объекты язык описывает как имеющие одно основное свойство: например, любимое стихотворение - это просто стихотворение. В этой связи предложения типа (36) и (38) выглядят странно, поскольку на глубинном уровне почти тождественны конструкциям типа Какое стихотворение - твоё любимое стихотворение.

При применении связки был предложение становится менее странным, поскольку объект не полностью отождествляется со своим свойством. Если мы спрашиваем, Что было главным фактором победы, то некоторый фактор, который в прошлом был фактором победы, сейчас может играть какую-нибудь другую роль. Поэтому конструкции с неодушевлёнными объектами приемлемы. 


\section{7. Заключение}

В нашей работе мы рассмотрели один из типов асимметрии между «одушевлёнными» и «неодушевлёнными» местоимениями. Как выяснилось, в конструкциях переспроса и близких к ним конструкциях «присвоения антецедента» язык старается избежать кореферентности между местоимением что и анафорическими местоимениями.

Как мы выяснили, это вряд ли объясняется формальным тождеством показателей. Гласный что в вопросительном местоимении (а, возможно, и конечные гласные в местоимениях она и оно) едва ли понимается носителями как показатель именительного падежа: общая нестандартность парадигм местоимений и противопоставления между именительным и всеми остальными падежами скорее делает формы неделимыми для носителя.

В то же время вряд ли играет роль различие в референциальных свойствах местоимений. Контекст переспроса не является стандартным референтным контекстом для вопросительных местоимений - речь не идёт ни о выборе класса референтов, ни о выборе конкретного объекта, а только об уточнении уже введённого в коммуникацию референта.

Скорее речь идёт о том, что даже для русского языка, где в целом вариант винительного падежа, совпадающий с родительным, и формы, совпадающие с именительным, не противопоставляются системой, эти формы всё-таки различаются в тех контекстах, где элементы с разным поведением сведены в одну конструкцию. Предельным случаем является конструкция переспроса Кого «его»? Тем самым, в этих конструкциях ключевую роль играет тип морфологического показателя: «одушевлённый» vs. «неодушевлённый» винительный.

Ещё один вывод может состоять в том, что вообще употребление местоимений для неодушевлённых референтов довольно сильно ограничено. Местоимения как таковые (во всяком случае, в русском языке) устроены так, что предназначены, прежде всего, для обозначения одушевлённых объектов. Исключение составляют ситуации, которые и в русском, и во многих других языках описываются особым местоимением (в русском — лексемой это — ср. Вася знал, что я приехал, а Петя этого не знал). Ограничения на местоименное маркирование неодушевлённых объектов могут проявляться в разных конкретно-языковых явлениях и разных свойствах местоимений: например, ограничениях на связочные конструкции; «одушевлённом» типе склонения и др., однако общая тенденция остаётся неизменной.

\section{Литература}

Воейкова М. Д. Винительный падеж. Материалы для проекта корпусного описания русской грамматики (http://rusgram.ru). На правах рукописи. М., 2011.

Крысько В.Б. Развитие категории одушевленности в истории русского языка. M.: Lyceum, 1994. 
Летучий А. Б. Местоимения и одушевлённость в русских конструкциях с нулевой связкой // Типология морфосинтаксических параметров. Материалы международной конференции / Под ред. Е. А. Лютиковой, А. В. Циммерлинга, М.Б. Коношенко. М.: Изд-во МПГУ, 2015. С. 200-223.

Падучева Е.В. Высказывание и его соотнесённость с действительностью. М.: Наука, 1985.

Idiatov D. A typology of non-selective interrogative pronominals. Antwerp: University of Antwerp PhD. 2007.

Malchukov A., de Swart P. Differential object marking and actancy variation // The Oxford handbook of case / ed. by A. Malchukov, A Spencer. Oxford: Oxford University Press, 2009.

\author{
Alexander B. Letuchiy \\ National Research University Higher School of Economics \\ (Moscow, Russia) \\ alexander.letuchiy@gmail.com
}

\title{
SYNTACTIC ASYMMETRY OF THE RUSSIAN PRONOUNS SYNTACTIC ASYMMETRY OF THE RUSSIAN PRONOUNS ČTO 'WHAT' VS. KTO 'WHO' AND MORPHOLOGICAL ANIMACY
}

The paper focuses on one syntactic restriction on the use of the interrogative pronoun čto 'what'. Contrary to kto 'who', čto disfavours constructions where it is syntactically parallel and co-referent to the anaphoric pronouns on 'he', ona 'she', and ono 'it'. For instance, in the construction kogo "ego" (lit. "who "he"), which the Russian speakers use to find out what the antecedent of the anaphoric ego is, the pronoun čto cannot be used if its form differs from the form of the anaphoric pronoun. For example, the context - Ja ego kupil. - Čto "ego" "- I bought it. — What "it"" is impossible, because the interrogative pronoun employs the "inanimate" inflection type, the accusative čto being identical to the nominative, while the anaphoric pronoun follows the "animate" type, where the accusative form ego is identical to the genitive one. I consider possible explanations of this fact and conclude that neither a purely formal explanation in terms of form identity, nor a semantic one, based on the referential properties of the pronouns, are satisfactory. The most plausible explanation is rather that in some constructions, grammatical characteristics of the two pronouns (including animacy and, to some extent, gender) must coincide, and the morphological animacy is even more important here than the semantic one.

Key words: animacy, interrogative pronouns, anaphoric pronouns, inflection type. 


\section{References}

Idiatov D. A typology of non-selective interrogative pronominals. Antwerp: University of Antwerp PhD. Antwerp, 2007.

Krys'ko V.B. Razvitie kategorii odushevlennosti $v$ istorii russkogo yazyka [The development of the category of animacy in the history of the Russian language]. Moscow, Lyceum, 1994. (In Russ.)

Letuchii A. B. [Pronouns and animacy in Russian zero copula constructions]. Mestoimeniya i odushevlennost' v russkikh konstruktsiyakh s nulevoi svyazkoi. Tipologiya morfosintaksicheskikh parametrov. Materialy mezhdunarodnoi konferentsii [Typology of morphosyntactic parameters. Proceedings of the international conference]. Ed. by E. A. Lyutikovoi, A. V. Tsimmerlinga, M. B. Konoshenko. Moscow, 2015, pp. 200-223. (In Russ.)

Malchukov A., de Swart P. Differential object marking and actancy variation. The Oxford handbook of case. Ed. by A. Malchukov, A. Spencer. The Oxford handbook of case. Oxford, 2009.

Paducheva E.V. Vyskazyvanie i ego sootnesennost's deistvitel'nost'yu [Utterance and its relations with reality]. Moscow, Nauka Publ., 1985. (In Russ.)

Voeikova M.D. Vinitel'nyi padezh. Materialy dlya proekta korpusnogo opisaniya russkoi grammatiki [Accusative case. The materials for the project structural descriptions of Russian grammar]. (http://rusgram.ru). Na pravakh rukopisi. M. 2011. (In Russ.) 


\section{И. А. Магеррамов}

Московский педагогический государственный университет

(Россия, Москва)

i.magerramov@mail.ru

\section{О ТИПОВЫХ НАРУШЕНИЯХ СИНТАКСИСА В СОВРЕМЕННЫХ МЕДИАТЕКСТАХ}

В статье рассматриваются синтаксические изменения, обусловленные композиционно-семантическими и функциональными особенностями современных медиатекстов. Постоянное стремление к расширению возможностей языкового выражения с целью формирования и удержания читательского интереса в средствах массовой информации (как печатных, так и электронных) приводит к поискам новых (или хорошо забытых старых) способов синтаксического оформления мысли. Одним из распространённых способов трансформирования синтаксических структур является их сегментирование, или парцелляция, способные акцентировать внимание адресата на отдельных аспектах описываемых событий, переориентировать его восприятие в нужную сторону и через язык (точнее, синтаксическую конструкцию) подвести читателя к тому или иному выводу по поводу излагаемых фактов. Однако чрезмерное увлечение авторов этим приёмом наводит на мысль, что многим сегодняшним журналистам, а вслед за ними и другим пишущим в СМИ явно тесно в рамках старого синтаксиса, не говоря уже о русском языке в целом. Игнорирование существующих грамматических норм при этом в расчёт не принимается и становится своего рода новой нормой.

Ключевые слова: медиатекст, синтаксис СМИ, сегментирование, парцелляция, грамматическая норма, нормы письменной речи.

Оковы тяжкие падут...

А. С. Пушкин

Демократические (и не только) процессы последних десятилетий, произошедшие в нашей стране, оставили существенный след во многих сферах общественной жизни, отразившись в том числе на развитии русского языка, включая практически все сферы его функционирования. Не осталась в стороне и область культуры речи. Многочисленные публикации как специалистов, так и рядовых ревнителей 
чистоты языка многократно демонстрировали нам, на какие высоты могут подняться и на какие глубины опуститься творческие личности в своём стремлении воспользоваться языком во всём его многообразии, со всем потенциалом возможностей. Особенно полно и ярко это проявляется в медиатекстах, ведь, как известно, «именно через сферу массовой коммуникации происходит интенсивное обновление «языка современности», основного словаря социума» [Какорина 1996: 177].

Не затрагивая здесь всех нюансов полемических оценок проблем культуры речи, отметим лишь, что наблюдательные авторы, в целом объективные в своих суждениях, не остаются равнодушными к явным нарушениям устоявшихся орфоэпических, лексических, грамматических и иных норм употребления языковых единиц. Однако в последнее время, то ли в связи с расширением сфер использования языка, включая интернет, различные электронные средства, то ли из-за заметного увеличения числа пользователей, то ли вообще из-за интенсификации социальной жизни отношение к ошибкам и недопустимому ранее языковому бескультурью стало более щадящим, более мягким. Подобная трансформация, достаточно широко распространённая в массовом сознании, получает теоретическое обоснование и со стороны филологов-специалистов. Прослеживается следующая логика рассуждений: раз норма динамична и возможен узус, который в скором времени дорастёт до статуса нормы, то почему сегодняшнее употребление надо считать нарушением? Может, это тот самый вариант, который вот-вот и станет нормой? Требуется только немного потерпеть и дать этому варианту зелёный свет.

Изменения, способствующие углублению выражения мыслей авторов публикаций и улучшению взаимопонимания между последними и читателями, можно было бы только приветствовать в плане развития перспективных коммуникативных возможностей языка, если бы не следующие соображения. Речь идёт о некоторых особенностях синтаксического употребления расчленённых и сегментированных конструкций, получивших широкое распространение в языке современных медиа. Частотность появления единиц данного типа позволяет говорить об усиливающейся тенденции и, следовательно, о возможности их изучения и описания как устойчивых структур в рамках так называемого публицистического стиля. Эта тенденция последовательно охватывает всё пространство газеты, включая как текстовый материал, так и заголовочный комплекс.

Как известно, не во всех сложноподчинённых предложениях, традиционно широко используемых в письменной речи, придаточные могут находиться в препозиции; кроме того, нельзя отрывать придаточное предложение от главного без ущерба для его грамматической принадлежности. В противном случае мы будем иметь дело с синтаксической единицей другого уровня. Тем не менее в последние годы в газетно-журнальных текстах участились случаи сознательного пренебрежения существующей жёсткой грамматической нормой с целью получения конструкции более «демократического» устно-разговорного характера, эффективность которой в рамках конкретного текста становится более высокой. Рассмотрим некоторые примеры, подкрепляющие приведённые рассуждения. На страницах газет и журналов, с телеэкрана вполне образованные авторы и выступающие очень часто 
позволяют себе по своему усмотрению сокращать или расширять состав устойчивой или цельной синтаксической конструкции, что, конечно же, является вольностью и приводит к нарушению структуры выражения:

Девочка хорошо чувствует (из выступления министра В. Скворцовой, 17.10.16, OPT).

Спустя 30 лет, как акробатический рок-н-ролл появился у нас, он уже... (тележурналист).

Распространённость элиминирования обязательного компонента из структуры цельной синтаксической конструкции (чувствует себя, спустя...nосле того) приводит к клишированности новообразований, и они развиваются в направлении новой нормы. Нередки случаи неоправданного расширения лексического состава конструкции, приводящего к возникновению нового канцелярского штампа, например: имеет место быть (вм. имеет место) - очень распространённый вариaнт.

Такое пренебрежение существующими грамматическими нормами, вызванное и, возможно, оправдываемое ритмом современной жизни, часто приводит к фразам-бессмыслицам, особенно в рекламе:

... передал школе новую интерактивную панель, которыми через два года будут оснащуены все школь Москвы (За Калужской заставой, 16.11.2016).

Представьте квартиру, в доме второго которого нет (телереклама).

Примечательно, что нарушение в первом из этих примеров не может быть объяснено ни опечаткой, ни какой-либо другой причиной, поскольку никакое исправление, кроме изменения всего предложения, невозможно.

Наибольший интерес в аспекте описываемой тенденции представляют случаи разрывания сложных синтаксических конструкций, в составе которых есть предикативные и полупредикативные единицы. Явление, о котором пойдёт речь, заключается в произвольной (или, скорее, творческой, с позиции автора газетного текста) трансформации сложной синтаксической конструкции в более простую, с помощью которой он (автор) стремится выразить достаточно насыщенное содержание. В процессе создания (написания) этой конструкции автору представляется необходимым упростить синтаксис, чтобы, возможно, он стал более доступным и зримым для читателя. Такое явление синтаксисты описывают как парцелляцию или сегментирование, что также может быть рассмотрено как стилистический приём (см.: [Валгина 2003]). М. А. Кормилицына считает его «сильным приёмом экспрессивизации», отмечая при этом, что «сейчас это явление встречается гораздо реже» [Кормилицына 2016: 24]. На наш взгляд, подобное мнение исследователя оправдано в отношении случаев, когда «парцелляции подвергаются фактически любые отрезки предложения» [там же]. В случаях же парцеллирования более сложных синтаксических структур говорить об угасании этой тенденции не приходится. Об этом свидетельствуют многочисленные примеры из самых различных газет и журналов последних лет. Отдельные наблюдения над описываемым приёмом были изложены автором в одной из предшествующих публикаций [Магеррамов 2014], однако неограниченный рост употреблений стимулирует необходимость 
продолжить рассмотрение интересующего нас явления с разных точек зрения. Обратимся к примерам:

1. Театр новейший, постдраматический - в «Золотом драконе» Сурковой. Где актёры отказываются от всяческих привязок к персонажу - возраста, гендера (Независимая газета, 8.10.2015).

2. Впрочем, и прекрасная Андалусия - это в исторически недавнем прошлом королевство вандалов, густо перемешавшихся с маврами и евреями. Не будет ничего удивительного и страшного и в темнокожих немцам. Если они не станут резать глотки инаковерящчим и инакодумающим. (Москва вечерняя, 21.12.2016).

3. Есть косвенные свидетельства того, что турки могли ослабить поддержку CCA, облегчив задачу по взятию Алеппо, и выступить посредниками в переговорах о выводе этих подразделений по гуманитарным коридорам. Ибо эти группировки ещё пригодятся Анкаре в переговорах о будущем Сирии «после Асада». (Там же).

4. Во всяком случае нельзя ставить знак равенства между официальной политикой Анкары и действиями террористов. Перед которыми надо объединиться всем наконец. (Там же).

5. Диалог мясника с коровой - это предельно мягкая метафора. Потому что диалоги с нами, которые идут в кабинетах власти, ещё жёстче (МК, 22.01.2016).

6. Среди них покоятся и легендарные сокровища Российского императорского дома. Которые, впрочем, не спасли российского цуаря и его близких от печальной участи. (Загадки истории, № 23, 2017).

Три из этих примеров являются сложноподчинёнными предложениями нерасчленённой структуры с придаточными определительными $(1,4,6)$ и два расчленённой структуры с причинными $(3,5)$ и условным (2) придаточными. Предложения с данными грамматическими значениями отличаются более жёсткой - негибкой - структурой, чем предложения некоторых других типов, о чём свидетельствует и фиксированная позиция придаточного. В то же время последовательное использование описываемого приёма, связанного с преодолением существующей нормы книжно-письменной разновидности литературного языка в самых различных СМИ, говорит о возникновении устойчивой тенденции, в основе которой лежат причины прежде всего коммуникативного, нежели синтаксического характера. В следующих примерах происходит разрывание сложноподчинённого предложения с придаточным присоединительным — особого вида СПП, который, по мнению исследователей, занимает промежуточное положение между предложениями нерасчленённой и расчленённой структуры. Содержание придаточного оформляется как добавочное, как замечание по поводу сказанного в главной части. Поскольку этот тип СПП практически аналогичен сложносочинённым предложениям с соединительными отношениями, предикативные части подобных предложений относительно самостоятельны, и это выступает основанием для активного использования их в медиатекстах: 
1. В федерации также отметили, что лечение спортсменки может продолжиться за рубежом. Что не является исключительным случаем (МК, 17.02.2014).

2. Нам объяснили, что 4 ноября 1612 года народное ополчение под командованием гражданина Минина и князя Пожарского очистило Кремль от ограниченного контингента польских и приравненных к ним интервентов. Что, типа, и подвело черту под Смутным временем (МК, 31.10.2014).

3. Но, так или иначе, до 2014 года 4 ноября воспринималось благодаря фактическому наполнению праздника как День русского национализма. Что едва ли соответствовало концепции кремлёвских чиновников, придумавиих сдвинуть 7 ноября на трое суток назад (там же).

4. Итак, День народного единства, утратив оппозиционное содержание, оказался на грани потери содержания вообще. Что априори было вполне закономерно (там же).

5. Но австралийцы на тендере выбрали испанский вариант, оценив «Мистраль» как слишком сложный, имеющий проблемы с мореходностью и очень дорогой. В результате чего верфям в Сен-Назере грозило закрытие, но тут как раз подвернулась Россия... (МК, 31.10.2014).

Углубление и расширение сферы распространения описываемой тенденции приводит к парцеллированию не только сложных синтаксических конструкций подчинительного, но и сочинительного характера, а также простых предложений с полупредикативными конструкциями - причастными и деепричастными оборотами (и даже без них). Доминирующей причиной является стремление выделить значимую (с точки зрения автора и с логико-композиционной позиции текста) информацию:

«Заявление Аймана аз-Завахири - это попытка найти примирение. И перестав бороться за материальные ресурсы, начать войну с общим врагом», - уверен востоковед. (Вечерняя Москва, 3.11.2015).

Исследователи языка СМИ последних десятилетий практически все новации в этой области связывают с существенной субъективизацией текста, основанной на демократизации сферы публицистики в целом и выражающейся в усилении индивидуальной личностной интонации. Возможно, так оно и есть, и разнообразие журналистского «я» становится отражением личностных характеристик и свойств конкретной личности. Тем не менее не до конца понятно стремление образованного журналиста, достаточно хорошо владеющего языком (как это видно из множества примеров), идти на сознательное нарушение грамматической нормы и разрушать устойчивый стереотип восприятия читателя. Для этого должны быть весомые причины коммуникативного и психолингвистического характера, в которых попробуем разобраться.

1. Возможно, автор действительно считает подобные синтаксические конструкции громоздкими и потому упрощает их для читателя. Но среди примеров есть очень простые, короткие, не нуждающиеся в упрощении. К тому же даже сложные синтаксические структуры, хорошо знакомые носителю языка, не представляют особой трудности для восприятия. 
2. Автор газетной статьи стремится специально подчеркнуть мысль, содержащуюся в постпозитивной части сложного предложения и в деепричастном обороте, и потому графически отделяет её от главной части, провоцируя задержку внимания читателя в нужном месте. Однако преодоление этой преграды, искусственно созданной на пути грамотного читателя, вызывает дополнительные, хотя и незначительные, неудобства при чтении и психологический дискомфорт, который также нельзя сбрасывать со счетов.

3. Журналист (автор) пытается настроить читателя на ту же волну восприятия действительности, на которой находится он сам, передавая широкую палитру субъективных эмоционально-экспрессивных оттенков содержания, раскрываемых с помощью эффективных конструкций, которые не всегда свойственны данному стилю речи. При помощи таких приёмов создаётся, как представляется автору текста, тональность разговорной речи. В то же время, как известно, разговорная речь характеризуется столь разнообразными особенностями, что нельзя её специфику передать одним лишь расчленением сложного предложения. При всей спонтанности, непринуждённости разговорной речи невозможно представить её письменную фиксацию в тех конструкциях и в том виде, которые рассматривались выше.

Таким образом, наблюдения и анализ показывают, что попытки мнимого достижения коммуникативных целей, приводящие к расчленению и парцелляции сложных синтаксических конструкций в медиатекстах, даже если рассматривать это как стилистические приёмы, предполагающие несколько другой синтаксический контекст и не столь широкое употребление, в новейших публикациях (часто даже в рамках одного материала) сопровождаются устойчивым нарушением грамматических норм письменной разновидности современного русского языка.

\section{Литература}

Какорина Е.В. Новизна и стандарт в языке современной газеты (Особенности использования стереотипов) // Поэтика. Стилистика. Язык и культура. Памяти Татьяны Григорьевны Винокур. М.: Наука, 1996. С. 169-180.

Валгина Н.С. Активные процессы в современном русском языке. М.: Логос, 2003. $304 \mathrm{c}$.

Кормилицына М.А. Содержательная неопределённость современных медиатекстов как результат нарушения в них баланса стандарта и творчества (на материале печатных СМИ) // Проблемы речевой коммуникации. Саратов: Изд-во Сарат. ун-та, 2016. - Вып. 16. С. 16-27.

Магеррамов И. А. Трансформация синтаксических конструкций в языке современных СМИ. - Риторика в современной России: традиции и новые задачи. Ярославль: Изд-во «Канцлер», 2014. С. 238-242. 


\author{
Iskander A. Magerramov \\ Moscow Pedagogical State University \\ (Russia, Moscow) \\ i.magerramov@mail.ru
}

\title{
CONCERNING STANDARD VIOLATIONS OF SYNTAX IN MODERN MEDIA TEXTS
}

In this article the syntactic changes caused by composite-semantic and functional features of modern media texts are considered. The constant aspiration to expand the opportunities of language expression in order to form and maintain the reader's interest in mass media (both printing, and electronic) leads to searching new (or well-forgotten old) ways of syntactic expression of a thought. One of widely spread ways of transformation of syntactic structures is their segmentation, or so-called parceling, which are aimed to focus attention of the addressee on separate aspects of the described events, to reorient his perception in the necessary sphere and to bring the reader to the appropriate conclusion concerning the stated facts through the language (to say more precisely, a syntactic construction).

However, excessive interest of authors in this reception suggests an idea that many today's journalists, and other people, reporting in mass media feel uncomfortable within old syntax, not to mention the Russian language in general. Ignoring of the existing grammatical norms is not taken into consideration at the same time and it becomes some kind of a new norm.

Key words: media text, syntax of mass media, segmentation, parceling, grammatical norm, standards of a written language.

\section{References}

Kakorina E.V. Novizna $i$ standart v yazyke sovremennoy gazety (Osobennosti ispol zovaniya stereotipov) [Novelty and standard in the language of a modern newspaper (Characteristics of using stereotypes)] // Poetics. Stylistics. Language and Culture. In honour of Tatyana Grigoryevna Vinokyr. Moscow, 1996, pp. 169-180. (In Russ.)

Valgina N.S. Aktivnyie processy v sovremennom russkom yazyke. [Active processes in modern Russian language]. Moscow, Logos Publ., 2003. (In Russ.)

Kormilitsina M.A. Soderjatel naya neopredelionnost' sovremennykh mediatekstov kak rezul tat narusheniya $v$ nikh balansa standarta i tvorchestva (na materiale pechatnikh SMI). [Substantial uncertainty of modern media texts as the result of breaking balance between standard and creativity (based on the materials of printed mass media] // Problems of speech communication. Saratov, 2016. Vol. 16, pp. 16-27. (In Russ.)

Magerramov I.A. Transformaciya sintaksicheskikh konstrukciy v yazyke sovremen$n y k h$ SMI. [Transformation of syntactical constructions in the language of modern mass media]. - Rhetoric in modern Russia: traditions and new approaches.-Yaroslavl, 2014, pp. 238-242. (In Russ.) 


\section{E. В. Маринова}

Нижегородский государственный университет им. Н. И. Лобачевского

(Россия, Нижний Новгород)

marinova@list.ru

\section{ЦЕННОСТНЫЕ ЭПИТЕТЫ В СИСТЕМЕ ЭТИЧЕСКИХ ПРЕДСТАВЛЕНИЙ СОВРЕМЕННЫХ ПОЛЬЗОВАТЕЛЕЙ ИНТЕРНЕТА}

Исследование проводилось в течение последнего десятилетия на материале текстов некоторых профессиональных и любительских интернет-сообществ и комментариев к ним на форумах, в блогах и под. Цель исследования - определить общее направление семантических сдвигов слов, отражающих традиционные этические представления носителей русского языка. В статье рассматриваются семантические и сочетаемостные особенности аксиологических, или ценностных, эпитетов разумный, полезный, правильный, здоровый, здравый и их отрицательных коррелятов (неразумный, неправильный, нездоровый и под.). Отмечаются нарушения привычной сочетаемости данных слов в контекстах, где они выступают в роли определений к обозначениям личностных качеств человека. Установлено, что прилагательные положительной оценочности используются активно в сочетании с обозначениями негативных качеств (разумная наглость, полезный эгоизм, правильная агрессия, здравый ичинизм и т.д.) и, напротив, положительные качества человека могут характеризоваться прилагательными отрицательной оценочности (неразумная честность, нездоровая доброта). Анализируемые контексты демонстрируют релятивизм в отношении к основным нравственным категориям, смешение этических оценок, на основании чего делается вывод о бытовании в современном сознании несвойственных русскому языковому менталитету ценностных ориентиров, одним из которых является агрессивный культ силы. Приводятся данные, согласно которым ранее рассматриваемые прилагательные подобные сочетаемостные свойства не проявляли.

Ключевые слова: ценностные эпитеты, новая сочетаемость, изменения языка, лингвистическая аксиология, интернет-поисковые материалы.

Изучение связи языковых инноваций с изменениями в духовной сфере социума становится в XXI в. всё более актуальным. ${ }^{1}$ K настоящему времени накоплены

1 Языковые инновации, свидетельствующие об изменениях в духовной сфере, по выражению А. Д. Шмелёва, и есть подлинные изменения языка [Шмелёв 2011: 92]. 
и обобщены важные наблюдения, касающиеся этого вопроса, в работах Е.Л. Березович, Анны А. Зализняк, М.А. Кронгауза, И.Л. Левонтиной, Т.Б. Радбиля, Е. В. Сенько, А. Д. Шмелёва, Е. Я. Шмелёвой и др. Значимыми изменениями с точки зрения лингвистической аксиологии являются:

- изменение коннотации слов карьера, амбиции, коммерсант и их производных (см., например: [Березович 2008; Зализняк 2008; Сенько 2010; Шмелёва 2011]);

— изменение сочетаемости прилагательных успешныци, эффективныци;

- разрастание ряда слов, выражающих высокую оценку обязательных атрибутов «успешного» человека (премиумныци, кутюрныци, статусный, резонанснылй и др.);

- использование в создании эргонимов «глобальных» метафор («Империя йогуртов», «Мир бетона», «Планета секонд-хенд»);

- десакрализация ряда слов духовной серы (икона стиля; библия стервы);

- деактуализация слов (и понятий) интеллигенция, интеллигент;

- функционирование оборотов, искажающих представления об истинной мужественности и женственности (гламурный подонок; бородатая девушка), о ценностях семьи (суррогатная мать, биологическая мать) и др.

К изменениям этого же плана можно отнести и нетрадиционное использование некоторых ценностных эпитетов (термин М. Бахтина) при характеристике нравственных качеств человека. Мы уже обращали внимание на некоторые отклонения в этой сфере в [Маринова 2014]. В частности, речь шла о синтагмах, в которых прилагательное здоровый активно используется в качестве определения к обозначениям человеческих недостатков: здоровый изинизм, здоровая агрессия, здоровая ревность, здоровая наглость и под. Слово здоровый во всех этих странных контекстах (в традиционной системе нравственных координат они воспринимаются как оксюморонные) имеет следующий оттенок: здоровыц̆ 'такой, который не причиняет вреда окружающим; безопасный и в то же время полезный для самого носителя качества'.

Есть некоторые основания утверждать, что слово здоровыц̆ ранее подобные сочетаемостные свойства не проявляло. Об этом можно судить, в частности, по данным «Словаря эпитетов русского языка» К. С. Горбачевича, в котором содержатся в качестве определяемых слов 12 обозначений отрицательных качеств (зависть, ревность, эгоизм и др.). Однако среди эпитетов к этим наименованиям прилагательного здоровый нет [Горбачевич 2000].

В интернет-поисковых материалах с обозначениями отрицательных качеств человека употребляется синоним и «родственник» слова здоровыц - прилагательное здравый 'разумный, правильный'. См., например: Здравый цинизм - это трезвость ума и рассуждений (forum.bakillar.az); Здравый эгоизм - это болезнь или спасение? (otvet.mail.ru); Да, оказывается, здравая агрессия нужна, чтобы объяснить свою позицию, отстоять свою правоту и в конце концов чтобы возвратить мирные отношения... (efamily.ru); Здравая зависть стимулирует к свершению подвигов (hochua.ua > Психология общения) и т.п. По-видимому, и в семантике слова здравыц̆ формируется тот же оттенок, что и у его синонима. 
Аналогичные сочетаемостные свойства проявляет, судя по нашим материалам, и слово разумнылй․․ Его новая сочетаемость также выходит за рамки привычной. См.: разумный ичинизм, разумное тщеславие, разумное высокомерие, разумный снобизм, разумный нарциссизм, разумная ревность, разумная месть, разумная жестокость, разумная зависть, разумная агрессия. Например: Разумный нарциссизм добиваться обоснованности самомнения (otvet.mail.ru); Умеренная, разумная ревность - спутницуа Любви (MillionStatusov.ru); Разумная зависть необходима. Она ведёт к развитию (otvet.ukrhome.net); Уверенность, разумная наглость и напористость при «кадрировании» слабой половинь человечества - работают (lipoisk.ru) и т.д.

Подобная картина наблюдается и с другими ценностными эпитетами - трезвый, полезный, правильный и др.: Полезный эгоизм - это не что иное, как чувство собственного достоинства плюс чувство самоуважения (proza.ru); Чаще всего у нас отключается правильный эгоизм с теми, кого мыл любим (Заповеди правильной эгоистки; блог); Я, в последние 4 года активно пребывая в так сказать артсреде, знаю, что такое артистический снобизм и высокомерие... Это правильный снобизм (facebook.com>fateev.evgeniy); Домашний очаг. ТОП-5 правил правильной агрессии (dom.goodhouse.com.ua); Правильное высокомерие - это когда требуешь от себя больше, чем от других (rusdemotivator.ru); Правильное властолюбие изначально, при создании первых людей, было предназначено (вложено в них)... (dyatel.3dn.ru «Пороки») и др.

С точки зрения лингвистической аксиологии интересно получить ответ на следующий вопрос: в массовом сознании изменилось только отношение к отрицательным качествам или положительные качества тоже подверглись переоценке? Для того чтобы выяснить это, мы продолжили поиск, гипотетически создавая сочетания, в которых прилагательные отрицательной оценочности (нездоровый, неразумный) употребляются с именами существительными, именующими положительные качества человека. По заданному поиску были обнаружены: неразумная честность, неразумная скромность, нездоровая скромность, нездоровая иелеустремлённость, а также нездоровая аккуратность, нездоровая честность и даже нездоровая доброта. Отметим, что в «Словаре эпитетов русского языка» К. С. Горбачевича слова нездоровый и неразумный в качестве эпитетов к наименованиям личностных качеств человека зафиксированы лишь в сочетаниях нездоровое любопытство и неразумное упрямство [Горбачевич 2000].

МАС содержит толкование двух переносных значений прилагательного нездоровый: 'приносящий вред, ущерб в моральном или общественном отношении';

${ }^{2}$ В переносном значении — 'основанный на разуме, оправдываемый здравым смыслом' разумный традиционно употребляется с нейтральными с точки зрения коннотации именами существительными, например: разумный довод [БТС]. Единственное исключение - устойчивое, благодаря роману Н.Г. Чернышевского «Что делать?», сочетание разумный эгоизм, значение которого в бытовом употреблении (в отвлечении от философско-этической позиции разумного эгоизма, разрабатываемой ещё в трудах Спинозы, Гельвеция и др.) можно сформулировать так: умение жить собственными интересами, не противореча при этом интересам других людей. 
'свидетельствующий о ненормальном, неблагоприятном состоянии кого-, чего-л.' [MAC]. Как видим, эти значения (особенно первое) соотносятся с тем значением, которое реализуют слова здоровыцй, здравылй в сочетаниях типа здоровый (здравый) цүинизм ('не причиняющий вреда окружающим; безопасный’). С точки зрения традиционной системы ценностей трудно представить себе доброту или скромность, «приносящую вред, ущерб», или «нецелесообразную» скромность (см. толкование переносного значения слова неразумный — 'лишённый разумных оснований, нецелесообразный’ [БТС]).

Новый, непривычный круг лексем, с которыми сочетаются в современной речи ценностные эпитеты, свидетельствует о некоторых семантических изменениях этих прилагательных в роли ценностных эпитетов: появляется новое значение или оттенок значения (как в случае со словами здоровый, здравый), актуализируется одно из периферийных значений слова (см. нездоровый).

Однако, на наш взгляд, это не просто новая сочетаемость слова как результат универсального и вечного процесса обновления языка. Это индикатор нового, нетрадиционного отношения говорящих к понятиям духовного, нравственного порядка. Анализируемые контексты демонстрируют релятивизм в отношении к основным нравственным категориям, смешение этических оценок, формирование в современном сознании несвойственных русскому языковому менталитету ценностных ориентиров (агрессивный культ силы, индивидуализм). То, что во все времена считалось достоинствами человека, личности, подвергается сомнению; отсутствие этих качеств уже не рассматривается как порок, недостаток человека.

В этой ситуации заслуживает внимания научной общественности мнение А.Д. Шмелёва о том, что современный «нормативный словарь не должен игнорировать возникающие новации, но в нём должно посредством специальных помет отмечаться, что словоупотребление, ориентированное на новую систему ценностей, воспринимается многими носителями языка (особенно представителями старшего поколения) как “неправильное”» [Шмелёв 2015: 111].

\section{Литература}

Березович Е.Л. «Отцы и дети» в лексической семантике (О «поколенческих» различиях в значениях слов аксиологической сферы в языке современного города) // Язык современного города. Тезисы докл. междунар. конф. Восьмые Шмелёвские чтения, М.: Инс-т рус. яз. РАН, 2008. С. 25-28.

БТС - Большой толковый словарь русского языка / под ред. С. А. Кузнецова. СПб.: Норинт, 2000.

Горбачевич К. С. Словарь эпитетов русского языка. СПб.: Норинт, 2000.

Зализняк Анна А., Левонтина И.Б., Шмелёв А.Д. Эволюция ключевых концептов русского языка в ХХ веке: аспекты изучения // Вестник РГНФ. 2008. № 1. C. $120-127$.

Маринова Е. В. Здоровые и нездоровые в современном дискурсе // Труды Института русского языка им. В. В. Виноградова. 2014. Вып. 1. № 2. С. 344-351. 
МАС - Словарь русского языка в 4-х томах. 2-е изд-е. М., 1981-1984.

Сенько E. B. Эволюция русской языковой картины мира // Лексикология. Лексикография (русско-славянский цикл). Русская диалектология. СПб.: изд-во СПбГУ, 2010. C. 61.

Шмелёв А.Д. Падение речевой культуры или изменение нормы? // Вопросы культуры речи. ХІ / отв. ред. А. Д. Шмелёв. М.: Языки славянской культуры, 2012. С. 72-73.

Шмелёв А.Д. Новое в русской лексике: проблемы кодификации // Неология и неография: современное состояние и перспективы. К 50-летию научного направления. СПб.: ИЛИ РАН, 2015. С. 110-111.

Шмелёва Е.Я. Изменения в оценке и самооценке человека в русском языке XXI века (яркие индивидуалисты, позитивные эгоисты и успешные карьеристы) // Вопросы культуры речи / отв. ред. А. Д. Шмелёв. М.: АСТ-ПРЕСС КНИГА, 2011. C. $95-101$.

\author{
Elena V. Marinova \\ Lobachevsky State University of Nizhni Novgorod \\ (Russia, Nizhny Novgorod) \\ marinova@list.ru
}

\title{
VALUE-BASED EPITHETS IN THE ETHICAL SYSTEM OF MODERN INTERNET USERS
}

The study was conducted in the last decade on the basis of texts of some professional and amateur Internet communities and comments to them at forums, blogs, etc. The aim of the research is to define the direction of semantic shift in the words that reflect the traditional ethical views of native speakers of Russian. The article describes semantic and collocational features of axiological, or value-based, epithets razumnyj, poleznyj, pravil'nyj, zdorovyj, zdravyj and their negative correlates (nerazumnyj, nepravil'nyj, ne$z$ dorovyj, etc.). The author notes violations of common combinability of these words in contexts where they function as attributes to words denoting personal qualities. The study revealed that adjectives of positive evaluation are actively used in combination with words denoting negative qualities qualities (razumnaja naglost', poleznyj egoism, pravil'naja agressija, zdravyj tsynizm, etc.), and, on the contrary, positive traits of a person can be characterized by adjectives of negative evaluation (nerazumnaja chestnost', nezdorovaja dobrota). The analyzed contexts show relativism towards major moral categories, confusion of ethical evaluations. The author makes a conclusion that in the mind of modern people there exist values that are alien to Russian linguistic mentality. One of such values is aggressive cult of strength. Previously the analyzed adjectives did not demonstrate such collocational features.

Key words: value-based epithets, new combinability, language changes, linguistic axiology, Internet search materials. 


\section{References}

Berezovich E.L. ["Fathers and sons" in lexical semantics ("generational" differences in the meanings of words of axiological sphere in the language of the modern city)]. Iazyk sovremennogo goroda. Tesizy doklddov mezhdunarodnoj konferentsii Vos'myie Shmelevskie chteniya [Abstracts of the international conference Eighth Shmelev reading]. Moscow, 2007, pp. 25-28. (In Russ.)

Gorbachevich K. S. Slovar' epitetov russkogo iazyka [Russian epithets dictionary]. Saint Petersburg, 2000.

Kuznetzov S. F. (Ed.). Bol'shoi tolkovyi slovar' russkogo iazyka [Big explanatory dictionary of Russian language]. Saint Petersburg, 2000.

Marinova E. V. [Healthy and unhealthy in modern discourse]. Trudy Instituta russkogo iazyka im. V. V. Vinogradova [Proceedings of the V.V. Vinogradov Russian Language Institute]. 2014. Edition 1, no.2, pp. 344-351. (In Russ.)

Sen'ko E. V. [The evolution of the Russian linguistic picture of the world]. Leksikologiya. Leksikografiya (russko-slavyanskiy tcykl). Russkaia dialektologiya [Lexicology. Lexicography (Russian-Slavic cycle). Russian dialectology]. Saint-Petersburg, 2010, p. 61. (In Russ.)

Slovar' russkogo iazyka v 4-kh tomakh [Russian dictionary in 4 volumes. 2nd ed.]. Moscow, 1981-1984.

Shmelev A. D. [Decline of speech culture or change of rules?]. Voprosy kul'tury rechi. XI [Issues of speech culture. XI / Edited by A. D. Shmelev]. Moscow, Iazyki slavianskoi kul'tury Publ., 2012, pp. 72-73. (In Russ.)

Shmelev A.D. [New phenomena in Russian lexicon: problems of codification]. Neologiya i neografiya: sovremennoie sostoyanie i perspektivy. K 50-letiyu nauchnogo napravleniya [Neology and neography: current status and prospects. The 50th anniversary of the scientific field]. Saint-Petersburg, ILI RAS, 2015, pp. 110-111. (In Russ.)

Shmeleva E. IA. [Changes in evaluation and self-evaluation in the Russian language of the XXI century (vivid individualists, positive egoists and successful careerists)]. Voprosy kul'tury rechi XI [Issues of speech culture]. Edited by A. D. Shmelev. Moscow, AST-PRESS KNIGA Publ., 2011, pp. 95-101. (In Russ.)

Zalizniak Anna A., Levontina I. B., Shmelev A. D. [The evolution of the Russian language key concepts in the XX century: aspects of study]. Vestnik RGNF, 2008, no. 1, pp. 120-127. (In Russ.) 


\author{
Н.А. Николина \\ Московский педагогический государственный университет \\ (Россия, Москва) \\ admin@riash.ru
}

\title{
ТИПЫ И ФУНКЦИИ КОНТАМИНИРОВАННЫХ ОБРАЗОВАНИЙ В СОВРЕМЕННОЙ РУССКОЙ РЕЧИ
}

В статье рассматриваются контаминированные образования, получившие широкое распространение в русской речи на рубеже XX-XXI в. Контаминация в ней из окказионального явления постепенно превращается в активно действующий способ современного словопроизводства. Контаминированные образования последовательно используются в языке СМИ, рекламы, в художественной речи, в жаргонах. Функции их в современной речи заметно усложняются: наряду с оценочной функцией, они выполняют номинативную функцию, служат знаком интертекстуальных отношений, участвуют в языковой игре, пополняют состав тропов в поэтических текстах. Выделяются два механизма, которые используются при образовании контаминированных слов: наложение морфов и усечение одного или двух мотивирующих слов. Междусловное наложение рассматривается в результате как одна из разновидностей контаминации, для которой в целом характерна нечеткость границ морфемного шва. Семантика контаминированного слова базируется на взаимодействии значений объединяемых слов, при этом на основе возникающих в процессе словопроизводства отношений соединения, противопоставления или сравнения в гибридном слове могут актуализироваться новые семантические компоненты. В художественной речи контаминированные образования регулярно используются для свертывания образной параллели и характеризуются высокой степенью идиоматичности семантики. Некоторые модели контаминированных единиц закрепляются в языке, по ним серийно образуются новые гибридные слова, в результате квазиморфы трансформируются в словообразовательные форманты, которые регулярно используются в процессе словопроизводства.

Ключевые слова: контаминация, графодеривация, междусловное наложение, усечение, оценка, семантика, сравнение, языковая игра.

В течение длительного времени контаминация в словообразовании рассматривалась в русистике преимущественно как окказиональный способ 
словопроизводства и оценивалась как маргинальное явление, в результате которого появляются искусственные единицы, используемые в основном как средство языковой игры. Однако в конце ХХ в. употребление контаминированных образований приобрело массовый характер, они регулярно используются в языке СМИ и рекламы, в разговорной речи, жаргонах, художественной речи; см., например: драконат, демокрад, проэзия, пропагандаторы, пунтаксис, пьятница, хамильярный, человолки. Состав контаминированных слов пополняется за счет заимствований из других языков, преимущественно английского: брексит, блог, драмеди, смог, эмотикон и др. Контаминация с периферии словопроизводства постепенно перемещается в центр современного экспрессивного словообразования. Между тем место контаминации в системе русского словопроизводства и ее соотношение с другими способами четко не определены: ее то включают в аббревиацию, то рассматривают как самостоятельный способ словообразования, при этом в ряде случаев разграничиваются собственно контаминация и междусловное наложение. Н.А. Янко-Триницкая, например, считает, что для междусловного наложения, в отличие от контаминации, характерно не «вытеснение» одного из компонентов слова, а наложение на конец основы одного слова «омонимичного начала другого слова» [Янко-Триницкая 2001: 471]. Отсутствует и единое обозначение контаминированных образований: в современной научной литературе параллельно используются такие термины, как аддиктуры, бленды, вставки, гибридные слова, контаминанты, слитки, слова-амальгамы, слова-свертки, телескопы, слова-саквояжи (термин, восходящий Л. Кэрролу). Контаминация, таким образом, в современной русистике и рассматривается по-разному, и получает разнообразные пестрые обозначения.

С нашей точки зрения, контаминация - самостоятельный способ компрессивного словообразования. Это образование производного слова на основе объединения компонентов двух (реже более) мотивирующих слов и стяжения их начальных и конечных элементов: ломастер (ломать + мастер), пьянварь (пьяный + январь), рейганомика (Рейган + экономика). В процессе создания контаминированных слов используются такие механизмы, как: 1) наложение морфов, приводящее к возникновению амальгированного морфосочетания и обусловливающее зыбкость морфемного шва, и 2) усечение компонентов объединяемых слов как с наложением их, так и без наложения. Ср.: хаосмос (хаос + космос) - бульмени (бульон + пельмени). Междусловное наложение, таким образом, целесообразно рассматривать не как самостоятельный способ словообразования, а как разновидность контаминации, обусловленную морфонологическими причинами.

«В отличие от сложного слова в контаминации наблюдается широкий диапазон усечений и комбинаций усеченных компонентов. Наличие «осколочного» элемента, или квазиморфа, в структуре контаминированного слова отличает контаминацию от словосложения» [Лаврова 2009: 39]. В отличие от аббревиации контаминация характеризуется взаимодействием и взаимопроникновением компонентов объединяемых лексических единиц, а также семантической конденсацией, которая не присуща аббревиатурам. 
В зависимости от степени сокращения объединяемых слов различаются три структурных типа контаминированных единиц:

1) гибридные слова, основанные на объединении усеченной части первого слова и второго слова, при этом, как правило, наблюдается наложение: инкогникто (инкогнито + никто), исповесть (исповедь + исповесть);

2) гибридные слова, основанные на объединении основы первого слова и усеченной части второго слова: бодросток (бодрый + подросток), либераллиссимус (либерал + генералиссимус), чадовище (чадо + чудовище), химература (химера + литература);

3) гибридные слова, основанные на объединении усеченных компонентов обоих мотивирующих слов: карикародия (карикатура + пародия), катастройка (катастрофа + перестройка).

В настоящее время формируется и четвертый тип контаминированных единиц, для которого характерна вставка компонента второго слова в состав первого, например, восхрустительныци, сосердияание, напартачить.

Контаминированные образования в современной русской речи представлены словами разных частей речи; ср.: трепортаж, трепортер, звучезарный, дургеневская, табактуально (И. Ильф и Е. Петров), язвивались (А. Вознесенский). При этом преобладают имена существительные, образованные или по модели существительное + существительное, или по модели прилагательное + существительное: коровей (корова + соловей), кошкелот (кошка + кашалот), ценизм (цена + цинизм), лжизнь (лживая + жизнь), хамильярный (фамильярный хам).

Объединенные компоненты мотивирующих слов могут быть семантически близки (мерзобразие) либо соотноситься друг с другом по модели «определяемое - определяющее» (лжизнь, монстранты, дургеневская). В основе гибридного слова часто лежит структура с оценочным предикатом, например, крадоначальник - 'градоначальник, который крадет', 'Евстигений-Евстигнеев-гений'. Реже контаминированные слова «представляют собой нечто вроде внутрисловных оксюморонов: господарищ (господин + товарищ), разочаровательный (разочаровать + очаровательный), преисподнебесье (преисподняя + поднебесье). В этом случае один из компонентов слова семантически «подчиняет» второй, нейтрализует его» [Козинец 2017: 8].

Семантика контаминированных образований базируется на значениях объединяемых слов и присущих им коннотаций, при этом она во многом обусловлена контекстом, в котором употребляется гибридное слово. В контексте в процессе словопроизводства могут актуализироваться и дополнительные, чаще оценочные семантические компоненты, связанные с отношениями противопоставления, соединения или сравнения, которые возникают между частями гибридного слова. Например, в новообразовании Ю. Мориц (пылай) шекспиртом свернута образная параллель 'пылай, как горит спирт, с таким же накалом страстей, как в трагедиях Шекспира':

Пьлай шекспиртом, а когда умрешь,

Ещуе поспорят - был ли ты на свете?.. 
В другом новообразовании Ю. Мориц кафказно также выражается значение сравнения и подвергается свертыванию образная параллель на Кавказе — как у Кафки.

Актуализация оценочных компонентов и регулярное свертывание сравнения обусловливают высокую степень идиоматичности семантики гибридных слов.

Контаминация в течение длительного времени использовалась преимущественно как средство языковой игры. В XIX в., например, контаминированные слова характерны для словотворчества Н.С. Лескова: бабеляр, бедуар, клеветон, толпучка и др. В ХХ в. активизация этого способа словообразования связано с творчеством футуристов и обэриутов, при этом «скорнение» служит уже средством создания сложного художественного образа и обновления арсенала тропов; см., например: петер, равнебен (В. Хлебников), локони, Летербург (Д. Хармс).

В конце XX в. активизируются различные виды компрессивного словопроизводства, среди них — контаминация. Контаминированные образования отражают различные идеологические позиции, точки зрения, участвуя в борьбе разных социальных групп и общественных движений: коопираты, кремледворец, коммутантыл, демократуры, демокрады, делегафрен, фашизоид, чубаучер и др.

Активность контаминированных образований на рубеже XX-XXI вв. отражается в их фиксации в словарях новых слов. Так, если в словарь «Новые слова и значения» 1984 г. было включено только одно гибридное слово - камазонка, то в словаре, содержащем неологизмы 1990 г., представлено уже 11 контаминантов, а в словарь новой лексики 2009 г. входят 17 гибридных единиц (господарищи, депутана, демокрады, гениалиссимус и др.).

Некоторые модели контаминированных образований постепенно закрепляются в языке, по ним серийно образуются новые гибридные слова, например: гайдарономика, рейганомика; Ирангейт, Кремльгейт, ЮАРгейт; вещуеголик, трудоголик, покупкоголик, пивоголик, чистоголик, шопоголик.

В результате в языке появляются новые словообразовательные форманты, восходящие к квазиморфам. Так, синкопированный элемент - оголик (от алкоголик) регулярно используется в составе гибридных слов со значением «пристрастие, одержимость». Аналогичный процесс характерен для английского языка; ср.: bookaholic, chocoholic, spendaholic, workaholic.

Контаминированные образования выполняют в современной речи различные функции. В разговорной речи, жаргонах, языке СМИ они служат для выражения экспрессивной оценки, чаще негативной: ложунги, Лохомотив, кафедряне, ЕГОдяи, зарубеженцьь. В языке СМИ (в его письменной форме) контаминация часто связана с графодеривацией - графическим выделением компонента одного слова, совпадающего с частью другого слова, и актуализацией его смыслов: СМИлостивиться, объЕГорить, ЦСКАзка. Грпфодеривация, или графиксация, иногда рассматривается как особый способ словообразования [Попова 2011], однако, на наш взгляд, это скорее графический прием выделения компонента гибридного слова, в котором используется наложение, и маркер этого морфонологического 
явления; так, например в заголовке Науке KPAHmbl! (Московский комсомолец, 25.09-02.10. 2013) выделяется компонент PAH, в результате гибридное слово KPAHmы приобретает семантическую многомерность и интерпретируется как высказывание $\mathrm{PAH}$ - кранты.

В языке рекламы контаминированные образования служат для привлечения внимания покупателей и воздействия на них, см., например, гибридные слова, используемые в рекламе крекера: восхрустительный, восхрустительно вкусно.

Значительно реже гибридные слова выступают в собственно номинативной функции - в этом случае они могут использоваться как термины или наименования животных, изделий либо продуктов питания: бестер, львигр, метон, корнфетьл, согурт, фругурт, унификс.

В художественной речи функции контаминированных образований усложняются. Они используются в ней как тропы, свертывающие образную параллель, как характерологическое средство (см., например, роман Т. Толстой «Кысь»), как маркер интертекстуальных отношений. Например, в стихотворении В. Мельникова гибридные слова отображают взаимодействие разных литературных течений: Растаял Гумилёд, раскрыв / На зависть сутрам / Ахматадулинский надрыв / ОБЭРИУТром. В стихотворении Г. Сапгира «Рометта» уже заглавие отсылает к трагедии В. Шекспира «Ромео и Джульетта» и подчеркивает неразрывную связь ее героев. В этом же произведении контаминированные образования Монтолетти и Капунтекки, актуализируя интертекстуальные связи, нейтрализуют различия, предполагаемые у враждующих семей: A в результате - страшная семья / Чудовищный мой недруг Монтолетти / Всей гидрою-драконом стоголовым / Все эти Капунтекки обступили...

Контаминация гибридных слов в тексте служит средством развертывания его сквозного мотива или темы. Например, в стихотворении А. Вознесенского «Грибница» повторяющиеся контаминированные образования, восходящие к слову мутанты, последовательно развивают мотив мутации современного человечества. Ср: $\mathrm{Mbl}$ - не люди, грибные мутантыл, / мы - тумантыл... Хохматантыл, мьл - тьмутаракантыл.

Контаминированные образования регулярно используются в поэтической речи, занимая сильные позиции в текстах, и служат приметой ряда идиостилей, например, стилей А. Вознесенского и Вилли Мельникова: Африкомендовали борьбу со СПИДом (А. Вознесенский); Не созерианье-сосердизанье / меня к природе пригвоздит (А. Вознесенский); Из процентщчины, из прожженщины / вырывается эпилепсия! (А. Вознесенский); Капризсморось дней в водостокна спешит зарешочень / Хрустит чешуявь, неразрыбная с жабракадаброй (В. Мельников); Стань дирижёрновом умолчий... (В. Мельников).

Итак, контаминированные образования все шире употребляются в различных сферах современной русской речи. Из периферийного приема создания окказионализмов, выполняющих преимущественно игровую функцию, и создающих комический эффект, контаминация постепенно превращается в приобретающий продуктивность способ компрессивного словообразования. 


\title{
Литература
}

Лаврова Н.А. Структура, значение и смысл контаминированного слова в современном английском языке. Монография. М.: Прометей, 2009. 183 с.

Козинеи С. Б. Словарь окказионализмов русского языка. Саратов: Саратовский источник, 2017. $165 \mathrm{c.}$

Попова Т.В. Графиксация как новое явление в языке и научной когниции // Вестник Челябинского государственного университета. 2011. № 24 (29). Филология. Вып. 57. С. 160-163.

Янко-Триницкая Н. А. Словообразование в современном русском языке. Сборник статей. М.: Индрик, 2001. 504 с.

\author{
Natalia A. Nikolina \\ Moscow State Pedagogical University \\ (Russia, Moscow) \\ admin@riash.ru
}

\section{TYPES AND FUNCTIONS OF CONTAMINATED CONSTRUCTIONS IN MODERN RUSSIAN SPEECH}

The article considers the contaminated constructions that had spread in Russian speech at the turn of $20^{\text {th }}-21^{\text {st }}$ centuries. The contamination gradually turns from the occasional fenomenon into the vibrant word-forming method. Contaminated units are sequentially used in language of mass media, advertising, literary texts and slangs. Their functions in the modern speech are complicated: together with the valuation function they have nominative functions, take on a nominative role, serve as a mark of intertextual relations, take a part in language game, fill up the list of tropes in the poetic text. There are two mechanisms using in contaminated words forming: overlapping of morphs and syncopation of reasoning word or words. Between-words overlapping is considered as the result of one of the contamination kinds for which haziness of morphemic structure is differential. The semantics of contaminated word is based on the cooperation of united words meanings. On the ground of developing in the word formation process relations of combination, opposition or comparison new semantic components can be updated in the hybrid word. In the literary text contaminated constructions are regularly used for coagulation of imaginative parallel and characterized by high degree of semantics idiomaticity. Some models of contaminated units are fixed in language. According to the models new hybrid words are built. As a result the quasimorphs are transformed into a derivational formants that are regularly used in the word-formating process.

Key words: contamination, graph derivation, between-words overlapping, syncopation, valuation, semantics, comparison, language game. 


\section{References}

Lavrova N. A. Structura, znacheniye i smysl contaminirovannogo slova v sovremennom angliyskom yazyke. Monograpfiya [Structure, meaning and significance of contaminated word in contemporary English. Monograph.]. Moscow: Prometey Publ., 2009. $183 \mathrm{p}$.

Kozinets S. B. Slovar okkazionalizmov russkogo yazyka [Dictionary of occasionalisms Russian language]. Saratov: Saratovskiy istochnik Publ., 2017. 165 p.

Popova T. V. Grafiksatsiya kak novoe yavleniye v yazyke nauchnoy kognitsii [Graphicacy as a new phenomenon in language and scientific cognition]. Vestnik Chelyabinskogo gosudarstvennogo universiteta. 2011. No 24 (29). Filologiya. Vol.57. Pp. 160-163.

Yanko-Trinitskaya N. A. Slovoobrazovaniye v sovremennom russkom yazyke. Sbornik statey [Word formation in modern Russian language]. Moscow: Indrik Publ., 2001. $504 \mathrm{p}$. 


\section{М. В. Трубицина}

Московский государственный университет имени М. В. Ломоносова, Московский педагогический государственный университет

(Россия, Москва)

jackisdead@yandex.ru

\section{СОГЛАСОВАНИЕ В КОНСТРУКЦИЯХ С НАЗВАНИЯМИ В РУССКОМ ЯЗЫКЕ*}

Настоящая статья посвящена феномену названий, а именно их согласовательным свойствам. В силу своей гибридной природы, названия, обладающие внутренней синтаксической структурой - как именной («Вся королевская рать», «Глазами клоуна»), так и не именной («Накануне», «Над пропастью во ржи») - имеют несколько различных стратегий выбора контролёра согласования. В статье представлен перечень таких стратегий, полученный путём анализа корпусного материала, и высказаны предположения о механизмах выбора контролёра.

Ключевые слова: названия, контролёр согласования, стратегии согласования, синтаксис, русский язык.

В работах последних лет, посвящённых русскому синтаксису, встречаются упоминания о синтаксическом подклассе имён собственных с уникальными свойствами - названиях [Testelets 2011, Холодилова 2013]. Синтаксическое поведение этого подкласса плохо изучено, вследствие чего даже в тех немногих работах, что рассматривают некоторые его свойства, высказаны предположения, противоречащие реальным языковым данным. Так, в статье Я.Г. Тестельца 2011 года приведены несколько типов именных групп с неполной падежной парадигмой, в том числе и так называемые «длинные имена собственные». В числе признаков, отличающих этот класс элементов от типичных именных групп, приводится не только их неполная парадигма, но и предположительная неспособность вызывать полноценное адъективное согласование (или попросту сочетаться с прилагательным). Примеры,

* Исследование выполнено в рамках проекта РНФ 16-18-02003 «Структура значения и ее отображение в системе лексических и функциональных категорий русского языка», реализуемого в МПГУ. 
приведённые в настоящей работе (а также некоторые примеры из доклада [Холодилова 2013]), однозначно указывают на ошибочность такого предположения, в особенности, если учесть, что примеры, приведённые в статье, не являются абсолютно уникальными.

На нынешнем этапе изучения названий как языкового феномена недостаточно тщательно описаны не только падежные парадигмы, но и стратегии согласования с названиями, т. е. перечень возможных контролёров согласования и механизмы выбора контролёра. Настоящая статья призвана обозначить ключевые шаги в изучении стратегий согласования с названиями.

Источниками примеров в статье послужили поисковая система Google (далее - [G]), Генеральный интернет-корпус русского языка, содержащий около 20 миллиардов токенов (далее - $[\Gamma])$ и корпус Araneum Russicum Maksimum семейства Aranea, содержащий 13,7 миллиардов токенов (далее — [A]).

Структура статьи такова: параграф 1 посвящён введению в понятие названия, параграф 2 - обсуждению известных стратегий выбора контролёра согласования, параграф 3 - обобщениям, которые можно сделать на основе рассмотренного материала.

\section{1. Что такое названия?}

Объект нашего исследования, по всей видимости, не имел прежде конвенционального обозначения в лингвистической терминологии. Довольно большой пласт языковых исследований посвящён именам собственным, однако наш объект является лишь их подклассом. Для обозначения этого подкласса «Русская грамматика» под ред. Н. Ю. Шведовой вводит термин «собственные наименования». Мы предлагаем использовать обобщающий термин название, по нашему мнению, наиболее точно передающий суть и свойства феномена. К типичным свойствам описываемого нами явления можно отнести: а) способность употребляться с родовым словом и без него и принимать падежную форму в случае его отсутствия (кинотеатра «Октябрь» vs. «Октября»); б) наличие внутренней синтаксической структуры (именной или не именной); в) денотатом названия является артефакт - предмет, созданный человеком, или коллектив, объединение людей. Как верно замечено в работе [Суперанская, Сталтмане 2007], в разряд онимов может переходить любая часть речи, субстантивируясь в функции собственного имени. Как следствие, свойство б) может выполняться таким образом, что внутренняя синтаксическая структура названия будет не именной («На западном фронте без перемен»). При этом она может иметь предположительно любую категорию: NP/DP, CP, AdvP, PP и т. д. Несмотря на это, очевидно, в процессе деривации предложения названия вне зависимости от их категориальной принадлежности вставляются в позиции именных групп. Название как единица словаря обладает признаком категориальной принадлежности «существительное» со всеми вытекающими свойствами. 


\section{2. Типы согласования}

Говоря о согласовании с названиями, мы имеем в виду прежде всего предикативное и адъективное согласование. В этом параграфе мы перечислим обнаруженные нами стратегии выбора контролёра согласования. Многие из этих стратегий дополнительно распределены в контекстах с некоторыми названиями.

\section{1. Согласование с именной верииной}

Здесь контролёром согласования, как и в случае с апеллятивной ИГ, является вершина ИГ. Для названий, по внутренней структуре представляющих собой именные группы, такой тип согласования является основным (хотя некоторые носители допускают также типы 2.5.и 2.6.).

(1)Сюда же попали и «Хроники Нарнии», написанные как бы для детей, и «Война миров», написанная как бы для любителей приключенческих романов, и многое другое; почему-то считается, что несерьезный читатель этих несерьезных книг не способен увлечься серьезным, не развлекательным кино. [Г]

(2) На рок-фестивале 1997 года «Песни XX века», проводимого «Театром ДДТ» на сцене Дворца Спорта «Юбилейный», «Зимовье Зверей» было единственным коллективом, выступившим в акустике (а в телевизионную версию и вовсе вошла композиция «Билль о правах», исполненная Арбениным а капелла). [G]

\section{2. Согласование с именем в номинативе, не являющцмся вершиной ИГ}

В работах [Карташов 2012] и [Холодилова 2013] на небольшой выборке примеров показано, что такой тип согласования довольно частотен для названий, где номинативное имя является подлежащим, обращением и др.

(3) Когда «Летят журавли» были отсняты, фильм послали на отзыв начальству. [Карташов 2012]

(4) «А зори здесь тихие» кажутся более «картинными», обстоятельства смягчены. [Карташов 2012]

Данные поиска в ГИКРЯ («А зори здесь тихие», ограничение 1 млрд) дали схожий результат.

Таблича 1

Распределение типов согласования для «А зори здесь тихие» в ГИКРЯ (абсолютные числа на 1 млрд токенов)

\begin{tabular}{|l|c|c|c|c|}
\hline Название & $\mathrm{Pl}$ & $\mathrm{SgM}$ (фильм) & $\mathrm{SgF}$ (книга) & $\mathrm{SgN}$ (дефолт) \\
\hline «А зори здесь тихие» & 3 & 1 & 1 & 0 \\
\hline
\end{tabular}

\section{3. Согласование с неноминативным именем}

В примерах (5) и (6) согласование, видимо, происходит с ИГ во мн. ч., находящимися внутри названия. Заметим, что в (6) названием является именная группа в генитиве, и тем не менее её вершина выступает контролёром. 
(5) «О мышах и людях» были и в книге, там это довольно важная часть сюжета, так что, думаю, дело тут не в Франко. [G]

(6) Хотя, действительно, «Глазами клоуна» были прочитаны довольно поздно и, кажется, правда не без труда — но и в них были замечательные места. [G и Холодилова 2013]

По всей видимости, только в таких случаях допустимо согласование с неноминативным именем в русском языке [Холодилова 2013].

\section{4. Согласование с неименным словом, интерпретируемым как имя}

Примеры (7-9) свидетельствуют о том, что, переходя в статус названия, апеллятивы теряют свои прежние морфосинтаксические свойства и интерпретируются синтаксисом как имена с типичной для имён морфологией. Так, «Намедни» оказывается существительным мн. ч., а «ВА-БАНКЪ» - существительным мужского рода.

(7) Как я указывал в самом начале, «Намедни» были выдвинуты на «ТЭФИ-95» по разряду передач об искусстве. [Холодилова 2013]

(8) «ВА-БАНКЪ» стал группой московской Рок-Лаборатории, в 1987 участвовал в «Рок-панораме». [G]

(9) В 1987 г. с лёгкой руки А. К. Троицкого «ВА-БАНКЪ» оказался первой в СССР непрофессиональной группой, сумевшей выехать за рубеж на фестиваль «Роб Реггей» в Варшаве. [G]

\section{5. Согласование по грамматическому роду родового слова}

Родовое слово для некоторого названия артефакта практически всегда предстает перед нами в единственном числе. Судя по всему, согласование происходит с некоторой вершиной, чьи признаки числа и рода означены так же, как у родового слова.

В работах [Pesetsky 2013, Лютикова 2015] обсуждается согласование по роду в случаях референции к лицу женского пола («наша новая врач»). Такие случаи в [Pesetsky 2013] предлагается анализировать при помощи нулевой вершины Ж, диктующей признак грамматического женского рода. Мы предлагаем аналогичный анализ для структур в (10) и (11): признак грамматического рода содержит некоторая нулевая вершина, присоединяющая название в качестве комплемента.

(10) К нашей теме вечера отлично подходит оскароносный «В поисках Немо». [A]

(11) Осенью 1999 года «Ногу свело!» отметила свой десятилетний юбилей. [G]

Возможно согласование с родовым словом в предикативной функции:

(12) ...«собор парижской богаматери» — я когда читала думала, что как мультик :biggrin: а оказалась интересной книгой (после этого очень нравится Гюго). $[\mathrm{G}]$

(13) «В поисках Немо» стал одним из самых любимых публикой фильмов Pixar, который принес 868 миллионов долларов сборов по всему миру. [А] 


\section{6. Согласование по числу}

В отличие от названий артефактов в предложениях с названиями коллективов не обнаруживается дефолтного согласования. Когда согласования по роду с вершиной или зависимым именем не происходит (ввиду отсутствия родовых признаков у названия или вследствие выбора носителя), предикат демонстрирует согласование по множественному числу.

(14) «Ногу свело» изображали нищих, просящих подаяния в одном из московских

метро, что было крайне негативно воспринято членами жюри. [G]

В статье [Лютикова 2015] приводится анализ структур типа двадиать один год прошёл/прошли. В таких именных группах происходит синтаксическое согласование по числу с нулевой вершиной Nmb. Мы предполагаем, что аналогичный механизм стоит за согласованием по числу в нашем случае.

Наблюдается асимметрия в выборе типа согласования у иноязычных названий коллективов:

(15) Rammstein перепели «Зеленоглазое такси». [G]

(16) Под занавес 2006 года «Blackmore's Night» решили поддержать модную на Западе традицию выпускать рождественские альбомы и выпустили сборник соответствующих мелодий Winter Carols, долгое время бывшую в чартах «Billboard». [G]

(17) После того как группа зарекомендовала себя важной единицей в Bay Areathrashmetal, Metallica поехала в Нью-Йорк в 1983 году. [G]

(18) ...На старичков W.A.S.P мы попросту опоздали (жалко, кстати), ну а Апокалиптика послужила прекрасным музыкальным фоном нашего похода обратно к поезду. [Г]

Иноязычные названия, похожие на слова женского рода, субстантивируются так же, как «Намедни» и «ВА-БАНКЪ» в примерах (7-9), в то время как для названий типа Rammstein такое не характерно. Такого не происходит в искусственных названиях, не имеющих апеллятивных аналогов:

(19) В это время Бони М выпускает только сборники «лучших хитов» со старых альбомов.

Таблица 2

Таблича 3

Соотношение абсолютных чисел типов согласования для иноязычных названий (не женского рода) на 1 млрд токенов (ГИКРЯ)

\begin{tabular}{|l|c|c|c|}
\hline $\begin{array}{c}\text { Название } \\
\text { коллектива }\end{array}$ & PI & SgM & Род.сл. \\
\hline Rammstein & 12 & 1 & 0 \\
\hline Blackmore's Night & 3 & 0 & 0 \\
\hline Slipknot & 22 & 1 & 0 \\
\hline
\end{tabular}

Соотношение абсолютных чисел типов согласования для иноязычных названий, похожих на слова женского рода на 1 млрд токенов (ГИКРЯ)

\begin{tabular}{|l|c|c|c|}
\hline $\begin{array}{c}\text { Название } \\
\text { коллектива }\end{array}$ & PI & SgF & Sg (Prs) \\
\hline Металлика & 3 & 16 & 11 \\
\hline Апокалиптика & 0 & 5 & 2 \\
\hline
\end{tabular}




\section{7. Дефолтное согласование}

Похоже, что такой тип согласования встречается только у артефактов. В предложениях с названиями коллективов в случае невозможности других стратегий или отказа от них носитель выбирает согласование по числу.

(20) А у меня "Ну, погоди" было почему-то с Микки-Маусом вместо волка. [G]

Стоит отметить, что отдельного статистического исследования заслуживает вопрос о зависимости позиции мишени согласования относительно позиции контролёра.

\section{8. Трудные для анализа случаи}

Зачастую невозможно понять, какая стратегия согласования используется в клаузах с названиями, содержащими существительные с тем же значением признака рода, что и у предполагаемого родового слова. Так, (21) можно интерпретировать как Роман следует и расширяет традиичию... ${ }^{1}$ или как «На маяк ${ }^{(\mathrm{ACCNOM})}{ }_{\text {» }}$ следует и расширяет традицию... Также можно допустить, что сочетание предлога и существительного в названии, образующее одно фонетическое слово, интерпретируется как единая ИГ в номинативе, как это происходит с неименными названиями (см. 2.4.). В примере (22) вопреки анализу [Холодилова 2013] также могут быть варианты интерпретации: помимо согласования с омонимичной номинативу ИГ в составе названия, женский род предиката может также объясняться согласованием с родовыми наименованиями «кинолента» («лента»), «кинокартина» («картина»), «мелодрама». Аналогичные проблемы вызывает анализ предложения (23).

(21) «На маяк» следует и расширяет традицию литературы модернизма Марселя

Пруста и Джеймса Джойса, где сюжет отходит на второй план, уступая место философскому самоанализу. [Википедия]

(22) Его «Покажи мне любовь» была одним из самых ярких впечатлений у меня в 2003 году. [Холодилова 2013]

(23) Как ни странно, «Руки вверх» выступят не в одноименном баре, а в «Облаках». [A]

Часто только контекст помогает догадаться, какой тип согласования используется в предложении. В предложении (24) согласование с нулевой вершиной числа более вероятно, поскольку речь идёт о коллективе создателей ресторана.

(24) Еще один плюс ресторану можно присвоить за винную и барную карты: «Рыбы нет» позаботились как о качественном вине по приятным ценам, так и о подборке авторских коктейлей — небольшой, но хорошо продуманной.

${ }^{1}$ Пример содержит грамматическую ошибку: происходит сочинительное сокращение дополнения, хотя падеж сокращенного и выраженного дополнения не совпадают. 


\section{3. Некоторые обобщения}

Существуют синтаксические отличия между согласованием названий артефактов и названий коллективов: и первым, и вторым свойственны все виды грамматического согласования, кроме дефолтного (этот вид согласования возможен только в конструкциях с артефактами). Названия коллективов же при отсутствии других доступных стратегий выбирают согласование по множественному числу.

Таблица 4

Сводная таблица сходств и различий в согласовании с названиями артефактов или названиями коллективов

\begin{tabular}{|l|c|c|}
\hline & Названия артефактов & Названия коллективов \\
\hline Согласование с именной вершиной & + & + \\
\hline Согласование с невершинным именем & + & $?$ \\
\hline $\begin{array}{l}\text { Согласование с неименным словом, интерпре- } \\
\text { тируемым как имя }\end{array}$ & + & Крайне редко \\
\hline $\begin{array}{l}\text { Согласование по грамматическому роду родо- } \\
\text { вого слова }\end{array}$ & + & + \\
\hline Согласование по числу & Не применимо & - \\
\hline Дефолтное согласование & + & + \\
\hline
\end{tabular}

Основания для выбора того или иного типа согласования при наличии нескольких опций не всегда понятны. Корпусное исследование не может дать ответ на этот вопрос. В дальнейшем необходимо исследовать речевые предпочтения носителей при помощи эксперимента.

\section{Литература}

Карташов A. Типы имён собственных и наименований и их грамматическая специфика в современном русском языке. Выпускная квалификационная работа на соискание степени бакалавра филологии. Санкт-Петербург, 2012. 87 с.

Лютикова $E$. A. Согласование, признаки и структура именной группы в русском языке // Русский язык в научном освещении. 2015. № 2. С. 44-73.

Розенталь Д.Э. и др. Справочник по правописанию, произношению, литературному редактированию. [Электронный ресурс] URL: http://evartist.narod.ru/text1/20.htm

Суперанская A. В. и др. Теория и методика ономастических исследований / Отв. ред. А. П. Непокупный. Изд. 2-е. М.: Изд. ЛКИ, 2007. 256 с.

Холодилова М. Свойства вершины у элементов названий в русском языке. Устный доклад. Русский язык: конструкционные и лексико-семантические подходы. Санкт-Петербург, 12-14 сентября 2013 г. 6 с.

Русская грамматика / Под ред. Н. Ю. Шведовой. В 2-х т. Т. ІІ. М.: Наука, 1980. 709 c.

Benko, V. Aranea: Yet Another Family of (Comparable) Web Corpora. In Petr Sojka, AlešHorák, Ivan Kopeček and Karel Pala (Eds.): Text, Speech and Dialogue. 17th 
International Conference, TSD 2014, Brno, Czech Republic, September 8-12, 2014. Proceedings. LNCS 8655. Springer International Publishing Switzerland, 2014. pp. 257264.

Benko, V. Compatible Sketch Grammars for Comparable Corpora. In Andrea Abel, Chiara Vettori, NatasciaRalli (Eds.): Proceedings of the XVI EURALEX International Congress: The User In Focus. 15-19 July 2014. Bolzano/Bozen: Eurac Research, 2014. pp. $417-430$.

Rychlý, P. Manatee/Bonito - A Modular Corpus Manager. In 1st Workshop on Recent Advances in Slavonic Natural Language Processing. Brno: Masaryk University, 2007, pp. 65-70.

Pesetsky D. Russian case morphology and the syntactic categories. - MIT Press, 2013. 173 p.

Testelets Y.G. Case Deficient Elements and the Direct Case Condition in Russian // Язык и речевая деятельность. Петербургское лингвистическое общество. Том 9. 2006. СПб.: Филологический факультет СПбГУ. 2010. pp. 126-143.

\section{Maria $V$. Trubitsina}

Lomonosov Moscow State University,

Moscow State University of Education

(Russia, Moscow)

jackisdead@yandex.ru

\section{AGREEMENT IN CONSTRUCTIONS WITH NAMES IN RUSSIAN}

In recent works on Russian syntax a syntactic phenomenon called Names (also Long Names, Long Proper Names) keeps being mentioned. The main criteria for an element of the class of Names is that is has its own inner syntactic structure and it denotes an artificial object or a group of people. The paper introduces a number of agreement strategies that appear to be present in sentences with names or titles in subject positions. For Names with a non-nominal internal structure several agreement patterns are complementary distributed among speakers and texts, but also in a single-speaker context.

Key words: Names, proper names, agreement, agreement patterns, Russian syntax.

\section{References}

Benko, V. Aranea: Yet Another Family of (Comparable) Web Corpora. In Petr Sojka, AlešHorák, Ivan Kopeček and Karel Pala (Eds.): Text, Speech and Dialogue. 17th International Conference, TSD 2014, Brno, Czech Republic, September 8-12, 2014. Proceedings. LNCS 8655. Springer International Publishing Switzerland, 2014. pp. 257-264.

Benko, V. Compatible Sketch Grammars for Comparable Corpora. In Andrea Abel, Chiara Vettori, NatasciaRalli (Eds.): Proceedings of the XVI EURALEX International 
Congress: The User In Focus. 15-19 July 2014. Bolzano/Bozen: Eurac Research, 2014. pp. 417-430.

Kartashov A. [Types of proper names and nominations and their grammatical specifics in Modern Russian]. Graduation work for a bachelor's degree in philology. SaintPetersburg, 2012. 87 p. (In Russ.)

Kholodilova M. [Head properties in elements of names in Russian] (Oraltalk). Russkiiyazyk: konstruktsionnye i leksiko-semanticheskie podkhody. [Russian language: constructive and lexical-semantic approaches]. Saint-Petersburg, September 12-14, 2013. 6 p. (InRuss.)

Lyutikova E. A. [Agreement, properties and structure of Nominal Phrases in Russian]. Russkii yazyk v nauchnom osveshchenii, 2015. No. 2. pp. 44-73. (In Russ.)

Pesetsky D. Russian case morphology and the syntactic categories. MIT Press, 2013. $173 \mathrm{p}$.

Rozental' D.E. et al. [Handbook of spelling, pronunciation, literary editing]. Spravochnik po pravopisaniyu, proiznosheniyu, literaturnomu redaktirovaniyu. Available at: http://evartist.narod.ru/text1/20.htm (accessed 21.01.2017) (In Russ.)

Russkaya grammatika [Russian Grammar], Vol. II. (ed.) N.Yu. Shvedova. Moscow: Nauka Publ., 1980. 709 p. (InRuss.)

Rychlý, P. Manatee/Bonito - A Modular Corpus Manager. In 1st Workshop on Recent Advances in Slavonic Natural Language Processing. Brno: Masaryk University, 2007. pp. 65-70.

Superanskaya A. V. et al. Teoriya i metodika onomasticheskikh issledovanii [Theory and methodology of onomastic research]. $2^{\text {nd }}$ edition. - Moscow, Izd. LKI, 2007. 256 p.

Testelets Y.G. Case Deficient Elements and the Direct Case Condition in Russian. Yazyk i rechevaya deyatel'nost'. Peterburgskoe lingvisticheskoe obshchestvo [Language and speech activity. Petersburg Linguistic Society]. Vol. 9. 2006. SPb.: Filologicheskii fakul'tet SPbGU. 2010. pp. 126-143. 


\section{Е. В. Урысон}

Институт русского языка им. В. В. Виноградова РАН, Российский государственный гуманитарный университет

(Россия, Москва)

uryson@gmail.com

\section{НАРЕЧИЕ СРАЗУ: СЕМАНТИКА И ГРАММАТИКА*}

Объект работы - семантика и синтаксис наречия сразу в двух типах контекстов: временно́м (уйти сразу после урока) и пространственном (Веник стоит сразу за дверью). Выявлены семантические мосты между данными значениями; в частности, продемонстрировано, что наречие сразу в пространственном значении сохраняет определенное указание на время. Показано, что данное наречие в каждом из этих значений обладает двумя семантическими актантами. Первый актант выражается словом, от которого наречие зависит синтаксически (сразу уйти; стоит сразу [за дверью]), что стандартно для наречий. Синтаксическая интерпретация выражения второго актанта (сразу после урока, сразу за дверью) не столь очевидна. Продемонстрировано, что соответствующая именная группа синтаксически подчиняется не самому наречию, а слову, от которого зависит наречие; данное явление распространено в сфере глагольного управления (смещение дополнения). Подобные двухактантные наречия в современной традиционной русистике принято считать наречными предлогами (ср. вокруг нас, далеко от дома). Обсуждается понятие наречного предлога. Приведены аргументы в пользу того, что класс слов, которые современная академическая грамматика трактует как наречные предлоги, естественно считать подклассом наречий: такое описание последовательнее и гораздо экономнее.

Ключевые слова: полисемия, наречие, наречный предлог, семантический актант, синтаксический актант, управление, соподчинение.

\section{1. Введение}

Объект предлагаемой работы - наречие сразу в двух своих значениях. Ср.

«Сразу временно́е» 'через кратчайший промежуток времени': сразу извиниться.

\footnotetext{
* Работа выполнена при поддержке РНФ (проект № 16-18-02054).
} 
«Сразу пространственное» 'на ближайшем расстоянии': Веник сразу за дверью.

У этого наречия есть и другие значения, ср. Съел сразу обед и ужин; Все говорили сразу, и он ничего не понимал. Эти значения не рассматриваются.

Слова со значением времени, как правило, имеют и пространственное значение: сосуществование в рамках одного слова пространственного и временного значений является, видимо, универсалией. Наречие сразу не является исключением.

Для дальнейшего нам понадобится следующее терминологическое уточнение: в соответствии со словоупотреблением, принятым в московской семантической школе, будем называть слово, взятое в одном из своих значений, лексемой. (Многозначное слово представляется тогда как набор лексем.)

И временная, и пространственная лексемы сразу подразумевают некоторую точку отсчета, «ориентир». Наречие сразу во временном значении предполагает, что некоторое событие (A1) произошло через кратчайший промежуток времени после другого события (А2), ср.

(1) Раздался взрыв (А2), и сразу завыла сирена (A1).

В пространственном значении наречие сразу указывает на положение в пространстве объекта A1 относительно другого объекта A2: первый объект находится в непосредственной близости от второго, или по-другому: объект А1 находится на кратчайшем расстоянии от объекта А2 (ниже семантика этой лексемы будет существенно уточнена). Ср.

(2) Веник (А1) сразу за дверью (А2).

Без указания двух событий (двух физических объектов) невозможно адекватно описать данные лексемы.

Тем самым, наречие сразу в обсуждаемых значениях имеет два семантических актанта: 'ориентир' и 'ориентируемое'. Этот факт интересен сам по себе: многие наречия имеют всего один семантический актант, ср. очень (любить), тепло (одеться), мало (говорить) и т.п. Мы сосредоточимся на выражении второго актанта лексем наречия сразу. В связи с этой задачей возникает вопрос о принадлежности слова сразу к так называемым наречным предлогам. Поэтому в ходе описания обсуждается статус наречных предлогов в системе частей речи; здесь мы опираемся на общий подход к представлению этого класса слов, предлагаемый в работе [Урысон 2017].

Изложение строится по следующему плану. Сначала обсуждается семантика временного и пространственного значений сразу. Затем сравнивается выражение семантических актантов сразу в пространственном и временном значениях и предлагается решение теоретических вопросов.

\section{2. Наречие сразу во временном и пространственном значениях}

Толкование временной лексемы сразу не вызывает затруднений:

(3) А2, сразу А1[Раздался взрыв [А2], и сразу завыла сирена [А1]]

'событие A1 имеет место через кратчайший промежуток времени после события А2'. 
Синонимы данной лексемы - выражение в ту же минуту (ср. Раздался взрыв, и в ту же минуту завыла сирена), а также немедленно (ср. Получив повестку, он немедленно пошел в военкомат).

Пространственная лексема сразу семантически гораздо богаче. Возьмем примеры:

(4) Чемодан стоит сразу у двери.

(5) Катя сидит сразу за первыл столом.

(6) С тропинки поверни направо. Там сразу растут белье.

(7) Повернешь налево - и сразу море земляники.

Как уже говорилось, данная лексема указывает на положение в пространстве объекта A1 относительно другого объекта А2. В (2) и (4) ориентируемый объект A1 - 'веник' ('чемодан'), а ориентир А2 - ‘дверь'; в (5) ориентируемый объект A1 - 'Катя', ориентир А2 — 'первый стол'; в (6) и (7) ориентируемый объект А1 'белые грибы' ('земляника'), а ориентир А2 - 'место поворота'.

При этом данная лексема предполагает наблюдателя, совершающего ряд последовательных действий (возможно мысленно), и данный объект он воспринимает сразу после какого-то действия - таким образом, эта лексема сразу сохраняет намек на время. Действие, которое совершает субъект, это обычно перемещение, в ходе которого субъект делает повороты, возможно, преодолевает препятствия, смотрит и т.п. В примерах (6)-(7) речь идет о перемещении и повороте субъекта перемещения, который одновременно является наблюдателем. В примерах (2), (4) и (5) прямого указания на перемещение нет, однако оно подразумевается и, возможно, упомянуто в предтексте. Ср.

(4а) Загляни в комнату. Чемодан стоит сразу у двери.

(5а) Бухгалтерия на третьем этаже. Катя сидит сразу за первым столом. [Подразумевается: Зайди в бухгалтерию.]

В этом отношении данная лексема сразу неожиданно сближается с глаголом вилять, представленным в контекстах типа Дорога сильно виляла. Этот глагол указывает на то, как пролегает на местности тропинка, дорога или подобный объект, и семантически сближается с глаголами виться, извиваться, змеиться и некоторыми другими. Ср. По склону змеятся <вьются> тропьл; Речушка извивается, следуя изгибам местности. Однако лексема вилять, в отличие от этих глаголов, предполагает наблюдателя, перемещающегося по описываемой дороге или тропинке [Апресян 2004].

Для лексемы сразу важно, что ориентируемый объект оказывается ближайшим к наблюдателю. Ср. нормальный контекст высказываний (4) - (5):

(8) Войдешь в комнату. Чемодан стоит сразу у двери.

(9) Загляни в читальный зал: она сидит сразу за первым столом.

Если же объект не является ближайшим к наблюдателю и не воспринимается им тут же, то наречие сразу неуместно. Ср. сомнительные примеры:

(10) * Войдешь в комнату. Чемодан стоит сразу за шкафом, который у окна.

(11) *Загляни в читальный зал: она сидит сразу за последним столом.

Предварительное толкование пространственной лексемы сразу таково: (12) А2 находится сразу за А1 [Чемодан [A2] стоит сразу за дверью [A1]] 
'объект A2 находится на кратчайшем расстоянии от объекта A1; наблюдатель, переместившись к А1, сразу может увидеть А2; после перемещения наблюдателя объект А2 является ближайшим к нему'. Как видим, пространственная лексема сразу толкуется через временную. Перейдем к синтаксису рассматриваемых лексем наречия сразу.

\section{3. Синтаксическое выражение семантических актантов данных лексем}

3.1. Временная лексема сразу. Примеры:

(13) Раздался взрыв (А2). И сразу завыла сирена (А1).

(14а) Сразу после взрыва (А2) завыла сирена (А1).

(14б) После взрыва (А2) сразу завыла сирена (А1).

(15а) Сразу за первым сильныл толчком (А2) последовала серия более слабых толчков (A1).

(15б) За первым сильным толчком (А2) сразу последовала серия более слабых толчков (A1).

Семантический актант A1 'ориентируемое событие' выражается стандартно для наречного актанта - глаголом (сказуемым), причем само наречие синтаксически подчиняется выражению этого семантического актанта, являясь его обстоятельством:

(16) Сразу Łзавыла [А1] (сирена).

Нас будет интересовать выражение актанта А2 ‘временной ориентир' (применительно к нашему случаю актант А2 можно назвать 'предшествующее событие').

Основные способы выражения актанта А2 'временной ориентир' ('предшествующее событие'):

(I) A2 может быть выражен пропозицией (отдельным предложением) в предтексте, ср. (13).

(II) А2 может быть выражен предложно-падежной группой: после + РОД, ср. $(14 \mathrm{a}, 6) ;$ или за + ТВОР, cp. (15a,б). Эта группа может находиться как в препозиции, так и в постпозиции к наречию.

Нам ясен набор семантических актантов лексемы сразу и их выражение. Теперь требуется уяснить синтаксическую структуру предложений типа (13)-(15б).

Казалось бы, ответ очевиден: предложно-падежная группа, выражающая семантический актант А2 лексемы сразу, синтаксически подчиняется этой лексеме, т.е. является и ее синтаксическим актантом. Ср.:

(17) сразу $\rightarrow$ после взрыва (А2); за толчком (А2) Ł сразу.

Такое описание как будто соответствует и интуиции: цепочки типа сразу после взрыва воспринимаются как словосочетания, т.е. такие сочетания, в которых компоненты связаны синтаксической зависимостью. Однако такое описание неправильно.

Вспомним известный критерий определения главного слова в словосочетании [Курилович 1962; Холодович 1979]: если удалить главное слово словосочетания, то нарушится грамматическая правильность предложения. Сp. 
(18) В вазе стоит белая $\leftarrow$ роза. * В вазе стоит белая $\leftarrow$.

При удалении слова сразу грамматическая правильность предложения не нарушается. Ср. одинаково правильные предложения внутри пар:

(19) Сразу после взрыва (А2) завыла сирена (А1). - После взрыва (А2) завыла сирена (A1)..

(20) За первым сильным толчком (А2) сразу последовала серия более слабых толчков (А1). - За первым сильным толчком (А2) последовала серия более слабых толчков (A1).

Итак, предложно-падежная группа, выражающая актант А2 'временной ориентир’ ('предшествующее событие’), не является синтаксическим актантом лексемы сразу.

Существует и иной подход к описанию подобных случаев. Он лежит в русле академической грамматики и восходит к Л.В. Щербе и В.В. Виноградову [Щерба 1974; Виноградов 1972; Грамматика-70; Грамматика-80]. В соответствии с этим подходом в примере (13) представлено наречие сразу, а в остальных примерах имеется наречный предлог сразу за или сразу после. При таком подходе придется считать, что слово сразу во временном значении представлено более чем одной лексемой - одна из них является наречием, а другая — наречным предлогом. Строго говоря, придется считать, что перед нами даже два наречных предлога: сразу после и сразу за.

С точки зрения современной лингвистики этот подход неудовлетворителен. Действительно, наречие сразу во всех трех случаях имеет одно и то же значение и один и тот же набор семантических актантов. Различаются эти случаи лишь способом выражения одного из актантов. Подобные единицы естественно описывать в рамках одного значения. Ср. назначить <выбрать> его председателем - назначить <выбрать> председателя (подробнее см. работу [Апресян 2010]).

В нашем случае естественно принять, что в контекстах типа Раздался взрыв, и сразу завыла сирена и типа Сразу за взрывом завыла сирена слово сразу представлено одной и той же лексемой, которая имеет (в частности) семантический актант ‘временной ориентир' ('предшествующее событие'). Различаются эти контексты способом выражения данного актанта. В синтаксической зоне словарной статьи лексемы сразу отмечается, что этот актант может быть выражен двумя способами: а) глагольной группой в предтексте; б) определенным предложно-падежным сочетанием. Такое описание вполне соответствует духу современной семантики и лексикографии ${ }^{1}$.

Итак, последовательности сразу за и сразу после не являются наречными предлогами. В цепочках сразу после взрыва, сразу за подземным толчком предложно-падежная группа не подчиняется наречию. Остается всего один способ

1 Заметим, что этот подход тоже был представлен в русистике: так называемые наречные предлоги считались наречиями, которые «могут управлять падежом (около дерева, возле дома), но это не составляет их назначения; это, если можно так выразиться, их право, а не обязанность» [Овсянико-Куликовский 1902: 261]. Данная точка зрения развивается в книге [Черкасова 1967]. 
представления данных случаев: и наречие сразу, и предложно-падежная группа после взрыва (или за подземным толчком) оба подчиняются глаголу (сказуемому) это соподчиненные обстоятельства времени.

Некоторая неожиданность состоит в том, что семантический актант А2 'временной ориентир' ('предшествующее событие') лексемы сразу синтаксически подчиняется не ей, а глаголу, от которого зависит и само слово сразу. Однако подобные случаи хорошо известны, правда, в области глагольного управления, где это явление называется смещением дополнения. Обзор таких случаев дан в работе [Апресян 2010: 121-122]. Приведем некоторые примеры: крепко сжимать руки $\rightarrow$ бандита VS. крепко сжимать $\rightarrow$ бандиту руки; обработать его $\leftarrow$ рань VS. обработать $\rightarrow$ ему раны [Там же]. Как видим, предлагаемый подход к описанию наречий вполне лежит в русле современного синтаксиса.

В нашем случае смещенный актант, строго говоря, не является дополнением. Однако суть явления та же: семантический актант лексемы синтаксически подчиняется не самой этой лексеме, а ее синтаксическому хозяину - глаголу.

3.1. Пространственная лексема сразу. Эта лексема отмечена стилистически как разговорная (ср. примеры выше) или нарративная. Приведем нарративные примеры из [MAC]:

(21) До хутора отсюда было рукой подать, лежал он сразу за лесной опушкой (Авдеев).

(22) Bы знаете, наш лагерь тут недалеко, сразу за речкой (Михалков).

Первый семантический актант (A1) этой лексемы сразу - 'ориентируемый объект’ - выражается именной группой (обычно подлежащим), которая подчиняется глаголу (обычно сказуемому), причем само наречие синтаксически подчиняется тому же глаголу, являясь его обстоятельством. Ср.

(16) Чемодан $[$ А1] $\leftarrow$ стоит $\rightarrow$ сразу (за дверью).

Сосредоточимся на выражении семантического актанта А2 'ориентир' этой лексемы. Существенно, что он почти всегда оформляется предложно-падежной группой, ср. сразу у двери, сразу за дверью, сразу за первым столом, сразу в первом ряду, сразу на полке и т.П. Кроме того, этот актант может быть выражен наречием там, ср. Там сразу будет магазин, а также (6).

Однако выражение этого актанта отдельным предложением в предтексте, столь характерное для временной лексемы сразу, в данном случае менее стандартно (и, возможно, стилистически отмечено). Ср. (7), а также

(23) Повернули направо - и сразу малинник!

В целом, данная лексема сразу тяготеет к употреблению с предложно-падежной формой или наречием там, оформляющими ее актант 'ориентир'. Невозможно:

(24) Войдешь в комнату. *Чемодан стоит сразу.

(25) Загляни в читальный зал. *Она сидит сразу.

(26) С тропинки поверни направо. *Сразу растут белье.

В этом отношении пространственная лексема сразу отличается от временной: высказывания типа Сразу раздался взрыв, без синтаксически выраженного актанта А2 'временной ориентир', вполне нормальны. 
Добавим, что предложно-падежная группа, выражающая актант А2 'пространственный ориентир' этой лексемы, практически обязательно находится в постпозиции к лексеме.

Казалось бы, пространственная лексема сразу формирует наречный предлог. Однако такое описание неудовлетворительно, так как мы получаем серию таких предлогов: сразу у, сразу за, сразу в, сразу на и, возможно, еще другие. Кроме того, существует еще там сразу, что никак нельзя интерпретировать как предлог. Наконец, в случаях типа (7) и (23) перед нами безусловно пространственное наречие сразу, а никак не наречный предлог. Остается признать, что во всех этих случаях представлено пространственное наречие.

Однако в отличие от временной лексемы сразу, данная лексема налагает гораздо более жесткие требования к выражению своего актанта А2 'пространственный ориентир'. Тем не менее, данная лексема не подчиняет синтаксически выражение этого актанта. Действительно, лексему сразу можно опустить, и предложение останется правильным. Ср.

(27) Войдешь в комнату. Чемодан стоит сразу у двери. VS. Войдешь в комнату. Чемодан стоит у двери.

(28) Загляни в читальный зал: она сидит сразу за первыли столом. VS. Загляни в читальный зал: она сидит за первым столом.

(29) С тропинки поверни направо. Там сразу растут белье. VS. C тропинки поверни направо. Там растут белье.

Между тем, как мы помним, если опустить главное слово в словосочетании, то предложение станет неправильным [Курилович 1962; Холодович 1979], ср. (18).

Остается признать, что и данная лексема сразу, и выражение ее семантического актанта A2 'пространственный ориентир' синтаксически подчиняются глаголу (сказуемому), являясь соподчиненными обстоятельствами места. Замечательно, что такое соподчинение уже почти обязательно, по крайней мере, в нейтральных высказываниях, и к тому же при данном соподчинении задан жесткий порядок обстоятельств относительно друг друга. Глагол как бы стремится передать свое управление наречию. Тем не менее, формально наречие синтаксически не подчиняет себе выражение своего семантического актанта А2 'пространственный ориентир’: перед нами то же явление «смещения дополнения», которое мы видели в случае временной лексемы сразу.

\section{4. Заключение}

Ни временная, ни пространственная лексема сразу не управляет предложно-падежным сочетанием, выражающим ее второй семантический актант 'ориентир': наречие и данное предложно-падежное сочетание являются соподчиненными обстоятельствами. Однако пространственная лексема сразу как бы срастается с этим предложно-падежным сочетанием: во-первых, его, как правило, невозможно опустить, и, во-вторых, его линейное расположение относительно наречия фиксировано - это всегда постпозиция. Временная лексема сразу ведет себя гораздо 
свободнее, ср. (13), а также (14a) - (14б), (15a) - (15б). В этом отношении пространственная лексема сразу гораздо ближе к управляющим предлогообразным наречиям типа вокруг (елки), далеко (от дома), которые академическая грамматика, вслед за Л. В. Щербой и В.В. Виноградовым, относит к классу производных предлогов.

Заметим, что последовательное различение управления одного слова другим и соподчинения обоих слов некоему третьему могли бы лечь в основу критерия выделения составных наречных предлогов. Так, слово далеко безусловно управляет предложно-падежной группой $o m+$ РОД, выражающей его семантический актант; ср. стоять далеко $\rightarrow$ от дома $\mathrm{VS} .{ }^{*}$ стоять $\rightarrow$ от дома. Но ни временная, ни пространственная лексема сразу не управляют выражением своего семантического актанта. Тем самым, наречие далеко обладает чертами предлога (оно способно управлять), а наречие сразу — нет. Однако, насколько нам известно, в рамках академического подхода данная проблематика не обсуждается.

Рассмотренные лексемы наречия сразу интересны и с точки зрения описания полисемии: пространственная лексема сразу в конечном счете толкуется через временную, однако указание на время относится к тонкой семантике лексемы и «спаяно» с указанием на наблюдателя и его подразумеваемое перемещение в пространстве.

\section{Литература}

Апресян Ю.Д. Словарная статья синонимического ряда ВИТЬСЯ // Новый объяснительный словарь синонимов русского языка. Изд. 2-е. М. - Вена, 2004.

Виноградов В.В. Русский язык (грамматическое учение о слове). М.: Высшая школа, 1972.

Грамматика 1970 - Грамматика современного русского языка. М.: Наука, 1970.

Грамматика 1980 - Грамматика современного русского языка. В 2 т. М.: Наука, 1980.

Курилович E. Основные структуры языка: словосочетание и предложение // Курилович Е. Очерки по лингвистике. М.: Изд-во иностранной литературы, 1962. C. $48-56$.

МАС - Евгеньева А. П. (ред.). Словарь русского языка. Т. 1-4. М., 1981-1984.

Овсянико-Куликовский Д. Н. Синтаксис русского языка. СПб.: Издание Д. Е. Жуковскаго, 1902.

Урысон Е. В. Предлог или наречие? (Частеречный статус наречных предлогов) // ВЯ, 2017, № 5 .

Холодович А.А. К вопросу о доминанте предложения // Холодович А. А. Проблемы грамматической теории. Л., 1979. С. 293-298.

Черкасова E. T. Переход полнозначных слов в предлоги. М.: Наука, 1967.

Щерба Л. В. О частях речи в русском языке // Языковая система и речевая деятельность. Л.: Наука, 1974. С. 77-100. 


\section{Elena V. Uryson}

V.V. Vinogradov Russian Language Institute of the Russian Academy of Sciences, Russian State University for the Humanities

(Russia, Moscow)

uryson@gmail.com

\section{SEMANTICS AND SYNTAX OF RUSSIAN ADVERB SRAZU 'IMMEDIATELY'}

The object of the paper is Russian adverb srazu 'immediately' in two meanings: 'at once' (cf. srazu ujti 'to leave at once') and 'directly or closely' (cf. stojat' v ocheredi srazu za devushkoj $v$ sinej kurtke 'to stand in the line directly behind the girl in the blue coat'). Semantic links between these meanings are discussed. It is demonstrated that srazu 'directly or closely' keeps a slight indication to the time of an event. It is shown that srazu 'immediately' in both meanings has two semantic actants. The first one is expressed by the predicate subordinating the adverb (srazu $\leftarrow$ ujti 'to leave $\leftarrow$ at once'; stojat' $\rightarrow$ srazu za devushkoj 'to stand $\rightarrow$ directly behind the girl'); this is quite common for adverbs. It is argued that the second semantic actant is expressed by a noun group (cf. srazu posle svad'by 'immediately after wedding', srazu za devushkoj 'directly behind the girl'), but on the syntactic level this noun group and the adverb are dependent of the same predicate. Traditional grammar assigns analogous adverbs with two semantic actants to adverbial prepositions; cf. vokrug (doma) 'around the house', daleko ot (doma) 'far from (the house)'. It is argued that according to economy principle adverbial prepositions should be described as a group of adverbs.

Key words: polysemy, adverb, prepositional adverb, semantic actant, syntactic actant, syntactic subordination.

\section{References}

Apresjan Ju. D. Slovarnaja statja sinonimicheskogo rjada VIT'SA [An entry of the synonymic row VIT'SA 'meander']. Novyj objasnitel'nyj slovar' sinonimov russkogo jazyka [A new explanatory dictionary of Russian synonyms]. 2nd ed. Moscow: Yazyki Slavyanskoi Kul'tury Publ., 2003.

Cherkasova E. T. Perekhod polnoznachnykh slov v predlogi [Transformation of autonomous words to prepositions]. Moscow: Nauka Publ., 1967.

Grammatika sovremennogo russkogo yazyka [Modern Russian grammar]. Moscow: Nauka Publ., 1970.

Grammatika sovremennogo russkogo yazyka [Modern Russian grammar]. Moscow: Nauka Publ., 1980.

Kholodovich A.A. K voprosu o dominante predlozhenija [Towards the problem of the sentence dominant]. Kholodovich A. A. Problemy grammaticheskoi teorii [Problems of grammar theory]. Leningrad: Nauka Publ., 1979. Pp. 293-298. 
Kurylowicz E. Osnovnyje struktury jazyka: slovosochetanije i predlozhenije [The basic structures of language: Phrase and sentence]. Kurylowicz E. Ocherki po lingvistike [Essays in linguistics]. Moscow, 1962. P. 48-56.

Ovsyaniko-Kulikovskii D. N. Sintaksis russkogo yazyka [Syntax of the Russian language]. St. Petersburg: Publication by D.E. Zhukovskii, 1902.

Slovar' russkogo yazyka [The dictionary of the Russian language]. Evgen'eva A.P. (ed.). Vol. 1-4. Moscow, 1981-1984.

Shcherba L.V. O chastiakh rechi v russkom jazyke [On parts of speech in Russian]. Yazykovaya sistema i rechevaya deyatel'nost' [Language system and speech activity]. Leningrad: Nauka Publ., 1974. Pp. 77-100.

Uryson E. V. Predlog ili narechije? (Chasterechnyj status narechnykh predlogov) [A preposition or an adverb? What part of speech adverbial prepositions belong to]. Voprosy jazykoznanija, 2017, no. 5.

Vinogradov V.V. Russkii yazyk (grammaticheskoe uchenie o slove) [The Russian language. A grammatic theory of the word)]. Moscow: Vysshaya Shkola Publ., 1972. 
М. Ю. Федосюк

Московский государственный университет имени М. В. Ломоносова

(Россия, Москва)

m.fedosyuk@yandex.ru

\section{ПРЕДЛОЖЕНИЕ КАК ТЕКСТ: СТИЛИСТИЧЕСКИЙ И КУЛЬТУРНО-РЕЧЕВОЙ АСПЕКТЫ}

В статье предпринята попытка дать системное объяснение целому ряду явлений лингвистики текста, синтаксиса предложения, стилистики и культуры речи. Текст предлагается рассматривать как такую коммуникативную единицу речи, которая с точки зрения содержания характеризуется смысловой законченностью, а с точки зрения формы - отдельностью оформления, т. е. выделенностью текста при помощи пробелов, заголовков и некоторых других средств. При этом назначение отдельности оформления состоит в том, чтобы проинформировать получателя о необходимости обнаружить в воспринимаемом им речевом произведении смысловую законченность. Предлагаемый подход дает основания говорить об иерархичности строения текста, в состав которого могут входить более мелкие компоненты (части, главы, наконец, абзацы), которые обладают отдельностью оформления, как следствие, относительной смысловой законченностью и тоже являются текстами. Исходя из предлагаемого подхода к тексту, минимальным по размерам текстом следует считать предложение. Квалификация предложений как минимальных текстов позволяет с единых позиций объяснить целый ряд известных фактов. Так, текстовая природа предложения объясняет причины, по которым составители официальных текстов стремятся к оформлению любых юридически самостоятельных компонентов делового документа в виде одного (нередко весьма громоздкого) предложения; дает ответ на вопрос о том, почему в художественной и разговорной речи для выражения повышенной коммуникативной значимости любого компонента сообщения он может быть оформлен в виде отдельного предложения и, наоборот, почему пониженная коммуникативная значимость сообщения выражается его оформлением в виде части сложносочиненного, бессоюзного сложного или сложноподчиненного предложения.

Ключевые слова: текст, предложение, отдельность оформления, смысловая законченность, официально-деловой стиль, степень коммуникативной значимости сообщения. 
Интенсивные исследования в области лингвистики текста начались на рубеже 1960-х и 1970-х гг., в тот период, когда в языкознании господствовал преимущественно структурный подход к языку. Новый объект исследования, текст, получил определение как «объединённая смысловой связью последовательность знаковых единиц, основными свойствами которой являются связность и цельность» [Николаева 1990: 507; ср. Гальперин 1981: 18]. И хотя исследователи обычно подчеркивали, что речь в данном случае идет как о формальной, так и о содержательной связности и цельности, основное внимание большинства лингвистов оказалось направленным на поиски формальных признаков связного текста. Таковых оказалось немного: местоимения, лексические или, шире, семантические повторы, вводные слова и сочинительные союзы, а также повторы времени и наклонения сказуемых [Гиндин 1972; Лосева 1980; Реферовская 1983; Севбо 1969; Солганик 1973]. При этом неожиданно выяснилось, что наличие формальных показателей связности текста совсем необязательно свидетельствует о его смысловой цельности и наоборот: отсутствие формальных показателей еще не дает оснований говорить о том, что текст смысловой цельности лишен.

Это убедительно демонстрируют два примера, которые в свое время были сконструированы С.И. Гиндиным:

(1) Я пошел в кино. Кино на Остоженке. Остоженка - одна из самых старых улии в Москве. Москва - центр всех железнодорожных путей страны. Железньле дороги — артерии народного хозяйства.

(2) Маша варила кашу. Иванов придет [Гиндин 1972: 11-12].

Несмотря на то что каждое из предложений примера (1) при помощи лексического повтора связано с предыдущим предложением текста, данная последовательность предложений лишена смысловой цельности и, как следствие, осмысленности. Напротив, хотя предложения в примере (2) не имеют ни лексических, ни грамматических показателей связи друг с другом, их сочетание легко может быть понято как обладающее смысловой цельностью сообщение о том, что Маша варила кашу, поскольку ждала в гости Иванова.

Учитывая сказанное, гораздо более продуктивным для лингвистики текста нам представляется такой подход, при котором, во-первых, четко разграничиваются содержательная и формальная стороны текста, а во-вторых, определяется функция формы текста по отношению к его содержанию. Таким образом, текст целесообразно определять как такую коммуникативную единицу речи, которая с точки зрения содержания обладает смысловой законченностью, а с точки зрения формы маркирующей эту законченность отдельностью оформления. При этом функция отдельности оформления состоит в том, что отдельность оформления указывает получателю на необходимость обнаружить в воспринимаемом им речевом произведении смысловую законченность, даже если таковая неочевидна [Федосюк 2012: 9-12]. Так, именно отдельность оформления сочетания предложений (2) Маша варила кашу. Иванов придет (ни перед этими предложениями, ни после них никаких других предложений нет) заставляет большинство получателей воспринимать данное сочетание как осмысленный текст. 
Рассмотрим еще два примера:

(3) Когда играет темнота, то вечер изепенеет.

Порою блешут злато и краса.

Таниую я и размышляю.

Как часто трогает меня трава.

Растет шершавый золотистый колокольчик.

Тропинки и гониьы внизу бушуют.

Растенье поиелует кто?

Поэт.

Отдельность оформления этого речевого построения, которая состоит в том, что и в начале, и в конце оно выделено пробелами, способна заставить любого получателя воспринимать его как текст и, следовательно, искать в нем смысловую законченность. Скорее всего, эта законченность будет обнаружена и читатель не без некоторых колебаний воспримет приведенную последовательность предложений как лирические размышления автора о природе. Между тем при создании этого речевого произведения никаких размышлений автора в него заложено не было, поскольку перед нами русский перевод немецкого оригинала, который был сконструирован программой автоматического порождения поэтических текстов компьютером [Моль, Фукс, Касслер 1975: 171].

\section{(4) Встреча}

Вот однажды один человек пошел на службу, да по дороге встретил другого человека, который, купив польский батон, направлялся к себе восвояси.

Вот, собственно, и всё (Д. Хармс).

Отдельность оформления этой цепочки предложений, состоящая в ее выделенности не только пробелами, но еще и заглавием Встреча, а также концовкой Bom, собственно, и всё, заставляет читателя ожидать от ее содержания смысловой законченности, которой данная цепочка, однако, не обладает. Это и создает необходимый для жанра абсурдистского рассказа комический эффект [Федосюк $1996]$.

Предложенный выше подход дает основания говорить об иерархичности строения текста. Так, в составе многих текстов можно обнаружить более мелкие компоненты (части, главы, разделы, наконец, абзацы), которые обладают отдельностью оформления и, как следствие, относительной смысловой законченностью.

Можно было бы утверждать, что минимальным по размеру текстом является абзац: именно отдельность его оформления заставляет получателя воспринимать содержание абзаца как относительно законченное по смыслу раскрытие определенной микротемы. Однако очевидно, что отдельностью оформления обладает и любое предложение. На эту отдельность указывает, во-первых, заглавная буква в начале, а во-вторых, точка, вопросительный или восклицательный знак на конце данной единицы. Все это дает основания именно предложение считать минимальным текстом.

Квалификация предложений как минимальных текстов позволяет объяснить целый ряд важных для стилистики и культуры речи явлений, в число которых входят: 
1. Характерная для официально-делового стиля тенденция к оформлению любых юридически самостоятельных компонентов текста в виде одного предложения. Так, в форме одного нередко весьма протяженного предложения обычно оформляются, с одной стороны, заявления, а с другой - отдельные статьи нормативных актов. Подобное оформление - это важное указание на смысловую целостность данного предложения-текста и на невозможность изолированного рассмотрения какой-либо из его частей.

Проиллюстрируем сказанное примерами (5) и (6), первый из которых, относящийся к XIX в., замечательным образом иллюстрирует высокую устойчивость правил построения официально-деловых текстов на русском языке.

(5) Его превосходительству господину директору государственного хозяйства и публичных зданий действительному статскому советнику и кавалеру

Ивану Устиновичу Пейкеру.

От студента Николая Гоголь-Яновского

Прочение.

Не имея возможности служить в вверенном Вам департаменте по причине воспоследующей в скором времени долговременной моей отлучки, прошу покорнейше Ваше превосходительство приказать выдать мне аттестат, выданньй из заведения в засвидетельствование моих успехов и поведения, представленный мною Вашему превосходительству.

Студент Николай Гоголь-Яновский. Февраля 25 дня 1830 года.

[Гоголь 1940: 382].

(6) 9. Диссертация на соискание ученой степени доктора наук должна быть научно-квалификационной работой, в которой на основании выполненных автором исследований разработаны теоретические положения, совокупность которых можно квалифицировать как научное достижение, либо решена научная проблема, имеющая важное политическое, сочиально-экономическое, культурное или хозяйственное значение, либо изложены новые научно обоснованные технические, технологические или иные решения, внедрение которых вносит значительный вклад в развитие страны. [Положение...]

2. Выражение повышенной коммуникативной значимости любого компонента сообщения посредством его оформления как отдельного предложения (иногда как парцеллированного компонента предложения), т. е. как такой коммуникативной единицы, которую, по замыслу отправителя, следует воспринимать как обладающую относительной смысловой законченностью. Подобный тип изложения в художественных текстах был подробно охарактеризован Н. Д. Арутюновой, которая назвала его актуализирующей прозой. «Точной и эксплицитной иерархии элементов “классического” предложения, - пишет Н. Д. Арутюнова, - противостоит в актуализирующей прозе тенденция к созданию эффекта коммуникативной равнозначности звеньев синтагматической цепочки, которая с этой целью дробится и из частей которой образуются отдельные высказывания. Ср. Bыходит великий 
гонщик. Без шапки. И ещуе какие-то люди с ним. Тоже рыжие (Ю. Олеша. Цепь); Нет той квартиры. Той постели. Тех книг и статей (В. Шкловский. Сергей Эйзенштейн); Нет, ему нужен был именно этот - чужой. Мечтанный. Невозможный. Неможный (М. Цветаева. Мой Пушкин)». «Проза подобного типа, - продолжает Н. Д. Арутюнова, - стремится создать у читателя прежде всего непосредственные, “актуальные” ощущения, вызвать “эффект присутствия”, оказать эмоциональное воздействие. К отрезкам сегментированного предложения может быть применен термин “словесный жест”, которым точно передается подчеркнутая актуализованность, дейктичность каждого сегмента» [Арутюнова 1972: 196].

3. Выражение пониженной коммуникативной значимости сообщения путем его оформления как части сложносочиненного или бессоюзного сложного предложения [Федосюк 2016; Шмелева 2013]. Подобное оформление информирует адресата о том, что каждая из предикативных единиц, входящих в состав сложного предложения, по замыслу отправителя, не претендует на хотя бы относительную смысловую законченность и только в совокупности эти единицы образуют законченное по смыслу сложное сообщение. Так, например, коммуникативная значимость самостоятельных предложений в примерах (7a) и (8a) понижается при их объединении в сложные предложения (7б) и (8б):

(7а) Парадные двери были заперты. Все спало. - (7б) Парадные двери были запертыл, и все спало (Л.Н. Толстой).

(8а) Лошади тронулись. Колокольчик загремел. Кибитка полетела... - (8б) Лошади тронулись, колокольчик загремел, кибитка полетела... (А.С. Пушкин).

4. Выражение пониженной коммуникативной значимости сообщения путем его оформления как части «двучленного» (в терминологии Н. С. Поспелова) сложноподчиненного предложения.

Напомним, что важной особенностью научного творчества Н.С. Поспелова было то, что в центре его внимания находились не только структурные характеристики сложноподчиненных предложений, но и их коммуникативные особенности. Такой подход позволил ученому выявить особую разновидность сложноподчиненных предложений, которую он назвал двучленными. В понимании Н. С. Поспелова двучленные сложноподчиненные предложения - это такие сложноподчиненные предложения, главные части которых являются автосемантичными, т. е. не нуждаются в смысловом распространении, и в результате формально подчиненные им придаточные части выступают не как смысловые распространители содержания главных частей, а в качестве носителей дополнительных сообщений. Как отмечал Н.С. Поспелов в статье 1950 г., «отчетливо двучленнными в своем современном составе (и исторически восходящими к сочетанию двух отдельных самостоятельных предложений) оказываются, во-первых, те случаи союзного и относительного подчинения, в которых распространение основного предложения “придаточной” частью не является необходимым для самого этого “главного” предложения. Таковы сложные предложения с теми присоединительными дополнительными придаточными, которые дополняют уже сложившееся высказывание. Например: Обе девииь надели желтые иляпки и красные башмаки, что бывало у них только 
в торжественные случаи (Пушкин). <..> Отчетливо двучленны также и те сложные предложения с относительным подчинением определительного значения, которые не могут иметь местоименно-указательных соответствий в главном предложении, так как определяемое существительное в таких предложениях берется в самом общем, неопределенном значении. Например: Облачко обратилось в белую тучу, которая поднималась, росла и облегала небо (Пушкин). Такого типа двучленные сложные предложения имеют своей основой не одну сложную форму суждения, а два взаимосвязанных суждения, выражающих качественный переход от простого к сложному, от низшего к высшему» [Поспелов 1990: 136-137].

К сожалению, ценные наблюдения Н.С. Поспелова над содержательной стороной сложноподчиненных предложений не были замечены многими его современниками, а используемая им терминология без достаточных на то оснований подверглась переосмыслению как направленная на чисто структурное описание синтаксиса. Освещая такое переосмысление, В.А. Белошапкова пишет: «В создании структурно-семантической классификации значительную роль сыграли труды Н. С. Поспелова, который выделил два основных типа сложноподчиненных предложений: тип двучленный и тип одночленный. Различия между двучленными и одночленными предложениями Н. С. Поспелов связывает с разным характером соотнесенности между главной и придаточной частью: в двучленных предложениях придаточная часть соотносится со всей главной частью в целом, в одночленных предложениях придаточная часть относится к одному слову в главной части, дополняя, развивая или конкретизируя его» [Белошапкова 1977: 218-219].

Иллюстрируя сказанное выше о выражении пониженной коммуникативной значимости сообщений посредством построения «двучленных» (по Н. С. Поспелову) сложноподчиненных предложений, сопоставим нижеследующие пары примеров. Легко заметить, что трансформация самостоятельных предложений в придаточные части «двучленных» сложноподчиненных предложений снижает их коммуникативную значимость, поскольку заставляет адресата воспринимать содержание всего сложноподчиненного предложения как одно законченное по смыслу сложное сообщение:

(9а) В одном месте мы спугнули несколько пар журавлей. Они с печальным криком полетели дальше. - (9б) В одном месте мы спугнули несколько пар журавлей, которые с печальным криком полетели дальше (Д.Н. Мамин-Сибиряк).

(10а) Пала роса. Это предвещзало завтра хорошую погоду. - (10б) Пала роса, что предвещало завтра хорошую погоду (Д.Н. Мамин-Сибиряк).

(11a) Шурочка крепко зажмурила глаза и шаловливо затрясла головой. Разбившиеся волосы запрыгали у нее по лбу. - (11б) Шурочка крепко зажмурила глаза и шаловливо затрясла головой, так что разбившиеся волосы запрыгали у нее по лбу (А.И. Куприн).

Подводя общие итоги всего вышеизложенного, еще раз подчеркнем целесообразность определения текста как такой коммуникативной единицы речи, которая с точки зрения содержания обладает смысловой законченностью, а с точки зрения формы - отдельностью оформления, функция которой состоит в информировании получателя о необходимости обнаружить в воспринимаемом им речевом 
произведении смысловую законченность. Предлагаемый подход дает основания говорить об иерархичности строения текста, в состав которого могут входить более мелкие компоненты (части, главы, разделы, абзацы), которые обладают отдельностью оформления и, как следствие, относительной смысловой законченностью. Минимальным по размерам текстом при таком подходе следует считать предложение. Квалификация предложения как минимального текста позволяет дать системное объяснение целому ряду фактов синтаксиса, стилистики и культуры речи.

\section{Литература}

Арутюнова Н. Д. О синтаксических типах художественной прозы // Общее и романское языкознание. М.: Изд-во Московского университета, 1972. С. 189-199.

Белошапкова B. A. Современный русский язык. Синтаксис. М.: Высшая школа, 1977. $248 \mathrm{c}$.

Гальперин И.Р. Текст как объект лингвистического исследования. М.: Наука, $1981.140 \mathrm{c}$.

Гиндин С.И. Внутренняя организация текста (элементы теории и семантический анализ): автореф. дис. ... канд. филол. наук / Моск. гос. пед. ин-т иностр. яз. им. Мориса Тореза.. М., 1972. 23 с.

Гоголь Н. В. Полное собрание сочинений: В 14 т. Т. 10. Письма, 1820-1835 / Ред. В.В. Гиппиус. М.; Л.: Изд-во АН СССР, 1940. 540 с.

Лосева Л. М. Как строится текст. М.: Просвещение, 1980. 96 с.

Моль А., Фукс В., Касслер М. Искусство и ЭВМ. М.: Мир, 1975.560 с.

Николаева T. М. Текст // Лингвистический энциклопедический словарь / гл. ред. В.Н. Ярцева. М.: Советская энциклопедия, 1990. С. 507.

Положение... - Положение о присуждении ученых степеней [Электронный pecypc]. URL: http://vak.ed.gov.ru/docs.

Поспелов Н. С. О грамматической природе сложного предложения // Н. С. Поспелов. Мысли о русской грамматике / Сост. Е.А. Иванчикова, М., Наука, 1990. C. $126-142$.

Реферовская Е.А. Лингвистические исследования структуры текста. Л.: Наука, 1983. $216 \mathrm{c}$.

Севбо И. П. Структура связного текста и автоматизация реферирования. М., Наука, 1969. 135 с.

Солганик Г.Я. Синтаксическая стилистика (Сложное синтаксическое целое). М.: Высшая школа, 1973. 216 с.

Федосюк М. Ю. Постулаты построения художественного текста (на материале рассказов Даниила Хармса) // Opuscula Polonica et Russica. IV / red. J. Wawrzyńczyk, E. Małek. Częstochowa: Wydawnictwo Wyższej szkoły pedogogicznej w Częstochowie, 1996. S. 23-32.

Федосюк М.Ю. Коммуникативная значимость минимальных сообщений и ее формальные показатели // Научное наследие Б.Н. Головина в свете актуальных проблем современного языкознания (к 100-летию со дня рождения Б. Н. Головина): 
Сборник статей по материалам Международной научной конференции. Н. Новгород: ДЕКОМ, 2016. с. 35-40.

Федосюк М. Ю. Синтаксис современного русского языка. М.: ИНФРА-М, 2012. $245 \mathrm{c}$.

Шмелева Т. В. Коммуникативный вес пропозиции // Вестник Московского университета. Сер. 9. Филология. 2013. № 5. С. 189-198.

\section{Mikhail Yu. Fedosyuk}

Lomonosov Moscow State University

(Russia, Moscow)

m.fedosyuk@yandex.ru

\section{A SENTENCE AS A TEXT: THE ASPECTS OF STYLISTICS AND SPEECH CULTURE}

The article attempts to give a systematic explanation to a number of phenomena of text linguistics, syntax, stylistics and speech culture. The text is proposed to be considered as such a communicative unit of speech, which, from the point of view of content, is characterized by a semantic completeness, and from the point of view of form, by a separate design, i.e., by highlighting the text with spaces, headings and some other means. The function of the separate design is to inform the addressee about the need to find a semantic completeness in the speech product perceived by him. The proposed approach gives grounds to talk about the hierarchy of the structure of the text, which may include smaller components (parts, chapters, and finally paragraphs). These components have a separate design, a relative semantic completeness and, as a consequence, also are texts. Based on the proposed approach to the text, the minimum size text should be considered to be a sentence. The qualification of sentences as minimal texts makes it possible to explain a number of well known facts from a common position. Thus, the textual nature of a sentence explains the reasons why the authors of official texts tend to design any legally independent component of a business document in the form of one (often quite cumbersome) sentence; gives an answer to the question why if the author wants to express the increased communicative significance of any component of a message, it can be framed as a separate sentence and vice versa, why the reduced communicative significance of a message is expressed by its design as a part of a complex or compound sentence.

Key words: text, sentence, separate design, semantic completeness, official style, the degree of communicative significance of a message.

\section{References}

Arutyunova N. D. [On the syntactic types of fictional texts]. Obshchee i romanskoe yazykoznanie [General and Romance Linguistics]. Moscow, Moscow St. Univ. Publ., 1972, pp. 189-199 (In Russ.). 
Beloshapkova V.A. Sovremennyi russkii yazyk. Sintaksis [The modern Russian language. Syntax]. Moscow, Vysshaya Shkola Publ., 1977. 248 p. (In Russ.).

Gal'perin I. R. Tekst kak ob"ekt lingvisticheskogo issledovaniya [Text as an object of a linguistic research]. Moscow, Nauka Publ., 1981. 140 p. (In Russ.).

Gindin S. I. Vnutrennyaya organizatsiya teksta (elementy teorii i semanticheskii anal$i z$ ) [Internal organization of the text (elements of the theory and semantic analysis)]. Avtoref. dis. kand. filol. nauk. Moscow, 1972. 23 p. (In Russ.).

Gogol' N. V. Polnoe sobranie sochinenii [Complete Works]. Volume 10. Moscow; Leningrad, Academy of Sciences of the USSR Publ., 1940. 540 p. (In Russ.).

Loseva L. M. Kak stroitsya tekst [How the text is constructed]. Moscow, Prosveshchenie Publ., 1980. 96 p. (In Russ.).

Mol' A., Fuks V., Kassler M. Iskusstvo i EVM [Arts and computers]. Moscow, Mir Publ., 1975. 560 p. (In Russ.).

Nikolaeva T.M. [Text]. Lingvisticheskii entsiklopedicheskii slovar [Linguistic Encyclopedic Dictionary], Moscow, Sovetskaya Entsiklopediya Publ., 1990, p. 507. (In Russ.).

Polozhenie o prisuzhdenii uchenykh stepenei [Regulations on awarding academic degrees]. Available at: http://vak.ed.gov.ru/docs (accessed 02.09.2017) (In Russ.).

Pospelov N.S. [On the grammatical nature of a complex sentence]. N.S. Pospelov. Mysli o russkoi grammatike [Thoughts on Russian grammar]. Moscow, Nauka Publ., 1990, p. 126-142. (In Russ.).

Referovskaya E. A. Lingvisticheskie issledovaniya struktury teksta [Linguistic research of text structure]. Leningrad, Nauka Publ., 1983. 216 p. (In Russ.).

Sevbo I.P. Struktura svyaznogo teksta i avtomatizatsiya referirovaniya [Structure of coherent text and automation of abstracting]. Moscow, Nauka Publ., 1969. 135 p. (In Russ.).

Solganik G. Ya. Sintaksicheskaya stilistika (Slozhnoe sintaksicheskoe tseloe) [Syntactic stylistics (Stuctured segment of speech)]. Moscow, Vysshaya shkola Publ., 1973. $216 \mathrm{p}$.

Fedosyuk M. Yu. [Postulates of the construction of a fictional text (based on stories by Daniil Kharms)]. Opuscula polonica et russica. IV. Częstochowa, Wyższa szkoła pedogogiczna w Częstochowie Publ., 1996, p. 23-32. (In Russ.).

Fedosyuk M. Yu. [Communicative significance of minimal messages and its formal indicators]. Nauchnoe nasledie B.N. Golovina v svete aktual'nykh problem sovremennogo yazykoznaniya (k 100-letiyu so dnya rozhdeniya B.N. Golovina) [The scientific heritage of B. N. Golovin in the light of current problems of modern linguistics (on the 100th anniversary of the birth of B. N. Golovin). Nizhnii Novgorod, DEKOM Publ., 2016, p. 35-40. (In Russ.).

Fedosyuk M. Yu. Sintaksis sovremennogo russkogo yazyka [Syntax of the modern Russian language]. Moscow, INFRA-M Publ., 2012. 245 p. (In Russ.).

Shmeleva T. V. [Communicative weight of a proposition]. Vestnik Moskovskogo universiteta. Ser. 9. Filologiya [Bulletin of Moscow University. Series. 9. Philology], 2013, no. 5, p. 189-198. (In Russ.). 


\author{
О.Е. Фролова \\ Московский государственный университет им. М. В. Ломоносова \\ (Россия, Москва) \\ olga_frolova@list.ru
}

\title{
СОЦИАЛЬНАЯ СТРАТИФИКАЦИЯ: ОТ МЕТАФОРЫ К СЛОВООБРАЗОВАНИЮ
}

В статье рассматриваются слова, являющиеся номинациями слоев социальной иерархии и социальных статусов: аристократ, барин, буржуа. Социальная стратификация исторически изменчива, национально специфична, динамична, отражается в лексике, законодательных документах и обиходной речи. Имена аристократ, барин, буржуа употребляются переносно и формируют положительные и отрицательные коннотации. Метафорические значения отражаются в словообразовании, поскольку от всех трех личных имен возникают абстрактные существительные, а у слов аристократ и барин - прилагательные, которые ведут себя как качественные и образуют формы сравнительной степени. Сравнительную степень способно образовывать также прилагательное буржуазный. Среди дериватов существительного буржуа выделяется не прилагательное, а существительное с пейоративной оценкой - буржуй. На основании анализа сочетаемости атрибутивных конструкций в Национальном корпусе русского языка можно описать фигуративные значения номинаций социальных статусов. В случае слова аристократ переносное значение амбивалентно, обозначает и положительные, и отрицательные качества, в атрибутивных словосочетаниях отражается перцептивный дискретный образ объекта. Слово барин в переносе связано с нелюбовью к труду и своеволием, а буржуа - с конформностью, отказом от индивидуальности и со следованием общепринятым моделям поведения.

Ключевые слова: социальный статус, оценка, словообразование, прилагательное, сравнительная степень, словарь, Национальный корпус русского языка, сочетаемость, перцептивность.

Слова, являющиеся номинациями социальных статусов, отражают устройство общества и национально-специфичную общественную иерархию [Крысин 1988]. Сословная структура динамична по своей природе, формируется постепенно, получает законодательное оформление [Лазаревский; Радаев, Шкаратан 1996; 
Сушкова-Ирина 2010]. Появление метафорических значений у номинаций социальных статусов является следствием развития общества, дает представление о результатах переосмысления социального устройства, формализованного в словообразовании, коннотациях и оценках (см. [Арутюнова 1978; Метафора 1988; Скляревская 1993; Теория метафоры 1990; Балашова 2014]).

Мы намереваемся рассмотреть три номинации социальных статусов аристократ, барин, буржуа, представляющие слои общества в XVIII и XIX вв., и их переносные значения. Первоначально показывая положение человека на общественной лестнице, позже данные лексические единицы формируют значения характеризующего типа. Наша цель - проанализировать такие метафорические переносы, для чего мы намереваемся рассмотреть толкования метафор в словарях, словообразовательные гнезда, сочетаемость и функционирование отыменных дериватов в речи на материале Национального корпусе русского языка (далее - НКРЯ).

Личное существительное аристократ является заимствованием, его значение словари определяют как «приверженец, защитник аристократического правления» [Даль 1978-1980, 1: 22]; «лицо, принадлежащее к аристократии (в 1 знач.)» [Ожегов, 1960:.27]; «привилегированная часть какого-л класса или какой-л. общественной группы» [MAC 1985-1988, 1: 45]. Коннотативные значения и переносы словари описывают с начала XX в.: «ирон. принимающий вид, подражающий приемам аристократа [Грот 1891-1930, 1: 64]; «перен. человек, сторонящийся масс, ставящий себя в исключительное положение; белоручка (разг. ирон.)» [Ушаков 1996, 1: 55]; «2. разг. о человеке изысканном, утонченном, но высокомерном» [БТС 2002: 46].

Словари отмечают наличие двух абстрактных существительных аристократичность и аристократизм [МАС 1985-1988,. 1: 44]. Аристократизм - «благородство, благородное изящество (в дворянско-буржуазном обществе)» [Ушаков 1996, 1: 55]; «в дворянско-буржуазном обществе: поведение, свойственное аристократу, внешняя изысканность» [Ожегов 1960: 27]; «свойственная аристократам манера поведения, внешняя изысканность, утонченность» [MАС 1985-1988, 1: 44]; «благородство поведения; изящество манер» [БТС 2002: 46].

Переносное значение слова аристократ амбивалентно: с одной стороны высокомерие и презрение к труду, с другой - следование хорошим манерам.

Наличие коннотаций отмечает Грот, переносные значение фиксирует Ушаков, он же приводит два прилагательных аристократический и аристократичный [Ушаков 1996: 1: 55].

Появление переносного значения отражается на поведении в речи адъективного и адвербиального дериватов аристократичный и аристократично. Наречие описывает признак предиката, прилагательное - градуируемое качество. НКРЯ фиксирует более 100 употреблений прилагательного аристократичный, которое принимает на себя характеризующие функции, в том числе и в форме сравнительной степени: таких употреблений в НКРЯ девять. Самое раннее относится к середине XIX в. Наречие аристократично выступает как компонент предикатного выражения. 
(1) лучшие представители тогдашней литературы старались.,, вести себя сколько можно аристократичнее в отношении к низким предметам, касающимся быта простого народа... [Н. А. Добролюбов. О степени участия народности в развитии русской литературы (1858)] [НКРЯ].

(2) «Никс» звучит гораздо аристократичнее, чем прежнее уменьиительное «Николаша» [К. М. Станюкович. Женитьба Пинегина (1893-1903)] [НКРЯ].

Пример 3 показателен, поскольку автор отдает себе отчет в оценочности семантики выбранных слов, выстраивая цепь прилагательных и переводя их из относительных в качественные.

(3) «Театральные аристократы, куда аристократичнее настоящих, фаты куда фатоватее, красавиь - красивее, герой - героичнее, мужики - мужиковатее, военные - более военны, и генераль кажутся на сиене генералиссимусами по сравнению с настоящими» [Ю. Писаренко. Хрестоматия актера: Сборник (1930)] [НКРЯ].

Анализируя сочетаемость прилагательных, мы выбирали в НКРЯ конструкции с абстрактными существительными, а также предполагающие сравнение: $N$ как у аристократа: аристократическое тело, лицо, достоинство, самолюбие, воспитание, чувство, презрение, пренебрежение, спокойствие, свойство, негодование, благоразумие, изящество; аристократическая рука/ручка, нога, фигура, легкость стана, голова, наружность, красота, изящность манер, манера, естественность, праздность, спесь, гордость, независимость, воспитанность, вежливость, аккуратность, тонкость, претензия, небрежность, обстановка; аристократический вкус, предрассудок, инстинкт, тон, говор, профиль, нос, вид, дух, душок, образ мыслей, характер, обычай; аристократические манеры, нравы, убеждения, замашки, черты, пальизы/пальчики. Прилагательное аристократичный показывает более скромный диапазон сочетаемости: аристократичный нос, ивет; аристократичная внешность, русская речь, изящность манер; аристократичное лицо; аристократичные манеры. Аристократично вести себя.

Итак, прилагательное аристократический описывает обстановку жилища, качества характера, внешность человека, причем позволяет «рассмотреть» ее в подробностях. Что касается дискретного описания внешности человека, прилагательные аристократический и аристократичный функционируют как однокоренные синонимы.

Перейдем к исконно русскому существительному барин. По словарям это «боярин, господин, человек высшего сословия; дворянин; иногда всякий, на кого другой служит, в противоп. слуге, служителю. <..> хозяин» [Даль 1978-1980, 1: 49]; «3. хозяин - дворянин в отношении к своему слуге, 4. вообще господин, хозяин» [Грот 1891-1930, 1: 115]; «лицо, принадлежащее к господствующим, эксплуатирующим классам (разг., теперь презрит.), 2. аристократ по привычкам и манерам (устар.), 3. (в знач. мн. употр. господа) хозяин (по отношению к прислуге; разг. дореволюи.), 4. лицо, принадлежащее к обеспеченному и образованному слою городского населения, интеллигент (дореволюц. разг. или ирон.). Одет барином. || Обращение к лицу интеллигентного вида (простореч. дореволюи.), 5. человек, 
избегающий грязной работы, белоручка (разг. неодобрит.)» [Ушаков 1996, 1: 90]; «2. перен. человек, к-рый не любит трудиться сам и предпочитает перекладывать работу на других (разг.)» [Ожегов 1960: 34]; «4. разг. о человеке, который уклоняется от труда, перекладывает свою работу на других» [МАС 1985-1988,. 1: 62]; «1. Хозяин, господин (обычно в обращении простолюдинов), 2. разг. о солидном (обычно богато одетом) человеке с важной походкой, степенными манерами, 3. разг. о человеке, ведущем праздный образ жизни, не желающем трудиться или чрезмерно избалованном, изнеженном» [БТС 2002: 59].

В прямом значении наряду с благородством рождения подчеркнуто владение собственностью. Переносное значение отмечает Ушаков, когда прямое становится историзмом. Пейоративность, также впервые отмеченная Ушаковым, присутствует в переносном значении личного имени и касается отказа от труда. Ушаков же показывает, как значение, описывающее социальный статус лица, владеющего некоей собственностью, «перетекает» на образованный класс и относится к интеллигенту.

В русском языке слово барство обозначает и сословие, и абстрактное качество: «состояние, быт, звание барина; сословие бар; все общие барские качества, по себе взятые; хлебосольство, тороватость, властолюбие, тщеславие, спесь и пр.» [Даль 1978-1980, 1: 49]; «1. звание, достоинство барина, 2. сословие дворян, особенно землевладельцев, в укоризненном значении, 3. барские свойства [Грот 1891-1930, 1: 117]; «сословие дворян (пренебр.). || собир. баре, господа, помещики, 2. изнеженность, избалованность, свойственная барам (разг.)» [Ушаков 1996, 1: 91]; «1. барская изнеженность, нежелание работать, 2. высокомерие, пренебрежительное отношение к людям, 3. собир. помещики, дворяне (устар.)» [Ожегов 1960: 35]; «1. собир. помещики, господа, 2. высокомерие, пренебрежение к нижестоящим людям, свойственное барам, 3. изнеженность, избалованность, стремление к праздности, свойственные барам» [МАС 1985-1988, 1: 62, 63]; «1. собир. в России до 1917 г.: помещики, господа., 2. внешность, манеры и образ жизни барина (степенность, праздность, высокомерие и т.п.)» [БТС 2002: 60].

Что касается отрицательных коннотаций абстрактного существительного, их отмечает Грот. Ушаков описывает семантику уже не социальной страты, а абстрактного существительного.

Ушаков же включает в словарь прилагательное барственный, а МАС — и данное прилагательное, и образованное от него абстрактное существительное барственность.

В словообразовательном гнезде с корнем бар- также присутствуют два прилагательных барский и барственный. В НКРЯ и в этом случае обнаруживаем более 100 документов с прилагательным барственный и одно употребление наречия в форме сравнительной степени.

(4) Я говорил, что в старину не было роскоши; но жили барственнее нынешнего

[М. А. Дмитриев. Мелочи из запаса моей памяти (1869)] [НКРЯ].

При выборе и анализе сочетаемости мы придерживались тех же принципов, что и в предыдущем случае. Сочетаемость прилагательного барский 
по материалам НРКЯ такова: барская кровь, жилка, снисходительность, спесь, наивность, лень, милость, ласка, воля, затея, забава, манера, дерзость, важность, стать, роскошь, праздность, брезгливость; барское самолюбие, приволье, пренебрежение, обличье; барский тон, азарт, гнев, кивок; барские замашки. Были также отмечены устойчивые сочетания: на барскую ногу, с барского плеча. Сочетаемость прилагательного барственный, как и случае с аристократичныц̆, менее репрезентативна: барственная натура, щедрость, небрежность, уверенность, плавность движений, повадка, напевность; барственный вид, тон речи, кивок; барственное спокойствие, высокомерие, лицо; барственнье манеры, замашки, интонации.

Сравнивая сочетаемость прилагательных аристократический и барский, получаем зону сходных определяемых имен: привычки, спесь, стать, жест, но только аристократичность позволяет описать внешность человека в деталях. Словосочетания *барский/ барственный нос, *барские/ барственные пальцьь не обнаруживаются в НРКЯ и выглядят странно. С другой стороны, своеволие, широта и бесконтрольность желаний присуща преимущественно барственности, поэтому странны словосочетания *аристократический/ аристократичный азарт, *аристократическое/ аристократичное приволье.

Слово буржуа сохраняет неизменяемость как один из признаков неосвоенности иноязычного заимствования русским языком, однако его прямое значение описано лишь в ХХ в. в словаре Ушакова: «лицо, принадлежащее к классу буржуазии» [Ушаков 1996, 1: 206]. Оттенок значения «о том, кто ведёт буржуазный образ жизни, подражает буржуазии» включает в толкование только БТС [БТС 2002: 104].

Слово буржуазия отражено в «Словаре русского языка XVIII в.», оно впервые употреблено в 1775 г. [СРЯ-18 1984-2009]. БАС указывает, что существительное буржуазия лексикографировано в «Настольном словаре для справок по всем отраслям знания» Ф.Г. Толля во второй половине ХІХ в. [БАС 1: 597]. Значение собирательного существительного имеет ряд особенностей: буржуазия - «франц. мещане, мещанство, горожане, среднее сословие, граждане, обыватели, торговый и ремесленный люд» [Даль 1978-1980, 1: 143]; «мещане, мещанство, среднее сословие» [Грот 1891-1930, 1: 294]; «1. в капиталистическом обществе — класс эксплуататоров, владеющий на правах частной собственности орудиями и средствами производства и извлекающий прибавочную стоимость посредством эксплуатации наемного труда, 2. в феодальном обществе - сословие горожан (истор.)» [Ушаков 1996, 1: 206]; «в капиталистическом обществе: класс собственников средств производства, существующий за счет прибавочной стоимости, получаемой в результате применения наемного труда» [Ожегов 1960: 61]; «господствующий класс капиталистического общества, являющийся собственником орудий и средств производства и живущий капиталистическим доходом, получая прибавочную стоимость эксплуатацией наемного труда» [МАС 1985-1988, 1: 126]; «класс капиталистического общества, владеющий средствами производства и существующий за счёт доходов с наёмного труда» [БТС 2002: 104]. 
Сложность толкования заимствования буржуа в том, что одна социальная группа, в зависимости от уровня благосостояния представителей, получает в русском языке две номинации: горожане мелкого и среднего достатка называются мещцнами, неслучайно Даль объясняет с помощью этой лексической единицы значение заимствованного слова буржуазия. Позже мещзанство будет названо мелкобуржуазной средой. Слово буржуазия и его дериваты вначале актуализируются в середине XIX в. по отношению к инокультурной среде (см. пример 5), когда же оно в конце XIX в. и начале XX в. употребляется по отношению к российской действительности, сфера его функционирования связана с экономикой, политикой и большими капиталами.

В словообразовательном гнезде представлено только одно прилагательное буржуазный и наречие буржуазно.

(5) Она принадлежала к почетному гражданству разврата, то есть ... буржуаз-

но жила на содержании у какого-то купца. [А. И. Герцен. Былое и думы. Часть третья. Владимир-на-Клязьме (1853-1856)] [НКРЯ].

Прилагательное в форме сравнительной степени в НКРЯ встречается в 7 документах.

(6) нет в мире музея буржсуазнее и кичливей этой усыпальницьь [И. Ф. Анненский.

Вторая книга отражений (1909)] [НКРЯ].

Сочетаемость прилагательного охватывает достаточно широкий диапазон имен: буржуазный невзыскательный вкус, дух, предрассудок, пережиток, лад, толк, нувориш, потребитель, индивидуалист, отдых, образ жизни, быт, уют, вид, материализм, комфорт, конформизм, пафос, дизайнер; буржуазная мораль, среда, роскошь, аккуратность, сентиментальность, благопристойность, добродетель, агрессивность, политкорректность, респектабельность, привычка, развлекательность, массовая культура/ масскультура, обстановка, затея; буржуазное мировоззрение, благополучие, мещанство, нутро, больиинство; буржуазнье свободы, условности, ценности.

Слово буржуазный преимущественно описывает поведение человека, организованное по конформной модели.

Оценка в данном словообразовательном гнезде выражена в существительном буржуй — «(разг.). Презрительное или бранное обозначение буржуа» [Ушаков 1996, 1: 206].

Итак, номинации социальных статусов получают метафорическое переосмысление, становясь средством оценки, причем в случае слова аристократ переносное значение амбивалентно, обозначает и положительные, и отрицательные качества, в атрибутивных словосочетаниях отражается перцептивный дискретный образ объекта. Слово барин в переносе связано с нелюбовью к труду и своеволием, а буржуа - с конформностью, отказом от индивидуальности и со следованием общепринятым моделям поведения. Появление оценочных сем отражается в словообразовании - в формировании прилагательных аристократичный и барственный, принимающих формы сравнительной степени. В словообразовательном гнезде буржуа резкая негативная оценка выражается словом буржуй. 


\section{Словари}

[БАС] - Словарь современного русского литературного языка / гл. ред. В. И.Чернышев: в. 17-ти т. М.: Изд-во Акад. наук СССР, 1948-1965.

[БТС] - Большой толковый словарь русского языка / авт. и рук. проекта С. А.Кузнецов. СПб.: Норинт, 2002.

[Даль] - Даль В. И. Толковый словарь живого великорусского языка: в 4 т. М.: Рус. язык, 1978-1980.

[Грот] - Словарь русского языка, сост. Вторым отделением Императорской Академии Наук / Под ред. Грота Я. К., Шахматова А.А., Т. 1-9. СПб., 1891-1930.

[MAC] - Словарь русского языка: в 4 т. / под ред. А. П. Евгеньевой. Изд. 3-е изд. М.: Рус. яз., 1985-1988.

[Ожегов] - Ожегов С. И. Словарь русского языка. 4-е изд. М.: Гос. изд-во иностранных и национальных словарей, 1960.

[СРЯ-18] - Словарь русского языка XVIII в. / АН СССР. Ин-т рус. яз.; Гл. ред.: Ю.С. Сорокин. Л.: Наука. Ленингр. отд-ние, 1984-2009. [Электронный ресурс]. URL: http://feb-web.ru/feb/s118/slov-abc/

[Ушаков] - Толковый словарь русского языка: в 4-х т. / под ред. Д. Н. Ушакова М.: Teppa, 1996.

\section{Литература}

Арутюнова Н. Д. Функциональные типы языковой метафоры // Известия Академии наук СССР. Серия литературы и языка. 1978. Т. 37. №4. С. 333-343.

Балашова Л. В. Русская метафорическая система в развитии XI-XXI вв. М.: Рукописные памятники Древней Руси: Знак, 2014. 632 с.

Крысин Л. П. Социальный компонент в семантике языковых единиц // Влияние социальных факторов на функционирование и развитие языка. Отв. ред. Ю. Д. Дешериев, Л. П. Крысин. М.: Наука, 1988. С. 124-143.

Лазаревский H. Сословия // Энциклопедический Словарь Ф.А.Брокгауза и И.А.Ефрона. В. 86-ти т. СПб.: 1890_1907. [Электронный ресурс]. URL: http:// www.vehi.net/brokgauz/

Метафора в языке и тексте / отв. ред. В.Н. Телия. М.: Наука, 1988. 176 с.

Национальный корпус русского языка. [Электронный ресурс]. URL: www.ruscorpora.ru

Радаев В.В., Шкаратан О.И. Социальная стратификация. М.: Аспект Пресс, 1996. $318 \mathrm{c}$.

Скляревская, Г.Н. Метафора в системе языка. СПб.: Наука, 1993. 152 с.

Сушкова-Ирина, Я.И. Динамика социальной стратификации и её представленность в картинах мира // Электронный журнал «Знание. Понимание. Умение». 2010. №4. Культурология. [Электронный pecypc]. URL: http://www.zpu-journal.ru/ e-zpu/2010/4/Sushkova-Irina/

Теория метафоры / Вст. ст. и сост. Н. Д. Арутюновой. М.: Прогресс, 1990. 512 с. 


\author{
Olga Ye. Frolova \\ Lomonosov Moscow State University \\ (Russia, Moscow) \\ olga_frolova@list.ru
}

\title{
SOCIAL STRATIFICATION: FROM METAPHOR TO DERIVATION
}

The article deals with words that are nominations of the strata of the social hierarchy: aristocrat, master, bourgeois. Social stratification is historically changeable, nationally specific, dynamic, reflected in vocabulary, legislative documents and everyday speech. Names aristocrat, master, bourgeois. Form shifts and form positive and negative connotations ..Metaphorical meanings are reflected in derivation, as all three words form abstract nouns, as far as nouns aristocrat and master form special adjectives, which behave as qualitative and are used in comparatives forms. The adjective bourgeois is also capable of forming a comparative degree. Among the derivatives of the noun bourgeois it stands out not an adjective, but a noun with a pejorative evaluation - a "bourzhuj". Based on the analysis of the compatibility of attributive designs in the Russian National Corpus, one can describe the figurative values of social status nominations. In the case of the word aristocrat, the figurative meaning is ambivalent, denotes both positive and negative qualities, in attributive phrases shows the perceptive discrete image of the object. The word master in the transfer is associated with dislike for work and self-will, and the bourgeois with conformance, rejection of individuality and following the generally accepted patterns of behavior.

Key words: social status, evaluation, derivation, adjective, comparative degree, dictionary, Russian National Corpus, compatibility, perceptivity.

\section{References}

Bol'shoi tolkovyi slovar' russkogo yazyka [Dictionary of the modern Russian literary language] The author of the project. S. A. Kuznetsov. St. Peterburg.: Norint Publ., 2002. (In Russ.)

Dal' V.I. Tolkovyi slovar' zhivogo velikorusskogo yazyka [Explanatory dictionary of the living Great Russian language] Vol. 1-4. Moscow, Rus. yazyk Publ., 1978-1980. (In Russ.)

Ozhegov S.I. Slovar' russkogo yazyka [Dictionary of Russian language]. $4^{\text {th }}$ edition. Moscow, Gos. izd-vo inostrannykh i natsional'nykh slovarei Publ., 1960. (In Russ.)

Slovar' russkogo yazyka [Dictionary of Russian language] vol. 1-4.Ed. A.P. Evgen'eva. $3^{\text {th }}$. edition. Moscow, Rus. yazyk Publ., 1985-1988. (In Russ.)

Slovar' sovremennogo russkogo literaturnogo yazyka [Dictionary of modern Russian literary language] / Ch. ed. by V. I. Chernyshev: Vol. 1-17. Moscow, Academia. of sciences USSR Publ., 1948-1965. (In Russ.)

Slovar' russkogo yazyka XVIII v. [Dictionary of the Russian language of the XVIII century] Ch. ed.:by Yu.S. Sorokin. Leningrad.: Nauka Publ., 1984-2009. Available at: http://feb-web.ru/feb/sl18/slov-abc/ (accessed 29.07.2017) (In Russ.) 
Slovar' russkogo yazyka, sost. Vtorym otdeleniem Imperatorskoi Akademii Nauk [Dictionary of the Russian language, comp. by the second department of the Imperial Academy of Sciences] Ed.by Grot Ya. K., Shakhmatov A. A., Vol. 1-9. St. Petersburg, 1891-1930. (In Russ.)

Tolkovyi slovar' russkogo yazyka [Explanatory dictionary of the Russian language] Vol 1-4. Ed. D. N. Ushakov Moscow, Terra Publ., 1996. (In Russ.)

Arutyunova, N.D. Phunctional nyyi tipy yazykovoy metaphory [Functional types of language metaphor] // Izvestiya Akademii nauk SSSR. Seriya literatury i yazyka. 1978. T. 37. № 4. pp. 333-343. (In Russ.)

Balashova, L. V. Russkaya metaforicheskaya sistema v razvitii XI-XXI vv. [Russian metaphorical system in the development of the XI-XXI centuries.]. Moscow: Rukopisnye pamyatniki Drevnei Rusi: Znak Publ., 2014. 632 p. (In Russ.)

Krysin, L.P. [Social component in the semantics of language units] // Vliyanie sotsial'nykh faktorov na funktsionirovanie i razvitie yazyka [The influence of social factors on the functioning and development of language]. Ed. By Yu.D. Desheriev, L.P. Krysin Moscow.: Nauka Publ., 1988. S. 124-143. (In Russ.)

Lazarevskii, N. [Estates] // Entsiklopedicheskii Slovar' F.A. Brokgauza i I. A. Efrona. [Encyclopedic Dictionary F. A. Publishers: Brokgauz and I. A. Efron] Vol. 1-86. Saint-Petersburg.: 1890_1907. Available at: http://www.vehi.net/brokgauz/ (accessed 29.07.2017) (In Russ.)

Metafora vyazyke i tekste [Metaphor in language and text] Ed. V. N. Teliya. Moscow: Nauka Publ., 1988. 176 p. (In Russ.)

National Russian Corpus. Available at:: www.ruscorpora.ru (accessed 29.07.2017) (In Russ.)

Radaev V. V., Shkaratan O. I. Sotsial'naya stratifikatsiya. [Social stratification] Moscow.: Aspekt Press Publ., 1996. 318 p. (In Russ.)

Sklyarevskaya, G. N. Metafora v sisteme yazyka. [Metaphor in the system of language] St. Peterburg.: Nauka Publ., 1993. 152 p. (In Russ.)

Sushkova-Irina, Ya. I. [Dynamics of social stratification and its representation in the picture of the world] // Elektronnyi zhurnal «Znanie. Ponimanie. Umenie». 2010. nn 4. Kul'turologiya. (In Russ.) Available at: http://www.zpu-journal.ru/e-zpu/2010/4/Sushkova-Irina/ (accessed 29.07.2017)

Teoriya metafory [Theory of metaphor] Introduction by N. D. Arutyunova. Moscow.: Progress Publ., 1990. 512 p. (In Russ.) 


\section{В. Н. Шапошников}

Московский городской психолого-педагогический университет

(Россия, Москва)

vladimirshaposhnikoff@yandex.ru

\section{СЕМАНТИЧЕСКИЙ ПОТЕНЦИАЛ ЧАСТИЦ И РАЗВИТИЕ ЛЕКСИКО-ГРАММАТИЧЕСКИХ ВАРИАНТОВ: ГРАНИЦЫ СЛОВА И ГРАНИЦЫ НОРМЫ}

Статья посвящена рассмотрению лексико-грамматической природы частиц и их функциональному наполнению. Как единицы морфологии они характеризуются определенными парадигматическими отношениями и синтагматическими связями, представляемыми морфологической валентностью и морфологической сочетаемостью. Их категориальное содержание обусловливает синонимию, существующую среди них и выделяемую при анализе. Среди частиц существует также антонимия и омонимия, свидетельствующие о комплексном характере семантики и природе их содержания. С синонимией дискурсивных слов закономерно связана полисемия. Частицы распространяют и расширяют свои семантические функции и развивают многозначность. Семантические свойства дискурсивного слова заключаются и выражаются в границах сферы его действия. Характеризуясь несамостоятельностью и не имея определенной синтаксической функции, частицы в той или иной степени включаются в морфосинтаксические конструкции. Рассматриваются речевые новации частиц. Рассматривается языковая норма и границы нормы в современной речи.

Ключевые слова: частицы, семантические функции, лексико-грамматические варианты, языковая норма, современный русский язык.

Определение лексико-грамматической природы частиц и их функционального наполнения обусловливается неоднозначностью их категориального статуса и уровневой принадлежности. Слова-частицы, объединяясь в те или иные группы, показывают яркие категориальные свойства, а, разделяясь на ряд категорий, различаются по природе своих типовых функций. Они выделяются на разных основаниях, соответствующих их сложносоотнесенной семантике. Содержание ряда частиц разделяется и распределяется по структурным уровням языка. В аппарате содержательного анализа частиц выделялись общие значения как их категориальное 
семантическое наполнение и частные значения, формируемые в актуальном членении предложения, выступающие в процессе функционирования и формулируемые аналогично толкованиям значений слов.

Частицы как единицы морфологии характеризуются определенными парадигматическими отношениями и синтагматическими связями, представляемыми морфологической валентностью и морфологической сочетаемостью. Характеризуясь несамостоятельностью и в целом не имея определенной синтаксической функции, частицы в той или иной степени включаются в морфосинтаксические конструкции. Их содержание и его природа обусловливают синонимию, существующую среди них и выделяемую при анализе. Синонимия частиц разворачивается в пределах одного их какого-либо логико-понятийного разряда. Синонимия частиц имеет предметно-понятийный или функциональный характер. Синонимичные частицы относятся к одному грамматическому разряду, объединяясь соответственным общим значениям образом, и различаются конкретными смысловыми признаками вносимыми дополнительными смысловыми оттенками. Среди частиц существует также антонимия (просто - лишь, уже - еще) и омонимия (же I, II), свидетельствующая о характере их семантики и природе их содержания.

С синонимией дискурсивных слов закономерно связана полисемия. Частицы распространяют и расширяют свои семантические функции и развивают многозначность. Партикулные единицы определенных разрядов и групп обладают не одним, а двумя и более значениями. Семантические валентности являются механизмом соединения значений слов.

Служебная часть речи развивается и изменяется в плане содержания. Образуются определенные содержательные корреляции с составом плана выражения. Образуются новые типы употребления у некоторых существовавших в современном русском языке частиц. В них развертываются определенные соотношения с имеющейся совокупностью средств. Так, частица единственно имела усилительноограничительное значение (Этим мы обязаны единственно ему). Она приобретает в современной устной речи смежное с ним по качеству выделительно-присоединительное значение. Тем самым устанавливается межчастеречное соотношение, поскольку эта семантическая функция союзного типа; таким способом выражаются отношения и связи между предметами мысли и элементами речи, синтаксически разъединенными (У них единственно помещение не проветривается (уст. речь 2010); Единственно, на работу далеко ездить; Единственно, могут быть пробки на дороге (Рос. газ. 10.6.17). Вместе с этим частица выражает эмоционально-оценочное значение.

Выступают также с совершенно новыми семантическими функциями единицы определенных разрядов: $а$, давай, дескать, еще, какой, как-то, особо, просто, прямо, ровно, такая/ой, уже. Тем самым расширяется содержательная область слов, включая в себя новые значения. Они обусловлены типами существовавших значений. Эти значения являются смежными в той предметно-понятийной области, к которой относятся имевшиеся значения частиц. Не представляя собой вполне самостоятельного, реального - материального значения, в этих словах лексическое 
значение совпадает с содержанием их грамматической, логической или экспрессивно-стилистической функции.

Таким образом, появляются новые единицы дискурсивного выражения. Их явления многократны и воспроизводимы в речи. Они фиксируются при выделении типов контекстов в структурно-семантическом анализе текстов, где выявляются семантические валентности как механизм соединения значений слов. Отмечаются определенные валентности и способы заполнения валентностей.

Расширение состава семантических функций частиц увязано с онтологией языкового знака и проецируется на субстанциональные границы слова. В языковых изменениях при их пересечении и разрыве возникает омонимия дискурсивных слов, определяемая в сфере действия этих единиц. В результате изменения сферы действия, функций и содержания слов образуется омонимия таких единиц в системе языка: единственный — частица единственный' (выражает выделительноограничительное значение); может - может' (разг. устн.: Я может пойду?); такой - такой'; вон - вон' (простреч., усилительное значение: Он вон не пошел!); вдруг - вдруг' и нек. др. Здесь в составившихся парах слова различаются категориальным значением и принадлежностью к разным частям речи: к какой-либо знаменательной части речи и частицам. Соответственно, функциональные омонимы выполняют разные синтаксические функции, имеют различные морфологические категории, различаются лексическим значением, имеют разный морфемный состав и характер сочетаемости. Так, единственный I. II имеет разные значения и выражает различные семантические роли определяемого существительного.

Другие развившиеся новые типы употребления и значения представляют прямое внутреннее соотношение с существовавшими частицами, которые имели разные семантические функции. Например, частица такой имела 1. выделительное значение и 2. усилительное значение, относившиеся к просторечию. Омонимичное местоимение такой в своем содержании представляет указание не на предмет как таковой, но на определенный признак, свойство этого предмета [Падучева 2002: 133]. Это значение импликативного типа: указываемое свойство предмета становится известно из контекста либо из реальной ситуации. В современной устной речи слово такая, а затем появившиеся формы такой и такие, выражает определительное значение, а также модальное значение. Организуется и преобразуется сфера действия частицы как показатель и фактор ее изменения. С этим появившимся значением такая употребляется в сочетании не с именем прилагательным либо существительным, а вместе с глаголом-сказуемым, являясь реализацией его семантической валентности и относясь к синтаксической категории предикативности (Я такая закричала, потом пошла в медпункт). С другим появившимся значением слово выступает в роли сказуемого (Он такой: А у вас какая циркулярка, китайская? (уст. речь 2015); Он такой: А мне трубочку! (уст. речь 2017).

В семантическом преобразовании дискурсивных слов возникает проблема нормы и границы нормы. Представляя морфологическую валентность, можно оценивать морфологическую сочетаемость, можно отличать правильное как соответствие свойствам системы и неправильное на морфологическом уровне речевых 
структур. Наблюдая морфологическую сочетаемость, можно получить информацию о закономерностях морфологической валентности. Сравним современное функционирование некоторых частиц. Частица было, соединяющаяся с глаголомсказуемым в форме прошедшего времени, придает ему значение действия начатого, но прерванного или не давшего желаемых результатов. Соответственна особая сочетаемость этой частицы с глаголами определенных семантических типов, впоследствии она начала соединяться и с причастиями. Она прикреплена к определенной синтаксической конструкции: является осложнением простого или составного глагольного сказуемого. При этом было образует видовую форму со значением начатого - неоконченного действия [Булаховский 1958: 388]. Отмечен еще один тип употребления было: Я было не узнал тебя попервоначалу; Я было хотел с вами поговорить о деле. Оно имеет значение предшествования.

В фиксируемом новом употреблении слова было изменяется фокусное соотношение обозначений входящих в структуру высказывания действий, что проявляется в структурном членении предложения; при этом частица отъединяется от глагола-сказуемого, которому изначально принадлежала, и соотносится со всем предложением в целом. Частицу было требуется отличать от омонимичных связки и полнозначного глагола. Ср.: Впотьмах долго ли было и башку сломить; Им все чаще говорить бывало не о чем (Л. Леонов); Не надо мне, не надо было Любви навстречу столько лет спешить (песня). Неумение опознать осложненное сказуемое ведет к интерпретации было в качестве вводного слова. Это видим, например, в расхожих повествовательных фразах, где было выделяется запятыми: Доярку, было, наняли, так она вскоре ушла, хоть и платили неплохо; Попыталась, было, узнать, какое отношение к нашему городу он имеет (газеты 2010); После краткого раздумья Дюрсо предложил, было, генеральный выход из положения (Л. Леонов). Обособления - вводные компоненты - не имеют синтаксической связи с членами предложения, в которое они введены; они связаны с предложением по смыслу и особой интонацией вводности. Синтаксическая позиция, фиксируемая в письме интонацией, влияет на семантику дискурсивного слова.

Семантическая функция частицы обусловливается синтаксисом. Отчасти такое употребление вызывается присущей незакрепленностью позиции было. Происходит актуализация определенной части информации в предложении. Происходит усиление информативной значимости не только члена предложения, к которому частица относится, но и самой частицы было.

Современная реализация лексемы характеризуется изменением стилевой сферы. Дискурсивное слово устраняется из устной речи, к которой изначально принадлежало. Слово становится устаревшим. Оно становится менее употребительным, а в попытках употребления используется в массе некорректно - неправильно (ср. примеры неверного употребления в предлагаемых заданиях студентам: *Спектакль должен было начаться через десять минут, но его отменили из-за технических проблем. 2016). Было перешло в письменную речь, иногда употребляясь в публицистических и художественных текстах. Так пришли употребления: Владимир Путин поднял голову от бумаг, в которые он было углубился (Вед. 21.7.13); 
Шофер двинулся было туда, куда ему указали, как вдруг услышал, будто вдогонку: Всё можно увидеть с другой стороны (Шишкин О. Ведьмёныш. 2013); С утра пошел было дождь. Соня с испугом смотрела на мокрых кур и лужи, но дождь прошел (Ю. Казаков).

Эти и подобные употребления было в общем вписываются в границы языковой нормы, однако имеют свои особенности синтаксических связей, синтаксической структуры и грамматического значения и морфологических связей.

Отличия сферы действия возрастают, и употребление оказывается на границе нормы. Как это: Неслышной поступью к нему подошла девушка, в которой Авдеев совсем было признал Дашу, если бы в ее лице не показалось ему совсем ей не свойственное холодное, даже жестокое выражение (Нежный А. Вожделение // Октябрь. 2014. 11). Здесь иное логическое соотношение между частями сложного предложения, в первом из которых находится сказуемое с было - уступительное отношение придаточного предложения, в котором служебное слово было имеет ограничительно-условное значение. Это соответствует перемене структурно-семантических параметров было.

В современной речи далее возникают радикальные употребления, занимающие иное место в отношении к норме. Например: Мои истошные вопли заставили ее взяться наконец за ухват, которым она начала было меня доставать. Короткий комментарий был уже вечером (Лит. газ. 2015.9); Так ведь русальницы загрызут доможириху и косточки выплюнут - такое злое до утех чаровное племя. Царь было стакнулся с русальницей, так едва ноги унес (Личутин В. Наваждение // Лит. газ 2015.10). В этом употреблении было синонимично частицам же, уж, $u$, вон, ведь. Пересечены границы сочетаемости, свойственные этой частице. Изменились синтаксические границы сферы действия единицы.

В современной речи возникают не приглагольные употребления было: Здесь и возрожденный в своих правах реализм, и потесненный было постмодернизм, и сложный синтез реализма и модернизма (Лит. газ. 2015.6). В контексте нарушены пределы лексического значения слова, его грамматической связи, грамматической семантики и синтаксической структуры; иного типа семантика подчиняющего глагола-сказуемого: содержится малый компонент действия (акциональности) у включающего было предиката-причастия; отсутствуют последующие синтаксические структуры противопоставления действий. Было соответствует другому предметнопонятийному значению: 'ранее, в некоторое время’. (На фоне нормы, в целом отсюда в результате высказывания возникает неполная ясность и точность.)

Структурно аналогичны на этом направлении выражения: Ныне театр сохраняет разносторонность, присущую было его учредителю (Вед. 10.2.15), где в содержании фрагмента предикации было отсутствует компонент акциональности, то есть руководящим причастием обозначено длительное состояние, а не свойственное норме короткое результативное действие; также отличается грамматическая семантика, а в грамматических отношениях отсутствует последующая синтаксическая структура, нормативно противопоставленная предикату с было. В соответствии с этим, было обозначает временное понятие 'ранее'. При этом данное 
предложение выражает сложное грамматическое значение времени. Обозначается действие, совершившееся ранее данного времени, результаты которого имеют место в настоящем (плюсквамперфект).

Отсюда следует рассматривать механизм и причины лексико-грамматического явления современной речи. Следует отметить аналогии нереальной/потенциальной модальности в грамматической системе. Отыскиваются в русском языке некоторые формы выражения отношения действия к реальности, хотя и относящиеся к просторечно-областным. Такова форма нереального наклонения и многократного способа действия, содержащая соотносительный по грамматическому виду с было компонент: Заходи быват (нижегор., моск. обл.) и нек. под. Такой компонент выражает также смысловые оттенки какого-либо члена предложения или предложения в целом, в данном случае синонимичный частицам же, -ка, ну.

Итак, следовательно, общее значение было составляется содержательными компонентами: 'время' и 'осуществимость явления - отношение к реальности'.

В новом выражении было имеет значение времени. Однако содержание материала этим не исчерпывается. Предстает грамматическое синкретическое явление, имеющее смешанный характер.

Употребление было формально расширяется. В современной речи появляется синтагматически расширенное употребление слова с личной глагольной формой, отличающейся типом лексического значения - обозначение длящегося действия, и отличается грамматически - несовершенным видом: Я < . .> примеривался было к кожаной авиационной куртке фасона «бомбер» (Е. Рейн). Выступает отличие морфологической связи, сочетаемости единицы и грамматического значения, синтаксической связи и синтаксической структуры вместе с ее семантикой. Выполнение в предложении несвойственной роли приводит к появлению у слова новых синтаксически обусловленных значений.

Каково место возникшего явления в морфологической системе? Притом что продолжает существовать стандартное употребление было в его нормативных функциях. Речевое явление не укладывается лишь в рамки части речи частицы: слово не только сообщает лексической и синтаксической единицам добавочное значение, но и имеет иное собственное значение. Употребления такого типа было по своей семантике близки модальным словам, то есть обозначению отношения говорящего к содержанию и оценки его реальности. Но есть и структурно-семантические отличия от этой грамматической категории: наличие в выражении семантики признака - процесса, и значения времени.

Данное употребление характеризуется ограниченностью, но не всеобщностью. Оно возникло только в письменной сфере разговорного стиля, возможно в разговорном письменном русском языке, и не присуще устной речи. Создается разрыв в общеязыковой картине. Такое употребление не становится достоянием разговорного общения и не становится нормой всего языкового общества. В письменной речи это употребление не общежанрово, но референциально замкнуто.

Подобно этому создается положение в области модальных частиц. Например, в современных речевых процессах выступают частицы, обозначающие передачу 
чужой речи: де, дескать, мол. В плане функционирования наблюдается аналогичная картина: существовала лексико-грамматическая единица устной речи, которая использовалась и в других стилевых сферах. Данная единица становилась устаревшей, стилистически маркируя дискурс. После этого изменения языковая единица сосредоточилась в иной, письменной сфере, в отдельных ее жанрах. Поэтому частица де выступает не только в имевшемся, но и в другом структурносемантическом качестве. Ср. типы употребления: Скажи барину: гости-де ждут, щи простынут (Пушкин) — и современное сформировавшееся: Выступать начал. Мол, фальсификация всё. Де, никакой протокол подписывать не буду (Данилюк С. Рублевая зона. 2004). Де выделяется пунктуационно, за каковой пунктуацией стоит структурно-семантическое отличие. Частица с изменившимся значением может вставать в начале предложения, занимая другое место в его темо-рематической структуре, и сосуществовать в синтагме с оформленной прямой речью. При этом изменяется характер ее связей с семантическими компонентами высказывания. Слово отчасти получает значение предиката и обозначает факт совершения действия. Категориальная семантика соответствует внутренней форме слова. Во всех этих случаях изменение сферы действия соответствует изменившемуся значению частицы и смыслового фокуса предложения. Изменилось смысловое содержание высказывания. Изменилось содержание де: один внутренний компонент составляет оценка - притом не только манеры речи, но и сообщаемой информации, содержания высказывания; другим семантическим компонентом является 'сомнение, недоверие'. В содержание дискурсивной единицы входит коннотация: игра, ерничество или насмешка над коммуникативным намерением адресата.

Подобным образом в той или иной степени изменяются другие частицы передачи чужого высказывания в современной речи.

Имеются стилевые различия образующихся единиц. Ряд партикулных единиц относится к разговорному стилю, являясь замкнутыми в одной сфере употребления. Другой ряд изменяющихся единиц относится к просторечию, имея соответствующие лексико-грамматические, семантические и стилевые характеристики. Например, новое дискурсивное слово чисто: Ну, мы во власти должны, чисто, людям помочь (Бакорина М. Девять граммов пластита. 2000).

Стилевая отнесенность некоторых частиц изменяется. Так частицы было и де устраняются из устной речи и функционируют в письменной сфере. Устаревает средство передачи чужой речи мол. Наоборот, частица якобы, относившаяся к книжной сфере, утрачивает оттенок книжности и расширяет сферу употребления, и при этом изменяет предметно-логическую функцию.

\section{Литература}

Богуславский И. М. Сфера действия лексических единиц. М.: Языки славянских культур, 1996. 328 с.

Булаховский Л. А. Курс русского литературного языка. Киев: Радянска школа, 1958.467 c. 
Падучева Е.В. Высказывание и его соотнесенность с действительностью. М.: URSS, 2002. $342 \mathrm{c}$.

\author{
Vladimir N. Shaposhnikov \\ Moscow City Psychological and Pedagogical University \\ (Russia Moscow) \\ vladimirshaposhnikoff@yandex.ru
}

\title{
SEMANTIC POTENTIAL OF PARTICLES AND THE DEVELOPMENT OF LEXICAL AND GRAMMATICAL OPTIONS: THE WORD AND NORM BORDERS
}

The article analyzes lexical-grammatical character of the particles and their functional filling. As the units of morphology they have the certain paradigmatic relations and syntagmatic connections, presented by morphological valency and morphological combinability. Their categorical contents condition synonymy, existing among them and revealing by the analysis. Among the articles the antonymy and homonymy also exist, evidencing for complex semantics and character of their contents. Regularly the polysemy connects with the synonymy of discourse words. The particles extend semantic functions and develop the polysemy. Semantic functions of the discourse word arrange and express themselves in the limits of their scope. As not independent units the particles haven't certain syntactic function, but they include themselves in the morpho-syntactic constructions. Diverse speech innovations in contemporary Russian language form. There is the language norm in the sphere of particles and the limits of the norm exist and arise.

Key words: particles, semantic functions, lexical-grammatical variants, language norm, contemporary Russian language.

\section{References}

Boguslavsky I. M. Sfera deistviya leksicheskich edinic [The Scope of lexical Units] Moscow, 1996.

Bulachovsky L.A. Kurs russkogo litareturnogo iazyka [Course of Russian Literary Language]. Kiev, Radanska shkola Publ, 1958.

Paducheva E. V. Vyskazyvanie $i$ ego sootnesennost $s$ dejstvitelnostju [Utterance and its Correlation with Reality]. Moscow: URSS Publ., 2002. 


\section{И. А. Шаронов \\ Российский государственный гуманитарный университет \\ (Россия, Москва) \\ Igor_sharonov@mail.ru \\ МОДА НА НЕИЗМЕНЯЕМОСТЬ: ИСТОРИЯ РАЗРАСТАНИЯ И СОВРЕМЕННОЕ СОСТОЯНИЕ}

В статье обсуждается тенденция к потере традиции склонения некоторых разрядов существительных на примере заимствованных имен на $y, u, o$ и $e$ и ударного $a$, русских топонимов на -ово, -ево, -ино, -ыно, фамилий на -ий. Данная тенденция берет начало с идеи сохранять неизменными в речи и на письме некоторые иноязычные (главным образом, европейские) слова и обороты. В основном это были имена собственные - антропонимы и топонимы (Кале, Витри, Квито, Корфу и т. д.), однако постепенно список стал расширяться названиями входящих в моду предметов западного обихода: рандеву, ревю, фортепьяно, желе, кофе, колибри, депо, бюро, пальто. Склоняемые варианты таких слов считались просторечными. Начиная с 20-х годов XX века поток заимствований, не приобретших в результате адаптации склонения, стремительно возрастает, многие слова становятся частотными и теряют «чужеземный флер». Несклоняемость начинает распространяться по аналогии среди русских топонимов на -о и -е: Купчино, Колпино, Репино. В самом деле, почему Конаково должно изменяться, если не изменяются Коломбо и Монако? Разрастающаяся мода на «экзотический компонент» в составе языка в течение последних двух веков приводит не только к расширению и изменению лексических пластов языка, но и оказывает воздействие на его грамматический уровень. Приведет ли эта тенденция к дальнейшему распространению аналитизма в русском языке в будущем, покажет время.

Ключевые слова: заимствования, адаптация иноязычных заимствований, языковая норма, неизменяемые слова, топонимы, антропонимы. 
«... русский язык склонен к склонению. Почему же вы не склоняете названий? Или почему бы тогда не говорить: “Я живу в Москва”?»

(Л.К. Чуковская.

«Записки об Анне Ахматовой. 1963-1966»).

Заимствование из других языков - естественный процесс взаимодействия языковых сообществ, в результате которого происходит обновление и обогащение лексического состава языка. В русском языке процесс адаптации, освоения чужого слова традиционно сопровождается изменением формы этого слова, его графической, фонетической и грамматической русификацией [Казкенова 2013].

Грамматическая русификация — конечный этап адаптации слова — предполагает подстраивание иноязычного слова под модели трех основных склонений русского языка (computer - компьютер; camera - камера; console - консоль), а также замену суффиксов их аналогами (lobbying - лоббирование; reclamation - рекламация; sexuality - сексуальность). В результате грамматического оформления происходит «упрятывание» чужеродного элемента в позицию корня, окружение его русскими словообразовательными и словоизменительными аффиксами. Русификация приводит к относительно мягкому присвоению заимствования в сознании носителей языка и постепенному неразличению исконно и неисконно русского слова.

Еще в XVIII веке в кругах высшего российского общества появляется мода сохранять неизменными в речи и на письме некоторые иноязычные (главным образом, европейские) слова и обороты. Если в Российской грамматике А. А. Барсова [Барсов 1981: 525] ${ }^{1}$ есть только упоминание о несклоняемых заимствованиях, то в последующих грамматиках XIX века такие слова, прежде всего, имена собственные - антропонимы и топонимы на $u, y, ю, o, e$, а также конечный ударный звук $a$ в заимствованиях из французского получают право на только частичную русификацию. В грамматике А. Востокова [Востоков 1831/1874] утверждается их несклоняемость. Автор пишет: «В географических собственных именах встречаются окончания $a a, o a, y a$, не употребительные в русском языке, как то: Санао, Гуa, Кanya, Мантуа. Сии склонять можно <..>. Но названия французские, кончающиеся на ios и произносимые Блоа, Труа, не склоняются. Равномерно несклоняемыми остаются все иностранные имена, кончающиеся на $е, u, o, y$, напр. Кале, Витри, Квито, Корфу» [Востоков 1874: 20]. Правило несклоняемости для таких слов нельзя было назвать жестким. Параллельно могли использоваться и их русифицированные склоняемые варианты: Дидро - Дидерот; Данте - Дант, в Сорренте (напр., рассказ И.С. Тургенева «Вечер в Сорренте») и т. д.

Вместе с именами собственными не стали склоняться некоторые нарицательные имена, названия входящих в моду предметов западного обихода: рандеву, ревю, фортепьяно, желе, кофе, колибри, депо, бюро, пальто, с которыми конкурировали

1 «Имена заимствованныя вышепоказаннымъ образомъ изъ чужихъ языковъ, скланяются по принятымъ ими Российскімъ окончаніямъ т: е: по второму и первому склоненію выключая нескланяемыя». 
(по мере распространения таких предметов в российском обществе) их русифицированные варианты: кофе - кофий, желе - желей, фрикасе - фрикасей. Ср.:

Hy, у нас, конечно, возня, трескотня, повара, фрикасеи; музыку выписываю [Ф. М. Достоевский. Село Степанчиково и его обитатели (1859)].

- Врешь, кто много этого кофия пьет, тот и в могиле не тлеет [В. И. Немирович-Данченко. Соловки (1874)].

Господа против прежнего сделались образованнее; даже из подлого звания которые мало-мальски в чины произошли - и те начали жеелеи да бламанжеи предпочитать [М. Е. Салтыков-Щедрин. Кисель (1885)].

Склоняемых форм кофе было даже две: кофий и кофей. Последняя наряду с неизменяемой указывалась в Словаре «Церковнославянского и русского языка», изданном в 1847 г. (см. [Рогожникова 1966: 74]).

Вторжению в русский язык особого разряда слов, для которых грамматические законы не писаны, способствовали их нестандартные конечные гласные $у$ и ю, для которых не нашлось подходящей аналогии в русских склонениях. Другие конечные гласные: $u$, $е$ и $о$, видимо, вызывали у филологов некоторое сомнение, однако экзотичность, чужеродная маркированность слов взяла верх. Я. К. Грот писал: «Затруднительно <..> употребление имен, которые по окончаниям своим не прививаются к языку, почему он или оставляет их без склонения. <.. > Сюда относятся особенно имена среднего рода на -о, и -е, <..>. У нас, правда, немало своих имен, оканчивающихся на -о, и -е, но мы чувствуем, что в подобных словах "о" имеет совсем другое значение и не составляет приметы рода и склонения» [Грот 1876; цит. по Мучник 1971: 250].

И.П. Мучник [Мучник 1971], автор исследования истории проникновения неизменяемых слов в русском языке с XIX до середины XX века, указывал в качестве причины разрастания неизменяемых форм в русском языке пиетет перед европейской культурой у русской аристократии, образованной части населения, носителей литературного русского языка. Отсюда прежде всего вытекает желание сохранять особый статус для западноевропейских заимствований, так сказать, «культурная варваризация» русского языка.

В конце XVIII и в XIX веке предпринимались регулярные попытки противостоять моде на использование в речи варваризмов. Д.И. Фонвизин, А.С. Грибоедов, И.П. Мятлев и многие другие высмеивали в своих сочинениях макароническую речь публики, претендующей на образованность; славянофилы и близкие им по мировоззрению публицисты выступали ярыми охранителями чистоты русского языка и сражались на этом поприще с «западниками» на страницах литературных журналов. А.С. Шишков и В. Даль, правда, без особого успеха пытались заменять вошедшие в язык заимствования придуманными ими на основании русских корней неологизмами. Принято иронически оценивать деятельность пуристов, особенно после статьи [Винокур 1929/1984], однако сопоставление числа неизменяемых слов в русском языке в XIX веке с аналогичным числом первой половины XX века, когда национальная идея была подавлена пафосом интернационала, говорит само за себя (подробнее об этом ниже). 
Хотя уже в начале XX века В.И. Чернышев отмечает перелом в восприятии нерусифицированных и русифицированных вариантов заимствований в пользу первых: «В старом языке иностранные слова на -о склонялись как имена среднего рода; другие иностранные слова переделывались на русский лад и склонялись соответственно приданным им окончаниям. Здесь литературный язык старого времени был в полном согласии с народным, в котором и теперь приняты словоупотребления в пальте, в депе, на бюре, жилей, филей и т. п. <..>. Книжная речь здесь, однако, взяла верх над народной, и мы теперь не склоняем подобных слов. Из прежних употреблений не чужды и современному языку: алой, кофей, эхо (склоняемое в единственном числе по среднему роду). Но вместо старых употреблений: на бюре, в домине, желей, какаом, каррея, лазарон, филей, чичерон, мадама - теперь приняты только несклоняемые формы этих слов: бюро, домино, желе, какао, карре, филе, лазарони и лащчиарони, чичероне, мадам» [Чернышев 1913 / ОКР 1984: 79-80].

Начиная с 20-х годов XX века поток неизменяемых, дополненный обширной лексической группой аббревиатур, стремительно возрастает. От некоторых заимствованных слов, заканчивающихся на согласный и потому склоняемых, образуются более экономные усеченные варианты на -о, которые не принято склонять: кинотеатр - кино; автомобиль - авто; метрополитен - метро и др. (см. [ЛРЛЯ 1981: 204]). Несклоняемость рассматриваемого типа заимствований получает в процессе кодификации литературной нормы статус строгого правила, русифицированные варианты не рекомендуются к употреблению. Склонение таких заимствований начинает считаться признаком грубого просторечия, необразованности говорящего [Граудина 1977]. Интересен в этом отношении диалог из романа «Пшеница и плевелы» Б. А. Садовского:

«На Невском Государю встретился пьяненький чиновник.

- Tы где служишь? - В пожарном депе.

Государь ульгнулся. - Депо не склоняется».

Найти подобный диалог в литературе XIX века представляется затруднительным. Роман писался автором в конце тридцатых - начале сороковых годов XX века.

В некоторых исследованиях несклоняемость рассматриваемых заимствований связывают с их недостаточной освоенностью (см., напр., [Маринова 2003]). Недостаточная освоенность таких слов вряд ли может быть объяснена через пассивность их использования. Уже в 60-е годы ХХ века становится очевидным, что неизменяемые существительные вошли в активный запас русского литературного языка. И.П. Мучник в своем исследовании представляет список из 340 нарицательных существительных [Мучник 1971: 251-253], более 80 из которых отнесены автором к общераспространенным ${ }^{2}$. Сам автор из осторожности говорит о некото-

${ }^{2}$ Объединенный список общераспространенных слов из списков И.П. Мучника: авто, бюро, вето, гестапо, гетто, депо, динамо, домино, какао, кило, кино, контральто, лото, метро, пальто, пианино, поло, радио, ситро, сопрано, стереокино, табло, танго, трико, трио, трюмо, фортепьяно, фото, харчо, шевро, эскимо, алоэ, ателье, атташе, бебе, галифе, драже, желе, каноэ, кафе, кашне, коммюнике, конферансье, кофе, купе, монпансье, мулине, пенсне, портмоне, пресс-папье, пюре, 
рой доле субъективности при выделении такой группы, однако время показало, что авторская интуиция была верна — как кажется, только два слова из предложенного списка не сохранились в современном языке: бебе и драпри. Социологические опросы 60-х-70-х годов XX века показали, что носители языка перестают замечать чужеродность активно используемых в речи неизменяемых заимствований.

Статистика употреблений целого ряда неизменяемых слов в Национальном корпусе русского языка демонстрирует их очень высокую частотность. Например: слово кофе на август 2017 г. имеет 13377 вхождений, пальто - 13 144, метро 7786, кафе - 7441, бюро - 7555, такси - 4459. Многие неизменяемые заимствования недавнего времени также используются в современной речи очень активно, о чем пишет Л. П. Крысин: «...несмотря на их грамматическую неосвоенность русским языком, они весьма употребительны: евро, киви, кутюрье, ноу-хау, масс-медиа, паблисити, портфолио, профи, хиппи, шоу, ток-иоу; из менее употребительных, но всё же встречающихся на страницах прессы, в теле- и радиоэфире: боди, роялти, прет-а-порте, уоки-токи и нек. др.» [Крысин 2008: 25].

Потеря иноязычного флера у неизменяемых в середине XX века привела к размыванию преград на пути массовой экспансии таких единиц в русский язык: количество грамматически неоформленных заимствований в последние десятилетия продолжает увеличиваться лавинообразно. «Современный словарь несклоняемых слов русского языка» И. Д. Успенской [Успенская 2009] содержит уже около 3000 единиц. «Самый новейший толковый словарь русского языка XXI века» Е. Н. Шагаловой, вышедший двумя годами позже [Шагалова 2011] добавляет к этому списку еще 60 единиц ${ }^{3}$, многие из которых приходят в язык со своими словообразовательными гнездами ${ }^{4}$ :

Пати: препати, коктейль-пати, фрик-пати, рейв-пати;

Фикшн, Нон-фикин, палп-фикин, сайенс-фикин, фанфикиен;

Шоу: слайд-шоу, кастом-шоу, фаер-шоу, фрик-иоу, пип-шоу, ток-иоу, риалити-иоу, фэшн-шоу. И т. д.

Уход от традиции калькирования суффикса tion, а также заимствование англицизмов в форме множественного числа приводит к формированию в языке группы

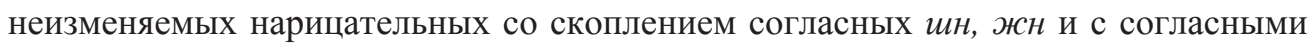

реле, сальто-мортале, суфле, тире, турне, филе, фойе, шимпанзе, шоссе, бигуди, виски, денди, драпри, жалюзи, иваси, жюри, кепи, леди, пари, пони, такси, шасси, янки, интервью, кенгуру, меню, рагу, бра, буржуа, га, мадам, мисс, миссис.

${ }^{3}$ Список неизменяемых, собранный из словаря [Шагалова 2011], не включающий словообразовательные гнезда многих представленных здесь единиц: биеннале, триеннале, бюстье, кутюрье, кумите, тофу, шоу, боди, бэгги, васаби, вики, джакузи, ди-ви-ди, дьюти-фри, комьюнити, кросс-кантри, лав-стори, массмедиа, милитари, мюли, мюсли, прайвеси, растафари, регги, роялти, сашими, секьюрити, си-ди, суши, тайчи, такс-фри, танкини, угги, фрисби, фэнтези, хелиски, ци, пати, вамп, нон-стоп, паблик релейшнз, постпродакшн, поул-позишн, фишинг-флеш, фьюжн, фэшн, экшен, эсэмэс, фикшн, промоушн, велькро, гаспачо, жиголо, мачо, кэндо, парео, тай-бо, техно, тэквондо, фанго.

${ }^{4}$ О вхождении в современный русский язык заимствований одновременно целыми словообразовательными гнездами см.: [Маринова 2013]. 
с и з на конце: постпродакшн, фьюжн, экшн, промоушн, паблик релейшнз, гёрлс, коммандос, маринз, праймериз, контрас, группиз, драгз и т. д.

Расширение неизменяемости у топонимов и антропонимов протекало не с меньшей активностью. Если вошедшие в язык преимущественно до XIX века топонимы на -bl/u: Фивы, Салоники, Афиныл, Дельфыл, Сиракузы и некоторые другие по традиции склоняются, более поздние Фиджи, Mapbl, Гаити, Чили, Нагасаки - уже нет. Некоторые ранее обрусевшие экзотические топонимы в XX веке были изменены в угоду новым, а потом и отделившимся республикам СССР и перестали склоняться. В 1936-м году Тифлис был переименован в Тбилиси, Батум - в Батуми, Сухум - в Сухуми. В 1993-м году Алма-Ата получила официальное наименование Aлматьл.

Модная тенденция продолжила свое развитие и в русских топонимах на -ово, -ево,-ино,-ыно. В 60-70-е годы ХХ века несклоняемость таких топонимов получает повсеместное распространение в разговорной речи [ГПРР 1976: 138-140]. Уже второе и третье поколение носителей языка используют топонимы Переделкино, Бородино, Строгино, Тушино, Царицьнно и т.д. как неизменяемые. Лишь в последние годы нормативисты начали активную борьбу за восстановление склонения таких слов - и встретили жесткое сопротивление «культурных носителей языка». Так, в 2016 году жители Петербурга собирали подписи за запрет склонения Купчино, Колпино, Репино, Волосово, Комарово и других близлежащих населенных пунктов и написали письмо министрам культуры и образования, которое было опубликовано на сайте Change.org:

«Учёные диктуют нам правила и нормы, которые не имеют никакой связи с реальностью! Все коренные жители привыкли говорить Купчино и Колпино, а такие нелепые выражения как "в Купчине" и "из Колпина" режут слух истинным петербуржцам. Простые люди хотят видеть и слышать родные и любимые названия без склонения окончаний».

Хотя распространение несклоняемости в таких словах произошло во многом под влиянием военного и географического жаргонов, однако, как кажется, воздействие не было бы столь значительным, если бы не подпитывалось аналогией с заимствованной топонимикой. В самом деле, почему Конаково должно изменяться, если не изменяются Коломбо и Монако?

Пытаются не отставать и антропонимы. Так, обрусевшие европейские фамилии на -off традиционно заменялись в XIX веке на -оф и склонялись: Мариенгоф, Генpux Фон Фитингоф. Русские фамилии на -ов, переделанные в западных странах на -off «возвращаются на родину» уже с $\phi ф$ и перестают склоняться: Дмитрофф, Щеглофф, Смирнофф, Иванофф. Славянские фамилии типа Rutkowski традиционно транслитерируются на -ий и изменяются по адъективному склонению. Однако в последние годы стало модно конечную -и на -ий не менять, и это, соответственно, выводит такие фамилии из разряда склоняемых: Рутковский/ая/ие $=>$ Рутковски, Пиперский/aя/uе $=>$ Пиперски. Вот русские фамилии, без особого труда обнаруженные в интернете: Станислав Буковски, Вика Боровски, Владимир Борщевски, Максим Вишневски. Список открыт. 
Грамматическая неоформленность имен все больше проникает в русский язык в качестве престижного способа русификации заимствований, способствуя наряду с другими тенденциями дрейфу языка в сторону аналитизма [Гловинская 1996: 237-273]. Мода на них расширяется несмотря на сложности в установлении рода (вспомним нескончаемый шум вокруг слова «кофе») и в выявлении категории числа [Смирнова 1979, 1981]. Расширяется, несмотря на то, что отсутствие окончаний требует предлогов и адъективных уточнителей, без которых синтаксическое значение единицы в предложении может вызывать затруднение при восприятии. Там, где таких «костылей» нет, употребление неизменяемых резко снижается. Так, для наиболее распространенных неизменяемых слов кофе (13377 употреблений) и пальто (13144 употребления) в Национальном корпусе не нашлось ни одного примера в дательном беспредложном, а в творительном беспредложном нашлось только по одному, и примеры эти не кажутся стилистически безупречными:

Как обильная и разнообразная трапеза идеально завершается кофе с бокалом изысканного коньяка, так и путешествие по Франиии будет обидно неполным, если не завершится хотя бы бегльм знакомством с Парижем. [В. Гаков. Во Францию - на машине времени (2001) // «Туризм и образование», 2001.03.15]

И мы покрылись пальто Сысоева и начали стремительно уходить из этого мира [Б. Окуджава. Искусство кройки и житья].

Продолжит ли данная тенденция свое победное шествие, все более сближая русский язык с аналитическими языками, или остановится на периферии грамматической системы, покажет время.

\section{Литература}

Барсов А. А. Российская грамматика Антона Алексеевича Барсова. М., 1981.

Винокур Г. О. Культура языка. Практическая стилистика как проблема // «Основы культуры речи. Хрестоматия». М. 1984. С. 163-173.

Востоков A.X. Русская грамматика Александра Востокова, по начертанию его же сокращенной грамматики полнее изложенная. Изд. 12. СПб., 1874.

Гловинская М.Я. Активные процессы в грамматике (на материале инноваций и массовых языковых ошибок) // Русский язык конца ХХ столетия (1985-1995). М.: Языки русской культуры, 1996. С. 237-304.

Граудина Л.К., Иикович В.А., Катлинская Л. П. Грамматическая правильность русской речи. Опыт частотно-стилистического словаря вариантов. М.: Наука, 1976. $456 \mathrm{c}$.

Граудина Л. К. Разговорные и просторечные формы в грамматике // Литературная норма и просторечие. М.: Наука, 1977. С. 77-111.

Грот Я. К. Филологические разыскания. Т.II. Материалы для словаря грамматики и истории русского языка. СПб., 1876.

Казкенова А. К. Онтология заимствованного слова. М.: Флинта, 2013. 248 с.

Крысин Л.П. Слово в современных текстах и словарях: Очерки о русской лексике и лексикографии. М.: Языки славянских культур, 2008. 321 с. 
Лексика русского литературного языка XIX — начала XX века. М.: Наука, 1981. 359 с. (ЛРЛЯ)

Маринова E.B. Освоение новых заимствований и сопутствующие процессы в русском языке начала XXI в. // Русский язык начала XXI века: лексика, словообразование, грамматика, текст. Нижний Новгород, 2014. С. 65-150.

Маринова Е. В. Экзотическая лексика как лингвистический феномен // Вест. Нижегор. ун-та им. Н.И. Лобачевского. Сер. Филология. 2003. № 1. С. 138-142.

Мучник И.П. Грамматические категории глагола и имени в современном русском литературном языке. М.: Наука, 1971. С. 245-280.

Рогожникова Р.П. Варианты слов в русском языке. М.: Просвещение, 1966. $160 \mathrm{c}$.

Смирнова Г.А. Категория рода несклоняемых существительных // Лингвистика и поэтика. М.: Наука, 1979. С. 86-105.

Смирнова Г.А. Категория числа несклоняемых существительных // Проблемы структурной лингвистики, 1981. М.: Наука, 1983. С. 132-147.

Успенская И. Д. Современный словарь несклоняемых слов русского языка. М.: АСТ, Астрель, 2009. 474 с.

Чернышев В. И. Правильность и чистота русской речи. Опыт русской стилистической грамматики. 3-е изд. Петроград, 1914-1915. Перепечатано в кн.: Основы культуры речи. М., 1984.

Шагалова Е.Н. Самый новейший толковый словарь русского языка XXI века. М.: Астрель, 2011. 413 с.

\author{
Igor A. Sharonov \\ Russian State University for the Humanities \\ (Russia Moscow) \\ Igor_sharonov@mail.ru
}

\title{
ABOUT THE TENDENCY NOT TO DECLINE BORROWED NOUNS IN HISTORICAL PERSPECTIVE AND CONTEMPORARY PERSPECTIVE
}

The paper is devoted to the increasing tendency for some lexical groups of Russian nouns to be used non-declined. The starting point of the tendency were some exotic toponyms, antropomyms and the names of fashionable western stuff ending at $u, i, o$, $e$, stressed $a$. The tendency has become conventional at the XX century and let the new waves of loan words be grammatically unarranged. It had presumably the influence upon typically Russian toponyms, ending at -ovo, -evo, -ino, -yno and some family names to be used non-declined. The question is bound to arise, if this is one more step to transfer Russian language to analytic languages, or Russian language would press the tendency.

Key words: loan words, grammatical arrangement of loan words, language norms, non-declined words, toponyms, antroponyms. 


\section{References}

Barsov A. A. Rossijskaja grammatika Antona Alekseevicha Barsova. M., 1981.

Vinokur G. O. Kul'tura jazyka. Prakticheskaja stilistika kak problema. Osnovy kul'tury rechi. Hrestomatija, M., 1984, p. 163-173.

Vostokov A. Russkaja grammatika Aleksandra Vostokova, po nachertaniju ego zhe sokrashhennoj grammatiki polnee izlozhennaja. SPb., 1874.

Glovinskaja M. Ja. Aktivnye processy v grammatike. Russkij jazyk konca XX stoletija (1985-1995). P. 90-141.

Grammaticheskaja pravil'nost' russkoj rechi. Opyt chastotnogo statisticheskogo slovarja variantov. M., 1974.

Graudina L.K. Razgovornye i prostorechnye formy v grammatike. Literaturnaja norma i prostorechie. M. 1977. P. 77-111.

Grot Ja. K. Filologicheskie razyskanija. T. II. Materialy dlja slovarja grammatiki i istorii russkogo jazyka. SPb., 1876.

Kazkenova A.K. Ontologija zaimstvovannogo slova. M. 2013.

Krysin L. P. Slovo v sovremennyh tekstah i slovarjah: Ocherki o russkoj leksike i leksikografii. M., 2008.

Leksika russkogo literaturnogo yazika XIX — nachala XX veka. M._ 1981.

Marinova E. V. Osvoenie novyh zaimstvovanij i soputstvujushhie processy v russkom jazyke nachala XXI v. Russkij jazyk nachala XXI veka: leksika, slovoobrazovanie, grammatika, tekst. Nizhnij Novgorod. 2014. P. 65-150.

Marinova E. V. Jekzoticheskaja leksika kak lingvisticheskij fenomen. Vest. Nizhegor. un-ta im. N. I. Lobachevskogo. Ser. Filologija. 2003. № 1. P.138-142.

Muchnik I. P. Grammaticheskie kategorii glagola i imeni v sovremennom russkom literaturnom jazyke. M., 1971, p. 245-280.

Rogojnikova R. P. Varianti slov v russkom yazike. M. 1966.

Smirnova G. A. Kategorija roda nesklonjaemyh sushhestvitel'nyh. Lingvistika i pojetika. 1979. P. 86-105.

Smirnova G. A. Kategorija chisla nesklonjaemyh sushhestvitel'nyh. Problemy strukturnoj lingvistiki, 1981, p132-147.

Uspenskaja I. D. Sovremennyj slovar' nesklonjaemyh slov russkogo jazyka. 2009

Chernyshev V.I. Pravil'nost' $i$ chistota russkoj rechi. Opyt russkoj stilisticheskoj grammatiki. 3-e izd. Petrograd, 1914-1915. Perepechatano v kn.: Osnovy kul'tury rechi. M., 1984.

Shagalova E. N. Samyj novejshij tolkovyj slovar' russkogo jazyka. XXI veka. 2011. 


\author{
М.В. Шульга \\ Московский государственный университет им. М. В. Ломоносова \\ (Россия, Москва) \\ shoulga@mail.ru
}

\title{
О РАЗВИТИИ СИНТЕТИЧЕСКИХ СРЕДСТВ В ДИНАМИКЕ РУССКОГО ЯЗЫКА*
}

По способам выражения грамматических значений современный русский язык характеризуется как язык с выраженной синтетичностью. На протяжении обозримого исторического периода русский язык существенно расширил свои синтетические возможности и арсенал синтетических средств. Привлекается внимание к тем процессам, которые оказывают на русский язык типологическое воздействие, меняют способы выражения грамматических значений и степень его синтетичности. Это способы формирования новых частей речи, новых грамматических категорий, способы выражения новых грамматических значений, развитие синтетических грамматических средств на основе аналитических и словообразовательных средств.

Показано, что формирование имени числительного на лексической основе счетных слов и словосочетаний осуществляется путем актуализации разнообразнейших синтетических средств, создания новых синтетических средств и единиц выражения грамматических значений.

Формирование грамматической категории вида на лексико-семантической базе способов глагольного действия сопряжено с развитием многообразных синтетических грамматических средств - аффиксации и чередований в основе. Категория вида вовлекла в выражение регулярного грамматического значения такие морфемы, которые до этого в выражении грамматических значений не участвовали, приставки и суффиксы.

Особо показательно для характеристики вектора развития грамматической системы расширение состава синтетических средств, формирование новых синтетических средств на базе аналитических и словообразовательных элементов.

Параллельное существование в системе русского языка и возникновение новых аналитических форм еще не свидетельствует о тенденции к аналитизму как к вектору развития русской грамматической системы.

* Данная статья является расширенной и уточненной версией доклада автора на V Международной научной конференции «Культура русской речи (Гротовские чтения)» в феврале 2017 года. 
Ключевые слова: типология языка, морфологический строй русского языка, синтетические формы, аналитические формы, тенденции развития морфологической системы.

Отправной точкой для рассуждений о росте аналитизма в грамматическом строе современного русского языка является представление о том, что «категории полных слов стабильны», а «разряды формальных слов подвижны, активно развиваются, пополняются» [Лекант 2014: 205].

Изредка встречаются работы, ставящие под сомнение наличие тенденции к аналитизму в русском языке [Тираспольский 1981: 37-49; Воротников 2001: 85-92; Дубова 2002; Тукова 2014: 212 и нек. др.].

Морфологические процессы развиваются медленно, и только ретроспективный взгляд позволяет определить основные векторы движения грамматической системы. Здесь комментируется с типологической точки зрения путь, который на протяжении обозримого исторического периода прошли части речи и грамматические категории русского языка, явив при этом возможности синтетизма.

1. Разграничение предметных и признаковых слов в ранней грамматической системе русского языка осуществлялось по принципу аналитических языков. Добро, лихо, право склонялись одинаково и употреблялись в соответствии с синтаксической позицией - как определяемые и как определяющие. Формирование прилагательного как особой части речи (в его противопоставлении имени существительному) происходило как преобразование аналитических форм в синтетические - как слияние именных форм с местоимением $u:$ добръ $+u \rightarrow$ добрыи, добро $+\digamma \rightarrow$ доброю, добра $+я " \rightarrow$ добрая.

Этот процесс существенно расширил состав синтетических форм и усилил позиции синтетизма в системе форм имени.

2. Многовековая история формирования имени числительного - это большая созидательная работа грамматической системы и актуализация разнообразнейших синтетических средств.

На протяжении веков на месте стандартных именных парадигм - местоимений (дъва, оба), прилагательных (триє, четыре) и существительных женского рода ( рода (съто)

- вырабатываются новые уникальные парадигмы: двух, mpex, четырех; ста, сорока;

- появляются новые флексии: двумя, тремя, четырьмя;

- складывается новый комплекс грамматических категорий - изменение по падежам; отсутствие изменения по числам и родам;

- формируется новый тип синтаксических связей, соединяющий в парадигме управление с согласованием.

На основе сочетаний с разнотипными синтаксическими связями пополняется лексический состав новой части речи: одинъ на деслте $\rightarrow$ одиннадияать; дъва

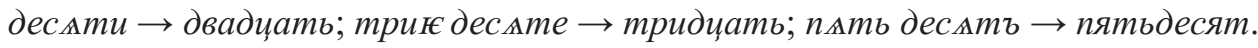


На теме числительных необходимо остановиться особо, поскольку в современных исследованиях история числительных рассматривается как явный случай укрепления аналитизма и упрощения системы склонения [Гловинская 2008 и др.].

При этом имеется в виду, что у числительных постепенно формируется двухпадежная парадигма: cmo - cma. Действительно, система падежных оппозиций у числительных сорок и сто стала проще даже по сравнению с системой XIX века. Но можно ли при этом говорить об упрощении грамматической системы? На наш взгляд, это поверхностный, «арифметический», подход к проблеме. Ведь парадигмы, в которые входили слова сорок и сто, остались, а в системе языка появилась две совершенно новые парадигмы, уникальные. Они дополнили имеющийся набор словоизменительных парадигм, то есть дополнили систему синтетических форм.

На наших глазах формируется еще одна специфическая парадигма: особая система форм у количественного существительного тыссяча со специфической для слов на - $а$ флексией Т. падежа -ью: тысячью.

Основные новообразования в формах современных числительных связаны со взаимным уподоблением их форм. Взаимная унификация форм - это обычный механизм, инструмент грамматикализации какого-то значения (подробнее [Шульга 2017]), в данном случае значения отвлеченного количества.

Так, омонимия форм Р.-Д.-П. ста, сорока - это частичное уподобление по системе падежных оппозиций числительным типа пять, одиннадияать, тридияать. Формы типа сорокью, четырью, тысячью - это уподобление тем же числительным по форме Т. падежа: сорокью, как десятью.

Другое направление взаимной унификации форм демонстрируют отмечаемые в современной речи формы двуми, пятьми, шестьми, десятьми. Здесь обобщена историческая модель трьми, четырьми, в современной системе реализованная в формах типа двумястами. Числительные стоят вне категории числа, в их парадигме, даже в литературном языке, свободно сочетаются разные по происхождению числовые формы: ед. число пяти, мн. число трех, дв. число тремя. Поэтому четырью и четырьми с позиций системы языка одинаково перспективны.

Контаминация разных числовых флексий также представлена в формах числительных - в современных формах двумя, тремя, четырьмя. Флексия -мя возникла в ходе унификации исторических форм дв. числа на -мa (дъвъма, объма) и форм мн. числа на -ми (трьми, четырьми). Аналогичный результат демонстрируют отмечаемые в современной речи формы четырмью, двумями, тремями.

Одно из активнейших направлений в эволюции числительных — это расширение их состава. Поэтому о лексикализации здесь можно говорить лишь с большими оговорками. На основе словосочетаний, как уже было сказано, появились новые обозначения чисел полтора , 11-19, 20, 30, 50,60, 70, 80, 200, 300, 400, 500, 600, $700,800,900$. Этот процесс продолжается. В современной речи как его проявления можно расценивать употребления типа: свыле пятьсот солдат; около семьсот 
новобранцеев. Здесь устранена внутренняя флексия - результат исторической членимости данных образований. Этот путь одолели числительные второго и третьего десятков: Р. двадияати (из дъвою деслту), тридиуати (из трии дес Атъ). Возможно, этот процесс затрагивает и составные названия чисел типа 552: c nятьсот пятьдесят двумя солдатами.

Таким образом, в истории имени числительного (вплоть до наших дней) нет места проявлениям аналитизма. Напротив, здесь представлены синтетические усилия и разнообразнейшие синтетические возможности языковой системы. Результатом этих усилий и явленных новых возможностей стало развитие и усложнение грамматической системы, а не ее упрощение.

3. В системе имен сформировалась новая грамматическая категория - категория одушевленности / неодушевленности. Она имеет регулярный и обязательный характер и выражается синтетическими средствами - через оппозицию падежных форм.

4. На утрату сложной системы глагольных форм ссылаются как на отправную точку аналитических тенденций в развитии русского глагола. Здесь упускают из виду, что были утрачены не только синтетические глагольные формы (аорист, имперфект), но и аналитические формы (перфект, плюсквамперфект). При этом появились новые синтетические временные формы - форма будущего времени типа напишу и форма прошедшего времени написал.

Указывают также на аналитический способ выражения значения лица в системе современных глагольных форм прошедшего времени: я писал. Но этот аналитический способ заместил аналитическую же древнюю форму писаль ecмb, он не повлиял на соотношение аналитических и синтетических глагольных средств.

При этом обходят вниманием тот факт, что важнейшее место в системе форм современного глагола составляют грамматические категории вида и залога.

Категория залога сформировалась на основе аналитических глагольных форм с частицей $c$ А местоименного происхождения.

Формирование грамматической категории вида на лексико-семантической базе способов глагольного действия сопряжено с развитием многообразных синтетических грамматических средств - аффиксации и чередований в основе. Категория вида вовлекла в выражение регулярного грамматического значения такие морфемы, которые до этого в выражении грамматических значений не участвовали приставки и суффиксы.

5. Особо популярная тема для исследования глагольных аналитических тенденций - наличие в русском языке двувидовых глаголов типа жениться, конфисковать. Преимущественно это глаголы иностранного происхождения, и их состав пополняется за счет новых заимствований. Однако вектор их грамматического развития направлен в сторону видовой парности. Так, Е. В. Петрухина констатирует, что «в современном русском языке наблюдается устойчивая тенденция к включению двувидовых глаголов, в основном иностранного происхождения, в системные видовые оппозиции и к формальной дифференциации видовых значений» 
[Петрухина 2009: 83-84]. В результате префиксации двувидового глагола и образования видовой пары мотивирующий двувидовой глагол теряет двувидовость и переходит в разряд глаголов несовершенного вида: демонстрировать - продемонстрировать. При этом Е. В. Петрухина справедливо отмечает, что те же двувидовые глаголы охарактеризованы по виду в причастных формах и у деепричастий, где суффиксы служат формальными показателями вида (атаковать: атакуемый - атакованный, атакуя - атаковав).

Нерегулярности в проявлении грамматических признаков глагольного вида (непарные, двувидовые глаголы) это следствие того, что данная сравнительно молодая грамматическая категория находится в стадии активного становления. Мы наблюдаем регуляризацию средств выражения вида, а не деструктивные процессы.

В целом история частей речи, грамматических категорий и средств русского языка не дает оснований для вывода о росте аналитических тенденций. Напротив, русский язык существенно расширил свои синтетические возможности и арсенал синтетических средств.

\section{Литература}

Воротников Ю.Л. Грамматический статус аналитических форм компаратива в русском языке // Словарь и культура русской речи. К 100-летию со дня рождения С.И. Ожегова. М., 2001. С. 85-92.

Гловинская М.Я. Активные процессы в грамматике // Современный русский язык. Активные процессы на рубеже XX-XXI веков / Отв. ред. Л.П. Крысин. М.: Языки славянских культур, 2008. С. 187-270.

Дубова О.А. Типологічна еволюція морфологічних систем української і російської мов: Монографія. Київ, 2002. 302 с.

Лекант П.А. Рост аналитизма в грамматическом строе современного русского языка // Русский язык: исторические судьбы и современность. Труды и материалы V Международного конгресса исследователей русского языка. М., 2014. С. 205206.

Петрухина Е.В. Русский глагол: категории вида и времени. М.: МАКС Пресс, 2009. $208 \mathrm{c}$.

Тираспольский Г.И. Становится ли русский язык аналитическим? // Вопросы языкознания. 1981. № 6. С. 37-49.

Тукова T.B. Усиление синтетизма грамматического строя современного русского языка // Русский язык: исторические судьбы и современность. Труды и материалы V Международного конгресса исследователей русского языка. М., 2014. C. 212-213.

Шульга М.В. Грамматические оппозиции в истории морфологии имени. М.: Индрик, 2017. 196 с. 


\author{
Maria $\boldsymbol{V}$. Shulga \\ Lomonosov Moscow State University \\ (Russia, Moscow) \\ shoulga@mail.ru
}

\title{
ON THE DEVELOPMENT OF SYNTHETIC MEANS IN THE DYNAMICS OF RUSSIAN LANGUAGE
}

Modern Russian language has obtained obvious synthetic properties in ways to express grammatical meanings - the conjunction of lexical and grammatical meanings in a word. In this article, we point out that throughout the foreseeable historical period, Russian language has significantly expanded its abilities to synthezise and has formed a whole arsenal of synthetic means. We focus on the processes that make a typological impact into Russian language and change both ways to express grammatical meanings and the degree of language synthesis. Those include some ways to form new parts of speech and grammatical categories, to express new grammatical meanings and to develop synthetic grammatical means based on analytical and wordformation elements.

We illustrate the formation of the numerals on the lexical basis of countable words and phrases by using various synthetic means and units which are actualized and invented to express the grammatical meaning.

Some synthetic grammatical means such as affixation and alternations in a word stem could be used to form the grammatical category of verb aspects based on lexico-semantic ways of verbal action. To express a regular grammatical meaning, the category of verb aspects has involved prefixes and suffixes - morphemes that has never participated to express grammatical meanings yet.

The formation and expantion of synthetic means on the basis of analytical and wordformation elements are particularly indicative for a modern vector of the grammatical system development.

Parallel functioning of analytical forms in the system of Russian language does not however indicate trends towards analytism as to a vector of the grammatical system development.

Key words: language typology, morphological system of Russian, synthetic forms, analytical forms, trends of morphological system development.

\section{References}

Vorotnikov, J. L. Grammaticheskij status analiticheskih form komparativa v russkom jazyke [Grammatical status analytical forms of comparative in the Russian language]. Slovar' i kul'tura russkoj rechi. K 100-letiju so dnja rozhdenija S. I. Ozhegova [Dictionary and culture of Russian speech. The 100th anniversary of the birth of S.I. Ozhegov]. Moscow, 2001, pp. 85-92. 
Glovinskaja, M.J. Aktivnye processy v grammatike [Active processes in the grammar]. Sovremennyj russkij jazyk. Aktivnye processy na rubezhe XX-XXI vekov [Modern Russian language. Active processes at the turn of 20-21 centuries]. L.P. Krysin (Ed.). Jazyki slavjanskih kul'tur Publ., Moscow, 2008, pp. 187-270.

Dubova, O. A. Typologichna evoljucija morfologichny system ukrajins'koji i rosijs'koji mov [Typological evolution of morphological systems of the Ukrainian and Russian languages]. Kyjiv, 2002.302 p.

Lekant, P.A. Rost analitizma v grammaticheskom stroe sovremennogo russkogo jazyka [The increase of analytism in the grammatical system of modern Russian language]. Russkij jazyk: istoricheskie sud'by i sovremennost'. Trudy i materialy V Mezhdunarodnogo kongressa issledovatelej russkogo jazyka [Russian Language: Its Historical Destiny and Present State. The Fifth International Congress of Russian Language Researchers. Lomonosov Moscow State University. Proceedings and materials]. Moscow, 2014, pp. 205-206.

Petruhina, E. V. Russkij glagol: kategorii vida i vremeni [Russian verb: the category of aspect and time]. Moscow, 2009. 208 p.

Tiraspol'skij, G. I. Stanovitsja li russkij jazyk analiticheskim? [Does Russian language analytical?]. Voprosy jazykoznanija. 1981, no. 6, pp. 37-49.

Tukova, T.V. Usilenie sintetizma grammaticheskogo stroja sovremennogo russkogo jazyka [Strengthening of synthesis of the grammatical structure of modern Russian language]. Russkij jazyk: istoricheskie sud'by i sovremennost'. Trudy i materialy V Mezhdunarodnogo kongressa issledovatelej russkogo jazyka [Russian Language: Its Historical Destiny and Present State. The Fifth International Congress of Russian Language Researchers. Lomonosov Moscow State University. Proceedings and materials]. Moscow, 2014, pp. 212-213.

Shul'ga, M. V. Grammaticheskie oppozicii v istorii morfologii imeni [Grammatical opposition in the history of the morphology of nominal categories]. Moscow, 2017. $196 \mathrm{p}$. 


\author{
С. Янурик \\ Будапештский университет им. Лоранда Этвеша \\ (Венгрия, Будапешт) \\ janurik@yahoo.com
}

\title{
АНГЛИЙСКИЕ ЗАИМСТВОВАНИЯ С ИСХОДОМ НА -Ш(Е)Н И -Ж(Е)Н В РУССКОМ ЯЗЫКЕ ПОСЛЕДНИХ ЛЕТ В СВЕТЕ СЛОВАРНЫХ И КОРПУСНЫХ ДАННЫХ
}

В статье рассматриваются процессы фонетико-графического и грамматического освоения новых английских заимствований с уникальным для русского языка консонантным исходом. Анализу подвергаются иноязычные неологизмы, оканчивающиеся на $-ш(e) н$ и -ж(e)н, зафиксированные в четвертом издании русского академического орфографического словаря 2012 г. В ходе исследования сопоставляются данные регистрации указанных англицизмов в современных лексикографических справочниках с учетом их графических вариантов и морфологических особенностей. Отмечаются колебания в выборе грамматического рода и склоняемости-несклоняемости этих слов на основе словарных и корпусных материалов. Выявляются отдельные случаи, когда лексикографическое представление английских заимствований не соответствует рекомендациям нормативного академического словаря. Анализируются расхождения в частотности употребления тех или иных вариантов написания у рассматриваемых нововведений в основном и газетном корпусах Национального корпуса русского языка. Приводятся количественные данные склоняемых и несклоняемых форм иноязычных неологизмов, относящихся к данной группе. При описании каждого из десяти англицизмов на -ш(e)н и -ж(е)н даются сведения о первой словарной фиксации слова и краткая характеристика его семантики. В заключительной части некоторых разделов также содержится информация о заимствованных существительных, которые способны выступать в функции несогласованного определения.

Ключевые слова: английские заимствования в русском языке, графические варианты, склоняемость, несклоняемость, морфологическая адаптация, словарная фиксация, корпусные данные.

В результате массового заимствования лексических единиц английского происхождения в русском языке конца XX — начала XXI века появилось и несколько 
иноязычных неологизмов с консонантным исходом, непривычным для фонетики и морфологии языка-реципиента. Среди них выделяется особая группа новых англицизмов, оканчивающихся на -щн и -жн (при наличии их фонетико-графических вариантов на -шен и -жен). В работах Е.В. Мариновой нововведениям данного типа посвящаются самостоятельные разделы, в которых автором проводится подробный анализ грамматических особенностей этих слов [Маринова 2008: 166171, Маринова 2014: 76-81].

По данным нового орфографического академического ресурса «Академос» Института русского языка им. В.В. Виноградова РАН, в последнем (четвертом) издании академического «Русского орфографического словаря» 2012 г. [РОС] зафиксировано всего девять английских заимствований с исходом на -шен (дисторшен, нон-фикшен, поул-позишен, промоушен, ресепшен, сейшен, солюшен, фешен, экшен) и один англицизм на -жен (фьюжен). В настоящей статье рассматриваются некоторые аспекты процесса графической и морфологической адаптации этих иноязычных неологизмов, сопоставляются данные их регистрации в современных лексикографических изданиях и анализируются случаи их употребления на основе контекстов, представленных в Национальном корпусе русского языка [НКРЯ].

Нормативными графическими формами исследуемых слов являются варианты с исходом на -шен и -жен: в [РОС] все англицизмы данной группы без исключения получили кодификацию последовательно именно в таком виде. Несмотря на это, в других лексикографических изданиях (словарях иностранных слов и неологизмов) наблюдается значительная вариативность при регистрации новых заимствований. Ниже дается краткое описание каждого из вышеупомянутых десяти англицизмов в современном русском языке.

\section{Нон-фикш(е)н}

Этот иноязычный термин, употребляющийся в русском языке с середины 1990-х годов, впервые зарегистрирован в неологическом словаре, охватывающем материалы данного десятилетия [НС3-90]. В русской лексикографии рассматриваемое заимствование, означающее 'жанр нехудожественной литературы', представлено чаще всего в написании нон-фикин. В то же время в академическом орфографическом словаре в качестве нормативной признается только форма нон-фикшен [РОС], а в словаре новейших иностранных слов зафиксировано оба варианта [Ш17]. Судя по словарным материалам, англицизм представляет собой существительное мужского рода, варьирующееся по признаку склоняемости-несклоняемости: ср. пометы «-а и неизм.» [НС3-90], «нескл. и неизм.» [РОС], и «-а» [Ш11, Ш17].

В НКРЯ в подавляющем большинстве случаев встречается графический вариант нон-фикин в неизменяемой форме, примеры же употребления слова в написании нон-фикшен ограничены единичными вхождениями. При анализе корпусных материалов обнаруживаются любопытные случаи использования английского заимствования в родительном падеже с окончанием - $a$ или без него в текстах одного и того же автора: «в отделы нон-фикина и хорошей прозы» (К. Мильчин: Бутик 
и супермаркет. // Русский репортер, 2012)», «хочется больше серьезного нонфикшн» (К. Мильчин: Призрачная англичанка гадит. // Русский репортер, 2014). Аналогично ведет себя в русском языке неологизм фикин, характеризующийся неустойчивостью морфологической адаптации слова, так же, как и новейшие композиты сайенс-фикин, фанфикин и палп-фикин [Ш17].

\section{Поул-позиш(е)н}

Этот спортивный термин в русском языке впервые зафиксирован в 1990-е годы. По данным неологического словаря, англицизм появился на страницах русских газет в 1993 г. в значении 'наиболее выгодное положение автомобиля, предоставляемое гонщику по итогам квалификационных заездов’ [НС3-90]. Графический облик слова является относительно устойчивым, в большинстве лексикографических изданий предпочитается форма поул-позишн. При этом в словарях иностранных слов Л.П. Крысина неологизм представлен в слитном написании: поулпозишн [КР09, КР12]. Распространенность дефисного написания подтверждается также корпусными данными: в основном и газетном корпусах НКРЯ присутствует исключительно этот графический вариант слова.

Нововведение английского происхождения в современном русском языке чаще всего употребляется как несклоняемое существительное женского рода. Однако интересно отметить, что в разных словарях одного и того же автора англицизм поул-позишн снабжен противоречивыми грамматическими пометами: «нескл., ж.» [Ш09], «неизм. и -а, м.» [Ш11], «нескл., м.» [Ш17]. В данных лексикографических изданиях колебания в роде и склоняемости слова иллюстрируются отрывками из публицистики последних лет: «сделал это с поул-позишна» (Советский спорт, 22.05.2005), «обошли обладателя поул-позишна» (АиФ-Online, 09.04.2007), «стартовал с поул-позишн» (АиФ-СЗ, 27.09.2010), «взял свой 27-й в карьере поулпозишн» (Ъ, 13.04.2013). При этом в НКРЯ склоняемых форм исследуемого заимствования совсем не встречается.

\section{Промоуш(е)н}

Этот широко употребляемый термин был заимствован из английского языка в начале 1990-х годов. В русской лексикографии он фиксируется с 1993 г. в вариантных написаниях промоушен и промоушн в значении 'содействие продвижению товара на рынке' [НС3-90]. Процесс графической адаптации неологизма не закончен и по сей день, в современных словарях по-прежнему сохраняется вариативность письменного оформления слова. На начальном этапе своего освоения англицизм с уникальным для русского языка консонантным исходом нередко использовался в неизменяемой форме: ср. название книги Л. Ханта «Основы телевизионного брэндинга и эфирного промоушн» (2003). В полном согласии с этой тенденцией, в словарях иностранных слов, вышедших в свет в первом десятилетии XXI века, часто находим помету «нескл.» при описании морфологических 
особенностей иноязычного термина [КР09, Ш09]. Однако в новых изданиях указанных справочников, составленных теми же самыми авторами, данное заимствование представлено уже как склоняемое существительное мужского рода [КР12, Ш11, Ш17].

Неустойчивость графического облика англицизма, а также его склоняемость подтверждаются и корпусными материалами. В основном корпусе НКРЯ преобладает вариант промоушн (41:21), в газетном же корпусе обе формы встречаются приблизительно с одинаковой частотностью (110:99, в пользу написания промоушн). Наличие вставочного гласного звука -e- в конце слова во многом способствует тому, чтобы иноязычный термин подчинялся общим правилам русской грамматики и начал изменяться по падежам. Об этом свидетельствуют и статистические данные в НКРЯ: в примерах в написании промоушен вхождения с разными флексиями оказываются в большинстве (в газетном корпусе - 55 из 99 , т. е. $55 \%$ ) или только немного уступают примерам в исходной форме слова (в основном корпусе - 9 из 21, т. е. $43 \%$ ). При этом для варианта промоушн неизменяемость характерна намного больше (32 из 41, т. е. $78 \%-89$ из 110, т. е. $81 \%$, соответственно).

\section{Ресепш(е)н}

В русской лексикографии это английское заимствование впервые зафиксировано в конце первого десятилетия XXI века в форме ресепшен и ресепшн [ССИС]. В дальнейших словарных изданиях отмечается не только вариативность в оформлении графического облика слова [Ш17], но и колебания по признаку склоняемости-несклоняемости неологизма [РОС]. В то же время в словаре иностранных слов Е.Н. Шагаловой изучаемое существительное мужского рода представлено в склоняемой форме: «ресепшн открыт не менее 14 часов в сутки», «наличие... сейфа на ресепшене» (Известия, 19.10.2011). В недавно вышедшем словаре англицизмов наряду с основным значением ('стойка регистрации в гостинице’) отмечается и новый семантический оттенок слова: 'место, куда прежде всего обращается клиент в общественном заведении' [САЗ].

Несмотря на относительно позднюю словарную фиксацию этого нововведения (см. выше), в НКРЯ наиболее ранние случаи его употребления приходятся на первые годы третьего тысячелетия: «с ресепшена позвонили» (Звезда, 2001), «человек на ,ресепшне“ объяснил» (Известия, 11.04.2002). При сравнении количественных данных всех вхождений англицизма в основном и газетном корпусах НКРЯ, можно прийти к следующим выводам:

1. в основном корпусе чаще встречается форма ресепшен $(24: 16)$, а в газетном наоборот, превалирует графический вариант ресепшн (110:62);

2. в обоих корпусах наблюдается взаимоотношение между наличием вставочного гласного звука -е- и склоняемостью слова: доля изменяемых форм намного больше в случае варианта ресепшен (8 из 24, т. е. $33 \%-43$ из 62, т. е. $69 \%)$, чем у ресепшн (4 из 16, т. е. $25 \%$ - 19 из 110 , т. е. $17 \%$ ). 
Рассматриваемое английское заимствование в русском языке употребляется не только в роли существительного, но может выполнять и функцию несогласованного определения: «это еще и стойка „ресепшн“» (Рекламный мир, 28.04.2003), «за стойкой ресепшен» (Русский репортер, 27.01.2011), ср. также лексикографическую регистрацию композита ресепшен-стойка [РОС].

\section{Сейш(е)н}

По данным неологического словаря, это английское заимствование известно в русском языке с 1987 г. в значении 'музыкальная вечеринка, неофициальный концерт’ [НС3-80]. Первоначальная вариативность графического облика слова сохранилась и в начале XXI века: во многих современных лексикографических изданиях иноязычный неологизм приводится в написаниях сейшен и сейшн. Несмотря на колебания в оформлении его письменной формы, нововведение широко употребляется в разговорной речи и сленге в качестве склоняемого существительного мужского рода. В словарях последних двух десятилетий рассматриваемое слово также часто закреплено в составе композитов типа джем-сейшен, рок-сейшен и др. [НСИС, ССИС, Ш09].

На основе анализа корпусных материалов можно прийти к интересным выводам относительно частотности графических вариантов английского заимствования и процесса его морфологической адаптации. В основном корпусе НКРЯ преобладает форма сейшен (38:28), а в газетном корпусе наблюдается обратная тенденция с преимуществом написания сейшн (34:23). При этом стоит отметить, что наличие или отсутствие вставочного гласного звука - $е$ - оказывает определенное влияние на склоняемость слова: в обоих корпусах вариант сейшн в большинстве случаев встречается в своей исходной форме (в основном - 22 из 28, т. е. $78 \%$; в газетном - 25 из 34, т. е. $73 \%$ ), а в примерах в написании сейшен доминируют вхождения с падежными окончаниями, нередко стоящие во множественном числе (сейшенов, сейшенах и т. д.), что совсем не характерно для исследуемой группы английских заимствований с исходом на -ш(е)н и -ж(e)н.

\section{Феш(е)н}

Этот англицизм появился в русском языке еще в середине XIX века. Его первую фиксацию можно найти в словаре Толля 1864 г. в написании фашион. Кроме основного значения 'мода' слово означало и 'высший свет, положение в высшем свете’ [Аристова 1978: 131]. В XX веке рассматриваемое иноязычное название вышло из употребления, и вернулось в русский язык только в начале XXI века, уже преимущественно в составе композитов типа фээнн-шоу, фэшн-бизнес и др. Именно в функции неизменяемой первой части сложных слов и регистрируется данное английское заимствование в современных русских лексикографических справочниках в форме фэшн- [РОС, Ш11, Ш17]. При этом в последних двух словарях закреплено также его использование в роли существительного в значении 'мода', 
с новым семантическим оттенком 'мода, следование тенденциям в одежде, косметике и т. п.’ В отличие от предыдущего издания, в котором слово описывается как склоняемое существительное мужского рода [Ш11], в новейшем словаре Е. Н. Шагаловой отмечаются колебания в категории рода: ср. дополнительную вариативную помету «нескл., ж.» [Ш17]. О неустойчивости морфологической адаптации англицизма свидетельствуют и примеры, приведенные автором словаря: «порождение этого фэшна» (Новая газета, 19.02.2007), «обязательное для фэшн разнообразие» (Ъ-Пермь, 10.09.2010). В то же время стоит отметить, что в этом же лексикографическом издании в словарной статье фасm-фэшн 'динамичное обновление коллекций в массовом сегменте рынка моды' о несклоняемости иноязычного термина не упоминается [Ш17].

В корпусных материалах однозначно доминирует графический вариант фэшн в функции определения. Написания фешн и фешен в НКРЯ представлены единичными примерами, так же, как и употребления англицизма в роли существительного: в основном корпусе 4 вхождения из 54 (т. е. 7\%), а в газетном - 16 из 148 (т. е. $11 \%$ ). Склоняемых форм исследуемого заимствования в НКРЯ совсем не обнаружено.

\section{Экші(е)н}

Первая регистрация иноязычного слова датируется 1993-м годом, в неологическом словаре он представлен в вариантных написаниях экшн и экшен [НС3-90]. Графический облик неологизма остается неустойчивым и по сей день, во многих лексикографических изданиях фигурируют обе формы [Комлев 1999, НСИС, Ш09, Ш11, Ш17]. Сфера употребления английского заимствования за последние десятилетия заметно расширилась: значение термина киноискусства и литературы ('жанр киноискусства, характеризующийся напряженным действием и быстрым развитием сюжета') распространилось и на мир компьютерных игр, в которых 'успех игрока зависит от скорости его реакции’ [СА3]. Наряду с этим, англицизм может выступать и в функции неизменяемого первого элемента композитов типа экшен-фильм, что получило отражение в современной русской лексикографии либо выделением формы экшен- / экшн- в отдельную словарную статью [Ш17], либо добавлением пометы «неизм.» при описании морфологических особенностей слова [POC].

Корпусные материалы свидетельствуют о том, что из двух графических вариантов рассматриваемого англицизма преимущество имеет форма экшн: в основном корпусе она превалирует в меньшей степени (88:66), а в газетном ее доля значительно больше (335:132). Указываемая словарями склоняемость неологизма подтверждается и корпусными данными, особенно при передаче этого заимствования в написании экшен: в обоих корпусах НКРЯ присутствуют все возможные грамматические формы слова в косвенных падежах (экшена, экшену, экшеном, экшене) в единственном числе и даже некоторые формы с окончаниями множественного числа (экшены, экшенов). Интересно отметить, что в газетном корпусе НКРЯ больше половины вхождений слов экщен встречается именно в склоняемой форме (36 из 66, т. е. $54 \%$ ). 


\section{Фьюж(е)н}

В русской неографии этот англицизм впервые зафиксирован еще в советское время [НС3-80]. До начала XXI века неологизм использовался исключительно для обозначения музыкального направления, возникшего на основе синтеза рока и джаза. О вторичном заимствовании слова и расширении его значения в других сферах жизни упоминает в своей монографии Е.В. Маринова, отмечающая употребление нововведения в лексике кулинарии [Маринова 2008: 171]. Первую регистрацию нового значения термина фьюжн находим в словаре иностранных слов 2008 г., в котором описание семантики слова дополнено еще одним смысловым оттенком: 'смешанный стиль в одежде, дизайне, интерьере' [НСИС]. В лексикографических изданиях последних лет английское заимствование чаще всего представлено в виде многозначного слова, однако не исключена и возможность его трактовки в рамках омонимии [ССИС]. Кроме этого, существует и третий способ словарного описания полисемантической лексемы, когда все отдельные значения слова объединены в обобщенную формулировку: 'сплав, слияние нескольких стилей и направлений в кулинарии, искусстве, интерьере' [САЗ]. При подаче сведений о грамматических особенностях неологизма фьюжн в современных словарях наблюдаются значительные расхождения, иногда даже у одного и то же автора-составителя приводятся противоречивые пометы: «неизм., ж. и с.» [Ш09], «неизм., м. и с.» [Ш11] и «нескл. и -а, м.» [Ш17].

В НКРЯ преобладают несклоняемые формы графического варианта фьюжн, нередко выступающие в роли определения в составе композитов типа фьюжн-ансамбль, фьюжн-музыка или в выражении в стиле фьюжн. Эта особенность англицизма нашла отражение во всех словарях Е.Н. Шагаловой, выделяющей форму фьюжн- в отдельную словарную статью [Ш09, Ш11, Ш17]. В корпусных материалах обнаруживаются примеры употребления этого неологизма как в женском, так и в мужском роде: «бум высокой европейской кухни, так называемой „фьюжн“»» (Бизнес-журнал, 30.01.2004), «татарский фьюжн во всем мире пошел на ура» (Русский репортер, 01.09.2011).

\section{Дисторш(е)н}

Первая фиксация иноязычного термина дисторшен обнаружена в последнем издании академического орфографического словаря [РОС]. В словаре иностранных слов Е.Н. Шагаловой новый англицизм представлен в форме графических вариантов дисторшен и дисторшн в значении 'эффект звучания, достигаемый искажением сигнала путем его ограничения по амплитуде, а также устройство, обеспечивающее такой эффект' [Ш17]. На настоящий момент рассматриваемое склоняемое существительное мужского рода в НКРЯ не встречается. 


\section{Солюш(е)н}

Употребление этого нового английского заимствования характерно в первую очередь для русского компьютерного жаргона. Его единственная лексикографическая регистрация находится в [РОС]. В сленге геймеров неологизм обозначает 'описание прохождения компьютерной игры, решение, подсказки' (http://teenslang. su/id/8032). В основном корпусе НКРЯ можно найти лишь одно вхождение данного жаргонизма, свидетельствующее о быстрой морфологической адаптации слова, несмотря на его низкую частотность в принимающем языке: «в одном из солюшнов на русском...» (Столица, 02.09.1997).

В заключение подведем итоги краткого обзора исследуемой группы иноязычных неологизмов. Нестабильность написания особенно характерна для англицизмов промоушн / промоушен, ресепшн / ресепшен, сейшн / сейшен и экшн / экшен. Кроме лексикографической регистрации вариантных написаний об отсутствии устойчивого графического облика у рассматриваемых слов, свидетельствуют также текстовые иллюстрации к словарным статьям и анализ вхождений этих лексических единиц в основном и газетном корпусах НКРЯ. При сравнении материалов русской лексикографической продукции последних двух десятилетий выясняется, что в остальных случаях составителями словарей предпочитаются формы без вставки гласного звука -е- (нон-фикшн, поул-позишн, фэшн и фьюжн). Количественное преимущество вариантов с исходом на -шн и -жн у этих неологизмов также подтверждается корпусными данными.

Вследствие заимствования возрастающего числа формально однотипных англицизмов в русском языке последних лет экзотичность звучания слов на -ин и -жн постепенно снижается и непривычный исход не мешает словоизменению иноязычных неологизмов [Маринова 2008: 168-171]. В академическом орфографическом словаpe $40 \%$ от общего числа анализируемых английских заимствований квалифицируется как склоняемое существительное (дисторшен, промоушен, сейшен и солюшен), два слова обнаруживают вариативность по признаку склоняемости-несклоняемости (ресепшен и экшен), остальные же получили в РОС помету «нескл.» (нон-фикшен, поул-позишен и фьюжен) или входят в группу неизменяемых прилагательных (фешен-). Однако на основе других словарных фиксаций, текстовых иллюстраций к словарным статьям в различных лексикографических изданиях, а также корпусных данных, не соответствующих рекомендациям РОС, можно прийти к выводу, что процесс графической и морфологической адаптации рассмотренных новых английских заимствований еще не завершился, поэтому вопрос о представлении данной группы слов в современной русской лексикографии остается открытым.

\section{Литература}

Аристова В. М. Англо-русские языковые контакты. Англизмы в русском языке. Л. : Издательство Ленинградского университета, 1978. 152 с. 
Комлев Н.Г. Словарь иностранных слов. М. : Эксмо-Пресс, 1999. 672 с.

[КР09] - Крыссин Л.П. 1000 новых иностранных слов. М. : АСТ-Пресс, 2009. $320 \mathrm{c}$.

[КР12] - Крысин Л.П. Современный словарь иностранных слов. М. : АСТПресс, 2012. 416 c.

Маринова E.B. Иноязычные слова в русской речи конца XX - начала XXI в.: проблемы освоения и функционирования. М. : Элпис, 2008. 495 с.

Маринова E.B. Освоение новых заимствований и сопутствующие процессы в русском языке начала XXI века // Новые тенденции в русском языке начала ХХІ века / ред. Л. В. Рацибурская. М. : Флинта, 2014. С. 36-133.

[НС3-80] - Новые слова и значения. Словарь-справочник по материалам прессы и литературы 80-х годов. СПб. : Дмитрий Буланин, 1997. 904 с.

[НС3-90] — Новые слова и значения. Словарь-справочник по материалам прессы и литературы 90-х годов ХХ века. Т. 1-3. СПб. : Дмитрий Буланин, 2009-2014. 811 с., 1392 с., 1360 c.

[НСИС] — Захаренко Е.Н., Комарова Л.Н., Нечаева И.В. Новый словарь иностранных слов. Изд. 3-е, испр. и доп. М. : Азбуковник, 2008. 1040 с.

[РОС] - Русский орфографический словарь. Изд. 4-е, испр. и доп. М. : АСТПресс, 2012. 896 c.

[САЗ] - Ходжагельдыев Б.Д., Шурупова О.С. Иллюстрированный словарь английских заимствований в русском языке последних лет. М. : Флинта, 2016. 148 с.

[ССИС] - Черкасова М.Н., Черкасова Л.Н. Современный словарь иностранных слов. Ростов-на-Дону: Феникс, 2009. 469 с.

[Ш09] - Шагалова Е.Н. Словарь новейших иностранных слов (конец XX начало XXI вв.). М. : АСТ, Астрель, 2009. 943 с.

[Ш11] - Шагалова E.H. Самый новейший толковый словарь русского языка XXI века. М. : АСТ, Астрель, 2011. 766 с.

[Ш17] - Шагалова Е.Н. Словарь новейших иностранных слов. М. : АСТПресc, 2017. 576 c.

\author{
Szabolcs Janurik \\ Eötvös Loránd University of Budapest \\ (Hungary, Budapest) \\ janurik@yahoo.com
}

\title{
ENGLISH LOANWORDS ENDING IN -U(E)H - RUSSIAN (ON THE BASIS OF LEXICOGRAPHIC AND CORPUS DATA)
}

The paper is devoted to the analysis of the phonetic-graphic and grammatical adaptation of new English loanwords ending in a group of consonants untypical of Russian. The author gives an overview of neologisms of foreign origin ending in $-u(e) \mu$ and $-\varkappa(e) H$ which are included into the latest edition of the academic orthographic dictionary of the Russian 
language published in 2012. In the study, dictionary entries of these Anglicisms are compared in various lexicographic works with a special emphasis on their graphic forms and morphological peculiarities. Variation in grammatical gender and declinability can be observed for this group of words on the basis of dictionary data and corpus materials. In some cases, the lexicographic representation of English loanwords does not correspond to the recommendations of the normative academic dictionary. Differences in the frequency of graphic variants of these neologisms are analyzed on the basis of the main section and the media section of the Russian National Corpus. A quantitative study of declinable and indeclinable forms of new words found in the Corpus are carried out. Other types of information are also provided, including the first registration of each of the ten Anglicisms concerned in Russian lexicography and a short description of their semantic features. In addition, it is mentioned that some of the examined nouns of English origin can also function as indeclinable adjectives after being borrowed into the Russian language.

Key words: English loanwords in Russian, graphic variants, declinability, indeclinability, morphological adaptation, lexicographic registration, corpus data.

\section{References}

Aristova V. M. Anglo-russkie yazykovye kontakty. Anglizmy v russkom yazyke. [English-Russian language contacts. Anglicisms in the Russian language]. Leningrad, Leningrad St. Univ. Publ., 1978. 152 p.

Komlev N. G. Slovar' inostrannykh slov. [A dictionary of foreign words]. Moscow, Eksmo-Press Publ., 1999. 672 p.

Krysin L.P. 1000 novykh inostrannykh slov. [1000 new foreign words]. Moscow, AST-Press Publ., 2009. 320 p.

Krysin L. P. Sovremennyi slovar' inostrannykh slov. [A modern dictionary of foreign words]. Moscow, AST-Press Publ., 2012. 416 p.

Marinova E. V. Inoyazychnye slova $v$ russkoi rechi kontsa XX - nachala XXI v.: problemy osvoeniya i funktsionirovaniya. [Foreign words in Russian speech of the end of the 20th century - the beginning of the 21st century: problems of adaptation and functioning]. Moscow, Elpis Publ., 2008. 495 p.

Marinova E. V. [The adaptation of new loanwords and the accompanying processes in the Russian language of the 21 st century]. Novye tendentsii v russkom yazyke nachala XXI veka. [New tendencies in the Russian language of the 21 st century.]. Edited by L. V. Ratsiburskaya, Moscow, Flinta Publ., 2014. pp. 36-133. (In Russ.)

Novye slova $i$ znacheniya. Slovar'-spravochnik po materialam pressy i literatury 80-kh godov. [New words and meanings. A dictionary based on the materials of press and fiction of the 1980s]. St. Petersburg, Dmitrii Bulanin Publ., 1997. 904 p.

Novye slova $i$ znacheniya. Slovar'-spravochnik po materialam pressy $i$ literatury 90-kh godov XX veka. T. 1-3. [New words and meanings. A dictionary based on the materials of press and fiction of the 1990s. Vol. 1-3]. St. Petersburg, Dmitrii Bulanin Publ., 2009-2014. 811 p., 1392 p., 1360 p. 
Zakharenko E. N., Komarova L.N., Nechaeva I. V. Novyi slovar' inostrannykh slov. Izd. 3-e, ispr. i dop. [A new dictionary of foreign words. 3th edition, improved and enhanced]. Moscow, Azbukovnik Publ., 2008. 1040 p.

Russkii orfograficheskii slovar'. Izd. 4-e, ispr. i dop. [Russian Orthographic Dictionary. 4th edition, improved and enhanced]. Moscow, AST-Press Publ., 2012. 896 p.

Khodzhagel'dyev B. D., Shurupova O. S. Illyustrirovannyi slovar' angliiskikh zaimstvovanii v russkom yazyke poslednikh let. [An illustrated dictionary of English loanwords in the Russian language of recent years]. Moscow, Flinta Publ., 2016. 148 p.

Cherkasova M. N., Cherkasova L. N. Sovremennyi slovar' inostrannykh slov. [A modern dictionary of foreign words]. Rostov-na-Donu, Feniks Publ., 2009. 469 p.

Shagalova E. N. Slovar' noveishikh inostrannykh slov (konets XX-nachalo XXI vv.). [A dictionary of the latest foreign words (the end of the 20th — the beginning of the $21 \mathrm{st}$ century)]. Moscow, AST, Astrel' Publ., 2009. 943 p.

Shagalova E. N. Samyi noveishii tolkovyi slovar' russkogo yazyka XXI veka. [A new explanatory dictionary of the Russian language of the 21 st century]. Moscow, AST, Astrel' Publ., 2011. 766 p.

Shagalova E. N. Slovar' noveishikh inostrannykh slov. [A dictionary of the latest foreign words]. Moscow, AST-Press Publ., 2017. 576 p. 


\title{
ОРФОГРАФИЯ И ОРФОЭПИЯ
}

\author{
Е.В. Бешенкова \\ Институт русского языка им. В. В. Виноградова РАН \\ (Россия, Москва) \\ evbeshenkova@gmail.com
}

\section{РЕТРОСПЕКЦИЯ КАК ФАКТОР ОРТОЛОГИЧЕСКОЙ ПОЛИТИКИ ОРФОГРАФИСТОВ. ЧАСТЬ 1}

Кодифицированная норма принципиально не может во всем совпадать с современной ей стихийной, узуальной нормой. Кодифицированная норма является результатом работы ученых и призвана не только отражать стихийно сложившуюся норму, но и исправлять ее в соответствии с выбранной целью кодификатора. Кодификатор тем самым не просто фиксирует обычай, а создает условия для реализации той потенции системы письма, того сценария развития, который ему представляется предпочтительным. Это предпочтение должно быть теоретически и фактически обосновано. Выбирая то или иное написание в качестве обязательной для грамотного человека нормы, орфографисты-кодификаторы учитывают целый ряд факторов, в том числе соответствие системе, текущему соотношению ее дихотомий, вектору развития системы, практике письма. Эти факторы часто предполагают разные решения, поэтому кодификатор вынужден отдавать предпочтение тому или иному фактору. Какие факторы оказывались предпочтительными для авторов словарей на протяжении века? Почему и в каких случаях прибегали они к изменению написания? Каким факторам соответствовали установившиеся в результате написания? В данной работе анализируются типы словарных разнонаписаний и пути их унификации на протяжении всего XX века. Материал ограничен данными Сводного словаря и некоторых словарей последних десятилетий. В статье описывается только материал, касающийся звуко-буквенных разнонаписаний, обусловленных противоречием системного и узуального факторов. Анализ материала показал, что первоначальная фиксация, опирающаяся на узуальный критерий, противоречащий системному критерию, постепенно заменялась на системный вариант. Это позволяет и сегодня среди множества узуальных вариантов выбирать с большей надеждой на успех именно системные варианты. 
Ключевые слова: ортология, политика орфографистов, ортологические факторы, норма, системный критерий, узуальный критерий, ретроспекция как критерий кодификавции.

Орфография как ортологическая наука включает в себя два аспекта: теоретический и практический. К теоретической части относится изучение объективных законов функционирования и исторической изменчивости нормативного письма в его соотношении с системой языка и узусом. В практической ортологической орфографии вырабатывается политика кодификаторов, выбираются конкретные словарные нормы, создаются правила правописания. Кодифицированная норма принципиально не может во всем совпадать с современной ей стихийной, узуальной нормой. Кодифицированная норма является результатом работы ученых и призвана не только отражать стихийно сложившуюся норму, зависящую от коллективного мышления и стихийных процессов стандартизации, но и исправлять ее в соответствии с выбранной целью кодификатора.

Кодификатор тем самым не просто фиксирует сложившийся (или не сложившийся) обычай, а создает условия для реализации той потенции системы письма, того сценария развития, который ему представляется предпочтительным.

Проанализируем, какие сценарии считались предпочтительными на протяжении последнего столетия, почему и насколько успешно иногда орфографисты прибегали к кодификации по системному ${ }^{1}$, а иногда по узуальному критерию, почему и с каким результатом они меняли ранее принятую кодификацию. Для этого сравним словарный материал разных эпох: для сравнительного анализа кодификационной политики мы использовали материалы «Сводного словаря современной русской лексики» ${ }^{2}$, которые охватывают словарную фиксацию лексики второй трети века (от словаря Д.Н. Ушакова 1935-1940 гг. и лексики 70-х годов). Отражение в Сводном словаре справочного отдела БАС позволяет увидеть и то, в каком состоянии было письмо в первой трети ХХ и несколько ранее. Для последующего полувека сводного словаря пока не создано, поэтому мы привлекаем материалы разных словарей, отражающих вариативность реального письма конца века.

В Сводном словаре есть длинный ряд орфограмм, которые были урегулированы правилами 1956 г. Данные Сводного словаря позволяют увидеть, сколь неустойчивым было наше письмо в середине века: практически все правила нарушались даже при словарной фиксации.

Несомненно, в целом политика орфографистов по коррекции кодификации в соответствии с правилами была успешной. Письмо стало значительно более единообразным, а сохранение лишь небольшого количества исключений делало систему

${ }^{1}$ Слово системный в данной работе употребляется в двух значениях: соответствующий системе правил и соответствующий системе письма.

2 Сводный словарь современной русской лексики. В 2 т. АН СССР. Ин-т рус. яз.; Под ред. Р.П. Рогожниковой. — М.: Рус.яз. 1991. 
более устойчивой. Хотя реальные колебания в отдельных словах встречались еще долго и встречаются до сих пор, авторы более поздних словарей их практически не отражали. Однако этап системного урегулирования (т.е. создание правил и словарная кодификация написаний слов, соответствующих правилу, а не узусу) прошел. В узусе стали появляться новые отклонения от правил.

В части буквенных орфограмм было только два правила, которые не привели к полной унификации написания: 1) правило о соблюдении единообразия графического облика морфов (это правило является одним из основных принципов письма) и исключение из него: правило о написании $b l / u$ в корне после приставки на согласный, 2) правило о передаче звука [э\#] ударного и соответствующего безударного после твердого согласного буквой $е$, в исключениях — э.

1а) Первое правило, т.е. правило о сохранении графического облика морфов, в первой половине XX века частотно нарушалось в случае встречи двух одинаковых согласных на стыке морфем. На стыке приставки и корня большинство слов писалось и пишется этимологически верно, но по данным Сводного словаря около пятидесяти слов отмечены в вариативном написании. Почти для всех было восстановлено и постепенно закрепилось этимологически правильное написание приставки и корня. Так, восстановлены написания многих слов с приставкой, восходящей к латинской приставке $a d$ и ее вариантам ag/ac/al/ap/ar/at/af/a/am/an, напр. аббревиатура (ср. бревиарий), акклиматизация, аккомодация, аккомпанемент, аккорд, аккуратный, аллегория, аллегретто, аллегри, аллегро, аппарат, аппендиu̧ит, апперцуепциия, аппликатура (но апеллящчия, аплодировать, апробацчия, апрош), ассамблея, ассенизатор, ассигнация, ассортимент, аттестат, аттракцион (но атрибут, атрибутивный, атрибуиия), аффект, аффинаж, аффинирование (хотя рафинирование). Однако слова с вариантами аг- и ар-получили разное написание, ср.: агломерат (ср. конгломерат), агрегат, агрессия, аранжировка, арест, аренда - агглютинация, арретировать. Восстановлено полное написание приставки диф- в дифференцииал, диффузия, но осталось дифракция. Из слов с этимологической приставкой o/ob/oc/op/of восстановлена удвоенная согласная в слове опnорmyнизм, но упрощена группа согласных в офис, официальнылй, а родственные оказия и окказионализм получили разное написание.

Политика орфографистов, направленная на восстановление этимологического написания на стыке приставки и корня, для иноязычных слов была успешной. В современном языке частотные ошибки встречаются именно в тех словах, в которых это написание не было восстановлено, напр. ап(n)елляция, диф(ф)ракция.

Новые заимствования воспроизводят написания в языке-источнике, напр. anплет, оффенсив-лайн (по данным словаря Шагаловой ${ }^{3}$. Кодификаторы и сегодня не сохраняют этимологически верное написание морфем, если в русском языке выделение этих морфем не поддерживается лексикой.

1б) Соблюдение правила единства написания морфем в заимствованных словах затруднено несколькими факторами: существованием иноязычных морфем

${ }^{3}$ Шагалова Е.Н. Словарь новейших иностранных слов. М., 2017. 
с чередованием, не свойственным русскому языку ${ }^{4}$, возможным разным написанием исторически однокоренных слов в разных языках 5 , сложностью идентификации морфем 6 , сосуществованием двух способов заимствования: фонетического и графического ${ }^{7}$, и, наконец, из-за разных способов звуковой передачи ${ }^{8}$. Разберем факторы, актуальные для современных заимствований.

Отличительной чертой современных заимствований является графически удвоенная согласная закрытого слога корня в словах с суффиксом на гласную, напр. сnлит сплиттер. В результате в русском языке появляются однокоренные слова с разным написанием корня, напр.: селинг при селлер, контроль, контролёр - контроллинг, контроллер, тревеллинг - тревел-чек, спот - споттинг. В $\mathrm{POC}^{9}$ зафиксировано 86 слов с графически удвоенной согласной и 20 слов с одиночной при графически удвоенной согласной в языке-источнике. Таким образом, в данной области письма можно констатировать преобладание несистемного подхода к кодифицированию нормы.

Сосуществование двух способов заимствования в наши дни является причиной колебания нескольких слов с приставкой re- в языке-источнике: $p(e / u) p a \check{\text { - }}$

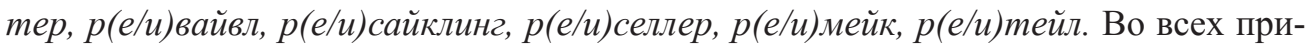
шедших ранее словах в русском языке эта приставка была транслитерирована как ре- (ревакциинация, регенерация, регресс, реорганизациия, ремилитаризация, реприватизация, реэвакуация), кроме двух слов-терминов риформинг (риформинг-установка) и рилизинг (рилизинг-факторы, рилизинг-гормоны) от англ. release, к которому также восходит и другой термин с другим написанием приставки: релиз. Кодификаторы сегодня рекомендуют системный вариант, соблюдающий единство написания морфемы, т.е. ремейк, рерайтер, ресейл, ресейлер.

2) Второе правило, т.е. правило о написании э/е после согласных, нарушалось частотно на протяжении всего столетия. Поскольку употребление буквы э какое-то время было ограничено позициями начала слова и после гласного, отдельные

${ }^{4}$ Из всех слов, восходящих к латинским корням с чередованием $\mathrm{b} / \mathrm{p}$, в русском языке это чередование сохранилось только в словах с корнем скрип/скриб: транскрипщия, инскрипта, постскриптум, скрипт, скрипторий, но транскрибировать, хотя по данным БАС и Ушакова колебания в написании имели слова адсорбция *адсорпция (нем. Adsorption от лат. adsorptio из ad-sorbeo) и резорбция и *резорпцияя. В первом случае кодификация была выбрана по этимологическому критерию, во втором - по системному.

${ }_{5}^{5}$ Напр., оказия - окказионализм.

${ }^{6}$ Например, не воспринимаются носителями русского языка как исторически однокоренные слова белладонна, беллетристика, бельведер, бельканто, бельэтаж, которые восходят к лат. bellus «милый, приятный».

${ }^{7}$ Например, французское еn в русском языке передается как звуковое соответствие $а н$ или как буквенное соответствие ен, напр. дантист - дентальный, пансион - пенсия, сантименть сентиментальный, серпантин - серпентин «камень змеевик». Слова английского языка с буквой $a$ передаются то как транслитерированные с русской буквой $a$, то как транскрибированные с буквами е (э), напр. данс и дэнс.

8 Западноевропейское сочетание $е и$ в русском может передаваться как эв (ев), ей или эу, сочетание $а и$ как ав или ау (напр,. авто и ауто, акванавт и Наутилус), $h$ - как $x$ или г или не передаваться вовсе, $c$ - как $\kappa$ или как $u, c$.

${ }^{9}$ РОС - Русский орфографический словарь. М., 2012 
словарные фиксации слов с э появились только в конце XIX в. (напр., муслинде-лэн Толль 1864 (mousseline de laine «шерстяной муслин») и мусли-де-лен Михельсон 1865, мэрия Михельсон 1898 (хотя мерия Чудинов 1910, мерия и мэрия Ушаков), пенснэ Даль. Слова мэр, пэр первоначально тоже писались с $e-$ мер (Яновский 1804, еще у Ушакова мер и мэр), пер (Б (справ. устар.)).

Но несмотря на распространение в узусе и фиксацию в отдельных словарях слов с э после согласной, постепенно нормой все-таки становилось написание с буквой e. Так, слова, фиксированные в XIX - начале XX в. в написании с буквой э (напр.: гобелэн, дэнди, джентльмэн, кабарэ, кашнэ, кэб, констэбль, матинэ, милэди, мулинэ, плэд, плэдик, порт-монэ, пэан, спардэк, турнэ), ко второй половине XX в. установились в словарной фиксации только с буквой $e$, хотя некоторые из них отмечены в вариативном написании еще в словаре Ушакова. При этом написание $e$ не зависело от произношения: $е$ пишется и после ставшего мягким согласного гобелен, и после согласного, сохранившего твердость портмоне, констебль и др. Слова, приходившие позже (бэдленд, бэкон, бэнди, гэнро, дзэрэн, истэблишмент, катэху, кэмпинг, нэ/айлон, матэ, мэдисон (танец), пенснэ, стэ/е/анд, сэт...), также получили единственную словарную кодификацию с буквой $е$ и такое же преимущественное узуальное написание. Судя по словарным фиксациям, процесс установления такого написания может занимать не один десяток лет, но он охватил все слова, кроме введенных исключений (мэр, пэр, сэр), а также собственных имен и их производных.

В теории ортологии такая норма обосновывалась наличием тенденции к смягчению согласного, особенно в безударном положении. Смягчение может сдерживаться написанием, а может и не сдерживаться. Если смягчение все-таки произойдет, а слово будет писаться с буквой э, то это приведет к разрушению сложившейся привативной оппозиции, т.е. к неразличению функций этих букв в позиции после согласного (и буква $е$, и буква э будут писаться и после мягких, и после твердых). Если последовательно отражать произношение, то велика вероятность появления однокоренных слов с разным написанием.

Поток заимствований в конце века принес в русский язык массу слов с этой

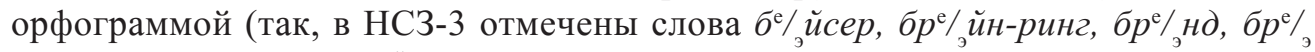

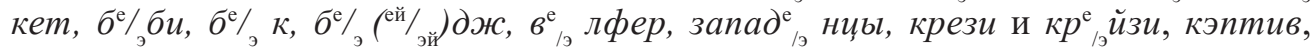

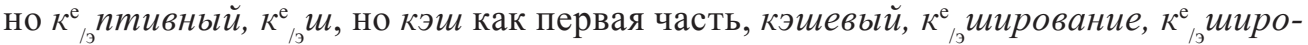

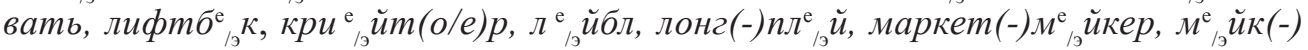

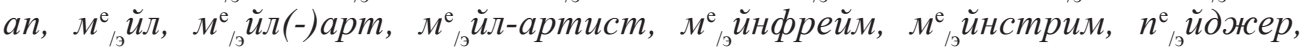
$n^{\text {e }}$ йнтбол). Однокоренные слова встречаются в разных написаниях, напр., кэn-

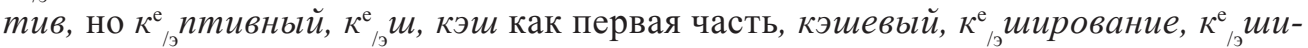
ровать. Политика орфографистов, направленная на сохранение привативной оппозиции $e-$ - была смягчена в последнее время: кодифицировано около ста слов с э после согласного. Однако по мере осваивания новых слов, однокоренные слова унифицировались в написании, установилось написание некоторых словообразовательных формантов, например, ер, ленд, мейкер, мен, вумен, фейс. Написание с е стало встречаться в практике письма значительно 
чаще. Словари последних лет, отражающие узус, а не кодификацию, фиксируют написание с $е$ для многих слов, отмеченных в вариативном написании или в написании только с буквой э в НС3-3. Например, в словаре Е. Н. Шагаловой зафиксированы написания: бейсербрейк, брейн..., бренд, беби «ребенок» (хотя появилось бэби «тип компьютерного корпуса» бейдж, лейбл, лонгплей, мейк(-) an, мейл, пейджер, пейнтбол, редимейд. Таким образом, можно констатировать действие тенденции расширения сферы употребления буквы $e$ после твердых согласных в освоенных словах. Новые слова, продолжающие приходить в язык в последние десятилетия, в значительной мере идут тем же путем, что и их предшественники. Написание слов с буквой э или вариативное написание с э/e фиксируется для большого числа слов, в том числе для тех, у которых уже есть однокоренные с устоявшимся написанием, напр., бейсер и новые однокоренные бейсраннер, но $\sigma_{\text {е }}^{\mathrm{e}}$ йсраннинг, устоявшееся мейл, но новое мэйлбокс, все слова на мен, но новое тротлм(е/э)н, устоявшееся написание корня ленд (диксиленд, Диснейленд, ленд-лиз...), но новые лэндспид-рейсинг (по словарю Шагаловой). Учитывая эту тенденцию и длительность процесса письменной адаптации слов, выявленную по материалам Сводного словаря, авторы академического нормативного словаря РОС не расширяют список слов с написанием буквы э. Это касается и последних заимствований. А для некоторых слов, ранее кодифицированных с буквой э, сейчас назрела необходимость в перекодификации, как для кендо, сенсей.

Таким образом, в данной области письма система сохраняет оппозицию маркированной буквы э, употребляющейся только после твердых согласных, и немаркированной буквы $e$, употребляющейся и после твердых, и после мягких согласных. Это дает основания орфографистам не торопиться зафиксировать в качестве нормы написания, свойственные входящим в язык единицам, как в начале XX в., так и в начале XXI в.

Сравнение выделенных типов слов с неустоявшимся написанием во второй трети XX века, предпринятых подходов к унификации их написания, с одной стороны, и типов слов в вариативном написании на рубеже веков, с другой стороны, позволяет более обоснованно подходить к сегодняшней кодификации. Прямое перенесение опыта политики нормирования во время одной социальной эпохи на материал другой социальной эпохи не всегда правомерен. Ретроспекция - это лишь один из критериев в общей палитре учитываемых при кодификации факторов. Он позволяет посмотреть на сегодняшние стихийные тенденции изменения написания как на точку в едином процессе, определить общий вектор изменений, его роль при появлении новых факторов влияния, учесть степень и время абсолютного принятия или непринятия обществом предыдущих кодификационных решений. Подытоживая анализ опыта работы кодификаторов на протяжении более ста лет, можно сказать, что отступления от политики сохранения системы приводило к последующей перекодификации, поэтому и сегодня тактической целью кодификаторов следует считать сохранение существующей системы и неуменьшение степени ее равновесности. 


\section{Литература}

НС3-3 - Новые слова и значения: словарь-справочник по материалам прессы и литературы 90-х годов ХХ века: в 3 т. СПб., 2014.

Русский орфографический словарь: около 200000 слов / Под ред. В.В. Лопатина, О.Е. Ивановой. Изд. 4-е, испр. и доп. М., 2012.

Сводный словарь современной русской лексики. В 2 т. АН СССР. Ин-т рус. яз.; Под ред. Р.П. Рогожниковой. - М.: Рус.яз. 1991.

Шагалова Е.Н. Словарь новейших иностранных слов. М., 2017.

\section{Elena V. Beshenkova}

V.V. Vinogradov Russian Language Institute of the Russian Academy of Sciences (Russia, Moscow) evbeshenkova@gmail.com

\section{RETROSPECTION AS A FACTOR IN THE ORTHOLOGIC POLICY OF SPELLING. PART 1}

The codified norm can't fundamentally coincide with the modern practice. The codified norm is the result of the work of scientists and is intended not only to reflect the spontaneously established norm, depending on collective thinking and spontaneous standardization processes, but also to correct it in accordance with the chosen goal of the codifier. The codifier thereby not only fixes the established (or not developed) custom, but creates conditions for the realization of that potency of the writing system, the scenario of development that seems preferable to it. This preference should be theoretically justified. Choosing a particular spelling as a norm for a literate person, spelling codifiers take into account a number of factors, including compliance with the system, the current ratio of its dichotomies, the system development vector, and the practice of writing. These factors are not built into a hierarchy, often they involve different solutions. Therefore, the codifier is forced to give preference to a particular factor. What factors were preferable for the author of the dictionaries for a century? Why did they change the codified spelling? What factors prevail with years? In this paper, we analyze the types of vocabulary divergences and ways of their unification throughout the 20th century. The material is limited to the data of the Consolidated Dictionary and some dictionaries of recent decades. The article describes only the material relating to the sound-letter varieties caused by the contradiction between systemic and practical factors. An analysis of the material showed that the initial fixation, based on an criterion of practice, contradicting the systemic criterion, was gradually replaced by a system variant. This allows today and among the many of the usual options to choose with greater hope for success is the system options.

Key words: orthology, spelling policy, orthologic factors, norm, system criterion, standard criterion, retrospection as a criterion for codification. 


\section{References}

Novye slova i znacheniya: slovar'-spravochnik po materialam pressy i literatury 90$k$ godov XX veka: $v 3 t$. [New words and meanings: dictionary-reference on the materials of the press and literature of the 90s of the twentieth century]. Spb., 2014.

Svodnyi slovar' sovremennoi russkoi leksiki [Consolidated dictionary of modern Russian language]. Vols 1-2. AN SSSR. In-t rus. yaz.; Pod red. R.P. Rogozhnikovoi. M.: Rus.yaz Publ. 1991.

Shagalova E. N. Slovar' noveishikh inostrannykh slov [The newest dictionary of foreign words]. M., 2017. 


\author{
Л. А. Вербицкая \\ Российская академия образования \\ (Москва, Россия) \\ president@pu.ru
}

\title{
ОСОБЕННОСТИ ФИКСАЦИИ ОРФОЭПИЧЕСКОЙ НОРМЫ СЕГОДНЯ
}

Статья посвящена описанию специфики орфоэпических и орфофонических особенностей произношения в русском литературном языке, вариантности и кодификации современной произносительной нормы.

Ключевые слова: произносительные нормы русского языка, орфоэпия, орфофония, вариантность нормы, кодификация произносительных норм.

Традиционно в нашем обществе сложилась ситуация, при которой, оценивая грамотную речь, в первую очередь обращают внимание на соблюдение правил правописания. Правила эти сформулированы достаточно чётко и просто: основной принцип написания - морфологический (он является ведущим и регулирует более $90 \%$ всех написаний), небольшая часть слов пишется в соответствии с принципом фонетическим (на письме отражается реальное произношение), часть - с традиционным, регулирующим написание непроверяемых гласных и согласных.

Правила написания меняются нечасто: последние изменения в свод правописания были внесены в 1956 году.

Вместе с тем нельзя не думать и о звучащей стороне нашей речи. А.П. Чехов писал: «В сущности ведь для интеллигентного человека дурно говорить должно считаться таким же неприличием, как не уметь читать и писать» [Чехов 1974-88: 267]. Лидерство в культурном и экономическом соревновании получают те страны, в которых развиты технологии и формы речевой коммуникации и нормализована речевая этика общества.

Каков язык - таков и человек, таково и общество. Через язык выражается вся сущность человека: мысли, чувства, воля, дела. Стиль жизни в определенной степени формируется стилем речи.

Всякая интеллектуальная профессия связана с языком. Например, политика есть общение, искусство объединять людей, а достижение этого возможно только с помощью слова. Поэтому слово - главное орудие политика. Успех в предпринимательстве связан с речью, ибо всякое дело организуется через слово. То же самое 
можно сказать и о речевом труде учителя, врача, юриста, военного. Речь общества воплощает в себе уровень культурного развития данного народа, способы восприятия мира. Речь тесно связана с культурой общества и оказывает влияние на мировоззрение людей.

Лингвистическая культура народа представляет собой исторически сложившийся набор языковых средств, посредством которых формируется своеобразный ракурс восприятия событий и явлений мира каждым членом социальной общности, позволяющих сохранить свою этническую принадлежность и приверженность традиционным духовным ценностям. Языковой среде каждого народа присуща уникальность используемых им языковых средств, как в формальном, так и в семантическом плане.

Языковое сообщество переживает разные периоды своего существования. Смена государственного строя, политические и экономические преобразования, новые социокультурные условия - все это, несомненно, не только обусловливает характер функционирования языка, но и способно привести к некоторым внутрисистемным языковым изменениям, свидетелями чего все мы стали в последние $20-30$ лет. Мы живем в период, когда языковая ситуация отличается нестабильностью, происходит своеобразное смешение, подмена диалектов, стилей, которые под воздействием процессов, происходящих в обществе, теряют свою функциональную прикрепленность.

При этом очень важно, чтобы звучала нормативная, с точки зрения орфоэпии (нормативного фонемного состава слова) и орфофонии (нормативной реализации фонем) речь.

Важно при изучении орфоэпической нормы понимать, что норма, во-первых, это категория внутриязыковая, присущая языку как системе, во-вторых, норма кодифицированная - это свод правил, предписывающих реализацию тех или иных единиц. Этот свод правил может быть сформулирован только в результате серьёзного экспериментально-фонетического исследования [Вербицкая 2001: 120].

Норма как категория лингвистическая определяется фонологической системой языка. При этом фонологическая система — это не только инвентарь фонем, но и дистрибуция фонем в речи, определенные оппозиции, в которые вступают фонемы, их сочетаемость, функциональная нагрузка и чередование фонем.

Норма произносительная является дальнейшим ограничением возможностей системы.

До середины прошлого столетия в течение 150-200 лет сосуществовали два различающихся варианта литературной произносительной нормы: московский и петербургский.

K XVIII веку в московском говоре уже в основном стабилизировались его главные отличительные особенности: современный тип литературного аканья и связанный с аканьем комплекс явлений, произношение г взрывного, твердое т в окончаниях глаголов 3-го лица единственного числа настоящего времени, местоименные формы меня, тебя, себя и т.п.

Некоторые культурные центры России имели известную самостоятельность, способствовавшую сохранению и выработке местных особенностей произношения. 
Наиболее самостоятельным и достаточно оформленным было петербургское произношение. Этому в значительной степени способствовало переселение столицы из Москвы в Санкт-Петербург.

Становление норм устной формы национального литературного языка - процесс более длительный, чем становление норм письменной формы языка. Большинство исследователей считает, что русское литературное произношение закрепилось, приобретя характер национальных норм, только в первой половине XIX века $(30-40$-е годы).

Как уже было сказано, в течение двух столетий существовало два равноправных варианта произносительной нормы: московский и петербургский (ленинградский). Московский вариант произносительной нормы сложился раньше петербургского. В основе петербургского произношения, по мнению В. И. Чернышева [Чернышев: 1970], лежит московский говор, так как в новой столице поселился прежде всего двор, высшие чиновники и знать, жившие до этого в Москве и говорившие по-московски. Однако в новой столице, строящейся заново, нужна была рабочая сила, которую набирали прежде всего из ближайших деревень. Петербургское произношение складывалось в первую очередь под воздействием окружающих город северновеликорусских и средневеликорусских говоров.

В лингвистической литературе довольно широко бытует утверждение, что особенности петербургского произношения объясняются влиянием письменной формы языка. В действительности влияние написания на формирование петербургсколенинградского произношения, как и на устную речь вообще, невелико (непонятно, почему письменная форма литературного языка не влияла на произношение москвичей). По-видимому, лишь небольшая часть признаков ленинградского произношения может быть объяснена влиянием орфографии. В основном же на особенности произношения воздействие оказывали более сложные факторы, и в их числе окружающие Петербург говоры.

Рассмотрение современной произносительной нормы требует подробного, исчерпывающего описания двух равноправных ее вариантов. Московский вариант, который многие исследователи считали основным, довольно подробно и систематично описан в литературе. В работах, посвященных описанию московской нормы, упоминаются и некоторые особенности петербургского произношения.

Описание петербургского произношения требует последовательного изложения всех орфоэпических особенностей, которыми это произношение отличалось от московского, независимо от времени, когда это различие имело место, и независимо от качества различия.

В фонетической литературе можно найти упоминание о 50 орфоэпических и орфофонических особенностях литературного произношения, относящихся к отдельным гласным и согласным, сочетаниям согласных и отдельным словам.

Наиболее яркими в звучащей речи начала-середины XX века были следующие особенности петербургско-ленинградского произношении, противоставляющие его московскому: 
1. Произнесение на месте орфографических е, а, я после мягких согласных в безударных положениях гласного /e/, а не /i/, т.е. веду/v'edu/, часы /č'esы/, nятак /p’etak/. Это устойчивая черта северновеликорусских говоров.

2. Произношение /e/ на месте орфографических е, я в заударных слогах, т.е. $n л а-$ чет как /plačet/, память как /pam’et'/.

3. Произношение /e/ в заударных открытых слогах, т.е. произношение слов поле, море как /pol'e/, /mor'e/.

4. Произношение /a/ в заударной флексии 3-го лица множественного числа глаголов II спряжения, т.е. ходят как /xod'at/ вместо московского /xod'ut/.

5. Произношение твердых губных перед ударным е в ряде слов и связанное с этим произношение открытого /ع/, например, слово ц̧вет как /cvet/ вместо /cv'et/.

6. Произнесение твердого $\mathrm{C}_{1}$ в сочетаниях $\mathrm{C}_{1} \mathrm{C}_{2}{ }_{2}\left(\mathrm{C}^{\prime}{ }_{1}-\right.$ мягкий произносился только в сочетаниях согласных одного активного артикулирующего органа, с помощью которого образованы согласные, например, /s't'/, /z'd'/: стена, здесь /s't'ena/, /z'd'es'/); так петербуржцы произносили каплет как/kapl'et/ в отличие от /kap'l'it/. Сохранились мягкие согласные лишь в суффиксе /stv/, т.е слово естественно, например, произносилось как /jes't'es't'v'enna/.

7. Произношение твердых губных согласных в конце слова или перед /i/, возникшее под влиянием северновеликорусских говоров, т.е. произнесение слов семь, кровь, объем, семья как /s'em/, /krof/, /abjom/, /s'emja/.

8. Произношение мягких заднеязычных в полных прилагательных мужского рода именительного падежа, т.е. крепкий, тихий как /kr'epk'ij/, /t’ix’'ij/ вместо московского /kr' ерkъj/, /t'iхъj/.

9. Произнесение мягкого /s'/ в возвратном постфиксе сь или ся, т.е. учусb, cmaрался как /uč'us'/, /starals'a/ вместо /uč'us/, /staralsa/.

10. Произношение на месте сочетания чн /č’n/ вместо московского /šn/, т.е. коричневый, конечно как /kar'ič'n'ivыj/, /kan'eč'na/.

11. Произнесение слова дождь как /došt'/ в отличие от московского /doš':/.

12. Произнесение твердых согласных перед /е/ в корнях отдельных заимствованных слов, например, сессия как /ses's'ija/ вместо /s'es's'ija/.

И еще три ярких орфофонических особенности в течение многих лет отличали петербуржцев-ленинградцев.

Это произнесение сочетаний сч, зч, щ как /šč'/ в отличие от московского /š':/, т.е. ищи как /išč'i/ вместо /iš’:i/, слабая палатализация /с̌'/ и смягчение аффрикаты /c/ перед /i/ в заимствованных словах, т.е. произнесение слов принципиально, лекциию как /pr' inc'ip'ial'na/, /l'ekc'iju/.

Орфоэпические особенности могут потенциально охватывать весь словарь, представлять собой так называемый открытый список (речь идет о признаках, связанных с произношением больших групп слов, как, например, слова с безударным орфографическим е в разных позициях, глаголы 3-го лица множественного числа II спряжения (типа ходят, держат), возвратные глаголы с частицей сь и т.п. (/učus', a не/učus/, как в Москве). Эти особенности могут относиться к произношению небольших групп слов и даже отдельных слов — так называемый закрытый 
список (это, например, слова с сочетанием чн: булочная, горничная (/bulačnaja/, a не /bulašnaja/) и др.

Орфофонические особенности обязательно охватывают весь словарь. Рассмотренные признаки петербургского произношения показывают, что основным для него было отсутствие последовательного иканья, преобладание твердых согласныхв позиции перед следующим мягким и др.

В большинстве случаев, как уже говорилось, особенности петкрбургского произношения определяются диалектным влиянием (приблизительно 80\%) и лишь небольшая часть - влиянием написания (приблизительно 20\%). Воздействие северновеликорусских говоров на произношение жителей Петербурга было двух типов: прямое воздействие диалектной особенности (например, отвердение губных согласных в конце слова), т.е. вторжение диалектного признака; или вторичное воздействие, т.е. появление особенности, которая образовалась в результате столкновения диалекта с литературным языком (например, возникновение в петербургском произношении более закрытого ударного /е/ по сравнению с московским).

Сравнение результатов исследования речи сегодняшних петербуржцев и москвичей показало, что существенных различий между ними нет. Так, на месте орфографических безударных е, а, я произносят /i/ и ленинградцы, и москвичи. Безударный /е/ сохраняется в некоторых случаях лишь в позиции абсолютного конца слова.

На месте орфографических е, я в начале слова произносится /ji/или /i/ и в небольшом количестве случаев — / je/. В спонтанной речи и в частотных словах только /i/. В заударных флексиях глаголов II спряжения 3-го лица множественного числа в значительном большинстве случаев произносят /a/ или /i/, но не /u/, как этого требовала старая московская норма: видят как /v'id'at/ или /v'id'it/, но не /v'id'ut/.

В прилагательных мужского рода единственного числа именительного падежа произносятся мягкие заднеязычные, т.е. великий как /v'il'ik'ij/, a не /v'il'ik'ъj/. В возвратных постфиксах — мягкий $/ \mathrm{s} \%$

$\mathrm{B}$ сочетаниях $\mathrm{C}_{1} \mathrm{C}_{2}{ }_{2}$ первый согласный мягкий только в тех случаях, когда оба согласных, входящих в сочетание, переднеязычные. Это свидетельствует о широком распространении в современном произношении сочетания твердого с последующим мягким.

Орфографическое сочетание чт произносится как /št/. Произношение орфографического сочетания чн как /с̌’n/ или /šn/ связано с конкретным словом, в состав которого оно входит, но существенных различий между петербуржцами и москвичами и в этом случае обнаружено не было.

В итоге можно утверждать, что в современном русском языке сформировалась единая произносительная норма, заимствовавшая часть черт старого московского произношения и часть черт старого петербургского.

Существенным фактором, способствующим установлению единой произносительной нормы, синтезировавшей особенности старого петербургского произношения и старого московского произношения, является распространение образования, рост культуры, интенсификация контактов. С этим связано и расширение сферы применения устной речи, речи спонтанной. 
Благодаря развитию средств массовой информации и особенно речи дикторов, ориентированной, как правило, на принятую кодифицированную норму, исчезают из речи горожан, живущих в зоне действия говоров, яркие диалектные черты.

При этом важно еще раз подчеркнуть, что побеждают и становятся нормативными те варианты, которые не противоречат системе.

Говоря о зависимости развития нормы от системы, следует сказать, что в фонологической системе русского языка наметился ряд закономерностей, определенных внутренних перестроек, которые могут привести к некоторым изменениям в норме.

Так, за счет расширения противопоставления твердых мягкими согласными перед гласным переднего ряда /е/ может увеличиться число позиций, в которых твердые и мягкие дифференцируются.

В сочетаниях $\mathrm{C}_{1} \mathrm{C}_{2}{ }_{2}$ идет процесс замены первого мягкого согласного твердым, так как все позиции ассимилятивного смягчения были позициями, где твердые согласные не противопоставлены мягким.

Намечается дальнейшее ограничение в употреблении гласных в безударной позиции: наблюдается тенденция к ослаблению функциональной нагрузки /u/: paзума как /razъma/, челюсть как /č'el'is't'/.

Происшедшие изменения нормы при речепроизводстве приведут к ее изменению и при речевосприятии.

Перечень основных особенностей современной русской орфоэпии и орфофонии дает возможность оценить те отклонения от нормы, которые встречались в речи дикторов радио и телевидения, государственных деятелей, разных групп носителей языка.

И.И. Цукерман определил норму как «диахронический лимит системы». Очевидно, что здесь подчеркнута зависимость нормы от системы и возможность выстраивания вариантов с учетом времени их появления. И.И. Цукерман говорил, что норма - это «постоянная борьба неотипа и архетипа» [Цукерман 1969].

Следует обратить внимание на то, что статье Л.В. Бондарко, Л.А. Вербицкой, Л.Р. Зиндераи В. Б. Касевича [1974: 20] "О типах произнесения и стилях произношения" четко противопоставляются два типа произношения: полного и неполного. При полном типе произношения абсолютно ясным является фонемный состав слова (например, веду /v’idu/, v’edu/ или v’adu/, а при неполном для определения фонемного состава слова требуется специальное исследование (например, фонемный состав слов добрая или доброе).

Ни один реальный текст не может состоять только из полного или неполного типа. Это всегда определенное соотношение того и другого стиля.

В последнее время лингвистов интересуют дифференциации различных типов в пределах одного языка, факторы, определяющие подобные дефференциации, нормализаторские процессы. Для этого в проводимых исследованиях учитывается вариативность языковых фактов, которая наиболее ярко проявляется в произношении. Именно такому типу варьирования (на уровне произношения) и посвящено множество исследований, в частности, исследований по классификации 
произносимых норм и их вариантов, выявлению специфики функционирования этих вариантов.

Классификация произносительных вариантов дана в работах К.С. Горбачевича [1978: 21], В.Я. Головиной [1983: 60] и др. Детально произносительная вариантность проанализирована в исследовании Л.А. Вербицкой [1993: 16], которая предлагает разграничивать орфоэпическую и орфофоническую вариантность, т. к. орфофоническая вариантность не подвергается кодификации и часто даже не замечается рядовыми носителями языка.

В современной лингвистике признано наличие в звуковой системе русского литературного языка двух подсистем: орфоэпической (фонологической) и орфофонической (фонетической). Фонетическая система стремится к стабильности, орфоэпическая система развивается под влиянием внутренних и внешних причин. В фонетическую подсистему объединяются все случаи, в которых процедура приведения фонемы к звуку описывается фонетическими законами. В эту подсистему попадут морфемы вне зависимости от их происхождения, семантики, морфологической природы и т.д. Критерий один - подчинение непреложным фонетическим законам. М.Л. Каленчук предложила разделять понятия фонетической обусловленности и орфоэпической прикрепленности, т.к. при фонетической обусловленности «фонетическая позиция однозначно требует появления того или иного варианта (действует фонетический закон)». При орфоэпической прикреплённости та или иная орфоэпическая позиция может «притягивать определённую реализацию фонемы, но возможность появления конкретного орфоэпического варианта предсказывается орфоэпической позицией только вероятностно, статистически (действует орфоэпический закон)» [Каленчук 1993: 28].

К орфоэпической подсистеме «относятся все случаи, когда процедура приведения фонемы к звуку осуществляется в терминах не фонетических законов, а орфоэпических, т. е. говоря иначе, все случаи орфоэпической вариативности» [Каленчук 1993: 28]. В связи с этим следует отметить, что Л. А. Вербицкая разграничивает вариативность и вариантность нормы. «Под первой следует понимать существование в данном синхроническом срезе равноправных вариантов выражения какойнибудь языковой единицы; под второй - наличие двух или нескольких вариантов, из которых один представляет отживающую норму, а другие, наоборот, возникающую, укрепляющуюся» [Вербицкая 1976: 19].

Категория вариантности рассматривается во многих разделах науки о языке. Вариантность нормы стала предметом лингвистической статистики, социологических исследований: «углублённая разработка конкурирующих вариантов существенна для теории языка, для выяснения некоторых тенденций его развития» [Горбачевич 1971: 21].

Варианты, появляющиеся в современном русском литературном языке, являются результатом территориальных, исторических, социальных условий жизни и деятельности носителей языка. В современных лингвистических работах продолжают изучаться такие типы варьирования, как территориальный, диахронический, социальный и функциональный. 
М.Л. Каленчук предлагает выделить в современном русском литературном языке социолингвистические и собственно языковые орфоэпические подсистемы: к первым относятся хронологические, территориальные, стилистические орфоэпические подсистемы, подсистема мужской и женской речи, ко вторым - подсистемы заимствованных слов, служебных слов, аббревиатур, имён собственных, междометий, терминов и др. [Каленчук 1993: 34-37].

Щербовская концепция русского нормативного произношения по-прежнему имеет неоценимое культурно-речевое значение, поскольку учит публичному произношению и необходимости отличать нормативные реализации от реализаций, свойственных спонтанной речи. Щербовские традиции плодотворно используются во множестве современных исследований и созданных по результатам этих исследований словарей.

Изучение произносительной нормы требует постоянного наблюдения, внимательного рассмотрения слабых точек системы, которые могут изменяться в первую очередь.

Решение кодификатора, т.е. квалификация того или иного варианта произношения как нормативного или ненормативного, допустимого или недопустимого определяется тремя основными факторами: распространенностью варианта в речи носителей литературного языка, произносительной традицией и соответствием варианта тенденциям развития языка.

Составители орфоэпических словарей в разной степени принимают во внимание эти факторы, по-разному оценивают роль того или иного фактора, поэтому в основе принятия конкретных решений в значительной степени лежит лингвистическая интуиция специалистов в области орфоэпии.

От кодификатора требуется известная смелость для того, чтобы узаконить вариант, который орфоэпическая традиция рассматривала как неприемлемый. Излишняя ориентация некоторых орфоэпических словарей на предшествующую произносительную традицию (часто это проявление так называемого "ученого пуризма") приводит к тому, что в них как нормативные часто представлены варианты произношения, которые уже не соответствуют реальной речевой практике основной массы носителей русского языка. Для современных орфоэпических словарей характерно признание довольно широкой вариантности в произношении, менее жесткая система запретительных помет.

Особое место среди лексикографических справочников занимает серия словарей-справочников «Давайте говорить правильно!», подготовленная на филологическом факультете Санкт-Петербургского государственного университета. Справочные пособия данной серии предназначены для самого широкого круга читателей и призывы помочь им избежать распространенных ошибок речи. Отличительной особенностью справочников данной серии является наличие пометы "неправильно!" и присутствием форм, не отвечающих нормам современного русского литературного языка, а также толкование получающих все большее распространение специальных терминов (из области политики, экономики, юриспруденции, церковной культуры, информационных технологий), недавних 
иноязычных заимствований и словообразовательных неологизмов. Первой из этой серии стала книга Л. А. Вербицкой «Давайте говорить правильно! Трудности современного произношения и ударения: краткий словарь-справочник. Лексическое ядро русского языка (с орфоэпическими и орфофоническими пометами)» [Вербицкая 2002]. В отличие от других орфоэпических словарей, грамматическая информация в данном справочнике сведена к минимуму. Каждое слово сопровождается фонематической транскрипцией (по Щербовской фонологической школе), причем только словарная форма слова: ср. ездить/jez'd'it'/, маневр /man'evr/, модерн /madern/, молочник /maloč'nik/, яйцо /jijco/ и т.д. В отдельных случаях указывается варианты произношения: ещзе /jis':o/, возм. /is:o/; желчный / zelč'nыј/, возм. /zolčnыј/; первое /p'ervai/, возм. /p'ervae/; термин/term'in/, возм. /t'erm'in/ и т.п. Однако запретительные пометы отсутствуют. Необходимо обратить внимание на то, что этот словарь-справочник, в отличие от всех остальных орфоэпических словарей и пособий, стремится провести орфоэпическую норму произношения [i] ([ы]) на месте орфографического «э» в начале слова не под ударением: ср. экономика /ыkanom'ika/, экран /ыkran/, элита /ыl'ita/, энтузиаст / ыntuz'iast/ и т.п. Включение такого типа сведений, обычно знакомых лишь узкому кругу специалистов-фонетистов, в издание, направленное на популяризацию представлений о произносительной норме, представляется чрезвычайно значимым явлением.

Большим событием в сфере кодификации русской произносительной нормы стал выход в 2012 г. «Большого орфоэпического словаря русского языка» (БОС) под редакцией Л.Л. Касаткина. В БОС включались слова, которые имеют варианты произношения в одинаковых фонетических позициях и на письме, сочетания букв, которые могут читаться по-разному в разных словах (було[ч']наяи бу-

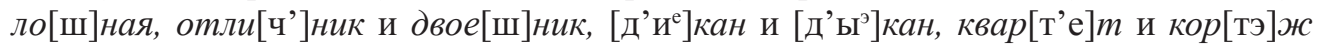
и т.п.), а также имеют варианты ударения в одной словоформе (ба́ржа - баржа́) или в разных словоформах парадигмы (мост, моста́, на мостý, но о мо́cme).

В словаре представлен максимально широкий набор произносительных вариантов для каждого из более чем 80000 включенных в него слов. БОС отличается от других орфоэпических словарей тем, что это уже не только орфоэпический словарь трудностей, но в известной степени и фонетический словарь русского литературного языка, в котором отмечаются варианты, принадлежащие к старшей и младшей норме (ср. ина́че и допуст. старш. и́наче; де[фст]венник, допуст. старш. де[фст']венник и допуст. устарелое де[фс'т']венник), а также варианты произношения, встречающиеся в разных фонетических позициях и в беглой речи (ср. вооружить в[ьа]ружать, в беглой речи возможно в[ь]ружать; явить - [и'

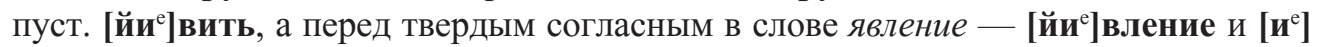
вление; я[в]ление и допуст. устарелое я[в']ление; здравствуйте - [здравствуй] те и допуст. [здрас']те, в беглой речи возможно [драс']те). Система запретительных помет имеет градацию: «не рекомендуется», «неправильно», «грубо неправильно»; ср. в форме готовьтесь — гото[ф’]тесь ! не рек. гото[ф]тесь; [жу]pu ! не рек. [ж’ури]; кори[ч']невый ! не рек. кори[ш]невый; ср. в форме готовься - гото [ф’] 
ся! неправ. гото[ф]ся; $ф a[$ н’е]pa ! неправ. фа[нэ]ра; капитали[3] $и$ ! грубо неправ. капитали[3’]м; симпати[ч'] ный ! грубо неправ. симпати[ш]ный.

Совершенно очевидно, что те или иные характеристики устной речи не могут быть регламентированы и проверены на основе письменной формы речи.

В заключение хотелось бы подчеркнуть, что исследования орфоэпии и орфофонии, решение проблем, связанных с кодификацией современной произносительной нормы, могут проводиться только фонетистами, получившими специальную подготовку в области анализа артикулярных, акустических, перцептивных характеристик сегментных и супрасегментных единиц речи.

Норма - это идеал, к которому должны стремиться все говорящие. От успешной реализации этого стремления зависит не только чистота русской речи, но и будущее развитие звуковой системы языка.

\section{Литература}

Аванесов Р. И. Русское литературное произношение. 6-е изд., перераб. и доп. M, 1984. - 383 c.

Алентаева Е.Ю. Фонетическая вариативность частотных слов под воздействием социальных факторов (на материале русских числительных): Дис. ... канд. филол. наук. СПб, 1999.

Аттиа А.М. Критерии нормативной оценки языковых вариантов в русской лингвистической традиции. Язык и общество на пороге нового тысячелетия. Итоги и перспективы: Тез.докл. международной конференции. М, 2001. С. 295-297.

Ахманова О.С., Данчинова И. А. Социолингвистика в свете эвристики и онтологии языка. Теоретические проблемы социальной лингвистики. М, 1981.

Барнет $B$. Проблемы изучения жанров устной публичной речи. Современная русская устная научная речь. Под общ. ред. О. А. Лаптевой. Красноярск, 1985. T. 1 - C. 40-43.

Беликов В. И., Крысин Л.П. Социолингвистика. М, 2001. 439 с.

Белл Т. Р. Социолингвистика: Цели, методы, проблемы. М, 1980.318 с.

Блумфилд Л. Язык. Пер. с англ. М, 1968. 500 с.

Бондарко Л.В. Фонетика современного русского языка. М, 1998. С. 247-267 (Гл. 11. Фонетика и произносительная норма).

Бондарко Л.В., Вербиц̧кая Л.А. О факторах, влияющих на фонетические характеристики языка, используемого для межнационального общения. Материалы IV симпозиума: Ареальные исследования в этнографии и языкознании. Л, 1978.

Борунова С.Н. О влиянии внутриязыковых факторов на распределение произносительных вариантов в современном русском литературном языке (ассимилятивная мягкость согласных). Филологические науки. 1980. №4.

Борунова С. Н., Воронцзова В. Л, Еськова Н.А. Орфоэпический словарь русского языка. Произношение, ударение, грамматические формы. М, 201

Большой энциклопедический словарь. Языкознание. Под ред. В. Н. Ярцевой. М, 1998.685 c. 
Ваулина Е. Ю. Давайте говорить правильно! Юридическая терминология современной России. Краткий словарь-справочник. М, 2006.

Ваулина Е. Ю., Скляревская Г.Н. Давайте говорить правильно! Трудности грамматического управления в современном русском языке. Краткий словарь-справочник. СПб, 2003.

Benpeва Т.И. Рефлексия как аксиологическая основа формирования стилистической нормы. Культурно-речевая ситуация в современной России. - Екатеринбург, 2000.

Вербиикая Л. А. Русская орфоэпия. СПб, 2013.

Вербиикая Л. А., Игнаткина Л.В., Сергеева Т.А., Гейльман Н. И. Литературное произношение. Разговорная речь. Проблемы и методы экспериментально-фонетического анализа речи. Под общ.ред. Л.Р. Зиндера и Л. В. Бондарко. Л, 1980. С. 100122.

Вербицкая Л. А. Вариантность нормы и типы произнесения. Экспериментальнофонетический анализ речи. -1997. - Вып. 3.

Вербицкая Л. А. Давайте говорить правильно. СПб, 2001.

Вербиикая Л.А. Русская орфоэпия: (К проблеме экспериментально-фонетического исследования особенностей современной произносительной нормы). М, 1976. $124 \mathrm{c}$.

Вербицкая Л. А. Современное русское литературное произношение (теоретические проблемы и экспериментальные данные): Автореф. дис. ... д- рафилол. наук. Л, 1977.

Вербиџкая Л.А. Социально обусловленные процессы в современном русском произношении. // Вопросы социолингвистики: Материалы советских социолингвистов к XII всемирному конгрессу социологов - M, 1990.

Вербиикая Л.А. Основные тенденции развития произносительной нормы русского языка. // Фонетика сегодня. М, 2010

Вербицкая Л. А. Роль языковой нормы в практике обучения русскому языку. // Вестник Московского государственного открытого педагогического университета им. М. А. Шолохова. М, 2011

Вербиикая Л.А. Русская литературная произносительная норма нового столетия. // Вестник Северо-Западного отделения Российской академии образования. СПб, 2010

Вербицкая Л. А. Языковая норма в практике обучения русскому языку. // Сборник материалов международной конференции "Русский язык в коммуникативном пространстве современного мира". - М, 2011.

Вербиикая Л.А., Игнаткина Л.В., Литвачук Н.Ф. и др. Региональные особенности реализации русской речи (на фонетическом уровне). // Вестник ЛГУ. 1984. № 8. Вып. 2. С. 71-80.

Вербиикая Л.А. Давайте говорить правильно! Трудности современного произношения и ударения. Краткий словарь-справочник. М, 2003.

Вещиккова И. А. Орфоэпия: основы теории и прикладные аспекты. — М. Флинта, 2007. $310 \mathrm{c}$. 
Ганиев Ж. В. Вариативность в русском произношении: перманентная борьба вокруг нормы (прошлое, современность). Дис. ... д- рафилол. наук. М, 2009.

Ганиев Ж. В. Неизменный принцип русской орфоэпии. М, 2009.

Ганиев Ж. В. Русский язык. Фонетика и орфоэпия. М, 1990. 173 с.

Ганиев Ж. В. Фонетический эксперимент и господствующая идеология. // Фонетика сегодня. Материалы докладов и сообщений V Международной научной конференции. - М., 2007. С. 46-48.

Гаспаров Б. М. Устная речь как семантический объект. Семантика номинации и семантика устной речи. // Лингвистическая семантика и семиотика 1. Учёные записки Тартуского госуниверситета. 1978. Вып. 442. С. 53-69.

Гловинская М.Я., Кузьмина С. М. Влияние социальных факторов на распределение фонетических вариантов в современном русском литературном языке. // Теоретическая фонетика и обучение произношению: Сб. ст. М, 1975.

Головин Б.Н. Вопросы социальной дифференциации языка. Вопросы социальной лингвистики. Л, 1969.

Головина В.Я. К типологии языковой вариантности. Вопросы языкознания. 1983 -№ 2.

Горбачевич К. С. Вариантность слова и языковая норма. Л, 1978.

Горшков А.И. Вопрос о вариантности норм в связи с пониманием языка как системы систем. Литературная норма и вариантность. М, 1981.

Граудина Л. К. Вопросы нормализации русского языка. М, 1980.

Еськова Н. А. Краткий словарь трудностей русского языка. М, 1999.

Замыслова В.Н. Варианты произношения сочетания согласныхносителями русского литературного языка (социолингвистический аспект). // Филологические страницы. - М., 1999. Вып. 1. С. 133-137.

Земская Е.А., Ширяев Е.Н. Устная публичная речь: разговорная или кодифицированная? // Вопросы языкознания. - М., 1980. № 2. С. 61-71.

Иванова Т. Ф. Новый орфоэпический словарь русского языка. М, 2005

Каленчук М.Л. Об устойчивости орфоэпического навыка. // Жизнь языка: Сб. статей к 80-летию М. В. Панова. М, 2001. С. 165-171.

Каленчук М.Л. Орфоэпическая система современного русского литературного языка: Дис. ... д-ра филол. наук. М, 1993.

Каленчук М. Л, Касаткин Л. Л, Касаткина Р. Ф. Большой орфоэпический словарь. Литературное произношение и ударение начала XXI века: норма и ее варианты. Под ред. Л. Л.Касаткина. М, 2012.

Каленчук М. Л, Касаткина Р.Ф. Словарь трудностей русского произношения. M, 2001.

Касаткин Л.Л. Современный русский язык. Фонетика. М, 2006. С. 178-222.

Касаткин Л. Л, Клобуков Е. В., Лекант П. А. Краткий справочник по современному русскому языку. Под ред. Леканта. 2-е изд., испр. и доп. М, 1995.- 380 с.

Князев С. В., Пожарицукая С. К. Современный русский литературный язык. Фонетика, орфоэпия, графика, орфография. М, 2005. - с. 226- 253.

Колесов В. В. Язык города. М, 1991. 190 с. 
Костомаров В.Г., Бурвикова Н. Д. Старые мехи и молодое вино: Из наблюдений над русским словоизменением конца XX века СПб. Златоуст, 2001. 72 с.

Крысин Л. П. Проблема социальной и функциональной дифференциации языка в современной лингвистике. Современный русский язык: Социальная и функциональная дифференциация. Отв. ред. Л.П. Крысин. М, 2003. С. 11-33.

Крысин Л. П. Речевое общение и социальные роли говорящих. Социально-лингвистические исследования. М, 1976.

Крысин Л.П. Социолингвистическое исследование вариантов современного русского литературного языка. М, 1980.

Крысин Л. П. Толковый словарь иноязычных слов. М, 2008.

Мечковская Н. Б. Социальная лингвистика. 2-е изд., испр. М, 1996. - 205 с.

Немченко В.Н. Вариантность слова в русском языке: Фонематические варианты. Нижний Новгород, 1992. 221 с.

Новый орфографический словарь русского языка под ред. В.В. Бурцевой. M, 2002.

Попов М. Б. Фонетика современного русского языка. СПб, 2014.

Проблемы и методы экспериментально-фонетического анализа речи. Под общей ред. Л. Р. Зиндера и Л. В. Бондарко. Л, 1980.

Родионова A. E. Язык «общества спектакля». [Электронный ресурс] http://www. situation.m/app/iartp_14.htm.

Розенталь Д. Э., Теленкова М.А. Словарь трудностей русского языка. М,2003.

Русский орфографический словарь под ред. В.В. Лопатина. М, 2007.

Русский язык конца XX столетия. Под ред. Земской Е.А.М. Языки русской культуры, 2000. 437c.

Рябцева Н.К. Новая лингвистика и моделирование естественного интеллекта. Русский язык: исторические судьбы и современность. Межд. конгресс исследователей русского языка. М, 2001. С. 112-113.

Семенюк Н.Н. Формирование литературных норм и типы кодификационных процессов. Языковая норма. Типология нормализационных процессов. М, 1996.

Скляревская Г.Н., Ваулина Е. Ю. Давайте говорить правильно! Новейшие и наиболее распространенные заимствования в современном русском языке. М.-СПб., 2004.

Скляревская Г.Н., Ваулина Е.Ю. Давайте говорить правильно! Новые и наиболее распространенные экономические термины в современном русском языке. Краткий словарь-справочник. М, 2006.

Скляревская Г.Н., Ваулина Е.Ю. Давайте говорить правильно! Новые и наиболее распространенные финансовые термины в современном русском языке. Краткий словарь-справочник. М, 2005.

Скляревская Г.Н., Ткачева И.О. Давайте говорить правильно! Политический язык современной России. М, 2004.

Словарь современных понятий и терминов под ред. В. А. Макаренко. М, 2000.

Тарковский Р. Б. Русская поэзия и московские орфоэпы. (К истории произношения слова «скучно» и подобных). ИР ЛИ РАН. Труды отдела древнерусской литературы. - СПб, 2004. Т. 55. С. 3-205. 
Тарковский Р.Б. Русская поэзия и московские орфоэпы. О произношении слов скучно, нарочно, конечно и подобных. - СПб. Дмитрий Буланин, 2006. 397 с.

Толковый словарь русского языка начала XXI века. Актуальная лексика. Под ред. Г.Н. Скляревской.

Химик B.В. Поэтика низкого, или Просторечие как культурный феномен. СПбГУ, 2000. 272 с.

Цукерман И.И. Вариантность как диахронический лимит системы // Письменные памятники и проблемы истории культуры народов Востока. Тез.докл. Л., 1968.

Чернышев В. И. Как говорят в Петербурге. - Избранные труды. Т.1. М., 1970.

Чехов А. П. Полное собрание сочинений и писем в 30 т., М., 1974-88, Т.16, с 267.

Ширяев Е.Н. Типы норм и вопрос о культурно-речевых оценках. Культурноречевая ситуация в современной России. Под ред. Н.А.Купиной. Екатеринбург, 2000. С. 13-21.

Ястрежембский В. Р. Языковая вариативность и лингвистическое объяснение. Проблемы языковой вариативности: Сб. обзоров. М, 1990. С. 48-52.

\author{
Lyudmila A. Verbitskaya \\ Russian Academy of Education \\ (Russia, Moscow) \\ president@pu.ru
}

\title{
PRESENT-DAY DOCUMENTATION OF THE ORTHOEPIC NORM
}

This paper is focused on the development of the orthoepic and orthophonic characteristics of the Russian literary pronunciation norm, as well as on the variation and codification of the modern pronunciation norm.

Key words: orthoepy, orthophony, modern pronunciation norm, sound variants.

\section{References}

Avanesov R.I. Russkoe literaturnoe proiznoshenie. [Russian literary pronunciation] 6-e izd., pererab. i dop. - M, 1984.-383 s.

Alentaeva E. Yu. Foneticheskaya variativnost' chastotnykh slov pod vozdeistviem sotsial'nykh faktorov (na materiale russkikh chislitel'nykh) [Phonetic variability of the frequency of words under the influence of social factors (on the material of Russian numerals)]: Dis. ... kand. filol. nauk. SPb, 1999.

Attia A. M. Kriterii normativnoi otsenki yazykovykh variantov v russkoi lingvisticheskoi traditsii. Yazyk i obshchestvo na poroge novogo tysyacheletiya. Itogi i perspektivy: Tez.dokl. mezhdunarodnoi konferentsii. [Criteria for regulatory evaluation of linguistic variants in the Russian linguistic tradition. Language and society on the threshold of the new Millennium. Results and prospects] M, 2001. S. 295-297. 
Akhmanova O. S., Danchinova I. A. Sotsiolingvistika v svete evristiki i ontologii yazyka. Teoreticheskie problemy sotsial'noi lingvistiki [Sociolinguistics in the light of heuristics and ontology language. Theoretical problems of social linguistics]. M, 1981.

Barnet V. Problemy izucheniya zhanrov ustnoi publichnoi rechi. Sovremennaya russkaya ustnaya nauchnaya rech' [Problems of the study of the genres of oral public speech. Modern Russian oral scientific speech]. Pod obshch. red. O. A. Laptevoi. Krasnoyarsk, 1985. - T. 1 - S. 40-43.

Belikov V. I., Krysin L.P. Sotsiolingvistika [Sociolinguistics]. M, 2001. 439 s.

Bell T.R. Sotsiolingvistika: Tseli, metody, problem [Goals, methods, problems]. M, 1980. $318 \mathrm{~s}$.

Blumfild L. Yazyk [Language]. Per. s angl. M, 1968. $500 \mathrm{~s}$.

Bondarko L. V. Fonetika sovremennogo russkogo yazyka [Phonetics of modern Russian language]. M, 1998. S. 247-267 (Gl. 11. Fonetika i proiznositel'naya norma).

Bondarko L.V., Verbitskaya L.A. O faktorakh, vliyayushchikh na foneticheskie kharakteristiki yazyka, ispol'zuemogo dlya mezhnatsional'nogo obshcheniya. Materialy IV simpoziuma: Areal'nye issledovaniya v etnografii i yazykoznanii [About the factors that affect the phonetic characteristics of the language used for international communication. Proceedings of the IV Symposium: Areal studies in Ethnography and linguistics.]. L, 1978.

Borunova S. N.Ovliyanii vnutriyazykovykhfaktorovna raspredelenieproiznositel'nykh variantov $v$ sovremennom russkom literaturnom yazyke (assimilyativnaya myagkost' soglasnykh) [On the impact of intra-language factors on the distribution of pronunciation variants of the modern Russian literary language (assimilative soft consonants)]. Filologicheskie nauki. 1980. №4.

Borunova S. N., Vorontsova V. L, Es'kova N. A. Orfoepicheskii slovar' russkogo yazyka. Proiznoshenie, udarenie, grammaticheskie formy [Pronouncing dictionary of the Russian language. Pronunciation, stress, grammatical forms]. M, 201

Bol'shoi entsiklopedicheskii slovar'. Yazykoznanie [Big encyclopaedic dictionary. Linguistics]. Pod red. V.N. Yartsevoi. M, 1998. 685 s.

Vaulina E. Yu. Davaite govorit' pravil'no! Yuridicheskaya terminologiya sovremennoi Rossii. Kratkii slovar'-spravochnik Let's speak correctly! Legal terminology in modern Russia. A brief dictionary]. M, 2006.

Vaulina E. Yu., Sklyarevskaya G.N. Davaite govorit' pravil'no! Trudnosti grammaticheskogo upravleniya $v$ sovremennom russkom yazyke. Kratkii slovar'-spravochnik [Let's speak correctly! Difficulties of grammatical management of modern Russian language. A brief dictionary.]. SPb, 2003.

Vepreva T.I. Refleksiya kak aksiologicheskaya osnova formirovaniya stilisticheskoi normy. Kul'turno-rechevaya situatsiya v sovremennoi Rossii [Reflection as the axiological basis for the formation of stylistic norms. Cultural-speech situation in modern Russia]. - Ekaterinburg, 2000.

Verbitskaya L.A. Russkaya orfoepiya [Russian orthoepy]. SPb, 2013.

Verbitskaya L.A., Ignatkina L.V., Sergeeva T.A., Geil'man N.I. Literaturnoe proiznoshenie. Razgovornayarech'. Problemyimetodyeksperimental'no-foneticheskogo 
analiza rechi [Pronunciation. Speaking. Problems and methods of experimental phonetic analysis of speech]. Pod obshch.red. L. R. Zindera i L. V. Bondarko. L, 1980. S. 100-122.

Verbitskaya L.A. Variantnost' normy i tipy proizneseniya. Eksperimental'no-foneticheskii analiz rechi. [Variability of norms and types of utterance. Experimental phonetic analysis of speech]-1997. — Vyp. 3.

Verbitskaya L. A. Davaite govorit' pravil'no [Let's speak correctly]. SPb, 2001.

Verbitskaya L. A. Russkaya orfoepiya: (K probleme eksperimental'no-foneticheskogo issledovaniya osobennostei sovremennoi proiznositel'noi normy) [Russian orthoepy: (To the problem of experimentally-phonetic research of features of modern pronunciation norm)]. M, 1976. $124 \mathrm{~s}$.

Verbitskaya L.A. Sovremennoe russkoe literaturnoe proiznoshenie (teoreticheskie problemy i eksperimental'nye dannye) [Modern Russian literary pronunciation (theoretical problems and experimental study)]: Avtoref. dis. ... d- rafilol. nauk. L, 1977.

Verbitskaya L.A. Sotsial'no obuslovlennye protsessy v sovremennom russkom proiznoshenii. [Social processes in the modern Russian pronunciation] // Voprosy sotsiolingvistiki: Materialy sovetskikh sotsiolingvistov k XII vsemirnomu kongressu sotsiologov - M, 1990.

Verbitskaya L.A. Osnovnye tendentsii razvitiya proiznositel'noi normy russkogo ya$z y k a$ [Main trends in the development of pronunciation norms of the Russian language] // Fonetika segodnya. M, 2010

Verbitskaya L.A. Rol' yazykovoi normy v praktike obucheniya russkomu yazyku [The Role of linguistic norms in the practice of teaching the Russian language] // Vestnik Moskovskogo gosudarstvennogo otkrytogo pedagogicheskogo universiteta im. M. A. Sholokhova. M, 2011

Verbitskaya L.A. Russkaya literaturnaya proiznositel'naya norma novogo stoletiya [Russian literary pronunciation norm of the new century] // Vestnik Severo-Zapadnogo otdeleniya Rossiiskoi akademii obrazovaniya. - SPb, 2010

Verbitskaya L. A. Yazykovaya norma v praktike obucheniya russkomu yazyku [Language norm in the practice of teaching the Russian language] // Sbornik materialov mezhdunarodnoi konferentsii "Russkii yazyk v kommunikativnom prostranstve sovremennogo mira". - M, 2011.

Verbitskaya L.A., Ignatkina L. V., Litvachuk N.F. i dr. Regional'nye osobennosti realizatsii russkoi rechi (na foneticheskom urovne) [Regional features of realization of Russian speech (phonetic level)] // Vestnik LGU. 1984. № 8. Vyp. 2. S. 71-80.

Verbitskaya L.A. Davaite govorit' pravil'no! Trudnosti sovremennogo proiznosheniya i udareniya. Kratkii slovar'-spravochnik [Let's speak correctly! The difficulties of modern pronunciation and accent. A brief dictionary]. M, 2003.

Veshchikova I. A. Orfoepiya: osnovy teorii i prikladnye aspekty [Orthoepy: basic theory and application aspects]. - M. Flinta, 2007. $310 \mathrm{~s}$.

Ganiev Zh. V. Variativnost' v russkom proiznoshenii: permanentnaya bor'ba vokrug normy (proshloe, sovremennost') [Variability in Russian pronunciation: permanent struggle around the norms (past, present)]. Dis. ... d- rafilol. nauk. M, 2009. 
Ganiev Zh. V. Neizmennyi printsip russkoi orfoepii [Core Principle of Russian orthoepy]. M, 2009.

Ganiev Zh. V. Russkii yazyk. Fonetika i orfoepiya [Russian language. Phonetics and orthoepy]. M, 1990. $173 \mathrm{~s}$.

Ganiev Zh. V. Foneticheskii eksperiment i gospodstvuyushchaya ideologiya [Phonetic experiment and the dominant ideology] // Fonetika segodnya. Materialy dokladov i soobshchenii V Mezhdunarodnoi nauchnoi konferentsii. — M., 2007. S. 46-48.

Gasparov B.M. Ustnaya rech' kak semanticheskii ob"ekt. Semantika nominatsii i semantika ustnoi rechi [Speaking as a semantic object. The semantics of the category and semantics of spoken language] // Lingvisticheskaya semantika i semiotika 1. Uchenye zapiski Tartuskogo gosuniversiteta. 1978. Vyp. 442. S. 53-69.

Glovinskaya M. Ya., Kuz'mina S. M. Vliyanie sotsial'nykh faktorov na raspredelenie foneticheskikh variantov $v$ sovremennom russkom literaturnom yazyke [The Influence of social factors on the distribution of phonetic variants of the modern Russian literary language] // Teoreticheskaya fonetika i obuchenie proiznosheniyu: Sb. st. M, 1975.

Golovin B. N. Voprosy sotsial'noi differentsiatsii yazyka. Voprosy sotsial'noi lingvistiki [Issues of social differentiation of language. The problems of social linguistics]. L, 1969.

Golovina V. Ya. K tipologii yazykovoi variantnosti. Voprosy yazykoznaniya [To the typology of linguistic variability. Questions of linguistics.]. — 1983 -№ 2.

Gorbachevich K. S. Variantnost' slova i yazykovaya norma [Variability of speech and language norm]. L, 1978.

Gorshkov A. I. Vopros o variantnosti norm v svyazi s ponimaniem yazyka kak sistemy sistem. Literaturnaya norma i variantnost' [The Question of the variance of standards in relation to understanding language as a system of systems. Literary norm and variation]. M, 1981.

Graudina L.K. Voprosy normalizatsii russkogo yazyka [The Issues of normalization of the Russian language]. M, 1980.

Es'kova N. A. Kratkii slovar' trudnostei russkogo yazyka [Concise dictionary of difficulties of Russian language]. M, 1999.

Zamyslova V.N. Varianty proiznosheniya sochetaniya soglasnykhnositelyami russkogo literaturnogo yazyka (sotsiolingvisticheskii aspekt) [Variants of the pronunciation of the combination soglashayasj of the Russian literary language (sociolinguistic aspect)] // Filologicheskie stranitsy. - M., 1999. Vyp. 1. S. 133-137.

Zemskaya E. A., Shiryaev E.N. Ustnaya publichnaya rech': razgovornaya ili kodifitsirovannaya? [Oral public speech: spoken or codified?] // Voprosy yazykoznaniya. M., 1980. №2. S. 61-71.

Ivanova T.F. Novyi orfoepicheskii slovar' russkogo yazyka [New pronouncing dictionary of the Russian language]. M, 2005

Kalenchuk M. L. Ob ustoichivosti orfoepicheskogo navyka [On stability of pronouncing skill] // Zhizn' yazyka: Sb. statei k 80-letiyu M. V. Panova. M, 2001. S. 165-171.

Kalenchuk M. L. Orfoepicheskaya sistema sovremennogo russkogo literaturnogo ya$z y k a$ [Orthoepic system of the modern Russian literary language]: Dis. ... d-ra filol. nauk. M, 1993. 
Kalenchuk M. L, Kasatkin L. L, Kasatkina R.F. Bol'shoi orfoepicheskii slovar'. Literaturnoe proiznoshenie $i$ udarenie nachala XXI veka: norma i ee variant [Large pronouncing dictionary. Literary pronunciation and stress in the beginning of the XXI century: the norm and its variants]. Pod red. L. L. Kasatkina. M, 2012.

Kalenchuk M. L, Kasatkina R.F. Slovar' trudnostei russkogo proiznosheniya [Dictionary of difficulties of Russian pronunciation]. M, 2001.

Kasatkin L. L. Sovremennyi russkii yazyk. Fonetika. [Modern Russian language. Phonetics]M, 2006. S. 178-222.

Kasatkin L. L, Klobukov E. V., Lekant P. A. Kratkii spravochnik po sovremennomu russkomu yazyku [Quick reference in the modern Russian language]. Pod red. Lekanta. 2-e izd., ispr. i dop. M, 1995.- 380 s.

Knyazev S. V., Pozharitskaya S. K. Sovremennyi russkii literaturnyi yazyk. Fonetika, orfoepiya, grafika, orfografiya [Modern Russian literary language. Phonetics, orthoepy, graphics and orthography]. M, 2005. - s. 226-253.

Kolesov V. V. Yazyk goroda [Language of the city]. M, 1991. $190 \mathrm{s.}$

Kostomarov V. G., Burvikova N. D. Starye mekhi i molodoe vino: Iz nablyudenii nad russkim slovoizmeneniem kontsa XX veka. [Old wineskins and new wine: From observations on the Russian inflection of the end of XX century] SPb. Zlatoust, 2001. $72 \mathrm{~s}$.

Krysin L.P. Problema sotsial'noi i funktsional'noi differentsiatsii yazyka $v$ sovremennoi lingvistike. Sovremennyi russkii yazyk: Sotsial'naya i funktsional'naya differentsiatsiya [The Problem of social and functional differentiation of language in modern linguistics. Modern Russian language: Social and functional differentiation]. Otv. red. L.P. Krysin. M, 2003. S. 11-33.

Krysin L.P. Rechevoe obshchenie i sotsial'nye roli govoryashchikh. Sotsial'nolingvisticheskie issledovaniya [Speech communication and social roles of the speakers. Socio-linguistic research]. M, 1976.

Krysin L.P. Sotsiolingvisticheskoe issledovanie variantov sovremennogo russkogo literaturnogo yazyka [Sociolinguistic study of the variants of the modern Russian literary language]. M, 1980.

Krysin L.P. Tolkovyi slovar' inoyazychnykh slov [Explanatory dictionary of foreign words]. M, 2008.

Mechkovskaya N.B. Sotsial'naya lingvistika [Social linguistics]. 2-e izd., ispr. M, 1996. - $205 \mathrm{~s}$.

Nemchenko V.N. Variantnost' slova v russkom yazyke: Fonematicheskie variant [Variability of speech in the Russian language: Phonemic variants]. Nizhnii Novgorod, 1992. $221 \mathrm{~s}$.

Novyi orfograficheskii slovar' russkogo yazyka [A new spelling dictionary of the Russian language], pod red. V. V. Burtsevoi. M, 2002.

Popov M. B. Fonetika sovremennogo russkogo yazyka [Phonetics of modern Russian language]. SPb, 2014.

Problemy $i$ metody eksperimental'no-foneticheskogo analiza rechi [Problems and methods of experimental phonetic analysis of speech]. Pod obshchei red. L. R. Zindera i L. V. Bondarko. L, 1980. 
Rodionova A.E. Yazyk «obshchestva spektaklya» [The Language of "society of the spectacle"]. [Elektronnyi resurs] http://www.situation.'m/app/iartp_14.htm.

Rozental' D.E., Telenkova M.A. Slovar' trudnostei russkogo yazyka [Dictionary of Russian language difficulties]. M, 2003.

Russkii orfograficheskii slovar' [Russian spelling dictionary], pod red. V. V. Lopatina. M, 2007.

Russkii yazyk kontsa XX stoletiya [Russian language of the late twentieth century]. Pod red. Zemskoi E. A. M. Yazyki russkoi kul'tury, 2000. 437s.

Ryabtseva N. K. Novaya lingvistika i modelirovanie estestvennogo intellekta. Russkii yazyk: istoricheskie sud'by i sovremennost' [New linguistics and modeling of natural intelligence. Russian language: its historical destiny and present state]. Mezhd. kongress issledovatelei russkogo yazyka. M, 2001. S. 112-113.

Semenyuk N. N. Formirovanie literaturnykh norm i tipy kodifikatsionnykh protsessov. Yazykovaya norma. Tipologiya normalizatsionnykh protsessov [The formation of literary norms and types of codification processes. Language norm. The typology of normalization processes]. M, 1996.

Sklyarevskaya G. N., Vaulina E. Yu. Davaite govorit' pravil'no! Noveishie i naibolee rasprostranennye zaimstvovaniya $v$ sovremennom russkom yazyke [Let's speak correctly! The newest and most common borrowings in the modern Russian language]. M.-SPb., 2004.

Sklyarevskaya G. N., Vaulina E. Yu. Davaite govorit' pravil'no! Novye i naibolee rasprostranennye ekonomicheskie terminy $v$ sovremennom russkom yazyke. Kratkii slovar'-spravochnik [Let's speak correctly! New and most common economic terms in modern Russian language. A brief dictionary]. M, 2006.

Sklyarevskaya G. N., Vaulina E. Yu. Davaite govorit' pravil'no! Novye i naibolee rasprostranennye finansovye terminy $v$ sovremennom russkom yazyke. Kratkii slovar'spravochnik [Let's speak correctly! New and the most common financial terms in modern Russian language. A brief dictionary]. M, 2005.

Sklyarevskaya G. N., Tkacheva I. O. Davaite govorit' pravil'no! Politicheskii yazyk sovremennoi Rossii [Let's speak correctly! The political language of modern Russia]. M, 2004.

Slovar' sovremennykh ponyatii $i$ terminov [A dictionary of modern concepts and terms], pod red. V.A. Makarenko. M, 2000.

Tarkovskii R.B. Russkaya poeziya i moskovskie orfoepy. (K istorii proiznosheniya slova «skuchno» $i$ podobnykh) [Russian poetry and the Moscow orthoepy. (The history of the pronunciation of the word "boring" and the like)]. IR LI RAN. Trudy otdela drevnerusskoi literatury. - SPb, 2004. T. 55. S. 3-205.

Tarkovskii R. B. Russkaya poeziya i moskovskie orfoepy. O proiznoshenii slov skuchno, narochno, konechno i podobnykh [Russian poetry and the Moscow orthoepy. About the pronunciation of words is boring, on purpose, of course, and the like]. - SPb. Dmitrii Bulanin, 2006. $397 \mathrm{~s}$.

Tolkovyi slovar' russkogo yazyka nachala XXI veka. Aktual'naya leksika [Explanatory dictionary of Russian language of the early twenty-first century. Relevant vocabulary]. Pod red. G. N. Sklyarevskoi. 
Khimik V.V. Poetika nizkogo, ili Prostorechie kak kul'turnyi fenomen [Poetics low, or Vernacular as a cultural phenomenon]. SPbGU, 2000. $272 \mathrm{~s}$.

Tsukerman I. I. Variantnost' kak diakhronicheskii limit sistemy [Variability as a diachronic limit of the system] // Pis'mennye pamyatniki i problemy istorii kul'tury narodov Vostoka. Tez.dokl. L., 1968.

Chernyshev V.I. Kak govoryat v Peterburge [As they say in St. Petersburg]. - Izbrannye trudy. T.1. M., 1970.

Chekhov A.P. Polnoe sobranie sochinenii i pisem v $30 t$. [Complete works and letters in 30 T.], M., 1974-88, T.16, s 267.

Shiryaev E. N. Tipy norm i vopros o kul'turno-rechevykh otsenkakh. Kul'turno-rechevaya situatsiya $v$ sovremennoi Rossii [Types of norms and the question of culture and language assessments. Cultural-speech situation in modern Russia]. Pod red. N. A. Kupinoi. Ekaterinburg, 2000. S. 13-21.

Yastrezhembskii V. R. Yazykovaya variativnost' i lingvisticheskoe ob"yasnenie. Problemy yazykovoi variativnosti [Language variation and linguistic explanation. The problem of language variability]: Sb. obzorov. M, 1990. S. 48-52. 


\author{
С.В. Друговейко-Должанская \\ Санкт-Петербургский государственный университет \\ (Россия, Санкт-Петербург) \\ s.drugoveyko@gmail.com
}

\title{
К ЧЕМУ (ЗИЦ)ПРЕДСЕДАТЕЛЮ ДЕФИС, ИЛИ ГРАФИКСАЦИЯ КАК СИМПТОМ
}

В статье рассматривается употребление слов с начальным элементом зии- в современных текстах, а также фиксация подобных образований в лексикографических источниках. Анализируемый материал свидетельствует не только об упорном стремлении пишущих к дефисному оформлению слов с элементом зиц- (вопреки орфографическим рекомендациям), но и об автономизации этого элемента, которая выражается в его способности использоваться в качестве существительного. В данном случае дефисация (разбиение слова дефисами на части с приданием этим частям другого значения) демонстрирует, что дифференцирующим написаниям в русском языке свойствен высокий функциональный статус «различителей тонких смыслов».

Ключевые слова: орфография, дефисные написания, дифференцирующие написания, графиксация, окказиональное словообразование.

Слова с начальным элементом зиц- не представлены в современных словарях не только толковых, но и орфографических. До недавних пор единственным лексикографическим напоминанием о существительных подобного типа могла служить статья в «Толковом словаре русского языка» под редакцией Д. Н. Ушакова:

ЗИЦРЕДАКТОР, а, $\boldsymbol{м}$. (нем. Sitzredaktor - редактор для отсидки) (полит. арго, дореволюц. и загр.). Подставной редактор, несущий официальную ответственность перед властями за журнал, газету и в случае репрессий отсиживающий в тюрьме наказание [Ушаков 1935: 1100].

Кроме этого, в комментарии к повести А. Стругацкого «Экспедиция в преисподнюю» зафиксировано толкование номинации зиџкапитан:

Двуглавый Юл, бывший знаменитый вольный пират, а ныне всего лишь зицкапитан, мрачно восседал в своем знаменитом кресле, поддерживая вконец обессилевшую правую голову обеими руками. 
Зицкапитан - до- и послереволюционная практика найма подставных лиц для отсидки тюремных сроков - зицпредседателей, зицредакторов, от нем. sitzen “сидеть”. В литературе - зицпредседатель Фунт, персонаж «Золотого теленка» И. Ильфа и Е. Петрова

Очевидно, что в сознании носителей русского языка зиц- связывается прежде всего с героем романа И. Ильфа и Е. Петрова «Золотой теленок» - зициредседателем Фунтом:

— Я — Фунт, — повторил он с чувством. - Мне девяносто лет. Я всю жизнь сидел за других. Такая моя профессия - страдать за других.

- Ах, вы подставное лицо?

- Да, - сказал старик, с достоинством тряся головой. - Я - зицпредседатель Фунт. Я всегда сидел. При Александре втором - Освободителе, когда Черноморск был еще вольным городом, при Александре третьем - миротворце, при Николае втором — кровавом. <..> Я должен только сидеть, в этом моя профессия. ${ }^{2}$

Подробный комментарий к роману свидетельствует:

Наем подставных лиц для отсидки тюремных сроков - зицпредседателей, зицредакторов, от нем. Sitzen 'сидеть' - практика, идущая от дореволюционных времен. В период цензурных репрессии после революции 1905 г. был большой спрос на подставных редакторов (Гиляровский, Москва и москвичи, гл. Москва газетная. Соч. т. 3, 147). В юмореске А. Аверченко «Гололедица» фигурирует «зицредактор» журнала («Ответственный редактор! Чуть что — в ответе я!»), человек невежественный и не имеющий отношения к журнальному делу (8 одноактн. пьес, 7-8)

В указанных источниках слова зищредактор, зицкапитан и зиципредседатель даны в слитном написании, которое соответствует действующим правилам орфографии: «Слитно пишутся... сложные слова с начальными частями, русскими и иноязычными, близкими к приставкам, напр.: всепрощзение, всеобъемлющий, ежемесячный, инопланетянин, инонациональный, лженаука, лжесоциалистический, общенародный, общепризнаннылй, полумесяи, полусладкий, полулежать, полушутя, самодостаточный, самолечение; панамериканский, квазинаучный, псевдоготика, псевдонародныйџ [ПАС: 117].

Однако в других книжных текстах эта орфографическая рекомендация нередко не соблюдается, например:

${ }^{1}$ Миры братьев Стругацких: Энциклопедия. Т. I (А-Л). - М.: АСТ; СПб.: Terra Fantastica, 1999. C. 114.

2 Цит. по: Ильф И., Петров Е. Золотой теленок: Роман. — М.: Панорама, 1995.

${ }^{3}$ Щеглов Ю.К. Комментарии к роману «Золотой теленок» / Ильф И., Петров Е. Золотой теленок: Роман. - М.: Панорама, 1995. С. 507. 
Таких редакторов называли «зиц-редакторами», так как настоящим редактором обычно был активный подпольщик, живший на нелегальном положении. Официально перед судом и полицией отвечал зиц-редактор ${ }^{4}$.

...Приходилось прибегать к подбору очередного «зиц-редактора»5.

Вопрос о происхождении номинаций с элементом зиц- выходит за рамки настоящего исследования, однако упомянем, что он остается дискуссионным: зиц- может быть связан как с немецким языком, так и с идиш. По высказанному в частной переписке мнению В.А. Дымшица, идиш более вероятен как источник: «И в том, и в другом языке sitzen - высокочастотный глагол, имеющий (кроме значения определенной позы) также и значение (разг.) 'сидеть = находиться в заключении, тюрьме' (напр., wegen Diebstahls sitzen - сидеть за кражу). Так что в основе неологизма авторов «Золотого теленка» скорее не существительное der Sitz (сидение, местопребывание и т. п.), а именно глагол, да еще в конкретном значении. Тем более что по данной модели создано огромное количество как словарных, так и окказиональных (не фиксируемых в словарях) сложных слов типа Schlafwagen 'спальный вагон', Esstisch 'обеденный стол'. То, что зиц- скорее из идиша, чем из немецкого, может следовать из написания. Немецкий корень глагола sitzen пишется через диграф tz, и немецкие слова с этой аффрикатой в данной позиции (в других позициях пишется z) обычно транслитерируются через ти: фамилия Катцеенберг, река Катцеенбах. А в идише этот звук передается одной буквой, и еврейские фамилии транслитерируют через и̧: Каџ, Кацеенелебоген».

В НКРЯ слова с элементом зиц- представлены в следующем объеме: основной - 14 документов, 21 вхождение; газетный - 36 документов, 39 вхождений. При этом в слитном написании они встречаются в редчайших случаях: кроме цитат из романа «Золотой теленок», нами обнаружены лишь два примера слитного написания номинации зицупредседатель:

Ставлю десять против одного, что этот «президент» на самом деле зицпредседатель, свадебный генерал. [Олег Дивов. Выбраковка (1999)];

Сейчас, ведя меня по коридору к своей двери, она уже успела разъяснить мне, что предприятие именуется «утильцех», что она добывает с других производств разные отходы и мастерит всякую мелочь: игрушки, абажуры, коврики. - А зицпредседателем у тебя кто? Юлька хитро подмигивает, давая понять, что все в порядке. [Е.С. Гинзбург. Крутой маршрут: Часть 2 (1975-1977)].

В остальных случаях пишущие отдают явное предпочтение дефисному написанию:

А вот как раз лицензии мошенника не остановят: сменил юридическое лицо, поставил нового зиц-председателя Фунта, купил ему

${ }^{4}$ Мительман М., Мительман М.И., Костюченко С. А. История Путиловского завода. Т. І. Л.: Изд-во социально-экон. лит-ры, 1961. С. 435.

5 Кремлев И. Л. Трубка Крокодила. М., 1965. С. 63. 
аттестат — и продолжай работать по старой схеме! [Андрей Веселов. Лицензия для управдома // «Русский репортер», 2014];

Честно говоря, это наше общество было теми еще «Роген унд Копытен»: кроме «зиц-председателя» и «виц-председателя» в нем не было больше ни одного функционирующего члена. [Игорь Ушаков. Записки неинтересного человека Тетрадка № 1 (2003) // «Вестник США», 2003.07.09];

Амнистированный монтажник, проводник поезда «Хабаровск-Москва», второй секретарь горкома, жуликоватый киевский профессор, бывший следователь-важняк, перешедший в бандитскую фирму зищ-президентом... [Сергей Эйгенсон. Дима и Василий Алексеевич (2003) // Интернет-альманах «Лебедь», 2003.07.07];

Что-то в последнее время зиц-редактор стал трусить... [Василий Аксенов. Любовь к электричеству (1969)];

...Немцы провозгласили не «блицкриг», а «зиц-криг» (стоячая война). [Л.К. Бронтман. Дневники и письма (1943-1946)].

По его словам, фигурируют какие-то «зиц-директора», то есть фактически подставные лица. [Максим ВОЛОДИН. Следственный комитет работает лучше Скотланд-Ярда // Комсомольская правда, 2011.03.16].

Зиц-председатель, зиц-президент, зиц-редактор, зиц-криг, зиц-директор ... При этом на выбор слитного/дефисного написания, очевидно, не влияет даже ближайшее контекстное окружение, ср.: «зий-председателя» и «виц-председателя», но не «блиикриг», $а$ «зиц-криг».

Предпочтение дефисного написания демонстрируют и иные примеры, обнаруженные путем google-поиска:

Под депешами ставилась подпись то зиц-председателя, то зиц-директора ${ }^{6}$; пригласить зиц-императором в Россию английского аристократа - Майкла Кентского...7;

от потешных зиц-атаманов ${ }^{8}$;

Отставки зиц-премьера Масимова 9 ;

Кто такой этот Медведев? Зиц-президент ${ }^{10}$;

Зиц-демократы не смогли свое предвыборное обещание... реализовать $^{11}$;

${ }^{6}$ URL: http://db.chgk.info/contact/question/taviv09.9/13?destination=/tour/taviv09.9

7 URL: http://anekdot.ru/an/an0909/x090909.htm

${ }^{8}$ URL: http://yooo.livejournal.com/394967.html

URL: http://www.atyraunews.com/showNews 1788.html

${ }^{10}$ URL: mrlgarik.f5.ru/profil

${ }^{11}$ URL: http://www.ttinform.lv/rus/news/6661/ 
Я имею в виду хозяина (не директора и не зиц-учредителя) $)^{12}$;

Бело-синие нардепы / развернули балаган. / В нем лапшу на уши лепит / их «шестерка», зиц-пахан ${ }^{13}$;

зиц-евреев поляжет много ${ }^{14}$;

Тут речь идёт не о зиц-председателе, а о зиц-собственнике ${ }^{15}$;

Кубарева закулисные финансисты назначили зиц-автором этой галиматьи для дебилов ${ }^{16}$;

Почему у рейтинга не появился новый фронтмен? Точнее появился зищфронтмен $^{17}$;

в «Дом искусств» со своим зиц-мужем Маяковским «знаменитая» Лиля все-таки не пришла ${ }^{18}$;

Внезапно нашедшихся зиц-родственников, внезапно вызывающих на историческую родину клепали в таких агентствах, на бумаге ${ }^{19}$;

Помните зиц-председателя Фунта из романа «Золотой теленок»? < ..> Вот на эту роль - зиц-победителя - и выдвинули 93-летнего Гранина ${ }^{20}$;

Симеон Бекбулатович: «зиц-хан» или Тохтамыш против Мамая 200 лет спустя ${ }^{21}$;

Тамадой единодушно избирается Амбарцумян. Впрочем, все понимают, что он скорее «зиц-тамада» - слишком уж величествен. Поэтому совершенно необходим вице-тамада, и в качестве такового выбирают меня! ${ }^{22}$;

Вся наша группа предназначалась в «зиц-солженицыны» 23 ;

Безальтернативным Путина делает устоявшийся набор надоевших зиц-кандидатов ${ }^{24}$;

${ }^{12}$ URL: http://www.urlashov.ru/chat/forums/forum13/topic50/?PAGEN_1=6

${ }^{3}$ URL: http://dykepole.com/lofiversion/index.php/t23.html

${ }^{4}$ URL: http://nicshe2003.livejournal.com/711347.html

${ }^{5}$ URL: http://www.peski.ru/gbook/index.php3?page=3\&showdate=2011-07-20

${ }^{16}$ URL: http://webcache.googleusercontent.com/search?q=cache:ErzMQ_QYuPwJ:www. newparadigma.ru/engines/npforum/read.aspx\%3Fshowtree $\% 3 \mathrm{D} 0 \% 26 \mathrm{~m} \% 3 \mathrm{D} 293171+\& \mathrm{~cd}=142 \& \mathrm{hl}=\mathrm{ru}$ $\& \mathrm{ct}=\mathrm{clnk} \& \mathrm{gl}=\mathrm{ru}$

${ }^{17}$ URL: http://roem.ru/2009/05/27/rating27052009/

${ }_{18}$ URL: http://www.dk1868.ru/history/gul1_2.htm

19 URL: http://oper.ru/news/read.php?t=1051609086

${ }^{20}$ URL: http://www.online812.ru/2012/12/12/007/

${ }^{21}$ URL: https://military.wikireading.ru/30934

${ }^{22}$ URL: https://www.litmir.me/br/?b=323\&p=52

${ }^{23}$ URL: http://www.sakharov-center.ru/asfcd/auth/?t=page\&num=9196

${ }^{24}$ URL: https://www.gazeta.ru/comments/2005/05/05_a_280635.shtml 
Нисколько, — ответила зиц-навигатор*, с перекошенным лицом сгибающая и разгибающая колени ${ }^{25}$;

Или нужен зиц-аналитик, на которого можно будет свалить все финансовые косяки ${ }^{26}$;

Стикер наклеен на руководство у Вас криво, у меня вообще вверх ногами. На сайте дистрибьютера даже нет почты для связи. Сам сайт сделан явно на коленке... Как выяснилось в настоящем расследовании - это обычное дело в фирмах-оборотнях. Иметь Зиц-сайт ${ }^{27}$;

Подставные продавцы, зиц-собственники жилья... То есть сии зиц-продавцы в конце концов отвечают ${ }^{28}$

Сотрудница структур «Росатома» Ольга Родина исполняет роль зиц-акционера при рейдере и серийном строителе финансовых пирамид Игоре Устинове... Наша сегодняшняя героиня, скромная сотрудница «Росэнергоатома» Ольга Викторовна Родина, совмещает в себе черты как миллионера Корейко, так и зиц-председателя Фунта. Точнее всего экономическое хобби Ольги Родиной будет характеризоваться термином «зиц-миллионер», помня, что приставка sitzen имеет значение и «сидеть в тюрьме» ${ }^{29}$;

«Зиц-миллиардер» Курченко пытается вывести арестованную нефть с Одесского НПЗ ${ }^{30}$;

«Зиц-олигарх» скрывается в РФ и получил российское гражданство ${ }^{31}$.

Зиц-автор, зиц-акционер, зиц-атаман, зиџ-демократ, зиц-директор, зиц-еврей, зицимператор, зич-кандидат, зич-миллиардер, зиц-миллионер, зиц-муж, зищ-навигатор,

${ }^{25}$ URL: https://ficbook.net/readfic/3624617/9886845. Симптоматично, что в этой публикации именование зиц-навигатор снабжено примечанием: «Приставка зиц- (от нем. sitzen — «сидеть», также имеет значение «сидеть в тюрьме») перед должностью используется, когда говорят о подставном лице. Выражение зицредактор (то есть редактор «для отсидки» на случай репрессий против печатного издания, подставной редактор) появилось в 1880-х годах в Германии, а потом перекочевало в Россию. В современном языке термин «зицпредседатель» используется, когда говорят о должностном лице, которое занимает свой пост формально и не имеет права принимать ответственные решения». Иначе говоря, слитные написания зицпредседатель и зицредактор опять-таки игнорируются пищущим, который выбирает дефисный вариант зиц-навигатор.

${ }^{26}$ URL: https://pikabu.ru/story/kakaya_strana_takie_i_analitiki_2922186

${ }_{27}$ URL: https://market.yandex.ru/product--delonghi-fgx-4/2637775/forum

${ }^{28}$ URL: http://bpmoskovsky.ru/novosti/naduvatelstvo-chto-maskiruyut-nuzhda-problemnyx-kvartir. html

${ }^{29}$ URL: http://info-kz.com/stati/100-s-chego-nachinaetsya-rodina-ili-igor-ustinov-skvoz-prizmuorganizovannoj-prestupnosti-i-frejdizma

${ }^{30} \mathrm{URL}$ : https://webcache.googleusercontent.com/search?q=cache:3Z0JI8gLXNEJ:https://censor. net.ua/news/308262/zitsmilliarder_kurchenko_pytaetsya_vyvesti_arestovannuyu_neft_s_odesskogo_ npz_glava_oga $+\& \mathrm{~cd}=12 \& \mathrm{hl}=\mathrm{ru} \& \mathrm{ct}=\mathrm{clnk} \& \mathrm{gl}=\mathrm{ru}$

${ }^{31}$ URL: https://censor.net.ua/news/306072/kurchenko_nanes_gosudarstvu_uscherb_na_5_milliardov_ zitsoligarh_skryvaetsya_v_rf_i_poluchil_rossiyiskoe 
зич-олигарх, зиц-пахан, зиц-председатель, зиц-президент, зиц-премьер, зиц-продавец, зиц-родственник, зиц-сайт, зиц-собственник, зиц-собственник, зиц-солженицььн, зицтамада, зищ-учредитель, зиц-фронтмен, зиц-хан - вот явно неполный список номинаций с элементом зиц-, которые окказионально используются в русской речи в современную эпоху, причем встречаются лишь в дефисном написании.

Лексикографическая лакуна, о которой мы упомянули в начале данной статьи, была лишь недавно восполнена в словаре «Новые слова и значения. Словарь-справочник по материалам прессы и литературы 90-х гг. ХХ в.», где появилась следующая словарная статья:

ЗИЦ-ПРЕДСЕДА́ТЕЛЬ* и ЗИЦПРЕДСЕДА́ТЕЛЬ*, я, $м$. О должностном лице, занимающем свой руководящий пост формально, без права принимать ответственные решения; подставное лицо (публ., ирон.). [Новые слова и значения 2009: 638-639]

Кроме того, в интернет-энциклопедии «Традиция» зафиксирована номинация зиц-президент с дефиницией 'жаргонное наименование должностного лица, политической марионетки, установленной на должность/роль президента страны с целью влияния на вектор развития страны, ее внутри-, внешнеполитические и экономические процессы, 32 .

Приведенные примеры свидетельствуют, что элементу зиц- приписывается ныне более широкое значение, нежели этимологически первичное 'подставной'. Сегодня зиц- оказывается равным квази-, псевдо-, фальи- — то есть, вообще говоря, таким словообразовательным элементам, которые рекомендовано писать слитно [РОС 2010: 286, 657, 847].

Заметим, что в некоторых контекстах элемент зиц- впрямую именуется «приставкой»:

Язык «обогащается» птичьими приставками, которые могут прижиться, а могут и нет. Но замещение происходит активно: подменный, подставной, якобы - имитационный, симулятивный, псевдо - зиц... Теперь вот «фэйк». (Оттенки смысла тоже размываются, а не уточняются.) $)^{33}$;

Он видит Медведева не «хромым утенком», а реальным президентом — без всякой приставки «зиц» ${ }^{34}$;

Должность председателя всегда чревата приставкой «зищ-» 35 ;

Его пригласили на роль зищ-председателя. Но очень часто бывает, что при повороте колеса приставка «зиц» к общему изумлению отпадает, и «зиц» становится - иногда на миг, иногда надолго —

${ }^{32}$ URL: https://traditio.wiki/

3 URL: http://m-yu-sokolov.livejournal.com/109562.html

${ }^{4}$ URL: http://www.flb.ru/info/42623.html

${ }^{5}$ URL: http://www.asidorov.by.ru/docs/blog/05-02-02.shtml

${ }^{6}$ URL: http://www.ryzkov.ru/print_new.php?id=675 
На роль Фунта периодически прочат ген. Лебедя, сегодня явилась новая кандидатура - судорожно раскручиваемый президент Чувашии Н. В. Федоров, это отдельная и интересная тема, но мы-то сейчас говорим о президентах без приставки «зиц-», т. е. не о чучелах, а о реальных полити$\operatorname{\kappa ax}^{37}$;

Следующий президент будет верным путинцем с приставкой «зиц» ${ }^{38}$.

Однако очевидно, что слово «приставка» используется в этих контекстах не в качестве лингвистического термина 'префикс', а в значении 'то, что приставлено, присоединено к чему-н.'.

Еще более любопытно, что у элемента зиц- проявилась способность полностью автономизироваться, то есть использоваться в значении существительного:

Я на эти посмотрел чудеса- / Повылазили глаза из глазниц: / Неужели и сидеть будешь сам? / Или все-таки нуждаешься в зиц ${ }^{39}$;

Она в банке была знатный менеджер, / я ж на фирме как фунт, типа «зиц», / я грустил как парнишка у Сэллинджера, / представляя себя с нею в Ritz ${ }^{40}$;

В данном случае зица извещают о его роли ${ }^{41}$;

сплавить надёжному зицу (подставному лицу) ${ }^{42}$;

Генеральный директор был форменным «зицем» из «Золотого теленка» ${ }^{43}$;

Действовать надо разумно. Как? Да ровно так, как действовал зиц-председатель Фунт из романа «Золотой теленок». Помните, он сидел во все времена и за всех. И жил славно. Так вот я предлагаю Вам стать таким зицем ${ }^{44}$;

Тарута же и Олег Мкртчан явно остались у разбитого корыта. Мальчиками на побегушках. Зицами, интересами которых можно пренебрегать ${ }^{45}$;

Скорее всего этими «зицами» будут уголовники, которые после его команды, будут знать, что дальше они могут воровать сколько смогут ${ }^{46}$;

\footnotetext{
${ }^{37}$ URL: http://www.conservator.ru/lib/msokol/2000/083.shtml

${ }^{38}$ URL: http://www.inosmi.ru/inrussia/20070625/235135.html

${ }^{39}$ URL: http://www.ristalishe.com/RistalischeN.aspx?num=34

${ }^{40}$ URL: http://gb.anekdot.ru/scripts/gb.php? component $=$ gb\&id $=6 \&$ page $=\&$ date $=2005-09-08 \&$ fu $=0$

${ }^{41}$ URL: http://www.eos.ru/eos_delopr/eos_delopr_intesting/detail.php?ID=16909\&SECTION_

${ }^{42}$ URL: http://informpskov.ru/business/58292.html

${ }^{43}$ URL: http://samlib.ru/n/nikolaew n m/hishniki.shtml

${ }^{44}$ URL: http://www.ng.ru/titus/2001-07-05/1_titus.html

${ }^{45}$ URL: http://fsbu.com.ua/index.php?action=printpage;topic $=110.0$

${ }^{46}$ URL: http://otvety.google.ru/otvety/thread?tid=13b94453b3744117\&pli=1
} $\mathrm{ID}=668$ 
На языке бизнеса такие люди называются зицами. Или зиц-председателями. То есть людьми, от которых ничего не зависит, и которые ничего не решают, но занимают высокопоставленные должности. <.. > В русском языке для обозначения зицов есть еще одно яркое фразеологическое обозначение - «свадебный генерал». Правда, свадебный генерал - это все-таки не совсем зиц. Зиц может быть и вполне незаметным ${ }^{47}$;

Достаточно вспомнить Пиночета, де Голля, Чон Ду Хвана... все они не были зицами, все они провели жесткие меры и в разной степени постепенно растеряли свою популярность ${ }^{48}$;

Поставить правильного человека на правильное место уже говорит об уме начальства. Надеюсь мы говорим не о зицах ${ }^{49}$.

В приведенных контекстах существительное зиц употребляется не только в значении ‘подставное лицо', но также и в значениях, синонимичных значениям номинаций марионетка ('человек, слепо действующий по воле других, являющийся послушным орудием в чужих руках') и свадебный генерал ('лицо, приглашённое лишь для представительства, обладающее мнимым авторитетом и не играющее никакой роли в каком л. деле'), и представлено в следующих формах: Им. п. ед. ч. (зиц), Р. п. ед. ч. (зица), Д. п. ед. ч. (зииу), Тв. п. ед. ч. (зицем), Р. п. мн. ч. (зицев/зицзов) Тв. п. мн. ч. (зицуами), П. п. мн. ч. (о зицах).

В лингвистической литературе отмечена способность деривационных аффиксов, аффиксоидов и связанных частей слов в окказиональном словообразовании «получать свободу и использоваться как слова» [Земская 2005: 196]. Однако, по мнению Е.А. Земской, «это относится прежде всего к активным аффиксам с четким единственным значением (приставкам и таким суффиксам как -изм, -ист, -ние и под.)»: «молодые люди заражаются самым страшным, на мой взгляд, “измом” - скептицизмом», «критика всяких “псевдо” и цыганщины», «свершилось здесь и некоторое “пере”» [Там же].

Однако рассматриваемый нами случай существенно отличается от описанных уже хотя бы потому, что способность к склонению обнаруживает и зиц-, используемый в качестве части составной номинации:

Администратор - это человек, который всем управляет и за все отвечает. Он может быть реальным директором-профессионалом, а может быть просто Зицем-председателем ${ }^{50}$;

При всей любви к «Зицу-председателю», «Старикам тут не место» и «Железной хватке», «Перекресток» им не ровня. И да, что же в данном случае снимали Коэны? ${ }^{51}$;

${ }^{47}$ URL: http://subscribe.ru/archive/economics.school.fighting/200409/14150609.html

48 URL: http://forum.ixbt.com/topic.cgi?id=54:504-23

49 URL: http://paidiev.livejournal.com/175277.html

${ }^{50}$ URL: http://colinfo.ru/barcelona/statiy/817-kak-otkryt-svoy-biznes-v-ispanii.html

${ }^{51}$ URL: http://forum.exler.ru/arc/index.php?s=0\&act=Print\&client=printer\&f $=125 \& \mathrm{t}=168842 \& \mathrm{st}=3600$ 
Хотя и тут, судя по всему, он исполняет роль Зица-председателя ${ }^{52}$.

Необходимость «исследований обыденной орфографической деятельности», которые позволили бы ответить на вопрос, «в какой мере орфографические парадигмы русского языка обладают способностью к семантизации» и «может ли русская орфография выполнять интерпретационную функцию», обоснована в работах Н. Д. Голева [Голев 2002: 16; Голев, 1997: 38-39]. И поскольку дифференцирующая природа слитных/раздельных/дефисных написаний в современном русском письме не вызывает сомнений, то представляется, что упорное стремление пишущих к дефисному оформлению слов с начальным элементом зиц- как раз и свидетельствует о сознательности подобного выбора. Написания типа зиц-автор, зиц-муж, зиц-президент можно отнести к графиксатам, то есть неолексемам, обязанным своим возникновением «такому способу образования слов, при котором в качестве словообразовательного оператора выступают графические и орфографические средства (графические выделения, знаки препинания и т. п.)» и которое принято обозначать термином графиксация [Изотов 1998: 45; Попова 2011: 161].

\section{Литература}

Голев Н. Д. Антиномии русской орфографии. Барнаул: Изд-во АГУ, 1997. 147 с.

Голев. Н.Д. Проблемы эстетизации русской орфографии // Вопросы филологии, методики преподавания иностранных языков и страноведения. Вып. IV. / исп. ред. В.В. Иваницкий, сост. Н.В. Семенова. НовГУ им. Ярослава Мудрого. Великий Новгород, 2002. С.16-25.

Земская Е. А. Словообразование как деятельность. М.: КомКнига, 2005. 224 с.

Изотов В.П. Параметры описания системы русского словообразования. Орел: Изд-во ОРГУ, 1998. 149 с.

Новые слова и значения. Словарь-справочник по материалам прессы и литературы 90-х гг. ХХ в. / сост. Т.Н. Буцева, Е.А. Левашов, Ю.Ф. Денисенко, Н. Г. Стулова, Н.А. Козулина, С.Л. Гонобоблева; отв. ред. Т.Н. Буцева. СПб.: Дм. Буланин, 2009. T. 1.

Попова T.B. Графиксация как новое явление в языке и научной когниции // Вестник Челябинского гос. ун-та. 2011. № 24 (239). Филология. Искусствоведение. Вып. 57. С. 160-163.

[ПАС] - Правила русской орфографии и пунктуации. Полный академический справочник. / Под ред. В. В. Лопатина. М.: Эксмо, 2006. 480 с.

[POC] — Русский орфографический словарь. М.: АСТ-ПРЕСС, 2010

[Ушаков] — Толковый словарь русского языка: В 4-х т. / под ред. Д. Н. Ушакова. М.: Сов. энцикл.: ОГИЗ, 1935-1940. Т. 1

\footnotetext{
${ }^{52}$ URL: http://nskib.ru/hobby/photo/972
} 


\section{Svetlana V. Drugoveyko-Dolzhanskaya \\ Saint-Petersburg State University \\ (Russia, Saint-Petersburg) \\ s.drugoveyko@gmail.com}

\section{WHAT DOES THE WORD (SITZ) PREDSEDATEL' HAVE A HYPHEN FOR, OR GRAFIKSATION AS A SYMPTOM}

The article deals with the use of words with the initial element of sitz-in modern texts, as well as with the fixation of such formations in lexicographic sources. The analyzed material not only testifies to the spellers' persistent tendency to hyphenate words with an element of sitz- (in contempt of orthographic recommendations), but also to the autonomation of this element, which is expressed in its ability to be used as a noun. In this case, the hyphenation (splitting the word into parts with hyphens and giving these parts a different meaning) demonstrates that the differentiating spellings in Russian are characterized by the high functional status of 'subtle meanings distinguishers'.

Key words: orthography, hyphenation, differentiating spellings, graphication, occasional derivation.

\section{References}

Golev N.D. Antinomii russkoi orfografii [Antinomy of the Russian spelling]. Barnaul: AGU publishing house, 1997. 147 pages.

Golev. N. D. Problemy estetizatsii russkoi orfografii [Problems of aestheticization of the Russian spelling] // Voprosy filologii, metodiki prepodavaniya inostrannykh yazykov i stranovedeniya. Vyp. IV. [Questions of philology, technique of teaching foreign languages and regional geography. Issue IV] / edition V. V. Ivanitsky, N. V. Semyonova. Yaroslav the Wise. Veliky Novgorod, 2002. Pp. 16-25. (In Russ.)

Zemskaya E. A. Slovoobrazovanie kak deyatel'nost' [Word formation as activity]. M.: Komkniga, 2005. 224 pages. (In Russ.)

Izotov V.P. Parametry opisaniya sistemy russkogo slovoobrazovaniya [Parameters of the description of system of the Russian word formation]. Eagle: ORGU publishing house, 1998. 149 pages. (In Russ.)

Novye slova i znacheniya. Slovar'-spravochnik po materialam pressy i literatury 90$k h g g . X X v$. [New words and values. The dictionary reference on materials of the press and literature of the 90 th of the 20th century] / сост. T. N. Butseva, E. A. Levashov, Yu.F. Denisenko, N. G. Stulova, N. A. Kozulina, S. L. Gonobobleva; отв. edition of T. N. Butsev. SPb.: Dm. Bulanin, 2009. T. 1. (In Russ.)

Popova T. V. Grafiksatsiya kak novoe yavlenie v yazyke i nauchnoi kognitsii [Grafiksation as the new phenomenon in language and a scientific cognition] // Vestnik Chelyabinskogo gos. un-ta [the Messenger the Chelyabinsk state. un-that]. 2011. No. 24 (239). Philology. Art criticism. Issue 57. Pp. 160-163. (In Russ.) 
Pravila russkoi orfografii i punktuatsii. Polnyi akademicheskii spravochnik [Rules of the Russian spelling and punctuation. Full academic reference book] / Under the editorship of V. V. Lopatin. M.: Eksmo, 2006. [I GRAZED] 480 pages. (In Russ.)

Russkii orfograficheskii slovar' [Russian spelling dictionary]. M.: AST-PRESS, [GREW] 2010. (In Russ.)

Tolkovyi slovar' russkogo yazyka [Explanatory dictionary of Russian: In 4 t.] / under the editorship of D. N. Ushakov. M.: Sov. энцикл.: OGIZ, 1935 - 1940. T. 1 [Ushakov]. (In Russ.) 


\author{
Л. В. Зубова \\ Санкт-Петербургский государственный университет \\ (Россия, Санкт-Петербург) \\ l-zubova@yandex.ru
}

\title{
ОРФОГРАФИЧЕСКАЯ СТИЛИСТИКА
}

О, неизбежность «ы» в правописаньи «жизни»! Иосиф Бродский

Статья содержит наблюдения над стилистическими функциями орфографии. Рассматриваются некоторые особенности орфографии в официально-деловом и научном стилях, написания, маркирующие высокий и сниженный стили, традиционно-поэтическая орфография, орфографические архаизмы. Анализируется стилистический аспект языковой игры с орфографией (в социальных сетях, в нейминге, в современной поэзии. Отмечаются тенденции к лексикализации написаний, нарушающих норму и к появлению аксиологических оппозиций нормативных и ненормативных вариантов написания слов. Анализ материала показывает, что многие слова, написанные с нарушением орфографических норм, психологически и социально востребованы, они фактически вошли в язык, получив определенные функции (особенно для снижения пафоса, категоричности, ослабления банальности или, напротив, демонстрации банальности, для выражения экспрессии). Вполне возможно, что некоторые из подобных написаний останутся в письменной форме языка и в перспективе могут быть кодифицированы. Во многом это связано, с тем, что любителями словесных забав являются грамотные люди, часто филологи и писатели, склонные к языковой рефлексии. Итак, кодифицированная или некодифицированная, но устойчивая вариантность написаний позволяет видеть в орфографии значительный стилистический ресурс.

Ключевые слова: стилистика, орфография, эрратография, словообразование, аксиология.

Об орфографической стилистике не говорится ни в одном учебнике, а она существует, поскольку возможны орфографические варианты и намеренные отступления от правил правописания, причем далеко не только как проявления языковой игры.

Орфографическим вариантам, легитимация которых дискуссионна (см., напр.: [Кузьмина 2001]), отказано в статусе стилистического средства (см. высказывания 
лингвистов в книге: [Бешенкова, Иванова 2016: 66]). Между тем, наблюдения над стилистическими функциями орфографических вариантов все чаще встречаются в лингвистике, напр., [Панов 1964], [Григорьев 1966], [Емельянова 1976], [Булохов 2001], [Голев 2004], [Гусейнов 2006], [Кронгауз 2012, 2013], [Еськова 2009], [Уткин 2009, 2011].

Ясно, что пришло время обобщить, продолжить и включить наблюдения над стилистическими функциями орфографии в курс стилистики русского языка.

Большинство наблюдений относится к стилистике ресурсов, но есть и материал для функциональной стилистики. Поскольку бесспорно могут быть выделены только официально-деловой и научный стили, обратим внимание на то, как проявляется орфографическая стилистика в языке науки и делопроизводства.

В языке философии, например, наблюдается «развитая модель дефисного отрицания не-: “не-являющемся”, “не-моральное”, “не-священным” < ..> В философских текстах дефисное написание не- позволяет не только ослабить прямое отрицание, но и привнести новую семантику, и что самое важное, концептуализировать сам формант не» [Азарова 2010: 28] ${ }^{1}$.

В официальных документах особым образом употребляются прописные буквы: Наймодатель обязуется: > ..> При выезде Нанимателя из Объекта, возвратить ему страховой депозит (n.6.1 настоящего Договора) после предъявления Нанимателем Найлодателю оплаченных счетов, квитанций, согласно n. 4.5 Договора («Договор найма жилого помещения»).

Далее рассмотрим ряд явлений орфографической стилистики, группируя материал по функциям нарушения нормы.

Связь орфографии с высоким стилем проявляется, прежде всего, в особом употреблении прописных букв.

В разных речевых жанрах высокий смысл может приписываться любым словам. Об их идеологическом употреблении см.: [Кронгауз 2012: 407].

Дискуссионна стилистика написаний $m b l$ и $T b l, b b l$ и $B b l$ при обращении (см.: [Геккина 2014]), Бог и бог (см.: [Еськова 2010]).

Регистры букв могут указывать на аксиологическое противопоставление: бог из бетономешалки / бог усвочвший армейские порядки / по ускоренному курсу в караулке / рядом с Маршалом чугунным на лошадке / как собачка с госпожою на прогулке! (В. Кривулин).

Прописная буква может быть маркером символа, персонифицированной аллегории, концептуализации образа ли понятия: ...зиная бессонный нюх / Леса и Озера, Вечера и Тумана / мы подражаем повадкам зверей и птиц, / передавая друг другу дурные вести, / мы говорим по-совиному, по-соловьиному, / дети Стыла и Стра$\boldsymbol{x a} .$. (И. Волков).

Высокий стиль создается и традиционно-поэтической орфографией. Безусловно, к ней относятся написания форм типа в сомнень $u^{2}$ (из-за чего поэты нередко

${ }^{1}$ Все выделения полужирным шрифтом в статье мои - Л.3.

2 Это отражено в лексикографии: [Литературный энциклопедический словарь 1987: 261]. 
ссорятся с редакторами). Обратим внимание на то, что буква «и» в этой форме вполне системна, соответствующий звук бывает ударным: в забытьи.

Стилистически маркированы орфографические архаизмы, например: мятель, лебядь, рясницы, имянинь, масляница, мачиха, снигирь, поцалуй, жолтый, чорт, язычёк, шоколат, безконечныли, блок-нот, спортсмэн, Катинька, Ваничка.

Широко известно, что А. Блок настаивал на различении написаний жолтылй и желтылй, метель и мятель (см.: [Орлов 1960: 568]). И. Бродский пишет чорт при обозначении мифологического персонажа и черт при инвективном употреблении.

В. Я. Лакшин рассуждает о вариантах чорт и черт у М. Булгакова: «Перечитал “Записки покойника” Булгакова < ..> Между прочим, он пишет слово “чорт” через “о”. “Черт” через “е” — привычный, литературный, домашний. “Чорт” через “о” — страшный чорт Гофмана и Достоевского, это и в самом деле нечистая сила. Вот что делает одна буква» [Лакшин 1991: 132-133]².

Интенция к повышению стиля имеется при употреблении букв Ђ и Ђ, окончаний - аго, -ыля в рекламе и нейминге. Неправильное написание таких элементов (галерея обувъ, лавкаъ, деловыя объды), если оно намеренное, переводит подобные написания в игровой регистр, но он не всегда таковым воспринимается.

Снижение стиля осуществляется многими способами. Наиболее традиционным из них является употребление строчной буквы вместо прописной. Принижение означаемого вплоть до инвективы выразительно представлено в реплике из книги С. Алексиевич «Время second-hand»: Я их всех ненавижу: горбачева, шеварнадзе, яковлева, - напишите с маленькой буквы, так я их ненавижу.

Д. Суховей обратила внимание на то, что «Лидер группы эго-футуристов Иван Игнатьев графически выворачивал наизнанку символическое значение слова: начинал со строчной буквы, а записывал заглавными те же слова, которыми оперировал символизм, например, жИЗНЬ, чАРЫ» [Суховей 2007: 149].

Стремление к снижению пафоса, скомпрометированного банальностью или фальшью, особенно характерно для современной культуры. Применительно к орфографии самым заметным способом снижения стала имитация ошибок. Исследователи отмечают такие стилистические функции эрратографии (термин Г. Ч. Гусейнова), как языковая игра, экспрессия, ирония, обозначение границы между своими и чужими, протест против строгих предписаний, не всегда логически объяснимых.

Во многих примерах из сетевого общения нет экспрессии, но очевидны модусные сдвиги к снижению пафоса и смягчению категоричности: 1) Я щетаю - это несправедливо с Вашей стороны, Павел Владимирович!! 2) Пичалька. Каникуль кончились. В этих репликах прочитывается и уступка стереотипам в употреблении слов, а шутливая форма становится маркером рефлексии над банальными словами.

Эрратография, выйдя за пределы сетевого общения, получила большую популярность в нейминге и рекламе. Можно выделить такой аспект орфографической стилистики, как маркетинговая эрратография. Имитация ошибок широко представлена на различных вывесках магазинов, ресторанов (Булошная, Казачёк, Пальчики

\footnotetext{
${ }^{3}$ Цитата приведена в статье: [Еськова 2009: 317].
} 
оближеш, Фкусно). Вероятно, таким способом, помимо привлечения внимания, дается сигнал целевой аудитории «мы свои, у нас нет официоза, мы веселые». То, что такие вывески вызывают раздражение и негодование людей, которые наивно приписывают создателям вывесок безграмотность, рекламе идет на пользу.

Яркой чертой эрратографии является слитное написание устойчивых речевых фрагментов ${ }^{4}$. Иногда такие фрагменты оформляются кавычками, указывающими на цитатность, иногда сами сращения выполняют функцию кавычек, маркирующих чужую речь как банальность, с которой приходится мириться: 1) Надо вернуться в Москву ненадолго. Мальчики мои там все съели. И вообще. Яжкемать. И яжежена; 2) Яжсематерям везде у нас дорога!!!! 3) ой! у меня там много примеров приводится. люди совершенно не понимают чётакова (реплика И. Левонтиной в Фейсбуке).

Сращения-цитаты часто встречаются в литературе: всё что звалося сердцумило / теперь зовется обылом (А. Горенко).

В таких случаях проявляется иконическая функция сращений. Она еще более наглядна, когда слитные написания соответствуют содержанию высказывания: 1) Тропинкаприлиплакботинку (Л. Виноградов); 2) бесконечнодолгоиграющая пластинка (А. Месропян); 3) Любой безлюдный метр, повыле ли, пониже - / Футляр для тыия, пустая нами нима (М. Степанова).

В первом примере изображено прилипание предметов прилипанием слов, во втором узуальное сращение долгоиграющая дополнено еще одним наречием, усиливающим образ длительности и семантикой, и длиной слова. В третьем, очень возможно, что сращение тылия произведено от строки М. Цветаевой из «Поэмы Конца»: Mbl же сросшиеся. Цветаевский подтекст подтверждается первой строкой стихотворения Степановой - строкой, в которой есть слова на месте этом зычном - ср. у Цветаевой: Первое письмо тебе на новом / - Недоразумение, что злачном - / (Злачном - жвачном) месте зычном, месте звучном («Новогоднее»).

В современной поэзии встретился пример удвоения буквы, не обозначающей звука, но входящей в звукоподражательное междометие: Дзенньв тихо по струнам резануло - / И на клочья распалось сердче (С. Круглов. «Зеркальце»).

Любопытен пример языковой рефлексии в Живом журнале, мотивирующий эрратографические написания их изобразительностью при отождествлении означаемого с означающим: У каждого свое счастье, щистье, сиастье, стчастье, стмцастье! Вы думаете написано неправильно? А где вы видели идеальное счаcmbe?

Обозначение экспрессии в разговорной речи, публицистике, художественной литературе прямым образом связано с орфографией. Некоторые экспрессивные написания в художественной литературе, изображающие форсированное произнесение звуков, рассматриваются в статье: [Пеньковский 1974].

Экспрессия может быть выражена и многими другими способами, например, отделением префикса: И настанет тот год и поход, / где ни кто ни куда не придет

\footnotetext{
${ }^{4}$ Ср. узуальные сращения, напр., сегодня, быстрорастворимый, втридорога.
} 
(В. Соснора). Д. Сабитова пишет в Фейсбуке: Bот у меня пришли две тетки на пробу, уборшицами. <..> ПАЧИМУ!!! ПАЧИМУ - я, доиент-филолог и у меня ваще лапки - ПАЧИМУ я все равно умею мыть польл лучше, чем они. ПАЧИМУ моя просьба вот тут и вот тут отмыть пятно кетчупа с пола руками - вызывает кивание головой и улььку: какая вы юмористка, сеньора! хахаха!

В социальных сетях и sms-сообщениях, а также и за их пределами широкое распространение получило изображение громкости речи или важности высказывания прописными буквами. Это явление вызывает критику и насмешки: ПОЧЕМУ НЕЛЬЗЯ ИСПОЛЬЗОВАТЬ КАПСЛОК? Объясняю: это невежливо. Дело в том, что капслок означает ИСТОШНЫЙ КРИК.

На разных картинках-мемах встречаются надписи: 1) Не пью, не курю, ругаюсь капсом; 2) Капс зажал - характер показал; 3) и не надо на меня капсом писать.

Прописная буква в начале слов как средство экспрессии представлена на сайте Animalzz.ru в контекстах такого типа: «Сорока, Которая Смеется Как Ребенок. Вы Такое Видели?

Вернемся к игровым заменам букв и рассмотрим такой важный аспект, как эрратографический способ словообразования. «Коллективное остроумие», по выражению М.А. Кронгауза [Кронгауз 2012: 257], играет в этом случае существенную роль. Искаженные написания, постоянно повторяясь и часто сопровождаясь языковой рефлексией, проявляют тенденцию к лексикализации с изменением семантики : 1) У блондинок МОЗГ или МОСК? 2) Ясно ведь, что "хочется" и «хочецца» - два принциипиально разных способа желать; 3) а моменты времени «щас» и «сейчас» не совпадают.

В социальных сетях стало часто употребляться слово алень при обозначении мужчин. Оно производно от олень, но не имеет отношения к рогам как знаку женской измены. Актуализируется признак «тягловое животное»: 1) Алень - это особь мужского пола, на которой можно ездить и погонять; 2) «Алень» - терпила в отношениях с бабами.

Обнаруживается тенденция к расширению значения этого слова: Алени, как правило, аленями являются абсолютно во всех проявлениях, не только в семейной жизни.

Отчетливо прослеживается аксиологическое отличие ненормативных написаний от нормативных: 1) Почитали бы чего по теме, товарисч песатель... Не позорились бы публично; 2) Учоный пытается выпендриваться; 3) жнызнь а не жсизнь... это про россиян.

Ю. В. Уткин так анализирует оппозицию сука - сиуко: «Иной пример - сцуко. $<$..> в функции инвективы эрративный вариант несет смягчающие коннотации, он менее категоричен и враждебен, в отличие от корректного варианта, эрратив может выражать положительную оценку» [Уткин 2011: 138].

На перспективы игровой эрратографии существуют противоположные точки зрения: она надоест и исчезнет [Гусейнов 2006] или может, к сожалению, стать новой нормой [Кронгауз 2012: 255]. Пока не происходит ни того, ни другого.

\footnotetext{
${ }^{5}$ Подробно этот аспект рассмотрен в статье: [Зубова 2012].
} 
Наиболее активными игры с орфографией были примерно в 2005-2010 гг. Но ослабление и утрата моды не привели к полному отказу от имитации ошибок. Многие такие слова психологически и социально востребованы, они фактически вошли в язык, получив определенные функции (особенно для снижения пафоса, категоричности, ослабления банальности или, напротив, выставления банальности напоказ).

Вполне возможно, что некоторые из подобных написаний в перспективе могут быть кодифицированы (ср.: тысяча и тыщиа). При этом ощутимо влияние искаженных написаний и на устную речь (пестня, женсчина, котеги).

По наблюдениям Ю.М. Кудрявцева и Ю.В. Уткина, «... в наиболее поздних по времени создания контекстах <..> доля лексикализованных эрративов и эрративов, содержащих морфологизированные эрратограммы, заметно выше, чем в текстах 2007-2008 гг. Предположительно это связано с тем, что начиная с 2008 г. популярность эрратографии как контркультурного явления постепенно уменьшалась. При этом “случайные” эрративы стали порождаться в неформальной письменной коммуникации значительно реже, в то время как морфологизированные эрратограммы и лексикализованные эрративы закрепились в узусе Рунета» [Кудрявцев, Уткин 2011: 163].

Авторы этой статьи справедливо утверждают: «В контексте изучения в современном языкознании графико-орфографического способа словообразования (В.П. Изотов, Т.В. Попова и др.) вопрос об орфографическом, точнее, “эрратографическом" способе, несомненно, заслуживает анализа с позиций словообразования» [Указ. соч.: 164].

В хаосе массового нарушения орфографических правил устанавливается некий порядок. И во многом это связано с тем, что любителями словесных забав являются грамотные люди, часто филологи и писатели, склонные к языковой рефлексии. Стоит помнить, что «Шутливая речь - ворота, сквозь которые прорываются новые языковые факты» [Панов 1990: 25].

Таким образом, сосуществование старого и нового при исторических изменениях орфографических норм, эмоциональное отношение носителей языка к этим изменениям, кодифицированная или некодифицированная, но устойчивая вариантность написаний позволяют видеть в орфографии значительный стилистический ресурс.

\section{Литература}

Азарова Н. М. Язык философии и язык поэзии - движение навстречу. М.: Логос / Гнозис, 2010. 496 с.

Бешенкова Е.В., Иванова О.Е. Теория и практика нормирования русского письма. М.: Лексрус, 2016. 424 с.

Букчина Б.3. Орфографические варианты // Литературная норма и вариантность. М.: Наука, 1981. С. 215-233.

Булохов В.Я. Экспрессивные орфографические написания // Русский язык в школе. 2013. № 1. С. 77-81. 
Геккина E.H. Тыканье, выканье и прописные буквы в метаязыковом диалоге // Современный русский язык в интернете / ред. Я.Э. Ахапкина, Е. В. Рахилина. М.: Языки славянской культуры, 2014. С. 222-228.

Голев Н.Д. Антиномии русской орфографии. М: УРСС, 2004. 158 с.

Григорьев В.П. Язык, орфография и писатель // Орфография и русский язык. М. : Наука, 1966. С. 97-127.

Гусейнов Г. Ч. Введение в эрратическую семантику (на материале «Живого Журнала») // Integrum: точные методы и гуманитарные науки М.: Летний сад, 2006. C. 383-405.

Еськова Н. А. Заставь дурака. Еще раз о Боге и боге // Русская речь. 2000. № 1. C. $45-47$

Емельянова Л.Л. Нарушение орфографической нормы как средство создания стилистического эффекта // Филологические науки. 1976. № 1. С. 107-113.

Еськова Н. А. Об орфографии впервые публикуемых и перепечатываемых текстов (в порядке постановки вопроса) // Русский язык в научном освещении. 2009. №2. С. 316-317.

Зубова Л. В. Потенциальная семантическая дифференциация вариантов слова // Вариативность в языке и коммуникации. М.: РГГУ, 2012. С. 101-124.

Кронгауз M. Русский язык на грани нервного срыва. 3D. M. : Астрель: CORPUS, 2012. $480 \mathrm{c}$.

Кронгауз М. Самоучитель олбанского. М.: ACT: CORPUS, 2013. 416 с.

Кудрявцев Ю.М., Уткин Ю. В. Целесообразность изучения девиаций в высшем профессиональном образовании (на примере эрратографии) // Мир образования образование в мире. 2011. №4. С. 161-165.

Кузьмина С.М. Об умягчении нравов русской орфографии (к проблеме вариативности написаний) // Жизнь языка: Сб. ст. к 80-летию М. В. Панова. М. : Языки славянской культуры, 2001. С. 406-411.

Лакшин В.Я. «Новый мир» во времена Хрущева: дневник и попутное (19531964) М. : Книжная палата, 1991. 269 с.

Литературный энизиклопедический словарь. М. : Советская энциклопедия, 1987. 752 c.

Орлов В. Александр Блок. Вступительный очерк // Блок А. Собрание сочинений: в 8 т. Т. 1. М.; Л.: ГИХЛ, 1960. С. VII-LXIII.

Панов М.В. И все-таки она хорошая! Рассказ о русской орфографии, ее достоинствах и недостатках. М. : Наука, 1964. 168 с.

Панов М.В. История русского литературного произношения XVIII-XX вв. М.: Наука, 1990. 453 с.

Пеньковский А.Б. О некоторых некодифицированных явлениях современной русской орфографии (о написаниях типа ид-уy, оч-чень) // Нерешенные вопросы русского правописания. М. : Наука, 1974. С. 94-121.

Правила русской орфографии и пунктуации: полный академический справочник. М. : АСТ-Пресс книга, 2011. 431 с. 
Суховей Д. Новые функции заглавных букв в поэтическом тексте. (На материале антологии «Девять измерений») // Русская филология 18. Тарту, 2007. С. 149-153.

Уткин Ю. В. Об эрратографии как орфографическом стилевом средстве // Актуальные проблемы гуманитарных и естественных наук. 2009. №2. С. 203-205.

Уткин Ю.В. Эрратография: аспекты изучения // Вестник Челябинского гос. ун-та. 2011. № 37 (252) Филология. Искусствоведение. Вып. 61. С. 136-139.

\section{Ludmila $V$. Zubova}

Saint Petersburg State University

(Russia, Saint Petersburg)

l-zubova@yandex.ru

\section{ORTHOGRAPHIC STYLE}

The article contains observations on the stylistic features of orthography. The point at issue are some peculiarities of spelling in the official and academic styles of writing, kinds of spelling that could mark formal and informal styles of writing, traditional poetic spelling, orthographical archaisms. The stylistic aspect of the wordplay with spelling in social networks, in product naming, in contemporary poetry has also became an object of interest in this article. It has been fixed the tendency to lexicalized spellings that disrupt the rule. They lead to the uprise of axiological oppositions built on normative and non-normative spellings. The analysis of the material shows that the disruption of orthographic norms is frequently motivated psychologically and socially. Actually, these words have entered the language, because of obtaining certain special functions, such as pathos reduction, weakening of the banality and the flatness or, on the contrary, the demonstration of the banality, also phrasing of the expression. It is possible that some of these spellings would enter in the formal written language because they are often created by peoples, first of all philologists and writers, who are able to the creative reflection. Hence, either formal or informal, but persistent variativity of spelling make it possible to perceive the orthography as a significant stylistic resource.

Key words: stylistic, spelling, artography, word formation, axiology.

\section{References}

Azarova N.M. Yazyk filosofii i yazyk poezii - dvizhenie navstrechu [Language philosophy and language poetry is a movement towards]. Moscow, Logos Publ., Gnozis Publ., 2010. 496 p.

Beshenkova E. V., Ivanova O. E. Teoriya i praktika normirovaniya russkogo pis'ma. [Theory and practice of standardizing Russian writing]. Moscow, Leksrus Publ., 2016. 424 p.

Bukchina B. Z. [Spelling variants]. Literaturnaya norma i variantnost' [Literary norm and the variance]. Moscow, Nauka Publ., 1981, pp. 215-233. (In Russ) 
Bulokhov V. Ya. [Expressive writing spelling]. Russkii yazyk v shkole. 2013. №1, pp. 77-81. (In Russ)

Emel' eanova L. L. [Violation of spelling rules as a means of creating stylistic effect]. Filologicheskie nauki. 1976. № 1, pp. 107-113. (In Russ)

Es'kova N. A. [About the spelling the first time published, and reprints of texts (in the order of the question)]. Russkii yazyk v nauchnom osveshhenii. 2009. № 2, pp. 316-317. (In Russ)

Es'kova N.A. [Make a fool. Again about God and god]. Russkaya rech', 2010. № 1, pp. 35-47. (In Russ)

Gekkina E. N. [Appeal to you and you and capital letters in metalinguistic dialogue]. Sovremennyi russkii yazyk v internete. Moscow, Yazyki slavyanskoi kul'tury Publ., 2014, pp. 222-228.

Golev N. D. Antinomii russkoi orfografii [Antinomies of Russian spelling]. Moscow, URSS Publ., 2004. 158 p.

Grigor'ev V.P. Language, spelling and writer]. Orfografiya i russkii yazyk. [Spelling and Russian language]. Moscow, Nauka Publ., 1966, pp. 97-127. (In Russ)

Guseienov G. Ch. [Introduction to erratic semantics (based on the "Live Journal")]. Integrum: tochnye metody i gumanitarnye nauki. Moscow, Letnii sad Publ., 2006, pp. 383-405.

Krongauz M. Russkii yazyk na grani nervnogo sryva. $3 D$ [Russian language on the verge of a nervous breakdown. 3D]. Moscow, AST Publ., 2012. 480 p.

Krongauz M. Samouchitel' olbanskogo [Teach Olbany]. Moscow, AST Publ., 2013. $416 \mathrm{p}$.

Kudryavcev Yu. M., Utkin Yu.V. [The feasibility study deviations in higher professional education (on the example of artography)]. Mir obrazovaniya - obrazovanie v mire [The world of education - education in the world]. 2011. №4, pp. 161-165. (In Russ)

Kuz'mina S. M. [About the softening of the mores of Russian spelling (to the problem of the variability of the spellings)]. Zhizn' yazyka. [The life of language] Moscow, Yazyki slavyanskoi kul'tury Publ., 2001, pp. 406-411. (In Russ)

Lakshin V. Ya. «Novyi mir» vo vremena Khrushcheva: dnevnik i poputnoe (19531964) ["New world" during the times of Khrushchev: the diary and associated (19531964)]. Moscow, Knizhnaya palata Publ., 1991. 269 p. (In Russ)

Literaturnyi entsiklopedicheskii slovar'. [Literary encyclopedia]. Moscow, Sovetskaya encyclopediya Publ., 1987. 752 p.

Orlov V. [Alexander Blok. An introductory essay]. Blok A. Sobranie sochinenii: v 8 t. T. 1. [Collected works in 8 volumes. Vol. 1]. Moscow, Leningrad, GIKHL Publ., 1960, pp. VII-LXIII. (In Russ)

Panov M. V. Istoriya russkogo literaturnogo proiznosheniya XVIII-XX vv. [The history of the Russian literary language of XVIII-XX centuries]. Moscow, Nauka Publ., 1990. $453 \mathrm{p}$.

Panov M. V. I vse-taki ona khoroshaya! Rasskaz o russkoi orfografii, ee dostoinstvakh i nedostatkakh [Still, she's good! The story about the Russian spelling, its advantages and disadvantages]. Moscow, Nauka Publ., 1964. 168 p. (In Russ) 
Pen'kovskii A. B. [On some tacit phenomena of modern Russian spelling (the spelling of the type $i d-u u$, och-chen')]. Nereshennye voprosy russkogo pravopisaniya [Unresolved issues the Russian spelling]. Moscow, Nauka Publ., 1974, pp. 94-121. (In Russ)

Pravila russkoi orfografii i punktuacii: polnyi akademicheskii spravochnik [Rules of Russian orthography and punctuation: complete academic reference]. Moscow, ASTPress kniga Publ., 2011. 431 p.

Sukhoveii D. [New features uppercase letters in a poetic text. (Based on the anthology “Dev eat' izmerenii”)]. Russkaya filologiya 18 [Russian Philology 18]. Tartu, 2007, pp. 149-153. (In Russ)

Utkin Yu. V. [About artography spelling as a stylistic tool]. Aktual'nye problemy gumanitarnykh i estestvennykh nauk. 2009. № 2, pp. 203-205. (In Russ)

Utkin Yu. V. [Artography: aspects of the study]. Vestnik Chelyabinskogo universiteta. 2011. № 37 (252), Chelyabinsk University Press, pp. 136-139. (In Russ)

Zubova L. V. [Potential semantic differentiation of word]. Variativnost' $v$ yazyke $i$ kommunikatsii. [Variability in language and communication]. Moscow, RGGU Press, 2012, pp. 101-124. (In Russ) 


\title{
О.Е. Иванова
}

\author{
Институт русского языка им. В. В. Виноградова РАН \\ (Россия, Москва) \\ olliva95@yandex.ru
}

\section{ОРФОГРАФИЧЕСКАЯ КОДИФИКАЦИЯ И СОЦИАЛЬНАЯ ДИНАМИКА}

Какие социальные обстоятельства влияют сегодня на кодификационную деятельность лингвистов? Насколько она эффективна? Статья содержит обобщенную характеристику современной политики в области орфографической кодификации. Принципиальные положения этой политики выработаны на основании традиций академизма и опыта создания орфографического словаря в новых социальных и языковых условиях. Сегодня кодификационная работа в словаре проводится непосредственно в процессе письменной адаптации слов, многие слова вводятся в словарь на начальном этапе своей жизни в русском письме. Кодификаторы исходят из представления о том, что слово, своевременно включенное в словарь в перспективной форме написания, быстрее пройдет путь неизбежных колебаний. Но в условиях живых адаптационных процессов в письменной практике часто невозможно избежать таких кодификационных решений, которые не будут приняты письмом сразу, и кодифицированный вариант слова будет существовать параллельно с вариантами узуса; подобные коллизии разрешаются на основе стратегий нормирования, принятых кодификаторами. Кодификаторам, выступающим как субъективный фактор письма, в нынешних социальных условиях приходится иметь дело с заметным понижением своего влияния на становление письменных норм, с ростом скептического отношения к академической кодификации и орфографическому словарю. Кроме того, особой чертой современности стало появление конкурентного источника письменной нормы, помимо словаря и правил, в виде государственных и корпоративных документов. Нормы законов, уставов, реестров - в том числе и письменные - имеют обязательную юридическую силу, часто закрепляют неверные написания, что ведет к конфликту письменных норм документов и норм общенационального словаря. В этих условиях цель нынешней деятельности лингвистов-кодификаторов видится в политике разумного консерватизма, направленной на поддержание традиционной системы письма, закрепленной в таких установлениях отечественной культурной традиции, как орфографический словарь и правила. 
Ключевые слова: орфография, кодификация, стратегии кодификации, орфографический словарь, правила орфографии, узус, узуальная норма, варианты написаний, перекодификация.

Современная русская письменная культура располагает двумя регуляторами правильности письма - правилами орфографии и пунктуации и академическим орфографическим словарем. Бо́льшая часть времени существования словаря пришлась на годы относительно стабильного социального развития, поэтому и словарь в течение почти сорока лет мало пополнялся и не правился ${ }^{1}$. Социальные сдвиги конца XX века, когда язык и письмо стали активно осваивать новые понятия и слова и подвергаться испытанию массовым иноязычным заимствованием, привели к необходимости модернизации орфографического словаря: был создан «Русский орфографический словарь», динамика развития которого впечатляет от 100 до 160 тысяч слов в 1999 г., затем к 180 (2005 г.) и, наконец, к 200 тысячам слов в издании 2012 г. $^{2}$

Опыт конкретной кодификационной работы, проводимой академическим орфографическим словарем, выявляет несколько опорных положений современной кодификационной политики в области орфографии, которая на практике в течение уже двадцати лет осуществляется составителями «Русского орфографического словаря». Сформулируем эти положения.

1. Кодификация орфографии как деятельность исходит из целей обеспечения удобной письменной коммуникации в интересах общества как целого, а не отдельных социальных, возрастных (старших и младших) или профессиональных групп (специалисты и неспециалисты). Правила и орфографический словарь создаются для всего общества.

Данное традиционное понимание функций словаря и правил опирается на фундаментальную концепцию культуры речи, понимаемой как ценностный капитал средств и способов устной и письменной коммуникации, которые с хронологической точки зрения основаны на традиции, на преемственности поколений, а в непрерывном настоящем - на связи всех слоев общества.

2. Кодификация как конкретное решение может не совпасть с массово преобладающим реальным употреблением. Норма - это не употребление, тем более не сиюминутное употребление, а выбор из системных возможностей той, которая, по мнению кодификатора, обеспечит единство коммуникации на всей территории, во всех социальных ярусах и на протяжении длительного периода. Известно неоднократно цитированное рассуждение С.И. Ожегова о неправомерности подхода к норме как количественному явлению: «Языковая норма - не статистическое

${ }^{1}$ Напомним: впервые общий «Орфографический словарь русского языка», опирающийся на единые «Правила русской орфографии и пунктуации», был издан в 1956 г. Словарь включал 100 тыс. слов и существовал до середины 90-х годов XX в. Из более чем тридцати изданий словаря лишь три - 1963, 1974 и 1991 годов - являются исправленными и дополненными.

${ }^{2}$ О концепции «Русского орфографического словаря» и его месте в академической лексикографической традиции см. [Иванова 2012]. 
явление, ибо распространенной и часто повторяющейся в языке может быть, как известно, и ошибка. Языковая норма есть прежде всего явление типическое, т. е. соответствующее сущности данного социально-исторического явления, а не просто наиболее распространенное, часто повторяющееся, обыденное» [Ожегов 1955: $14]$.

3. Кодифицированная норма в орфографии понимается традиционно - как предписание использовать на письме только одну форму написания слова.

Критерий правильности в современной орфографии имеет свой вид, не такой, как в разделах звучащего языка - в орфоэпии, стилистике, грамматике, где норма может иметь и градационный характер. На протяжении XIX в. и первой половины $\mathrm{XX}$ в. общество провело колоссальную работу по переходу от хаоса в правописании к единым нормам письма. Эти нормы и обобщены в правилах орфографии и пунктуации и закреплены орфографическим словарем.

4. Правила и орфографический словарь нацелены на поддержание системы русского письма и письменной традиции.

Орфографические правила, сформулированные к настоящему времени, или отражают системное устройство русского письма, или накладывают нормативные ограничения на реализацию системы, или отсылают к перечню индивидуальных норм в словаре. Орфографический словарь, в свою очередь, включает как слова, пишущиеся в соответствии с правилами (в том числе и исключения из правил), так и слова с традиционным, «закрепившимся» написанием (так называемые «словарные слова» в школьной терминологии).

5. Правила и орфографический словарь придерживаются принципа невариативной кодификации. Ни в одном из разделов современных правил орфографии не введено «разрешения» писать одно и то же слово или тип слов разными способами. Попытки теоретически обосновать вариативность в области слитного / дефисного / раздельного написания в 60-е годы и на рубеже веков [Панов 1964; Кузьмина 2001] не нашли поддержки и практического воплощения, как и более поздние призывы к либерализации письма. «Решение ничего не решать, а только признать объективное наличие колебаний и расшатанности нормы» [Ожегов 1955: 18] ни во времена выработки общих правил, ни в настоящее время не может соответствовать функциям развитого литературного языка. Поэтому в настоящем академический словарь привержен идее не давать варианты написаний ${ }^{3}$ хотя бы и узуально доминирующие (например, не давать плеер и плейер при наличии также плэйер; риелтор и риэлтор при наличии также риелтер, риэлтер и реелтор; секонд-хенд и сэконд-хэнд при наличии также секонд-хэнд, сэконд-хенд). Словарь в целом продолжает ориентироваться в предписаниях на правила (например, надо писать плеер, риелтор, секонд-хенд) и/или присущие языку тенденции, характери-

${ }^{3}$ В словаре есть единичные статьи с вариантами как дань орфографической традиции, например, в терминосистемах (магнетохимия и магнитохимия) или как уступка варьирующейся узу-

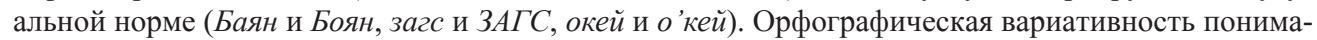
ется нами строго (в смысле [Бешенкова 2016(б): 64-65]). 
стики, отражаемые на письме (например, следует писать ремейк, рерайтер, а не римейк, рирайтер, экшен, а не экшн), на орфографический прецедент, на историческую тенденцию в областях, живущих без правил (фитнес как бизнес, велнес как фитнес).

Пополнение словаря тысячами новых слов, значительную часть которых составляют заимствования и термины ${ }^{4}$, усложнили в настоящее время кодификационную работу, поскольку она проводится непосредственно в процессе письменной адаптации слов и в сжатые сроки. Многие слова вводятся в словарь на начальном этапе своей жизни в письме, когда их судьба в узусе еще не сложилась и может разрешиться различным образом (массмедиа - масс-медиа, экзит-полл - экзитпол - экзитполл - экзитпол), затем они обрастают «родственниками» - либо однокоренными словами (например, массмедийный ${ }^{5}$, массмедийщик), либо словами с той же общей частью (например, массискусство, масскульт, масскультура, масслит, масс-старт; часть бэк в составе слов бай-бэк, бэк-вокал, бэкграунд, бэккантри, бэк-офис, бэкслеш, бэкхенд, фастбэк, хетчбэк), начинают активно приспосабливаться к русской системе письма, допуская возможность анализировать их с точки зрения лингвистических оснований правил русской орфографии. Все эти адаптационные явления неизбежно отражаются на внешней стороне слова: появившись в русском письме, например, через транслитерацию (иоппинг англ. shopping), слово постепенно подчиняется внутренним закономерностям принявшего его языка, меняя написание (шопинг), или, отражая внешней формой особенности освоения слова в произношении (промоушн англ. promotion, экщн англ. action и под.), при словоизменении на русской почве слово начинает эту форму менять, уходя от несвойственного русскому языку явлению слоговости шипящего (частотно в косвенных падежах пишут промоушена, промоушеном, экшена, экшеном, но пока наряду с формами промоушна, промоушном, экшна, экшном), некоторые же из аналогичных слов раньше других принимают адаптивную форму (только сейшен, сейшеном, солюшен, солюшеном). Включая подобные слова в словарь причем в разное время, в разные издания - кодификатор должен предвидеть их будущую орфографическую судьбу. (А для этого надо учесть предписания соответствующих правил орфографии, принять во внимание действие исторических тенденций и аналогий в областях письма, которые существуют не по правилам, учесть наличие уже имеющихся родственных слов, орфографических прецедентов и прочее.) Слово, своевременно включенное в словарь в перспективной форме написания, имеет шансы быстрее пройти путь неизбежных колебаний (например, слова типа бренд, лейбл, слеш, тренд). Но вполне возможна и ситуация, когда вопреки всем тенденциям, закономерностям, правилам и аналогиям кодифицированное слово принимает в живом употреблении форму, не выводимую из той

${ }^{4}$ Введение терминологической лексики в словарь общего типа было ограничено, сфера бытования этих слов была достаточно узкой. Всё изменилось с развитием общества и средств массовой коммуникации. Принципы орфографической кодификации терминов и объем их включения в словарь рассматриваются в [Иванова 2015].

${ }^{5}$ В написании «Русского орфографического словаря» (2012). 
информации, которой оперируют кодификаторы (например, установилась узуальная норма ${ }^{6}$ барсетка вместо словарно зафиксированного этимологически объясняемого траслитерированного борсетка от ит. borsetta «сумочка», puтейл вместо ретейл от англ. retail «в розницу»). Иными словами, невозможно полностью избежать таких кодификационных решений, которые не будут приняты письмом сразу и будут существовать долгое время параллельно с узуальными вариантами․ Подобные коллизии должны разрешаться, исходя из стратегий нормирования, принятых для себя кодификаторами, и завершаются либо перекодификацией в соответствии с правилами или узусом (при первоначально кодифицированном борсетка возможно изменение на барсетка), либо принятая кодификация не меняется - в расчете на изменение узуальной судьбы слова (разыскной при преобладающем розыскной, легинсы при преобладающем леггинсы, ретейл, ретейлер при массовом ритейл, ритейлер).

В современном обществе есть одно весьма существенное обстоятельство бытования правил и словаря. Речь идет о роли лингвистов-кодификаторов как субъективном факторе письма ${ }^{8}$. Миссия кодификатора состоит в создании условий для реализации нужной потенции системы письма, выявлении точек колебаний, а далее - в выборе нормативного написания, которое задает тем самым вектор письму в данной области. Однако степень воздействия субъективного фактора на письмо может быть заметно разной в различных социальных условиях. Так, предшествующее поколение кодификаторов - авторов и редакторов словаря советской эпохи - могло уверенно рассчитывать на то, что предписанные словарем письменные нормы с неизбежностью распространятся и будут доминировать в обществе, эта уверенность основывалась на проводимой государством централизованной языковой политике. В условиях же нынешней общественной либерализации и фактического устранения государства от целенаправленной поддержки единых правил и единого словаря прямое влияние этого фактора на письменную практику общества уменьшилось. На поле кодификационной деятельности кроме специалистов по орфографии появились новые субъекты — чиновники госорганов и функционеры корпораций, создающие в недрах своих организаций документы обязательной

6 «Под письменным узусом мы понимаем совокупность всех написанных текстов. $<\ldots>$ Под письменным грамотным узусом мы понимаем совокупность текстов, прошедших корректуру $<. .>$. Под нормой письма понимается совокупность наиболее устойчивых традиционных реализаций единиц письма, отобранных и закрепленных общественной письменной практикой. <..> Кодифицированная норма (кодификация) - закрепленная лингвистами некоторая единица письма как нормативная» [Теория и практика нормирования 2016: 18].

7 Впрочем, в современном обществе значимость словарной кодификации понижена, часто о ней и вовсе не знают. Внимание к содержанию словарей актуализируется лишь в моменты общественного обсуждения какой-нибудь частной проблемы. Обычный пользователь, в том числе грамотный, обращается к различным электронным ресурсам, некритически воспринимая «закачанную» в них информацию.

${ }^{8}$ Взаимодействие объективного и субъективного факторов в функционировании современного письма с точки зрения теории саморазвивающихся систем рассматривается Е.В. Бешенковой [Бешенкова 2016(a): 10-43]. 
юридической силы, нормы которых - в том числе и письменные - обязательны для применения в нижестоящих бюрократических звеньях. Понятно, что если в этих документах употреблено слово, написанное с отклонением от правила, которому оно должно подчиняться (Государственная Дума вместо Государственная дума, «кругльий стол» вместо кругльй стол, демо-версия вместо демоверсия), то эта ошибка будет тиражироваться. Так возникает ненужная конкуренция норм орфографического словаря и норм документов, и создаются условия для искусственной вариативности написаний.

Когда интересуются, как правильно пишется (произносится, изменяется) то или иное слово, обычно хотят услышать определенный ответ. Предоставление выбора - можно писать и так и этак - воспринимается, как правило, сдержанно, а чаще с недоумением. На уровне обыденного сознания вариативность соответствует максиме «пиши как хочешь». Можно считать подобные воззрения на нормы письма недостатком, проявлением издержек господствовавшего «режима» в орфографии (термин Т.М. Григорьевой) и проч., но обычные граждане, обращаясь к словарю, ищут в нем разрешения возникшей у них проблемы, а не приглашения к размышлению. Иное дело лингвисты, изучающие системные возможности языка и их реализацию в разнообразных единицах живого узуса - динамичного, изменяющегося, модного, диктующего вкусовые предпочтения разным группам носителей языка. Погружение в толщу вариативности, предлагаемую живым письмом, давление множества разнонаправленных факторов на становление норм разных типов слов, неучёт стратегической цели орфографической кодификации ${ }^{9}$ и непроведение принципиальной разницы между вариативностью в узусе и в кодификации обуславливают тот факт, что именно филологи выступают сейчас инициаторами отражения вариативности в словаре нормативного типа. В высказывании: «Вариативность - не антипод норме, а способ ее обретения» (И. В. Нечаева), — выделим слово обретение. Орфографическая вариативность слова в текстах до словарной фиксации естественна, понятна и логична, но в нормативном словаре место есть лишь готовой к употреблению норме, имеющей перспективы существования в системе русского письма. По крайней мере, именно такая сверхцель всегда была и должна быть, по нашему мнению, у орфографического словаря русского языка.

В советское время усвоение единых письменных норм в обществе было целью государства: здесь и школа с ее ныне критикуемым орфографоцентризмом, и политика издания словарей, финансируемая государством, и система редактуры и подготовки текстов для печати. В годы социальных сдвигов ситуация коренным образом изменилась: государство устранилось от протекционистской издательской политики; коммерциализация издательского дела привела к сосуществованию многих словарей разного качества и, как следствие, отсутствию принятого

9 «... кодификаторы имеют своею целью сохранение системы письма, сложившейся исторически, и могут не учитывать действующих на современном этапе лингвистических или психолингвистических факторов. А именно эти факторы являются частотно причинами возникновения колебаний в узусе. Эти причины часто перестают быть актуальными в изменившихся социальных условиях, поэтому строить на них стратегию кодификации нельзя» [Бешенкова 2016(б): 71]. 
обществом и поддерживаемого государством единого орфографического словаря; одновременно произошло и разрушение сложившейся практики редактуры текста. Все эти обстоятельства способствуют развитию факторов сопротивления официальной кодификации («пишу, как считаю нужным», «не хуже вас знаю, как писать»). Среди этих факторов, например, перенесение явлений иноязычных систем на свой родной язык и, как следствие, неприятие введенной кодификации на русском языке, а также нарастание тенденции к переоценке авторитета кодификаторов («у нас в министерстве свои специалисты, не менее квалифицированные», «выражаю собственное "я" или корпоративное "мы”»). И у части сообщества специалистов сформировалось мнение о том, что в период активных языковых изменений, сопровождающих социальные и культурные сдвиги, единая общепринятая кодификация письменных норм вряд ли возможна [Шмелев 2017: 117], да и не нужна.

Однако на смену колебаниям и хаотичным изменениям (как в обществе, так в письме) обычно приходит эпоха стабильного существования, и цель нынешней деятельности лингвистов-кодификаторов - руководствуясь разумным консерватизмом, противодействовать явлениям разрушения в отдельных звеньях системы письма, не закреплять на письме живые преходящие колебания, чтобы поддержать традиционное русское письмо. В связи с этим считаем, что возможности и цели орфографической кодификации в период значительных языковых изменений, конечно, нуждаются в обсуждении, но по существу дело идет о самом сохранении таких институтов отечественной культурной традиции, как единый орфографический словарь и единые правила.

\section{Литература}

Бешенкова Е.В. Орфография дескриптивная и ортологическая // Бешенкова E. В., Иванова O. E. Теория и практика нормирования русского письма. М.: Лексpyc, 2016. C. 10-43. (a)

Бешенкова E.B. Орфографическая вариативность и политика нормирования // Бешенкова E.B., Иванова O. E. Теория и практика нормирования русского письма. М.: Лексрус, 2016. С. 63-98. (б)

Бешенкова Е.В., Иванова О.Е. Теория и практика нормирования русского письма. М.: Лексрус, 2016. 424 с.

Иванова O.E. «Русский орфографический словарь» и академическая традиция // Вопросы культуры речи. Вып. 11. М.: Языки славянской культуры, 2012. С. 129138.

Иванова O.E. Стратегии орфографической кодификации в области терминологии // Русский язык в научном освещении. № 2 (30). М., 2015. С. 21-44.

Кузьмина С.М. Об умягчении нравов русской орфографии (к проблеме вариативности написаний) // Жизнь языка. Памяти Михаила Викторовича Панова. М., 2001. C. 406-411.

Ожегов С.И. Очередные вопросы культуры речи // Вопросы культуры речи. Вып.1. М., 1955. С. 5-33. 
Панов М. В. О слитных и раздельных написаниях // Вопросы русской орфографии. М., 1964. С. 100-119.

Шмелев А.Д. Возможна ли кодификация языковых норм в эпоху социальных и культурных изменений // Международная научная конференция «Культура русской речи» (Гротовские чтения). Москва, 16-18 февраля 2017 г. Тезисы докладов. M., 2017. C. 117.

\section{Olga E. Ivanova}

V.V. Vinogradov Russian Language Institute of the Russian Academy of Sciences (Russia, Moscow) olliva95@yandex.ru

\section{ORTHOGRAPHIC CODIFICATION AND SOCIAL DYNAMICS}

The article contains a generalized description of the modern policy in the field of orthographic codification. The basic regulations of this policy are developed on the basis of the traditions of academicism and the experience of creating an orthographic dictionary in new social and linguistic conditions. Today, the codification work in the dictionary is carried out directly in the process of written adaptation of words, many words are entered into the dictionary at the initial stage of its life in the Russian writing. Codifiers proceed from the concept of a word that is timely included in the vocabulary in a perspective form of writing has a chance to go quicker through the path of inevitable fluctuations. But in conditions of living adaptation processes in written practice it is often impossible to avoid such codification decisions that will not be accepted by the writing at once and will exist in parallel with the variants of the wording; such collisions are resolved on the basis of the normalization strategies adopted by codifiers. What is the codification activity of linguists today, how effective is it? Codifiers acting as the subjective factor of the writing, in the current social conditions have to deal with a significant decrease in its influence on the development of written standards, with increasing skepticism about the academic codification and orthographic dictionary. Moreover, the emergence of a competitive source of written rules, besides the dictionary and regulations in the form of public and corporate documents became a special feature of modernity. Norms of laws, statutes, registers, including writing norms - are legally binding, often fix misspellings, which leads to a conflict of written rules of the nationwide dictionary and regulations of the documents. In these circumstances, the purpose of the current activity of linguistic codifiers seen in the policy of reasonable conservatism, aimed at maintaining the traditional writing system, fixed in such native cultural tradition institutes as an orthographic dictionary and rules.

Key words: orthography, orthographic codification, strategies of codification, orthographic dictionary, spelling rules, usage, conventional norm, spelling variants, recoding. 


\section{References}

Beshenkova E. V. [Descriptive and orthologic orthography]. Beshenkova E. V., Ivanova O. E. Teoriya i praktika normirovaniya russkogo pis'ma. [Theory and practice of normalization the Russian writing]. Moscow, Lexrus publ., 2016, pp. 10-43. (a) (In Russ.)

Beshenkova E. V. [Orthographic Variation and Rate Policy]. Beshenkova E. V., Ivanova O. E. Teoriya i praktika normirovaniya russkogo pis'ma. [Theory and practice of normalization the Russian writing]. Moscow, Lexrus publ., 2016, pp. 63-98. (b) (In Russ.)

Ivanova O.E. [«The Russian orthographic dictionary» and Academic tradition]. Voprosy kul'tury rechi [Topics in the culture of speech]. Issue 11. Moscow, Languages of Slavonic culture publ., 2012, pp. 129-138. (In Russ.)

Ivanova O.E. [Strategies for Standardizing Spelling of scholarly Terminology]. Russkii yazyk v nauchnom osveshchenii. Moscow, 2015, no. 2 (30), pp. 21-44. (In Russ.)

Kuz'mina S.M. [Softening of manners in Russian orthography (to the problem of spelling variation]. Zhizn' yazyka. Pamyati Mikhaila Viktorovicha Panova [Life of language. Articles in honor of M. V. Panov]. Moscow, Languages of Slavonic culture publ., 2001, pp. 406-411. (In Russ.)

Ozhegov S.I. [Proximate issues of the culture of speech]. Voprosy kul'tury rechi [Topics in the culture of speech]. Issue 1. Moscow, 1955, pp. 5-33. (In Russ.)

Panov M.V. [On merged and separate spellings]. Voprosy russkoi orfografii [Questions of Russian spelling]. Moscow, 1964, pp.100-119. (In Russ.)

Shmelev A. D. [Is it possible to codify language norms in the era of social and cultural change]. Mezhdunarodnaya nauchnaya konferentsiya "Kul'tura russkoi rechi» (Grotovskie chteniya). Moskva, 16-18 fevralya 2017 g. Tezisy dokladov. Moscow, 2017, p. 117. (In Russ.) 


\section{И. Б. Иткин}

Институт востоковедения РАН,

Национальный исследовательский университет «Выстая школа экономики»

(Россия, Москва)

ilya.borisovich.itkin@gmail.com

В. Д. Пекарская

Национальный исследовательский университет «Высшая школа экономики»

(Россия, Москва)

vikpek.96@gmail.com

\section{МЕЖДУНАРОДНЫЙ СКАНДАЛ \\ (СЛОЖНЫЕ СЛОВА С ПЕРВЫМ КОМПОНЕНТОМ МЕЖ- МЕЖДУ- В ИСТОРИИ РУССКОГО ЛИТЕРАТУРНОГО ЯЗЫКА)}

Статья посвящена закономерностям выбора вариантов меж- между- в словах типа межличностный, межэтажный междуэтажный, междуцарствие, межсезонье и т.д. Показано, что соответствующие правила существенно различны для прилагательных и существительных. Несмотря на то, что самое частотное прилагательное данного типа — международный - употребляется только с междy-, для подавляющего большинства прилагательных предпочтительным (а нередко - единственно возможным) является вариант меж-. При этом на протяжении последних 70-80 лет употребительность прилагательных с между- (типа междуведомственный) устойчиво снижается, а употребительность прилагательных с меж- (типа межведомственный) столь же устойчиво растет. Сложные существительные делятся на несколько групп. Существительные с суффиксом -u(e), а также некоторые давно возникшие существительные с суффиксом -b(e) и односложным корнем требуют варианта между- (междуиарствие, междувластие; междуречье, междурядье, междупутье). Существительные с суффиксом -ь(е) и неодносложным корнем требуют варианта меж- (межсезонье, межвременье). Редко употребляющиеся существительные с суффиксом -ье и односложным корнем допускают оба варианта с некоторым преобладанием меж- (межбровье междубровье, межгорье междугорье). Отдельно рассматриваются редкие варианты меже(межеумок) и междо- (междоусобный, междоузлие), употребление которых обусловлено стремлением избежать стыка двух $y$. В заключении делается вывод о наличии нестрогой, но достоверно наблюдаемой связи между выбором одного 
из конкурирующих вариантов и частеречной принадлежностью композитов и обсуждается вопрос о стилистическом статусе лексем с меж- и между-.

Ключевые слова: русский язык, сложные слова с меж- и между-, языковая вариативность, хронологическая динамика, части речи.

\section{1. Введение}

В русском языке имеется большая и продуктивная группа слов с начальным компонентом меж- или между- (в редчайших случаях также междо-, меже-) $)^{1}$ : межличностный, межсезонье, международный, междуречье, междоузли, межеумок и т.д.

По всей видимости, слова на меж- между- никогда не были предметом нормативного упорядочивания. Так, в [Грамматика-80: 231-232, 306, 313] меж- и между- трактуются как равноправные варианты, в соответствующих параграфах фигурируют пары типа межгорье и междугорье, межведомственньй и междуведомственный, междуэтажный и межэтажный и др. Примерно те же пары приводятся — без каких-либо помет — в [ОСРЯ 1989: 248].

Тем самым, ситуация, сложившаяся к настоящему моменту в рассматриваемой группе слов, целиком и полностью представляет собой результат естественного развития. Ситуация эта представляется весьма нетривиальной. С одной стороны, едва ли может быть поставлен под сомнение факт отсутствия строгих правил выбора между вариантами меж- и между- и существования дублетных пар. С другой стороны, о всеохватной вариативности говорить также не приходится: такие формы, как *междуличностный, *междусезонье, *межнародный, *межречье и т.д., вероятно, могут изредка встретиться в некодифицированных текстах, но в литературном языке они невозможны. Насколько нам известно, вопрос об употреблении элементов меж- и между- не привлекал внимания исследователей; едва ли не единственное наблюдение на этот счет обнаруживается в уже упомянутой «Грамматике-80»: «Вариант префикса между- используется реже, чем меж-» [Грамматика-80: 306].

Настоящая статья ставит своей целью как описание современной картины взаимодействия элементов меж- и между- в составе сложных слов, так и анализ изменений, происшедших в этой сфере в недавнее время. Основным источником исследования служит материал Национального корпуса русского языка (НКРЯ); при необходимости привлекаются также данные Интернета и разговорной речи.

\section{2. Элементы меж- и между- в составе сложных прилагательных}

Утверждение «Грамматики-80» о большей частотности варианта меж- интуитивно кажется вполне справедливым. Однако попытка «в лоб» проверить это

${ }^{1}$ Одни исследователи рассматривают элементы меж- и между- в качестве "первой части сложных слов" (см., например, [Ожегов 1983: 304]), другие - в качестве приставок (см., например, [Грамматика-80: 754 и др.]). В настоящей работе мы придерживаемся первой из этих точек зрения, впрочем, полагая данный вопрос во многом схоластическим. 
утверждение на материале прилагательных приводит к неожиданному результату: суммарное число вхождений прилагательных с между- составляет 29.650, суммарное число вхождений прилагательных с меж- - всего 7.1052. Разгадка этого парадокса заключается в том, что прилагательное международный, встречающееся в текстах примерно в 4 раза чаще, чем все остальные прилагательные данного типа (как с меж-, так и между-), вместе взятые (28.740 вхождений в НКРЯ!), не имеет варианта с меж-.

Помимо международный, варианта с меж- не имеют также довольно частотное прилагательное междугородный междугородний $(530(386+144)$ вхождений $)$ и редкое междурядный (19; по-видимому, под прямым влиянием слова междурядье (см. ниже)). Кроме того, вариант между- чаще встречается в паре междуэтажный межэтажный (39:21); возможно, это обусловлено стремлением избежать экзотического буквосочетания жэ.

Для всех остальных прилагательных данного типа, представленных в НКРЯ сколько-нибудь статистически значимое число раз (таких прилагательных не менее 50), вариант с меж- является либо единственно возможным, либо по крайней мере значительно более частотным. Всего прилагательные с первой частью между(без учета лексем международный, междугородный междугородний, междурядный и междуэтажный) встретились в Корпусе около 600 раз, а прилагательные с первой частью меж-, как сказано выше, - более 7.000 раз. Показательны числовые данные, например, по таким лексемам, как меж(*ду)региональный (683:0), меж( *ду)личностный (305:0), меж(*ду)этнический (296:0), меж(*ду)отраслевой (242:0), меж(*ду)дисциилинарный (221:0), меж(??ду)видовой (170:1), меж(??ду) религиозный (129:1), меж(??ду)клеточныий (108:1), меж(??ду)континентальный (225:2), меж('?2у)молекулярный (77:2), меж(??ду)национальный (791:9), меж(??ду) государственный (464:11), меж('วу)партийный (62:12), меж('วу)областной (18:9).

Лишь в пяти случаях вариант между- встретился в Корпусе 15 и более раз:

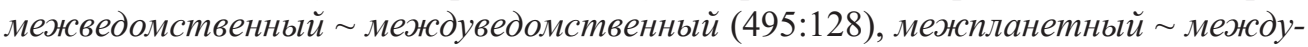
планетный (760:37), межпарламентский междупарламентский (57:20), межзвездный междузвездный (471:15), межрайонный междурайонный (156:15).

Хронологическая динамика соотношения вариантов меж- и между-для каждой из этих пар представлена на Графиках 1-5 (все графики построены для периода с 1900 г. по настоящее время со сглаживанием 30):

Как видно, по крайней мере в течение последних 70-80 лет частота употребления варианта между- во всех случаях имеет тенденцию к снижению (иногда до нулевой отметки).

Любопытна история прилагательного междупланетный. Эта лексема, в современном языке почти не употребляющаяся в прямом значении, иногда встречается

${ }^{2}$ Все количественные данные, относящиеся к Национальному корпусу русского языка, приводятся по состоянию на 17 августа 2017 г. Приводимые нами цифры, разумеется, имеют приблизительный характер (особенно это касается тех случаев, где речь идет о трех- и более значном числе вхождений); однако, как кажется, во всех рассматриваемых нами группах примеров доля "шума" пренебрежимо мала. 

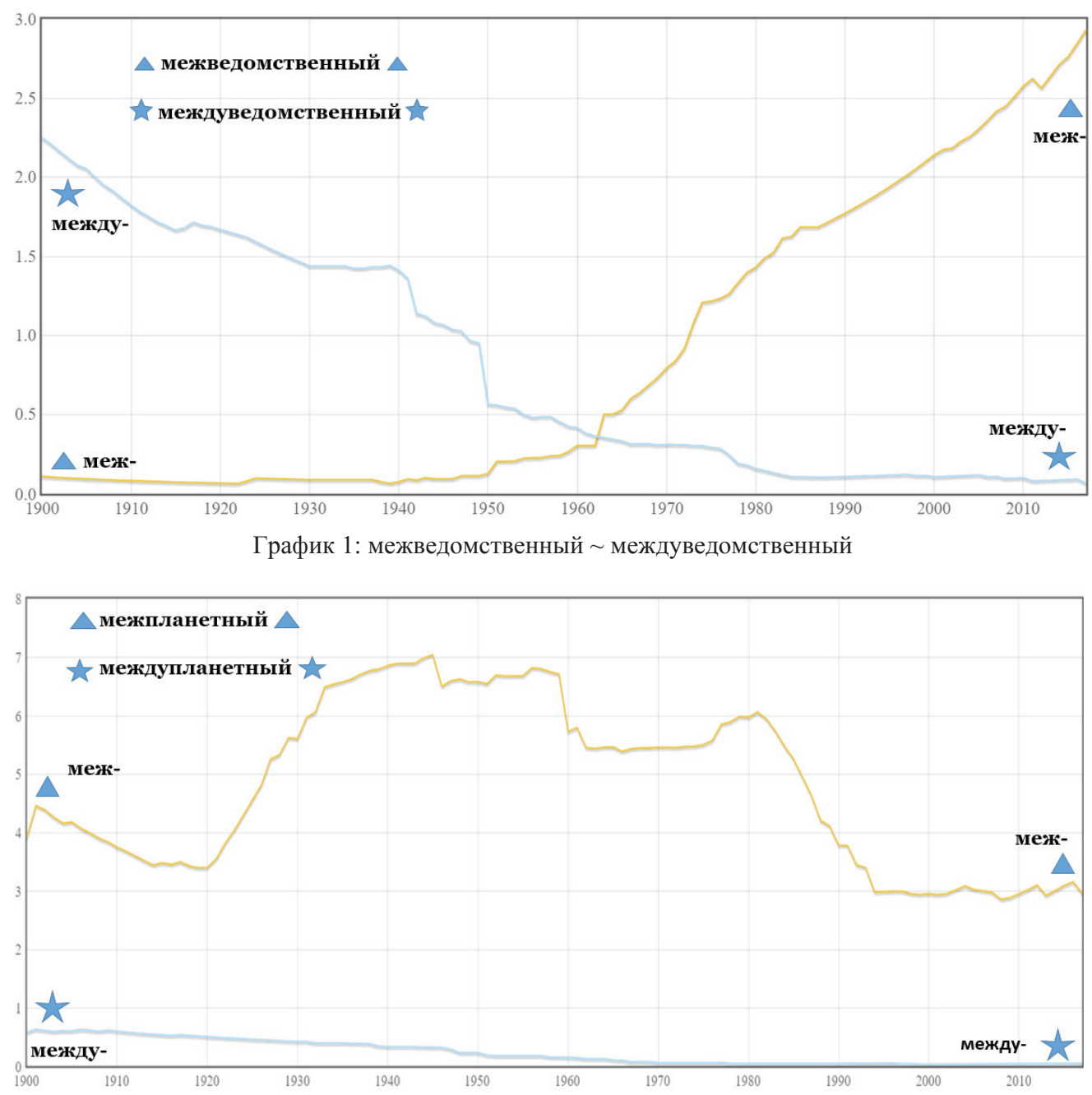

График 2: межпланетный междупланетный

в разговорной речи с целью иронического преувеличения масштабов какого-либо события или явления, ср., например: Господи, да ведь он мне все уже объяснил тогда! А я, дуралей междупланетный, не понял ни слова! [Вячеслав Рыбаков. Вода и кораблики (1992)]; А с чего вы решили, что всё скупили международные корпорации? Вы снимки Марса видели? Там у них кроме песка - ни хрена больше нет! Вот откуда заговор-то идёт! Междупланетный Заговор! А может,$>$ иеждузвёздный!.. (Интернет). Источником такого употребления является название знаменитой XXXVII главы романа И. Ильфа и Е. Петрова «Двенадцать стульев» (1927) - «Междупланетный шахматный конгресс». Однако, несмотря на явно иронический характер этого названия, сам по себе выбор формы междупланетный, судя по всему, не имел для Ильфа и Петрова никаких юмористических 

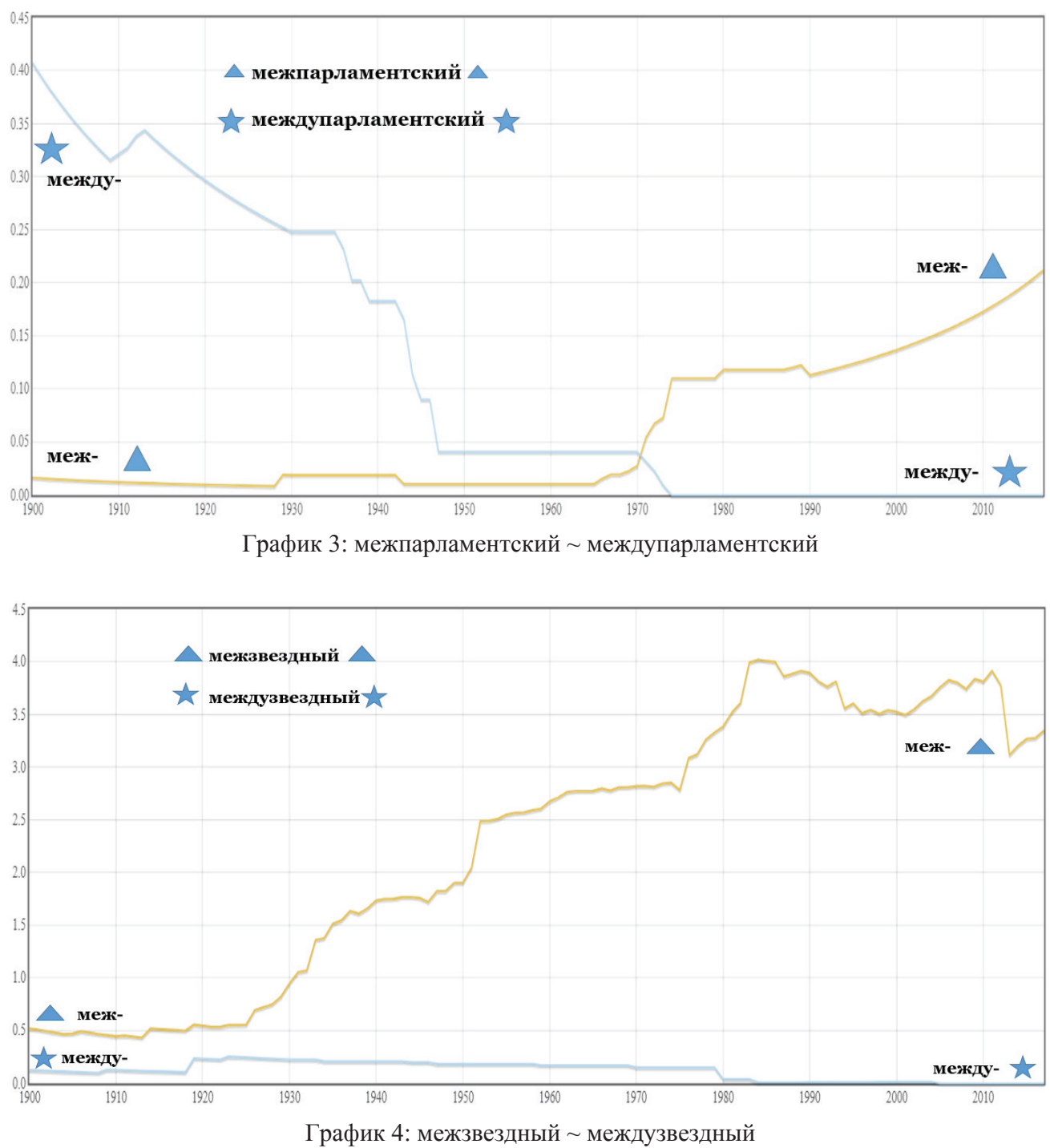

коннотаций: в 20-е - 30-е годы XX века этот вариант хотя и встречался уже значительно реже варианта межпланетныци, был вполне нейтральным: он представлен, например, у Е.И. Замятина, О.Э. Мандельштама, Яна Ларри и других авторов.

Хотя вариант междуэтажный встречается в НКРЯ чаще варианта межэтажный, для этой пары характерна та же хронологическая динамика, см. График 6.

Таким образом, прилагательные международный, междугородный междугородний и междурядный представляют собой яркое исключение из общей картины, однозначно свидетельствующей о быстром вытеснении варианта между- вариантом меж-. Ситуация со словом международный показывает, что включение 

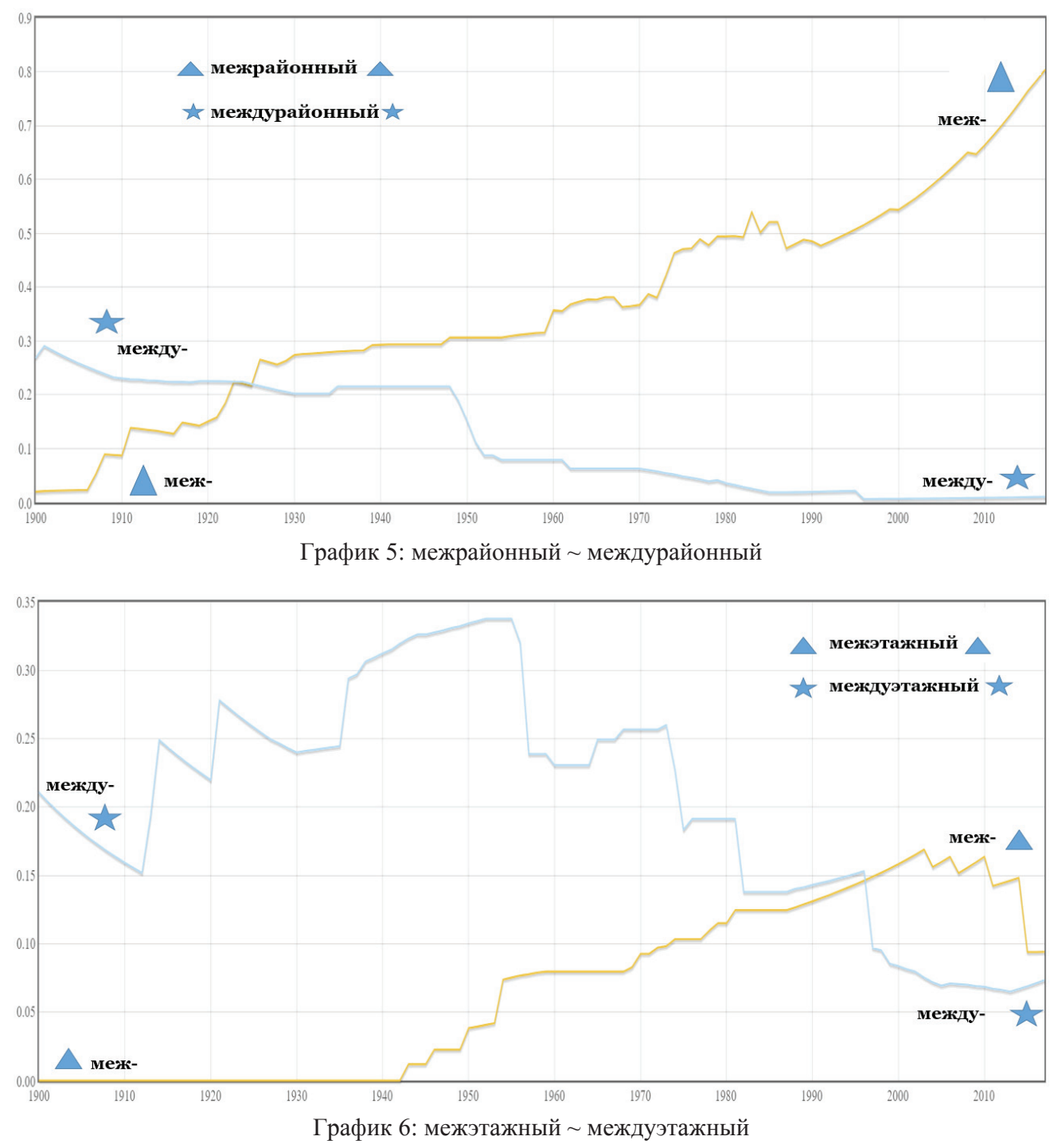

в общий подсчет одного-единственного очень частотного слова, ведущего себя нестандартным образом, может полностью исказить статистические данные и потенциально привести к неверным выводам. Этот пример представляется весьма интересным и методологически значимым.

\section{3. Элементы меж- и между- в составе сложных существительных}

Под «сложными существительными» в настоящем разделе понимаются существительные ср. p. на -ие/-ье. Это связано с тем, что существительные типа международник или междисииплинарность не представляют интереса 
в рассматриваемом отношении, поскольку сохраняют в неизменном виде основу мотивирующего прилагательного. Особняком стоят лексемы межгород, воспринимаемая как сокращение, и междусобойчик, образованная непосредственно от выражения между собой.

В отличие от прилагательных сложные существительные в целом демонстрируют некоторое преобладание варианта между-: около 650 вхождений против примерно 350 вхождений с меж-.

По характеру соотношения вариантов меж- и между- сложные существительные делятся на несколько групп.

1) Существительные с суффиксом -ие требуют варианта между-. В первую очередь речь идет о словах междуцарствие (143 вхождения) и междувластие (6), однако данная группа способна окказионально проявлять продуктивность, ср. отсутствующий в НКРЯ редкий биологический термин междуперстие «промежуток между копытами у парнокопытных» и журналистский неологизм междумуллие (о ситуации в Афганистане).

К этой же группе относятся «старые» (в том числе выходящие из употребления) существительные с суффиксом -ье и односложным корнем: междуречье (очень часто в качестве имени собственного; 211), междурядье (82), междупутье (9), межоупарье (6).

2) Существительные с суффиксом -ье и неодносложным корнем требуют варианта меж-: межсезонье (166), межвременье (15), межреберье (14), межозерье (6).

3) Не очень частотные существительные с суффиксом -ье и односложным корнем, представляющие собой не столько полноценные единицы языка, сколько регулярно воспроизводимые окказионализмы, допускают оба варианта с некоторым преобладанием меж-, ср. межбровье междубровье (11:3), межгорье междугорье (7:3), межалазье междуглазье (2:1).

\section{4. Особые случаи}

Наряду с между- и меж- в сложных словах рассматриваемого типа встречаются также редкие варианты междо-, ср. междометие, междоусобие (и однокоренные), междоузлие, и меже-, ср. межеумок (и однокоренные). Если оставить в стороне старый искусственно созданный термин междометие, во всех остальных случаях использование вариантов междо- и меже- обусловлено стремлением избежать стыка двух гласных $y$. В то время как вариант меже- встречается только перед корнем -ум-, модель «междо- + $y$...» опять-таки способна окказионально проявлять продуктивность, ср. пользующийся некоторой популярностью в Интернете (примечательным образом, не только русском, но и болгарском (!)) иронический неологизм междоушие «мозги, пространство между одним и другим ухом».

Запрет на сочетание двух $у$ не является абсолютно строгим: основа междоусобвстретилась в НКРЯ 1483 раза, основа междуусоб- — 121 раз; наряду с междоушие в Интернете попадается и вариант междуушие. 


\title{
5. Заключительные замечания
}

Как мы показали выше, на протяжении последних десятилетий в сложных прилагательных с начальным компонентом меж- между- наблюдается достаточно активный процесс вытеснения второго из этих вариантов первым, объясняемый, скорее всего, его большей краткостью. В существительных тот же процесс, если и имеет место, протекает значительно медленнее; таким образом, можно говорить о наличии некоторой связи между выбором одного из конкурирующих вариантов и частеречной принадлежностью производного слова.

Интересно, что если предлоги меж (исконно русский) и между (церковнославянский) «поменялись» стилистическими статусами, то в сложных словах такого эффекта нет: слова с меж- могут восприниматься как официальные и канцелярские, но не как устаревшие, тогда как некоторые слова с между- (междуцарствие, междуперстие) имеют книжную и даже «высокую» окраску.

\section{Литература}

Русская грамматика. В 2-х томах. Т. І. / Под ред. Н. Ю. Шведовой. М.: Институт русского языка имени В. В. Виноградова, 1980. 784 с.

Ожегов С. И. Словарь русского языка. Изд. 14-е. М.: Русский язык, 1983. 816 с.

[ОСРЯ] - Орфоэпический словарь русского языка. Произношение, ударение, грамматические формы. Изд. 5-е, испр. и доп. / Под ред. Р.И. Аванесова. М.: Русский язык, 1989. 688 с.

\author{
Iliya B. Itkin \\ Institute of Oriental Studies (Russian Academy of Sciences); \\ National Research University Higher School of Economics \\ (Russia, Moscow) \\ ilya.borisovich.itkin@gmail.com \\ Viktoria D. Pekarskaya \\ National Research University Higher School of Economics \\ (Russia, Moscow) \\ vikpek.96@gmail.com
}

\section{AN INTERNATIONAL SCANDAL (COMPOUND WORDS \\ WITH THE FIRST COMPONENT MEZH- MEZDU- - IN THE HISTORY OF RUSSIAN LITERATURE LANGUAGE}

The article investigates patterns of choice between two competing initial components mež- and meždu- in such words as mežličnostnyj (interpersonal), mežètažnyj mežduètažnyj (interfloor), mežducarstvie (interregnum), mežsezon'e (inter-season) and 
so on. It is shown that rules applicable for adjectives and nouns are considerably different. Despite the fact that the most frequently used adjective of this type - meždunarodnyj (international) - attaches meždu- only, the majority of adjectives preferably appear to have (often the only possible) initial component mež-. Moreover, the usage of mežduadjectives (e.g. mežduvedomstvennyj - interdepartmental) declines steadily throughout the last 70-80 years, while the usage of mež-adjectives (e.g. mežvedomstvennyj - interdepartmental), on the contrary, demonstrates stable growth. The current research shows that compound nouns can be divided into certain classes. Nouns ending with -ie and some long-standing nouns that have monosyllabic root followed by - 'e demand the mežduvariant: mežducarstvie (interregnum), mežduvlastie (inter-power), meždureče (interfluve area), meždurâd'e (inter-row area), mežduput'e (intertrack space). Nouns with - 'e, in which this - ' $e$ is preceded by more than one syllable allow, the mež- variant: mežsezon'e (inter-season), mežvremen'e (intertemporal period). Uncommon monosyllabic nouns ending with - 'e allow both variants with preference of the mež- variant: mežbrov'e meždubrov'e (area between eyebrows), mežgor'e $\sim$ meždugor'e (area between mountains). Rare variants with meže- (mežeumok (underwit)) and meždo- (meždouzlie (interstitial position), meždousobnyj (internal (about a conflict))) require special consideration. They are used to avoid the confluence of two $u$ vowels. Thus, there is some loose but ostensive connection between the choice of one of the competing variants and the part of speech of the derived word. The stylistic status of mež- and meždu- lexemes is also discussed in the conclusion.

Key words: Russian language, compounds with $m e \check{z}$ - and $m e z ̌ d u$-, linguistic variation, chronological dynamics, parts of speech.

\section{References}

Russkaya grammatika [Russian grammar]. Vol. I. Ed. by N.Yu. Shvedova. Moscow: Institut russkogo yazyka imeni V.V. Vinogradova Publ., 1980. 784 p.

Ozhegov S. I. Slovar' russkogo yazyka [Dictionary of the Russian language]. $14^{\text {th }}$ edition. Moscow: Russkii yazyk Publ., 1983. 816 p.

Orfoepicheskii slovar' russkogo yazyka. Proiznoshenie, udarenie, grammaticheskie formy [Orthoepic dictionary of the Russian language. Pronunciation, stress and grammatical forms]. $5^{\text {th }}$ edition. Ed. by R. I. Avanesov. Moscow: Russkii yazyk Publ., 1989. $688 \mathrm{p}$. 


\author{
В.В. Каверина \\ Московский государственный университет имени М. В. Ломоносова \\ (Россия, Москва) \\ kaverinal@yandex.ru
}

\title{
ОСНОВНЫЕ ТЕНДЕНЦИИ УПОТРЕБЛЕНИЯ КОНСОНАНТНОГО УДВОЕНИЯ В ЗАИМСТВОВАННЫХ СЛОВАХ
}

В статье рассматривается употребление двойных согласных в словах, заимствованных в русский литературный язык на разных этапах его развития. Освоение иноязычий происходит постепенно, и в ходе этого процесса написание их может варьироваться. Было замечено, что если слово пришло в русский язык в самом начале XVIII века или ранее, то консонантное удвоение этимона обычно утрачивается. Позднее, напротив, две согласные слова-источника чаще сохраняются. Колебания в орфографии иноязычий, как правило, отражают различия в передаче этимона в разных иностранных языках. Кроме того, написание ранних заимствований впоследствии может изменяться, при этом устраненное в первоначальном варианте удвоение нередко восстанавливается, и орфография слова закрепляется именно в таком виде. В середине XX века усиливается тенденция к консонантному удвоению в иноязычиях, и данный процесс захватывает даже те слова, в этимоне которых не было удвоенных согласных. Стремление к сохранению двойных согласных и даже появлению новых таких групп в орфографии тесно связано с орфоэпией и влечет за собой произношение долгих согласных звуков, зачастую вопреки современной орфоэпической норме.

Ключевые слова: история русского письма, удвоение согласных, орфография заимствований.

Заимствования, пришедшие в русский язык в Петровскую эпоху или ранее обычно не сохраняли удвоение этимона. Об этом писал Я.К. Грот: «В иностранных словах, заимствованных в более или менее отдаленные времена, даже еще в петровскую эпоху, удвоение согласных большею частью пропало. Слова грамота, арест, офииер, батарея, атака, карета, команда, комендант, камергер, канцелярия всеми бесспорно пишутся так, вместо граммата, аррест, оффищер и т. д. Но с другой стороны, иногда и в старинных заимствованиях сохраняется удвоение, например, пишут: коллегия, аттестат» [Грот 1899: 776]. Повышение интереса к нормам письма приводит к тому, что исходное удвоение сохраняется всё чаще, 
и большинство иноязычий, появившихся в XVIII и XIX столетиях, пишется с двумя согласными по сей день. Оставалась неизменной с момента появления слова в русских текстах орфография многих таких заимствований: аллегория, аллигатор, аннотация, барокко, баџилль, генералиссимус, гиппопотам, диссертация, иллюзия каллиграфия, колоннада, корреспондент, кристаллический, миллиард, миллиграмм, профессор, режиссер, терраса.

Особый интерес представляют случаи, когда заимствованное с одной согласной слово в процессе освоения получает консонантное удвоение под влиянием орфографии этимона или слов того же происхождения из других языков. Так, слово «аббат» первоначально записывалось как опать (1490 г.) [Словарь 1975: 18], в начале XVIII в. получило варианты написания: onamъ, anamъ, aбать, аватъ, авват и, наконец, знакомое нам аббать [Словарь 1984: 8]. Приведенное разнообразие, очевидно, объясняется влиянием языков-посредников, через которые могло быть заимствовано данное слово: «Лат. abbas, -tis, непоср. и через ит. ab(b)ate, фp. l'abbé, нем. Abt, пол. opat» [Словарь 1984: 8]. Закрепление варианта написания через два б, вероятно, было поддержано французской орфографией: «Достоин ли моей похвалы тот Француской Аббат, который желая снискать благосклонность своего Епископа, превозносит до небес его глупости. ПД I 35. || Аббат, или Аббе во Франции назывались и тъ, кои еще не пострижены, но токмо носят черное или виолетовое платье... изъявляя желание свое быть в духовном звании и никакой не имЂют должности. Ян. I 4. [Словарь 1984: 8]. Именно в таком виде слово было закреплено в «Словаре церковно-славянского и русского языка» 1847 г. [Словарь 1847, 1: 1].

Другим подобным примером может послужить слово «ипподром», однокоренные образования которого встречаются в древнерусских текстах с одной $n$ : «Употребляя книжные заимствования, переводчик «Жития Андрея Юродивого» обычно пассивно следует оригиналу. Так, грецизм иподромиє используется исключительно в соответ-

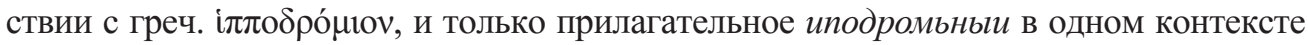
передает греч. $\theta \dot{\varepsilon} \alpha \tau \rho o v$ (это слово в византийском греческом также означало 'ипподром’), в то время как в «Истории Иудейской войны» иподроумиє в одном контек-

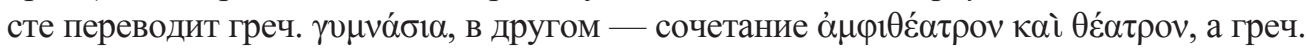
ілло́ $\rho \rho \mu \varsigma$ переводится как конеристаниє [ИИВ, II: 66, 609]; в «Пчеле» подроумиє со-

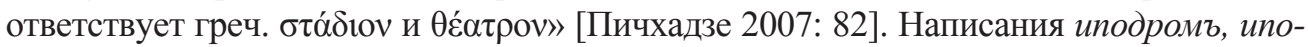
дромие и иподрумие с одной $n$ стабильны вплоть до конца XVII в. [Словарь 1979: 247]. Вариативность в корне появляется в XVIII столетии: «Созда же царь и полату велику и иподрому дивну. Козм. 96. БЪгание сие <на конях и в колесницах $>$ производилось на ристательном мъстђ, кое называемо было Гипподромом. Арг. II 553. Я зрђл, как жилистой рукой Он шесть коней на Ипподромь Вмиг осаждал в бъгу. Држ. Соч. II 79» [Словарь 1997: 110]. Закрепление написания с двумя $n$, по мнению М. Фасмера, обусловлено влиянием французского языка: «Позднее заимств. из франц. hippodrome; напротив, др.-русск. иподрумие (Новгор. І летоп. и др.), иподромие (Пов. врем. лет,

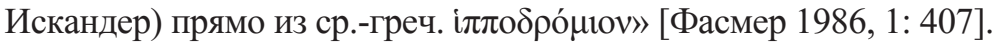

Колебания в процессе освоения наблюдаются и в слове «коралл», что, как и в рассмотренных ранее случаях, связано с влиянием разных языков-источников. Фасмер 
возводит происхождение слова к немецкому Koralle или польскому koral co ссылкой на греческий первоисточник: «через нов.-в.-н. Koralle или польск. koral, koralik

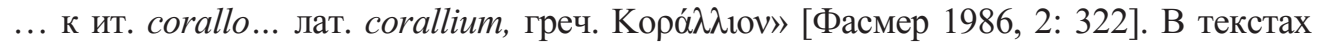
XVII века отмечается варьирование одной и двух букв $л$ : КОРАЛЬ и КОРАЛЛУСЬ [Словарь 1980: 305]. В XVIII веке также отмечается варьирование, но уже с преимущественным написанием удвоенной л: «КОРА́ЛЛ (-ал), а и КОРА́ЛЬ, я, м. род. мн. -ов и -ал. И в ть мраморы врђзываны каменья цвътные ... и корали и янтари. Собрать в Смирнь разное анатольское дерево, лавы, мраморы, кораллы» [Словарь 1998: 167]. В «Словаре Академии Российской» 1789-1794 гг. закреплен вариант с удвоением: КОРАЛЛЬ [Словарь 2001-2006], данное написание кодифицируют и словари XIX столетия. Однако в словаре Ушакова зафиксированы написания как с одной, так и с удвоенной л со ссылкой на греческое происхождение слова: «КОРАЛ, КОРАЛЛ коралла, м. (греч. korallion)» [Толковый словарь 1935-1940]. Окончательно закреплено написание с двумя л в «Словаре иностранных слов» 1949 г. [Словарь 1949: 335].

Подобно приведенным выше словам, нестабильное написание на этапе освоения имели многие иноязычия. Колебания в сторону утраты удвоения, как правило, завершались его сохранением, к примеру, в словах аббревиатура, аккуратный, аллея, апелляция, артиллерия, ассамблея, ассигнаџия, ассистент, аттестат, вилла, грамматика, дилемма, идиллия, колонна, массив, миллион, параллель, параллелепипед, параллелограмм. Число же заимствованных слов, удвоение в которых было на этапе вхождения слова в русский язык, но с течением времени исчезло, значительно меньше (например, акула, амуниция, апартаменты, галерея). Тем более интересно проследить становление орфографии таких слов.

Слово «галерея» предположительно пришло в русский язык в начале XVIII в. из немецкого или французского языков, которыми заимствовано из итальянского с основным значением 'церковная паперть'. Впервые слово упоминается в книге Куракина «Архив». В русском словаре слово «галерея» впервые встречается с 1731 г. со значением 'верхний ярус театра, здания' [Семенов 2003]. М. Фасмер происхождение слова возводит к немецкому Gallerie или французскому galerie, высказывая сомнения о польском заимствовании: «Предположение о заимствовании через польск. galeria (Христиании) не объясняет места ударения русск. слова» [Фасмер 1986, 1: 386]. В «Словаре русского языка XVIII века» зафиксировано преимущественное написание слова с одной буквой л [Словарь 1989: 84]. Варьирование происходит под влиянием итальянского galleria (galla-), французского galerie, немецкого Gallerie, голланлского galery (galde-), польского galerya: «Под земляными валами добрые галле́рии и своды построены...С адмиральскаго корабля рђзныя галдареи сшибло... Построена весьма изрядная ратуша или биржа, при которой есть галлерея для купцов... В Ливорнъ у гран-дука галерия, в которой разныя вещи от пиктуры и от скульптуры древней...» [Словарь 1989: 84]. В «Словаре Академии Российской» 1789-1794 гг. закреплен вариант с удвоением: ГАЛЛЕРЕЯ [Словарь 2001-2006]. Однако уже в первой половине XIX столетия начинает нарастать число написаний без удвоения, что, вероятно, объясняется влиянием французского языка, которое усиливалось в то время. Именно такую орфографию закрепил «Словарь церковно-славянского 
и русского языка» в середине ХІХ века: ГАЛЕРЕЯ [Словарь 1847, 1: 254]. Интересно, что в словаре Ушакова опять отражены колебания в орфографии данного слова со ссылкой на итальянское происхождение: «ГАЛЕРЕЯ, ГАЛЛЕРЕЯ, галереи, ж. (ит. galleria)» [Толковый словарь 1935-1940]. Окончательно закреплено написание с одной л в «Словаре иностранных слов» 1949 г. [Словарь 1949: 137].

Приведенные факты позволяют подвергнуть сомнению неоднократно высказывавшуюся мысль о том, что в русском языке происходит «процесс освобождения от удвоенных согласных в написаниях заимствованных слов» [Обзор 1965: 165]. С осторожностью подходить к устранению удвоения в иноязычиях рекомендовал ещё Грот: «...в словах, заимствованных в позднейшее время, нет основания исключать все двойные буквы, но употребление их может быть несколько ограничено, когда оно не вызывается правильным произношением» [Грот 1899: 778]. Стремление сохранять двойные согласные, возникшее в XIX столетии, отмечает А.В. Суперанская: «Именно тогда [в XIX в. - В.К.] обратил на себя внимание тот факт, что многие заимствованные слова, писавшиеся в русском языке с одним согласным, имеют удвоенные согласные в тех языках, откуда они заимствованы. В связи с этим и в русском языке в них стали удваивать согласные. Так постепенно создалась иллюзия, что в иностранных языках интервокальные и конечные согласные должны быть удвоены, хотя в действительности это далеко не всегда так» [Суперанская 1959: 164].

Есть основание полагать, что сохранение и закрепление удвоенных согласных в орфографии иноязычий связано с «наивными представлениями о языке» [Болычева 2007: 340-341], в соответствии с которыми заимствованные слова должны писаться по-особому, в частности, с двумя согласными. Большой интерес в связи с этим представляют слова, где часто ошибочно пишут двойные согласные: алогизм, алюминий, амуниция, галерея, импресарио, коридор, масон, продюсер, раса, рококо, элегия. А. В. Суперанская в статье 1964 г. приводит примеры гиперкорректных написаний с незаконным удвоением согласных: «массон, фоллиант, славянофилл, гамадрилл, муллат, мулл, панорамма, маррокен, аттол, пичикатто, асс, тисс, хакасс» [Суперанская 1964: 80]. Тенденцию к консонантному удвоению усматривает в таких написаниях И. В. Нечаева уже в наше время: «...в нынешней языковой ситуации для новых заимствований доминантным является удвоенное употребление согласных, имеющих такое удвоение в этимоне. Об упрощении сдвоенных написаний на начальной стадии освоения заимствований речь не идет» [Нечаева 2011: 57]. Это, по мнению Нечаевой, «косвенно подтверждается распространением в узусе гиперкорректных написаний, т.е. написаний с удвоенной согласной, не оправданных этимологически <Cp. импрес(с)арио - impresario(ит), пал(л) ета — palette (ф), продюс(с)ер — producer(a), стрим(м)ер — streamer(a), тиф(ф) ози — tifoso(ит), хе/эви-метал(л) — heavy metal(a)>» [Нечаева 2011: 57].

В последнее время наметилась тенденция не только не избавляться от удвоений, но и употреблять долгие согласные на месте удвоенных букв вопреки орфоэпической норме. В отличие от предшествующих периодов, в современном русском языке удвоенные согласные в заимствованных словах не только не устраняются, но даже могут влиять на произношение данных слов носителями русского языка. Лингвисты 
стали обращать внимание на то, что грамотность как важный фактор формирования коллективного сознания носителей языка оказывает всё большее влияние на их фонетические представления и даже является движущей силой изменения произносительных норм [Болычева 2009: 120-131]. И это, на наш взгляд, в эпоху тотальной грамотности не случайно. Действительно, «буквы проникают в наше сознание в раннем возрасте и формируют алгоритм приоритета (или презумпции) буквы, который потом оказывает влияние на некоторые лингвистические решения» [Болычева 2007: 340-341]. Исследование показало, что наши современники нередко произносят долгие звуки в заимствованиях в соответствии с двойными согласными на письме, даже вопреки орфоэпической норме, что, очевидно, со своей стороны, поддерживает закрепление таких написаний. Пишут правильно две согласные буквы, произнося долгий согласный в нарушение орфоэпической нормы, в 32 словах из 66: апелляция, артиллерия, ассигнация, асимметрия, ассамблея, ассистент, биссектриса, галлюиинация, гиппопотам, грамматика, диссертаџия, идиллия, ипподром, каллиграфия, капилляр, коллектив, колоннада, комиссар, коррелящия, оппонент, параллелепипед, параллелограмл, режиссер, терраса, территория, террор, тоннель, корреспондент, кристаллический, массив, миллиграмм, оппозиция. Долгие звуки нередко произносят и в предложенных нами иноязычиях с одной согласной, где встречаются гиперкорректные случаи удвоения: алогизм, алюминий, амуниция, галерея, импресарио, коридор, масон, продюсер, раса, рококо, элегия.

Подведем итоги. Освоение иноязычий происходит постепенно, и в ходе этого процесса написание их может варьироваться. Как правило, если слово пришло в русский язык в самом начале XVIII века или ранее, то консонантное удвоение этимона утрачивается. Позднее, напротив, две согласные слова-источника чаще сохраняются, а колебания в орфографии иноязычий обычно отражают различия в передаче этимона в разных иностранных языках. Кроме того, написание ранних заимствований впоследствии может изменяться, при этом устраненное в первоначальном варианте удвоение нередко восстанавливается, и орфография слова закрепляется именно в таком виде. В середине XX века усиливается тенденция к консонантному удвоению в иноязычиях, и данный процесс захватывает даже те слова, в этимоне которых не было удвоенных согласных. Стремление к сохранению двойных согласных и даже появлению новых таких групп в орфографии тесно связано с орфоэпией и влечет за собой произношение долгих согласных звуков, зачастую вопреки современной орфоэпической норме.

\section{Литература}

Болычева E.M. О презумпции буквы в наивных представлениях о языке и некоторых актуальных проблемах фонетики // Русский язык: исторические судьбы и современность. III Межд. конгресс исследователей русского языка. Труды и материалы. / Составители М. Л. Ремнёва, А. А. Поликарпов. М.: МАКС Пресс, 2007. С. 340-341.

Больчева Е.М. Интуитивное фонетическое знание и лингвистические теории: противоречия и соответствия // Вопросы русского языкознания: Сб. Вып. ХІІІ. 
Фонетика и грамматика: настоящее, прошедшее, будущее: к 50-летию научной деятельности Софии Константиновны Пожарицкой / Сост. С. В. Князев, А. В. Птенцова; Отв. ред. М. Л. Ремнева, С. В. Князев. М. : Изд-во МГУ, 2009. С.120-129.

Грот Я.К. Спорные вопросы русскаго правописанія отъ Петра Великаго донынъ. Филологическое разысканіе Я.Грота // Труды Я. К. Грота / Филологические разыскания. Т.2. СПб. :Типографія Министерства Путей Сообщенія, 1899. С. 471801.

Нечаева И. В. Актуальные проблемы орфографии иноязычных заимствований. М. : Издательский центр «Азбуковник», 2011. 168 с.

Обзор предложений по усовершенствованию русской орфографии (XVIIIХХ вв.). М. : Наука, 1965. 500 с.

Пичхадзе А. А. О функционировании греческих книжных заимствований в древнерусском языке // Русский язык в научном освещении. 2007. № 1(13). С. 73-84.

Семенов А.В. Этимологический словарь русского языка. Серия «Русский язык от А до Я». М. : ЮНBЕC, 2003. 704 с. [Электронный ресурс]. URL: http://www. slovorod.ru/etym-semenov/sem-g.htm\#ga

Словарь Академии Российской 1789-1794: В 6 т. М. : МГИ им. Е.Р. Дашковой, 2001-2006. [Электронный ресурс]. URL: http://it-claim.ru/Projects/ESAR/SAR/ PDFSAR/Framesetpdf.htm

Словарь иностранных слов / Лёхин И.В., Петров Ф.Н.М. : Государственное изд-во иностранных и национальных словарей, 1949. 805 с.

Словарь русского языка XI-XVII вв. Вып. 1. М. : Наука, 1975. 371 с.

Словарь русского языка XI-XVII вв. Вып. 6. М. : Наука, 1979. 359 с.

Словарь русского языка XI-XVII вв. Вып. 7. М. : Наука, 1980. 403 с.

Словарь русского языка XVIII века. Вып. 1. Л. : Наука, 1984. 224 с.

Словарь русского языка XVIII века. Вып. 5. Л. : Наука, 1989. 256 с.

Словарь русского языка XVIII века. Вып. 9. СПб. : Наука, 1997. 270 с.

Словарь русского языка XVIII века. Вып. 10. СПб. : Наука, 1998. 256 с.

Словарь церковно-славянскаго и русскаго языка, составленный вторым отдъленіемъ Императорской Академіи Наукъ : в 4 т. СПб. : Въ Типографіи Императорской Академіи Наукъ, 1847. Т. 1. 415 с.

Суперанская A. B. Написание заимствованных слов в современном русском языке // Проблемы современного русского правописания. М.: Наука, 1964. С. 69-100.

Суперанская A.B. Об одной ошибке в написании географических названий // Вопросы культуры речи. Вып. 2. М. : Изд-во Академии наук, 1959. С. 163-167.

Толковый словарь русского языка: В 4 т. / Под ред. Ушакова Д.Н. М. : Государственный институт «Советская энциклопедия», ОГИЗ (Т. 1); Государственное издательство иностранных и национальных словарей (Тт. 2-4), 1935-1940. [Электронный ресурс]. URL: http://ushakovdictionary.ru/

Фасмер М. Этимологический словарь русского языка : в 4 т. М.: Прогресс, 1986. T. $1.576 \mathrm{c}$.

Фасмер М. Этимологический словарь русского языка : в 4 т. М.: Прогресс, 1986. T. 2. $672 \mathrm{c}$. 


\section{Valeria $V$. Kaverina \\ Lomonosov Moscow State University \\ (Russia, Moscow) \\ kaverina1@yandex.ru}

\section{MAIN TRENDS IN RUSSIAN CONSONANT DOUBLING IN LOAN WORDS}

The article focuses on the double consonants in words borrowed by Standard Russian at various stages of its evolution. The incorporation is taking place gradually, the spelling being varied. It has been observed that if a word was borrowed at the very beginning of $18^{\text {th }}$ century or earlier, the double consonant of the original form is often lost. On the contrary, during a later period the double consonant of a loan is retained. Variations in the spelling of loan words normally reflect the differences in rendering the original forms in different foreign languages. Besides, the orthography of earlier borrowings could change, not infrequently the lost doubling in the original being restored and standardized. The middle of the $20^{\text {th }}$ century shows a stronger tendency for consonant doubling in loans and the process involves even those words which originally had no double consonants at all. The retention of double consonants and the appearance of new groups of the kind in orthography is indissolubly connected with orthoepy and results in the prolongation of consonants, which very often does not conform with the present orthoepic norm.

Key words: history of Russian spelling, consonant doubling, orthography of borrowings.

\section{References}

Bolycheva E. M. [On a Letter Presumption in the Naïve Conceptions and Current Issues of Phonetics]. Russkij jazyk: istoricheskie sud'by i sovremennost'. III Mezhd. kongress issledovatelej russkogo jazyka. Trudy i materialy [The Russian Language: History and Modernity. The Proceedings of the 3d International Congress of Researchers into Russian]. M.: MAKS Press, 2007, pp. 340-341. (In Russ.)

Bolycheva E. M. [Intuitive Phonetic Knowledge and Linguistic Theories: Contradictions and Correspondences]. Voprosy russkogo jazykoznanija: Sb. Vyp. XIII. Fonetika $i$ grammatika: nastojashhee, proshedshee, budushhee: $k$ 50-letiju nauchnoj dejatel'nosti Sofii Konstantinovny Pozharickoj [Issues of Russian Studies: Issue 13. Phonetics and Grammar: Present, Past, and Future. To S.K. Pozharitskaya's 50 years Jubilee]. M., MSU Press, 2009, pp. 120-129. (In Russ.)

Grot Ya. K. [Arguable Issues of Russian Spelling since Peter I until the Present Time. A Philological Study by Y.K. Grot]. Trudy Ja. K. Grota. Filologicheskie razyskanija [Y.K. Grot's collection of works]. Vol. 2. Saint-Petersburg: Ministry of Transport's Printing-House, 1899, pp. 471-801. (In Russ.)

Nechayeva I. V. Aktual'nye problemy orfografii inojazychnyh zaimstvovanij [Current Issues of Loan Orthography]. M., Azbukovnik Publishing Centre, 2011. 168 p.

Obzor predlozhenij po usovershenstvovaniju russkoj orfografii (XVIII-XX vv.) [A Survey of Suggestions for the Improvement of Russian Orthography]. (18-20cc.) M.: Nauka Publishers, 1965. 500 p. 
Pitchkhadze A. A. [On the Functioning of the Greek Literary Borrowings in Old Russian]. O funkcionirovanii grecheskih knizhnyh zaimstvovanij $v$ drevnerusskom jazyke [Russian from an Academic Perspective]. Russkij jazyk v nauchnom osveshhenii. 2007. no. 1(13), pp. 73-84. (In Russ.)

Semenov A. V. Jetimologicheskij slovar' russkogo jazyka. Serija «Russkij jazyk ot A do $J a »$ [A Dictionary of Russian Etymology. Series Russian from A to Ya]. M.: YUNVES, 2003. 704 p. Available at: http://www.slovorod.ru/etymsemenov/sem-g.htm\#ga

Slovar' Akademii Rossijskoj 1789-1794 [A Dictionary by the Academy of Russia 1789-1794: 6 v.] M.: E.R. Dashkova MSI, 2001-2006. Available at: http://itclaim.ru/ Projects/ESAR/SAR/PDFSAR/Framesetpdf.htm

Slovar' inostrannyh slov [A Dictionary of Borrowings]. Lekhin I. V., Petrov F. N. M.: State Publishers of Foreign and National Dictionaries, 1949. 805 p.

Slovar' russkogo jazyka XI-XVII vv. [A Dictionary of Russian of $11^{\text {th }}-17^{\text {th }} \mathrm{cc}$.] Issue 1 . M.: Nauka Publishers, 1975. 371 p.

Slovar' russkogo jazyka XI-XVII vv. [A Dictionary of Russian of $11^{\text {th }}-17^{\text {th }} \mathrm{cc}$.] Issue 6. M.: Nauka Publishers, 1979. 359 p.

Slovar' russkogo jazyka XI-XVII vv. [A Dictionary of Russian of $11^{\text {th }}-17^{\text {th }} \mathrm{cc}$.] Issue 7. M.: Nauka Publishers, 1980. 403 p.

Slovar' russkogo jazyka XVIII veka [A Dictionary of Russian of $18^{\text {th }} \mathrm{c}$.] Issue 1. L.: Nauka Publishers, 1984. 224 p.

Slovar' russkogo jazyka XVIII veka [A Dictionary of Russian of $18^{\text {th }} \mathrm{c}$.] Issue 5 . L.: Nauka Publishers, 1989. 256 p.

Slovar' russkogo jazyka XVIII veka [A Dictionary of Russian of $18^{\text {th }}$ c.] Issue 9. L.: Nauka Publishers, 1997. 270 p.

Slovar' russkogo jazyka XVIII veka [A Dictionary of Russian of $18^{\text {th }}$ c.] Issue 10. L.: Nauka Publishers, 1998. 256 p.

Slovar' cerkovno-slavjanskago i russkago jazyka, sostavlennyj vtorym otdЊleniem\# Imperatorskoj Akademii Nauk [A Dictionary of Old Slavonic and Russian Compiled by the Second Department of the Russian Academy of Science]. 4 v. Saint-Petersburg. Imperian Academy Publishers, 1847. Vol. 1. 415 p.

Superanskaya A.V. [The Spelling of Loan Words in modern Russian] Problemy sovremennogo russkogo pravopisanija [Issues of Russian Spelling]. M.: Nauka Publishers, 1964, pp. 69-100. (In Russ.)

Superanskaya A.V. [About One Error in the Spelling of Place Names] Voprosy kul'tury rechi [Issues of Speech Culture]. Issue 2. M.: Academy of Science Publishers, 1959, pp. 163-167. (In Russ.)

Tolkovyj slovar' russkogo jazyka [A Unilingual Dictionary of Russian]. 4 v. Ed. By Ushakova D.N. M.: State Institute "Soviet Encyclopedia", OGIZ) V.1; State Publishers of Foreign and National Dictionaries (V. 2-4), 1935-1940. (In Russ.) Available at: http:// ushakovdictionary.ru/ 2

Fasmer M. Jetimologicheskij slovar' russkogo jazyka [A Dictionary of Russian Etymology]. 4 v. M.: Progress Publishers, 1986. V. 1. 576 p.

Fasmer M. Jetimologicheskij slovar' russkogo jazyka [A Dictionary of Russian Etymology]. 4 v. M.: Progress Publishers, 1986. V. 2. 672 p. 


\section{М. С. Картышева}

Институт русского языка им. В. В. Виноградова РАН

(Россия, Москва)

mariyakartysheva@gmail.com

\section{СОВРЕМЕННОЕ УПОТРЕБЛЕНИЕ И ИСТОРИЧЕСКАЯ ДИНАМИКА РАСПРЕДЕЛЕНИЯ ПЕРВЫХ КОМПОНЕНТОВ ДВУ-/ДВУХ- В СЛОЖНЫХ СЛОВАХ}

В статье рассматриваются принципы распределения первой части дву- или двух- в сложных словах. В справочниках предлагаются принципы выбора одной из частей в сложном слове, однако эти принципы не всегда сформулированы однозначно (например, как применять смысловой критерий о парности предметов, если сложные слова с первой частью дву- и двух- обозначают «вдвойне») или вовсе противоречат действительности. Кроме того, был проанализирован словарный материал: словари также дают противоречивые рекомендации, с какой частью писать сложное слово. В настоящее время узуальное написание сложных слов с первой частью дву- или двух- не соответствует рекомендациям справочников и словарей, поэтому предлагается не придумывать новые правила, которые не работают, а соотнести данные словарей и реального письма, исключить из словарей варианты, которые не существуют в действительности.

Ключевые слова: орфография, современное письмо, сложные слова, правила, кодификация, словарь, справочник.

В современной практике письма не существует определенного правила, согласно которому следует выбирать написание первой части дву- или двух- в сложных словах. Некоторые рекомендации представлены только в «Справочнике по правописанию и стилистике» Д.Э. Розенталя и в словаре-справочнике «Грамматическая правильность русской речи» под ред. Граудиной, Ицковича, Катлинской, остальные справочные пособия основываются на рекомендации одного из этих изданий. Оба справочника при этом дают разные рекомендации. В статье мы рассмотрим, какие принципы выбора написания дву- или двух- предлагают авторы справочников и как эти принципы отражаются в узусе.

В [Розенталь 1997] указывается, что оба написания равноправны, однако часть слов не допускает вариантов и имеет написание с первой частью дву-. При этом 
по материалам РОСа оба варианта написания зафиксированы только для 36 слов, с первой частью двух - 240 слов, а с первой частью дву- - 120 слов. Такая статистика однозначно опровергает утверждение о равноправии употребления обеих частей (см. Приложение 1).

В [Граудина, Ицкович, Катлинская 1976] признается допустимость обоих вариантов написания в том случае, если в опорной основе названо два элемента или предмета. Однако данный комментарий кажется не совсем ясным, т.к. сложные слова с первой частью дву- и двух- изначально подразумевают наличие двух объектов, названных опорной основой. Например, двуногий - имеющий 2 ноги, двухголовыци — имеющий 2 головы.

В [Розенталь 1997] предлагается использовать фонетический принцип разграничения написаний с дву- и двух-: если второе опорное слово начинается на любую гласную, то предпочтительно написание с двух-. В РОСе 25 слов имеет написание с двух- и 13 - с дву-, а 2 слова - и с дву-, и с двух-. Такое соотношение, однако, не дает права считать фонетический критерий абсолютным.

Также в [Граудина, Ицкович, Катлинская 1976] при выборе дву- или двух- рекомендуется обращать внимание на качество первого согласного опорного корня: если вторая часть начинается на заднеязычную согласную («к», «г», «Х»), то предпочтительнее написание с дву-. Анализ словарных фиксаций ставит под сомнение и этот критерий:

0

$$
\text { ДВУХ }+\Gamma
$$
1. двуглавый
2. двуглазый
3. двугласны
4. двугорбый
5. двугранный
6. двугривенник, -а
7. двугривенничек, -чка
8. двугривенный, -ого
9. двугубый
ДВУХ⿰К
1. двухкамерный
2. двухканальный
3. двухкаскадный
4. двухкассетник, -а
5. двухкассетный
6. двухквантовый
7. двухквартирный
8. двухкилевой
9. двухкилограммовый (2-килограммовый)
10. двухкилометровка, -и, р. мн. -вок

$$
\text { ДВУ+К }
$$

1. двуколка, -и, р. мн. -лок

2. двуколочка, -и, р. мн. -чек

3. двуколочный двуконный

4. двукопытные, -ых

5. двукратность, -и

6. двукратный; кр. ф. -тен, -тна

7. двукрылый 
11. двухкилометровый (2-километровый)

12. двухкнопочный

13. двухколейный

14. двухколенный

15. двухколенчатый

16. двухколёска, -и, р. мн. -сок

17. двухколёсный

18. двухколонный

19. двухколоночный

20. двухкомнатный

21. двухкомплектный

22. двухкомпрессорный

23. двухконтурный

24. двухкоординатный

25. двухкопеечный (2-копеечный)

26. двухкорпусный

27. двухкрасочный

28. двухкруговой

29. двухкулачковый

30. двухкурковый

\section{ДВУХ्X}

1. двухходовка, -и, р. мн. -вок

2. двухходовой и двухходовый

\section{ДВУ+X}

1. двуходка, -и, р. мн. -док

2. двухолмие, -я

В [Граудина, Ицкович, Катлинская 1976] предложен лексический принцип: если опорное слово обозначает меру счета во времени и пространстве или денежную единицу, то употребляется первая часть двуx-. Действительно, бо́льшая часть слов, в которых опорное слово имеет данное значение, пишутся с первой частью двух- (двухдюймовый, двухдневный, двхдолларовый, двухвековой, двухаршинный и др.), кроме слов двугривенник, двугривенничек, двугривенный.

В [Граудина, Ицкович, Катлинская 1976] говорится, что за терминами или устойчивыми словосочетаниями закрепляется один из вариантов написания. Это верно. Например, в РОСе мы находим такие термины, как двуокись, Двуречье, двубратственный, двухзамещенный. При этом закрепленность слова в узкой сфере функционирования не помогает выбрать, какую часть - двy- или двух- — следует писать. Возможны варианты, когда одно написание закрепилось за термином или устойчивым словосочетанием, а другое - за обычным словом: двухжильный провод и двужильный человек, двухлетний ребенок и двулетнее растение.

Если рекомендации справочников о выборе дву- или двух- не совпадают со словарями, то необходимо проанализировать, как словарные рекомендации отражаются в узусе, действительно ли пишущие придерживаются тех написаний, которые 
предлагают словари. В первую очередь, были проанализированы признанные равноправными в РОСе вариативные написания слов с первой частью дву- и двух-. Обращение к Национальному корпусу русского языка показало, что варианты из словаря функционируют и в узусе как варианты. Из 36 слов 9 слов пишутся преимущественно с компонентом двух-, 12 слов — с первой частью дву-, остальные 15 слов либо совсем не представлены в НКРЯ, либо в недостаточном количестве, чтобы делать выводы о преобладающем написании.

Очевидно, что на протяжении веков слова с первым компонентом дву- и двухменяли свой облик. Чтобы определить, есть ли тенденция в выборе одного или другого компонента, был проанализирован список слов с компонентами двуи двуx- из БАСа. При этом БАС имеет расхождения с «Русским орфографическим словарем» в современном написании некоторых слов: слова двухцветный, двухмерный, двустворчатьй, двусторонний, двусторонность имеют в РОСе равноправные варианты написания, а слово двухкопеечник вовсне не зафиксировано в словаре.

В результате была обнаружена только одна историческая тенденция: 13 слов из 56 закрепились с вариативным написанием, это же вариативное написание отражается в современных орфографических словарях. Остальные слова стали писаться либо с первой частью дву-, либо с двух-.

Также имеются исторические фиксации с первой частью дво/два/двое, в дальнейшем подобные написания были вытеснены написаниями с дву- и с двух-: двуглавый, двугласнылй, двуязычныци, двухмесячный, двуногий и др.

Изучение современных справочников, обращение к историческому материалу опровергло наличие каких-либо универсальных принципов, которые помогут пишущему безошибочно выбрать первую часть дву- или двух- в сложных словах. Таким образом, опираться следует на словарные рекомендации, а в словарях при этом следует уточнить список вариативных написаний, т.к. в узусе их меньше, чем в словарях, вероятно, потому что пишущие уже выбрали одно из написаний как основное.

Приложение

\section{Список вариантов из «Русского орфографического словаря»}

$\begin{array}{ll}\text { двуголосный } & \text { двухголосный } \\ \text { двуголосый } & \text { двухголосый } \\ \text { двудонный } & \text { двухдонный } \\ \text { двудушевой } & \text { двухдушевой } \\ \text { двудушник } & \text { двухдушник } \\ \text { двузначность } & \text { двухзначность } \\ \text { двузначный } & \text { двухзначный } \\ \text { двуклассный } & \text { двухклассный } \\ \text { двукомпонентность } & \text { двухкомпонентность } \\ \text { двукомпонентный } & \text { двухкомпонентный }\end{array}$




$\begin{array}{ll}\text { двулетний } & \text { двухлетний } \\ \text { двумерный } & \text { двухмерный } \\ \text { двуместный } & \text { двухместный } \\ \text { двуосновный } & \text { двухосновный } \\ \text { двупольный } & \text { двухпольный } \\ \text { двуполярный } & \text { двухполярный } \\ \text { двусветный } & \text { двухсветный } \\ \text { двускатный } & \text { двухскатный } \\ \text { двусловный } & \text { двухсловный } \\ \text { двусложность } & \text { двухсложность } \\ \text { двусложный } & \text { двухсложный } \\ \text { двуслойный } & \text { двухслойный } \\ \text { двуспальный } & \text { двухспальный } \\ \text { двустволка } & \text { двухстволка } \\ \text { двуствольный } & \text { двухствольный } \\ \text { двустворчатый } & \text { двухстворчатый } \\ \text { двустопный } & \text { двухстопный } \\ \text { двусторонний } & \text { двухсторонний } \\ \text { двусторонность } & \text { двухсторонность } \\ \text { двустрочный } & \text { двухстрочный } \\ \text { двуступенчатый } & \text { двухступенчатый } \\ \text { двуцветность } & \text { двухцветность } \\ \text { двуцветный } & \text { двухцветный } \\ \text { двучленный } & \text { двухчленный } \\ \text { двушёрстный } & \text { двухшёрстный } \\ \text { двуядерный } & \text { двухъядерный } \\ & \end{array}$

\section{Литература}

[БАС] — Большой академический словарь русского языка / Рос. акад. наук, Ин-т лингвист. исслед.; [ред.: Л. И. Балахонова]. — Москва; Санкт-Петербург: Наука, 2004-.

Граудина Л. К., Иикович В.А., Катлинская Л. П. Грамматическая правильность русской речи (опыт частотно-стилистического словаря вариантов)/ М.: Наука, 1976.- $453 \mathrm{c}$.

Розенталь Д.Э. Справочник по правописанию и стилистике. / М.: Комплект, 1997. - $384 \mathrm{c.}$

[РОС] — Русский орфографический словарь: около 200000 слов / [О.Е. Иванова и др.]. — Изд. 4-е, испр. и доп. — Москва: АСТ-Пресс, сор. 2012. — 879 с. 
Maria S. Kartysheva

V.V. Vinogradov Russian Language Institute of the Russian Academy of Sciences

(Russia, Moscow)

mariyakartysheva@gmail.com

\section{MODERN USAGE AND HISTORICAL DINAMIC OF DUSTRIBUTION FIRST COMPONENTS DVU-/DVUKH- IN COMPOUND WORDS}

In the article considering principles of allocation first part two-or double- in multiple words. handbooks providing principles of selection one part in multiple words. but these principles sometimes formulated ambiguous, for example how to use notional norms about things twoness, if multiple words with first parts two- or double- means 'twice" or quite or conflict with reality. Beside dictionary materials were analyzed: they also provide us contradictory reference, how to write multiple word. Nowdays usual writing of these words with first part two- double- don't corresponded handbooks and dictionaries references, that's why considered don't contrive new unworkable rules and compare datas from dictionaries and real writing for excluding from dictionaries not existed versions.

Key words: orthography, compound words, rules, codification, dictionary.

\section{References}

Bol'shoi akademicheskii slovar' russkogo yazyka [Big Academic dictionary of the Russian language]/ Ros. akad. nauk, In-t lingvist. issled.; [red.: L. I. Balakhonova]. Moskva; Sankt-Peterburg: Nauka, 2004-.

Graudina L.K., Itskovich V.A., Katlinskaya L.P. Grammaticheskaya pravil'nost' russkoi rechi (opyt chastotno-stilisticheskogo slovarya variantov) [The grammatical correctness of russian speech (experience of frequency-stylistic version dictionary)]/ M.: Nauka, 1976.- $453 \mathrm{~s}$.

Rozental' D.E. Spravochnik po pravopisaniyu $i$ stilistike [Handbook of spelling and style]/ M.: Komplekt, 1997. - 384 s.

ROS - Russkii orfograficheskii slovar': okolo 200000 slov [Russian orthographic dictionary: about 200000 words.]/ [O. E. Ivanova i dr.]. — Izd. 4-e, ispr. i dop. — Moskva: AST-Press, cop. 2012. - 879 s. 


\title{
И. В. Нечаева
}

\author{
Институт русского языка им. В. В. Виноградова РАН \\ (Россия, Москва) \\ inechaeva@mail.ru
}

\section{УПОТРЕБЛЕНИЕ ПРОПИСНОЙ ГРАФЕМЫ: АРГУМЕНТЫ И ФАКТОРЫ}

В статье исследуются факторы, влияющие на выбор написания (с прописной или строчной графемы) для различного рода номинаций. Речь идет о факторах узуальном, парадигматическом, дистрибутивном и факторе экономии. На актуальных языковых примерах показано, что данные факторы могут находиться в оппозиции друг к другу, что вызывает узуальную вариативность.

Узуальный фактор выражается в частотности определенных написаний в практике употребления среди грамотных носителей языка и выполняет в основном диагностическую роль в отношении соблюдения норм письма, однако при значительном преобладании тех или иных орфограмм может способствовать коррекции орфографической нормы. Парадигматический фактор действует как инструмент унификации на основе различных парадигматических связей. Дистрибутивный фактор выражается в ситуативной обусловленности написаний исходя из требований контекста. Фактор экономии основан на желательности минимизировать количество прописных графем в тексте (что соответствует русской орфографической традиции).

Каждый из этих факторов и основанный на нем критерий орфографического выбора может служить вспомогательным инструментом кодификатора; при этом в основе орфографических решений лежит лингвистический статус наименования - обычно с точки зрения его соответствия понятию имени собственного. Что касается составных неоднословных наименований, то проблема может заключаться в определении состава номинации.

Ключевые слова: прописная графема, орфография, факторы правописания, имя собственное, лингвистический статус номинации, орфографическое правило.

1. Сегмент орфографической нестабильности в области употребления прописной графемы ${ }^{1}$ (далее - ПГ) затрагивает несколько различных случаев. Это

${ }^{1}$ По отношению к прописной лингвистически более корректным является употребление термина графема, нежели буква; обоснование понятия графемы дано в [Зализняк 1979]; см. также [Нечаева 2017: 144]. 
— формирование нормы применительно к новым явлениям в языке;

- динамика кодифицированной нормы, выражаемой словарно или в виде орфографического правила;

- неполная применимость кодифицированной нормы к языковому явлению;

- узуальная коррекция нормы, действующей де-юре.

Эти случаи будут рассмотрены в ходе дальнейшего изложения.

Разумеется, динамика орфографических установлений - совершенно нормальное явление, однако потребности обучения, книгоиздания и других форм пользования языком в каждый конкретный момент времени требуют орфографической однозначности. Обсуждения спорных явлений на разных уровнях, в том числе на заседаниях Орфографической комиссии РАН, показывают, что механизм становления нормы в области ПГ на данный момент - малоизученное явление.

2. Становление норм употребления ПГ зависит от многих факторов. Понятие правильности найденного решения может - сознательно или бессознательно быть основано на различных критериях, обусловленных соответствующими факторами. Чаще всего это

— частотность написаний, т.е. уз уальны й факто р;

- унификация подобных случаев, т.е. фак тор п а рад иг матичес к и й;

- укоренившееся со времен Я.К. Грота (и даже ранее) соображение о желательности минимизировать количество прописных в тексте, «не расточать больших букв» [Грот 1876: 360], т.е. фактор эк о но м и и;

- ситуативная обусловленность написаний, выражающаяся в требованиях конкретного контекста, т.е. ди с т и бути в ны й фактор.

Соответствующие данным факторам критерии орфографического выбора в реальной орфографической ситуации могут находиться в оппозиции друг к другу, что создает дополнительные орфографические трудности и рождает нормативную неоднозначность. Какой из факторов в этом случае должен оказать решающее воздействие на орфографию - этот вопрос нередко является дискуссионным. Между тем главной лингвистической основой для определения буквенного регистра какой-либо номинации может (и должно) быть отношение к имени собственному, т.е. определение статуса рассматриваемого наименования с точки зрения соответствия / несоответствия этому понятию. Спорные случаи выбора прописной / строчной графемы следует рассматривать прежде всего в аспекте языкового статуса данной номинации. К сожалению, именно этот фактор, который должен служить базисом орфографических решений, часто оказывается вне поля зрения орфографиста, руководствующегося в основном внешними критериями: соображениями экономии (минимизации количества ПГ в тексте) и унификации написаний. Что касается составных неоднословных наименований, то здесь актуален вопрос о границах данной номинации, что не всегда очевидно.

3. Существует ряд номинаций, узуальное написание которых противоречит кодифицированной норме. Понятие узуального написания требует уточнения. К сожалению, опыт и лингвистические наблюдения показывают, что неумение 
работать с узусом - весьма распространенная проблема. Узус - это языковой материал, в котором отражается жизнь языка. Наблюдение за функционированием языка в области письма должно служить своевременному выявлению регулярных орфографических колебаний (не являющихся банальной ошибкой²) с целью их изучения. К сожалению, нередко приходится сталкиваться с неумением и даже нежеланием замечать такие колебания, с недооценкой диагностической роли узуса для выявления орфографических проблем.

Необходимо при этом иметь в виду, что не любой текст можно считать пригодным для такого рода наблюдений. Пригодным является спонтанный письменный текст образованного носителя языка³. Орфографические новации, встречающиеся в таком тексте, показательны как для фиксации динамики письменного языка в целом, так и для верификации корректности уже существующих кодификаций. Иногда имеют место попытки рассматривать в качестве узуального материала для исследования художественные и публицистические тексты разных лет, например помещенные в НКРЯ. Разумеется, пользование таким богатым по контенту и удобным в практическом плане источником, как Национальный корпус русского языка, очень облегчает исследовательскую работу; однако важно понимать, что подвергнутые корректорской обработке тексты, к тому же взятые без учета времени их издания, не репрезентативны в отношении изменений письменного языка, поскольку они представляют не реальную языковую ситуацию, а, скорее, уровень владения издательских работников существующим нормативными источниками (изданными в прошлом), которыми они пользуются в силу своих профессиональных обязанностей (тем более если речь идет о статистическом анализе встречающихся написаний). Отсутствие в подобных изданиях графической вариативности отнюдь не свидетельствует об отсутствии орфографической неоднозначности в языке.

4. В качестве примера узуальной коррекции нормы могут служить официонимы Государственная дума и Федеральное собрание. Кодифицированное на данный момент написание этих номинаций в отношении второго члена номинации (со строчной) не соблюдается не только в спонтанном узусе, но даже во многих печатных текстах, прошедших стадию корректуры: прежде всего, в тексте конституции РФ $\Phi^{4}$, а также на сайте Государственной д/Думы ${ }^{5}$, в текстах $\mathrm{CMИ}^{6}$, в заданиях

${ }^{2}$ Известно, что едва ли не каждое языковое изменение поначалу считается ошибкой, однако следует уметь отличать нормативные отклонения, обусловленные неграмотностью или случайные, от типического и симптоматического в языке.

3 Таковыми, например, являются тренировочные работы для подготовки к сдаче ЕГЭ, написанные учителями высокой квалификации, материал которых активно используется автором данной статьи, а также тексты квалифицированных интернет-пользователей, СМИ, Википедии и некоторых других интернет-ресурсов.

${ }^{4}$ Конституция РФ, статья 95: «1. Федеральное Собрание состоит из двух палат - Совета Федерации и Государственной Думы».

${ }^{5}$ Например: «Выступление Председателя Государственной Думы Вячеслава Володина на Рождественских парламентских встречах в Государственной Думе 26 января 2017 года».

${ }^{6}$ Например: В завершение конференции президент ПГ «МАИР» Виктор Макушин обратился к участникам с просьбой содействовать движению за отмену НДС в сфере переработки черных 
для ЕГЭ и др. - практически везде узуальная норма противостоит кодифицированной.

Казалось бы, подобное тотальное давление узуса должно привести к изменению кодификации. Однако узуальный фактор встречает сопротивление со стороны фактора экономии: аргумент о нежелательности распространения сферы употребления ПГ выдвигается постоянно. Другой распространенный аргумент - учет парадигматического фактора: существуют историзмы Боярская дума и Государственная дума 1900-х гг., и встает вопрос об унификации приведенных написаний с названием современного парламента. Не думается, тем не менее, что унификация в данном случае целесообразна: подобные случаи семантически обусловленных различий в написаниях в области ПГ встречаются регулярно, ср., например, кремль 'средневековая русская крепость' и Кремль 'современная правительственная резиденция': никому не приходит в голову унифицировать эти орфограммы. Границы применения унификации тот камень преткновения, о который постоянно спотыкаются кодификаторы.

5. Пример динамики кодифицированного написания представляет лексема Перестройка в значении 'период в новейшей истории России'7. Можно заметить, что данная лексема постепенно преодолевает переходную стадию от нарицательного к собственному имени, поскольку ослабление у слова буквального лексического значения (т.е. частичная десемантизация) при усилении номинативной функции - это то, что свойственно собственным именам (о свойствах имени собственного см., например, [Суперанская 1973: 57]). Совершен переход в иной денотативный ряд: семантика глагольного действия ослаблена, историко-политические ассоциации выходят на первый план (см. об этом также [Нечаева 2017: 148]). Таким образом, по лингвистическим основаниям орфографическую модификацию перестройка $\rightarrow$ Перестройка можно считать оправданной. В узусе такие написания встречаются нередко.

Как и в предыдущем случае, иногда выдвигаются контраргументы, основанные на парадигматическом факторе. В качестве примера приводятся наименования отmепель $^{8}$ и застой ${ }^{9}$, которые предлагается считать орфографическими коррелятами

металлов через обращение с запросами по данной теме к губернаторам «своих» областей, депутатам местных законодательных собраний, письма в Государственную Думу и Федеральное Собрание РФ [Ломопереработчики выступают против возвращения НДС на лом черных металлов // РБК Daily, 2008.01.21].

7 Значение данного слова (или словосочетания «горбачевская перестройка») имеет много различных толкований: «масштабные перемены в идеологии, экономической и политической жизни СССР во второй половине 1980-х годов»; «общее название нового курса советского партийного руководства, совокупности политических и экономических перемен, происходивших в СССР с 1985 по 1991 годы»; «осуществлявшиеся в СССР в 1885-1991 годах реформы и преобразования в области экономики, общественной и государственной жизни, направленные на развитие демократии, гласности, на выход страны в мировое сообщество» и др. Все они нуждаются в усовершенствовании.

${ }^{8}$ Хрущевская оттепель - неофициальное обозначение периода в истории СССР после смерти И.В. Сталина, продолжавшегося около десяти лет (середина 1950-х - середина 1960-х годов) (Википедия).

${ }^{9}$ Период застоя или Эпоха застоя - пропагандистско-литературное клише, используемое для обозначения периода в истории СССР, охватывавшего два с небольшим десятилетия, 
к перестройке. Однако это совсем не очевидно: судить по приведенным толкованиям довольно затруднительно, они разнотипные и также нуждаются в усовершенствовании. Важнее другое: известно, что в системе языка постоянно сосуществуют названия, находящиеся на разных этапах перехода от нарицательных к собственным (для некоторых, возможно, процесс онимизации вообще не имеет завершения). Должна ли унификация служить сдерживающим фактором при обретении словом иного статуса и насколько такое сдерживание может быть эффективным? Следует ли принимать решения о названиях, уже приблизившихся к статусу онима, под влиянием каких-то гипотетических будущих возможностей для других номинаций? Это вызывает сомнение. Однако в отношении названия «оттепель» («хрущевская оттепель») изменение написания нам представляется возможным. В узусе данная номинация часто заключается в кавычки - признак осознаваемой потребности ее графического выделения.

6. В «Русском орфографическом словаре» зафиксировано 34 слова с начальной частью ВИП..., написанной прописными, например: ВИП-ателье, ВИП-зал, ВИПзона, ВИП-клиент, ВИП-ложа, ВИП-персона, ВИП-ресторан, ВИП-сервис, ВИПтусовка и др. При этом в словаре есть также самостоятельная словарная статья $« В И П,-\mathrm{a} »$.

Это соответствует правилам «Полного академического справочника», $\S 205$ и 206:

$\S 205$. «Звуковые инициальные аббревиатуры пишутся прописными буквами, например: ООН, МИД, НОТ, ОМОН, ГАИ, СПИД, ГЭС, ГРЭС. По традиции пишутся строчными буквами некоторые (немногие) звуковые аббревиатуры: вуз, втуз, доm, дзот. Отдельные аббревиатуры могут писаться и прописными, и строчными буквами, напр.: НЭП и нэп, ЗАГС и загс».

$\S 206$. «В приставочных, сложных словах и составных наименованиях, характеризующихся слитным или дефисным написанием, буквенные и звуковые аббревиатуры сохраняют прописные буквы, например: суперЭВМ, МГД-генератор, УВЧ-терапия...» [ПАС 2009: 168-169].

Из приведенного правила следует, что традиция строчных написаний аббревиатур существует лишь для некоторых старых наименований, а все новые следует оформлять прописными. При этом узуальная картина преобладающих написаний иная: орфография слов с начальной частью вип... колеблется, однако строчная явно преобладает. Вот типичные примеры:

Им тоже не нравится рисковать собственной жизнью ради того, чтобы вип-пассажир добрался до загородного дома на 20 минут быстрее, чем все остальные [В. Антипин. Постой, членовоз! // «Русский репортер», № 3 (181), 2011.01.27];

так называемого «развитого социализма» - с момента прихода к власти Л.И. Брежнева (1964) до XXVII съезда КПСС (февраль 1986), а ещё точнее - до январского Пленума 1987 года, после которого в СССР были развернуты полномасштабные реформы во всех сферах жизни общества (Википедия). 
Второй этаж был на роли вип-зоны [Л. Зорин. Глас народа // «Знамя», 2008];

Получилось что-то вроде корпоративной вечеринки с вип-гостями из мира политики [Ю. Богомолов. Новый год на трезвую голову // «Известия», 2003.01.12];

Под особо пристальным вниманием франиузских телевизионщиков находились так называемые «випы» разного калибра от министра обороны Франции до знаменитых футболистов [Ю. Богомолов. Дэвис. Русский. Россия впервые выиграла чемпионат мира по теннису // «Известия», 2002.12.02].

В данном случае узуальный фактор «действует заодно» с фактором лингвистическим: иноязычная по происхождению аббревиатура (very important person) превратилась в обычное слово с нарицательной семантикой, изменяемое по определенному типу склонения (випьl, випов, с випами и т.д.), что и определило ее написание. Помимо прочего, оформление прописными слов типа ВИП-зона и др. производит неблагоприятное визуальное впечатление, поскольку выглядит нарочитым выделением того, что в таком выделении не нуждается. Попытка унификации написания ВИП... с другими аббревиатурами, предпринятая в словаре, оказалась бессильной ${ }^{10}$.

7. Действие дистрибутивного фактора, выражающегося в дестабилизирующем влиянии контекстных условий на написание устоявшихся, казалось бы, наименований можно видеть на следующем примере (взятом из реального контекста - из тренировочной работы по истории для подготовки к ЕГЭ): «в Древней и средневековой Руси слово “кабала" означало долговое обязательство, ставящее должника в личную зависимость от заимодавца». Устойчивое наименование с закрепленным написанием (Древняя Русь) встретилось в одном контексте с тематически однотипным словосочетанием, которое не считается собственным именем (средневековая Русь); каждая из этих номинаций обозначает в данном контексте определенный период в истории страны.

Очевидно, что эти номинации несколько различны: Древняя Русь - это также название государства, т.е. хрононим и топоним одновременно, а средневековая $P y c b$ - только хрононим, но в данном контексте они употребляются в аналогичной хронологической функции. Текст с различным орфографическим оформлением данных аналогичных понятий вызывает следующие вопросы: применимо ли кодифицированное написание Древняя Русь (с прописной) в данном конкретном случае? должно ли контекстное окружение влиять на орфографию подобных наименований исходя из требований ситуативной унификации (что было бы логично) - или следует настаивать на постоянном написании каждого из этих понятий? возможно, следует допустить вариативность в написании таких наименований, как д/Древняя Русь, в зависимости от контекста? ${ }^{11}$

10 Решение Орфографической комиссии РАН от 24 мая 2017 г.: использовать для написания «вип» во всех случаях строчные графемы.

11 Данный вопрос также был обсужден на заседании Орфографической комиссии РАН 14.05.2017. Рекомендация ОК РАН: признать возможность изменения написаний в зависимости от контекста и отразить эту возможность в правилах. 
8. В отношении составных неоднословных наименований, как уже было сказано, может возникнуть проблема определения состава данной номинации. Какие элементы следует считать входящими в номинацию, а какие - свободно присоединяющимися? От ответа на этот вопрос зависит выбор буквенного регистра в отношении компонентов номинации. В эту проблемную область попадают явления довольно различные: это, к примеру, з/Зимняя / л/Летняя / б/Белая Олимпиада и з/Зимние / л/Летние Олимпийские игры.

О существовании проблемы с названиями Олимпийских игр нам не дают забыть довольно частотные узуальные употребления прописных в определении (при наличии и альтернативных строчных):

На этой карте мы собрали все города, где когда-то проходили Летние Олимпийские игры. http://works.doklad.ru/view/F-nHZtt_4VQ.html;

Следуюшая Зимняя Олимпиада - 2018 года - пройдет в городе Пхёнчхан. Читайте подробнее на FB.ru: http://fb.ru/article/142461/gde-proydet-zimnyayaolimpiada-goda;

Поначалу на Бельх Олимпиадах ожидаемо доминировали скандинавы, но со временем в число фаворитов Зимних олимпийских игр вошли и атлеть из других регионов. http://olimp-history.ru/node/12.

Как видим, в противоречие вступают узуальный фактор и фактор экономии прописных в тексте. Но в основе проблемы вопрос лингвистический: имеем ли мы дело с цельной неоднословной номинацией или со свободно присоединяющимся к номинации определением? Неочевидность ответа на этот вопрос и демонстрирует стихийный узус.

9. Возникающие под воздействием различных факторов орфографические колебания иногда затрагивают явления, в отношении которых существуют правила правописания.

Примером тому является, в частности, употребление так называемого «Bbl-вежливого». Правило основано на действии дистрибутивного фактора, который и должен определять конкретную орфограмму. Оказалось, однако, что существующее правило $^{12}$ дает ответы не на все вопросы, которые могут появиться в конкретной ситуации письменного общения. Относительно подробно это рассмотрено в [Нечаева 2017: 158-159]. Вопросы может вызвать ситуация, когда «вы» обращено к одному, но не конкретному лицу, заранее не известному (например, в тестовых заданиях для ЕГЭ) или когда текст не относится ни к одному из перечисленных в правиле жанров. Недостаточная определенность правила требует корректировки. Направление этой корректировки может быть различным:

12 « 202. С прописной буквы пишутся местоимения Вы и Ваш как форма выражения вежливости при обращении к одному конкретному лицу в письмах, официальных документах и т.П., напр. Поздравляем Вас..., Сообщаем Вам..., В ответ на Ваш запрос... Так же пишутся слова Вы и Ваш в текстах, предназначенных для многократного использования, типа анкет, реклам, листовок» [ПАС 2009: 166]. 
a) сфера применения «Вы» с прописной может быть сужена, в этом случае правило можно сформулировать примерно следующим образом: «с прописной буквы пишутся местоимения $B b l$ и Ваш только при личном обращении к определенному лицу»;

б) сфера применения «Вы» с прописной может быть расширена, в этом случае правило можно сформулировать примерно так: «с прописной буквы пишутся местоимения $B b l$ и Baw как форма выражения вежливости при обращении к одному лицу (т.е. любому, в текстах любых жанров); при неопределенном количестве лиц, к которым обращено высказывание, выбор прописной или строчной буквы делает пишущий».

Таким образом, правило становится одновременно более определенным, а во втором случае и более толерантным. Необходимость его усовершенствования несомненна.

10. Кратко затронем такое относительно новое и не регламентированное в настоящее время орфографическое явление, как написание двусловных автомобильных брендов типа Форд Фокус, Тойота Камри, Лада Калина (см. также [Нечаева 2017], [Николенкова 2017]). В «Полном академическом справочнике» ${ }^{13}$ подобные двойные названия на данный момент не учитываются (а в узусе встречаются также и тройные).

Данный случай относится к одному из самых сложных в орфографии ПГ. Это можно объяснить с точки зрения факторов правописания. Мы видим, что ни один из перечисленных факторов здесь не работает: узус демонстрирует широкую вариативность без отчетливой тенденции к преобладанию одного из вариантов, подходящих орфографических аналогов с точки зрения парадигматики не находится, дистрибутивный фактор может быть задействован только в отношении корреляции «марка изделия - изделие». Некоторое влияние может иметь лишь фактор экономии, но здесь он не имеет отчетливых лингвистических обоснований. Поэтому все попытки дать сколько-нибудь убедительные рекомендации по написаниям этих названий пока не приводят к успеху.

11. Таким образом, на употребление ПГ оказывают смешанное влияние различные факторы, в том числе узуальный, парадигматический, дистрибутивный и фактор экономии. Как ни заманчиво было бы разработать иерархию этих факторов, с тем чтобы выделять наиболее значимый из них в случае их противоречивого влияния на орфографию, сделать это вряд ли возможно.

Узуальный фактор задействован в основном при диагностировании орфографического неблагополучия; решающее влияние на формирование нормы он оказывает лишь при значительном преобладании тех или иных орфограмм. Однако частотные узуальные написания, в том числе противоречащие кодификациям, являют

$13 \S 200$. «Названия производственных марок технических изделий (машин, приборов и т.п.) заключаются в кавычки и пишутся с прописной буквы, напр.: автомобили «Москвич-412», «Волга», «Вольво», «Жигули», «Тойота», <..> стиральная машина «Эврика», <...> видеомагнитофон «Панасоник». Однако названия самих этих изделий (кроме названий, совпадающих с собственными именами - личными и географическими) пишутся в кавычках со строчной буквы, напр.: «москвич», «тойота», «вольво» (автомобили), «боинг», «фантом» (самолеты), «панасоник» (магнитофон); но: «Волга», «Ока», «Таврия» (автомобили), «Руслан» (самолет), «Минск» (холодильник); исключения: «жигули», «мерседес» (автомобили)» [ПАС 2009: 165-166]. 
собой спонтанную письменную реакцию узуса на изменения в статусе наименований, поэтому оставлять их без внимания не следует.

Влияние парадигматического фактора как унифицирующего инструмента в орфографии, на наш взгляд, преувеличено: время от времени проявляется стремление «загонять» в ряды орфографических подобий различные явления на основе их внешних связей, без учета более глубоких лингвистических различий.

Дистрибутивный фактор (зависимость написания слова или наименования от его контекстного окружения) весьма часто применяется в правописании, и далеко не только в области употребления ПГ, поэтому сбрасывать его со счетов было бы неправильно.

Фактор экономии (минимизация прописных в тексте), на наш взгляд, является значимым не сам по себе, а лишь в сочетании с лингвистическим фактором, когда он поддерживается языковыми свойствами номинации.

Перечисленные факторы и основанные на них критерии кодификаторских решений - всего лишь внешние, вспомогательные инструменты кодификатора. Главное - лингвистический статус наименования, он и должен служить основой орфографического облика слова.

\section{Литература}

Грот Я. К. Спорные вопросы русского правописания от Петра Великого доныне. СПб., 1876. 461 с.

Зализняк A. A. О понятии графемы // Balcanica. Лингвистические исследования. М.: Наука, 1979. С. 134-152.

Нечаева И.В. Прописная графема и ее функции в современном письме // Русский язык в научном освещении. 2017. № 1 (33). С. 143-161.

Николенкова Н. В. Проблемы орфографического оформления названий товарных знаков в XXI в.: лингвистические наблюдения // Stephanos. 2017. T. 2, №22. С. 9-17.

ПАС - Правила русской орфографии и пунктуации. Полный академический справочник. / под ред. В. В. Лопатина. М.: АСТ-ПРЕСС КНИГА, 2009. 432 с.

Суперанская A. В. Общая теория имени собственного. М.: Наука, 1973. 367 с.

\section{Iya $V$. Nechaeva}

V. V. Vinogradov Russian Language Institute of the Russian Academy of Sciences (Russia, Moscow)

inechaeva@mail.ru

\section{THE USE OF CAPITAL GRAPHEME: ARGUMENTS AND FACTORS}

This paper investigates the factors that affect the choice of the way of writing (small or capital grapheme) for nominations of different kind. We are dealing with usage, paradigmatic, distributive, and economic factors. By contemporary language examples it is 
shown that these factors may be at variance with each other, which gives rise to usage variativity.

The usage factor manifests itself in the frequency of certain way of writing in the usage practice among well-educated native speakers and plays primarily the diagnostic role as regards adherence to spelling norms. However, for a significant prevalence of certain orthograms the usage factor may be conductive to corrections of the orthographic norm. The paradigmatic factor acts as a unification tool based on different paradigmatic relationships. The distributive factor shows up in the situational conditionality of spelling proceeding from context requirements. The economic factor stems from the tendency to minimize the number of capital graphemes in the text, which corresponds to the Russian orthographic tradition.

Each of these factors and its reliant criterion of orthographic choice may serves as an auxiliary codification tool. In this case, orthographic solutions are underlain by the linguistic status of the appellation, commonly from the viewpoint of its conformity with the notion of a proper name. As for compound non-one-word appellations, the problem may lie with determining the appellation composition.

Key words: capital grapheme, orthography, factors for spelling, proper name, linguistic status of nomination, orthographic rule.

\section{References}

Grot Ya. K. Spornye voprosy russkogo pravopisaniya ot Petra Velikogo donyne. [Moot Points of Russian Orthography from the Time of Peter the Great to This Day]. St.Petersburg, 1876. 461 p. (in Russ.)

Zaliznyak A. A. [On the notion of grapheme] // Balcanica. Lingvisticheskie issledovaniya. [Balcanica. Linguistic research] Moscow, Nauka, 1979, pp. 134-152. (in Russ.)

Nechaeva I. V. [Capital grapheme and its functions in modern writing] // Russkii yazyk v nauchnom osveshchenii, 2017, no. 1 (33), pp. 143-161. (in Russ.)

Nikolenkova N.V. [Problems of orthographic design of trademark appellations in the XXIst century: linguistic observations] // Stephanos, 2017, vol. 2, no. 22, pp. $9-17$ (in Russ.)

Pravila russkoi orfografii i punktuatsii. Polnyi akademicheskii spravochnik [Rules of Russian Orthography and Punctuation. Complete Academic Reference Book]. Ed. by V.V. Lopatin. Moscow, AST-PRESS KNIGA, 2009. 432 p. (in Russ.)

Superanskaya A.V. Obshchaya teoriya imeni sobstvennogo. [General theory of a proper name]. Moscow, Nauka, 1973. 367 p. (in Russ.) 


\section{Н.В. Николенкова \\ Московский государственный университет им. М.В.Ломоносова \\ (Россия, Москва) \\ natanik2004@mail.ru}

\section{УПОТРЕБЛЕНИЕ ПРОПИСНОЙ БУКВЫ: ИСТОРИЯ И СОВРЕМЕННАЯ КОДИФИКАЦИЯ}

В статье будет рассмотрено отражение в изданиях начала XX в. орфографических поисков в тех зонах, которые не привлекали внимания теоретиков реформы русской письменности этого периода. В первую очередь такой зоной оказывается употребление прописных букв. При недостаточности формулировок действующих правил, сформулированных Я.К. Гротом, у авторов и издателей текстов в этот период возникает понимание необходимости самостоятельной выработки принципов написания в целом ряде пунктов - это названия учреждений и обществ, наименование государственных и административных должностей, названия производственных марок. Называя выработку принципов оформления таких названий зоной «стихийной» кодификации, мы описываем разные направления ее в изданиях периферии Российской империи (Баку и Тифлис), выбирая преимущественно тексты коммерческо-делового характера. Этот анализ позволяет сравнить период столетней давности с современной орфографической ситуацией, когда правила часто описывают более архаичное положение дел, чем в начале XX в. Сопоставление двух периферийных орфографических зон и направление стихийной кодификации их в разный период истории русской письменности, мы нашли определенные сходства в типе реализации правила употребления прописной буквы в узусе начала $\mathrm{XX}$ и начала XXI вв.

Ключевые слова: реформа орфографии, орфографические правила, прописная буква.

Описывая период начала XX в., исследователи останавливаются в первую очередь на спорах, которые ведут между собой сторонники и противники орфографической реформы [Григорьева 2004]. Теоретические вопросы, лингвистические и нелингвистические обоснования необходимости изменений (упрощений) в русском письме, позиция представителей учительской общественности - эти проблемы освещены достаточно широко. Гораздо меньше внимания уделяется специфике 
изданий этого времени - содержательной, стилистической, жанровой, региональной, не установлена зависимость от указанных факторов объема и регулярности орфографических инноваций. Между тем анализ изданий предреформенного периода позволяет понять, насколько назревшей была реформа орфографии и все ли орфографически проблемные зоны проведенная реформа учла.

Мы рассмотрели не исследованные никогда с лингвистической точки зрения источники - издания, осуществленные на периферии Российской империи. Большая часть - это вышедшие в типографиях г. Баку издания коммерческо-делового характера: уставы (например, «Уставъ Акціонернаго Общества "Кавказское Буровое Товарищество"», далее УКБТ-16), отчеты (например, «Отчетъ Бакинскаго Общества Взаимнаго Кредита за 1915 годъ», далее ОВК-15; «Отчетъ Бакинскаго Биржевого комитета за 1916 годъ», далее ОББК-16). В Баку издается литература, связанная с нефтяной промышленностью («Краткій очеркъ состоянія нефтяной промышленности въ 1916 году», далее ОСНП-16) ${ }^{1}$ [Николенкова, Тахирзаде 2017: 112]. Значительно большая часть литературы публиковалась в типографиях Тифлиса: это и художественные тексты, и коммерческо-деловые («Уставъ тифлисскаго общества благоустройства верхней части горы св. Давида “Верхняго Тифлиса"»; далее УБГ-16). В Тифлисе выходил ежегодник, распространяющийся по всему Кавказу, — «Кавказский календарь» (мы использовали выпуски за два года - КК-14 и КК-15), в котором публиковались объявления рекламного характера из всех крупных городов. В Тифлисе встречаются и издания научного характера («Труды XVIII-го Съъзда Русскихъ Естествоиспытателей и Врачей», прошедшего в Тифлисе в июне 1913 г. и изданного в 1916; далее ТСЕВ-16). Отбор материала позволил увидеть, как по-разному функционировали типографии в различных частях Российской империи - качество подготовленных в тифлисских типографиях изданий намного выше бакинских.

Анализ текстов позволил выявить в них два типа орфографических написаний. Во-первых, это демонстрирующие консерватизм и следование правилам Я.К.Грота. К этой группе оказались отнесенными все пункты, разбираемые лингвистами при обсуждении путей реформирования русского письма: исключение Ђ; исключение или частичное сохранение ъ; исключение I с заменой на И и т.д. [Григорьева 2004: 251-259; 281-286]. Если в начале XIX в. орфографический разнобой в этой зоне отмечался, то к концу XIX в. - особенно в исследованных текстах делового содержания - консерватизм едва ли не усилился, а соответствие правилам для грамотных людей оказывается нормой. Во-вторых, мы выделили зону «стихийной» кодификации, когда отсутствие или несовершенство правила в руководствах по орфографии вызывает у грамотных носителей необходимость самим создавать если не формулировки правил, то по крайней мере тенденцию на письме

1 Эти и некоторые другие источники исследованы в магистерской диссертации «Орфографические поиски начала XX века и их отражение в изданиях бакинских типографий» Тахирзаде Айшанды Мазахир гызы, написанной под руководством доц. Николенковой Натальи Владимировны и защищенной 7.06.2017 в филиале МГУ в г.Баку. 
[Николенкова, Тахирзаде 2017: 116-118]. Для бакинских изданий центральной из этих зон оказывается область написания имен восточного происхождения [там же]. И абсолютно для всех изданий самой проблемной зоной, стихийная кодификация в которой выявляется наиболее отчетливо, оказывается написание организаций, должностей и званий - элементов административной системы Российской империи, а также различных условных названий (обществ и товарных марок).

В правиле Я.К. Грота прописная буква рекомендована в таких случаях: имена Бога и высших существ в религиях; титла «царствующаго въ Россіи Дома», собственные личные имена и прозвища, собственные географические имена, название «высшихъ государственныхъ и ученыхъ учрежденій Россіи, также различныхъ русскихъ обществъ», некоторые имеющие особенное значение названия праздников, недель и дней, заглавия книг и названия кораблей [Грот 1894: 88-91]. В этом же разделе академик высказал несколько известных суждений: что от больших букв происходит пестрота письма, с которой вообще-то желательно бороться, однако от них есть и «нђкоторая практическая польза: при бњгломъ чтеніи или при пересмотрЂ прочитанного онъ дают глазу точки опоры» [там же: 87]. Формулируя правило, Грот признает, что это лишь опорные точки, ибо точных указаний на все встречающиеся случаи дать невозможно. Такой поверхностный подход обусловил и ситуацию применения правила в текстах. В результате анализа мы сделали вывод, что заслуга Грота «в упорядочении орфографии прописных букв» [Каверина 2001: 125] представляется преувеличенной.

В деловых текстах, во многом носящих характер документа, систематизация написаний была необходима. Однако невозможность ее заложена уже в формулировке Грота: «если названіе состоитъ изъ двухъ или нъсколькихъ словъ, то большою буквою можеть быть отмъчаемо или только первое, или же и второе слово, смотря по тому, считать ли его въ этомъ случађ за собственное, или за нарицательное имя» [там же: 90]. Формулировка заставляет авторов деловых изданий самим решать лингвистический вопрос о характере входящих в название имен. Результатом будет два противоположных подхода. Более простой демонстрируют издания Баку: прописная буква начинает употребляться в каждом слове, которое входит в наименование (Бакинское Общество Взаимнаго Кредита, Бакинский Биржевой Комитетъ, Бакинская Биржа), в названии любой структуры, имеющей отношение к его деятельности: Оценочная Комиссія, Правленіе и Совътъ, Уставъ Общества, Общее Собраніе, Ревизионная Комиссія, Кладовая Общества, Гл. Бухгалтеръ (ОВК-15), Котировочная Комиссія, Товарищъ Председатель, Биржевые Маклеры (ОББК-16). Также оформляются любые государственные и административные должности, к примеру, в УКБТ-16: Министръ Торговли и Промышленности, Намъстникъ Императорскаго Величества на Кавказъ (последнее регулятно в КК-14/15). И бакинские, и тифлисские издатели выбирают не только лингвистические способы выделения имен «царствующего Дома»: используют разрядку (КК-14/15, ТСЕВ-16), применяют написание с использованием всех прописных букв: ИМПЕРАТОРА Александра 2-го, Отдел ИМПЕРАТОРСКАГО Русскаго Географическаго общества (ОББК-16 и ТСЕВ-16). 
Тифлисские издания выстраивают правило употребления прописных букв в названиях учреждений более сложно: 1) написания с прописных обнаруживается при первом официальном употреблении названия какой-нибудь организации (Съезд Русских Естествоиспытателей и Врачей; Об-во Коломенскаго Машиностроительнаго Завода, Артистическое Об-во, Высшіе Женскіе Курсы) и далее при полном употреблении её; 2) в названии, которое включает много нарицательных слов, число прописных сокращается (Тифлисское Общество благоустройства верхней части горы, Акціонерное Общество Каспійскаго машиностроительного и котельного завода), что соответствует построению правила Грота; 3) далее в деловых текстах слово Общество (Съезд) употребляется также с прописной. При этом множественное число теряет прописную - съъзды русскихъ естествоиспытаталей и врачей. Называя должности, тифлисские издатели пытаются выстроить некоторую иерархию: Председатель Общества, Председатель Правления, Общее Собраніе и члены общества, делегаты съъзда, ученыя секціи. Такая попытка связи прописной буквы с иерархическим положением в системе берет начало еще в церковнославянских правилах употребления прописной, когда предлагалось писать Царь, Патріархъ, но епископъ [Кузьминова 2007: 65]. В течение XVIII в. при неупорядоченном и бессистемном употреблении прописной упорядочить эту область не удалось.

Еще одной зоной «стихийной» кодификации будет употребление кавычек, которые в руководстве Грота рекомендованы только при выделении цитаты и прямой речи [Грот 1894: 108]. Однако практика письма требовала решить вопрос об оформлении условных названий, которые распространяются не только на названия обществ и организаций, но и на производственные марки. Обычно в кавычках употребляется название условное: Русское Товарищество «Нефть», Тв-во «Соучастники», О-во «Олеанафтъ», двигатели шведские «Авансъ», цементъ марокъ «Звђзда» и «ЦҺпь». Зона разнобоя связана с ситуацией использования в названии топонима или антропонима: «Арамаздъ» Нефтепр. О-во, «Волга» Пароход. Общество, «Арванитиди Бр.» Т.Д., «Бенкендорфъ и К» Т. Д., в фирмъ «Густавъ Листъ»;

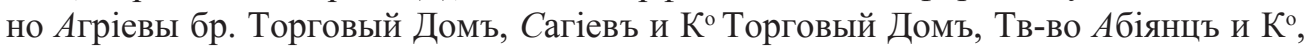
Торг. Домъ Бр. Захарьенко, Акціонерное Общество Невской писчебумажной фабрики бывш. Бр. Варгуниныхъ, магазинъ Маркъ Майзельсонъ, часы Лонжинъ, Тиссо и т.д. Единственное интуитивно лингвистическое решение - написание имени собственного без кавычек, если оно не в прямом падеже: печи Сименсъ Мартена, Мраморное заведеніе А.Андролетти съ $C$-ми, заводы Гартмана.

Разнобой и необходимость стихийной систематизации мы связываем с недостаточной формулировкой правила и вынесением его на периферию русского письма. Подготовка к реформе поставила в центр обсуждения общества только часть орфографических проблем, тогда как другие, не менее важные, оказались вне сферы внимания кодификаторов и позднее: крайне обобщенно сформулировано правило о прописной в Проекте Главнауки [Григорьева 2004: 298], не было уделено ему внимание в проекте реформы 1964 г. [там же: 299-311]. И хотя сегодняшние правила уделяют много внимания написанию прописной буквы, все же зачастую и в них 
присутствуют анахронизмы, не позволяющие воспользоваться ими при орфографическом оформлении многих современных написаний, в том числе написаний организаций и производственных марок, номинации которых правилу не соответствует [Николенкова 2017]. О том, чтобы правила были обращены в будущее, речь не шла и не идет.

Ряд параллелей начала XX в. и начала XXI в. до сих пор являются предметом спора орфографистов. К примеру, уже 100 лет назад появлялись названия, в которых употреблялось сразу два слова для определения формы организации: Нефтепромышленное Предпріятіе «Каспийско-Черноморское Общество», Акціонерное Общество «Кавказское Буровое Товарищество», Об-во «Спортъ» Акціонернаго Общества Сулинскаго завода. Распространившиеся сегодня номинации типа «Государственное бюджетное общеобразовательное учреждение города Москвы "Лицей № 1535"», «Федеральное государственное бюджетное образовательное учреждение высшего образования “Московский государственный университет имени М.В.Ломоносова”» им полностью параллельны, что позволяет сопоставить стихийные поиски 1910-х гг. и современные орфографические решения. В узусе не упорядочены по сей день написания ряда организаций и должностей: правило противопоставляет тексты официальные, где используется прописная, и неофициальные, в которых пишется строчная буква [Правила 2006: 187], однако решение о том, каков статус текста, предлагается принять самому пишущему. В результате возникает тенденция к вариативности прописной/ строчной на письме, что создает ощущение полной свободы на письме. Приходилось в начале века решать вопрос и о сочетании в одном тексте названий на кириллице и на латинице: паровыя машины завода «Робей и $\mathrm{K}^{\circ}$ », компрессоры Ingersoll Rand $\mathrm{C}^{\circ}$, заводъ «Dubdridge Jron Works», система «Фербэнксъ» (КК-14). Сегодня такие комбинации типичны при описании производственных изделий и торговых марок.

Изучение «стихийной» кодификации эпохи подготовки реформы русской орфографии и вообще переломных для русской письменности периодов нам кажется интересным материалом для орфографических поисков сегодняшнего дня.

\section{Литература}

Грамматика 1648 г. / Предисл., научн. коммент. подг. текста и сост. указателей Е. А. Кузьминовой. М.: МАКС Пресс, 2007. 624 с.

Григорьева Т. М. Три века русской орфографии (XVIII-XX вв.). М.: Элпис, 2004. $456 \mathrm{c}$.

Каверина В.В. Прописные буквы в истории русской орфографии // Древние языки в системе университетского образования: их исследование и преподавание. М.: Изд-вл МГУ, 2001. С. 122-127.

Николенкова Н.В. Проблемы орфографического оформления названий товарных знаков в XXI в.: лингвистические наблюдения // Stephanos. Мультиязычный научный журнал. № 2 (22), 2017. С. 9-17. 
Николенкова Н .В., Тахирзаде А. Реформа русской письменности начала XX в. и ее отражение в изданиях бакинских типографий 1915-1916 гг. // Stephanos. Мультиязычный научный журнал. №4 (24), 2017. С. 111-121.

Правила русской орфографии и пуктуации. Полный академический справочник. / Под ред. В. В. Лопатина. М.: Эксмо, 2006. 480 с.

Русское правописаніе. Руководство, составленное по поручению Второго отделения Императорской Академии наук академикомъ Я.К. Гротомъ. 11 изд. СПб., 1894. $120 \mathrm{c}$.

\author{
Natalia $\boldsymbol{V}$. Nikolenkova \\ Moscow Lomonosov State University \\ (Russia, Moscow) \\ natanik2004@mail.ru
}

\title{
USAGE OF CAPITAL LETTERS: HISTORY AND MODERN CODIFICATION
}

The article deals with the reflection of spelling studies in the editions of the early 20th century in those areas that did not attract the attention of theoreticians of the reform of Russian written language of this period, and, namely, the use of capital letters. Given the inadequate formulations of the existing rules formulated by Y.K. Grot, the authors and publishers of texts in this period have an understanding of the need for individual development of the principles of writing in a number of areas - these are the names of institutions and clubs, the names of state and administrative positions, and the names of brands. The author names the development of those principles a zone of "spontaneous" codification and describes it in the publications of the periphery of the Russian Empire (Baku and Tiflis), choosing primarily commercial and business texts. This analysis allows us to compare the period of a hundred years ago with the modern spelling situation, when the rules often describe a more archaic state of affairs than at the beginning of the 20th century. Comparing the two peripheral spelling zones and areas of their spontaneous codification in different periods of the history of Russian writing, we have found certain similarities in the type of implementation of the rule of capitalization in the early 20th and early 21 st centuries.

Key words: orthography reform, spelling rules, capital letter.

\section{References}

Grammatika 1648 g. Predisl., nauchn. komment., podg. teksta i sost. ukazatelei E. A. Kuz'minovoi [Grammar of 1648]. Moscow, MAKS Press Publ., 2007. 624 p.

Grigor'eva T.M. Tri veka russkoi orfografii (XVIII-XX vv.) [Three centuries of Russian orthography (XVIII-XX centuries)]. Moscow, Elpis Publ., 2004. 456 p.

Kaverina V.V. [Capital letters in the history of Russian spelling]. Drevnie yazy$k i v$ sisteme universitetskogo obrazovaniya: ikh issledovanie $i$ prepodavanie [Ancient 
languages in the system of university education: their research and teaching]. Moscow, 2001, pp. 122-127. (In Russ.)

Nikolenkova N. V. [Problems of spelling of the names of trademarks in the XXI century: linguistic observations]. Stephanos, 2017, no. 2 (22), pp. 9-17. (In Russ.) Available at: http://stephanos.ru/izd/2017/2017_22_01.pdf. (accessed 30.08.2017)

Nikolenkova N. V., Takhirzade A. [Reform of Russian writing at the beginning of the 20th century. And its reflection in the publications of the Baku printing houses of 19151916.]. Stephanos, 2017, no. 4 (24), pp. 111-121. (In Russ.) Available at: http://stephanos.ru/izd/2017/2017-24-10.pdf. (accessed 30.08.2017)

Pravila russkoi orfografii i puktuatsii. Polnyi akademicheskii spravochnik. Pod red. V. V. Lopatina [Rules of Russian spelling and punctuation. Full academic reference]. Moscow, Eksmo Publ., 2006. 480 p.

Russkoe pravopisanie. Rukovodstvo, sostavlennoe po porucheniyu Vtorogo otdeleniya Imperatorskoi Akademii nauk akademikom" Ya. K. Grotom" [Russian spelling]. SPb., 1894. 120 p. 


\section{А. А. Плетнева}

Институт русского языка им. В. В. Виноградова РАН

(Россия, Москва)

csl_centr@mail.ru

\section{НАРОДНОЕ ПРАВОПИСАНИЕ И РЕФОРМА ОРФОГРАФИИ 1917-1918 ГОДОВ}

В статье рассматриваются проблемы предыстории орфографической реформы 1917-1918 гг. Обсуждение программы этой реформы началось еще в XIX веке, причем наиболее активными ее сторонниками были сельские учителя. Педагоги считали, что упрощение орфографии облегчит учебный процесс и будет способствовать успехам народного образования. В статье показывается, что в результате реформы орфографическая норма вобрала в себя ряд особенностей, присущих народной письменности (лубки, крестьянские письма). Крестьянская орфография не была нормированной, однако обладала рядом специфических черт, некоторые из которых были позаимствованы авторами реформы.

Ключевые слова: орфография, орфографическая реформа, народная письменность, лубок, неграмотность, малограмотность.

История орфографической реформы 1917-1918 годов обычно описывается как история комиссий и других институций, готовящих реформу. При этом в центре внимания исследователей оказывается в основном филологическая оценка реформаторских проектов и вклад филологов в решение проблемы упрощения орфографии. Между тем созданию комиссий, состоящих из профессионалов, предшествовал другой период, когда о необходимости орфографической реформы говорили в основном педагоги. Сама идея упрощения русской орфографии связана с развитием народной школы в последней трети XIX века. Учителя словесности, обучавшие крестьянских детей, постоянно сталкивались с тем, что ученики плохо усваивали орфографические правила. Такое положение дел естественным образом приводило к мысли, что существующие правила надо менять. В периодической печати звучали голоса учителей, размышляющих о том, как должно выглядеть обучение русскому языку и как должен выглядеть свод орфографических правил.

Учителя, сторонники реформы, утверждали, что упрощение орфографических правил существенным образом изменит ситуацию с преподаванием русского 
языка. Не будет необходимости тратить так много времени на заучивание правил, а освободившееся время можно будет использовать на приобретение других полезных умений, таких как: умение читать и пересказывать текст, умение вести дискуссии, письменно излагать свои мысли. «Не лучше ли же, - писала группа калужских учителей, - вместо бессодержательных упражнений на употребление буквы «ять» заняться с учениками хотя бы стилистическими упражнениями и дать им навык, действительно полезный и необходимый, ясно излагать свои мысли, так как жалобы на то, что кончившие курс народной школы не могут толково написать письма, к сожалению, вполне справедливы» [Мусорные буквы 1895]. Чтобы выяснить отношение учителей к реформе русской орфографии, педагогическое общество Новороссийского университета провело специальный опрос и пришло к выводу, что учителя «единогласно сочувствуют упрощению современного русского правописания, причем некоторые с особой скорбью говорят об этом важном и даже наболевшем <..> вопросе». В подготовленном этим обществом докладе говорилось, «что современное правописание тормозит достижение других более важных задач школы, например, мешает изучению русского языка и наработке искусства устного и письменного изложения» [Доклад 1903: 2]. В газетных и журнальных статьях часто звучала мысль, что дети крайне негативно относятся к курсу словесности, особенно им не нравится диктант и списывание текста [Голос учителя 1914: 43]. В 1914 г. журнал «Для народного учителя» опубликовал материалы Первого всероссийского съезда по народному образованию. В разделе о методах преподавания говорилось, что не стоит уделять орфографии так много внимания. «Одной из основных задач изучения родного языка должно быть развитие творческих начал в душе ребенка и умение выражать это творчество правильной речью, как устной, так и письменной» [Резолюция 1914: 13].

Другим вопросом, который волновал учителей, был вопрос о том, что уровень грамотности не должен быть главным критерием при оценке образованности человека. Учителя писали, что нужно перестать снижать оценки за ошибочные написания [Резолюция 1914: 14]. Эта позиция демонстрирует, что общество стало воспринимать орфографию как социальный барьер, препятствующий выходцам из низших сословий получить образование. Однако противники орфографической реформы писали, что идея игнорировать правила правописания в начальной школе, может, напротив, привести к еще большему социальному неравенству. По их мнению, снижение требований к орфографии препятствовало бы поступлению крестьянских детей в среднюю школу, ведь они не могли сдать необходимые экзамены. Возможность была только одна - снизить требования к орфографии не только в народной школе, но и в других типах начальных учебных заведений, тогда бы все ученики оказались в равном положении. Именно об этом, изучив анкеты школьных учителей, заявляла орфографическая комиссия Новороссийского университета [Доклад 1903: 1-2].

Сторонники орфографической реформы в своих рассуждениях часто обращались к авторитету создателей славянской письменности Кириллу и Мефодию. 
Обычно ссылка на солунских братьев приводилась, чтобы показать, что новый фавит, а следовательно, и новые орфографические правила служат делу развития национального языка и грамотности. На первом заседании Орфографической комиссии 1904 года звучали слова о том, святой Кирилл дополнил греческий алфавит буквами, обозначающими особые славянские звуки. П.Н. Сакулин ${ }^{1}$ говорил, что если раньше введенные Кириллом буквы $b$ и в были совершенно необходимы, потому что обозначали особые звуки, то теперь пришла пора исключить их из алфавита, потому что особых звуков, обозначенных этими буквами, больше нет. Такое исключение было бы в духе деятельности солунских братьев, ориентировавшихся на фонетический строй языка [Протокол 1905: 37]. О деятельности Кирилла и Мефодия вспоминал и академик А. А. Шахматов, когда на Первом Всероссийском съезде преподавателей русского языка в средней школе говорил о необходимости разрыва с существующей традицией. Создатели славянской письменности преодолели существующие стереотипы о том, что богослужение возможно только на трех священных языках и создали славянскую письменность. Изменение орфографии — такой же разрыв культурной традиции [Григорьева 2004: 110].

Характерно, что на кирилло-мефодиевскую миссию ссылались не только сторонники орфографической реформы, но ее противники. Ведь исключение ряда букв из русского алфавита, букв, которые были общими для русского и церковнославянского языка, вело, по мысли консерваторов, к разрыву с наследием святых братьев. Увеличение расстояния между русским и церковнославянским языками, с точки зрения противников реформы, привело бы к тому, что крестьяне стали бы хуже понимать церковнославянский язык, не смогли бы читать Псалтирь и Часослов. В изменении орфографии видели и покушение на всю русскую культуру, которая укоренена в прошлом, общем для всех славян.

У противников орфографической реформы были и другие аргументы, не только сугубо консервативного характера. Так, например, они писали о вреде фонетического принципа при освоении орфографии. Школьник, учащийся грамотно писать, запоминает облик слова целиком, у него есть визуальный образ слова, а правила в процессе освоения письма вторичны ${ }^{2}$. Профессор Варшавского университета А.В. Михайлов в книге о преподавании русского языка в школе отмечал, что школьные правила не позволяют ученику самостоятельно составить грамотный

${ }^{1}$ В дореволюционных изданиях эта фамилия пишется с двумя к: Саккулин, а в послереволюционных - с одной к: Сакулин.

2 «Ученики по буквам ищут слово, а не в слове ищут знакомые буквы. Совершенно не изощряется сила зрительного анализа у детей, ибо работа не исходит от видимого слова как целого, a, напротив, изощряется сила синтеза (слияния) основанного исключительно на слуховых представлениях. Подобным образом и при обучении письму все усилия употребляют на то, чтобы создать у детей привычку строить письменное слово по слышимым звукам, по слову. Произноси слово, слушай его звуки, записывай их и выйдет письменное слово - вот правило звукового письма. Не приучают думать о целом слове, прежде чем написать его и считают досадными и «трудными» все случаи, когда необходимость все-таки заставляет представить сначала целое слово» [Мироносицкий 1917: 7-8]. 
текст. Правила имеют большое количество исключений, есть случаи, когда нормативное правописание противоречит правилам школьной грамматики. В результате ученикам приходится запоминать большие объемы информации, в которой нет системы. С точки зрения Михайлова, запоминать следует только визуальный облик слова, а вдаваться в вопросы, почему то или иное слова пишется так, а не иначе, нет никакой необходимости. Он отмечает, что реформа орфографии - бессмысленное дело. Менять нужно систему преподавания, а не алфавит и правила правописания [Михайлов 1911: 246].

Озабоченность учителей по поводу усвоения детьми правил орфографии была связана с еще одной вещью. Сельские учителя хорошо знали, что грамотные крестьяне в своей повседневной практике писали не так, как их этому учили в школе. Ученик четырехклассной школы успешно сдавал выпускной экзамен, на котором демонстрировал свое знание русской орфографии, а уже через некоторое время учителя отмечали, что он начинал писать, игнорируя правила правописания.

Об особенностях крестьянской орфографии писал в свое время ученик Бодуэна де Куртенэ В.А. Богородицкий, посвятивший этому феномену статью «Изучение малограмотных написаний». Идея изучать подобные написания была по-своему революционной, ведь до Богородицкого отступления от стандартной орфографии квалифицировались исключительно как неграмотность и отсутствие образования и, следовательно, не могли быть объектом научного описания. Богородицкий же попытался найти закономерности и принципы в крестьянском письме, зафиксировать общее и частное [Богородицкий 1901]. Так, например, он отмечал, что крестьяне, закончившие начальную школу, то есть изучившие правила русской орфографии, в своих письмах почти не употребляют букв в и $i$. «Один грамотник, - пишет Богородицкий, - вовсе не писал буквы $b$, а между тем произносил eе, читая печатные книги. Чтобы убедиться, знаком ли он с рукописным начертанием этой буквы, я написал ее и спросил, знает ли он эту букву; оказалось, что знает. Тогда я полюбопытствовал узнать, почему он не пишет этого знака. Наш грамотник отвечал, что он пишет попросту, без этой буквы, и многие так пишут, в печатных же книгах буква эта употребляется. Также он говорил и про букву $i$, которая тоже не встречалась в его написаниях» [Богородицкий 1901: 4]. В статье Богородицкого описываются и другие особенности народного письма, например, указывается, что в нем отсутствует особая буква $\breve{u}$, вместо нее пишется $u$ [Богородицкий 1901: 4-5]. Еще одной чертой, на которой фиксирует свое внимание исследователь, является наличие двух графем на месте русской буквы $e$. «В одной серии малограмотных писем, - отмечает Богородицкий, — я встретил два знака для гласного е: $\varepsilon$ и е, первый знак употребляется в начале слова, второй в середине и конце» [Богородицкий 1901: 5] 3 .

${ }^{3}$ В связи с этим наблюдением следует отметить, что подобное распределение вариантов буквы $e$ характерно для церковнославянской орфографии, где в начале слова пишется е-широкое, а не в начале - е-узкое. 
Работа Богородицкого демонстрирует, что в крестьянской среде было свое особое представление об орфографии. Важно отметить, что такое представление сформировалось не на рубеже XIX - XX веков, а значительно раньше. Подтверждением этого являются лубочные листы, воспроизводящие тексты, написанные в стандартной орфографии, например, лубочные перепечатки газетных заметок4. При сравнении газетного и лубочного текста мы видим, что лубок пытается избавиться от букв $b$ и $i$. Замена происходит не всегда, но тем не менее если мена $b$ на $e$ встречается достаточно часто, то $e$ на $b$ не меняется практически никогда. Для лубка также характерно написание и-восьмеричного перед гласным (-ие, -ия, -ию), за исключением позиции -ии, которая записывалась как іи или же, наоборот, как $u{ }^{5}$. И хотя лубочные газеты - реалия конца XVIII в., есть достаточное количество свидетельств того, что подобная ситуация сохранялась и на всем протяжении XIX в. Главным аргументом здесь является орфография крестьянских и солдатских писем ${ }^{6}$.

При сравнении проектов орфографических реформ с практикой крестьянской орфографии бросается в глаза то, что вопрос о том, какие «лишние» буквы исключать из алфавита был решен в соответствии с принципами народной орфографии. Но если по поводу буквы $ъ$ разногласий не было, то вопрос о выборе между $u$ и $i$ не был столь однозначным. Если орфографическая комиссия при Педагогическом обществе Московского университета высказывалась в пользу $u$, то орфографическая Комиссия Новороссийского университета предпочитала сохранение буквы $i^{7}$. B пользу буквы $i$ писали, что сближает русский алфавит с алфавитами других европейских языков и у нее проще начертание. Вот как комментировал выбор буквы $i$ составитель «Упрощенной русской азбуки» К. А. Сорокин: «Из букв $i-u-v$ я принял $i$, так как $v$ встречается только всего

${ }^{4}$ Основными читателями лубка были горожане, не принадлежащие к образованным слоям общества, и крестьяне [Рейтблат 2001: 157; Гриц и др. 2001: 13-20]. Подробнее об орографии лубочных текстов см. [Плетнева 2013: 81-89, 106-110].

5 Подробнее о лубочных газетах см. [Плетнева 2016: 206-226].

${ }^{6}$ Об этом см., например, [Йокояма 2014: 305-330]. Даже в сегодняшней языковой практике можно найти подтверждение существования в прошлом особой народной орфографии и вычленить ее основные принципы. Речь идет о письмах Агафьи Лыковой, отшельницы из семьи старообрядцев-беспоповцев, которая воспитывалась на церковнославянском Букваре и Псалтири. В ее письмах, написанных на русском языке, отчетливо прослеживается влияние церковнославянской письменности. В них есть знаки придыхания, титла, буквы омега, от, два графических варианта для буквы $y$, но при этом буквы $ъ$ и $i$ почти не встречаются. Факсимильное воспроизведение этих писем см. [Толстова 2010: 114-127].

7 Аргументировалось это следующим образом: «Отдавая вопреки решению Московского общества предпочтение букве $i$ перед буквой $u$ Комиссия имела в виду два соображения: а) первое и главное: четкость письма от присутствия надстрочной точки увеличится, между тем как проектированное единообразное употребление буквы и только бы затруднило чтение рукописного текста, особенно в таких сочетаниях букв, как ишиш, шиш, шии, иши, ши, иш: лишиш (ср. лішіш), слышиш (ср. слышіш), старшии (но старшіі = современному старшіе), пиши (ср. піші), кши (ср. кші), киш (ср. кіш); б) кроме того буква і сближает русский алфавит с западноевропейским, а буква и отдаляет» [Доклад 1903: 3]. 
в нескольких словах: мvро, мvровареніе, мvропомазаніе и т.п.; буквы же $u$ - $i$ хотя встречаются одинаково часто, но начертание $i$ проще и в иностранных языках этот звук изображается таким же образом» [Сорокин 1903: 3]. Апелляция к «иностранным языкам» весьма показательна. Реформаторские проекты конца XIX — начала XX века, как правило, были ориентированы на европейскую традицию. Так что мог победить и вариант $i$, однако, как мы знаем, реформированная орфография в соответствии с народной орфографической традицией сохранила $u$, а не $i$.

Возможно, народная орфография повлияла и на выбор нормативного написания приставок на -c- и -з-. В лубочных листах правописание $c$ перед глухим согласным было распространено достаточно широко. В «гротовской» орфографии предусматривались довольно сложные правила правописания приставок на -c- и -з-, и наиболее логичным и соответствующим принципам устройства русской орфографии было бы писать -з- во всех случаях. Однако был избран другой вариант, который соотносился с традицией народной орфографии.

\section{Литература}

Богородииякий В. Изучение малограмотных написаний. Казань, 1901.

Голос учителя (Из учительских писем) // Для народного учителя. 1914, № 3.

Григорьева Т.М. Три века русской орфографии. М., 2004.

Грии T., Тренин В., Никитин М. Словесность и коммерция. Книжная лавка А.Ф. Смирдина. М., 2001.

Доклад Комиссии по упрощению русского правописания. Новороссийск, $<1903>$. На правах рукописи.

Йокояма О. Письма русских крестьян. Тексты и контексты. Т. II. М., 2014.

Мироносиикий П. П. В защиту родной письменности (По поводу мероприятий к упрощению родного правописания) $<1917>$.

Михайлов A. B. Опыт введения в изучение русского литературного языка и письма. Варшава, 1911.

Мусорные буквы // Неделя, 1895, №47 (19 ноября), стлб. 1494-1495.

Плетнева А. А. Лубочная Библия: язык и текст. М., 2013.

Плетнева $A$. A. Лубочные перепечатки газет: к вопросу об орфографическом единстве лубочной письменности // Русский язык в научном освещении. 2016. № 2 (32). С. 206-226.

Протокол заседания комиссии по вопросу о русском правописании. СПб., 1905.

Рейтблат А. И. Как Пушкин вышел в гении. М., 2001.

Резолюции пятой секции «О методах преподавания в начальной школе» // Для народного учителя. 1914, №3.

Сорокин К.А. Упрощенная русская азбука и правописание. СПб., 1903.

Толстова Г. А. Полуустав в XXI веке (письма Агафьи Лыковой в собрании Красноярского краеведческого музея). Красноярск, 2010. 


\section{Alexandra A. Pletneva}

V.V. Vinogradov Russian Language Institute of the Russian Academy of Sciences

(Russia, Moscow)

csl_centr@mail.ru

\section{POPULAR SPELLING AND THE ORTHOGRAPHY REFORM 1917-1918}

The article deals with the problems of the prehistory of the 1917-1918 orthographic reform. It was already in the 19th century that the discussion of the program of this reform began, and rural teachers came to be its most active supporters. Teachers used to believe that simplification of spelling would facilitate the learning process and contribute to the success of public education. The article shows that as a result of the reform, the orthographic norm absorbed a number of features inherent in popular writing (cheap popular prints, peasant letters). Peasant orthography was not standardized, but it had a number of specific features, some of which were borrowed by the authors of the reform.

Key words: orthography, orthographic reform, popular writing, cheap popular print, illiteracy, low-literacy.

\section{References}

Bogorodickij V. Izuchenie malogramotnyh napisanij [The study of illiterate spellings]. Kazan', 1901.

Golos uchitelya (Iz uchitel'skih pisem) [The voice of the teacher (From teacher letters)]. Dlya narodnogo uchitelya [For national teacher]. 1914. № 3.

Grigor'eva T. M. Tri veka russkoj orfografii [Three centuries of Russian spelling]. M., 2004.

Gric T., Trenin V., Nikitin M. Slovesnost' i kommerciya. Knizhnaya lavka A.F. Smirdina [Literature and Commerce. Bookshop of A.F. Smirdin]. M., 2001.

Doklad Komissii po uproshcheniyu russkogo pravopisaniya [The report of the Commission on the simplification of Russian spelling]. Novorossijsk, $<1903>$. Na pravah rukopisi.

Jokoyama O. Pis'ma russkih krest'yan. Teksty i konteksty [Letters of Russian peasants. Texts and contexts]. Tom II. M., 2014.

Mironosickij P.P. V zashchitu rodnoj pis'mennosti (Po povodu meropriyatij $k$ uproshcheniyu rodnogo pravopisaniya) [In defense of his native literature (concerning measures to simplify the native spelling) $<1917>$.

Mihajlov A. V. Opyt vvedeniya v izuchenie russkogo literaturnogo yazyka i pis'ma [The experience of the introduction to the study of the Russian literary language and letters]. Varshava, 1911.

Musornye bukvy [Garbage letters]. Nedelya, 1895, no. 47 (19 noyabrya), stlb. 1494 1495 . 
Pletneva A. A. Lubochnaya Bibliya: yazyk i tekst [Cheap popular Bible: language and text.]. M., 2013.

Pletneva A. A. Lubochnye perepechatki gazet: $k$ voprosu ob orfograficheskom edinstve lubochnoj pis'mennosti [Cheap popular reprints of Newspapers: the issue of spelling the unity of cheap popular literature]. Russkij yazyk v nauchnom osveshchenii, 2016. No. 2. Pp. 206-226.

Protokol zasedaniya komissii po voprosu o russkom pravopisanii [The minutes of the meeting of the Commission on the question of the Russian spelling]. SPb., 1905.

Rejtblat A.I. Kak Pushkin vyshel v genii [As Pushkin was published in Genii]. M., 2001.

Rezolyucii pyatoj sekcii «O metodah prepodavaniya v nachal'noj shkole» [Resolution of the fifth section of "methods of teaching in elementary school"]. Dlya narodnogo uchitelya, 1914, № 3 .

Sorokin K. A. Uproshchennaya russkaya azbuka i pravopisanie [Simplified Russian alphabet and spelling]. SPb., 1903.

Tolstova G. A. Poluustav v XXI veke (pis'ma Agaf'i Lykovoj v sobranii Krasnoyarskogo kraevedcheskogo muzeya) [The Cyrillic alphabet in twenty-first century (letters Agafia's in the collection of Krasnoyarsk Museum of local lore)]. Krasnoyarsk, 2010. 


\section{С.К. Пожарицкая}

Московский государственный университет им. М. В. Ломоносова

(Москва, Россия)

sofkonst@yandex.ru

\section{ОРФОЭПИЯ В ЭПОХУ КОРПУСКОЙ ЛИНГВИСТИКИ: ДИНАМИКА ВАРИАНТОВ И ИХ ОЦЕНКА}

Темой статьи является обсуждение статуса орфоэпии как научной дисциплины: предмет и границы орфоэпии; характер орфоэпических рекомендаций и эволюция словарных помет в связи с динамикой акцентных и грамматических вариантов литературного произношения. Рассматриваются возможности использования данных НКРЯ для формулирования некоторых прогнозов относительно дальнейших изменений орфоэпической нормы и орфоэпических рекомендаций в связи с этим.

1. Предметом орфоэпических рекомендаций типа «правильно»/«неправильно» не могут быть позиционные модификации фонем типа [см']ex/[c'м']еx, поскольку они не фиксируются слухом «наивного говорящего», не являются предметом его сознательного выбора и не ведут к коммуникативному конфликту.

2. Предметом рекомендаций и оценки по шкале «старое»/«новое» могут быть варианты слов, отличающиеся звукотипами, как ж[а]ле́mь/ж[ы]ле́mь, [сейф]/

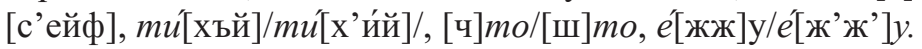

3. Акцентные варианты слова являются самым подвижным и востребованным участком орфоэпии. Специальное внимание уделяется динамике глагольной акцентуации, которая проявляется в разнице между декларируемым (reported) и peальным (actual) употреблением акцентного варианта, а также в хронологии изменения словарных помет (дружи́m $\rightarrow$ дую́сит, родился́ $\rightarrow$ роди́лся и т.п.).

4. Для описания вариантов грамматических форм особенно существенны данные НКРЯ и сопоставление Основного и Газетного корпусов. В статье рассматриваются варианты форм поезжай/езжай, одеть/надеть, тычу/тыкаю, мучу/мучаю, род.мн. носок/носков и чулок/чулков и графики, демонстрирующие динамику новых форм.

В заключение следует отметить разницу между орфографической и орфоэпической нормой: если орфографическая норма практически однозначна и не допускает вариантов (исключение - свобода употребления букв $е$ и ё), то орфоэпия 
допускает варианты, и офоэпические пометы словарей должны быть по преимуществу рекомендательными, не претендующими на блокирование изменения языка.

Ключевые слова: система, узус, нормативные пометы, динамика, варианты, корпус.

Орфоэпия не является самостоятельной научной дисциплиной. У нее нет своего объекта исследования; она вторична по отношению к фонетике, акцентологии, грамматике, где существует понятие нормы и возможность оценки существующих вариантов по шкале «правильно» - «неправильно» и по шкале «старое» - «новое». Она является дисциплиной прикладного характера, называемой, в частности, «правилами пользования устной речью». Вопрос о предмете орфоэпии и о границах применения орфоэпических рекомендаций является предметом дискуссии, и разные способы его решения определяют различия в содержании орфоэпических словарей.

1. Существует устойчивая традиция связывать орфоэпию с фонетикой в широком смысле слова, понимаемой как сведения не только о позиционной реализации фонем, но и о вариантах фонемного состава слова. Р. И. Аванесов пишет по этому поводу: «Объем понятия орфоэпии не является вполне устоявшимся. Одни понимают орфоэпию суженно, как совокупность норм произношения в собственном смысле слова, исключая из нее вопросы ударения, практически очень важные. Другие, напротив, понимают орфоэпию очень широко - как совокупность не только специфических норм устной речи (т.е. норм произношения и ударения), но также и правила образования грамматических форм (ср., например, в русском языке свече́й или свеч, кольха́ется или кольі́шется, тяжеле́е или тяже́ле), которые в равной мере относятся также и к письменному языку. Такое понимание представляется наиболее целесообразным» [Аванесов 1984: 13]. Эта позиция Р.И. Аванесова определила содержание Орфоэпического словаря русского языка, созданного под его руководством [ОС 83]. Изданный позднее Большой орфоэпический словарь [БОС 2012] не включает варианты грамматических форм, но детально представляет ударение и варианты позиционного варьирования звуков в составе слова.

Функцией орфоэпии является оценка существующих в устной речи вариантов звукового облика слова и рекомендация одного из них (возможно - двух) с целью установления единообразия. Однако единообразие звучащей речи достижимо только в определенных пределах, которые определяются бесконфликтностью процесса коммуникации. При этом разные «аспекты» произношения слова оказываются в неравном положении: место ударения и морфемная структура слова находятся в «светлом поле» сознания говорящего; они поддаются его сознательному контролю и поэтому подлежат воздействию орфоэпических рекомендаций. Что же касается фонетического аспекта речи, то он формируется в основном бессознательно и может контролироваться сознанием только тогда, когда различие звуков достигает уровня звукотипа, т.е. по сути дела, когда различие переходит 
границы фонетики и становится фактом фонологии, а именно, фонемного состава слова.

В связи с этим целесообразность орфоэпических рекомендаций в области позиционных модификаций фонем и включение этого раздела в состав орфоэпического словаря вызывает сомнение. С. С. Высотский пишет в связи с этим: «У славистов есть понятие не только орфоэпии, но и орфофонии. Лингвисты время от времени об этом напоминают. Вот Дмитрий Николаевич Ушаков давно уже об этом хлопотал, чтобы лингвисты не путали эти понятия. Надия Александровна Янко-Триницкая писала об этом, чтобы не путали по плохой традиции разные вещи, когда к фонетике относят фонемный состав слова, что́ на деле принадлежит области лексики и морфологии, а не собственно фонетике, не живому произношению» [Высоцкий 1984: 24]. Та же идея лежит в основе описания ленинградского произношения («Петербургской орфоэпической нормы») Л. А. Вербицкой: «В самом общем виде можно сказать, что орфоэпия - это правила, определяющие нормативный фонемный состав слова, а орфофония - это правила произношения вариантов фонем» и далее: «Сознательной кодификации подвергается именно орфоэпия, так как фонемный состав слов хорошо осознается носителями языка» [Вербицкая 1976: 27].

Непопулярное ныне слово «орфофония» синонимично понятию «описательная фонетика», предметом которой является изучение позиционных модификаций фонем; таких, как степень сближения безударных [е] и [и] в системе экающего и икающего вариантов литературной нормы типа [н'е $\left.{ }^{\prime}\right] c y^{\prime} /\left[\mathrm{H}^{\prime} \mathbf{u}^{\mathrm{e}}\right] c y^{\prime} /\left[\mathrm{H}^{\prime}\right.$ и] $c y ́$, делабиализация и понижение ступени подъема безударного [у] в направле-

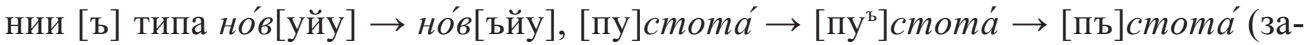
метим, что варианты реализации $<$ у $>$ описаны в БОС в восемнадцати позициях), [c] или [с:] в масса и массаж; степень мягкости первого согласного в результате коартикуляции в двух- и трехкомпонентных кластерах с замыкающим мягким согласным, напр., [c], [c·], [c'] в слове стих, означающем «стихотворение»,

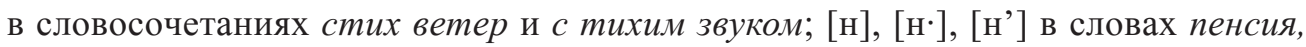
инстинкт.

Орфоэпические рекомендации в этой области практически бесперспективны, поскольку различия этого уровня не мешают коммуникации, тем более что у говорящих обычно отсутствует адекватное представление о звуковом составе произносимого ими слова - такие факты широко известны; их называют «парадоксом социолингвистики». Так, при проверке «Вопросника по современному русскому произношению» [Баринова 1971: 325] оказалось, что всего 18,5 \% опрошенных заявили, что они произносят мягкое [3'] в слове зверей, а в магнитофонной записи произношения тех же лиц оказалось $72 \%$ случаев мягкого [3'] в этом слове. Возможно, здесь играет роль и орфографический фактор, в силу которого в избе и в резьбе могут быть произнесены по-разному (в и[зб'], в ре [з'б']

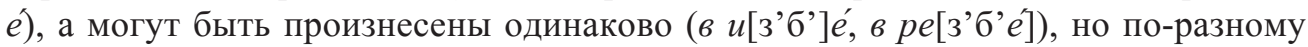
оценены испытуемым. Можно предположить, что при одинаковом произношении бо́льшая часть испытуемых припишет себе твердое произношение первого 
согласного в слове без обозначенной мягкости в избе, чем в слове с обозначенной мягкостью в резьбе. Сопоставление письменных ответов на вопрос об употребляемом варианте родительного партитивного падежа (чая/чаю, творога/творогу и т.п.) с данными устного интервью показало только 73,7\% случаев их совпадения [Русский язык по данным массового обследования 1974: 163]. Похожие результаты дает и сопоставление акцентных вариантов акцентуации глагольных форм - реально употребляемых, (actual usage по терминологии Э. Марклунд Шараповой), с теми, которые говорящий называет правильными и приписывает себе (reported usage). Так, reported usage нормативного балова́лся (не-N ба́ловался) составляет $38.7 \%$ от общего числа полученных ответов, actual usage - $6.5 \%$ [Marklund 2000: 297-302].

Экспериментальное исследование мягкостной коартикуляции некоторых консонантных кластеров (нси, нсти), осуществленное путем сопоставления инструментальных данных относительно степени мягкости первого согласного с аудиторской оценкой ее, показало, что участники эксперимента практически не слышат полумягкости: аудиторская оценка полумягких согласных совпала с реальной полумягкостью первого согласного только в $10 \%$ произнесений; в $80 \%$ он был квалифицирован как твердый, в 10\% — как мягкий [Кушавина 2017]. Результаты экспериментальной работы Д.А. Кушавиной уточняют и подтверждают ранее высказанное мнение С. М. Кузьминой: «В современном литературном языке в сочетаниях «согласный + мягкий согласный» наблюдается вариативность мягкого/ твердого первого согласного ([с'н']ег/[сн']ег, [д’в']ерь/Ддв']ерь и т.п.). По данным вопросника, преобладающим является твердый вариант (его частость $\approx 0,720$ ), однако, как показало сравнение с ответов на вопросник с данными магнитофонных записей, частость твердого варианта в этих данных завышена» [Русский язык по данным массового обследования 1974: 82].

Орфоэпические оценки неприменимы к фонетическим деформациям разговорного характера. Эллипсис гласных и согласных, упрощение консонантных кластеров, стяжение гласных и редукция слоговой структуры слова обусловлены фразовой позицией слова в ситуации общения и регулируются только ей. Произношение [гр’ит] (говорит), [ун’ьрс'т’е́т] (университет), [тада́] (тогда), [то́къ] (только) не подлежит оценке с точки зрения орфоэпической «правильности»; оно принадлежит другому речевому регистру и выполняет там свою естественную функцию. Такие варианты «нормальны», хотя и не «нормативны».

В принципе не подлежат нормативной оценке и диалектизмы как элементы другой системы, однако иногда они проникают в орфоэпические словари в практике борьбы «за чистоту речи» - напр., «печь (глаг.) - пеку́, печёт (неправильно пекёт)»; то же - относительно стригёт, текёт [Горбачевич 2000: 162].

2. Мена звукотипов (ж[а]леть/ж[ы]леть, е[жж]у/е[ж’ж']y, [ч'] то/[ш]то, $m u\left[\mathrm{x}^{\prime} \mathrm{b}\right] \breve{u} / m u[\mathrm{xъ}] \breve{u},[\mathrm{~T}] е р p o p /\left[\mathrm{T}^{\prime}\right]$ еррор) обычно осознается говорящими и может быть причиной коммуникативного конфликта, который проявляется в негативной реакции одного из участников акта коммуникации. Следовательно, орфоэпическая рекомендация здесь может быть востребованной, она уместна. Однако такие 
варианты, как правило, отражают динамику узуса, и нормативная помета в этом случае не должна иметь запретительного характера. Объективная оценка таких вариантов скорее всего может быть дана по шкале «старое - новое», которая предоставляет говорящему возможность осознанного выбора варианта; роль орфоэпии сводится к тому, чтобы «объяснить ситуацию» говорящему. Следует сказать, что ситуация свободы выбора далеко не всегда удовлетворяет людей, осложняя их жизнь; тем не менее, ситуация объективно такова.

3. Акцентные варианты слова являются самым востребованным и самым сложным участком орфоэпического нормирования, поскольку тенденции изменения акцентных норм реализуются на конкретных лексемах и развиваются, постепенно распространяясь на всё большее количество слов, относящихся к одной и той же грамматической категории. «Отсутствие фиксированного места ударения, разноместность его делает ударение в русском языке индивидуальным признаком каждого слова», — пишет Р. И. Аванесов [Аванесов 1984: 13].

Происходящие здесь процессы неоднородны относительно слов разных грамматических категорий: наблюдается усиление (не безусловное!) подвижности ударения в одних классах слов (именах) и стабилизация - в других (глаголах).

Один из самых активных процессов настоящего времени - смещение ударения на окончание в субпарадигме мн. числа и мена $<$ и $>$ на $<$ a $>$ в им. мн. преимущественно многосложных, а иногда и односложных имен, не только исконно русских, но и заимствованных (арбитражи́, тренера́, склады́, крема́). Нормативная оценка таких форм не имеет объективных оснований и базируется только на узусе. Ответ на вопрос «почему можно говорить инспектора́, но нельзя - лектоpá?» мог бы быть таким: «потому, что квалифицированное большинство говорящих употребляют эти слова именно с таким ударением». Однако во-первых, мы не располагаем статистическими данными для такого утверждения (хотя это поправимо с применением социолингвистических методов исследования), а во-вторых, следует учитывать, что любой орфоэпический сдвиг имеет свои причины, которые не всегда понятны, но всегда «заслуживают уважения», и попытки затормозить эти процессы путем запретительных помет приводят к конфликту между нормативными пометами словарей («эксплицитной нормой») и узусом («имплицитной нормой»), где в конечном счете проигрывает «законодатель». Так, по данным Э. Марклунд Шараповой, которая, в том числе, сопоставляла пометы разных словарей, форму нали́л, имеющую в разных словарях пометы доп. и разг. (N на́лил), употребляют и признают правильной 92,5 \% говорящих; отда́л (пометы доп., разг.) - 64.5\% (N о́тдал); роди́лся (N роди́лся и родился) - 93.5\%; на́чался (пометы неправ., не рек.) - 58.5\% (N начался); вклю́чишь (пометы неправ., разг.) - 85.8\% (N включи́шь); позво́ним (пометы не рек., простореч.) - $32 \%$ (N по́звоним).

Активная тенденция перемещения ударения с окончания на основу наблюдается в формах глаголов на -umь (тип 4 b - [Зализняк 2015]).

Динамику этого процесса демонстрирует эволюция помет в словарях, которые содержат орфоэпические рекомендации: 


\begin{tabular}{|l|c|c|}
\hline & дружи́т & дру́жит \\
\hline Словарь 1847 & $\mathrm{N}$ & - \\
\hline Огиенко 1914 & $\mathrm{N}$ & - \\
\hline Ушаков 1935-1940 & $\mathrm{N}$ & - \\
\hline БАС 1950-1965 & $\mathrm{N}$ & просторечие \\
\hline Аванесов-Ожегов 1960 & $\mathrm{N}$ & $\mathrm{N}$ \\
\hline МАС 1957-1961 & $\mathrm{N}$ & $\mathrm{N}$ \\
\hline Ожегов-Шведова 1972 & $\mathrm{N}$ & $\mathrm{N}$ \\
\hline Горбачевич 2000 & устарелое & $\mathrm{N}$ \\
\hline ОС 1983 & допустимо устаревающее & $\mathrm{N}$ \\
\hline РПП 1996 & устаревающее & $\mathrm{N}$ \\
\hline БТС 1998 & - & $\mathrm{N}$ \\
\hline БОС 2012 & - & \\
\hline
\end{tabular}

Принадлежащий к той же категории глагол варить полностью утратил акцентный вариант вари́m, рекомендованный в свое время Д.Н. Ушаковым [Ушаков 1935-1940], а формы глагола включить с ударением на корневом гласном, которые в [ОС 83] имеют запретительную помету (включи́m !неправ. вклю́чит), [БОС 2012] дает с разрешительной пометой: «включи́m и допуст. младш. вклю́чит». При этом по данным Э. Марклунд Шараповой вклю́чишь произносят 85,8 \% говорящих. Следует ли в связи с этим изменить оценки и предложить в качестве нормативного вклю́чит, а включи́m дать с пометой (дon. yстар.)? На первый взгляд, это противоречит мнению Р. И. Аванесова, который писал: «...нередко этой пометой (не рек. С.П.) оцениваются варианты, о которых можно предположить, что не в очень далекой перспективе они станут нормативными. Но само содержание пометы этого не предполагает, так как прогнозирование не входит в задачи нормативного словаря» [ОС 83: 6]. Однако прогнозирование при помощи достаточно надежных статистических данных, которые могут быть получены в настоящее время с помощью НКРЯ, могло бы сблизить рекомендации словарей с узусом.

4. Имеется целый ряд вариантов грамматических форм, требующих орфоэпической оценки. Сдвиг нормы в морфологии, как и в акцентной сфере, не всегда имеет системный характер, хотя это и противоречит одному из общепринятых критериев нормативности.

4.1. Системным сдвигом можно считать мену формообразовательного разряда глагола на более продуктивный - например, типов 4 а (ездить, 6 а (капать), 6 с (скакать) на тип 1а (делать), который Т. Нессет называет «целевым» [Нессет 2010], и устранение чередования, которое наблюдается в глаголах исходного типа: брешу/брехаю, брызжу/брызгаю, каплю/капаю, машу/махаю, скачу/скакаю, тычу/тыкаю, езжу/ездию, лажу/лазию и др. Орфоэпическая судьба однотипных слов при этом может быть совершенно различной: например, вариант пахаю приводится только в одном словаре с пометой не рекомендуется [Горбачевич 2000], и это согласуется с данными Т. Нессета, у которого соотношение пахаю - пашу равно 0.6\% (2 из 355) [Нессет 2010: 125]; варианты каплю/капаю, по оценкам словарей, устойчиво равноправны, и данные Т. Нессета это подтверждают, хотя 


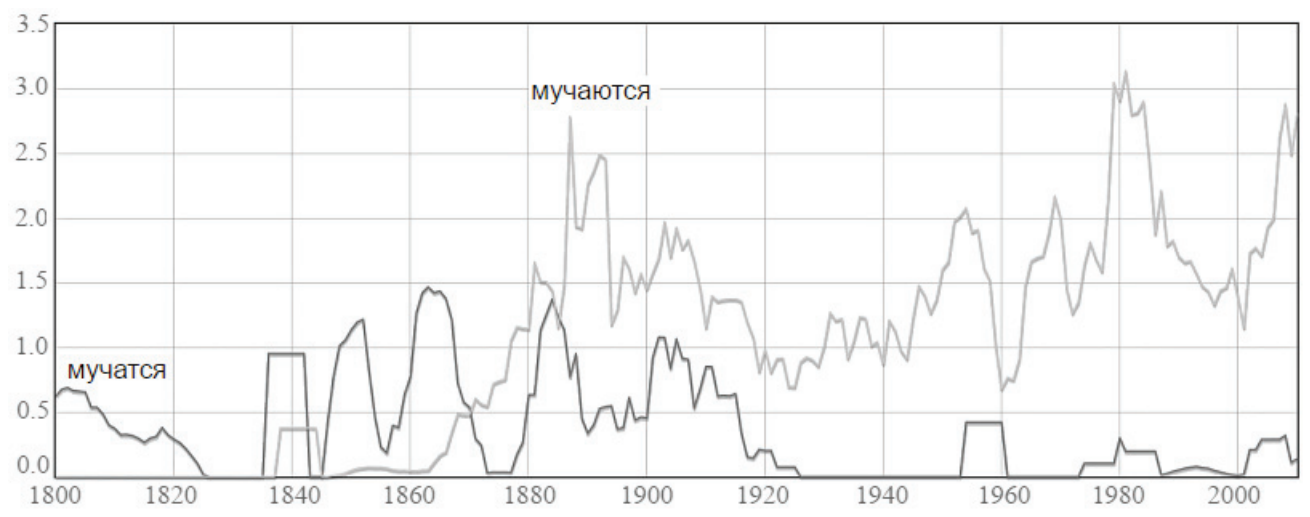

Рис. 1. Частота форм мучатся и мучаются в Основном корпусе НКРЯ

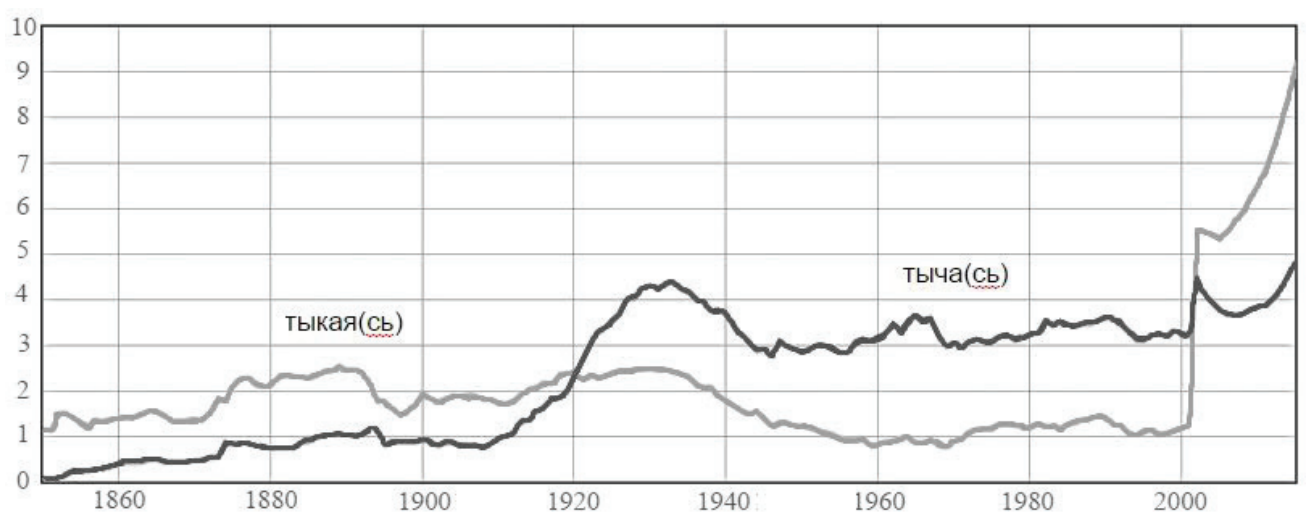

Рис. 2. Частота деепричастий тыкая(сb), тыча(сь) в Основном корпусе НКРЯ

и свидетельствуют о некоторым предпочтении нового варианта, который составляет $58 \%$ (106 из 184). Но здесь, вероятно, сыграл роль фактор семантики; а именно, закрепленность разных формальных вариантов за некоторыми оттенками значения и частотность разных словосочетаний в связи с этим.

В некоторых случаях корпусные данные демонстрируют такую динамику форм, которую правильно было бы учитывать при формулировании помет в орфоэпических словарях. Так, [ОС 83] предлагает считать варианты форм глагола мучиться - мучусь ... мучатся и мучаюсь ... мучаются — равноправными, тогда как по данным НКРЯ их узуальный статус существенно различен: графики показывают, что процесс вытеснения старых форм типа 4 а (мучусь) новыми типа 1 а (мучаюсь) практически почти завершен ${ }^{1}$.

Похожую картину демонстрирует и график деепричастных форм глагола $m b l-$ каmb.

1 Рисунки 1, 2, 3 выполнены Е.Р. Добрушиной и опубликованы в статье [С.К. Пожарицкая, Е.Р. Добрушина 2017]. 
Как видим, «новая» форма тылкаясь, уже в середине XIX века имевшая преимущество перед «старой» формой тычась, уступила ей в 20-е годы XX века, а в начале XXI «взяла реванш» в виде резкого скачка опережения. Однако, судя по данным ГИКРЯ, можно думать, что здесь кроется разница между спонтанной речью: (mbl$\kappa a(c b):$ mыча $(c b)$ — (60:40 из 11700) и профессиональной: тыкка(сь): тыча(сь) — (26:74 из 800). Возможно, что именно по этой причине диаграмма НКРЯ не совпадает с данными Т. Нессета, у которого новая форма типа 1 а тыкаю составляет только $21 \%$ употреблений (119 из 558).

4.2. Вариантные формы императива глаголов ехать, ездить (езжай? поезжай? exaй? едь? езди?) аномальны по отношению к системе. В Грамматическом словаре А. А. Зализняка относительно ехать говорится: «...nовел. нет (в знач. повел. употр. поезжа́й [также простореч. езжа́й], с отрицанием не езди)» [Зализняк 2015: 684].

Но рекомендуемая нормой форма поезжай тоже находится вне системы, поскольку в СРЛЯ отсутствуют соотносительные с ней формы *nоезжать, *nоезжаю ${ }^{2}$, и в этом смысле у нее нет преимущества перед отвергаемой формой езжай, которая тоже не имеет опоры в виде * езжать, *езжаю. Обе формы аномальны по отношению к системе, однако частотность езжай(те) имеет положительную динамику, а поезжай(mе) - отрицательную. При этом в Основном корпусе НКРЯ нормативная форма поезжай(те) имеет некоторое преимущество (60\%:40\%), а в Газетном, который в большей степени ориентирован на язык СМИ XXI века - наоборот (20\%:80\%).

Учитывая динамику вариантов, словарная рекомендация относительно езжай не должна иметь характера запрета; запрет здесь вряд ли будет воспринят.

Сравнение рисунков 1, 2, 3 подтверждает наблюдение М.Я. Гловинской, высказанное ею в монографии [Русский язык по данным массового обследования: 120]: «Любопытно отметить, что в речи поколения 40-х годов нередко наблюдается замедление темпа убывания или возрастания традиционного варианта; развитие как бы затормаживается». Несколько раньше (в 20-е годы) показывает «затормаживание» формы $u x-$ ний «График распределения прилагательного ихний по годам по отношению к общему числу всех словоупотреблений» в работе [Добрушина 2013: 185]. Очевидно, в этот период происходит стабилизация нормы, которая раныше была более «свободной».

4.3. Однокоренные глаголы одеть и надеть конкурируют в аналогичных контекстах: надеть шапку/одеть шапку. Реально существующее семантическое различие между этими глаголами, узаконенное нормой как необходимость говорить одеть ребенка, но надеть шапку, не ощущается говорящими как значительное; игнорирование его не провоцирует коммуникативного конфликта, и это различие стирается в современной речи, как устной, так и письменной. При этом экспансия наблюдается со стороны одеть и проявляется в возможности сказать надеть/ одеть шапку, но только одеть ребенка. Вытеснение надеть его «парой» одеть

2 Заметим, что в севернорусских говорах Архангельской обл., кроме императива поезжай, встречаются редкие формы императива от переходных глаголов повеза́й, понеса́й, повешай: Ну дак понесайте буде тюфяк (Акичкин Починок Устьянский р-н); бабушка, грит, кушай - а я гу нет, повеза́й домой (Михалевская Устьянский $\mathrm{p}-\mathrm{H})$; здесь перчатки пове́шаю - пове́шай на солнышке, скорее высохнут (Вельский р-н.) 


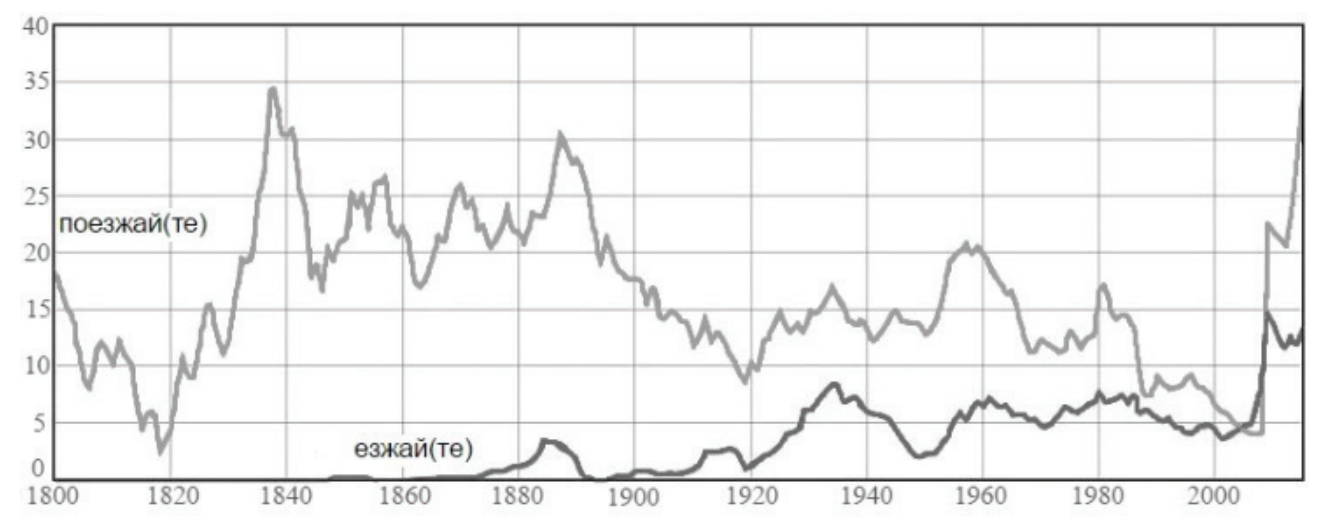

Рис. 3. Частота форм поезжай(те)/езжай(те) в Основном корпусе НКРЯ

наблюдается по крайней мере с 40-х годов XIX века. Исследованная А. А. БончОсмоловской представительная база интернет-текстов XXI века (комментарии, живые журналы и т.д.) показывает равноправие этих глаголов при прямых дополнениях со значением артефактов, и это один из примеров победы узуса (имплицитной нормы) над декларируемой эксплицитной [Бонч-Осмоловская 2006: 6].

5. Главный вопрос орфоэпии - критерии оценки функционирующих в узусе вариантов. В дискуссиях на эту тему выявляются две позиции, одну из которых называют субъективной, другую - объективной.

Субъективной оценкой фактов орфоэпической вариативности называют позицию априорного представления о нормативности варианта, основанного на традиции, следовании образцам и личном вкусе автора рекомендаций. К этому способу оценки вариантов отрицательно относились в свое время А. М. Пешковский и А. А. Шахматов: «Первой и самой замечательной чертой его («литературно-языкового идеала» - С.П.) является поразительный консерватизм, равного которому мы не встречаем ни в какой другой области духа. Из всех идеалов это единственный, который лежит целиком позади. «Правильной» всегда представляется речь старших поколений, предшествовавших литературных школ. Нормой признается то, что было и отчасти то, что есть, но отнюдь не то, что будет» [Пешковский 1959] и «Главный и единственный авторитет в языке - это обычай, употребление» и далее: «Странно было бы вообще, если бы ученое заведение вместо того, чтобы указывать, как говорят, решалось указывать, как надо говорить» [Шахматов 1899].

Примером субъективного подхода к орфоэпической оценке варианта может быть такое высказывание А.Б. Шапиро: «Даже если девяносто процентов будут говорить доку́мент, это не может стать литературной нормой» (цит. по Крысин 2004: 304). Почему? Никаких системных запретов мы здесь не видим: иноязычные слова с финалью -мент часто имеют ударение на предшествующем слоге ср. парла́мент, регла́мент, поскольку место ударения определяется источником заимствования, но этот аргумент часто утрачивает свое значение в практике разговорной речи. К тому же, в русском языке наблюдается тенденция передвижки ударения с последнего слога на предпоследний в иноязычных заимствованиях. 
Но решающим фактором является узус, и если 90\% говорящих почему-либо предпочитают говорить доку́мент, то это уже узуальная норма, которую лингвистам остается только признать и кодифицировать.

Пример победы системы над узусом - изменение схемы согласования существительного кофе. Традиция согласования его по мужскому роду (черный, бразильский...кофе) возникла на базе ранее усвоенного заимствования этого слова в склоняемой форме кофий или кофей (черный кофий/-ей), и предпочтение варианта черное кофе в связи с преобразованием основного слова и вхождением его в класс несклоняемых заимствований с окончанием -e (-o) - системно, перспективно и не подлежит орфоэпической дискриминации, как бы ни противоречило это вкусам и привычкам говорящих.

Но разная нормативная оценка форм род.п. слов носки ( $\mathrm{N}$ носок и носков) и чулки (N чулок) [OC 83] основана только на узусе и при этом держится достаточно прочно: в Газетном корпусе НКРЯ (объем 228 млн слов, тексты 2001-2015 гг) форма носков встретилась 508 раз, а равноценная ей форма носок - 1 раз; нормативная чулок - 59, ненормативная чулков - $3^{3}$. Никаких системных оснований для разной нормативной оценки этих форм нет, но тем не менее, в узусе удерживаются разные формы род. падежа для носки и чулки, и данные НКРЯ подтверждают оценку словарей.

Объективная оценка произносительных вариантов основывается на том, что в орфоэпии узус диктует правила, а не правила - узус, и определению орфоэпических правил и помет в словарях должны предшествовать серьезные социолингвистические исследования, которые у нас были начаты в 60-е годы XX-го столетия под руководством М.В.Панова. Они выявили впечатляющие сдвиги в произносительном узусе середины XX-го века по сравнению с концом XIX-го («младшая» и «старшая» орфоэпические нормы) и определили основные методы социолингвистических исследований эпохи середины XX века, которые могут быть дополнены открывшимися возможностями Национального корпуса русского языка (НКРЯ).

В заключение следует отметить разницу между орфографическими и орфоэпическими рекомендациями: если орфографическим рекомендациям естественно быть регламентирующими и однозначно запретительными, то орфоэпические пометы должны быть по преимуществу рекомендательными, не претендующими на блокирование изменения языка.

\section{Литература}

Аванесов Р. И. Русское литературное произношение. М., 1984

Аванесов Р.И., Ожегов С.И. Русское литературное произношение и ударение. M., 1959.

Баринова Г.А., Ильина Н.Е., Кузьмина С.М. О том, как проверялся вопросник по произношению // Развитие фонетики современного русского языка. М. 1971. C.315-342.

\footnotetext{
3 Устное сообщение Е.Р. Добрушиной.
} 
[БАС 1948-1960] Словарь современного русского литературного языка: В 17 томах. Москва-Ленинград. 1948-1960.

[БАС 2006] Большой академический словарь русского языка. Т. 5 (ред. К. С.Горбачевич). СПб., 2006.

Бонч-Осмоловская А. А. Практика против грамматики: «одеть» и «надеть» в современном русском языке // Собрание сочинений: к шестидесятилетию Льва Иосифовича Соболева. М., 2006.

[БОС 2012] — Каленчук М. Л., Касаткин Л. Л., Касаткина Р. Ф. Большой орфоэпический словарь русского языка. М., 2012.

Вербицкая Л.А. Русская орфоэпия. (К проблеме экспериментально-фонетического исследования особенностей современной произносительной нормы)., Ленинград, 1976.

Высотский С.С. О московском народном говоре // Городское просторечие. Проблемы изучения. М., 1984.

Горбачевич $K . C$. Словарь трудностей произношения и ударения в современном русском языке. Л., 2000.

Добрушина Е.P. Норма-кодификация против нормы-интуиции или двести лет вместе с «ихний» // Русский язык в научном освещении. №2 (26). М., 2013. С. 181-204.

Зализняк А. А. Грамматический словарь русского языка. М., 2016.

Крыссин Л. П. Языковая норма в проекции на современную речевую практику // Русский язык сегодня, № 4, М., 2004.

Кушавина Д.А. Коартикуляция переднеязычных носовых согласных по мягкости в позиции перед зубными в современном русском литературном языке // Дипломная работа. МГУ. М., 2017.

[MАС] Евгеньева А. П. (ред.). Словарь русского языка: В 4-х томах. М., 19851988.

Огиенко И. И. Русское литературное ударение (справочник и словарь русского ударения). Киев, 1914.

Ожегов С. И., Шведова Н. Ю. Словарь русского языка. М., 1972.

[OC] Аванесов Р. А. (ред.) Орфоэпический словарь русского языка. Произношение. Ударение. Грамматические формы. М., 1983.

Пешковский А. М. Объективная и нормативная точка зрения на язык. // Пешковский А. М. Избранные труды. М., 1959.

Пожариикая С.К., Добрушина Е.Р. Орфоэпический взгляд на некоторые вариантные явления русского литературного языка в эпоху корпусной лингвистики // Компьютерная лингвистика и интеллектуальные технологии. По материалам ежегодной международной конференции «Диалог» 2017. Вып. 16, Том 2 из 2, М., 2017. С. 351-360.

[РПП] Введенская Л.А., Червинский П. П. Русское произношение и правописание. Словарь-справочник. Феникс, Ростов-на-Дону, 1996.

Русский язык по данным массового обследования. Под ред. Л. П.Крысина. М. 1974.

[Словарь 1847] Востоков (ред.). Словарь церковнославянского и русского языка, составленный Вторым отделением Императорской академии наук, Типография Императорской академии наук, СПб., 1847. 
[Ушаков] Толковый словарь русского языка. Под ред. Д.Н. Ушакова. М., 19351940. (4 т.).

Фонетика современного русского языка. Народные говоры. Ред. М. В. Панов. Москва, 1968.

Шахматов А. А. Несколько слов по поводу записки И. Х.Пахмана, План нового Академического словаря с точки зрения иноязычного, Записка И. Х.Пахмана, Сб. ОРЯС ИАН LXVII (1), 1899.

Marklund Sharapova Elisabeth Implicit and Explicit Norm in Contemporary Russian Verbal Stress, Studia Slavica Uppsaliensia. 40, Uppsala, 2000.

Nesset Tore Suffix shift in Russian verbs: a case for markedness? Суффиксальный сдвиг в русских глаголах: вопрос маркированности? Russ Linguist 34: 123-138. 2010 .

\author{
Sofia K. Pozharitskaja \\ Lomonosov Moscow State University \\ (Moscow, Russia) \\ sofkonst@yandex.ru
}

\title{
ORTHOEPY UNDER THE SCRUTINY OF CORPUS LINGUISTICS: DYNAMICS OF VARIATION AND DYNAMICS OF ATTITUDES
}

We discuss the status of orthoepy as a linguistic discipline; its scope and limitations; the nature of orthoepic prescriptions and the evolution of dictionary marks in its connection to the evolution of the stress and grammar of standard Russian. We consider the use of Russian National Corpus as an instrument of prediction of further orthoepic changes and envisaging prescriptions resulting from this change.

1. Prescription can not apply to contextual modifications of phonemes ([см']ex/[c' '⿳'] $e x)$, because they are not perceived by a "lay speaker", are not subject to his or her conscious choice and can not lead to communicative failures.

2. On the other hand, prescription may apply to variants that are different in 'sound types' (звукотип, е.g. ж[а]ле́ть/ж[ы]ле́ть, [сейф]/[с'ейф], ти [хъй]/ти́[х’и́й], [ч]то/ [ш]mo, é[жж]y/é[ж’ж']y); these variants may be suggested to represent newer vs. older norms.

3. Stress variants are the most dynamic domain of orthoepy. Special focus is on the change in verbal stress as reflected in the difference between the prescribed vs. real usage and in the chronology of dictionary marks (дружи́m $\rightarrow$ дружит, родился́ $\rightarrow$ роди́лся еtс.).

4. The use of the data of Russian National Corpus and, more specifically, comparative analysis of the main corpus and the corpus of newspapers is an important method of analysis of grammatical variation. We consider the competition between such forms as поезжай/езжай, одеть/надеть, тычу/тыккю, мучу/мучаю, их/ихний and provide charts showing positive dynamics of the more recent variants. 
In conclusion, we stress the difference in the nature of orthographic and orthoepic marks in the dictionaries. Orthographic marks may be prescriptive and prohibitive. Orthoepic marks may only, in most cases, have a status of recommendations; they can not (be regarded as means to) block language change.

Key words: system, usus, normativ labels, dynamics, variants, corpus.

\section{References}

Avanesov R. I. Russkoe literaturnoe proiznoshenie [Standard Russian pronunciation]. Moscow, 1984.

Avanesov R.I., Ozhegov S.I. Russkoe literaturnoe proiznoshenie i udarenie [Standard Russian pronunciation and stress]. 1959.

Barinova G. A., Il'ina.N.E., Kuz'mina S.M. O tom, kak proverialsia voprosnik po proiznosheniju [How the pronunciation questionnaire was checked] Razvitie fonetiki sovremennogo russkogo jazyka [Evolution of modern Russian phonetics], Moscow, 1971.

Slovar' sovremennogo russkogo literaturnogo jazyka: V 17 tomakh [Dictionary of modern standard Russian: in 17 volume]. Moscow-Leningrad.

Bol'shoi akademicheskii slovar' russkogo yazyka [The Great Academic Dictionary of Russian]. V.5 SPb.

Bonch-Osmolovskaja A.A. Praktika protiv grammatiki: «odet'» i «nadet'»v sovremennom russkom jazyke [Usage vs. grammar: «odet'» and «nadet'» in modern Russian]. Sobranie sochinenij: $k$ shestidesiatiletiju L'va Iosifovicha Soboleva [Collected Works: In honor of Lev Iosifovich Sobolev]. Moscow, 2006.

Kalenchuk M.L., Kasatkin L.L., Kasatkina R.F. Bol'shoi orfoepicheskii slovar' russkogo yazyka [A comprehensive dictionary of russian orthoepics], AST — Press, Moscow.

Gorbachevich K.S. Slovar' trudnostej proiznjshenija I udarenija v russkom literaturnom jazyke [Dictionary of difficult cases of word pronunciation and stress in standard Russian]. Sankt-Peterburg, 2000.

Dobrushina E.R. [Kodified norm vs. intuitive norm, or two centuries with ikhnij]. Russkij yazyk v nauchnom osveshscenii. No. 2. M. 2013. P. 181-204. (In Russ.).

Krysin L.P. Jazykovaja norma v proektsii na sovremennuiu rechevuju praktiku [Language norm as projected on modern language usage]. Russkii jazyk segodnia [Russian language today], no 4. 2004.

Kushavina D.A. Korrelacija po palatalizacii koronalnych nosovych soglasnych $v$ sovremennom russkom jazyke [Palatalizing coarticulation of coronal nasals followed by palatalized dentals in modern standard Russian]. BA Thesis. Mansucript. Moscow: MSU, 2017.

Marklund Sharapova Elisabeth. Implicit and Explicit Norm in Contemporary Russian Verbal Stress, Studia Slavica Upsaliensia. 40, Uppsala, 2000.

Slovar' russkogo jazyka v 4 tomakh [Dictionary of Russian]. in 4 volumes Evgen'eva A.P. (ed.), Russkii jazyk, Moscow,1985 -1988. 
Fonetika sovremennogo russkogo literaturnogo jazyka. Narodnye govory [Modern Russian phonetics. Standard language and dialects]. Panov M. (ed.), Moscow, 1968.

Nesset Tore. Suffix shift in Russian verbs: a case for markedness? Russian Linguistics, 34, pp. 123-138, 2010.

Ogienko I. I. Russkoe literaturnoe udarenie (spravochnik i slovar' russkogo udarenija) [Stress in standard Russian (reference dictionary of Russian stress)]. Kiev, 1914.

Orfoepicheskii slovar' russkogo iazyka. Proiznoshenie. Udarenie. Grammaticheskie formy [Orthoepic dictionary of Russian. Pronunciation. Stress. Inflection]. Avanesov R. I. (ed.) 1983, Moscow.

Ozhegov S. I., Shvedova N. Yu. Slovar' russkogo yazyka [Dictionary of Russian]. Moscow, 1972.

Peshkovski A.M. Ob"ektivnaja i normativnaja tochka zrenija na jazyk [Objective and prescriptive view on language], Peshkovski A. M. Izbrannye trudy [Selected works], Moscow, 1959.

Pozharitskaja S.K., Dobrushina E.R. Orfoepicheskij vzgliad na nekotorye variantnye javlenija russkogo literaturnogo jazyka $\mathrm{v}$ epochu corpusnoj lingvistiki [Orthoepical point of view to some variation cases in standard Russian in the epoch of corpus's linguistique]. Computational Linguistics and Intellectual Technologies: Proceedings of the International Conference "Dialogue 2017” Vol. 16, 2, Moscow, 2017, pp 351-360.

Russkii jazyk po dannym massovogo obsledovanija [Russian language: data from sociolinguistic overview]. Krysin L.P. (ed.), Moscow, 1974.

Shakhmatov A. A. Neskol'ko slov po povodu zapiski I.Kh. Pakhmana, Plan novogo Akademicheskogo slovaria s tochki zrenija inojazychnogo [A few words on I.Kh. Pahman's notes. Plan of a new academic vocabulary from the point of view of a foreign]. Zapiska I.Kh. Pakhmana [Note by I. H. Pahman], Coll. ORYAS IAN LXVII (1), 1899.

Ushakov D. N. (ed.) Tolkovyi slovar' russkogo yazyka [Dictionary of Russian]. 19351940

Verbitskaia L.A. Russkaia orfoepiia (K probleme eksperimental'no-foneticheskogo issledovaniia osobennostei sovremennoi proiznositel'noi normy). [Russian orthoepy (Towards experimental phonetic studies of the modern pronunciation standard)]. Leningrad, 1976.

Vostokov A. Kh. (ed.) Slovar' tserkovnoslavianskogo i russkogo iazyka, sostavlennyi Vtorym otdeleniem Imperatorskoi akademii nauk [Dictionary of Church Slavonic and Russian, compiled by the second department of the Imperial Academy of Sciences]. St. Petersburg, 1847.

Vvedenskaja L.A., Chervinsky P.P. Russkoe proiznoshenie i pravopisanie. Slovar'spravochnik [Russian pronunciation and spelling. A reference dictionary]. Feniks, Rostov-na-Donu, 1996.

Vysotsky S. S. O moskovskom narodnom govore [On Moscow vernacular]. Gorodskoe prostorechie. Problemy izucheniia [Urban vernacular. Issues in empirical research], Moscow, 1984.

Zaliznyak A. A. Grammaticheskij slovar' russkogo jazyka [Russian grammatical dictionary]. Moscow, 2016. 


\section{С.В. Феликсов}

Православный Свято-Тихоновский гуманитарный университет

(Россия, Москва)

svfeliksov@gmail.com

\section{ТИПЫ ВАРИАНТНЫХ НАПИСАНИЙ РЕЛИГИОЗНОЙ ЛЕКСИКИ В ЛЕКСИКОГРАФИЧЕСКИХ ПРОИЗВЕДЕНИЯХ ГРАЖДАНСКОЙ ПЕЧАТИ ВТОРОЙ ПОЛОВИНЫ ХVIII ВЕКА}

В предлагаемой статье на основе лексикографических произведений гражданской печати второй половины XVIII века — «Церковного словаря» $(1773-1794$ гг.) протоиерея Петра Алексеева, «Краткого славянского словаря» игумена Евгения (Романова) (1784 г.) и «Словаря Академии Российской» $(1789$ - 1794 гг.) - pacсматриваются основные типы вариантных написаний, коснувшиеся религиозной лексики, а также обусловившие их причины. В результате лингвистического анализа автором делается вывод, согласно которому указанные словарные сочинения являются ценными источниками в вопросе изучения истории правописания религиозной лексики, в значительной мере отражая орфографические колебания, связанные с ее кодификацией. Все многообразие вариантных орфографических форм религиозной лексики, встречающихся в данных произведениях, в работе классифицировано и рассмотрено в соответствии с тремя основными типами: графикоорфографическим, морфологическим и этимолого-словообразовательным. Отмечается, что основные причины, вызвавшие орфографические колебания в области написании религиозной лексики, были обусловлены, с одной стороны, собственно языковыми факторами, связанными с недостаточной разработанностью ко второй половине XVIII века теории русского правописания и правил орфографии, а с другой стороны, культурными противоречиями, проявлявшимися в противопоставлении церковной и гражданской письменных традиций.

Ключевые слова: религиозный стиль, религиозная лексика, вариантные написания, история орфографии, русская лексикография, церковный словарь, словарь академии российской, Петр Алексеев, Евгений Романов, XVIII век.

XVIII век характеризуется его современниками как время «великаго несогласія» в области русского правописания [Свظтовъ 1779: 7]. Как подтверждают исследования по истории языка, многие печатные тексты того времени содержали «самый 
широкий и пестрый диапазон колебаний» в области орфографии [Биржакова 1972: 183]. В то же время именно в этот период «происходит процесс постепенного создания теории правописания и правил орфографии» [Григорьева 2004: 33], а также формирование «русского научно-богословского языка» [Флоровский 1991: 113].

Важно отметить, что ко второй половине XVIII в. культурный конфликт, проявлявшийся в оппозиции церковнославянского и русского языков, во многом обусловивший орфографические противоречия, ощущается общественным языковым сознанием не так остро, как это было в начале века. В связи с этим образовавшееся «гражданское наречие» получает «отсутствовавший у него прежде престиж» [Живов 2017: 1087], постепенно «захватывая» область богословской литературы, и начинает в целом претендовать на роль «универсального языка культуры» [Живов 2017: 954]. Данное обстоятельство обусловило появление лексикографических сочинений, выпущенных в светских типографиях, в которых с той или иной мерой полноты описывается язык церковных текстов.

В свете сказанного особый исследовательский интерес представляет вопрос, связанный с анализом особенностей графико-орфографической кодификации в словарных произведениях этого периода важнейшего в культурном отношении и наиболее устойчивого в плане своего языкового оформления тематического пласта слов, обозначающих понятия религиозной сферы.

Первыми масштабными опытами орфографической кодификации конфессиональной лексики не только во второй половине XVIII в., но и в целом в истории русской письменности стали следующие сочинения: 1) «Церковный словарь» протоиерея П. А. Алексеева (первое издание: «Церковный словарь» (1773 г.) (Алекс. 1773), «Дополненіе къ Церковному словарю» (1776 г.) (Алекс. 1776), «Продолженіе Церковнаго словаря» (1779 г.) (Алекс. 1779); второе издание: «Церковный словарь» (1794 г.) (Алекс. 1794)); 2) «Краткой словарь славянской» игумена Евгения (Романова) (1784 г.) (Ром. 1784); 3) «Словарь Академій Россійской» (1789 - 1794 гг.) (CAP). Данные труды, в значительной мере отражая орфографические колебания в области кодификации религиозной лексики, представляют особый интерес в плане своего изучения в заявленном в теме статьи аспекте, вследствие этого они составили источниковедческую основу для настоящего исследования.

Представим результаты лингвотекстологического анализа указанных словарных изданий, классифицировав различные случаи вариантных написаний религиозной лексики в соответствии со следующими типами: графико-орфографическим, морфологическим и этимолого-словообразовательным.

I. Графико-орфографический тип вариантных написаний религиозной лексики. Графико-орфографический тип нашел выражение в виде вариантных написаний религиозной лексики 1) графемного и 2) фонетико-фонологического характера.

\section{1. Вариантные написания графемного характера.}

Как известно, одной из причин вариативности в русской письменности XVIII в. является неупорядоченность, связанная с употреблением дублетных графем [Каверина 2010: 37]. В рассматриваемых словарях нашли отражение следующие типы графемного варьирования, коснувшиеся как гласных, так и согласных омофоничных букв. 


\section{Графемные варианты слов с различием гласных букв $\boldsymbol{i}$ - $\boldsymbol{\text { и. }}$}

Буква $i$ в соответствии с требованиями грамматик XVII - XVIII вв. регулярно употребляется только в позиции перед [j] на конце слова, в остальных случаях в той или иной мере в ее написании наблюдается вариативность.

Варианты $i-u$ в рассматриваемых словарях наблюдаются в следующих основных случаях: а) в корне заимствованных слов на месте греческой «йоты»:

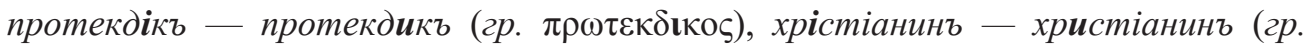

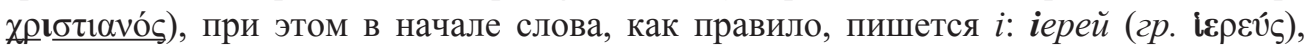

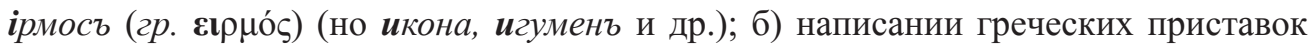
$<a r h i>,<a n t i>$ в позиции перед согласной: архімандрить - архимандрить (гр.

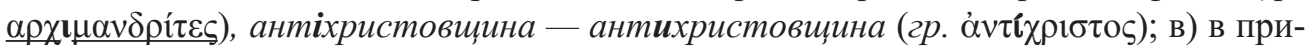
ставке <pri> в позиции перед гласными буквами: богопріимецъ - богоприимецъ, пріобщиттися - приобщитися (плоти и крови).

Наблюдения над употреблением в текстах анализируемых словарей букв $i$ и $u$ в словах религиозной семантики свидетельствуют о вытеснении близкой к латинской манере начертания буквы $i$ буквой $u$ в соответствии с общей орфографической тенденцией второй половины XVIII в. Такая орфографическая установка составителей словарей, противополагаясь взглядам В. Е. Адодурова, В. Н. Татищева, В.К. Тредиаковского, ратовавших за выведение из употребления буквы $u$, в то же время полностью согласовалась с мнением М.В. Ломоносова, А. А. Барсова, Н. Г. Курганова, считавших, что буква $i$ не является функционально значимой для русской графической системы.

Графемные варианты слов с различием гласных букв $v-\boldsymbol{u}$. Вариативность написания $v-u$ при сопоставлении рассматриваемых источников наблюдается при кодификации заимствованной религиозной лексики в положении между согласны-

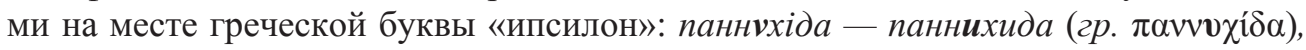

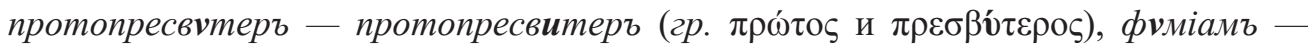
фиміамъ (гр. $\theta v \mu і \alpha \mu \alpha)$. При этом в анализируемых словарях намечается устойчивая тенденция к графической русификации - замене $v$ на $u$ в указанной позиции, которая в целом была характерна для текстов второй половины XVIII в. Буква $V$ под влиянием греческой традиции сохраняется в ряде религиозных заимствований

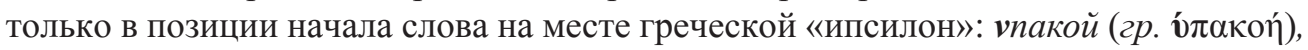
vпостась (гр. ن்

Графемные варианты слов с различием согласных букв 3 - s. Вопреки усилиям В.Е. Адодурова, В.Н. Татищева, В.К. Тредиаковского, пытавшихся ввести в активное употребление букву $s$, в орфографии анализируемых словарей при лексикографировании религиозной лексики эта графема занимает второстепенное место. Колебания в написании з $-s$ наблюдаются лишь в ограниченном количестве лексических единиц, в частности в написании корней славянских слов звъзда-sв взда, зв ър $b-\boldsymbol{s} в$ ър $b$, злый - sлый, змій - sмiŭ, где вариант написания с з является основным для САР и словаря Е. Романова. В то же время написание с $s$, видно, под латинофильским влиянием, актуализируется в тексте второго издания «Церковного словаря» П. А. Алексеева, вопреки орфографии первого издания, где также в приведенных словах писалась 3. 
Графемные варианты слов с различием буквенных написаний согласных $v$ $\boldsymbol{b}, \boldsymbol{\theta}-\boldsymbol{\phi}, \boldsymbol{\psi}-\boldsymbol{n c}, \boldsymbol{3}-\boldsymbol{\kappa}$. Данные орфографические варианты наблюдаются при сопоставлении рассматриваемых словарей в религиозных словах греческого проис-

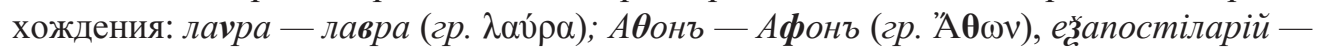

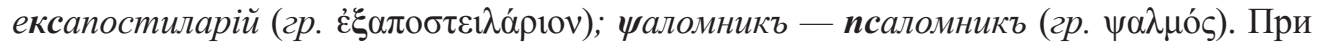
этом во всех анализируемых источниках отражается активный процесс графической русификации наиболее употребительной заимствованной лексики, проявляющийся в написании в значительной группе греческих слов букв $8, \phi$, а также буквосочетаний $n c$ и $\kappa c$. В то же время колебания в написании данных букв не устраняются полностью, в этой связи примечателен факт того, что во втором издании «Церковного словаря» П.А. Алексеева в отдельных случаях наблюдается тенденция к реставрации написаний заимствованных слов с греческими буквами $v, \theta$, $\psi$,

Таким образом, отмеченные графемные колебания при кодификации религиозной лексики в рассматриваемых словарях, с одной стороны, свидетельствуют об опоре их составителей в большей степени на эллинофильскую (а не латинофильскую) графическую традицию, а с другой — в определенной мере отражают процесс графической русификации, связанный с освобождением текстов, изданных в светских типографиях, от дублетных, в частности «клерикальных букв».

\section{2. Вариантные написания фонетико-фонологического характера.}

Данный тип вариантных написаний религиозной лексики, нашедших отражение в рассматриваемых словарных источниках, затрагивает как согласные, так и гласные фонемы в иноязычных и славянских словах, отражая различные языковые процессы, характерные для русской письменности второй половины XVIII в.

1. Вариантные написания, вызванные различной традицией чтения греческих текстов, сложившейся в рамках рейхлинового и эразмового типов произношения. В частности, этой причиной объясняется наличие в словарях вариантных написаний греческих слов с различением буквенных обозначений: $v-e, e-u, \varepsilon-\sigma$,

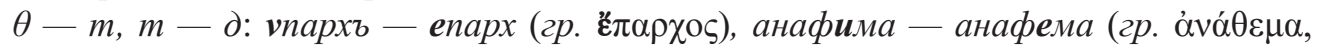

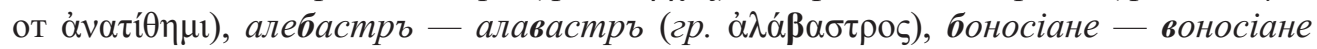

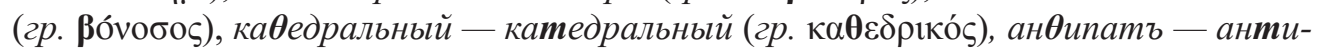

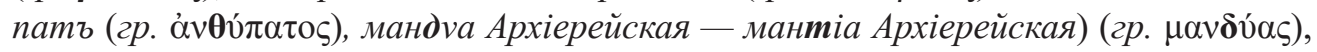
где первый вариант отражает освященную религиозной практикой рейхлиновскую норму чтения, а второй — эразмову, обусловленную западным влиянием.

2. Другая группа вариантных написаний иноязычной религиозной лексики, помещенной в рассматриваемых изданиях, обусловлена различием огласовки слова (греческой «сигмы») в греческом и латинском языках, приводящим к различению буквенных написаний согласных $c-$ з: агіасма - агиазьма (гр. $\alpha \gamma i \alpha \sigma \mu \alpha)$,

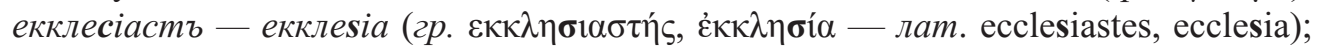

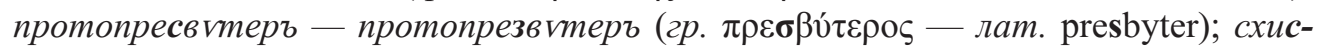

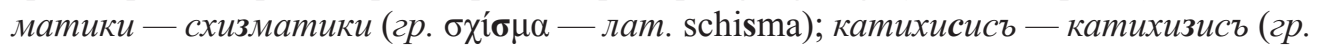

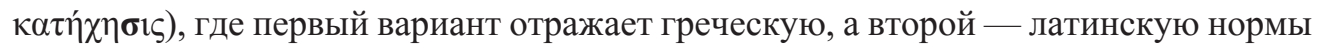
чтения. 
Указанные выше группы вариантных написаний охватывают незначительную часть религиозной лексики, содержащейся в рассматриваемых словарях. При этом основная часть данных слов последовательно оформляется составителями в соответствии с принятой к тому времени традицией церковного чтения, отражая греческую (рейхлиновскую) норму произношения.

3. В рассматриваемых словарях находят широкое распространение вариантные написания, связанные с процессом адаптации заимствованной религиозной лексики:

a) вариантные написания с различением корневых гласных и согласных, обусловленные наличием разных орфографических форм в языке-источнике: велзе-

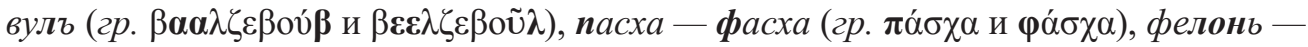

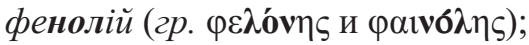

б) вариантные написания с меной корневых гласных и согласных, обусловленные различием фонемного облика слова в языке-источнике и языке-посреднике: купреяновщина - кvпр ъяновщцина (гр. Kvлрıаvós, лат. Сурrianus), ромская - рим-

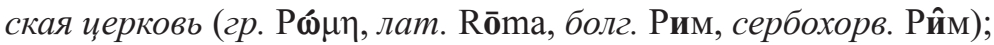

в) вариантные написания с различением корневых гласных и согласных, вызванные влиянием «народного» произношения: алтарь - олтарь (лат. altāre),

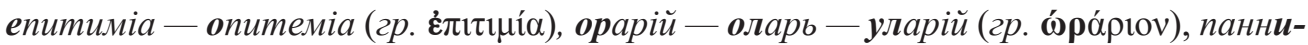
$\boldsymbol{x и д а ~ - ~ п а н а ф и д а ~ ( г р . ~ \pi \alpha v v v \chi i ́ \delta ~} \alpha)$, кардиналь - гординаль (лат. cardinālis);

г) вариантные написания слов с одинарными / удвоенными буквами, вызванные

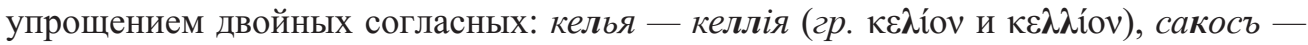

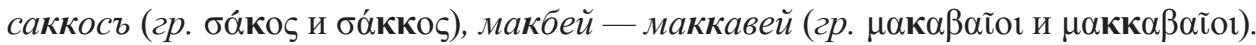

Приведенные примеры показывают, что орфографические колебания являются следствием действия различных фонетических (диссимиляция, ассимиляция, выпадение звуков, метатеза) и лексико-семантических процессов.

4. Помимо указанных случаев, в рассматриваемых словарях наблюдаются вариантные написания религиозных слов славянского происхождения:

а) широко представлены варианты, связанные с обозначением на письме мягкости буквосочетаний с $л, p, \mu, m$, д: епископи селстіи - епископы сельстіи, пастырство - пастырьство, кознствуюшій - козньствуюшій, пятдесятница - пятьдесятникъ, господствіе - господьствуемый; в связи с этим необходимо отметить, что написание «фонетического $b$ » в середине слова не было четко регламентировано в грамматиках того времени и предполагало «принципиальную вариативность» [Каверина 2010: 237].

б) обусловленные конкуренцией старославянских и древнерусских форм: свъица-свъча, юродство - уродство.

Таким образом, наличие вариантных написаний фонетико-фонологического характера, встречающихся в рассматриваемых словарных источниках при кодификации религиозной лексики, обусловлено, с одной стороны, различными культурными противоречиями, характерными для XVIII в., которые нашли отражение на семиотическом уровне в виде конкурирующих тенденциозных орфографических форм, а с другой стороны, недостаточной упорядоченностью к тому 
времени правил передачи звукового облика слова графическими средствами русского языка.

\section{II. Морфологический тип вариантных написании религиозной лексики.}

Процесс формирования нового секулярного языка в XVIII в. обусловливает поиск и новой морфологической нормы, находя отражение в текстах того времени в виде появления вариантных грамматических форм [Живов 2017: 975]. Морфологические варианты в рассматриваемых словарях представлены как у заимствованных, так и славянских религиозных слов.

\section{1. Собственно морфологические варианты.}

1. Варианты, связанные с различием заимствованных существительных в грамматическом роде. Данные грамматические ряды, приспосабливаясь к русской морфологической системе, возникают как путем мены флексий (e/я) (богословіе

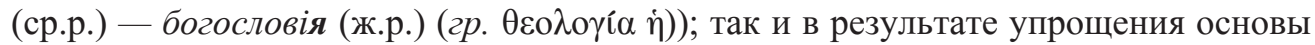

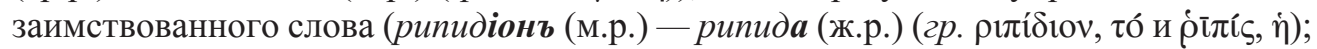

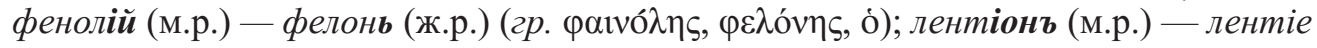

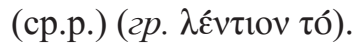

\section{2. Морфолого-фонематические варианты.}

1. Варианты падежных окончаний, обусловленные конкуренцией церковнославянских и русских морфологических форм у имен прилагательных а) в им.П. ед.ч. м.p. с твердой и мягкой типами основ (ветхой завъть - ветхій завъть), б) в им.П. мн.ч. ж.р. (изарскія двери - царскіе двери). При этом основным написанием при кодификации являются формы с флексиями -iй, -ie.

2. Вариантные написания финалей греческих существительных и субстантивированных прилагательных женского рода (на - $\alpha$ и - $\eta$ ) ia - iя: литургіа - литургія

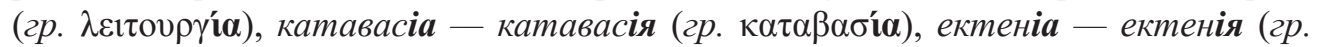

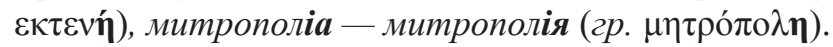

3. Варианты церковнославянских и русских форм глаголов:

а) инфинитива с конкуренцией суффиксов -ти /-ть (животворить - животворити, вождельть - вождельти); б) изъяв. накл. наст. вр. 1 лица ед. ч. (исповъдую - исповъдаю, кошунствую - кошунаю, бъснуюся - бъсюся). При этом ведущей формой является церковнославянская.

Морфологический тип вариантных написаний коснулся ограниченного круга грамматических форм. Как видно из приведенных примеров, наличие данных вариантов объясняется, прежде всего, смешением и аналогическим воздействием унаследованных от старого строя языка парадигматических различий.

3. Этимолого-словообразовательный тип вариантных написаний религиозной лексики. В рассматриваемых словарях нашел отражение процесс появления словообразовательных дублетов как у славянских, так и заимствованных слов, обозначающих религиозные понятия, обусловленный формированием моделей русской словообразовательной системы в XVIII веке.

1. Варианты форм заимствованных существительных им.п. ед.ч., имеющих в финальной части сочетание (суффикс) -ий и упрощенную форму, заканчивающуюся на мягкий согласный, а также конкурирующие формы с суффиксами -uй/-uон-(-ion-): 


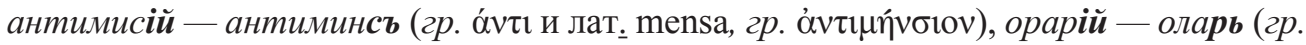

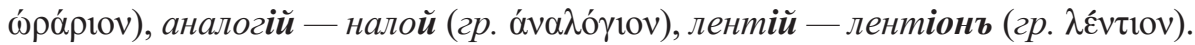

2. Варианты форм существительных им.п. мн.ч. заимствованных слов (na vліане

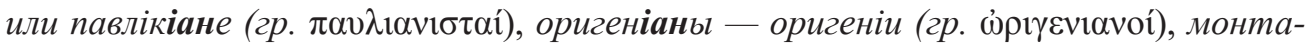

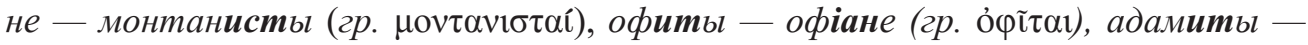

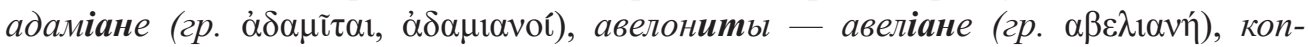

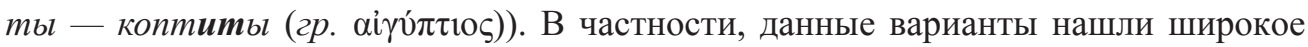
отражение в «Церковном словаре» П. Алексеева у слов, обозначающих названия древних еретиков. Как видно, эти формы отражают процесс освоения русским языком словообразовательной структуры слов с распространенными в XVIII в. суффиксами иноязычного происхождения: -иан-, -ист-, -um-.

3. Варианты, связанные с чередованием «гласный $(e, o)$ / ноль звука» в корне, обусловленные конкуренцией русских и церковнославянских форм слов: доблественный - доблственный, ложица - лжица, промысел - промыслл.

4. Варианты, обусловленные появлением однокорневых разносуффиксальных параллелей у славянских слов и их конкуренцией, с суффиксами:

а) конкретных существительных -ник-/-ец-, Ø/ец, -тель/-ец, ниц-/-иц-, -ник-/ичк-, Ø/-ищ-: иестодневникъ - иестодневецъ, вредословъ - вредословецъ, жизнодатель - жизнодавець, нарукавницы - нараквицы, ұаломникъ - псаломмикъ, собор - соборище;

б) абстрактных существительных оm-/-ocmь, -uj-/ -сть-, -иј-/-ниј-, -ниј-/-сть-: доброта - добрость, благота - благость, преподобі[jэ] - преподобство, чрезсоборі[jэ] - чрезсобирані[jэ], благоговьні[jэ] - благогов ьинство.

Приведенные выше примеры, иллюстрируя процесс этимолого-словообразовательной адаптации, свидетельствуют, не только о существовании во второй половине XVIII в. альтернативных словообразовательных моделей при образовании религиозной лексики, которые отражают тенденцию, связанную с переоформлением средствами русского языка иноязычных новаций.

Таким образом, основные причины, вызвавшие орфографические колебания в области написании религиозной лексики, зафиксированные в рассматриваемых словарях, были обусловлены как собственно языковыми факторами, связанными с недостаточной разработанностью ко второй половине XVIII века теории русского правописания и правил орфографии, так и культурными противоречиями, проявлявшимися в противопоставлении церковной и гражданской письменных традиций.

\section{Источники}

Алексъевъ П. А. Дополненіе къ Церковному словарю. М., 1776.

Алексњевъ П. А. Продолженіе Церковнаго словаря. М., 1779.

Алексђевъ П. А. Церковный словарь / П. А. Алексъевъ. М., 1773.

Алексъевъ П. А. Церковный словарь. СПб., 1794.

Романовъ Е. Краткой словарь славянской. СПб., 1784.

Словарь Академіи Россійской. СПб., $1789-1794$. 


\title{
Литература
}

Биржакова E.Э. Очерки по исторической лексикологии русского языка XVIII века: Языковые контакты и заимствования. Л.,1972.

Григорьева Т. М. Три века русской орфографии (XVIII - XX вв.). М., 2004.

Живов В.М. История языка русской письменности. Т. 2. М., 2017.

Каверина В.В. Становление русской орфографии в XVII-XIX вв.: правописный узус и кодификация: дис. ... д-ра. филол. наук. - М., 2010.

Св ътовъ В. П. Опыть новаго россійскаго правописанія. СПб., 1787.

Флоровский Г. Пути русского богословия. Вильнюс, 1991.

\author{
Sergey $V$. Feliksov \\ Saint Tikhon's Orthodox University \\ (Russia, Moscow) \\ svfeliksov@gmail.com
}

\section{TYPES OF ALTERNATIVE WRITING OF RELIGIOUS LEXICON IN LEXICOGRAPHIC WORKS OF THE CIVIL PRESS OF THE SECOND HALF OF THE $18^{\mathrm{TH}}$ CENTURY}

In the offered article on the basis of lexicographic works of the civil press of the second half of the XVIII ${ }^{\text {th }}$ century - "The church dictionary" $(1773$ - 1794) of the archpriest Pyotr Alekseev, "The short Slavic dictionary" of the abbot Evgeny (Romanov) (1784) and "the Dictionary of Academy Russian" (1789 - 1794) - the main types of alternative writing which concerned religious lexicon and also caused them the reasons are considered. As a result of the lingovtekstologichesky analysis the author draws a conclusion according to which the specified dictionary compositions are valuable sources in a question of studying of history of spelling of religious lexicon, considerably reflecting the spelling fluctuations connected with its codification. All variety of the alternative spelling forms of religious lexicon which are found in these works in work is classified and considered according to three main types: graphic-spelling, morphological and etimologo-word-formation. It is noted that the main reasons which caused spelling fluctuations in the area writing of religious lexicon were caused, on the one hand, by actual language factors connected with insufficient readiness to the second half of the $\mathrm{XX}^{\text {th }}$ century of the theory of the Russian spelling and rules of spelling, and on the other hand, the cultural contradictions shown in opposition of church and civil written traditions.

Key words: religious style, religious lexicon, alternative writing, spelling history, Russian lexicography, church dictionary, dictionary of academy Russian, Pyotr Alekseev, Evgeny Romanov, $\mathrm{XX}^{\text {th }}$ century. 


\section{References}

Birzhakova E. Je. Ocherki po istoricheskoj leksikologii russkogo jazyka XVIII veka: Jazykovye kontakty i zaimstvovanija [Sketches on a historical lexicology of Russian of the 18th century: Language contacts and loans]. Leningrad, 1972.

Grigoreva T.M. Tri veka russkoj orfografii (XVIII $-X X v v$.) [Three centuries of the Russian spelling (the XVIII $-X^{\text {th }}$ centuries)]. Moscow, 2004.

Zhivov V.M. Istorija jazyka russkoj pismennosti [History of language of the Russian writing]. Moscow, 2017, vol. 2.

Kaverina V.V. Stanovlenie russkoj orfografii v XVII-XIX vv.: pravopisnyj uzus i kodifikacija : dis. ... d-ra. filol. nauk [Formation of the Russian spelling in the 17-19th centuries: pravopisny usage and codification. Dr. philol. sci. diss.]. Moscow, 2010.

Svetov V.P. Opyt novago rossijskago pravopisanija [Experience of new Russian spelling]. Saint Petersburg, 1787.

Florovskij G. Puti russkogo bogoslovija [Ways of the Russian divinity]. Vilnius, 1991.

Научное издание

\section{Труды Института русского языка \\ им. В. В. Виноградова \\ Выпуск 13, 2017 г.}

Культура русской речи

Оригинал-макет Л.Е. Голод

Дизайн обложки И.А. Тимофеев

Подписано в печать 00.00.2017. Формат 70×100 1/ 16

Бумага офсетная. Печать офсетная

Усл.-печ. л. 31. Заказ № 1148

Тираж 300 экз.

Издательство «Нестор-История»

197110 СПб., Петрозаводская ул., д. 7

Тел. (812)235-15-86

e-mail: nestor_historia@list.ru

www.nestorbook.ru 